GEOLOGY, ALTERATION, AND THE ROLE OF FLUIDS IN Cu-Ni-PGE MINERALIZATION OF THE FOOTWALL ROCKS TO THE SUDBURY IGNEOUS COMPLEX, LEVACK AND MORGAN TOWNSHIPS, SUDBURY DISTRICT, ONTARIO

$$
\text { by }
$$

CATHARINE ELIZABETH GODDARD FARROW, B.Sc. (Hons.), M.Sc.

$$
\begin{gathered}
\text { A thesis submitted to } \\
\text { the Faculty of Graduate Studies and Research } \\
\text { in partial fulfilment of } \\
\text { the requirements for the degree of } \\
\text { Doctor of Philosophy }
\end{gathered}
$$

Department of Earth Sciences

Carleton University

Ottawa, Ontario

December, 1994

(c) copyright

1994, Catharine E.G. Farrow 
National Library

of Canada

Acquisitions and

Bibliographic Services Branch

395 Wellington Street

Ottawa, Ontario

K1A ON4
Bibliothèque nationale

du Canada

Direction des acquisitions et des services bibliographiques

395, rue Wellington

Ottawa (Ontario)
Your file Votre référence

Our file Notre référence
THE AUTHOR HAS GRANTED AN IRREVOCABLE NON-EXCLUSIVE LICENCE ALLOWING THE NATIONAL LIBRARY OF CANADA TO REPRODUCE, LOAN, DISTRIBUTE OR SELL COPIES OF HIS/HER THESIS BY ANY MEANS AND IN ANY FORM OR FORMAT, MAKING THIS THESIS AVAILABLE TO INTERESTED PERSONS.
L'AUTEUR A ACCORDE UNE LICENCE IRREVOCABLE ET NON EXCLUSIVE PERMETTANT A LA BIBLIOTHEQUE NATIONALE DU CANADA DE REPRODUIRE, PRETER, DISTRIBUER OU VENDRE DES COPIES DE SA THESE DE QUELQUE MANIERE ET SOUS QUELQUE FORME QUE CE SOIT POUR METTRE DES EXEMPLAIRES DE CETTE THESE A LA DISPOSITION DES PERSONNE INTERESSEES.
THE AUTHOR RETAINS OWNERSHIP OF THE COPYRIGHT IN HIS/HER THESIS. NEITHER THE THESIS NOR SUBSTANTIAL EXTRACTS FROM IT MAY BE PRINTED OR OTHERWISE REPRODUCED WITHOUT HIS/HER PERMISSION.
L'AUTEUR CONSERVE LA PROPRIETE DU DROIT D'AUTEUR QUI PROTEGE SA THESE. NI LA THESE NI DES EXTRAITS SUBSTANTIELS DE CELLECI NE DOIVENT ETRE IMPRIMES OU AUTREMENT REPRODUITS SANS SON AUTORISATION.

ISBN $\quad 0-612-02946-8$ 
Name

Dissertation Abstracts International is arranged by broad, general subject categories. Please select the one subject which most nearly describes the content of your dissertation. Enter the corresponding four-digit code in the spaces provided.

\section{Subject Categories}

\section{THE HUMANITIES AND SOCIAL SCIENCES}

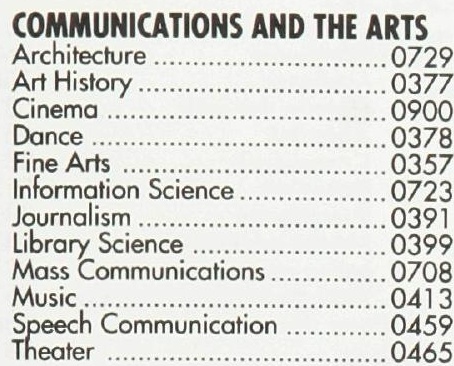

\section{EDUCATION}

General ...

Administration ............................05

Adult and Continuing

Agricultural .......................... 0517

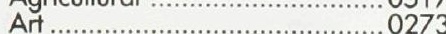

Bilingual and Multicultural .......... 0282

Business ........i.......................0688

Community College ................... 0275

Early Childhood ....................... 0518

Elementary .............................. 0524

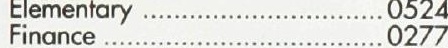

Guidance and Counseling ........... 0519

Health ..................................... 0680

Higher ................................ 0745

History of ................................. 0520

Home Economics ........................ 0278

Industrial ..................................... 0521

Language and Literature ............. 0279

Mathematics .......................... 0280

Music .................................. 0522

Philosophy of .............................. 0998
Physical .............................. 0523

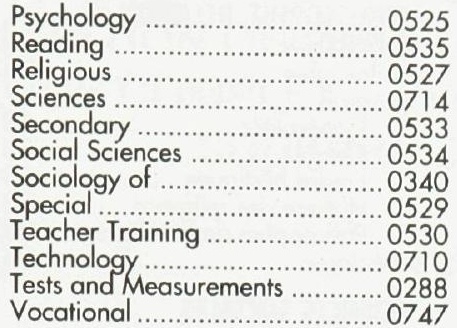

\section{LANGUAGE, LITERATURE AND}

LINGUISTICS

Language

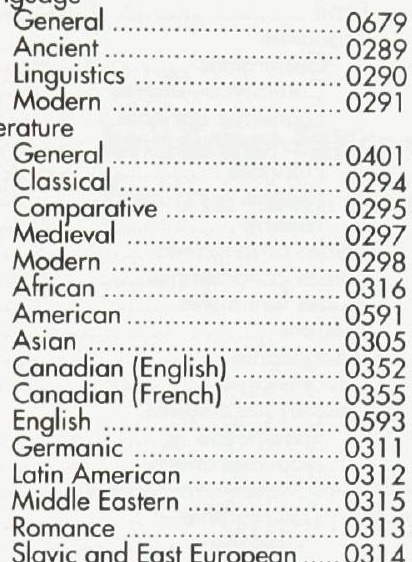

Slavic and East European ..... 0314
PHILOSOPHY, RELIGION AND

\section{THEOLOGY}

Philosoph

Religion 0422

General

Biblical Studies

History of

Philosophy of

Theology

\section{SOCIAL SCIENCES}

American Studies

Anthropology

Archaeology .......................0324

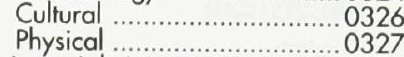

Business Administration

General

Accounting .....................0310

Banking ......................................... 02770

Management ............................ 0454

Marketing …......................... 0338

Canadian Studies

Economics

Agricultura

Agricultural ...................... 0503

Commerce-Business ................ 0505

Finance

History

Labor

Folklore

Geography

History

General

0310
772
354
338

0501

0505
0508
0509

0510

0511

0358
0366

0351

0578
SUBJECT CODE
0318

0320

0469

0323

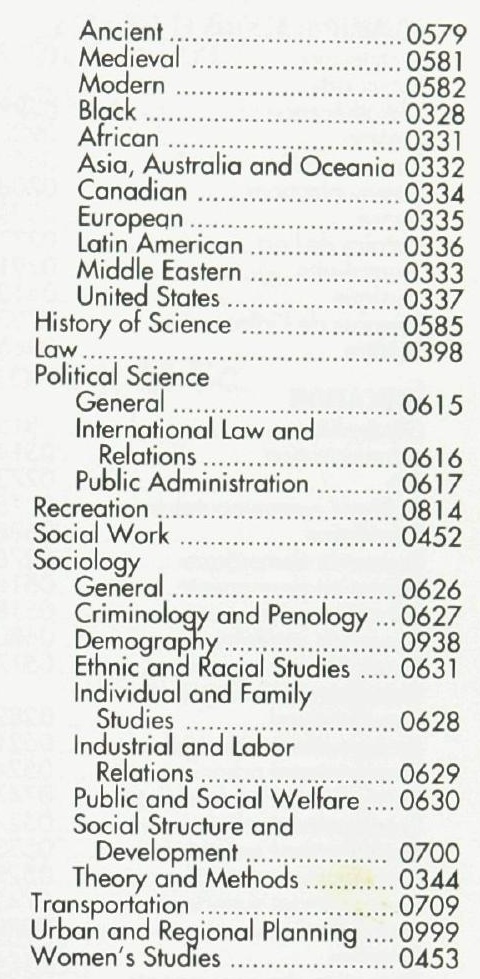

THE SCIENCES AND ENGINEERING

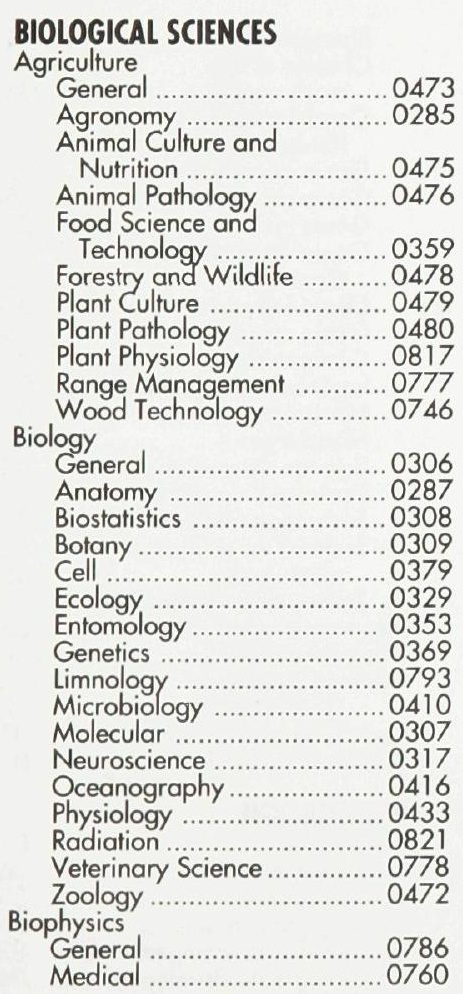

EARTH SCIENCES

Biogeochemistry

Geochemistry

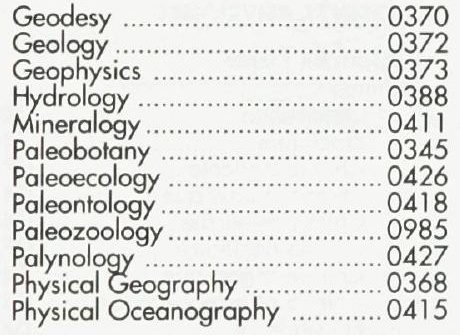

\section{HEALTH AND ENVIRONMENTAL}

\section{SCIENCES}

Environmental Sciences .............0768

Health Sciences

\begin{tabular}{|c|c|}
\hline 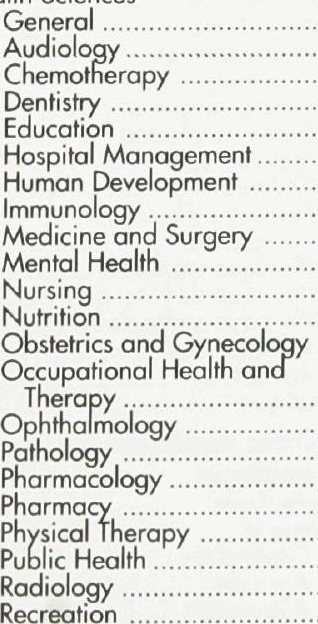 & \\
\hline
\end{tabular}

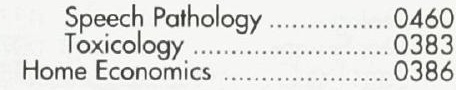

\section{PHYSICAL SCIENCES}

Pure Sciences

Chemistry

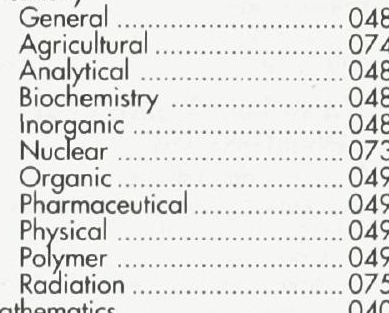

Mathematics

Physics

General

Acoustics

Astronomy and

Astrophysics

Atmospheric Science

Atomic

Electronics and Electricity

Elementary Particles and

High Energy ...

Fluid and Plasma

Molecular

Nuclear

Optics

Radiation

Solid State

Statistics

Applied Sciences

Applied Mechanics

Computer Science

0383
0386

0756

0463

0346

0984
Engineerin

General .

Aerospace.

Agriculfura

Biomedical

Chemical

Civil

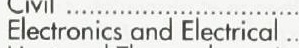

Heat and Thermodynamics

Hydraulic ....

Industrial

Marine

Materials Science

Mechanical

Metallurgy

Mining

Nuclear

Packaging
Petroleum

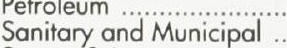

System Science

Geotechnology

Operations Research..................0428

Plastics Technology .................... 0795

Textile Technology

\section{PSYCHOLOGY}

General ....

Behavioral
Clinical

Developmental

Experimenta

Industrial

Personality

Physiological

Psychobiology

Social

0537

.0538

0540

.0541

0542

0543
0544

0348

0545

0546

0547
0794

0548

0743

0551

0552

0549

0765

0554

428

0795
0994
0621

0384

0622

0620

0624

0625

0989

0349

0632 
Nom

Dissertation Abstracts International est organisé en catégories de sujets. Veuillez s.v.p. choisir le sujet qui décrit le mieux votre thèse et inscrivez le code numérique approprié dans l'espace réservé ci-dessous.

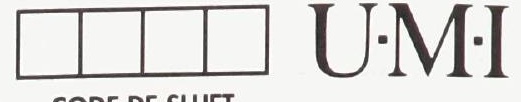

CODE DE SUJET

\section{Catégories par sujets}

\section{HUMANITÉS ET SCIENCES SOCIALES}

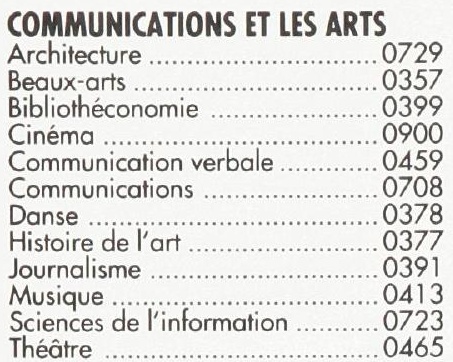

\section{EDUCATION}

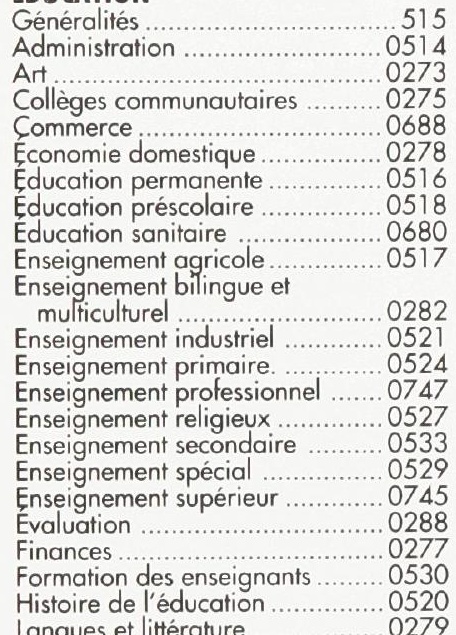

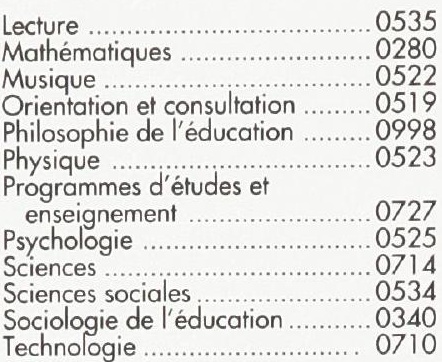

\section{LANGUE, LITTÉRATURE ET}

LINGUISTIQUE

\section{Langues}

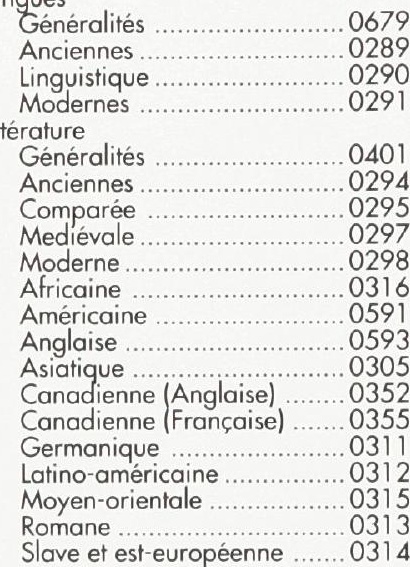

\section{SCIENCES ET INGÉNIERIE}

\section{SCIENCES BIOLOGIQUES}

Agriculture

Agronomie.

Alimentation et technologie alimentaire

0359

0479

Elevage et alimentation .......... 0475

Exploitation des péturages ...0 0777

Pathologie animale ............. 0476

Pathologie vegetale ............048 0817

Physiologie vegetale .............0.0478
Sylviculture et faune ............047

Technologie du bois .............. 0746

Biologie

Généralités ..................... 030

Statistiques)

........ 0308

Biologie moléculaire ........... 0307

Botanique ..................... 0309

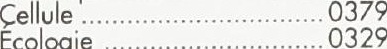

Entomologie ........................ 0353

Génétique ........................ 0369

Limnologie ......................... 0793

Microbiologie ........................................

Neurologie ...................... 0317

Océanographie ................. 0416

Radiation

Science vétérinaire …............. 0778

Zoologie ......................... 0472

Biophysique

Généralités ........................ 0786

Medicale

\section{SCIENCES DE LA TERRE}

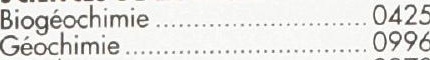

Géodésie ........

Géographie physique
Géologie ............................ 0372

Géophysique ......................... 0373

Hydrologie ............................. 038

Océanographie physique ........... 0415

Paléobotanique 0345

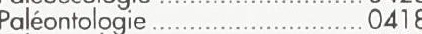

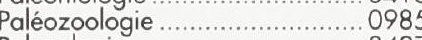

Palynologie ............................. 0427

\section{SCIENCES DE LA SANTÉ ET DE}

\section{L'ENVIRONNEMENT}

Economie domestique ............ 0386

Sciences de l'environnement ..... 0768

Sciences de la santé

Généralités .................. 0566

Administration des hipitaux .. 0769

Alimentation et nutrition ....... 0570

Audiologie ....................... 0300

Chimiothérapie ................. 0992

Dentisterie 0567

Développement humain ........ 0758

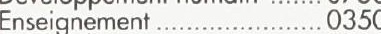

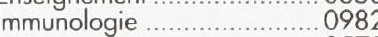

0575

Médecine du travail et

thérapie 0354

Médecine et chirurgie ......... 0564

Obstétrique et gynecologie ...0380

Ophtalmologie ................. 038

Orthophonie ............................ 0460

Pathologie ........................ 057

Pharmacie ..................... 0572

Pharmacologie 0419

Physiothérapie 0382

Radiologie $\ldots 57$

Santé publique ................... 0573

Soins infirmiers ................. 0569

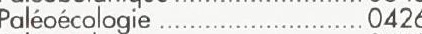

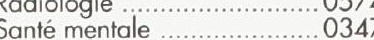

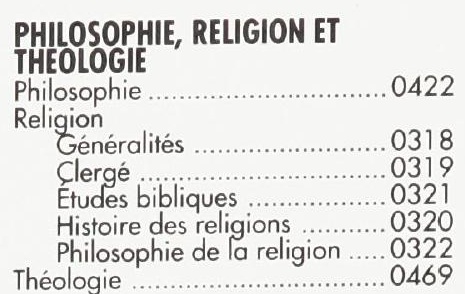

\section{SCIENCES SOCIALES}

Anthropologie

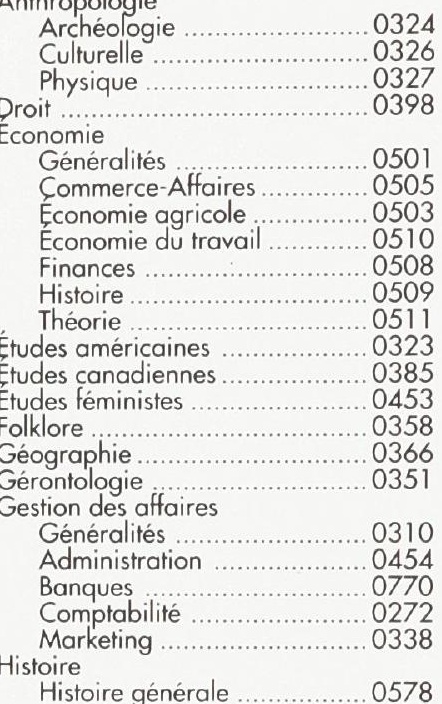

\section{SCIENCES PHYSIQUES}

Sciences Pures

Chimie

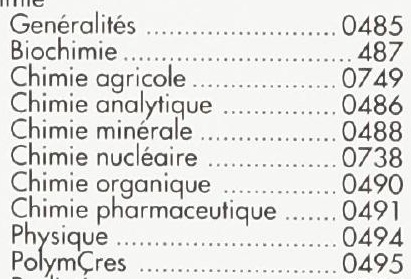

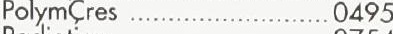

Mathématiques .......................... 0405

Physique

Généralités ....................... 0605

Acoustique ........................... 0986

Astronomie ef

astrophysique ................ 0606

Electronique et électricité ...... 0607

Fluides et plasma ................. 0759

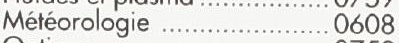

Optique .............................. 0752

Particules (Physique

nucleaire) ......

Physique atomique ......... 0748

Physique de l'état solide ........061 1

Physique moléculaire ............0609

Physique nucléaire ...............0610

Statistiques ...................... 0463

Sciences Appliqués Et

Technologie

Informatique

Ingénierie

Généralités

Agricole

Automobile ....................... 0540

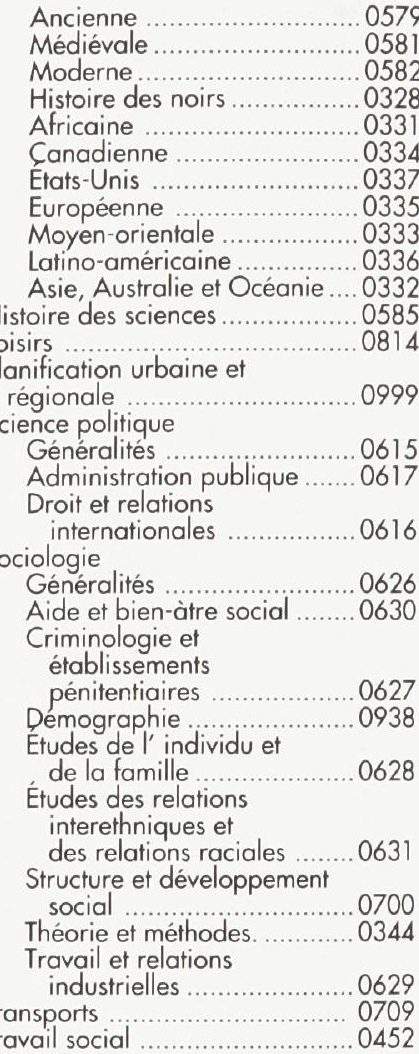

Biomédicale

Chaleur et ther

modynamique

Condifionnement

(Emballage)

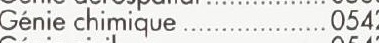

Génie civil ..................

électrique

Génie industriel

Génie mécanique ................. 0548

Génie nucléaire ...................... 0552

Ingénierie des systämes ......... 0790

Mecanique navale .............. 0547

Métallurgie ...................... 0743

Science des matériaux 079

Technique du pétrole ......... 0765

Technique minière ...............055

Techniques sanitaires ef

municipales .................... 055

Mécanique appliquée..............

Géotechnologie ....................... 0428

Matières plastiques

(Technologie)

Recherche opérationneile.......... 0795

Textiles et tissus (Technologie) .... 0794

\section{PSYCHOLOGIE}

\section{Généralités}

Personnalité

Psychobiologie

Psychologie clinique

. 0622

Psychement ....0384

Psychologie du développement ..0620

Psychologie expérimentale .........0623

Psychologie industrielle ............... 0624

Psychologie physiologique .........098

Psychometrie ......................... 0632 


\section{ABSTRACT}

The footwall rocks to the Sudbury Igneous Complex (SIC) in the North Range are composed of gneisses and migmatites of the Levack Gneiss Complex. They represent the granulite-facies equivalents of a volcanicsedimentary succession. The Sublayer Breccia and more leucocratic Footwall Breccia are igneous breccias located along the margin of the Main Mass of the SIC with the footwall rocks.

Assemblages of K-feldspar + epidote + quartz \pm amphibole \pm chlorite occur as replacement pods and veins in Footwall Breccia and most footwall lithologies. They are the result of metasomatism associated with the intrusion and cooling of the SIC.

Epidote + amphibole \pm quartz \pm chlorite \pm albite \pm calcite alteration assemblages are associated with two different styles of Cu-Ni-PGE mineralization in the footwall rocks. The first is characterized by dark green alteration selvages to $\mathrm{Cu}$-rich veining, and the second is Epidote Zone-style alteration dominated by the development of epidote, actinolite and magnetite rich alteration facies within Footwall Breccia.

Individual $\mathrm{Cu}$-rich vein deposits show distinct geochemical variations (i.e., $\mathrm{Pt} /[\mathrm{Pt}+\mathrm{Pd}]$ ratios) and precious metal mineral assemblages. However, the precious metal mineral assemblages are dominated by tellurides and bismuthides for both Cu-rich vein deposits and the Epidote Zone.

Temperatures of formation of the alteration assemblage associated with sulphide mineralization estimated from assemblage and mineral chemical characteristics, fluid inclusion microthermometry, and stable isotope geothermometry were $\approx 300^{\circ} \mathrm{C}$. The results also indicate that a thermal gradient existed, with the highest temperatures having occurred in the Epidote Zone $\left(<400^{\circ} \mathrm{C}\right)$, closest to the SIC, and the lowest in the Strathcona Mine Deep Copper Zone $\left(\approx 300^{\circ} \mathrm{C}\right)$, appoximately $600 \mathrm{~m}$ from the SIC contact.

Fluid-inclusion analyses and interpretation suggest that the hydrothermal fluids were very saline, multicomponent solutions. Semi-quantitative analyses of fluid inclusion daughter minerals and accidental phases in quartz and sulphide minerals show that the deposits have characteristic daughter mineral assemblages, dominated by $\mathrm{Ca}-\mathrm{Na}$ chlorides. Local lithological influence on the availability of specific elements in the fluids is suggested.

Variations in ${ }^{87} \mathrm{Sr} /{ }^{86} \mathrm{Sr}(0.703$ to 0.713$)$ and $\mathrm{Sm} / \mathrm{Nd}$ ratios are strong among and within deposits, suggesting that the fluids were not well mixed, SIC magmatic fluids. The broad stable isotopic and chemical compositional 
similarities between the mineralizing brines of this study and of present-day, deep saline formational brines in the Canadian Shield indicate that similar crustal brines, heated by the cooling SIC, were a likely fluid source during footwall Cu-Ni-PGE deposition in the Sudbury area.

The deposit-scale (and locally smaller) similarities of individual products of hydrothermal activity suggest that individual hydrothermal cells were developed within the footwall and reacted with their host rocks. The hydrothermal cells extended into the ore-bearing Footwall Breccia and Sublayer and scavenged metals. The metals were carried into the footwall where they were deposited as $\mathrm{Cu}-\mathrm{Ni}$-PGE veins in dilation fractures developed in a tectonically unstable crust. Hydrothermal activity focused by the impermeability of footwall ultramafic units resulted in the the formation of the Epidote Zone. 


\section{ACKNOWLEDGEMENTS}

Financial support for this thesis was provided by an NSERC operating grant to Dr. D. Watkinson, Falconbridge Ltd. (Exploration) and an NSERC 1967 Science and Engineering Scholarship.

This research has benefited from discussions with numerous Sudburyarea geologists including T. Barnett, P. Binney, B. Churchill, C. Coats, D. Comba, D. Conroy, the late D. Money, C. Moore, P. O'Link, B. Schillikens, P. Severin, P. Snajdr, M. Sweeny, P. Tirschmann and F. Twilley of Falconbridge Ltd., G. Skippen of Carleton University, K. Hattori (Rb/Sr, Nd/Sm analyses) of the University of Ottawa, J. Guse, S. Jeffries, G. Morrison, E. Pattison and W. Peredery of Inco Ltd., H. Gibson and D. James of Laurentian University, B. Dressler, P. Lightfoot and T. Muir of the Ontario Geological Survey, and G. Chai (Barnet PGE), R. Eckstrand and I. Jonasson of the Geological Survey of Canada.

Invaluable support at Carleton was provided by A. Briggs (thin sections), R. Conlon (XRD), S. Hill, J. Hogg, D. Marshall (flincs and Raman), S. Thayer (organization) and J. Watkinson (plates). Peter Jones was an integral part of the mineral chemistry and SEM-EDS fluid inclusion work. John Everest deserves a medal for the assistance he provided me with during the final preparation of this thesis.

My sincere thanks to A.-M. Fouillac (stable isotopes), D. and M. Ohnenstetter, and Z. Johan of the BRGM-CNRS, Orléans, France for their assistance both during and after my stay in France (it was too short!).

Sue Burbidge helped me tread the fine line between sanity and insanity (she prefers one side over the other). Helping Sue out on the entertainment and dark ale committee were G. Dix, F. Ford, A. Galley, J. Hogg, J. Jacob, P. Jones, H. Gibson, A. MacDonald, Pascal (does he have another name?), G. Ranalli, T. Simonetti, G. Skippen, R. Taylor and R. Westendorp.

I would like to acknowledge the support and encouragement given to me by a number of my OGS colleagues, especially H. Newsome, R. Sage and F. Breaks, all of whom completed $\mathrm{PhDs}$ while working full-time.

Thank you to the friends who opened their doors (and refrigerators, etc.) and shared their homes with me during my thesis travels. They include Mike Sweeny and Myra Gerow (Sudbury), Daniel and Maryse Ohnenstetter (France), Sue Burbidge, Doreen Ames and Al Galley, Jack and Anne Hogg, Barb and Dave Watkinson (Ottawa). 
Jack Hogg and George Skippen helped me "hang in there" during a cold week one February. I am grateful.

It is hardest to write about the people who matter the most to a project. I find it difficult to put the appropriate words to paper. However...

My supervisor, Dave Watkinson, taught me important scientific and life lessons, supported me, put up with me, guided me and encouraged me. I hope one day I am able to give as much to a student or a colleague.

The completion of this thesis would not have been possible without the tireless support, encouragement and understanding of my husband, best friend and love, David. 


\section{TABLE OF CONTENTS}

THESIS TITLE

ACCEPTANCE FORM

ABSTRACT

ACKNOWLEDGEMENTS

TABLE OF CONTENTS

\section{CHAPTER 1 INTRODUCTION}

1-1. General Statement and purpose of study

1-2. Location and access

1-3. Methods of study

1-4. Previous work

1-5. Nomenclature

\section{CHAPTER 2 FIELD RELATIONSHIPS}

2-1. Introduction 15

2-2. Regional geology 15

2-2a. Origin of the Sudbury Structure 18

2-3. Detailed geology of contact units of Levack and Morgan townships 19

2-3a. Footwall Units 20

i. Gneiss 20

Felsic Gneiss (FGN) 21

Intermediate Gneiss (GN) 22

Mafic Gneiss (MGN) 23

ii. Metatexite 23

iii. Diatexite 24

Homogeneous Diatexite $\quad 26$

Tonalitic Diatexite $\quad 26$

iv. Mafic and Ultramafic Units 27

Metadioritic and gabbroic rocks 28

Metapyroxenite/amphibolite $\quad 30$

v. Granite 30

vi. Dykes 31

vii. Banded iron formation 32

viii. Sudbury (or "Levack") Breccia (SDBX) 33

ix. Metamorphic history 35

Shock-metamorphic features $\quad 35$

2-3b. Contact units of the Sudbury Igneous Complex 36

i. Contact breccias 36 
Footwall Breccia (LGBX) $\quad 36$

Sublayer Breccia (SLBX) 40

2-3c. Metasomatism $\quad 42$

2-3d. Alteration 44

2-3e. Structure 45

2-4. Geological setting of some North Range deposits 47

2-4a. Footwall Cu-Ni-PGE deposits 48

i. Barnet property 48

ii. Strathcona Mine 48

iii. McCreedy West Mine $\quad 49$

iv. Summary 49

2-4b. Cu-Ni-PGE mineralization in the Footwall Breccia 50

i. Longvack Mine 50

ii. Fraser Mine Epidote Zone 51

2-5. Discussion

CHAPTER 3 ALTERATION AND SULPHIDE PETROGRAPHY AND MINERAL CHEMISTRY

3-1. Introduction

3-2. Footwall Cu-Ni-PGE deposits $\quad 75$

3-2a. Alteration Mineralogy $\quad 75$

i. Sudbury Breccia host lithology 75

ii. Diatexite and gneissic host lithologies 78

iii. Mafic host lithologies 78

3-2b. Mineralogy of sulphide veins 78

3-2c. Mineral chemistry 80

i. Epidote 81

Allanite $\quad 82$

ii. Amphibole 82

iii. Chlorite 86

iv. Less common alteration minerals 86

v. Cl-rich alteration minerals 87

$\begin{array}{ll}\text { 3-3. Fraser Mine Epidote Zone } & 88 \\ & 88\end{array}$

3-3a. Subdivision of the Epidote Zone 94

3-3b. Ore mineralogy 95

3-3c. Mineral chemistry 195

i. Epidote 96

$\begin{array}{ll}\text { ii. Amphibole } & 96 \\ \text { iii. } & 96\end{array}$

iii. Less common alteration minerals 96

3-4a. Mineral chemistry 98 
3-4b. Nature of the fluid: petrographic implications

i. Cu-rich veins

ii. Epidote Zone

CHAPTER 4 METAL GEOCHEMISTRY

4-1. Introduction

4-2. Footwall Cu-Ni-PGE vein deposits

4-2a. Barnet Property

i. Metal abundances

ii. Element ratios

138

iii. Correlation coefficients

138

iv. Chondrite-normalized abundances

140

4-2b. Summary

141

141

4-3. Cu-Ni-PGE mineralization in the Footwall Breccia 142

4-3a. Fraser Mine Epidote Zone 142

i. Metal abundances 142

ii. Element ratios 143

iii. Correlation coefficients 146

iv. Chondrite-normalized abundances 147

Method to metal geochemistry

v. Relative element gains and losses: application of the Isocon

Results

4-3b. Summary 153

4-4. Discussion $\quad 154$

4-4a. Cu-rich sulphide veins 154

4-4b. Epidote zone 155

1993)

4-4c. Assessment of deposit classification of Barnes et al. (1988;

4-4d. Comparison of Epidote Zone and Cu-rich sulphide vein fluids

CHAPTER 5 PLATINUM-GROUP AND OTHER UNCOMMON MINERALS

190

5-1. Introduction

5-2. PGM and other trace minerals in footwall Cu-Ni-PGE vein deposits 191

5-2a. Petrography

i. Barnet Property

ii. Strathcona Mine Deep Copper Zone

iii. Strathcona Mine Copper Zone

iv. McCreedy West Mine Cu-rich stringers

v. Longvack Property $\mathrm{Cu}$-rich veinlets

5-3. PGM and other trace minerals in Fraser Mine Epidote Zone

5-3b. Petrography 
5-3c. Summary

5-4. Mineral chemistry

5-4a. Froodite, $\mathrm{PdBi}_{2}$

5-4b. Sobolevskite, PdBi

5-4c. Michenerite, PdBiTe, and Platinian Michenerite, (Pd,Pt)BiTe

5-4d. Merenskyite, $(\mathrm{Pd}, \mathrm{Pt})(\mathrm{Te}, \mathrm{Bi})_{2}$, and Moncheite, $(\mathrm{Pt}, \mathrm{Pd})(\mathrm{Te}, \mathrm{Bi})_{2}$

5-4e. Insizwaite, $(\mathrm{Pt}, \mathrm{Pd})(\mathrm{Bi}, \mathrm{Te})_{2}$

5-4f. Niggliite, PtSn

5-4g. Sperrylite, $\mathrm{PtAs}_{2}$

5-4h. Palladian Melonite, $(\mathrm{Ni}, \mathrm{Pd})(\mathrm{Te}, \mathrm{Bi})_{2}$, and Platinian Melonite, $(\mathrm{Ni}, \mathrm{Pt})(\mathrm{Te}, \mathrm{Bi})_{2}$

5-4i. Ag-Au Alloy, (Ag, $\mathrm{Au})$

5-4j. Hessite, $\mathrm{Ag}_{2} \mathrm{Te}$

5-4k. Naumannite, $\mathrm{Ag}_{2} \mathrm{Se}$

5-4I. Tellurohauchecornite, $\mathrm{Ni}_{9} \mathrm{BiTeS}_{8}$

5-4m. Bismuthinite, $\mathrm{Bi}_{2} \mathrm{~S}_{3}$

203

203

204

5-4n. Bismuth tellurides

204

204

i. Strathcona Mine Copper Zone

204

ii. McCreedy West Mine Cu-rich stringers

205

iii. Longvack Property Cu-rich stringers

205

iv. Fraser Mine Epidote Zone

5-5. Discussion

205

206

206

5-5a. Cu-rich footwall vein deposits 206

5-5b. Epidote Zone $\quad 207$

5-5c. Implications for fluid composition 208

\section{CHAPTER 6 FLUID-INCLUSION STUDY}

6-1. Introduction

234

6-2. Petrography of transparent minerals

6-3. Microthermometry

6-3a. Isochores

6-3b. Discussion of traditional methods

6-4. SEM-EDS analyses

6-4a. Introduction

$6-4 \mathrm{~b}$. Semi-quantitative and quantitative SEM-EDS results

6-4c. Discussion

i. Comparison of daughter mineral populations from quartz- and sulphide- hosted fluid inclusions

ii. Inferences about fluid composition

iii. Comparison of North and South Range daughter mineral

populations

iv. Comparison with present-day groundwaters 
7-1. Introduction 274

7-2. Stable Isotope study $\quad 275$

$7-2 a$. Introduction 275

7-2b. Oxygen isotopes 276

7-2c. Hydrogen isotopes $\quad 276$

7-2d. Carbon isotopes 277

$7-2 e$. Oxygen vs. hydrogen isotopes 277

$7-2 f$. Fluid composition 278

$7-2 \mathrm{~g}$. Geothermometry 280

7-2h. Discussion 281

i. Composition and origin of altering fluids 282

7-3. Radiogenic isotope study 282

7-3a. Rubidium/Strontium and Samarium/Neodymium 282

7-4. Discussion 283

7-4a. Comparison with Sudbury-area groundwaters 284

$\begin{array}{ll}\text { CHAPTER } 8 \text { DISCUSSION } & 299\end{array}$

8-1. Introduction 299

8-2. Discussion 299

$\begin{array}{ll}\text { REFERENCES } & 317\end{array}$

\section{LIST OF TABLES}

Table 1-1. Glossary of terms specific to Sudbury geology. 12

Table 2-1. Chronology of rock units in the Onaping-Levack-Morgan area. 55

Table 2-2. Timing relationships associated with Footwall Breccia emplacement.

Table 2-3. Summary of metasomatic mineral characteristics. 57

Table 2-4. Metasomatic mineral paragenetic sequence. 58

Table 3-1. Summary of alteration mineralogy and textural relationships associated with Cu-Ni-PGE footwall veining.

Table 3-2. Summary of ore mineralogy from Cu-Ni-PGE footwall veining from the Barnet Property, Strathcona Deep Copper and Copper zones, and McCreedy 
West.

Table 3-3. Sulphide mineral paragenetic sequence in Cu-rich sulphide veins.106

Table 3-4. Epidote and allanite mineral chemistry, Cu-rich deposits.

Table 3-5a. Amphibole mineral chemistry, Cu-rich deposits.

Table 3-5b. Hastingsitic and actinolitic amphibole mineral chemistry from Strathcona Deep Copper Zone alteration compared to coexisting hastingsitic and actinolitic amphibole from hydrothermal alteration in the Salton Sea geothermal system.

Table 3-6. Chlorite mineral chemistry, Cu-rich deposits.

Table 3-7. Other alteration mineral chemistry, Cu-rich deposits.

Table 3-8. Subdivision of Epidote Zone alteration into facies.

Table 3-9. Epidote mineral chemistry, Fraser Epidote Zone.

Table 3-10. Amphibole mineral chemistry, Fraser Epidote Zone.

Table 3-11. Mineral chemistry of less common alteration minerals, Fraser Epidote Zone.

Table 4-1. Barnet property $\mathrm{Ni}, \mathrm{Cu}, \mathrm{Co}, \mathrm{S}, \mathrm{Ir}, \mathrm{Rh}, \mathrm{Pt}, \mathrm{Pd}$ and $\mathrm{Au}$ geochemical data and selected ratios from this study.

Table 4-2. Pearson correlation matrix for Barnet Property geochemical analyses from this study.

Table 4-3. Chondrite-normalized Barnet property $\mathrm{Ni}, \mathrm{Ir}, \mathrm{Rh}, \mathrm{Pt}, \mathrm{Pd}, \mathrm{Au}$ and $\mathrm{Cu}$ geochemistry from this study.

Table 4-4. Fraser Epidote Zone metal geochemistry showing averages and standard deviation for each facies.

Table 4-5. Selected ratios for Fraser Epidote Zone metal geochemistry showing averages and standard deviations for each facies.

Table 4-6. Pearson correlation matrix for all Fraser Epidote Zone geochemical analyses. 
Table 4-7a. Pearson correlation matrix for EPDZact facies geochemical analyses.

Table 4-7b. Pearson correlation matrix for ACTZmag facies geochemical analyses.

Table 4-7c. Pearson correlation matrix for MAGZ facies geochemical analyses.

Table 4-8. Chondrite-normalized Fraser Epidote Zone geochemistry showing averages and standard deviations for each facies.

Table 5-1. Summary of platinum-group minerals and other trace minerals identified as part of this study.

Table 5-2. Summary of precious metal minerals from the Barnet property. 212

Table 5-3. Summary of precious metal and platinum-group minerals from the Strathcona Mine Deep Copper Zone.

Table 5-4. Summary of precious metal and platinum-group mineralogy from the Strathcona Mine Copper Zone.

Table 5-5. Summary of precious metal and platinum-group mineralogy from McCreedy West Cu-rich stringers.

Table 5-6. Summary of precious metal and platinum-group mineralogy from the Longvack property.

Table 5-7. Summary of precious metal and platinum-group mineralogy from the Fraser Mine Epidote Zone.

Table 5-8. Epidote Zone alteration facies and associated sulphide, precious, trace, and alteration minerals.

Table 6-1. Summary of fluid inclusion petrography from each study location. 255

Table 6-2. Summary of fluid inclusion microthermometry from each study location.

Table 6-3. Comparison of fluid inclusion data from a variety of PGE-bearing deposits.

Table 6-4. Summary of data on solid phases in fluid inclusions analyzed by 
SEM-EDS from the Sudbury area.

Table 7-1. Stable isotope data from the Barnet Property, Strathcona Mine Deep Copper and Copper zones, and Fraser Mine Epidote Zone.

Table 7-2. Calculated fluid isotopic compositions using various fractionation equations and temperatures.

Table 7-3. Oxygen isotope fractionations $(\Delta, \% 0)$ for mineral pairs, calculated temperatures and fluid compositions.

Table 8-1. Summary of microthermometric temperatures, calculated 0 isotopic temperatures from coexisting mineral pairs, and related sample information for the deposits studied in detail.

\section{LIST OF FIGURES}

Figure 1-1. Barnet Trench Extension Geology map.

Back Pocket

Figure 1-2. Part of Morgan (East) and Levack (West) township geology map.

Back Pocket

Figure 1-3. Pike Lake Property (SE Sheet) and Longvack Property (S Sheet) geology map.

Back Pocket

Figure 1-4. Pike Lake Property (NE Sheet) and Longvack Property (N Sheet) geology map.

Back Pocket

Figure 1-5. Map of "Epidote Zone" patch exposed in Exploration Drift 46-190,

Fraser Mine, showing the relationships amongst the different alteration facies. 13

Figure 1-6. Map of the Sudbury Structure with locations of North and South range mines and deposits included in this investigation.

Figure 2-1. Generalized geology map of the Onaping-Levack area.

Figure 2-2. Compilation map of areas mapped as part of this study.

Figure 2-3. Diagrammatic portrayal of generalized contact relationships between Sublayer norite and Footwall rocks.

Figure 2-4. Sketch of outcrop on Coleman Mine Road, northwest of Strathcona Mine. 
Figure 2-5. Contoured stereograms of poles to foliations/gneissosity data for the Morgan, Barnet, Longvack and Pike Lake properties superimposed on the geological compilation map of Figure 2-2.

Figure 2-6. Contoured stereograms of poles to joints data for the Barnet, Longvack and Pike Lake properties superimposed on the geological compilation map of Figure 2-2.

Figure 2-7. Schematic geological section of the Strathcona area.

Figure 3-1. Schematic diagram of a Cu-rich vein and surrounding alteration. 120

Figure 3-2. Epidote compositional (Pistacite \%) variation in Cu-rich vein settings.

Figure 3-3. Amphibole compositional ( $\mathrm{Mg} \mathrm{\# )} \mathrm{variation} \mathrm{in} \mathrm{Cu}$-rich vein settings.

Figure 3-4. Epidote compositional (Pistacite \%) variation in different alteration facies of the Epidote Zone.

Figure 3-5. Amphibole compositional (Mg \#) variation in different alteration facies of the Epidote Zone.

Figure 3-6. $\log \mathrm{fO}_{2}$ vs. $\log \sum \mathrm{S}$ diagram showing sulphide and oxide stabilities at $300^{\circ} \mathrm{C}$ and $2 \mathrm{~kb}$.

Figure 3-7. $\log \mathrm{fO}_{2}$ vs. pH diagram showing sulphide and oxide stabilities at $300^{\circ} \mathrm{C}$ and $\sum \mathrm{S}=0.05 \mathrm{M}$ in the system $\mathrm{Fe}-\mathrm{S}-\mathrm{O}-\mathrm{H}$.

Figure 4-1. Comparison of $\mathrm{Pt} /(\mathrm{Pt}+\mathrm{Pd})$ frequency plots from a) Barnet, b) Deep Copper Zone, c) Copper Zone, and d) McCreedy West.

Figure 4-2. Barnet Property (a) and Strathcona Deep Copper Zone (b) $\mathrm{Pt} /(\mathrm{Pt}+\mathrm{Pd})$ vs. $\mathrm{Cu} /(\mathrm{Cu}+\mathrm{Ni})$ diagrams.

Figure 4-3. Pd/Ir vs. Ni/Cu diagram with "Cu-rich sulphide veins", "flood basalts" and "layered intrusions" fields from Barnes et al. (1988; 1993). 178

Figure 4-4. Ni/Pd vs. Cu/Ir diagram with "Cu-rich sulphide veins", "flood basalts" and "layered intrusions" fields from Barnes et al. (1988; 1993).

Figure 4-5. Chondrite-normalized plot of Barnet analyses compared to those from the Strathcona Deep Copper and Copper zones, and disseminated and 
massive sulphide vein ores in Sudbury Breccia from McCreedy West.

Figure 4-6. Samples from the Epidote Zone that are more intensely altered than the EPDZ facies have low $\mathrm{Cu} /(\mathrm{Cu}+\mathrm{Ni})$ ratios $(<0.1)$.

Figure 4-7. Ir/Pd vs. Pt/Pd diagram showing broad Ir/Pd ratios (0.0004-0.05) over a relatively narrow range of Pt/Pd $(0.72-2)$ ratios (LGBX trend).

Figure 4-8. Plots of $\mathrm{Pd} / \mathrm{Ir}$ vs. $\mathrm{Ni} / \mathrm{Cu}$.

Figure 4-9. Ni/Pd vs. Cu/lr.

Figure 4-10. PGE whole rock/chondrite profiles for a) Sublayer, b) Footwall Breccia, c) LGBXepdz, d) EPDZ, e) EPDZact, f) ACTZ, g) EPDZmag, h) ACTZmag, i) MAGZ and j) a variety of footwall lithologies from Fraser Mine. 185

Figure 4-11. PGE whole rock/chondrite profiles for EPDZact to MAGZ compilation compared to a) Fraser Mine Sublayer and Footwall Breccia, and b) McCreedy West Mine disseminated and massive sulphide in Footwall Breccia.

Figure 4-12a. Element gains and losses (\%) from various alteration facies of the Epidote Zone for $\mathrm{S}, \mathrm{Fe}, \mathrm{Ni}, \mathrm{Cu}, \mathrm{Zn}$ and $\mathrm{Pb}$.

Figure 4-12b. Element gains and losses (\%) from various alteration facies of the Epidote Zone for $\mathrm{Co}, \mathrm{Se}, \mathrm{Ag}, \mathrm{Au}, \mathrm{Re}$ and Os.

Figure 4-12c. Element gains and losses (\%) from various alteration facies of the Epidote Zone for Ir, Ru, Rh, Pt and Pd.

Figure 5-1. Pt vs. Pd plot for analyzed samples from the Epidote Zone.

Figure 5-2. This $\mathrm{Bi}-(\mathrm{Pd}+\mathrm{Pd}+\mathrm{Ni})-(\mathrm{Te}+\mathrm{Se})$ ternary plot shows that froodite analyzed in this study is similar in composition to that reported from Deep Copper Zone, Coleman Mine and several South Range mines.

Figure 5-3. This $\mathrm{Bi}-(\mathrm{Pd}+\mathrm{Pt}+\mathrm{Ni})-(\mathrm{Te}+\mathrm{Se})$ plot shows in detail the compositional characteristics of michenerite and platinian michenerite from Copper Zone and McCreedy West Cu stringers from this study compared to michenerite and platinian michenerite reported by Cabri and Laflamme (1976) for several locations, and by Li and Naldrett (1992; 1993a) for Deep Copper Zone.

Figure 5-4. Ni - Pd - Pt plot showing michenerite, merenskyite and moncheite compositions from this study compared to michenerite and merenskyite 
compositions from the Lindsley Mine, Deep Copper Zone "Moncheite" (Springer, 1989), and michenerite, merenskyite and moncheite compositions from a variety of Sudbury locations.

Figure 5-5. $\mathrm{Te}+\mathrm{Bi}-\mathrm{Pd}-\mathrm{Pt}$ ternary diagram of merenskyite, moncheite and merenskyite/moncheite solid solution compositions from this study compared to those from other Sudbury locations.

Figure 5-6. $\mathrm{Bi}-\mathrm{Pd}+\mathrm{Pt}+\mathrm{Ni}-\mathrm{Te}+\mathrm{Se}$ diagram showing moncheite compositions from the Epidote Zone, McCreedy West Mine Cu-rich stringers and Strathcona Mine Deep Copper Zone compared to those from McCreedy West and Creighton mines reported by Cabri and Laflamme (1976).

Figure 5-7. This $\mathrm{Ni}$ vs. $(\mathrm{Pd}+\mathrm{Pt})$ diagram shows the linear relationship between increased $\mathrm{Ni}$ content and decreased $(\mathrm{Pd}+\mathrm{Pt}$ ) from high-Ni palladian melonite from the Epidote Zone (FR46-150-4) and the Barnet Property (CFAS-5C1), and a moncheite-like mineral with a lower Ni content from both the Epidote Zone (FR46-287-7) and the Strathcona Mine Deep Copper Zone (S37-1).

Figure 5-8. $\mathrm{Pd}-\mathrm{Ni}-\mathrm{Pt}$ ternary diagram showing moncheite and palladian melonite compositions from the Epidote Zone, Barnet and Strathcona Mine Deep Copper Zone.

Figure 5-9. $\mathrm{Pd}-\mathrm{Te}+\mathrm{Bi}-\mathrm{Pt}$ ternary diagram showing palladian melonite and platinian melonite compositions from the Epidote Zone, Barnet and Strathcona Mine Deep Copper Zone.

Figure 6-1. Eutectic $\left(T_{e}\right)$ and final melting $\left(T_{f m}\right)$ temperatures for fluid inclusions from the Deep Copper Zone, Barnet and the Epidote Zone.

Figure 6-2. Frequency distribution diagrams of homogenization temperatures (vapour to liquid) and salt cube melting temperatures for polyphase fluid inclusions from Strathcona Deep Copper Zone.

Figure 6-3. Frequency distribution diagram of homogenization temperatures and salt cube melting temperatures for fluid inclusions from the Barnet Property. 264

Figure 6-4. Frequency distribution diagram of homogenization temperatures and salt cube melting temperatures for fluid inclusions from the Fraser Mine Epidote Zone.

Figure 7-1. Oxygen isotope values for mineral separates from Barnet, Deep Copper Zone, Copper Zone and the Epidote Zone. 
Figure 7-2. Oxygen isotope values for mineral separates from Barnet, Deep Copper Zone, Copper Zone and the Epidote Zone.

Figure 7-3. Hydrogen isotope values for amphibole and epidote mineral separates from Strathcona Mine Deep Copper and Copper zones, Fraser Mine Epidote Zone and the Barnet Property.

Figure 7-4. Carbon isotope values from calcite mineral separates from the Strathcona Mine Deep Copper Zone and the Fraser Mine Epidote Zone.

Figure 7-5. Hydrogen ( $\delta D)$ vs. oxygen $\left(\delta^{18} O\right)$ isotope values for epidote (squares) and amphibole (ovals) mineral separates from the Fraser Mine Epidote Zone, Barnet Property, and Strathcona Mine Copper and Deep Copper zones.

Figure 7-6. Variations between $\delta^{18} \mathrm{O}$ and $\delta \mathrm{D}$, compared to the $\mathrm{Mg} \#$ of amphibole (a, b) and the Ps (\%) content of epidote (c, d).

Figure 7-7. Variation in ${ }^{87} \mathrm{Sr} /{ }^{86} \mathrm{Sr}$ with increasing distance from the Sudbury Igneous Complex.

Figure 7-8. $€ \mathrm{Nd}(1.85 \mathrm{Ga})$ vs. $€ \mathrm{Sr}(1.85 \mathrm{Ga})$ for epidote from Strathcona Mine Deep Copper Zone, Norite from the Sudbury Igneous Complex and Fraser Mine.

Figure 7-9. $\delta \mathrm{D}$ vs. $\delta^{18} \mathrm{O}$ diagram showing calculated Epidote Zone (EPDZ) and Cu-rich vein fluid compositions compared to Canadian Shield formational brine compositions, including Sudbury Brines; ocean water (present-day); magmatic water; Salton Sea and Yellowstone saline waters.

Figure 8-1. Ternary plot for $\mathrm{Na}-\mathrm{Ca}-(\mathrm{Mg}+\mathrm{Fe}+\mathrm{Pb}+\mathrm{K}+\mathrm{Ba})$ of highly saline waters or brines from present-day Sudbury deep groundwaters, ocean water, Salton Sea geothermal brines, and Sudbury area fluids associated with Cu-Ni-PGE mineralization.

Figure 8-2. Model of sequence of events (illustrated in figures $8-2 a$ to $8-2 d$ ) that contributed to the development of footwall ores in the North Range of the Sudbury Structure.

\section{LIST OF PLATES}

Plate 2-1a. Banding in intermediate gneiss, Morgan Property.

Plate 2-1b. Elongate xenolith (schollen) in foliated tonalitic diatexite. Pike Lake 
Plate 2-2a. Sudbury Breccia veinlet following a pre-existing pegmatitic vein in a clast in a larger Sudbury Breccia body. Barnet Trench \#3.

Plate 2-2b. Sudbury Breccia in the Barnet Trench Extension.

Plate 2-3a. Sulphide-bearing mafic norite intruding Footwall Breccia. Pike Lake Property.

Plate 2-3b. Close-up of mafic norite intrusion into Footwall Breccia as shown in Plate 2-3a. Pike Lake Property.

Plate 2-4a. Mafic clasts in Footwall Breccia with felsic mineral selvages. 46-190 Exploration Drift, Fraser Mine.

Plate 2-4b. Bleb of pyrrhotite-rich sulphides with a selvage of dark alteration consisting of amphibole + chlorite \pm epidote. Pike Lake Property.

Plate 2-5a. K-feldspar + quartz granophyric intergrowth with epidote in diatexite clast in Sudbury Breccia. Barnet Trench Extension.

Plate 2-5b. K-feldspar -rich pervasive metasomatism in Sudbury Breccia matrix and clasts. Barnet Trench Extension.

Plate 2-6a. Structure filled by colloform-textured, zoned K-feldspar + quartz vein with minor chlorite, amphibole and epidote in diatexite. Barnet Trench Extension.

Plate 2-6b. The same structure as shown in Plate 2-6a filled by chalcopyrite with K-feldspar + quartz + chlorite and radiating epidote crystals from the "preore" metasomatic event. Barnet Trench Extension.

Plate 2-7a. Chalcopyrite-rich stringers oriented along gneissosity in a large gneissic clast in Sudbury Breccia. Barnet Trench \#3.

Plate 2-7b. Up to $50 \mathrm{~cm}$ wide chalcopyrite-rich vein in Sudbury Breccia with $>20$ $\mathrm{cm}$ wide dark alteration selvage along margin. A23 vein, 3700 Level, Strathcona Mine Deep Copper Zone.

Plate 2-7c. Approximately $15 \mathrm{~cm}$ wide chalcopyrite-rich vein cross-cutting gneissosity in gneissic clast in Sudbury Breccia. A2 vein, 3700 Level, Strathcona Mine Deep Copper Zone. 
Plate 2-7d. Chalcopyrite-rich vein becoming more quartz and calcite-rich at its termination. D5 vein, 4200 Level, Strathcona Mine Deep Copper Zone.

Plate 3-1a. Zoned epidote inclusions within and along the margin of a chalcopyrite-rich vein (black). Epidote zonation is the result of slight Fe content variations. Sample S42-D5, 4200 Level, Strathcona Mine Deep Copper Zone.

Plate 3-1b. Quartz and calcite with a later, cross-cutting, chalcopyrite-rich veinlet. Sample S42-D13, 4200 Level, Strathcona Mine Deep Copper Zone. 128

Plate 3-1c. Subhedral epidote in quartz with abundant trails of fluid inclusions along the margin of a chalcopyrite-rich stringer. Sample S37-1, 3700 Level, Strathcona Mine Deep Copper Zone.

Plate 3-1d. Backscattered electron image of a remnant of a zoned allanite grain (light grey) in a zoned epidote crystal within chalcopyrite (light grey). Sample DCO-87-2, 3900 Level, Strathcona Mine Deep Copper Zone.

Plate 3-2. Comb-textured vein with actinolite crystals up to $1 \mathrm{~cm}$ long along the vein margin and chalcopyrite in the vein core. Sample S37-A23, 3700 Level, Strathcona Mine Deep Copper Zone.

Plate 3-3a. Bornite after chalcopyrite (white) extending into quartz and epidote on margin of Cu-rich vein. Sample S37-1, 3700 Level, Strathcona Deep Copper Zone.

Plate 3-3b. Chalcopyrite and millerite -rich bleb (light grey) with acicular to subhedral actinolite inclusions. Sample CFA-052, Barnet Trench \#4.

Plate 3-4. Sphalerite inclusions (orange-brown) with hastingsite (dark green) at margin of chalcopyrite-rich vein. Sample S37-8B, 3700 Level, Strathcona Mine Deep Copper Zone.

Plate 3-5a. Footwall Breccia with angular mafic clasts $<25 \mathrm{~m}$ from a welldeveloped Epidote Zone patch. 46-190 Exploration Drift, Fraser Mine.

Plate 3-5b. Weakly altered Footwall Breccia (LGBXepdz) from near an Epidote Zone patch. Sample F46-4A, 46-190 Exploration Drift, Fraser Mine.

Plates 3-6a and 3-6b. Colour-enhanced backscattered electron images showing unstable magnetite (light bronze) being replaced by ilmenite (orange) in weakly altered Footwall Breccia (LGBXepdz). Sample FR46-147-6. 
Plate 3-7a. EPDZ facies. Footwall Breccia clast-like textures remain at this degree of alteration, althought the matrix has been pervasively epidotized. Sample F46-4C, Exploration Drift 46-190, Fraser Mine.

Plate 3-7b. EPDZact facies. Epidote content is greater than amphibole content. Sample FR46-287-2.

Plate 3-8a. ACTZ facies. Original Footwall Breccia matrix is almost entirely actinolite. Sample F46-4E, Exploration Drift 46-190, Fraser Mine.

Plate 3-8b. ACTZ facies. Backscattered electron image of abundant titanite (grey) grains in pentlandite (white) and amphibole. Sample F46-4E, Exploration Drift 46-190, Fraser Mine.

Plate 3-9a. MAGZ facies. Magnetite occurs as equant grey grains with interstitial pentlandite (white). Epidote and actinolite are the silicate minerals (dark grey). Sample FR46-147-10.

Plate 3-9b. MAGZ facies. As above in cross-polarized, transmitted light.

Plate 3-10a. EPDZact facies. Backscattered electron image of pyrite (dark grey) with galena (white) and chalcopyrite (light grey) inclusions. Sample FR46287-7.

Plate 3-10b. ACTZ facies. Backscattered electron image of subhedral pyrite with Se-bearing galena inclusions adjacent to unstable pentlandite. Sample F46-4E, Exploration Drift 46-190, Fraser Mine.

Plate 5-1a. Colour-enhanced backscattered electron image of naumannite and associated chalcopyrite inclusions in pyrite. Sample CFA-016B, Barnet Trench Extension.

Plate 5-1b. Backscattered electron image of euhedral palladian melonite in quartz with nearby chalcopyrite and amphibole. Sample CFAS-5C1, Barnet Trench Extension.

Plate 5-1c. Backscattered electron image of euhedral merenskyite in chalcopyrite. Sample CFA-046, Barnet Trench Extension.

Plate 5-1d. Colour-enhanced backscattered electron image of hessite (left) and merenskyite (right) on either side of void space in chalcopyrite. Sample CFA-912, Barnet Trench \#2.

Plate 5-2a. Backscattered electron image of a large composite grain of froodite. 
michenerite, parkerite and hessite. Sample 27AOCO-K1B, 27AOCO stope, Strathcona Mine Copper Zone.

Plate 5-2b. Backscattered electron image of a composite grain of sobolevskite, froodite and hessite. Sample 27AOCO-K1B, K vein, 27AOCO stope, Strathcona Mine Copper Zone.

Plate 5-2c. Backscattered electron image of a concentration of PGM hosted by chalcopyrite, amphibole and epidote. Precious metal minerals include hessite, froodite, electrum, niggliite, sperrylite and an unknown insizwaite-like mineral. Sample 27AOCO-H1, H vein, 27 AOCO stope, Strathcona Mine Copper Zone.

Plate 5-3a. Backscattered electron image of a composite grain of michenerite partially rimmed by hessite and tellurohauchecornite in a millerite host. Sample MW-500-1, 500 level, McCreedy West Mine.

Plate 5-3b. Backscattered electron image of an electrum grain at the junction of chalcopyrite, chlorite and quartz. Sample MW-600-1, 600 level, McCreedy West Mine.

Plate 5-4a. Backscattered electron image of a moncheite and hessite intergrowth in host pyrite at contact with magnetite and pentlandite. MAGZ facies. Sample FR46-147-11, Fraser Mine Epidote Zone.

Plate 5-4b. Backscattered electron image of three moncheite grains in pyrite. EPDZact facies. Sample FR46-287-7, Fraser Mine Epidote Zone.

Plate 5-4c. Backscattered electron image of euhedral moncheite in amphibole with several smaller inclusions. ACTZmag facies. Sample FR46-287-6. Fraser Mine Epidote Zone.

Plate 5-4d. Backscattered electron image of a concentration of moncheite grains within irregularly-shaped magnetite and serpentine. Sample FR46-15013, Fraser Mine.

Plate 5-4e. Backscattered electron image of horseshoe-shaped tsumoite in pentlandite with titanite inclusions (black). EPDZmag facies. Sample FR46264-10, Fraser Mine Epidote Zone.

Plate 5-4f. Elongate merenskyite in amphibole along cleavage planes. Sample FR46-150-13, Fraser Mine Epidote Zone.

Plate 6-1a. Three phase (liquid + vapour + salt cube) fluid inclusion in quartz 
with nearby chalcopyrite. Sample S37-1iii, 3700 level, Strathcona Mine Deep Copper Zone.

Plate 6-1b. Two phase (liquid + vapour) fluid inclusion with a negative crystal shape in quartz. Sample S37-1, 3700 level, Strathcona Mine Deep Copper Zone.

Plate 6-1c. Three phase (liquid + vapour + salt cube) fluid inclusion in quartz. Sample S37-1, 3700 level, Strathcona Mine Deep Copper Zone.

Plate 6-1d. Polyphase (liquid + vapour + salt cube +3 non-birefringent solid phases) fluid inclusion in quartz. Sample S37-1, 3700 level, Strathcona Mine Deep Copper Zone.

Plate 6-1e. Polyphase fluid inclusions with several solids including a round, non-birefringent phase in quartz. Sample S37-D5, 3700 level, Strathcona Mine Deep Copper Zone.

Plate 6-1f. Polyphase (liquid + vapour +2 high relief, non-birefringent phases + 1 low relief, non-birefringent phase) fluid inclusion in quartz. Sample F46-31, Exploration Drift 46-190, Fraser Mine.

Plate 6-2a. Colour-enhanced secondary electron image of a broken surface in quartz showing three opened fluid inclusions. Sample S37-1, 3700 level, Strathcona Mine Deep Copper Zone.

Plate $6-2 b$. Secondary electron image of a broken surface in pyrite showing two large, $\mathrm{NaCl}$-bearing fluid inclusions. Sample 48-92-5, 4800 level, Fraser Mine Epidote Zone.

Plate 6-2c. Secondary electron image of a large $\mathrm{NaCl}$ cube in a fluid inclusion with a negative crystal shape in bornite. Sample STN-4, 3900 level, Strathcona Mine Deep Copper Zone.

Plate 6-2d. Secondary electron image of a large $\mathrm{NaCl}$ cube in a fluid inclusion in pyrite. Sample F48-92-2, 4800 level, Fraser Mine Epidote Zone.

Plate 6-2e. Secondary electron image of two $\mathrm{NaCl}$ and two $\mathrm{PbCl}_{2}$ daughter solides with an accidental cassiterite rod in an opened fluid inclusion in chalcopyrite. Sample CFA-92-3, Barnet property.

Plate 6-2f. Secondary electron image of an opened fluid inclusion in quartz with three daughter phases. Sample S42-B23, 4200 level, Strathcona Mine Deep Copper Zone. 
Plate 6-2g. Secondary electron image of an opened fluid inclusion in quartz with an adjacent halite cube.

Plate 6-2h. Secondary electron image of an opened fluid inclusion in chalcopyrite.

Plate 6-2i. Secondary electron image of an empty opened fluid inclusion in quartz.

Plate 6-2j. Secondary electron image of "boiled" Ca-rich chloride in quartz. Sample S37-1, 3700 level, Strathcona Mine Deep Copper Zone.

Plates 6-3a and b. Backscattered electron image of native Ag (white) with a mottled rim of $\mathrm{AgCl}_{2}$ (chlorargyrite). Sample STN-4, Strathcona Mine Deep Copper Zone.

Plates 6-3c and d. Secondary electron image of a native $\mathrm{Ag}$ grain in an opened fluid inclusion in chalcopyrite from the Barnet property.

\section{LIST OF APPENDICES}

APPENDIX I. Barnet Property Trench Report

APPENDIX II. Sample Location Information and Mapping of the Barnet Trench Area, the Strathcona Mine Deep Copper Zone, and the Fraser Mine Epidote Zone.

APPENDIX III. Modification of Layered Complex Terminology to Metamorphic Terminology for Figure 1-2.

APPENDIX IV. Silicate, Oxide and Carbonate Mineral Chemistry.

APPENDIX V. Metal Geochemistry Methods and Analyses.

APPENDIX VI. Platinum-Group Mineral and Uncommon Mineral Chemistry. 368

APPENDIX VII. Fluid Inclusion Study.

APPENDIX VIII. Isotope Geochemistry. 


\section{CHAPTER 1: INTRODUCTION}

\section{1-1. GENERAL STATEMENT AND PURPOSE OF STUDY}

Magmatic Ni-Cu-platinum-group element (PGE) deposits occur where sulphide-silicate immiscibility has occurred in high temperature mafic magmas The sulphide solubility of the silicate magma is dependent upon magma composition, temperature, oxygen fugacity, and sulphur fugacity. Because of their density, immiscible sulphide magmas settle through the silicate host magma and tend to accumulate at the base of the still partially liquid silicate magma. Where economic, the sulphide-rich accumulations are known as "magmatic sulphide ores". To account for the Ni-Cu-PGE ores of the Sudbury area, it has been suggested that assimilation and possibly magma mixing of $\mathrm{SiO}_{2}$-rich crustal material with an initial mafic magma lowered the sulphur solubility of the mafic magma to initiate the formation of magmatic ores (Irvine, 1975). Cu-rich footwall ore genesis has traditionally been ascribed to the fractionation of $\mathrm{Ni}$-bearing $\mathrm{Fe}$ monosulphide crystals in the contact ores, and segregation and subsequent migration of a $\mathrm{Cu}$-rich residuum into the footwall (Hoffman et al., 1979; Naldrett et al., 1982; Li et al., 1992; Li and Naldrett, 1993b).

The dominantly magmatic origin for the sublayer-hosted Ni-Cu-PGE deposits of the Sudbury Structure is well established (Hawley, 1962; Naldrett and Kullerud, 1967; Naldrett, 1979; Hoffman et al., 1979; Naldrett et al., 1982; Naldrett, 1984; Naldrett et al., 1986). However, the nature of the footwall rocks 
and their possible influence on $\mathrm{Cu}, \mathrm{Ni}$ and platinum-group element deposition in the North Range of the Sudbury Structure has been speculated about for some time (Coats and Snajdr, 1984). In addition, alteration associated with this mineralization has traditionally been ignored or declared insignificant with respect to the genesis of the orebodies. The spatial relationships of ore deposition, alteration assemblages and lithological variation exist on two scales and are convincing evidence for fluid activity in metal deposition. Large scale, broad alteration zones are related to areas of Sudbury Breccia and Cu-rich mineralization (i.e., Barnet property). On a smaller scale, Cu-rich veins, stringers and disseminations are commonly rimmed by alteration selvages that may include epidote, amphibole, chlorite, quartz, albite and calcite. The geochemistry of the alteration mineral assemblages provides information on the nature of the fluids that were responsible for precipitation of the vein minerals as well as the alteration minerals.

The purposes of this thesis were to 1) map and identify the nature of part of the Archean footwall rocks (gneissic or layered complex) along the contact of the Sudbury Igneous Complex in order to determine the possible influence of footwall rocks on $\mathrm{Cu}-\mathrm{Ni}$-PGE deposition, 2) determine the existence of a hydrothermal system that may have had an effect on footwall Cu-Ni-PGE deposition, 3) document the various styles of alteration and associated Cu-rich veining and Footwall Breccia mineralization with emphasis on mineral identification, textural relationships and mineral chemistry, 4) characterize the 
fluid associated with modifying and concentrating this mineralization with the use of fluid inclusion and isotopic $\left(\delta^{18} \mathrm{O}\right.$ and $\delta \mathrm{D}$, and to a lesser extent $\mathrm{Rb} / \mathrm{Sr}$ and $\mathrm{Sm} / \mathrm{Nd}$ ) studies, 5) geochemical study to determine metal distribution in the Footwall Breccia-hosted Fraser "Epidote Zone", 6) integrate and compare data from all study locations and propose new models to deal with the complexities of Sudbury ore genesis, including the relationships among brecciation, intrusion, and remobilization and precipitation of metals by fluids.

\section{1-2. LOCATION AND ACCESS}

Surface field studies were carried out in Levack and Morgan townships, located on the North Range of the Sudbury Structure, approximately $35 \mathrm{~km}$ northwest of the city of Sudbury, Ontario (Figure 1-1). Access to Fraser and Strathcona mines, Pike Lake, Longvack and Barnet properties, the Inco Wedge, and the western part of the Morgan West property from Sudbury is via Highway 144 northwest to the Onaping turn-off, $2 \mathrm{~km}$ northeast along Highway 544, and a further $10 \mathrm{~km}$ northeast along a Falconbridge Ltd. mine road. Access to the properties was facilitated by truck on drill and maintenance roads, and by foot on cut lines where available.

Access to most of the rest of the Morgan West property from Sudbury is via Highway 144 to Chelmsford, then north to the partially maintained, gravelbased, Nickel Offset road. An old logging road leading west is intersected approximately $8 \mathrm{~km}$ north on the Nickel Offset road. This road can only be travelled by 4 -wheel drive vehicle. Island Creek, located on the eastern part of 
the property is $3.2 \mathrm{~km}$ east of the Nickel Offset road. There are no roads on the Morgan West property due to the rugged topography of the area. Access on the property was by helicopter and by walking cut lines.

\section{1-3. METHODS OF STUDY}

Surface mapping during the 1989 and 1990 field seasons was completed while in the employ of Falconbridge Ltd. (Exploration) and was complemented by numerous underground sampling and mapping trips to the Strathcona, Fraser and $\mathrm{McC}$ reedy West mines. Property mapping was facilitated by using enlarged 1:2500 scale Ontario Ministry of Natural Resources air photos and north-south grids cut on $100 \mathrm{~m}$ line spacing with pickets at $25 \mathrm{~m}$ intervals. The Longvack property and Inco Wedge area lacked cut lines but mapping control was possible due to the existence of numerous maintenance and drill roads, small ponds and abundant large outcrops in the area. Detailed outcrop-scale maps are located on three 1:2500-scale base maps (Figs. 1-2, 3 and 4).

To facilitate detailed 1:100 scale mapping of the Barnet Trench Extension a grid of $5 \mathrm{~m}$ squares was measured off L100E on the Barnet property where it intersected the trench extension (Appendix I; Fig. 1-1). Remapping of the old Barnet trenches (\#1 to \#5) was completed using the pre-existing maps of P.A. Tirschmann of Falconbridge Ltd. (Figure II-1).

Level plan maps of the Strathcona Deep Copper Zone are modified from those provided by Falconbridge Ltd. (Figs. II-2a, b and c). Sample locations have been transferred to these maps. 
Detailed sampling and logging of the Fraser Mine "Epidote Zone" was completed using 4 diamond drill cores provided by Falconbridge Ltd. (Figs. II-3a, b, c and d). Falconbridge Ltd. supplied 15 other drill core logs from which additional lithological and geochemical data have been synthesized (Appendix II). Detailed mapping was carried out in 46-190 and 48-571 Exploration Drifts (Figure 1-5).

Mineral chemical analyses were carried out at the BRGM-CNRS microprobe facility in Orleans, France, and at the Carleton University microprobe and scanning electron microscope (SEM) facility.

Metal geochemical analytical data from surface and diamond drill core samples for the mapped properties and the Fraser Epidote Zone were supplied by Falconbridge Limited Exploration. Detailed metal geochemical analyses from the Epidote Zone were performed by X-Ray Assay Laboratories of Don Mills, Ontario.

Conventional fluid inclusion microthermometric measurements were made using the Modified U.S.G.S. freezing/heating stage at Carleton University. Scanning electron microscope studies of daughter and accidental minerals were completed using the Carleton University JEOL 6400 SEM.

For mineral chemical, geochemical and fluid inclusion daughter mineral studies, comparisons were made with analytical results from Strathcona's Copper Zone and McCreedy West Cu-stringers. 
Stable isotope analyses were completed by A.-M. Fouillac of the BRGM, Orleans, France.

\section{1-4. PREVIOUS WORK}

The redistribution of metals including $\mathrm{Cu}, \mathrm{Ni}$ and $\mathrm{PGE}$ by hydrothermal processes in a variety of other mafic- and ultramafic-associated ore deposits has been well documented. Hydrous alteration (Schiffries and Skinner, 1987; Ballhaus et al., 1988), pegmatite development (Schiffries, 1982; Ballhaus, 1988), halogen (Boudreau et al., 1986; Boudreau and Kruger, 1990) and PGE (Harney et al., 1990) content variation, stable isotope (Dunn, 1986) and fluid inclusion (Ballhaus and Stumpfl, 1986; Boudreau and McCallum, 1986) evidence has been recently documented to support the existence of a hydrothermal component for mafic layered intrusions such as the Bushveld and Stillwater intrusions. These studies are contrary to traditional models linking their metallic mineral deposits to purely magmatic liquation processes.

Fluid inclusion studies from a variety of $\mathrm{Cu}, \mathrm{Ni}$ and PGE deposits have shown that $\mathrm{Cl}$-rich fluids are often associated with the concentration of these orebodies (Ballhaus and Stumpfl, 1986; Boudreau and McCallum, 1986; Johan and Watkinson, 1987; Nyman et al., 1990; Watkinson, 1990; Watkinson and Ohnenstetter, 1991; Tellier et al., 1991). These findings are supported by recent experimental and theoretical work that has shown that significantly high PGE concentrations may be transported as chloride complexes (Mountain and Wood, 
1988a; 1988b; McKibben et al., 1990; Sassini and Shock, 1990; Hsu et al., 1991 Stumpfl, 1992).

The association of Ni-Cu-PGE mineralization and a variety of alteration types has been recognized in the Sudbury district since early this century (Wandke and Hoffman, 1924; Lausen, 1930; Lochhead, 1955). More recently, the controversy concerning the relationship between magmatic and hydrothermal contributions to the origin of the footwall mineralization has heightened (Fleet, 1977; 1979; Abel et al., 1979; Abel, 1981; Farrow and Watkinson, 1992; Farrow et al., 1992a; 1992b; 1992c; 1994; Li and Naldrett, 1992; 1993d; Li et al., 1992; Watkinson et al., 1993).

Numerous studies have, however briefly, illustrated the ubiquitous, variably developed alteration that is spatially associated with $\mathrm{Ni}-\mathrm{Cu}-\mathrm{PGE}$ deposits throughout the Onaping-Levack-Morgan area. Diamond drilling and detailed observation of underground and surface exposures have provided supporting evidence for the important effect aqueous fluids have had in modifying and concentrating ore in the area (Barnett and Tirschmann, 1989; Foy, 1989; Tirschmann, 1989; Farrow and Sweeney, 1990; Sweeney and Farrow, 1990; Sweeney et al., 1990; Farrow and Watkinson, 1992; Twilley, 1993).

Most of the footwall deposits of the North Range of the Sudbury Structure (Barnet, Strathcona Mine Copper and Deep Copper zones, and the veins of the McCreedy West and East deposits) are Cu-rich and PGE-bearing. Typically Cu- 
$\mathrm{Ni}-\mathrm{PGE}$ deposits that have formed as a result of hydrothermal concentration or modification of previously existing magmatic deposits consist of $\mathrm{Cu}$ and PGE rich assemblages such as at the Salt Chuck deposit, Alaska (Watkinson, 1990; Watkinson et al., 1991; Watkinson and Melling, 1992), Rathbun Lake deposit (Rowell and Edgar, 1986), New Rambler deposit, Wyoming (McCallum et al., 1976; Nyman et al., 1990), Two Duck Lake intrusion, Coldwell Complex (Watkinson et al., 1983; 1986; Dahl et al., 1986; Watkinson and Dahl, 1988, Good and Crocket, 1989; Mulja and Mitchell, 1989; Ohnenstetter et al., 1992), and Lac-des-Iles (Watkinson and Dunning, 1979; Macdonald, 1988; Tellier et al., 1991). The Fraser Epidote Zone orebody is unique in that it is composed of a Ni-rich, $\mathrm{Cu}$-poor sulphide assemblage, dominated by pentlandite and pyrite. Township-scale surface mapping of the Onaping-Levack-Morgan Township area of the North Range was completed by Langford (1960), Muir (1983), and Lafleur and Dressler (1985). A summary of North Range footwall mapping was provided by Dressler (1984b; 1984c). Most published reports have dealt with specific aspects of host-rock lithology with respect to economic $\mathrm{Ni}-\mathrm{Cu}$ PGE deposits in the area (Naldrett and Kullerud, 1967; Cowan, 1968; Abel et al., 1979; Patterson, 1979; Abel, 1981; Coats and Snajdr, 1984; Naldrett, 1984; Naldrett et al., 1984; Morrison et al., 1992). Some INCO Ltd. and Falconbridge Ltd. geologists (Cluff, 1969; Lee, 1987; Barnett and Tirschmann, 1989; Foy, 1989; Tirschmann, 1989; Bleeker, 1992) have studied more detailed aspects of North Range geology. 
Metal geochemical studies of footwall Cu-Ni-PGE deposits have focused on established mines and have assumed that the ore-forming processes have been magmatic-dominated and driven by sulphide magma fractionation (Naldrett and Kullerud, 1967; Keays and Crocket, 1970; Chyi and Crocket, 1976; Hoffman et al., 1979; Naldrett et al., 1982; Kostopoulos, 1984; Li and Naldrett, 1989; 1990; 1992; 1993a; 1993b; 1993c; Li et al., 1992; Naldrett and Pesseran, 1992; Naldrett et al., 1992).

No stable isotope investigations have been previously reported for the North Range of the Sudbury Structure. Whole-rock radiogenic Rb-Sr and SmNd studies have been completed by Naldrett et al., 1985; Deutsch et al., 1989 and Faggart et al., 1985. None has illustrated the isotopic characteristics of alteration minerals associated with $\mathrm{Ni}-\mathrm{Cu}-\mathrm{PGE}$ mineralization. The first publication dealing with fluid inclusions associated with $\mathrm{Cu}$-rich mineralization in the North Range was produced as a result of this study (Farrow and Watkinson, 1992). A recent investigation by Li and Naldrett (1993d) supported the fluid characteristics described by Farrow and Watkinson (1992).

\section{1-5. NOMENCLATURE}

During the 1989 field season, the Morgan property was mapped under the assumption that this part of the footwall complex was part of an Archean igneous, cumulus-textured, layered complex as suggested by Coats and Snajdr (1984). As a result, individual units were mapped as felsic (LCF), intermediate (LCI) and mafic (LCM) components of an original layered complex. Mapping 
completed during the 1989 field season indicated that the footwall rocks to the Sudbury Igneous Complex in Morgan and Levack Townships, commonly referred to as the Levack Gneiss Complex, are indeed part of an Archean granulite-grade gneiss/migmatite complex. Subsequent mapping (1990 field season and later) was completed using appropriate metamorphic nomenclature. The identification of gneiss, metatexite and diatexite (Brown, 1973) was made according to the following amounts of leucosome (Mehnert, 1968) present:

$$
\begin{aligned}
& <10 \%=\text { gneiss } \\
& 10 \text { to } 50 \%=\text { metatexite } \\
& >50 \text { to } 100 \%=\text { diatexite }
\end{aligned}
$$

Original mapping was corrected to this format using existing notes and descriptions (Appendix III) or was remapped (i.e., Barnet trenches II-1). The term "agmatite" for migmatitic breccias in the North Range footwall has been used by Langford (1960), Cowan (1968) and Greenman (1970) but is not used here.

The subdivision of different gneisses is based on the following proportion of felsic bands $(\mathrm{Cl}>65)$ in the rock:

felsic gneiss $=>65 \%$ intermediate gneiss $=35$ to $65 \%$ mafic gneiss $=<35 \%$. 
Sudbury Breccia outcrops are identified where Sudbury Breccia matrix accounts for $\geq 10 \%$ of the total rock volume. Otherwise, the proportion of Sudbury Breccia was estimated (in percentage) and is listed on the map.

The leucocratic contact breccia unit only found in the North and East Ranges of the Sudbury Structure is commonly referred to as "Late Granite" or "Granite" breccia by industry geologists. Neither term is adequate in that although the matrix is quartzo-feldspathic, it is not granitic. "Footwall Breccia" is the currently accepted term for this unit (Pye et al., 1984), and will be used throughout the text of this thesis although it is not considered to be an adequate term in light of the fact that many types of footwall breccia exist in this part of the footwall, including migmatitic breccias and Sudbury Breccia. The unique quality of its geology and ore deposits has resulted in terminology specific to the Sudbury area. These are summarized in a glossary of terms specific to Sudbury geology in Table 1-1.

Figure 1-6 is a map of the Sudbury Structure with locations of North and South range mines and deposits included in this investigation. 
Table 1-1. Glossary of terms specific to Sudbury geology.

\begin{tabular}{|c|c|c|}
\hline TERM & ACRONYM & DESCRIPTION \\
\hline Footwall Breccia & LGBX & $\begin{array}{l}\text {-igneous (?) breccia with a felsic, quartzo-feldspathic matrix } \\
\text { containing a variety of clast lithologies. } \\
\text {-major basal contact unit of the SIC in the North \& East } \\
\text { ranges. } \\
\text {-hosts much of the ore in the North \& East ranges. } \\
\text {-also known as Late Granite Breccia, \& Granite Breccia. }\end{array}$ \\
\hline $\begin{array}{l}\text { Levack Gneiss } \\
\text { Complex }\end{array}$ & & $\begin{array}{l}\text {-gneisses and migmatites of the Southern Province in the } \\
\text { North Range of the Sudbury Structure. }\end{array}$ \\
\hline $\begin{array}{l}\text { Main Mass of the } \\
\text { Sudbury Igneous } \\
\text { Complex }\end{array}$ & & -noritic, quartz gabbroic \& granophyric phases of the SIC. \\
\hline North Range & & $\begin{array}{l}\text {-the hilly terrain representative of the northern SIC, } \\
\text { associated footwall gneisses \& migmatites, \& lower } \\
\text { members of the Onaping Formation. }\end{array}$ \\
\hline Sublayer & SLBX & $\begin{array}{l}\text {-igneous breccia with a noritic to quartz dioritic matrix \& } \\
\text { mafic \& ultramafic clasts located at the base of the norite of } \\
\text { the Main Mass of the SIC. } \\
\text {-hosts much of the ore on the South Range, and some in } \\
\text { the North and East ranges. } \\
\text {-also known as Dark Norite Breccia (DNBX) in the North } \\
\text { Range. }\end{array}$ \\
\hline Sudbury Breccia & SDBX & $\begin{array}{l}\text {-pseudotachylite-like breccia composed of a matrix of } \\
\text { comminuted footwall rock and clasts of both footwall and } \\
\text { exotic rock lithologies. } \\
\text {-SDBX is sometimes referred to as Levack Breccia (LVBX) } \\
\text { in the North Range. }\end{array}$ \\
\hline Sudbury Event & & $\begin{array}{l}\text {-the catastrophic event (either impact or endogenic, or } \\
\text { combination of the two) that caused the development of } \\
\text { SDBX, the intrusion of the SIC, and the development of } \\
\text { associated orebodies. }\end{array}$ \\
\hline $\begin{array}{l}\text { Sudbury lgneous } \\
\text { Complex }\end{array}$ & SIC & $\begin{array}{l}\text {-oval-shaped in plan view. } \\
\text {-composed from base to top of norite, quartz gabbro \& } \\
\text { granophyre. } \\
\text {-age }=1.85 \mathrm{Ga} \text {. } \\
\text {-ore-bearing sublayer is at base of norite. }\end{array}$ \\
\hline Sudbury Structure & & $\begin{array}{l}\text {-physical elements or features (including lithologic, } \\
\text { structural and geographic) specific to the development and } \\
\text { evolution of the SDBX, SIC, Whitewater Formation, and } \\
\text { associated orebodies. }\end{array}$ \\
\hline Whitewater Group & & $\begin{array}{l}\text {-consists of the breccias of the Onaping Formation at the } \\
\text { upper SIC contact, Onwatin Formation shales \& } \\
\text { Chelmsford Formation turbidites. }\end{array}$ \\
\hline
\end{tabular}



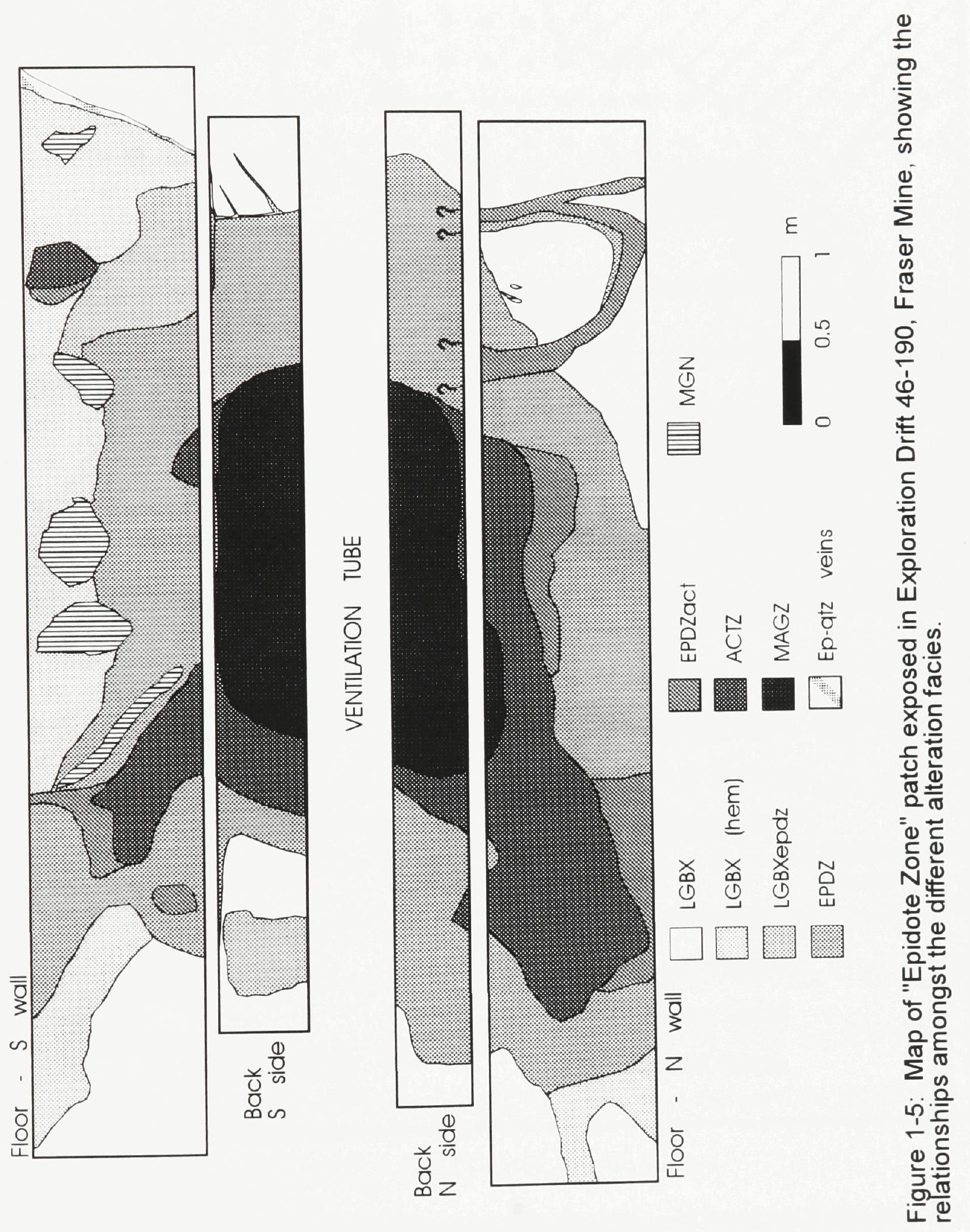


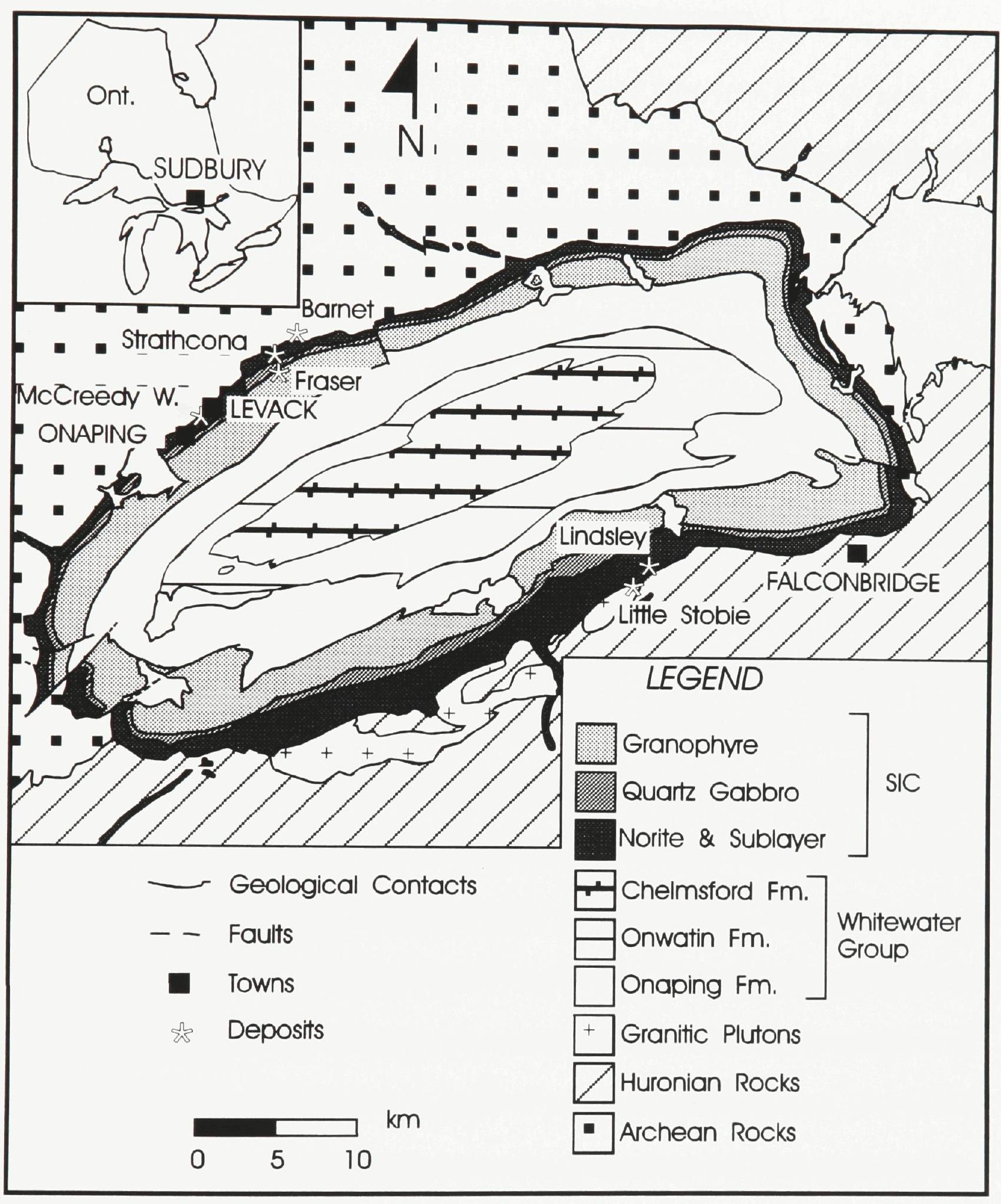

Figure 1-6. Map of the Sudbury Structure with locations of North and South range mines and deposits included in this investigation. 


\section{CHAPTER 2: FIELD RELATIONSHIPS}

\section{2-1. INTRODUCTION}

Most of the published information that exists on the geology of the North Range exists as Ontario Geological Survey reports and township maps (Langford, 1960; Muir, 1983; Lafleur and Dressler, 1985). The mapping described in this chapter is an attempt to more clearly identify these Sudbury Igneous Complex footwall rocks, and to determine the relationships between possible lithologic and structural controls on the location of $\mathrm{Cu}-\mathrm{Ni}$-PGE mineralization.

\section{2-2. REGIONAL GEOLOGY}

The Sudbury district of central Ontario has a century-long mining history. The Sudbury Structure is characterized by the roughly oval-shaped surface expression of the $1849 \mathrm{Ma}$ (Krogh et al., 1984) Sudbury Igneous Complex (SIC), a layered igneous complex consisting of basal Lower Zone norites, transitional Middle Zone quartz gabbro and Upper Zone granophyre (Fig. 1-1). The complex was intruded along the contact between the Archean Superior Province gneisses and migmatites in the north, and the Southern province Huronian Supergroup to the south. The Grenville Front is located $17 \mathrm{~km}$ south of this contact. The strata above the SIC consist of the Whitewater Group breccias and sedimentary rocks, including the Onaping, Onwatin and Chelmsford formations.

Krogh et al. (1984) determined a metamorphic age of $2711 \pm 7 \mathrm{Ma}$ for the footwall rocks of Levack Township. These rocks consist of a variety of mafic to 
felsic gneisses and migmatites including units of anorthosite, gabbro, norite, diorite, quartz diorite and granodiorite. Felsic rocks and most leucosomes are tonalitic in composition. Possible layered ultramafic units have been identified in the Fraser and North mines (Coats and Snajdr, 1984; Snajdr, pers. comm., 1990). Roughly north-trending equigranular to glomeroporphyritic pre-SIC diabase dykes both crosscut and occur as disrupted trains in the footwall rocks. The glomeroporphyritic dykes are similar in appearance to Matachewan Diabase.

The contact metamorphic aureole developed in footwall units from the intrusion of the SIC is subdivided into 3 zones of decreasing metamorphic grade outward from the SIC/footwall contact. These include a pyroxene hornfels zone (up to $250 \mathrm{~m}$ wide), a hornblende hornfels zone and an albite-epidote hornfels zone (Coats and Snajdr, 1984; Dressler, 1984b).

Sudbury Breccia (referred to as Levack Breccia in the Onaping-Levack area) is slightly older than the Igneous Complex and is likely related to the formation of the Sudbury Structure itself, whether or not its origins are impactrelated or volcanogenic. It strongly resembles and is considered to be very similar to the pseudotachylites described by Shand (1916) from the type location of the Vredefort Structure in South Africa (Dressler et al., 1991; 1992). It consists of footwall rock fragments in a grey to black, fine-grained to aphanitic matrix of comminuted footwall rock that forms irregular dykes, stringers and masses within the host footwall units (Speers, 1957; Dressler, 1984). The 
similarity of the chemical composition of wall rocks and "matrix" supports this "in situ" origin for the Sudbury Breccia, although there is evidence for the addition and subtraction of some elements (Dupuis et al., 1982). Some Sudbury Breccias display more than one episode of brecciation (Dressler, 1984b; Peredery and Morrison, 1984). Other investigations on the nature and origin of the Sudbury Breccia include studies by Fairbairn and Robson (1942; 1943), Yates (1948), Everitt (1974), Dupuis (1979), Brockmeyer (1986) and Muller-Mohr (1988).

The contact of the SIC is characterized by breccias that have been emplaced along its basal margin. The mafic Sublayer forms discontinuous lenses and sheets (Pattison, 1979; Dressler, 1984a; 1984b) along the contact between the Lower Zone norites and the footwall units. The more leucocratic Footwall Breccia (also referred to as "Late Granite Breccia, Leucocratic Breccia or Granite Breccia": Langford, 1960; Souch et al., 1969; Greenman, 1970; Coats and Snajdr, 1984) forms an irregular, discontinuous zone between the base of the complex (either Sublayer or the Lower Zone norites) and is only found along its northern and eastern contacts, and in some radial offset dykes (Foy, Whistle) The breccia contains fragments of mafic footwall rocks as well as rare sulphide clasts in a fine- to medium- grained, grey, quartzo-feldspathic matrix. Most of the orebodies in the North and East Ranges are located within these contact breccias, or in quartz dioritic radial offset dykes that extend from the base of the SIC into footwall rocks. Despite the economic importance of the Footwall 
Breccia, its relative age and origin have been matters of great debate. It has been interpreted as being locally recrystallized and metasomatic (Cowan, 1968), metamorphic (Greenman, 1970; Pattison, 1979), igneous (Pattison, 1979) and remobilized footwall rocks (Coats and Snajdr, 1984). Pattison (1979) included the Footwall Breccia in the Sublayer, whereas Peredery (1972) and Dressler (1984a; 1984b) have attributed its origin to impact-related melting processes.

The youngest units are post-SIC, east-trending, quartz diabase dykes and northwest-trending olivine diabase dykes that are part of the Sudbury dyke swarm. The olivine diabase dykes cross-cut the older quartz diabase dykes (Coats and Snajdr, 1984).

Further details of the regional geology of the Sudbury region are discussed in the Ontario Geological Survey Special Volume 1, The Geology and Ore Deposits of the Sudbury Structure (Pye et al., 1984).

Significant differences exist between the geology of the South Range of the SIC and that of the North and East Ranges. These include variations in the units within the SIC and the lack of Footwall Breccia along the SIC contact in the South Range.

\section{2-2a. ORIGIN OF THE SUDBURY STRUCTURE}

The origin of the Sudbury Structure has been the topic of controversy since the early 1960's, when it was first proposed that it was the result of a huge meteorite impact (Dietz, 1964). Since then many comparisons have been made between the Sudbury Structure and the Ries impact crater in Germany (Dressler, 
1984b). A current and concise comparison of factors supporting an impact or endogenic origin of the Sudbury Structure is provided in Ontario Geological Survey Guidebook 8, Geology and Mineral Deposits of the Sudbury Structure (Dressler et al., 1992).

It is beyond the scope of this thesis to evaluate all the evidence for or against an impact origin of the Sudbury Structure. For the purposes of this argument it is sufficient to understand that a period of great crustal instability existed, due to impact-related processes, endogenic processes, or both, at the time of its formation and the development of its ore deposits. The event that caused the formation of the Sudbury Structure will be referred to as the Sudbury Event in this thesis.

\section{2-3. DETAILED GEOLOGY OF CONTACT UNITS OF LEVACK AND MORGAN}

\section{TOWNSHIPS}

The Onaping-Levack area is part of an intensely mineralized part of the SIC contact that is approximately $10 \mathrm{~km}$ long (Figure 2-1). The major lithologic units encountered in the area are shown in chronologic order in Table 2-1. The time of emplacement of the Sublayer and Footwall Breccia, in addition to their genetic relationship are points of contention to be further discussed later in this chapter. Figure 2-2 is a compilation of the mapped rocks of this study. The peak metamorphism in the footwall gneisses and migmatites was granulite grade. However, relict granulite mineralogy has been retrograded during a period of metamorphism associated with the development of a contact 
metamorphic aureole enveloping the SIC (James et al., 1991). The outward limit of contact thermal metamorphism is variable and not well-defined. However, in support of the investigation of Coats and Snajdr (1984) evidence for thermal metamorphism/recrystallization is intermittent beyond $1 \mathrm{~km}$ from the SIC contact. Coats and Snajdr (1984) defined the following limits for hornfels development:

a) 0 to $250 \mathrm{~m}$ from SIC contact = pyroxene hornfels,

b) 250 to $600 \mathrm{~m}=$ hornblende hornfels,

c) 600 to $1000 \mathrm{~m}=$ albite + epidote hornfels.

\section{2-3a. FOOTWALL UNITS}

\section{i. Gneiss}

Throughout the southeastern Pike Lake, Longvack and Barnet properties gneisses occur as large, scattered inclusions in tonalitic diatexite. On the Morgan Property to the east, gneissic and metatexitic rocks are the dominant lithologies.

The gneisses are well-banded, with thicknesses ranging from a few millimetres to $1 \mathrm{~m}$. Gneissosity is defined by grain size or mineralogical variation. Contacts between bands may be gradational over a distance of several centimetres, but characteristically are $<1 \mathrm{~cm}$. Individual bands range in width from several millimetres to $>1 \mathrm{~m}$, but most commonly are approximately 10 $\mathrm{cm}$ wide (Plate 2-1a). They consist of granoblastic intergrowths of orthopyroxene, clinopyroxene, amphibole (hornblende), biotite, plagioclase and quartz, with minor chlorite and apatite, indicative of granulite grade 
metamorphism. Garnet-bearing rocks occur locally. Retrograde amphibole (actinolite) may be poikiloblastic and symplectic intergrowths of opaque minerals occur within orthopyroxene. Where biotite occurs it defines a foliation fabric and may be pseudomorphous after amphibole (hornblende) that is in equilibrium with pyroxene. The retrograde replacement of orthopyroxene by amphibole (actinolite) and talc is common.

The presence of concordant tonalitic veins is ubiquitous in gneissic rocks. Later generation discordant and concordant granitic and pegmatitic veins also occur.

\section{Felsic Gneiss (FGN)}

Overall compositions of felsic gneiss are tonalitic, with dominantly granoblastic quartzo-feldspathic (tonalitic to granitic) leucosomes further defined by quartz ribbons and more mafic bands of fine-grained, hornfelsed plagioclase, orthopyroxene and clinopyroxene (now dominantly amphibole) with minor biotite. Retrograde metamorphic reactions similar to those affecting pyroxenes in the diatexite have occurred in the felsic gneiss. This has resulted in the replacement of orthopyroxene by talc, and of clinopyroxene by chlorite, actinolite, biotite and Fe-Ti-oxides. Garnet is rare, but where it does exist, it is as large ( $3 \mathrm{~mm}$ to $1 \mathrm{~cm}$ in diameter), fractured grains. Trace amounts of finegrained, euhedral magnetite or pyrite occur. Felsic gneiss samples may or may not be strongly hornfelsic depending on distance from the SIC contact. Fine- to 
medium-grained intermediate to mafic bands range in thickness from several millimetres to $>75 \mathrm{~cm}$.

\section{Intermediate Gneiss (GN)}

Intermediate gneiss grading into metatexite is the most common lithology in the west-central (from the Barnet property to L23E) part of the Morgan property. The felsic and mafic segregations exhibit considerable variation in grain size and composition. Band widths range from $3 \mathrm{~mm}$ to $1 \mathrm{~m}$, although widths between 5 to $10 \mathrm{~cm}$ are the most common.

Mafic bands are fine- to medium-grained, foliated to massive and equigranular, and are composed of approximately $40 \%$ granoblastic plagioclase (variably saussuritized), 5 to $30 \%$ recrystallized and partly altered orthopyroxene and clinopyroxene (commonly replaced by amphibole and biotite), trace to $60 \%$ hornblende (displaying local replacement by biotite), and trace to $10 \%$ inequigranular quartz (Sweeny and Farrow, 1990). Trace minerals include apatite and magnetite. Common alteration minerals are chlorite, epidote and talc. Locally myrmekitic intergrowths of quartz and feldspar were observed (Sweeny and Farrow, 1990).

Felsic bands are fine- to medium-grained, and are composed of $60 \%$ granoblastic plagioclase, 10 to $35 \%$ quartz, up to $15 \%$ orthopyroxene (local replacement by talc) and 10\% clinopyroxene, 10\% amphibole (after pyroxene). $5 \%$ biotite and $1 \%$ apatite (Sweeny and Farrow, 1990), but may locally be devoid of mafic minerals. 


\section{Mafic Gneiss (MGN)}

Mafic gneiss is rare in the study area, although it is more common to the northeast. It occurs as alternating bands of fine-grained, granoblastic gabbroic rocks and $3 \mathrm{~mm}$ to $50 \mathrm{~cm}$ wide bands of pyroxenite/amphibolite. Original pyroxenes have been replaced by amphibole, chlorite and biotite. Sulphides include streaks of $1 \%$ to $3 \%$ disseminated pyrite.

\section{ii. Metatexite}

Metatexite occurs as blocks within diatexite and at the Footwall Breccia/footwall contact on the southeastern part of the Pike Lake property. Reinterpretation of original Morgan property mapping suggests that it also occurs at its western end, adjacent to the Barnet property, where the local footwall lithology changes from dominantly gneissic to diatexitic.

Metatexites are recognized by the fact that pre-migmatization fabrics are not disrupted. The tonalitic to granodioritic migmatite leucosome is commonly concordant to original gneissosity and occurs as veins and injections (from 1 to 5 $\mathrm{cm}$ wide); the gneissosity maintains its regional trend. Injected leucosome veins can be discontinuous ( $<1 \mathrm{~m}$ in length), continuous or contorted. Later, ptygmatically-folded granitic and pegmatitic veins are discordant.

Almost all footwall units appear as rafts within the metatexite. However, dioritic (DIOR), gabbroic (GAB), pyroxenitic (PXT) and diabasic (DIA) fragments tend to be boudinaged. Typical migmatitic features such as net-veining, and the occurrence of schollen and schlieren, are visible. 
iii. Diatexite

Diatexite is the dominant lithology on the Pike Lake and Longvack properties and comprises approximately $15 \%$ of the Barnet property. Zones of well-developed Sudbury Breccia (SDBX) cut the diatexite.

The composition of the dominant migmatite leucosome (Mehnert, 1968) has been established using the IUGS classification of igneous rocks (Streckeisen, 1976) as tonalite, with less common abundances of leucocratic quartz diorite/gabbro and granodiorite according to varying quartz and less commonly K-feldspar abundances. Quartz content may be as high as $45 \%$ and mafic mineral content from $<5 \%$ to $40 \%$ (amphibole, pyroxene) in leucocratic homogeneous diatexite. Granoblastic plagioclase can account for 25 to $65 \%$ of the rocks. Leucosomes are medium- to coarse-grained, and texturally may be massive, foliated or banded. Common alteration minerals include sericite and clay minerals after plagioclase, chlorite and amphibole after pyroxenes, and epidote. Contact metamorphism has resulted in the recrystallization of quartz and plagioclase close to the Sudbury Igneous Complex contact.

Advanced stages of partial melting result in the destruction of the original rock fabric and the domination of migmatitic leucosome. Common restite compositions include fine-grained diorite (rarely biotite-bearing), melanocratic gabbro (GAB), pyroxenite/amphibolite (PXT), diabase (DIA) and gneissic rocks, and are represented by blocks (up to $100 \mathrm{~m}$ in length) and rafts (schollen) or streaks (schlieren) within diatexite (Plate 2-1b). They may be lensoid with brittle 
terminations or intensely convoluted due to ductile deformation. Contacts with the migmatite leucosome range from sharp to relatively diffuse. Contacts between felsic gneiss (FGN) and leucosome tend to be gradational and difficult to discern. Where contacts between xenoliths and tonalitic leucosome are diffuse ( $>1 \mathrm{~cm}$ wide), there is evidence for magma mixing and volatile activity in the crystallization of large ( $>5 \mathrm{~mm}$ long) amphibole crystals. On the Pike Lake property these large amphiboles are commonly associated with quartz-rich pods. Incipient gneissosity is developed where schlieren and schollen have been elongated subparallel to foliation. Pyroxenes in these xenoliths are now masses of actinolite, chlorite, talc and epidote. Fabrics including foliation of mafic minerals and the development of elongate lenses of recrystallized quartz are the result of a later regional tectonic/metamorphic event, possibly late in the migmatite-forming event.

Matrix mafic minerals form a convoluted texture in diatexite adjacent to Footwall Breccia (LGBX) due to ductile deformation and recrystallization of the footwall host rocks during LGBX emplacement.

Disseminated to blebby pyrite and chalcopyrite mineralization within diatexite is relatively insignificant, except in the vicinity of mineralized Sudbury Breccia (Appendix I). The sulphides occur both in the leucosome and in mafic clasts. Where they do occur they are ubiquitously enveloped by a fine-grained epidote-rich selvage $<1 \mathrm{~mm}$ wide. Rare disseminated pyrrhotite and pyrite may occur along clast contacts or contacts with banded units. 


\section{Homogeneous Diatexite}

Tonalitic Diatexite (TON)

Outcrops of homogeneous tonalitic diatexite (TON) consist of white, beige or pink, migmatite leucosome with suspended mafic schollen and schlieren that account for $<10 \%$ of the rock. With higher percentages of restitic material this rock grades into inhomogeneous diatexite and metatexite.

In thin section tonalitic diatexite exhibits a well developed hornfelsic texture. Plagioclase composes 60 to $77 \%$ of the leucosome, and is recrystallized (average grain size $0.06 \mathrm{~mm}$ ) and variably altered to a mixture of clay minerals and sericite. Quartz forms larger aggregates (average $0.9 \mathrm{~mm}$ diameter) of polygonal grains exhibiting undulose extinction and composes 10 to $40 \%$ of the rock. K-feldspar, where present, is perthitic (Sweeny and Farrow, 1990). Accessory minerals are apatite and traces of zircon. Secondary minerals are chlorite (locally after biotite), epidote, biotite after hornblende and minor fibrous actinolite. Anhedral magnetite grains contain exsolved hematite lamellae and lenses. The mafic minerals are commonly completely replaced and relict clinopyroxene grains were rarely observed. Typical mafic mineral content ranges between 10 and $25 \%$. Secondary actinolite seldom occurs in excess of $15 \%$, whereas biotite is less common $(<5 \%)$ and is associated with amphibole. Trace amounts of apatite are ubiquitous and are distributed relatively evenly throughout the rock. 
Homogeneous diatexite can be massive to foliated with an incipient fabric developed where mafic schlieren and schollen have been elongated subparallel to foliation. More commonly schollen resemble elongate to irregularly-shaped rafts of fine-grained, equigranular diorite (DIOR). Less abundant xenolith lithologies include gabbro (GAB), pyroxenite (PXT) and diabase (DIA). Weakly defined foliation defined by elongate mafic mineral and quartz aggregates is commonly convoluted in the leucosome. In thin section, foliation may be defined by subparallel orientations of mafic mineral aggregates, now altered to actinolite, chlorite and epidote, and by quartz ribbons.

Patches of anorthosite (AN) locally $>1 \mathrm{~m}$ in diameter occur within TON and are characterized by a larger average grain size (3-9 $\mathrm{mm}$ in diameter) in hand specimen and paucity of quartz and mafic minerals (both $<5 \%$ of total rock volume). Plagioclase may be variable saussuritized. Contacts between diatexite and anorthositic segregations vary from diffuse to sharp.

\section{iv. Mafic and UItramafic Units}

Mafic and ultramafic units locally occur within diatexite and FGN, and may or may not be brecciated. Compositions include diorite, gabbro, norite, gneiss. pyroxenite, amphibolite and diabase. These rocks are metamorphic equivalents of mafic and ultramafic intrusive protoliths of similar composition. Original pyroxene-rich rocks are now largely amphibolites, with little relict clinopyroxene visible. Fine-grained, saussuritized plagioclase may form up to $15 \%$ of the pyroxenite/amphibolite. 
Sulphides are more concentrated in these mafic and ultramafic rocks than in more felsic footwall units. They occur as disseminated to blebby pyrrhotite and minor pyrite.

\section{Metadioritic and Gabbroic Rocks}

Blocks (locally $>30 \mathrm{~m}$ wide) of massive to brecciated (metatexite to inhomogeneous diatexite), fine-grained dioritic, gabbroic and noritic rocks (DIOR; DIOR/bx), occur throughout the study area. However, both varieties are concentrated at the contact between Footwall Breccia and footwall diatexites and gneisses.

These rocks are commonly equigranular, and massive to weakly foliated, the foliation defined by alignment of mafic minerals and/or narrow $(<1 \mathrm{~cm}$ wide) quartz and feldspar stringers. They are strongly to moderately magnetic and may contain small ( $<5 \mathrm{~mm}$ in diamter) clots of magnetite (Sweeny and Farrow, 1990). Where enveloped by diatexite or felsic gneiss, contacts are gradational with an increase in felsic component and brecciation, but are seldom more than $10 \mathrm{~m}$ wide.

The fine-grained dioritic/gabbroic/noritic rocks are composed of 30 to $50 \%$ granoblastic, saussuritized plagioclase, 40 to $60 \%$ mafic minerals (orthopyroxene, clinopyroxene, amphibole and biotite) and traces to $15 \%$ interstitial quartz and recrystallized quartz aggregates. In order of abundance, mafic minerals include actinolite (secondary), orthopyroxene, clinopyroxene and biotite. Accessory minerals are apatite, magnetite and pyrite. Magnetite is most 
commonly associated with amphibole-rich varieties and pyrite with biotite-rich rocks. Other alteration products are talc, chlorite, epidote and sericite. Clinopyroxene and orthopyroxene are partially replaced by amphibole and biotite (Sweeny and Farrow, 1990).

Metagabbroic bodies are most common along the northern boundary of the Morgan property and as inclusions in Sudbury Breccia in the Barnet trenches. They are composed of 20 to $45 \%$ saussuritized plagioclase, 0 to $30 \%$ clinopyroxene, 0 to $5 \%$ orthopyroxene, 45 to $55 \%$ amphibole and accessory apatite and magnetite.

The breccias are dismembered mafic and ultramafic bodies within felsic gneiss, metatexite and homogeneous diatexite, and are characterized by rounded to angular clasts of similar mafic composition (melanocratic diorite and gabbro, pyroxenite, amphibolite, mafic gneiss and diabase) in a net-textured, fine- to coarse-grained matrix of tonalitic, anorthositic and granitic leucosome. They are composed of between 10 and $40 \%$ leucosome. Adjacent to Footwall Breccia contacts, the leucosome may be locally replaced by Footwall Breccia matrix material. Clast size is relatively limited when compared with Footwall Breccia, Sudbury Breccia and more common types of diatexite, with variations between $1 \mathrm{~cm}$ and $5 \mathrm{~m}$. Clasts are less variable in size within individual occurrences, and are angular to sub-angular in shape. They may be rotated but commonly appear to have been brecciated "in situ". Sulphide mineralization in 
mafic breccias includes disseminated to blebby pyrite, and more rarely chalcopyrite within the mafic clasts and matrix.

The only significant sulphide mineralization within mafic breccia is at the Eclipse showing at L19+80E, $0+50$ S on the Morgan property. It is characterized by rounded to sub-angular mafic inclusions (80\%) less than $2 \mathrm{~m}$ in diameter, in a feldspathic matrix (20\%). The mafic inclusions contain 5 to $7 \%$ blebby to nettextured pyrrhotite, chalcopyrite and pentlandite. Chalcopyrite stringers up to 2 $\mathrm{cm}$ wide and $30 \mathrm{~cm}$ long occur in both the matrix and clasts. Original sulphide textures have been obliterated by recrystallization.

\section{Metapyroxenite/Amphibolite}

Isolated metapyroxenite/amphibolite units up to $75 \mathrm{~m}$ across in felsic gneiss and diatexite in the central part of the Morgan property. Host rock contacts are commonly sharp, but locally may be gradational and irregular. They are fine- to coarse-grained, massive to foliated, black and weakly magnetic. The rocks are composed of 3 to $20 \%$ granoblastic plagioclase (variably saussuritized), 0 to $25 \%$ poikiloblastic orthopyroxene with partial replacement by talc, amphibole and magnetite, 0 to $50 \%$ clinopyroxene with partial replacement by actinolite, 9 to $20 \%$ biotite and 25 to $75 \%$ hornblende (local replacement by biotite). Indiviual amphibole crystals may be as long as 1 $\mathrm{cm}$. Accessory euhedral apatite crystals may constitute a trace to $3 \%$ of the rock. Chlorite, pyrrhotite and pyrite also occur (Sweeny and Farrow, 1990). 
v. Granite

Later granitic to granodioritic stringers, veins $(<5 \mathrm{~cm}$ to $>1 \mathrm{~m}$ wide) and patches (20 $\mathrm{cm}$ to $2 \mathrm{~m}$ in diameter) are commonly found within metatexitic and diatexitic units. They both cross-cut and conform to previously developed rock fabrics. A large body (>100 m wide) occurs in the northwest corner of the Morgan property.

The granites characteristically lack mafic minerals ( $<20 \%$ amphibole and rarely pyroxene) and an obvious fabric, contain $>5 \% \mathrm{~K}$-feldspar and are pink to beige to grey. Large, fractured, white feldspar phenocrysts $(<3 \mathrm{~cm}$ long) are are dominantly plagioclase. Magnetite-rich blebs are common. Textural types are variable and include massive, medium- to coarse-grained, hypidiomorphic to allotriomorphic equigranular, porphyritic, granophyric, aplitic and pegmatitic. Field relationships suggest that they are the result of a later partial melting event than the quartzo-feldspathic leucosomes of metatexite and diatexite because they tend to cross-cut these features. They may be related to the intrusion of the large Cartier Batholith to the north.

\section{vi. Dykes}

Three types of disrupted remnants of mafic dykes occur throughout the Levack Gneiss Complex. The most abundant dykes are fine-grained to aphanitic, dark grey to black, and strongly magnetic. Widths of these finegrained to aphanitic dykes vary between $6 \mathrm{~cm}$ and $20 \mathrm{~m}$ although their sharp contacts can contain minor embayments of host rock up to $1 \mathrm{~cm}$ in length. 
Diabasic rocks ("pyroxene hornfels" in mine terminology) are fine- to mediumgrained, equigranular, black to dark green in colour, and exist as clasts within diatexite that are offset by brittle faults. They may be 5 to $25 \mathrm{~m}$ wide and are composed of granoblastic quartz ( 0 to $5 \%$ ), plagioclase (25 to $30 \%$ ), clinopyroxene (25 to $30 \%$ ), rare orthopyroxene, secondary amphibole after pyroxene and biotite. Up to $3 \%$ of the rock may be composed by apatite. Epidote and chlorite (from 5 to 30\%) are common (Farrow and Sweeny, 1990; Sweeny and Farrow, 1990). Locally, dykes cut host rock fabrics, and are identifiable over several tens of metres, although they are most common as fragments in Sudbury Breccia and rarely in Footwall Breccia. They are fine- to medium-grained, strongly magnetic, and exhibit remnant glomeroporphyritic ( $>5$ $\mathrm{mm}$ in diameter) texture, reminiscent of Matachewan-type dykes.

Disseminated pyrite and less abundant chalcopyrite occurs in disrupted diabase dykes throughout the study area. Given the limited extent of these dykes it is not likely that their sulphide mineralization is volumetrically important.

\section{vii. Banded Iron Formation}

Three outcrops of chert-magnetite iron formation were identified in felsic gneiss and metatexite on the Morgan property between L10E and L11E from $4+40 \mathrm{~N}$ to $5+00 \mathrm{~N}, 1.6 \mathrm{~km}$ north of the SIC contact. The finely laminated $(\mathrm{mm}$ to $\mathrm{cm}$ scale) iron formation is highly contorted and locally occurs as a trail of fragments in the metatexite. Host rocks in an area of approximately $20 \mathrm{~m}$ by 100 $\mathrm{m}$ surrounding the exposures are intensely silicified, and are characterized by 
abundant quartz ribbons and veins up to $25 \mathrm{~cm}$ wide that contain $<25 \%$ disseminated to semi-massive pyrite (Sweeny and Farrow, 1990).

Clinopyroxene-rich bands ( 0.7 to $1 \mathrm{~cm}$ wide) occur between quartz- and magnetite-rich bands; locally the clinopyroxene is replaced by patches of amphibole and chlorite. Rare plagioclase-rich bands up to $0.75 \mathrm{~cm}$ wide are strongly saussuritized.

The occurrence of banded iron formation in the North Range footwall is convincing evidence against the layered complex hypothesis (Sweeny and Farrow, 1990).

viii. Sudbury (or "Levack") Breccia (SDBX)

Sudbury Breccia (SDBX) occurs throughout the study area, commonly as isolated veins and as small (10 to $100 \mathrm{~m}$ in diameter) units that form elongate NE- to SW-trending zones oriented obliquely to the regional foliation and gneissosity on the east side of the Longvack fault. Sudbury Breccia bodies or dykes tend to follow pre-existing structural trends, rock fabrics or lithologic contacts (Plate 2-2a). These may have represented existing zones of weakness along which Sudbury Breccia zones were formed (Dressler, 1984b). These zones are identified by the rotation of clasts with respect to regional fabrics and the occurrence of more than $10 \%$ SDBX matrix in outcrop (Plate 2-2b).

Individual SDBX veins display variable widths between 1 and $50 \mathrm{~cm}$, boudinaged textures and abrupt terminations. Injection of SDBX dykes and veins commonly disrupts dominant host rock fabrics. 
The SDBX matrix is characteristically aphanitic and grey to dark grey on fresh surfaces. Sugary-textured, recrystallized varieties occur near contacts with Footwall Breccia and as clasts within Footwall Breccia. Chlorite-rich porphyroblasts, formed from contact metamorphism due to intrusion of the SIC, also dot the SDBX matrix adjacent to the Footwall Breccia contact. In the vicinity of sulphide veining, Sudbury Breccia matrix has recrystallized to biotite-rich masses. This has been observed at Barnet and in the McCreedy East Cu-rich stringers (G. Morrison, pers. comm., 1992), and may be related to a pre-ore metasomatic event (see below).

Clasts range in size from $<1 \mathrm{~mm}$ to many tens of metres. Those $<2 \mathrm{~m}$ in diameter are rotated and rounded. Clast compositions are dominated by tonalitic diatexite (TON) and felsic gneiss (FGN), although gneiss (GN), metatexite (MTX), mafic gneiss (MGN), anorthosite (AN), granite (GR), finegrained diorite (DIOR), melanocratic gabbro, diorite, pyroxenite (PXT), Matachewan diabase (MDIA) and diabase clasts also occur. Exotic fragments, including banded iron formation, quartzite and flow-banded rhyolite have been identified in a large mass of SDBX in the NE corner of the Morgan West property.

Locally, in dyke-like structures, Sudbury Breccia displays a "fluidal" texture typified by wispy, elongate felsic fragments $<2 \mathrm{~cm}$ in length (cataclastic flow structures of Dressler, 1984b; flow banded breccia of Peredery and Morrison, 1984). The elongate fragments tend to be oriented subparallel to 
large fragment (>30 cm in diameter) and SDBX vein boundaries. This texture and the otherwise rounded shape of small $(<10 \mathrm{~cm}$ in diameter) clasts suggest that transport and abrasion were important in the emplacement of these veins. Local swirled texture suggests turbulent flow.

Zones of Sudbury Breccia are the most common hosts of footwall Cu-rich vein deposits in the North Range (Appendix I).

ix. Metamorphic History

The age of $2711 \pm 7$ Ma reported by Krogh et al. (1984) corresponds to a granulite facies metamorphic event at $\mathrm{P}=600-800 \mathrm{MPa}$ for $\mathrm{T}=750-800{ }^{\circ} \mathrm{C}$, representative of mid-lower level crustal rocks (James et al., 1991). A late Archean retrograde event overprinted the granulite assemblages at $\mathrm{T}=500-550$ ${ }^{\circ} \mathrm{C}$ and $\mathrm{P}=200-300 \mathrm{MPa}$ (James et al., 1991). Biotite-garnet thermometry on granulite-facies orthopyroxene-garnet gneiss samples, collected as part of this study, within $1.8 \mathrm{kms}$ from the SIC contact yield temperatures of 800 to $950{ }^{\circ} \mathrm{C}$. James et al. (1991) have attributed this to conditions caused by the formation of the Sudbury Structure at $1.85 \mathrm{Ga}$. In addition, they noted that coarse subidioblastic garnet is variably replaced by symplectic orthopyroxene + cordierite + plagioclase + magnetite + hercynite intergrowths, and that similar symplectic intergrowths reported in the literature are considered to have formed at pressures as low as $400 \mathrm{MPa}$. 


\section{Shock-Metamorphic Features}

Planar features in quartz and kink bands in biotite are the two most common shock-metamorphic features encountered in footwall rocks of this study The occurrence of highly fractured garnet grains within the gneisses of the North Range are also considered evidence for impact-related shock-metamorphism (Dressler, 1984b).

\section{2-3b. CONTACT UNITS OF THE SUDBURY IGNEOUS COMPLEX}

\section{i. Contact Breccias}

\section{Footwall Breccia (LGBX)}

Footwall Breccia occurs in all mapped areas and locally attains thicknesses of $225 \mathrm{~m}$ in the vicinity of Strathcona Mine (Figs. 1-2 and 3). However, overall thickness varies between $<50 \mathrm{~m}$ and $225 \mathrm{~m}$. Although extremely undulose, contacts between Footwall Breccia and Felsic Norite of the SIC are sharp, whereas those with footwall units are more diffuse, with clasts of footwall rock occurring in the Footwall Breccia and pods of Footwall Breccia (up to several metres in diameter) occurring in diatexite close to the contact where the footwall rocks may be variably brecciated. With decreasing distance from the Footwall Breccia contact, footwall fabrics are increasingly disrupted and the rock is more strongly recrystallized.

Contacts between the Footwall Breccia and Sublayer may be gradational and difficult to discern, especially in the vicinity of economically mineralized areas. Obvious structural controls on these undulose contacts are not evident. 
The contact between Footwall Breccia and diatexite is locally marked by both large (some $>10 \mathrm{~m}$ in diameter) clasts of melanocratic diorite/gabbro or mafic gneiss. Thick (up to $100 \mathrm{~m}$ wide) occurrences of brecciated diorite, gabbro, pyroxenite and diabase along the Footwall Breccia contact are especially well developed on the Pike Lake property but have also been identified on the Longvack and Morgan properties. Local gradational contacts exist between Footwall Breccia and Sudbury Breccia. This relationship has been recognized by several workers (Coats and Snajdr, 1984; Dressler, 1984b; G. Morrison, pers. comm., 1992). Furthermore, it has been suggested that Sudbury Breccia development provided the ground preparation for later Footwall Breccia intrusion (G. Morrison, pers. comm., 1992). A diagrammatic representation of the relationships between Footwall Breccia and adjacent units is shown in Figure 24.

The identification of sharp contacts within the unit in underground exposures at Fraser and on surface reveal that the Footwall Breccia was emplaced as pulses of magmatic material that was intruded prior to the SIC (Table 2-2). Figure 2-4 and Plates 2-3a and b show the encroachment of clastfree mafic norite on previously emplaced phases of Footwall Breccia. The Footwall Breccia may be subdivided into many more phases than the "grey breccia" and "barren breccia" suggested by Greenman (1970). Cowan (1968) indicated that darker breccia cross-cuts the lighter-coloured, barren breccia. By 
comparison, the more mafic Sublayer has been recognized as containing 3 intrusive facies (Naldrett et al., 1984).

The Footwall Breccia matrix is characterized by a heterogeneous, white, grey or pink, aphanitic to fine-grained quartzo-feldspathic matrix. Small, stubby plagioclase laths are surrounded by poikilitic, optically continuous quartz that may compose up to $40 \%$ of the rock. Quartz has also replaced some of the matrix plagioclase. Plagioclase is variably saussuritized. Porphyroblasts of Kfeldspar also occur. Up to $20 \%$ of the matrix is composed of amphibole, biotite, chlorite and epidote. Relict clinopyroxene aggregates are rare.

The amount and types of clasts in Footwall Breccia are a reflection of the local footwall rocks. They include diatexite, gneiss, diorite, gabbro, pyroxenite, anorthosite, diabase, granite and Sudbury Breccia, and tend to show replacement of original pyroxene by amphibole, talc, chlorite and biotite. Mafic clasts are less common where the adjacent footwall rock is tonalitic diatexite with few xenoliths. Felsic and intermediate inclusions locally have diffuse contacts with Footwall Breccia matrix, suggestive of some partial melting, whereas mafic clasts rarely are enveloped by a selvage of felsic minerals (Plate 2-4a). Clast size typically ranges from several millimetres to $>10 \mathrm{~m}$.

Footwall Breccia rich in sulphides tends to be darker due to an increase in mafic clast content (mineralized "grey breccia" of Greenman, 1970). For example, relatively dark Footwall Breccia with an abundance of mafic clasts (dominantly pyroxenite, melanocratic gabbro, diabase, gneiss, diorite, quartz 
diorite and norite) and locally $<50 \%$ matrix extends north from the southern contact between Footwall Breccia and Felsic Norite to the Longvack open pits and west on the Longvack property.

Sulphide enrichment occurs in Footwall Breccia throughout the Morgan, Longvack and Pike Lake properties, but is concentrated in the vicinity of the Longvack pits and in Footwall Breccia at L19E and L17E on the Morgan property. Numerous trenches on INCO property $200 \mathrm{~m}$ to the northeast of the Longvack deposit host massive pyrrhotite and chalcopyrite. Within these trenches are occurrences of large (up to $5 \mathrm{~cm}$ long), poikilitic, optically continuous pyrrhotite crystals. Round $\mathrm{mm}$-sized magnetite grains are the dominant inclusion in the pyrrhotite. Sulphide mineralization in the Footwall Breccia, although less intense, is continuous between the INCO and Longvack locations. Blebs of pyrrhotite have selvages of chalcopyrite and later subhedral, recrystallized pyrite and are characterized by rims of dark alteration (Plate 2-4b). These are more common within Footwall Breccia matrix than in clasts. Locally the sulphide blebs appear to be much later than the Footwall Breccia matrix and envelop laths of altered plagioclase. Pentlandite rarely occurs as flames within the pyrrhotite and mm-sized magnetite grains are rounded and strongly resorbed. Stringers, blebs and disseminations of chalcopyrite up to $4 \mathrm{~cm}$ wide occur in the Footwall Breccia matrix, in epidotized intermediate to mafic clasts, and most commonly within semi-massive to massive pyrrhotite. Sulphides also exist along clast/matrix contacts. Where these occur, disseminated sulphides 
extend into the matrix. Rarely is chalcopyrite more abundant than pyrrhotite, but where it does occur it is close to the contact between the Footwall Breccia and the footwall. Pyrite also occurs as disseminations in both Footwall Breccia matrix and mafic clasts, but it is most commonly found as a later, recrystallized product of pre-existing sulphides. Chalcopyrite and pyrrhotite stringers and disseminations rarely extend from the Footwall Breccia/footwall contact into the footwall units. Disseminated to blebby pyrite tends to occur in Footwall Breccia surrounding brecciated mafic units, possibly due to having been derived from the incipiently mineralized mafic breccia. Chalcocite may form on the edges and along fractures of chalcopyrite blebs and disseminations.

\section{Sublayer Breccia (SLBX)}

The occurrence of contact Sublayer is limited to outcrops in the vicinity of Strathcona and Coleman mines, and at L5+00S, L32E on the Morgan property. Contacts between the Sublayer and Footwall Breccia are gradational and irregular. Contacts between the Sublayer and the felsic norite were not observed.

The Sublayer matrix is noritic to quartz noritic and contains a variety of mafic to ultramafic clast types. The matrix is composed of $40 \%$ fine- to mediumgrained, tabular plagioclase, 10 to $40 \%$ pyroxene (orthopyroxene > clinopyroxene) and minor biotite, quartz, magnetite and apatite (Sweeny and Farrow, 1990). Inclusions are commonly composed of recrystallized quartz, feldspar and hydrous mafic minerals (Sweeny and Farrow, 1990). Weak to 
moderate patchy alteration includes the breakdown of orthopyroxene to talc, biotite and magnetite. Other alteration minerals include sericite, chlorite and actinolite. Plagioclase is typically much fresher than the pyroxenes.

Blebby, disseminated, locally net-textured and semi-massive pyrrhotite, and less commonly chalcopyrite, are the dominant styles of sulphide mineralization in the Sublayer. Pentlandite occurs as flames and blebs within pyrrhotite. Magnetite is as rounded or irregularly-shaped grains with the pyrrhotite. Sulphides typically occur in the matrix, but may exist as part of the clast population as well. Pyrrhotite also occurs within talc-rich masses after orthopyroxene.

\section{ii. Felsic Norite (FNOR)}

Felsic norite of the SIC occurs in the southeast corner of the Longvack property and along the southeast margin of the Morgan property. Isolated outcrops of Footwall Breccia occur in felsic norite up to $100 \mathrm{~m}$ from the Footwall Breccia/felsic norite contact, evidence of the shallowly-dipping, undulose contact between the two rock types.

The felsic norite is fresh, massive, medium-grained and hypidiomorphic equigranular. Locally the plagioclase is sericitized and amphibole and talc replace clinopyroxene and orthopyroxene. Locally there is a thin, slightly hematitized, finer-grained and darker "chilled" margin in the felsic norite at its contact with Footwall Breccia.

Felsic norite contains no economic sulphide mineralization. 
However, disseminations of pyrite and pyrrhotite do occur.

\section{2-3c. METASOMATISM}

Throughout footwall rocks and Footwall Breccia of Morgan and Levack townships within approximately $900 \mathrm{~m}$ of the SIC contact, including Strathcona Deep Copper and Copper zones, and McCreedy West, patches of granophyric quartz (Quartz \#1) + K-feldspar and of well developed crystalline epidote occur (Table 2-3; Plate 2-5a). These are attributed to metasomatic processes caused by the intrusion of the SIC before footwall ore formed. Field and textural relationships, and detailed mapping at the Barnet trenches, Deep Copper and Copper Zones, and on the Pike Lake property, have shown that this metasomatic event occurred after the intrusion of the Footwall Breccia and before Cu-rich footwall mineralization was emplaced.

Epidote-rich veinlets ( $<3 \mathrm{~cm}$ wide), pods or pervasive alteration of clasts in the footwall are dominantly fracture-controlled and are concentrated in zones of Sudbury Breccia and Footwall Breccia, although they are also common within diatexite and felsic gneiss (Plate 2-5b). Felsic clasts and clast/matrix margins in both breccia-types are particularly susceptible to epidote and K-feldspar replacement metasomatism.

A paragenetic sequence for the metasomatic minerals is presented in Table 2-4. Patches of elongate laths of epidote (up to $2 \mathrm{~cm}$ long) with a second generation of central euhedral quartz (Quartz \#2) tend to be $<15 \mathrm{~cm}$ in diameter Fine-grained K-feldspar and graphic intergrowths of K-feldspar + quartz are 
variably developed around the quartz and epidote pods and veins. Albitic plagioclase laths are visible within granophyric quartz $+\mathrm{K}$-feldspar intergrowths. Early-formed albite is replaced by granophyric quartz + K-feldspar. Rarely does the granophyric quartz $+\mathrm{K}$-feldspar replace radiating masses of optically continuous quartz. Titanite and zoned allanite, typically as inclusions in epidote, are important accessory minerals in this assemblage, whereas apatite is rare. Chlorite occurs interstitially to all other phases and locally replaces K-feldspar and epidote. Chlorite veins with varying proportions of amphibole, epidote and quartz are common in the Barnet trenches.

Footwall Breccia in the southeastern part of the Pike Lake property shows extensive replacement of matrix material by granophyric K-feldspar and quartz, similar to the metasomatism visible in Sudbury Breccia, diatexite and gneiss. Veins of granophyric quartz and K-feldspar from $3 \mathrm{~mm}$ to $30 \mathrm{~cm}$ wide are ubiquitous. Dressler (1984b) and Coats and Snajdr (1984) described this kind of granophyre as locally part of the Footwall Breccia matrix but did not recognize its development outside this unit. By contrast, Cowan (1968) recognized Kfeldspar-rich masses and rosettes of epidote in the footwall gneisses, migmatites and Sudbury Breccia, but assumed that they were post-ore. The $\mathrm{Na}$ metasomatism of Naldrett and Kullerud (1967) is a different phenomenon and is related to the albitization of plagioclase in mafic and ultramafic inclusions in the Footwall Breccia. Other workers (Coats and Snajdr, 1984) refute the existence of this kind of $\mathrm{Na}$ metasomatism. 
Biotite is at least incipiently developed in the Sudbury Breccia matrix in the vicinity of $\mathrm{Cu}$-rich footwall veins. Its occurrence is related to this relatively high-temperature, metasomatic event. Although Cowan (1968) suggested that the biotite was the result of metasomatism, he did not relate it directly to the Kfeldspar + quartz + albite + epidote metasomatism.

Sulphide minerals are seldom found in this epidote-rich metasomatic assemblage, other than as late blebs overprinting the original metasomatic assemblage. However, Cu-rich veining in the Barnet trenches both cross-cuts and conforms to structures occupied by quartz + epidote $+\mathrm{K}$-feldspar (Plate 2$6 a$ and $b)$.

\section{2-3d. ALTERATION}

Weak pervasive hematitization is ubiquitous in tonalitic diatexite in sulphide mineralized parts of the Longvack property (see also Foy, 1989). Felsic footwall rocks (felsic gneiss, diatexite and Footwall Breccia) on Morgan and Pike Lake properties tend to be less altered. Pink, hematite-stained grain rims and networks of red to pink microfractures in feldspars are common. Along late fractures hematitization may extend for several centimetres into the host rock. Hematite staining in the Felsic Norite is limited to fault zones.

Weak to intense, pervasive epidotization of mafic xenoliths and saussuritization of plagioclase in mafic xenoliths within tonalitic diatexite and Sudbury Breccia is common. 
Distinctive dark green/brown/grey alteration selvages up to $1 \mathrm{~cm}$ thick surround blebs of sulphides (dominantly pyrrhotite-rich) in Footwall Breccia and its associated clasts on the Longvack and Pike Lake properties. This alteration resembles the dark selvages on footwall chalcopyrite-rich veins composed of fine-grained epidote, actinolite, chlorite and minor quartz at Barnet, Strathcona Deep Copper Zone and McCreedy West, and has a similar mineralogy. Mafic clasts in this altered Footwall Breccia have weakly to intensely pervasive epidotization. This style of hydrothermal alteration in the Footwall Breccia lead Mitchell and Mutch (1956) to suggest that the ore in the Footwall Breccia at Hardy Mine is hydrothermal in origin. Cowan (1968) also noted thin alteration selvages dominated by epidote, talc (after pyroxene) and chlorite around sulphides in the Hanging Wall and Main zones at Strathcona Mine.

A much later period of alteration is associated with late brittle faulting in the area and is represented by up to $4 \mathrm{~m}$ wide zones of intense hematitization and epidotization and, more rarely, chloritization. Original rock textures are commonly still visible within these zones (see also Appendix I for details of later brittle faulting in the Barnet trenches). In intensely hematitized or epidotized rocks, chloritization of mafic minerals is variably developed. Malachite is locally developed on fracture surfaces in chalcopyrite-bearing rocks.

\section{2-3e. STRUCTURE}

The major fault in the Morgan-Longvack area is the N-S to NNW-trending Longvack Fault. Lafleur and Dressler (1985) reported that the Pike Lake, 
Fecunis and Longvack faults represent dextral offsets bounding a northwestdirected thrust block. The Longvack Fault was found to cut through the Longvack pits, evidence being the faulted blocks of tonalitic diatexite and subhorizontal slickensides. Massive sulphides in the pit walls may be banded, with a cataclastic texture. To the south of the Longvack pits, the faulted contact between Footwall Breccia and Felsic Norite is marked by a $2 \mathrm{~m}$ wide zone of mylonite.

The Morgan Property is crossed by NE-SW and NW-SE faults that appear as major lineaments on air photos. The Titan fault cuts through the centre of the property and was intersected in drill holes M-17 and M-38 (Sweeny and Farrow, 1990). Between L19E and L21E, the Felsic Norite/Footwall Breccia contact has been sinistrally offset along a SW-NE- trending fault, although the vertical component along the fault is unknown (Sweeny and Farrow, 1990). A NS-trending fault can be traced along L18E and L19E from $1+00 S$ to $8+00 \mathrm{~N}$ on the Morgan property by the development of protomylonitic textures, lithologic differences, and strong pervasive hematitic, epidotic and chloritic alteration. The orientation of movement along this fault has not been determined (Sweeny and Farrow, 1990).

The gneissosities and foliations in the study area dip steeply $\left(>50^{\circ}\right)$. Poles to foliations and contours calculated from measurements taken during the course of this study are plotted in Figures 2-5a, b, c and d. Morgan and Barnet property, and INCO Wedge measurements correspond to those shown by 
Dressler (1984; Fig. 6.2) for the northeast sector with a northwest-southeast trend, oblique to the SIC contact in the area. However, on the Longvack and Pike Lake properties, gneissosities and foliations have a southwest-northeast trend and correspond to the north sector of Dressler (1984; Fig. 6.2). This indicates that pre-Sudbury Event foliations have been disrupted, between Morgan and Longvack properties, by movement along a large regional structure probably represented by the Longvack fault. The origin of the Longvack fault may have coincided with the Sudbury event, but episodic reactivation of the structure has continued throughout the area's geologic history.

Stereograms of joint measurements taken from the Barnet (and INCO Wedge), Longvack and Pike Lake properties are shown Figure 2-6. An orthogonal joint set with a dominant trend to the southwest-northeast and the other trending northwest-southeast occurs on all three properties. A third, shallowly dipping joint orientation was measured on the Longvack property. These three joint orientations are roughly outlined for sector 8 by Dressler (1984; Figure 6-3). Jointing is superimposed on regional trends as a result of late (post-Sudbury event) movement along the Longvack Fault. It is unrelated to footwall Cu-Ni-PGE deposition (see Appendix I).

\section{2-4. GEOLOGICAL SETTING OF SOME NORTH RANGE DEPOSITS}

A schematic section through the Strathcona area shows the projected locations of the Barnet Main Cu Zone, Longvack Open Pit Mine, Strathcona 
Deep Copper and Copper zones, and the Fraser Mine Epidote Zone, and their geological settings (Figure 2-7).

\section{2-4a. FOOTWALL Cu-Ni-PGE DEPOSITS}

\section{i. Barnet Property}

The Cu-rich veins of the Barnet showing are 1500 m northeast of the Strathcona and Coleman headframes and less than $500 \mathrm{~m}$ from the ore-bearing Footwall Breccia of the mined-out Longvack open pits. Although the most intensely mineralized zone at Barnet is located in Sudbury Breccia, its distance from the Footwall Breccia (approximately 300m), low PGE content (Barnett and Tirschmann, 1989; Farrow and Sweeney, 1990), and style of alteration suggest a similarity to the Copper Zone in the Strathcona Mine (Plate 2-7a). The mineralogical and geochemical interpretation of this relationship will follow in chapters 3,4 and 5. Barnet property Cu-rich mineralization extends to the southwest to a zone of Cu-rich veins in Sudbury Breccia on the west shore of the NE lake of the Longvack property. A detailed report on Barnet trench and surrounding geology is given in Appendix I.

\section{ii. Strathcona Mine}

The Strathcona Mine is located in a zone of thickened Sublayer referred to as the Strathcona Embayment (Coats and Snajdr, 1984). The Strathcona Hanging Wall zone occurs in Sublayer, whereas the Main zone deposits are in Footwall Breccia surrounding the embayment. The Deep Zone sulphides extend up to $200 \mathrm{~m}$ beneath the SIC contact into the footwall and may have been 
tectonically emplaced (Dressler, 1984b). The Copper Zone (Zone 36) and Deep Copper Zone (Zone 38) comprise Cu-rich veins that extend into footwall units at approximately 300 and $600 \mathrm{~m}$, respectively, from the contact (Plates 2-7b, c and d). The Copper Zone is located in footwall gneisses and migmatites, whereas the Deep Copper Zone is located in Sudbury Breccia.

The more distal Deep Copper Zone is richer in PGE than is the Copper Zone. Details of the $\mathrm{Cu}, \mathrm{Ni}$ and PGE contents of the Deep Copper Zone are presented by Naldrett et al. (1982), Coats and Snajdr (1984), Naldrett (1989), Li and Naldrett (1989; 1990; 1992), Li et al. (1992) and Money (1992).

iii. McCreedy West Mine

The McCreedy West (formerly Levack West) deposit is located at the western end of the Onaping-Levack mineralized belt. The Main ore zone at McCreedy West consists of mineralized Footwall Breccia that occupies a footwall embayment (Hoffman et al., 1979; Coats and Snajdr, 1984). This grades into Footwall Ore Zone Cu-rich veins that extend into footwall units and associated Sudbury Breccia (Coats and Snajdr, 1984; J. Guse, INCO Ltd., pers. comm., 1992).

\section{iv. Summary}

Although Cu-rich veins occur in the diatexites and gneisses of the footwall units of the SIC (i.e., part of the Barnet showing, Strathcona Copper Zone), the most common host is Sudbury Breccia. On a broad scale, Sudbury Breccia development is localized along lithological boundaries (Plates 2-7a and d). On a 
smaller scale, the distal extensions of Cu-rich vein systems show individual veins and stringers to be localized along clast/matrix boundaries. Regardless of their origin these breccias were critical to the permeability of the rocks after the Sudbury event due to their clast/matrix competancy contrasts when compared to the host Archean gneisses and migmatites; thus, they may have functioned as structural traps for $\mathrm{Ni}$-, $\mathrm{Cu}$ - and PGE-rich precipitation. However, $\mathrm{Cu}$-rich veins cross-cut both Sudbury Breccia matrix and clasts, indicating that the Sudbury Breccia was completely lithified before ore-forming processes began (this study; Bleeker, 1992). Alteration is more common in Sudbury Breccia zones than in their host Archean rocks (Sweeny and Farrow, 1990), also suggesting that these zones were more permeable to overall fluid movement.

\section{2-4b. Cu-Ni-PGE MINERALIZATION IN THE FOOTWALL BRECCIA}

\section{i. Longvack Mine}

The Longvack open pit mine, located approximately $1000 \mathrm{~m}$ northeast of the Strathcona Mine, was operated from 1956 to 1961 (Coats and Snajdr, 1984). It consisted predominantly of pyrrhotite-rich Footwall Breccia ore that extended down-dip, along the basal contact of the Sudbury Igneous Complex contact. At depth the orebody was mined in underground workings of the Longvack South Mine from 1968 to 1977 (Coats and Snajdr, 1984). Today, all that remains of the Longvack pits are the west and north walls. The rest of the pits have been filled. Samples for this study were collected from the walls, where vestiges of the original orebody remain. 


\section{ii. Fraser Mine Epidote Zone}

The Fraser Mine is located $1000 \mathrm{~m}$ southwest of Strathcona Mine. The main ore zone occurs as mineralized Footwall Breccia and footwall rocks that are part of the top of the large McCreedy East orebody (G. Morrison, INCO Ltd., pers. comm., 1992). The Fraser Mine "Epidote Zone" consists of lenticular alteration masses largely developed in Footwall Breccia that are dominantly composed of epidote and amphibole with less abundant magnetite, pyrite and pentlandite. They range in thickness from $<1 \mathrm{~m}$ to $>150 \mathrm{~m}$, although the exact shape of these bodies is unknown since, except for two exposures in exploration drifts, they have only been encountered in exploration diamond drill holes. Where they are elongate they are typically oriented subparallel to the Sudbury Igneous Complex contact. Mining of the main concentration of these zones is in its incipient stages. Drilling and underground exposures have revealed a layer of mafic-ultramafic footwall rocks underlying areas of well developed Epidote Zone. Epidote Zone-style alteration has not been encountered in surface mapping.

The Epidote Zone is of economic interest despite its relatively low sulphide content because of its $\mathrm{S} / \mathrm{Ni}$ ratio of approximately 6 (see Chapter IV). By comparison, the $\mathrm{S} / \mathrm{Ni}$ ratio for unaltered Footwall Breccia-hosted ore is typically $>30$ (F. Twilley, Falconbridge Ltd., pers. comm., 1990). Proven, probable and possible ore reserves for zone $4 A$ are $1,160,000$ tonnes of $1.73 \%$ 
$\mathrm{Ni}$ and $0.29 \% \mathrm{Cu}$, and for zone $4 \mathrm{~B}$ are 887,000 tonnes of $1.49 \% \mathrm{Ni}$ and $0.22 \%$ Cu (Twilley, 1993).

\section{2-5. DISCUSSION}

The footwall rocks of Morgan and Levack townships are not part of a layered igneous complex, but they represent the granulite-facies equivalents of a volcanic-sedimentary succession. Because of the high grade of metamorphism and subsequent retrograde events, original textures have been destroyed.

Original mafic and ultramafic rocks (i.e., dykes, flows, small intrusions, etc.) that existed in the succession are now isolated and brecciated bodies within the host gneisses, metatexites and diatexites. A high concentration of these rocks occurs at the contact between the Footwall Breccia and the footwall at Fraser Mine, and are spatially associated with the Epidote Zone.

Table 2-2 is a summary of timing relationships in the North Range associated with Footwall Breccia emplacement. Field relationships suggest that the Footwall Breccia was emplaced before the Sudbury Igneous Complex. The undulating contact between the Footwall Breccia and footwall units is the result of footwall compositional variation. Mafic breccias acted as refractory thermal buffers to melting and their subsequent assimilation into the Footwall Breccia was because of their high melting temperatures. Elsewhere, tonalitic diatexite, with a quartzo-feldspathic composition similar to that of the Footwall Breccia matrix, was more readily incorporated. A distinct contact between the Footwall Breccia and diatexite is difficult to determine due to recrystallization of the 
footwall rocks. This problem is simplified where diatexite or gneiss retain original fabrics, since Footwall Breccia matrix is typically fine-grained to aphanitic and massive.

Assemblages of K-feldspar + epidote + quartz \pm amphibole \pm chlorite occur as replacement pods and veins in Footwall Breccia and in most footwall lithologies. Epidote-rich veins are also present in the Main Mass of the SIC. Both occurrences may represent hydrothermal veins and replacements generated during intrusion and cooling of the Sudbury Igneous Complex in a similar fashion to those of the Bushveld Complex (Schiffries and Skinner, 1987).

Whereas magmatic sulphide mineralization is ubiquitous within the Sublayer, it is not within the Footwall Breccia. Sulphide content and style of mineralization within the Footwall Breccia is extremely variable. Although some of it may be of magmatic origin, hydrothermal events have strongly modified any magmatic or possibly "tectonically" emplaced ore. Surface and underground mapping has shown a strong spatial relationship on a mine scale (such as at Strathcona Mine) among Cu-Ni-PGE -bearing Sublayer, Footwall Breccia and footwall rocks, suggesting that magmatic sulphides in the Sublayer and part of the Footwall Breccia provided a source for later modification by a hydrothermal system that existed in the Footwall Breccia and footwall, and was driven by the heat from the cooling Sudbury Igneous Complex.

There is a close spatial association between sulphides and dark, finegrained, actinolite + epidote + quartz + chlorite alteration selvages in both the 
Footwall Breccia and footwall units. Large alteration bodies such as the Epidote Zone in the Fraser Mine may represent channelways for the movement of these metal-rich fluids.

High precious metal values (>1000 ppb $\mathrm{Pd}$ and $\mathrm{Pt}$ ) near the Footwall Breccia contact (Sweeny et al., 1990) support the hypothesis that PGE, Au and Ag were transported with $\mathrm{Cu}$-rich fluids, and that these metals were scavenged from previously deposited Footwall Breccia mineralization. High $\mathrm{Cu}$ and associated relatively low precious metal values from the chalcopyrite-rich zone of Sudbury Breccia in the NE corner of the Longvack property (Sweeny et al., 1990), suggest that it represents the continuation of sulphide mineralization in the main $\mathrm{Cu}$ zone of the Barnet property to the northeast (Appendix I). This mineralization extends through a wedge of INCO "ground" separating Falconbridge's Longvack and Barnet properties. 


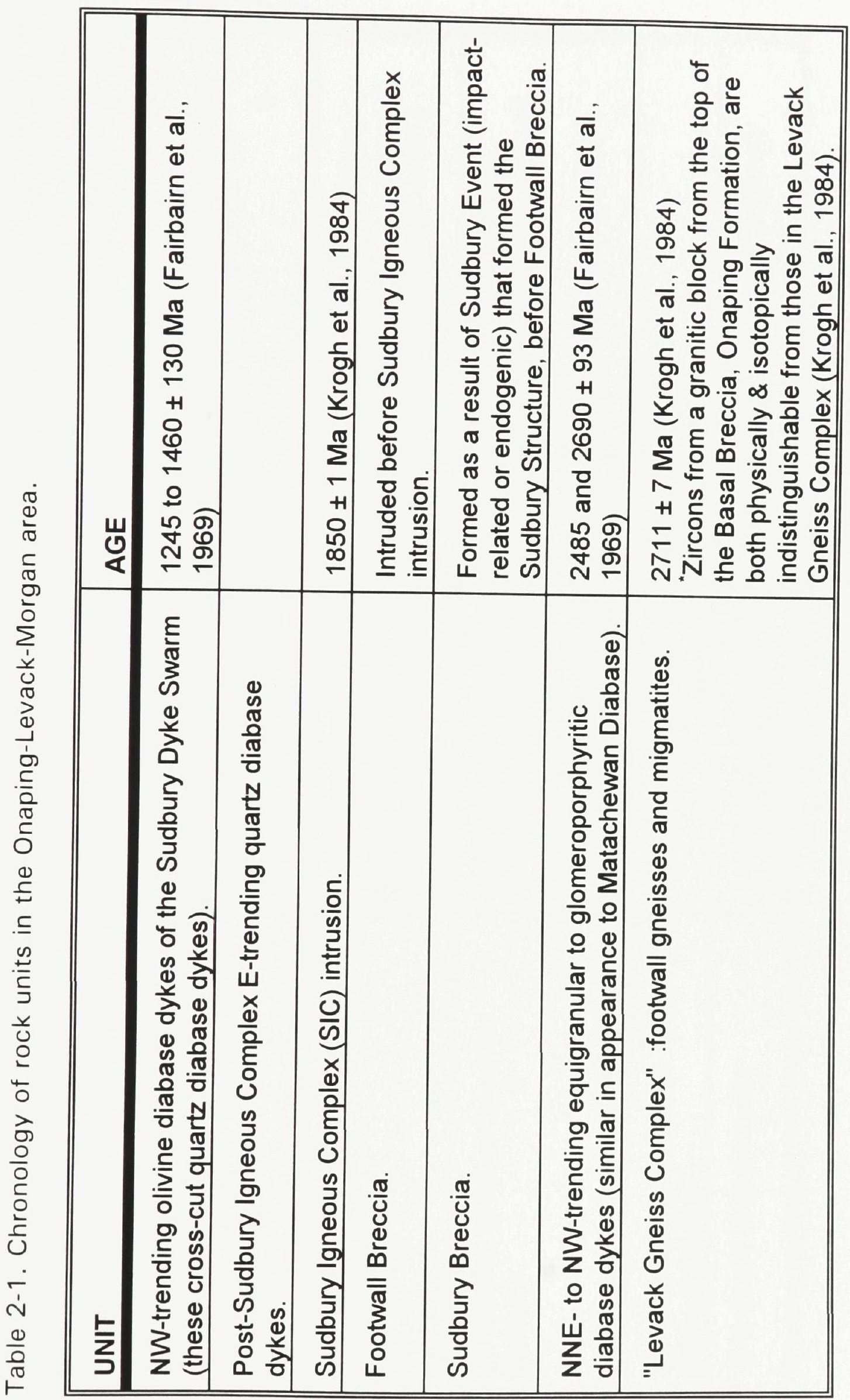




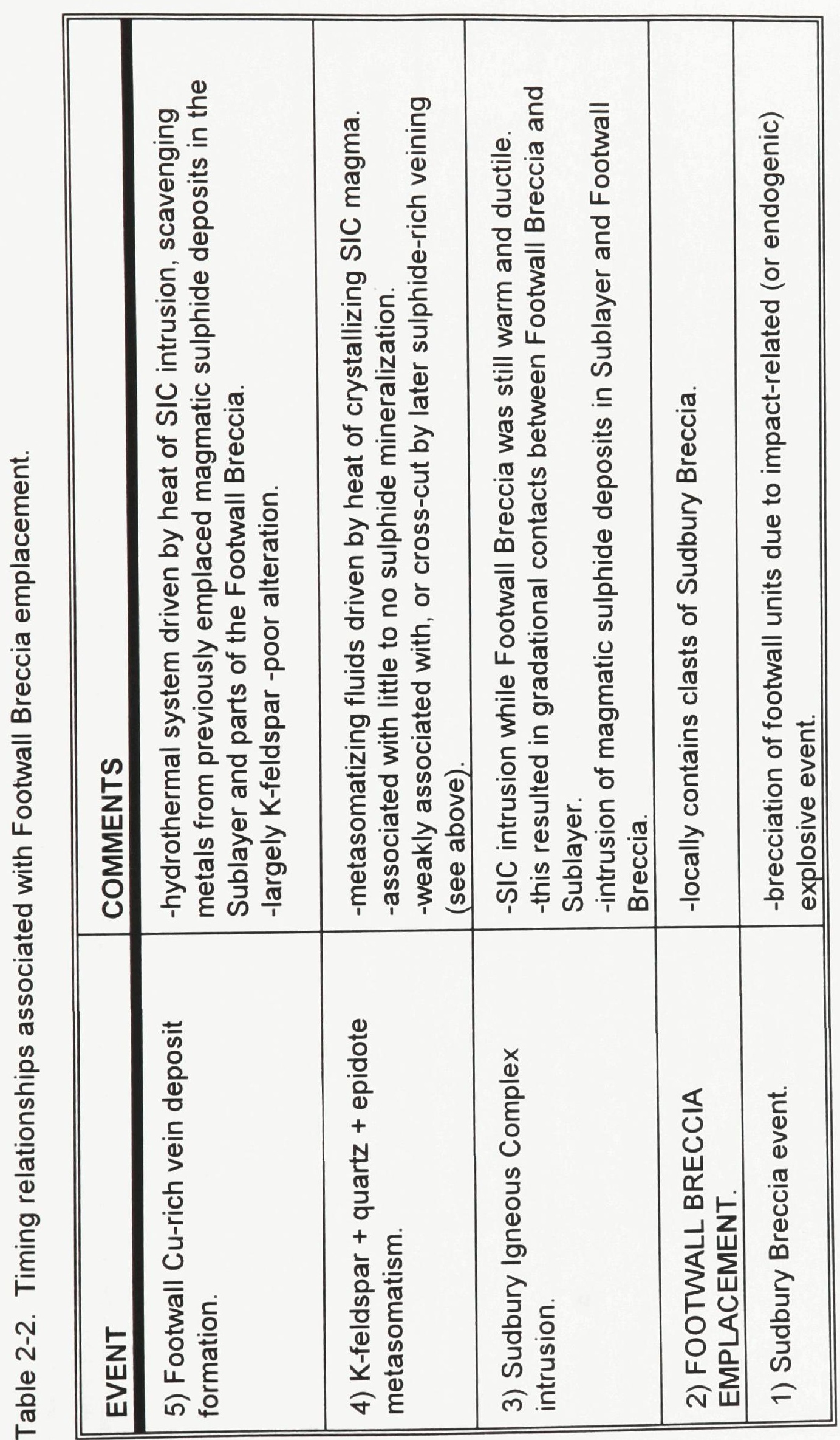




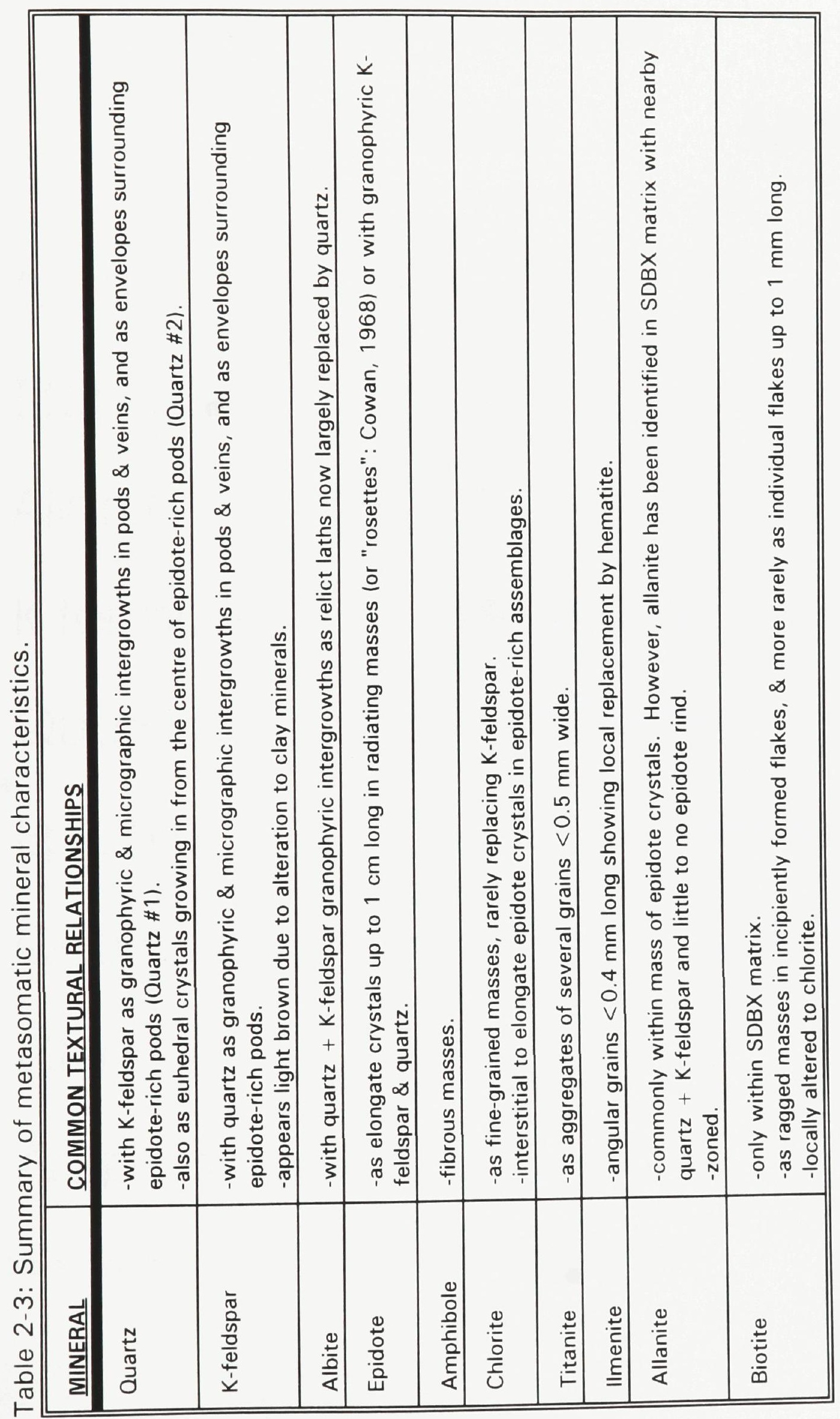


Table 2-4: Metasomatic mineral paragenetic sequence.

\section{Early \\ Late}

Albite

Titanite

Allanite

K-feldspar

Quartz \# 1

Epidote

Quartz \#2

Chlorite

Amphibole

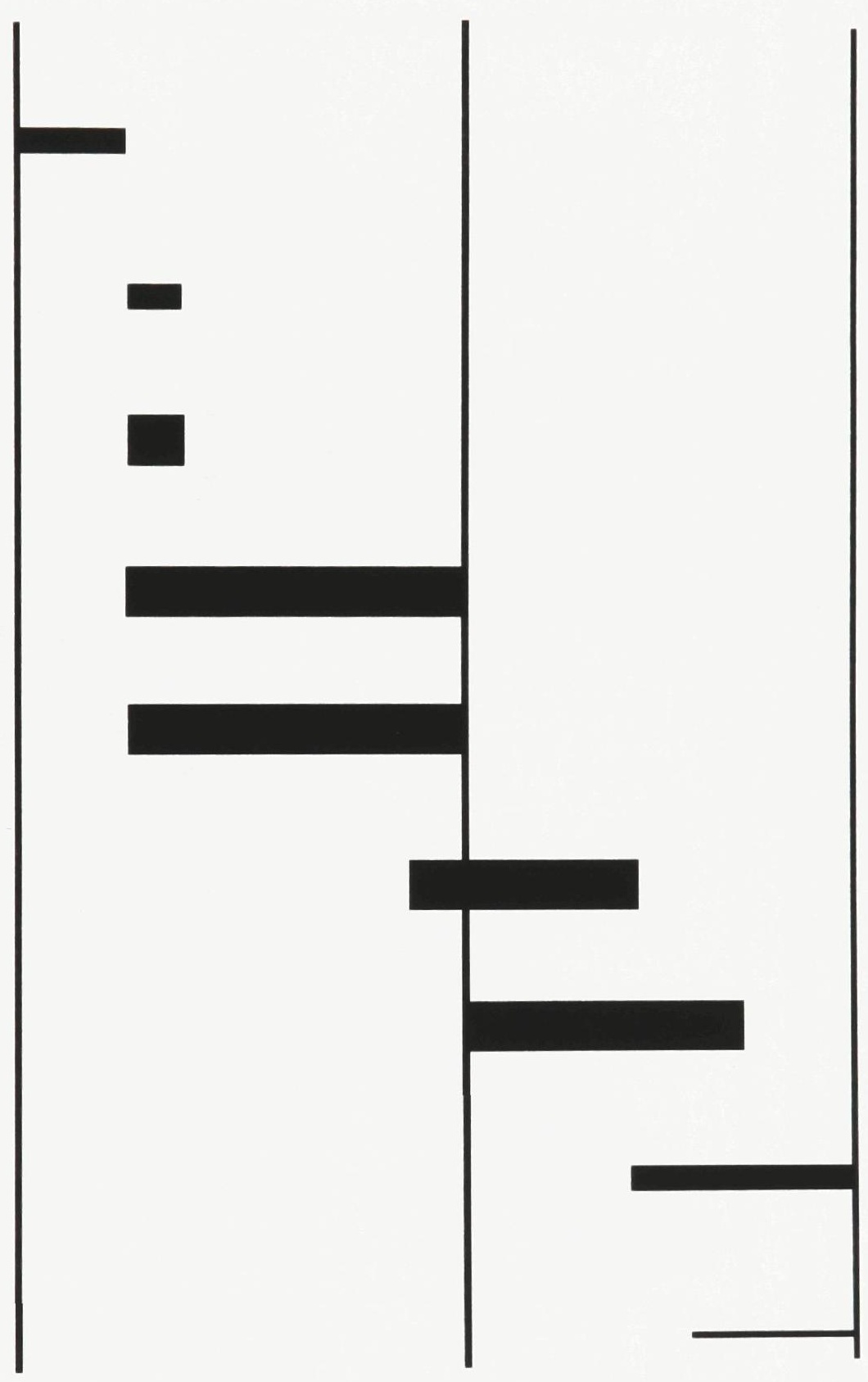

Note: Bar thickness corresponds to mineral abundance. 


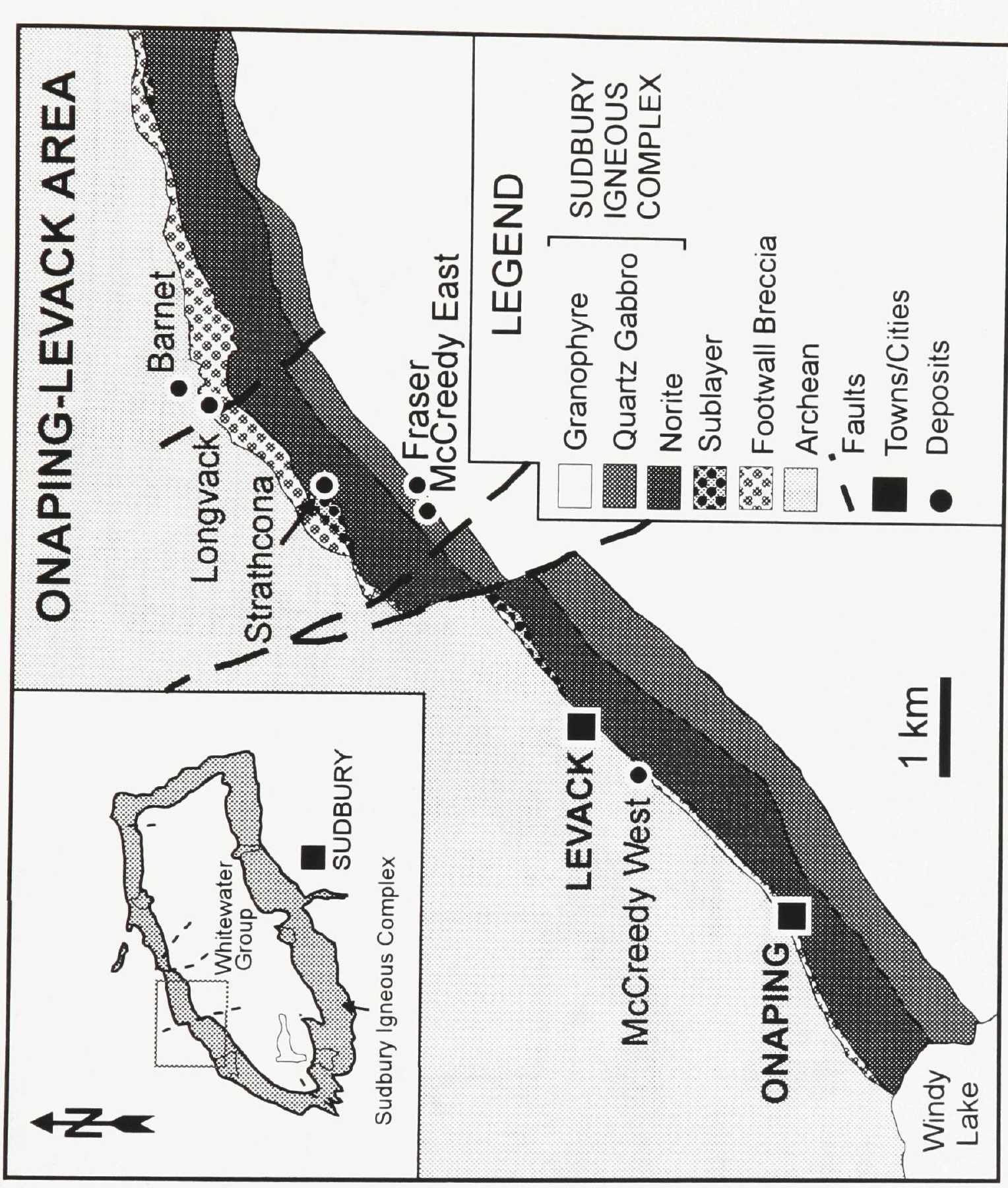

5
$\frac{5}{5}$
0
$\frac{0}{0}$
$\frac{0}{0}$

$\stackrel{0}{=}$

4

옹

$\stackrel{0}{=}$

뜸

밈ำ

ণ্ণ

ปั

త

을 월

은

ㄷํ은

号

प 지

을 的

$\varepsilon \pi$

ते प्ष

음

㟧

올

D

๑ั

(1)

‥ 옹

ㄷํㅇ

(1)

บับ 훈음 


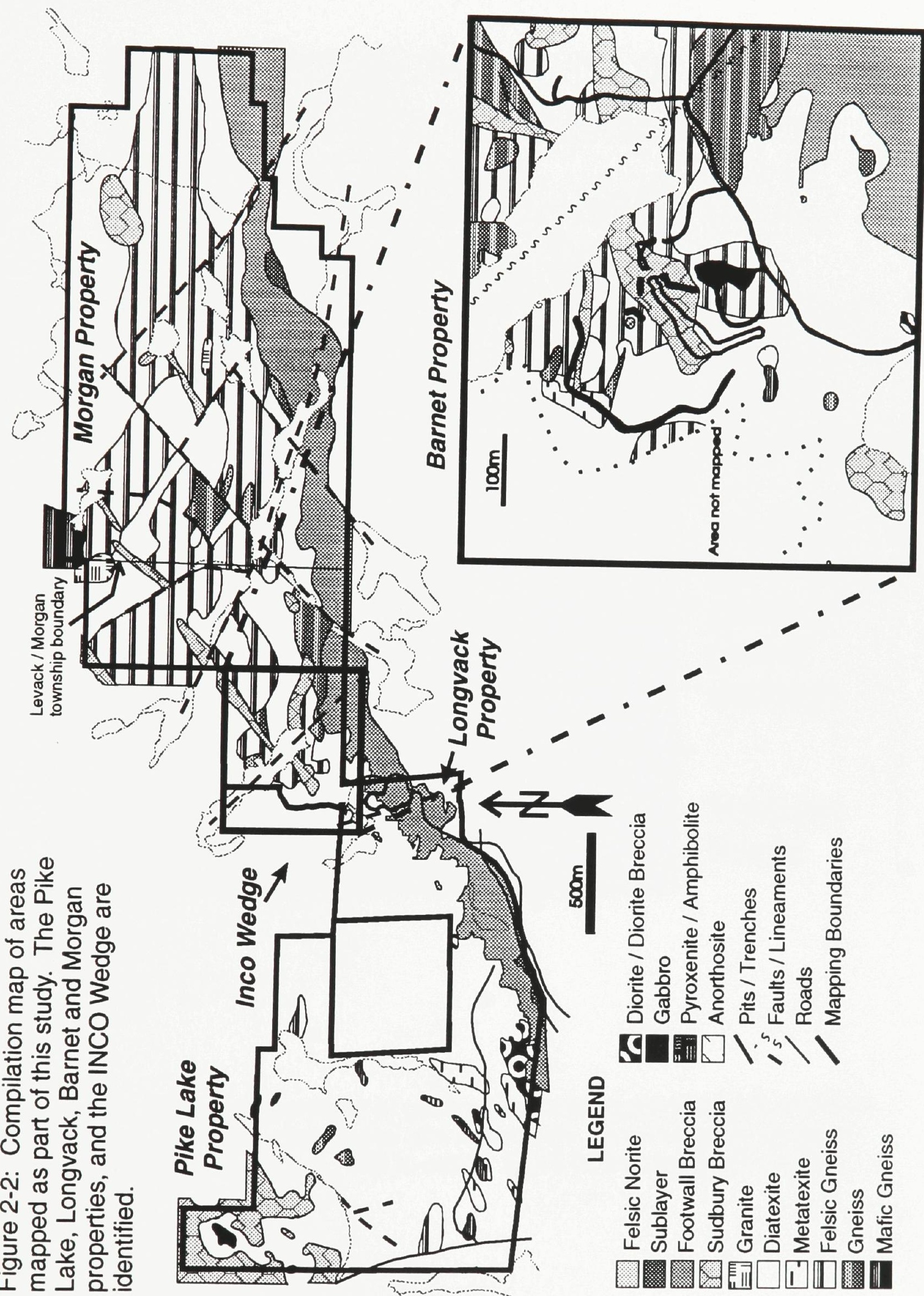




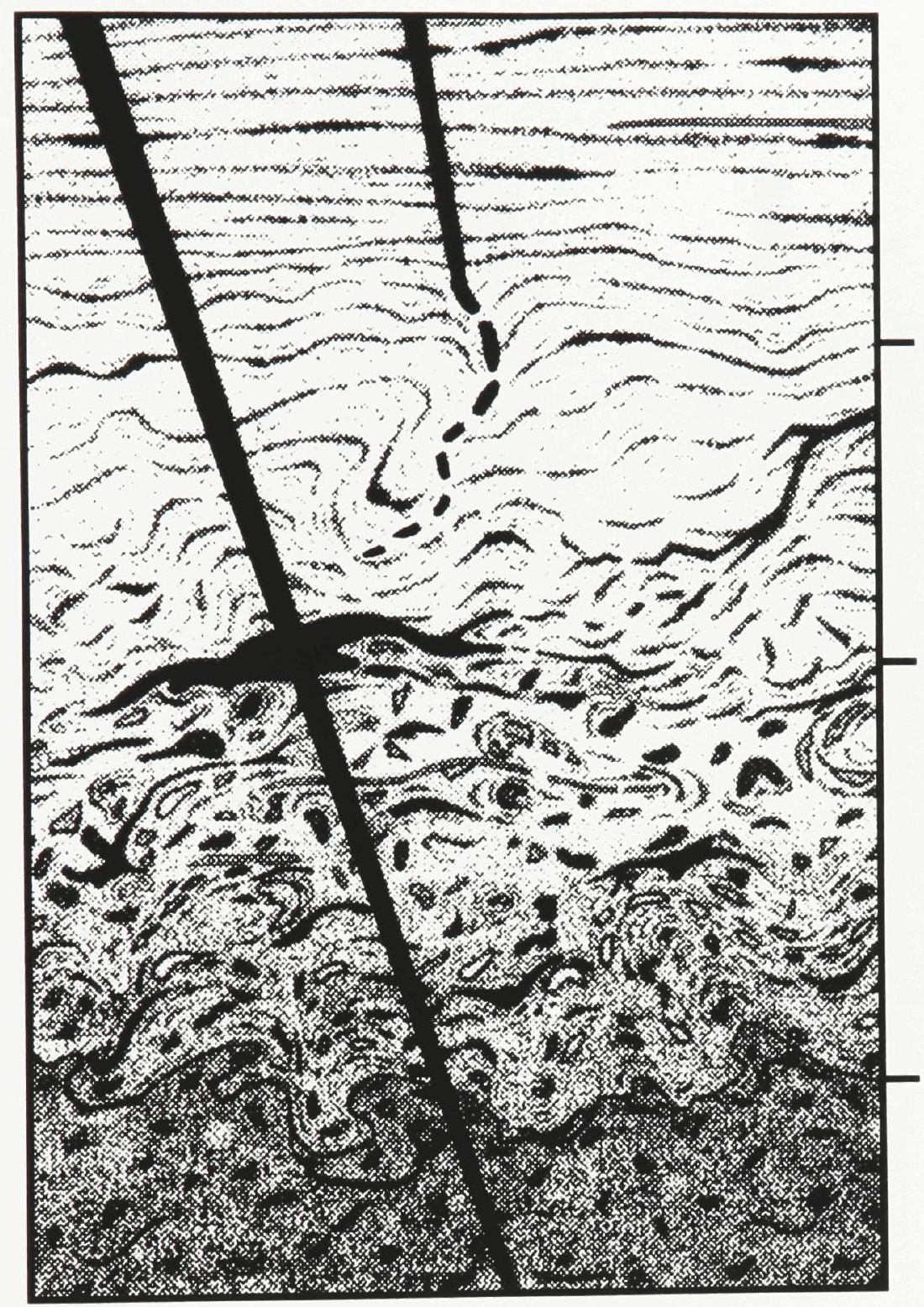

Layered Footwall (brittle fracture)

Deformed Footwall (ductile deformation)

Footwall Breccia (zone of partial melting)

Sublayer Norite

Figure 2-3: Schematic portrayal of generalized contact relationships between the Sublayer and footwall gneisses and migmatites. Sulphides are shown in dark grey and dykes in black. Not to scale. From Coats and Snajdr (1984). 


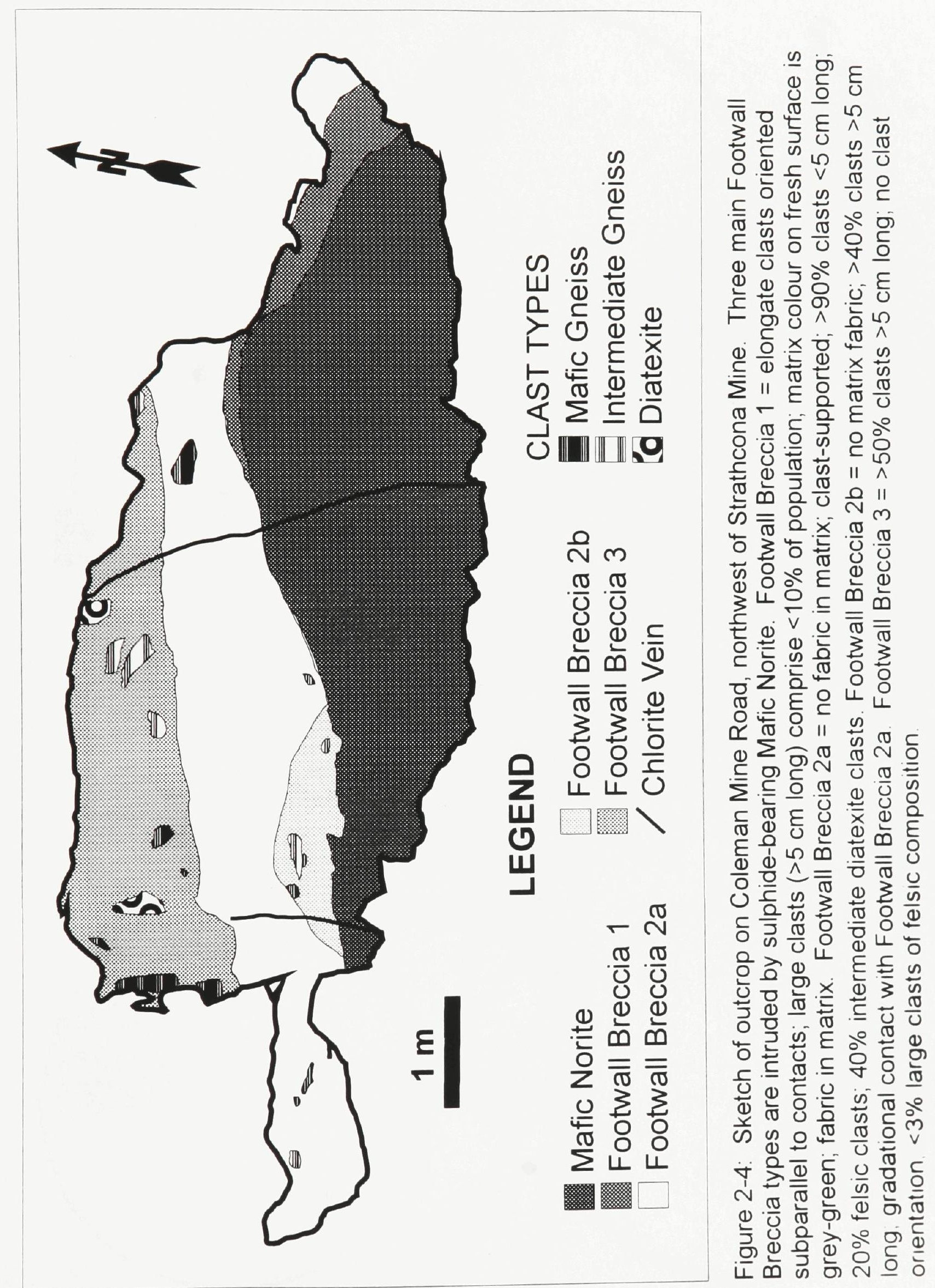




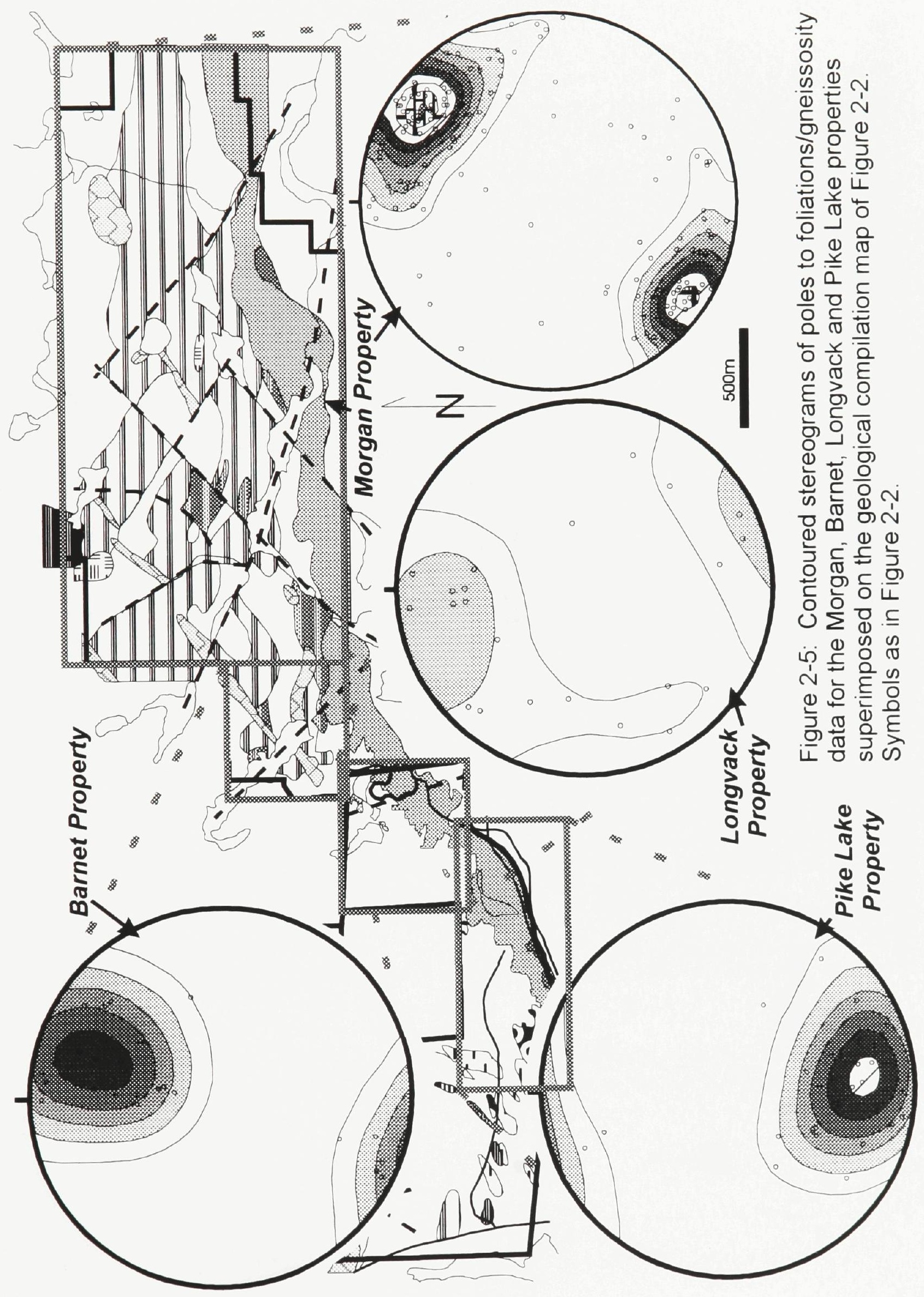




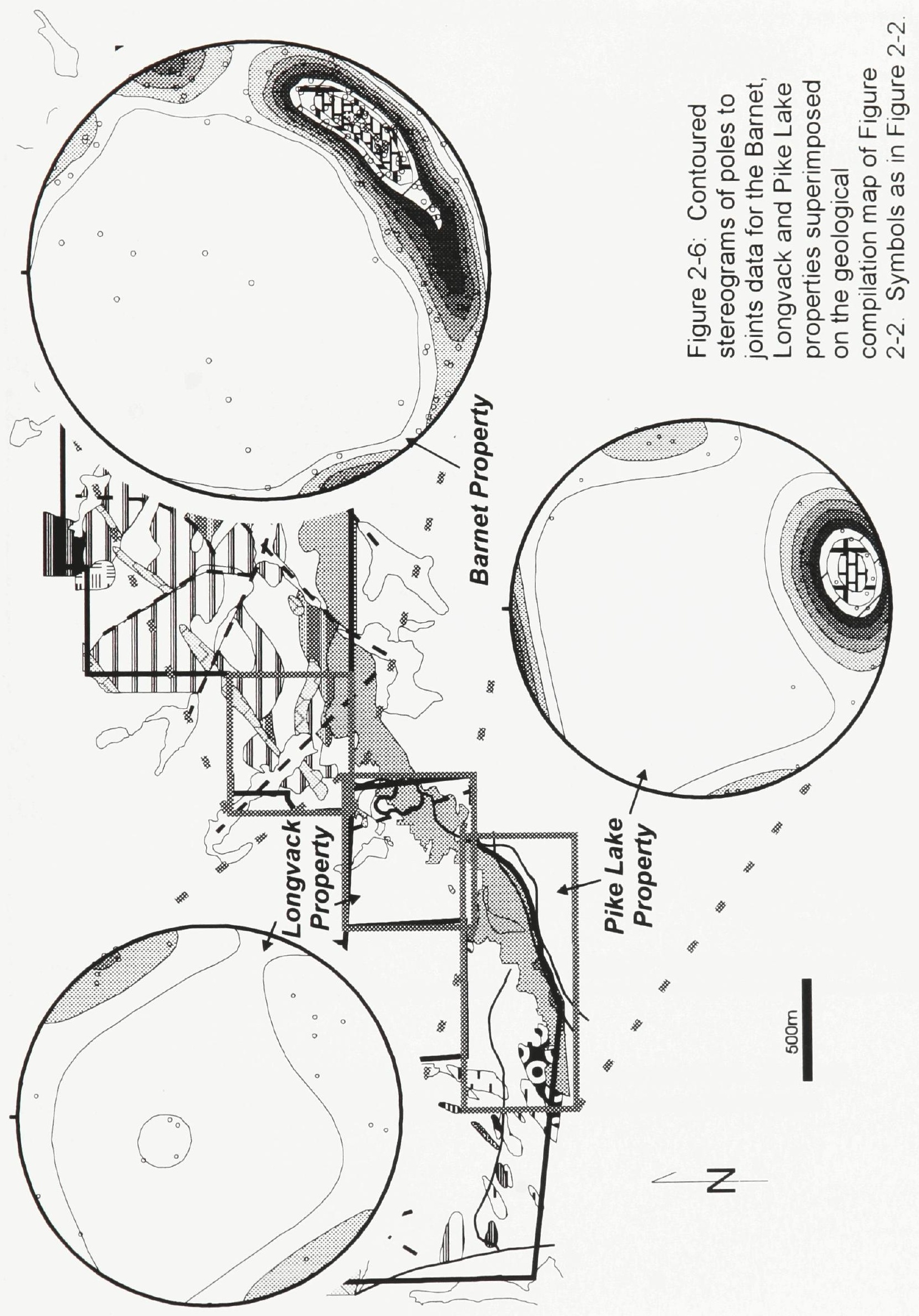




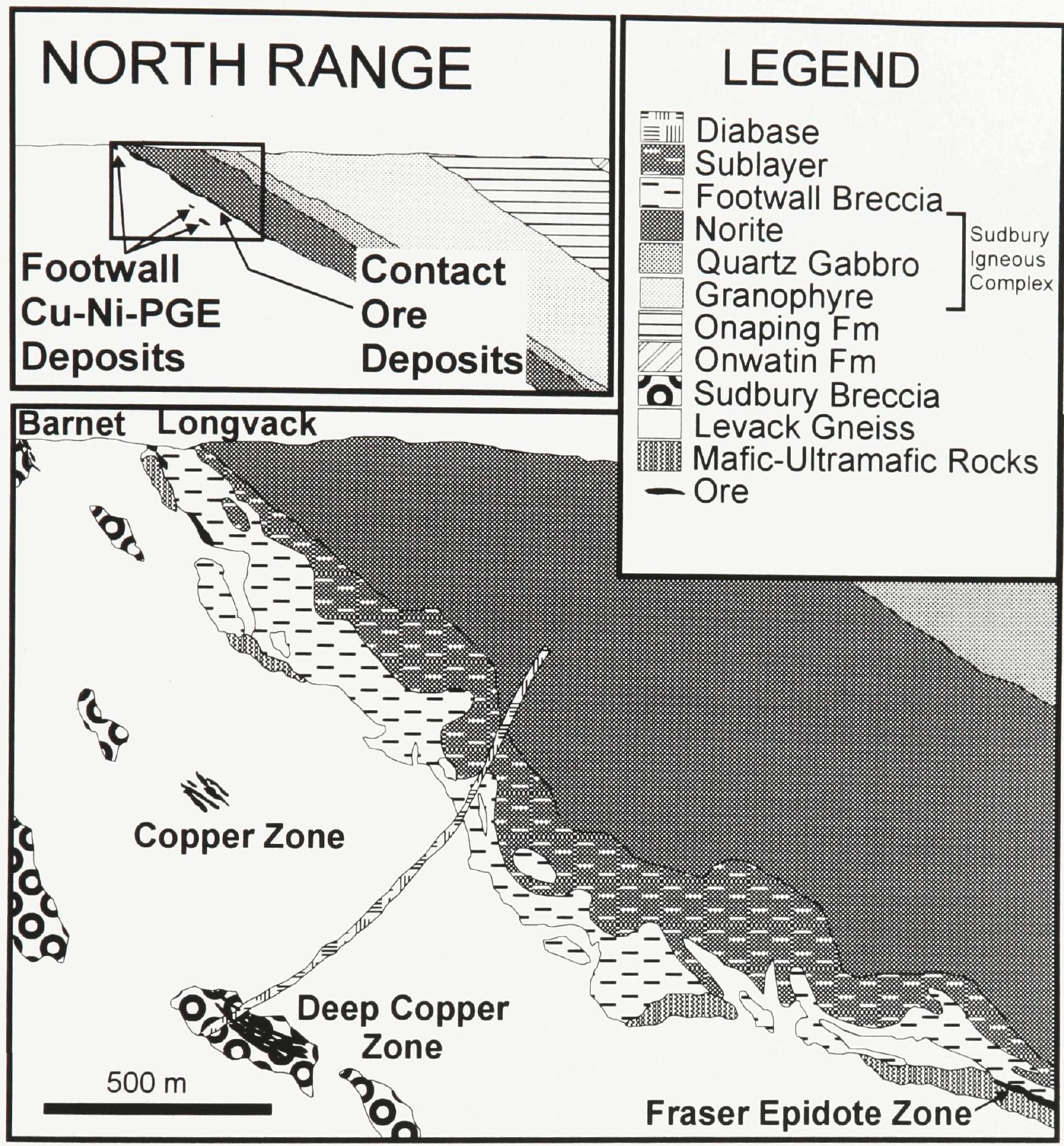

Figure 2-7: Schematic geological section of the Strathcona area. Contact deposits such as the Strathcona Mine Main and Deep zones have been removed for simplicity. 


\section{PLATE CAPTIONS}

Plate 2-1a: Banding in intermediate gneiss, Morgan Property. Quartzofeldspathic bands have higher relief.

Plate 2-1b: Elongate xenolith (schollen) in foliated tonalitic diatexite. Pike Lake Property.

Plate 2-2a: Sudbury Breccia veinlet following a pre-existing pegmatitic vein in a clast in a larger Sudbury Breccia body. Barnet Trench \#3.

Plate 2-2b: Sudbury Breccia in the Barnet Trench Extension. Clasts are rotated, and clast types include diabase, felsic gneiss and tonalitic diatexite. 

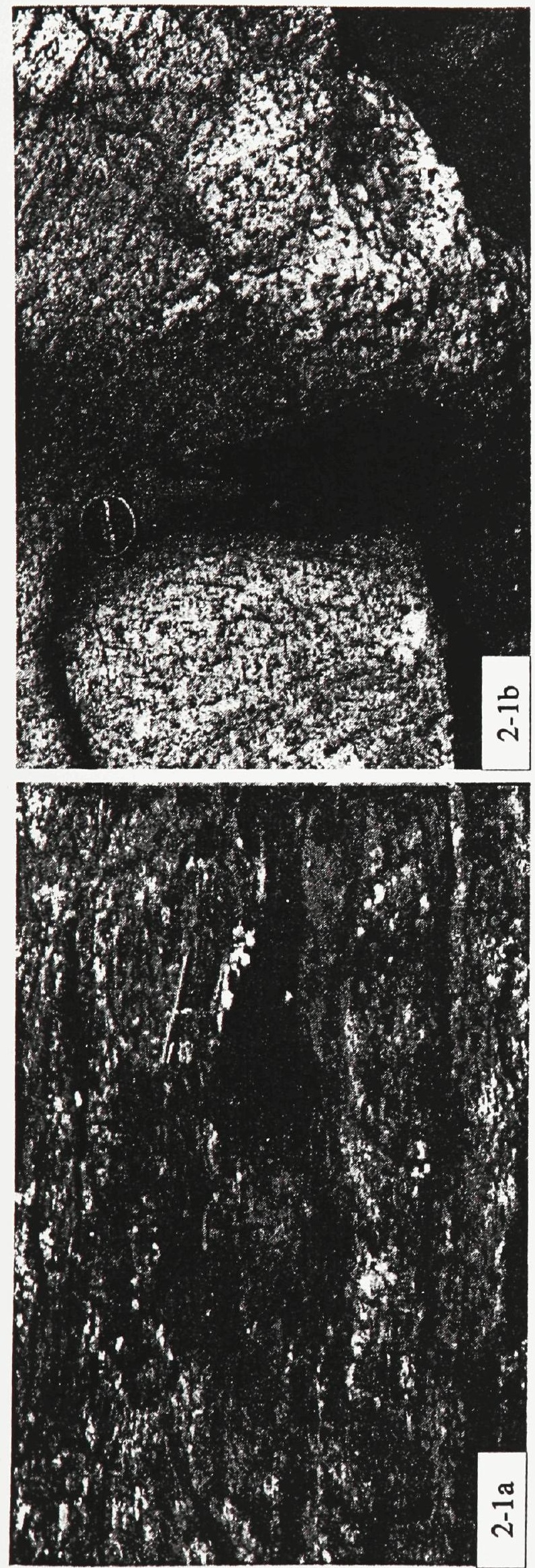
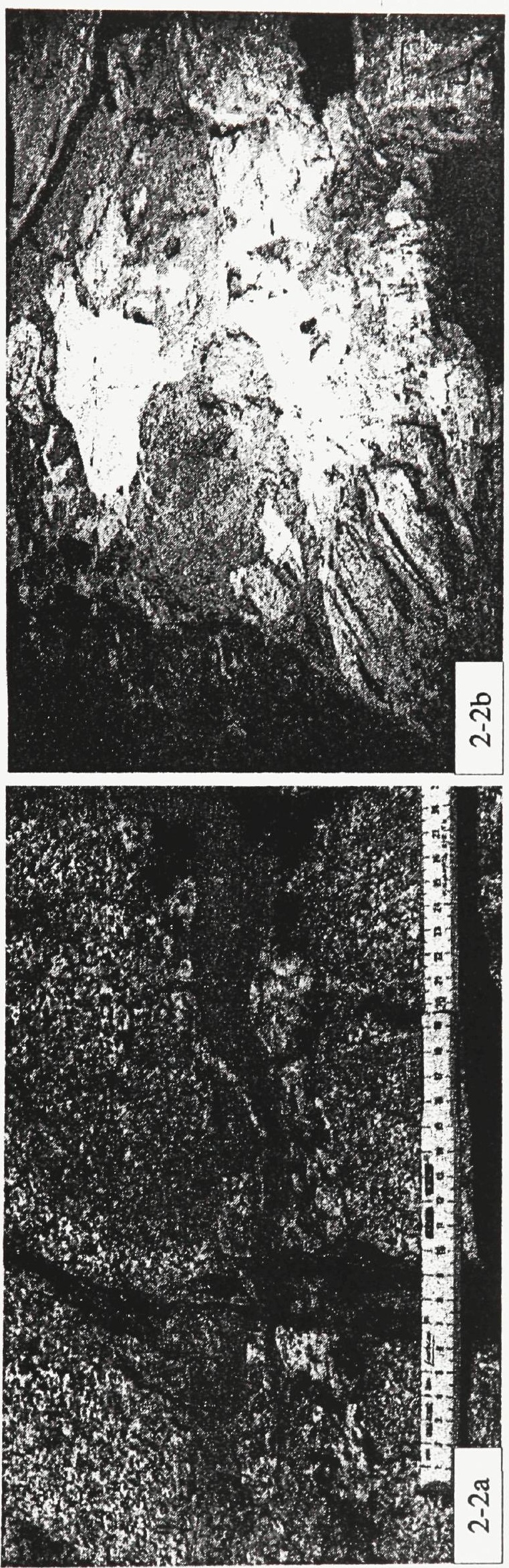


\section{PLATE CAPTIONS}

Plate 2-3a: Sulphide-bearing mafic norite intruding Footwall Breccia. The Footwall Breccia at this location can be subdivided into several phases (see Figure 2-4). Pike Lake Property.

Plate 2-3b: Close-up of mafic norite intrusion into Footwall Breccia as shown in Plate 2-3a. Pike Lake Property.

Plate 2-4a: Mafic clasts in Footwall Breccia with felsic mineral selvages. 46-190 Exploration Drift, Fraser Mine.

Plate 2-4b: Bleb of pyrrhotite-rich sulphides with a selvage of dark alteration consisting of amphibole + chlorite \pm epidote. Pike Lake Property. 

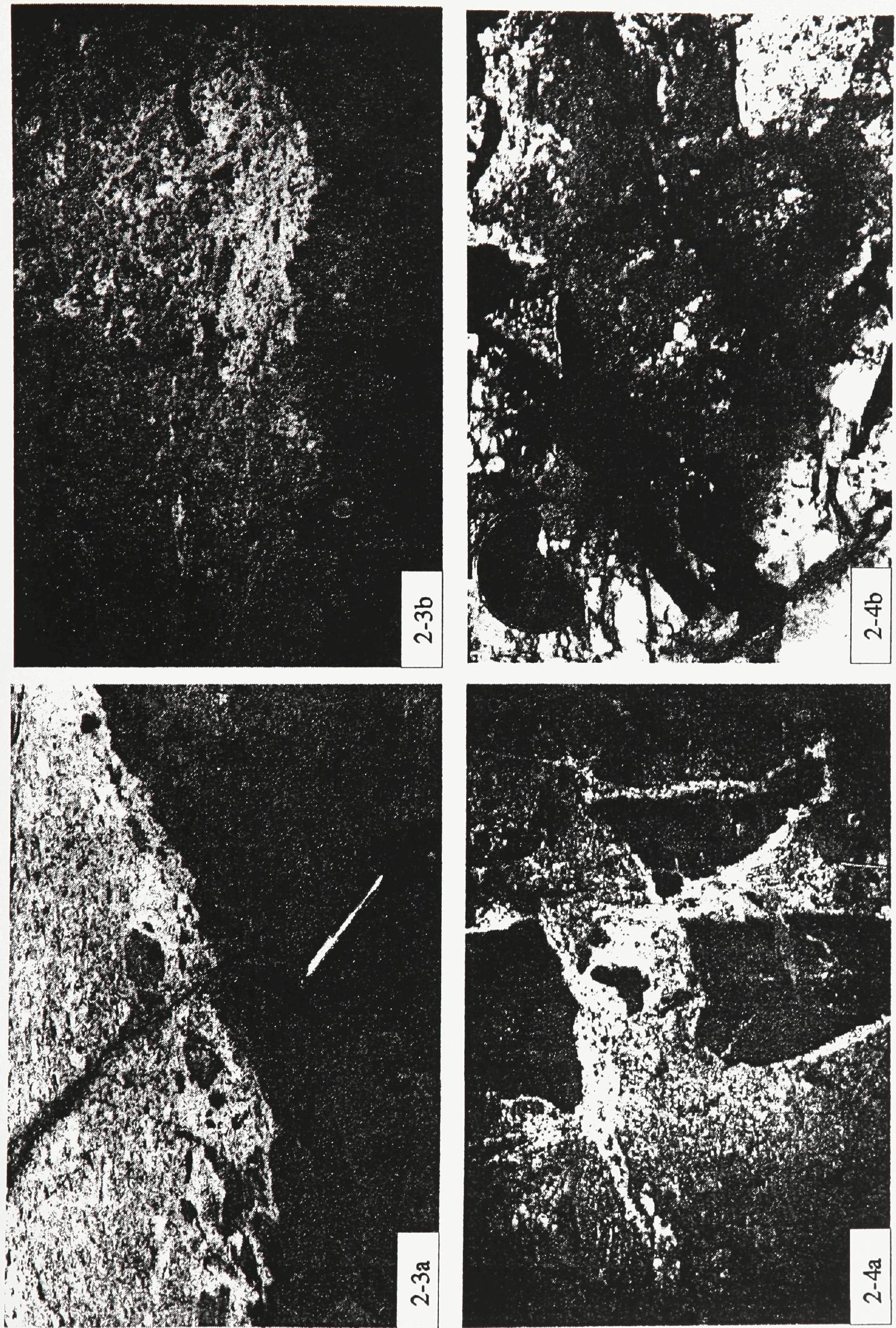


\section{PLATE CAPTIONS}

Plate 2-5a: K-feldspar + quartz granophyric intergrowth with epidote in diatexite clast in Sudbury Breccia. Rusty blebs of chalcopyrite are up to $2 \mathrm{~cm}$ wide.

Barnet Trench Extension.

Plate 2-5b: K-feldspar -rich pervasive metasomatism in Sudbury Breccia matrix and clasts. A $20 \mathrm{~cm}$ wide chalcopyrite-rich vein is visible in the top left of the photograph. Barnet Trench Extension.

Plate 2-6a: Structure filled by colloform-textured, zoned K-feldspar + quartz vein with minor chlorite, amphibole and epidote in diatexite. The mafic minerals are concentrated along the outer margin of the vein. To the left, but out of the field of view of this photograph, the same structure is filled by a $15 \mathrm{~cm}$ wide chalcopyrite-rich vein. Barnet Trench Extension.

Plate 2-6b: The same structure as shown in Plate 2-6a filled by chalcopyrite with K-feldspar + quartz + chlorite and radiating epidote crystals from the "preore" metasomatic event. Barnet Trench Extension. 

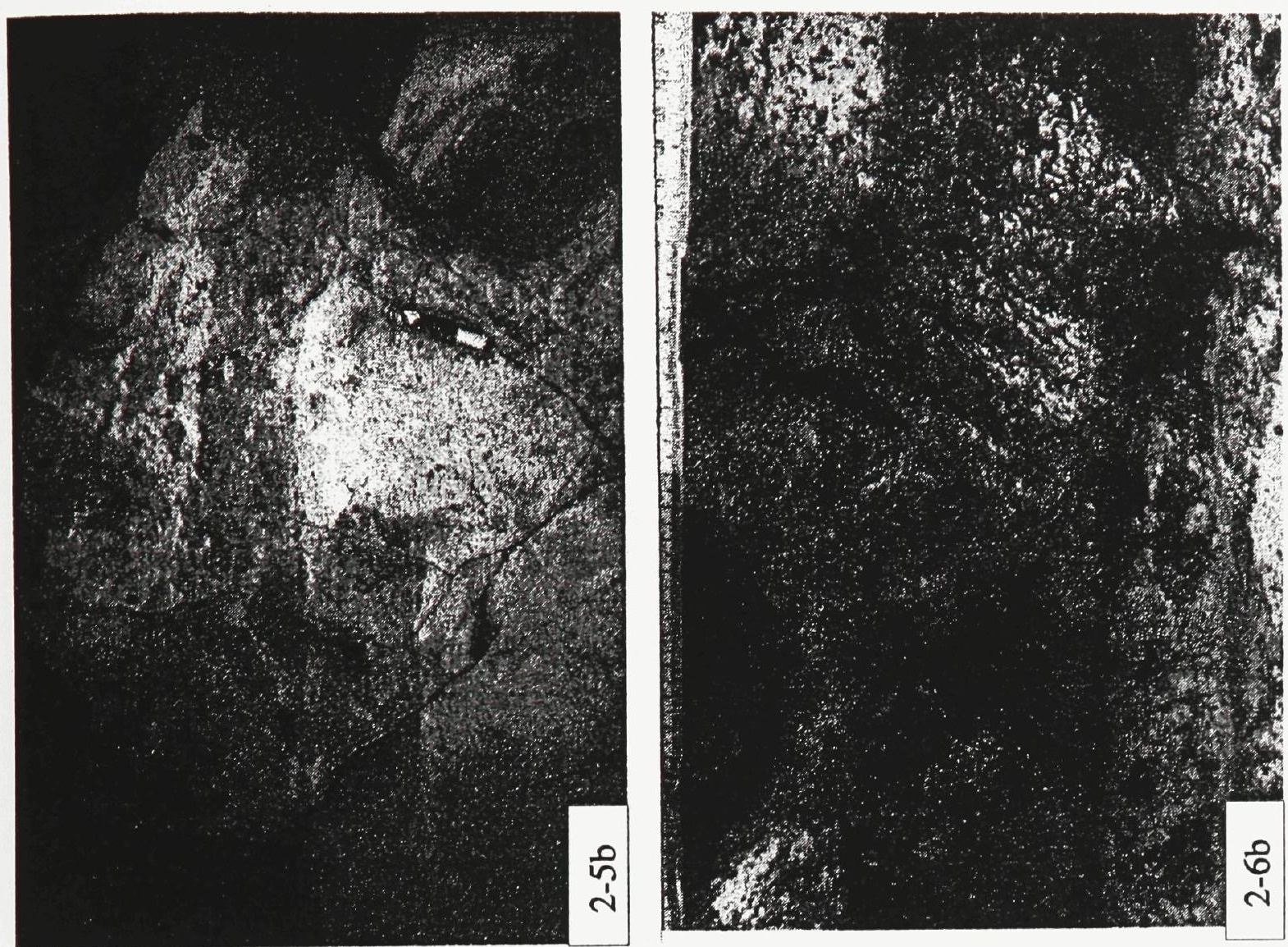

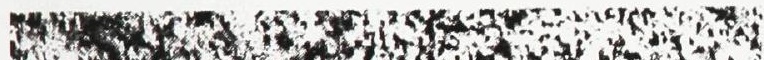

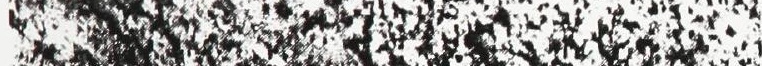

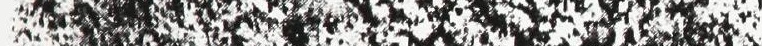

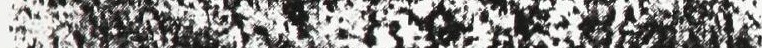

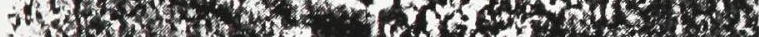

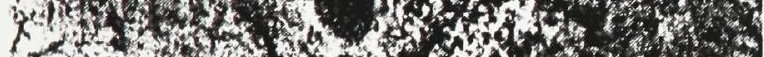

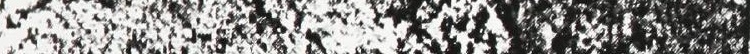

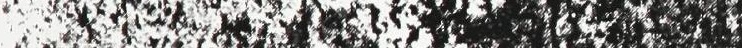

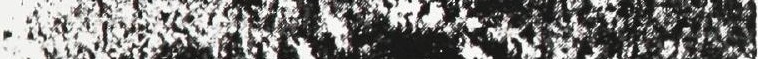

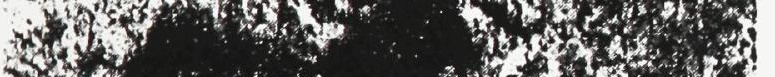
X16 n

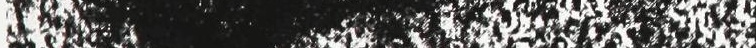
74.

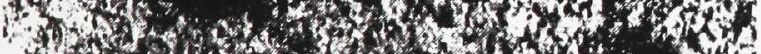
in Got

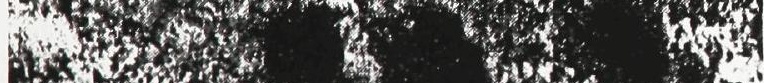
moto C.

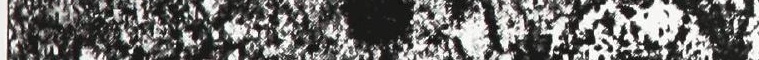

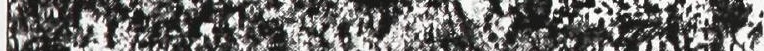

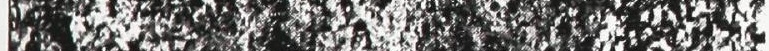

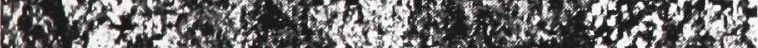

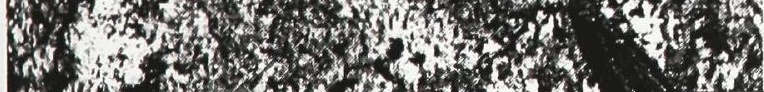

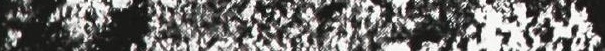

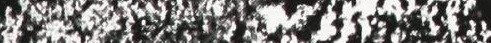

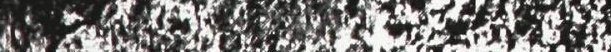

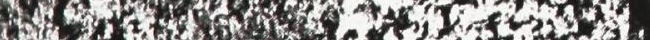

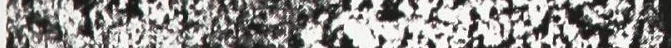

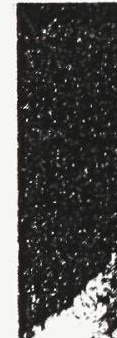

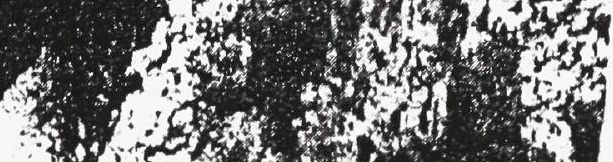

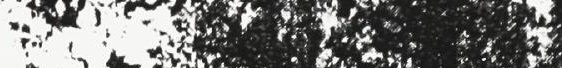

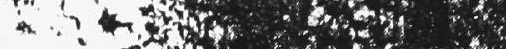

- 7.4

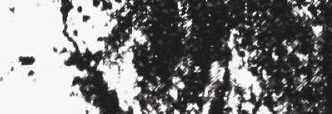

等,

$+4$ r.

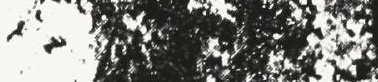

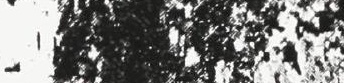

- 4 and

- 1 o

a do n

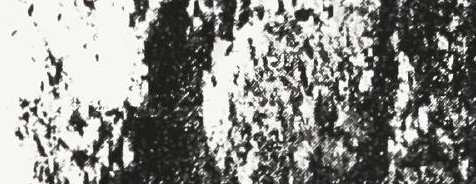

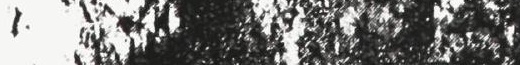

$\therefore$. 


\section{PLATE CAPTIONS}

Plate 2-7a: Chalcopyrite-rich stringers oriented along gneissosity in a large gneissic clast in Sudbury Breccia. Barnet Trench \#3.

Plate 2-7b: Up to $50 \mathrm{~cm}$ wide chalcopyrite-rich vein in Sudbury Breccia with $>20$ $\mathrm{cm}$ wide dark alteration selvage along margin. A23 vein, 3700 Level, Strathcona Mine Deep Copper Zone.

Plate 2-7c: Approximately $15 \mathrm{~cm}$ wide chalcopyrite-rich vein cross-cutting gneissosity in gneissic clast in Sudbury Breccia. Below is a chalcopyrite-rich vein up to several centimetres wide oriented along the contact between a Sudbury Breccia dyke and gneiss. A2 vein, 3700 Level, Strathcona Mine Deep Copper Zone.

Plate 2-7d: Chalcopyrite-rich vein becoming more quartz and calcite-rich at its termination. D5 vein, 4200 Level, Strathcona Mine Deep Copper Zone. 

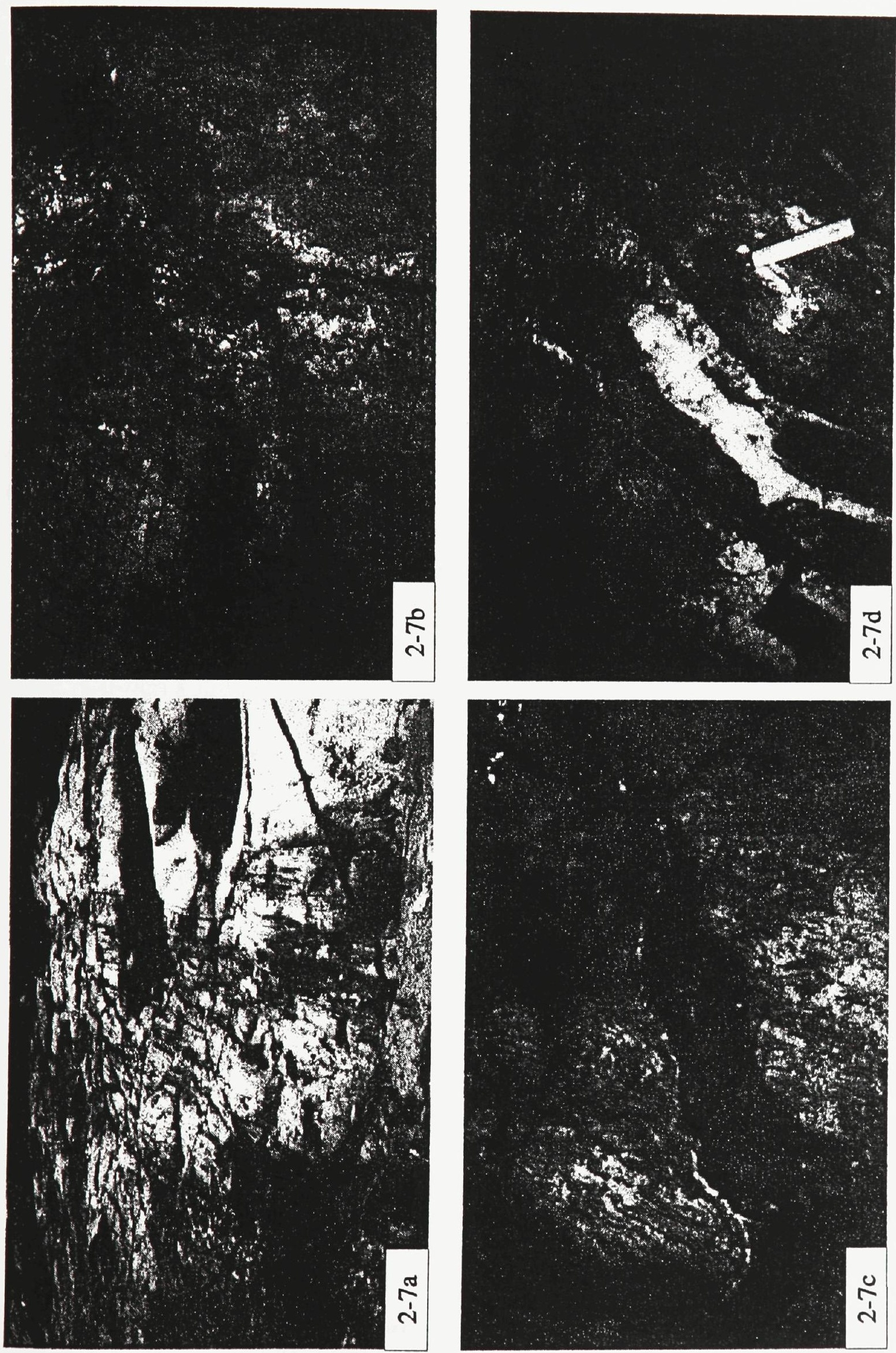
CHAPTER 3: ALTERATION AND SULPHIDE PETROGRAPHY AND MINERAL

\section{CHEMISTRY}

\section{3-1. INTRODUCTION}

Recent investigations of magmatic PGE-rich deposits such as some developed within the Bushveld (Schiffries, 1982; Schiffries and Skinner, 1987; Ballhaus and Stumpfl, 1986; Ballhaus, 1988; Ballhaus et al., 1988; Johan and Watkinson, 1987; Boudreau and Kruger, 1990; Stumpfl, 1992) and Stillwater (Boudreau et al., 1986; Boudreau and McCallum, 1986; Stumpfl, 1992) complexes have suggested that $\mathrm{Cl}$-rich hydrothermal fluids were important in ore zone development in magmatic sulphide deposits.

Previous investigators overlooked or ignored alteration associated with Cu-rich sulphide veins in footwall deposits in the Sudbury North Range on the basis that there was not enough volume of altered rock to be considered important in deposit genesis. However, Abel (1981) and Abel et al. (1979) recognized the dark alteration selvages adjacent to most of the veins. More recently, Li et al. (1992; 1993d) described "hydrothermal ore" as Cu-rich mineralization characterized by abundant epidote, quartz and calcite at sulphide vein terminations of "magmatic ore". However, this thesis provides the first detailed study of the alteration mineralogy and chemistry. This chapter presents detailed petrographic and mineral chemical data on two different types of alteration and associated $\mathrm{Cu}-\mathrm{Ni}$-PGE mineralization: that associated with $\mathrm{Cu}$-rich footwall veining and the Epidote Zone including subdivision of the latter based 
on easily identifiable "index" minerals that correspond to alteration intensity. Sulphide petrography and silicate mineral chemistry are used to further characterize these subdivisions. Mineralogy and mineral chemistry of pre-ore epidote + quartz + K-feldspar -rich metasomatism, described in Chapter 2, is also outlined in this chapter.

\section{3-2. FOOTWALL CU-Ni-PGE DEPOSITS}

\section{3-2a. ALTERATION MINERALOGY}

Although host rocks adjacent to $\mathrm{Cu}-\mathrm{Ni}$-PGE veins may appear relatively fresh in hand specimen thin sections reveal that the rocks are ubiquitously altered. Recrystallized, stubby plagioclase laths are variably altered to albite, clay minerals, epidote and opaque minerals (Fe-Ti oxides). The rest of the host rock, whether SDBX matrix, gneiss or diatexite, contains fine- to coarse-grained aggregates of amphibole, epidote and chlorite. Quartz occurs in polygonal aggregates. Typically, sulphides appear to have overgrown the earlier-formed alteration mineral assemblage. Where sulphides are disseminated they are most highly concentrated in areas of epidote, amphibole and chlorite alteration.

Table 3-1 is a summary of alteration mineralogy associated with Cu-Ni-PGE footwall stringers. Figure 3-1 is an idealized sketch of Cu-Ni-PGE vein alteration.

\section{i. Sudbury Breccia Host Lithology}

Where the dominant host lithology is Sudbury Breccia, dark green to black alteration selvages are variably developed along the margin of sulphide 
veins. They are typically 0.1 to $5 \mathrm{~cm}$ wide, but locally attain widths of $1 \mathrm{~m}$. Alteration mineralogy is dominated by fine- to medium-grained aggregates of amphibole, epidote and chlorite, although very coarse-grained monomineralic pods of actinolite occur (Plates 3-1a, b and c). More commonly, amphibole occurs as dark green masses up to $0.3 \mathrm{~cm}$ in diameter and where enclosed by sulphides occurs as mm-sized acicular crystals. These crystals may be several $\mathrm{cm}$ in length within the sulphide veins.

Anhedral and subhedral epidote grains have as much as $40 \%$ sulphide and amphibole inclusions. Fine- to medium-grained epidote is concentrated at the immediate contact of the sulphide veins and blebs. Equigranular epidote masses are common in the outer $1 \mathrm{~cm}$ of the sulphide veins, along the contact with the alteration selvage. Although allanite is commonly associated with epidote in epidote + quartz $+\mathrm{K}$-feldspar metasomatized footwall rocks, what is believed to be remnant zoned allanite has only been encountered in one sample from Deep Copper Zone (Plate 3-1d). In it allanite occurs as the core to an epidote crystal in chalcopyrite at the margin of a sulphide vein.

Chlorite occurs as fine-grained masses that extend into the breccia matrix. Chlorite is most commonly associated with quartz and amphibole, and less commonly with epidote.

Locally biotite occurs as $<1 \mathrm{~mm}$ wide brown selvages surrounding sulphide blebs at vein contacts and throughout the Sudbury Breccia matrix. Biotite is especially common where it occurs as selvages that surround sulphide 
blebs in pyroxene-rich clasts in SDBX. SDBX hosting sulphide veins may also contain up to $15 \%$ ragged biotite throughout its matrix. The biotite in the Sudbury Breccia matrix may not be related to the alteration assemblage associated with sulphide vein formation, but to the earlier $\mathrm{K}$-rich metasomatism developed throughout the footwall rocks of the North Range. This biotite may subsequently be replaced by chlorite, probably as a result of alteration associated with the sulphide mineralizing event.

Quartz is concentrated along the edge of, and up to several centimetres into, the sulphide veins as individual grains and as recrystallized mosaics that display sharp optical extinction. Quartz- grain margins are typically irregular, containing abundant, micron-sized inclusions of the mineral with which they are in contact. Acicular amphibole is common in quartz within sulphide veins. Quartz is also found as inclusions in, and along the margins of, sulphide veins in rocks that do not normally contain quartz as part of their original mineralogy, indicating that quartz deposition occurred during footwall alteration and mineralization.

Where magnetite occurs near Cu-rich veining or quartz + K-feldspar metasomatism it is unstable, revealed by broken grain margins and contacts along ilmenite oxy-exsolution lamellae. Ilmenite may grow as more stable grains adjacent to or over the unstable magnetite. Rarely the magnetite is replaced by chalcopyrite. 
Albite crystals occur within sulphides at vein contacts. Such albitization has affected all original plagioclase as part of the alteration process. In addition, feldspar grains adjacent to the main alteration selvage are typically dusty due to the development of a variety of minute inclusions, including clay minerals.

Calcite is compositionally pure and occurs as inclusions in, and as part of selvages along, chalcopyrite-rich veins. It also locally occurs as the dominant mineral at terminations of sulphide veins.

\section{ii. Diatexite and Gneissic Host Lithologies}

Alteration mineralogy associated with Cu-rich mineralization in footwall gneisses and diatexites is similar to that developed in SDBX, but displays slightly different textural relationships. The most notable difference is the much larger grain size variation, locally from $0.1 \mathrm{~mm}$ to $>1 \mathrm{~cm}$ in length, attained by amphibole, epidote and quartz (Plate 3-2). Dark green alteration halos may be up to $15 \mathrm{~cm}$ wide.

The granoblastic plagioclase in the footwall diatexites and gneisses is relatively fresh away from the alteration, or slightly saussuritized. This suggests that the alteration assemblages associated with ore development in the Onaping-Levack-Morgan area are not the result of regional metamorphism.

\section{iii. Mafic Host Lithologies}

Mafic host rocks are altered to amphibole-, chlorite- and epidote- rich alteration assemblages. 


\section{3-2b. MINERALOGY OF SULPHIDE VEINS}

The Cu-rich sulphides at Strathcona, McCreedy West and Barnet occur as massive veins, veinlets and disseminations. A summary of mineralogy from each location is given in Table 3-2. Thin section examination has shown that the sulphides have replaced alteration minerals at the sulphide-silicate boundary. They overgrow epidote, quartz, amphibole and albite, and commonly invade amphibole along cleavage traces and grain boundaries. Cowan (1968; pg.51) also suggested this order of events for sulphide stringers at Strathcona Mine, where "the first stage was the introduction of an iron-calcium-rich metasomatic fluid which produced a zone of alteration in and adjacent to the fractures" leading to quartz + epidote alteration, followed by the emplacement of the sulphides.

Locally alteration minerals (especially quartz and epidote) and sulphides appear to have precipitated together. Where sulphides have grown with alteration minerals, such as epidote, the silicate contains numerous irregularly shaped sulphide inclusions that make the host mineral appear translucent in transmitted light microscopy.

The dominant sulphide is chalcopyrite, with variable amounts of cubanite. pentlandite, pyrrhotite and minor pyrite. Millerite and bornite are most common in the distal extensions of the large vein systems (Plates 3-3a and b).

Magnetite, and less commonly ilmenite, is best developed near vein margins and is commonly replaced by chalcopyrite and cubanite along grain edges. 
Cubanite, before the discovery of the Copper and Deep Copper zones at Strathcona, was only found with calcite in fracture-fillings in mafic norite and was believed to have been deposited by hydrothermal fluids (Cowan, 1968).

Veins may be zoned in Deep Copper and Copper zones from chalcopyrite/cubanite to magnetite- and pentlandite- rich bands parallel to vein margins. Millerite is found in this type of banding most commonly at McCreedy West.

Disseminated sulphides are ubiquitous in most strongly developed alteration selvages and extend into the host rock. Halos of very fine-grained chalcopyrite disseminations extend into the host rock and its alteration for up to several millimetres even around chalcopyrite-rich veinlets.

A wide variety of accessory minerals and PGM, dominantly Pt- and Pdrich bismuthides and tellurides, have been identified in the Strathcona Deep Copper and McCreedy West orebodies (Cabri and Laflamme, 1976; Springer, 1989; Watkinson, 1990; Li and Naldrett, 1992). Additional investigations of PGM from the Barnet Property, Strathcona's Deep Copper and Copper zones, and McCreedy West are presented in Chapter 5. Other trace minerals in footwall vein sulphides include sphalerite $(\mathrm{ZnS})$, galena $(\mathrm{PbS})$, Se-bearing galena $([\mathrm{Pb}, \mathrm{Se}] \mathrm{S})$, altaite $(\mathrm{PbTe})$ and parkerite $\left(\mathrm{Ni}_{3}[\mathrm{Bi}, \mathrm{Pd}]_{2} \mathrm{~S}_{2}\right)$. Ferro-tantalite was identified by SEM-EDS in one sample of quartz inclusions in chalcopyrite.

\section{3-2c. MINERAL CHEMISTRY}


Silicate, oxide and carbonate mineral analyses and analytical methods are presented in Appendix IV. Alteration mineral chemistry from Barnet and the adjacent INCO Wedge, and the Deep Copper Zone, were compared with those from Strathcona's Copper Zone and McCreedy West Cu-rich stringers to attempt to identify compositional characteristics specific to individual locations and host lithologies.

\section{i. Epidote}

All analyzed epidotes from Barnet, except those from sample CFA-052, were part of a metasomatic assemblage with K-feldspar and quartz (Table 3.3). Similar occurrence of analyzed epidote in samples CFA-052 and CFA-006 as fine-grained alteration halos on blebs and veinlets of chalcopyrite-rich sulphides has resulted in their similar pistacite (Ps in \%) components. This alteration epidote contains much higher Ps (\%) contents than metasomatic epidote.

Epidote commonly has overgrowths that are visible microscopically but that are diificult to distinguish chemically. All Barnet samples have rims enriched in $\mathrm{Si}$ and $\mathrm{Ti}$, and cores enriched in $\mathrm{Ca}$; $\mathrm{Mn}$ contents were only enriched in rims with high $\mathrm{Fe}$ contents. Electron microprobe traverses across Barnet metasomatic epidote show general decreases in Ps (\%) content at their cores (Appendix IV). Although rim Ps (\%) contents tend to be higher, they show considerable variation, possibly due to late-stage $\mathrm{fO}_{2}$ fluctuations in the metasomatizing fluid. Deep Copper Zone epidotes have cores enriched in $\mathrm{Ca}$, and, except for one sample (S39-K631) occurring with quartz and millerite, have 
rims with higher Fe. Ps (\%) values are much higher than those reported for a limited number of analyses by Li and Naldrett (1993d). In general, alteration epidotes from all deposits have higher Ps (\%) and a more narrow compositional range than early metasomatic epidote (Figure 3-2). The consistently higher $\mathrm{fO}_{2}$ of the hydrothermal fluid resulted in higher $\mathrm{Fe}^{3+}$ substitution in the site normally occupied by $\mathrm{Al}^{3+}$. McCreedy West epidote analyses show broad compositional variation from different mine levels and within the same level. All epidotes show a broad range of Ps component within and between deposits, from 23.9 to 30.3 $\%$. The sample from Copper Zone has very high Al contents, yielding much lower Ps content (20.2\%).

\section{Allanite}

Detailed analyses of a large ( $1 \mathrm{~mm}$ long), partially resorbed, allanite crystal with oscillatory zoning in sample CFA-92-3 from Barnet were completed. The pattern of compositional zoning corresponds to strong variation in $\mathrm{Cl}$ and $\mathrm{Th}$ contents. SEM photomicrographs show the various zones and the analyzed line scans (Appendix IV). The occurrence of $\mathrm{Cl}$-rich zones within the allanite suggests that REE were mobile in $\mathrm{Cl}-$ rich fluids during the metasomatizing event. Allanite was also identified in epidote + quartz alteration associated with Cu-rich veining at Deep Copper Zone. Jago et al. (1994) reported allanite in Curich orebodies at Victor Deep and McCreedy East.

\section{ii. Amphibole}


Primary amphiboles from unaltered footwall gneisses and migmatites have not been analyzed. Optical properties suggest that they are hornblendes. Amphiboles are dominantly actinolite, but ferro-actinolite and, in McCreedy West, ferro-hornblende also occur (Table 3-5a; Figure 3-3). One analyzed sample from the Deep Copper Zone is hastingsite and has extremely high halogen contents ranging from 1.53 to $3.56 \mathrm{wt} . \% \mathrm{Cl}$ and from 0 to $1.01 \mathrm{wt} . \%$ F. This hastingsite is intergrown with sphalerite inclusions near the margin of a chalcopyrite-rich vein. In other samples, predominantly those with sphalerite along the chalcopyrite-rich margins, hastingsite has been identified by its characteristic blue-green pleochroism (Plate 3-4). Li and Naldrett (1993d) reported ferro-tschermakitic hornblende from Deep Copper Zone alteration with between 0.86 and 2.99 wt. \% Cl. In all cases, coexisting low-Al actinolite also occurs along the vein margins and in the altered host rock. For all actinolitic amphiboles, $\mathrm{Cl}$-contents are seldom above detection limits, even for amphibole spatially associated with a $\mathrm{Ag} / \mathrm{AgCl}$ intergrowth in bornite (sample STN-4; see Chapter 6) from the Deep Copper Zone suggesting that variations in $\mathrm{Cl}$ content in amphibole was not likely to have been the result of variations in $\mathrm{Cl}$ activity in the fluid. Actinolite analyzed by Li and Naldrett (1993d) also contained little or no $\mathrm{Cl}$.

Leake (1978) suggested that igneous amphiboles have a maximum Si per formula unit content of 7.3. Chivas (1981) and Hendry et al. (1985) proposed that actinolitic amphibole with Si p.f.u. contents of $>7.3$ crystallized under 
subsolidus conditions in the presence of fluid at high $\mathrm{fO}_{2}$. All actinolitic amphiboles analyzed in this study contain $>7.3$ p.f.u. Si and are considered to have formed under similar conditions.

The occurrence of coexisting $\mathrm{Cl}$-rich hastingsitic and $\mathrm{Cl}$-poor actinolitic amphiboles has been documented in hydrothermally altered metasandstones, metabasites and veins at depths between $3100 \mathrm{~m}$ to $3180 \mathrm{~m}$ and temperatures above $350^{\circ} \mathrm{C}$ in the Salton Sea geothermal system (Enami et al., 1992). It has been suggested that coexisting actinolitic and hastingsitic amphiboles represent a miscibility gap in the calcic amphibole series (Cooper and Lovering, 1970; Tagiri, 1977; Maruyama et al., 1983; Ishizuka, 1985; Enami et al., 1992) that becomes narrower with increasing Mg-content. Enami et al. (1992) concluded that the $\mathrm{Cl}$-content of calcic amphibole is crystal chemically controlled by $\mathrm{X}\left(\mathrm{Fe}^{2+}\right)$ and the proportion of the edenite component $\left\{{ }^{[\mathrm{A}]}(\mathrm{Na}, \mathrm{K}){ }^{[4]} \mathrm{AI} \square_{-1} \mathrm{Si}_{-1}\right\}$. Table 3-5b represents a comparison of coexisting actinolitic and hastingsitic amphibole from the Salton Sea geothermal system and compositionally similar amphiboles from the Deep Copper Zone that formed under similar temperature and pressure conditions.

Primary $\mathrm{Cl}$-rich magnesio-hastingsite and secondary $\mathrm{Cl}$-poor actinolite occur in the Salt Chuck Cu-PGE deposit in Alaska. The actinolite is considered to have formed in the presence of a highly oxidized, $\mathrm{C}-\mathrm{O}-\mathrm{H}-\mathrm{S}-\mathrm{Cl}$-bearing fluid associated with sulphide and PGE remobilization (Watkinson et al., 1991). It is possible that $\mathrm{Cl}$ in the fluid was complexed entirely with $\mathrm{Cu}, \mathrm{PGE}, \mathrm{Ca}, \mathrm{Na}$, etc.. 
and was not available for secondary actinolite crystallization (Watkinson et al., 1991).

In each of the Sudbury, Salton Sea and Salt Chuck examples, the hastingsitic amphibole and ferro-tschermakite are $\mathrm{Cl}$-bearing, suggesting that these compositional structures, including higher Al content, may accomodate the substitution of halogens for $\mathrm{OH}$ more readily than actinolite. Coupled substitution of $\mathrm{Al}^{3+}$ into tetrahedral sites and $\mathrm{Fe}^{3+}$ in octahedral sites (Ito and Anderson, 1983), increase in the abundance of large octahedral cations (Volfinger, 1985), and higher temperatures (Vanko, 1986) have all been suggested as factors that result in higher $\mathrm{Cl}$ contents in amphiboles.

Ni-bearing amphiboles have been identified in some Deep Copper Zone samples. The highest values (average $0.70 \mathrm{wt} . \% \mathrm{NiO}$ ) were encountered in a Deep Copper Zone sample coexisting with chlorite and millerite. These values are not the result of minute $\mathrm{Ni}$-sulphide inclusions as no $\mathrm{S}$ was detected in the analyses and no sulphide inclusions were identified during back-scattered electron inspection. $\mathrm{Ni}$ is incorporated into the $\mathrm{C}$-site in amphiboles that can also accomodate $\mathrm{Al}^{3+}, \mathrm{Cr}^{3+}, \mathrm{Fe}^{3+}, \mathrm{Fe}^{2+}, \mathrm{Ti}^{4+}, \mathrm{Mg}^{2+}$ and $\mathrm{Mn}^{2+}$ (Deer et al., 1985).

Amphiboles from the Deep Copper Zone contain Mg- and Fe-rich compositional domains (Table 3-5a), whereas individual amphiboles from McCreedy West display a more narrow compositional range. Cl-contents in McCreedy West amphiboles are all below detection limits. Like epidote, amphibole compositions vary among and within individual deposits. 


\section{iii. Chlorite}

Most analyzed chlorite is brunsvigite or ripidolite (Table 3-5). Exceptions to this is diabantite occurring with epidote and chalcopyrite from the INCO Wedge. Daphnite with a very high Fe content $(\mathrm{Mg} \#=0.18)$ is found in the analyzed sample from Copper Zone. Analyzed chlorite from McCreedy West has lower Mg \# than chlorite from other Cu-Ni-PGE footwall deposits. Again, there is broad compositional variation among samples from the same deposit.

Ni-bearing chlorite occurs at Barnet $(0.62$ wt. \% NiO) and Copper Zone. In the Copper Zone sample coexisting amphibole is also Ni-bearing.

\section{iv. Less Common Alteration Minerals}

K-feldspar of metasomatic origin from Barnet has no detectable $\mathrm{Na}$, unlike K-feldspar spatially associated with alteration from the Deep Copper Zone (Table 3-6a).

Biotite in recrystallized Sudbury Breccia from the Deep Copper Zone and McCreedy West has variable composition highlighted by Fe and $\mathrm{Mg}$ variation (Table 3-6b). Biotite of pre-ore metasomatic origin from Deep Copper Zone has a higher $\mathrm{Mg} \#(0.31 \pm 0.05)$ than that from ore-related alteration at $\mathrm{McC}$ reedy West $(0.18 \pm 0.02)$. Li and Naldrett (1993d) reported slightly higher $\mathrm{Cl}$ contents (1.31 to 2.13 wt.\%) for Deep Copper Zone annites and have suggested that the percentage of $\mathrm{Cl}$ increases with increased $\mathrm{Fe}$ content. $\mathrm{Cl}$ contents are higher $(0.93 \pm 0.06$ wt. \%) in Deep Copper Zone biotite. 
Magnetite adjacent to $\mathrm{Cu}$-rich veins at McCreedy West is locally altered to ilmenite. As a result, magnetite from $\mathrm{McC}$ reedy West is enriched in $\mathrm{Si}, \mathrm{Ti}, \mathrm{Cr}$ and Mg compared to Copper Zone magnetite (Table 3-6c). The analyzed Copper Zone magnetite is within a chalcopyrite-rich vein and appears to be slightly resorbed, with growth zones identified by biotite ( $\mathrm{Cl}$-rich), chlorite and quartz inclusions.

Pyroxenes of metamorphic origin display different compositions between different deposits (Table 3-6e). The Strathcona Deep Copper Zone pyroxene in Sudbury Breccia may be part of a fragment of unknown origin. It is similar in composition to low Ca pyroxene characteristic of Strathcona Sublayer inclusions (Naldrett et al., 1984). Pyroxene in Levack Gneiss from the McCreedy West mine is more Mg-rich, and is possibly remnant of the granulite grade metamorphic event that affected the footwall rocks.

\section{v. Cl-rich Alteration Minerals}

Other silicates associated with Cu-rich veining include (Table 3-6d) prehnite and stilpnomelane coexisting with a Cl-rich greenalite-like mineral. All but the greenalite-like mineral, which has only been identified in the Deep Copper Zone, have been identified in Deep Copper Zone and McCreedy West Cu-rich stringers. Cl-rich stilpnomelane and greenalite have also been identified in spessartine + biotite + epidote + quartz -bearing assemblages at the contact of the Lindsley Mine 4B Ni-Cu-PGE orebody (Watkinson, 1994). 
Other reported occurrences of $\mathrm{Cl}$-bearing hydrous minerals in footwall orebodies include ferropyrosmalite $\left[(\mathrm{Fe}, \mathrm{Mn})_{8} \mathrm{Si}_{6} \mathrm{O}_{15}(\mathrm{OH}, \mathrm{Cl})_{10}\right]$ at Deep Copper Zone (Li and Naldrett, 1993d), with up to 6.54 wt.\% Cl, Cl-rich grunerite at Victor Deep and McCreedy East (Jago et al., 1994), and Fe-Mn -chloride at Deep Copper Zone (Springer, 1989), Victor Deep and McCreedy East (Jago et al., 1994), and this study (Chapter 6).

Al-rich prehnite occurs with calcite, quartz, epidote, chlorite and chalcopyrite and appears to be late in the paragenetic sequence. Inoue and Utada (1991) reported temperature of formation of these minerals from 200 to $300{ }^{\circ} \mathrm{C}$. Elders et al. (1981) and Cavarretta et al. (1982) reported a range in temperature of 250 to $350{ }^{\circ} \mathrm{C}$ for prehnite-, epidote- and actinolite- bearing assemblages.

\section{3-3. FRASER MINE EPIDOTE ZONE}

\section{3-3a. SUBDIVISION OF THE EPIDOTE ZONE}

The individual alteration masses of the Epidote Zone are typically most intensely altered in their central parts. They may be subdivided into facies identified by one or two "index" minerals that correspond to increasing degrees of alteration and associated changes in fluid composition. These minerals are epidote, amphibole and magnetite (Table 3-7). This subdivision applies only to the Footwall Breccia matrix, because clast compositions are generally more mafic and variable in composition than the matrix, and tend to favour amphibole 
crystallization. It was developed through detailed core logging and sampling (Figures II-1a, b, c and d), inspection of available Falconbridge Limited diamond drill logs (Appendix II) and mapping available underground exposures.

The matrix of the Footwall Breccia is characterized by an igneous and locally granoblastic texture that includes subhedral plagioclase laths with approximately 5 to 35 volume \% interstitial quartz aggregates of variable grain size. Also included are altered clinopyroxene aggregates, amphibole, chlorite, epidote and biotite. The breccia matrix has been interpreted as being dominantly igneous (Pattison, 1979), metamorphic (Greenman, 1970; Pattison, 1979), and recrystallized and metasomatic (Cowan, 1968). It is proposed here that the Footwall Breccia is igneous in origin, since its matrix texture, including grain size and shape of plagioclase and quartz, is significantly different from the granoblastic footwall tonalitic diatexites that display stubby, recrystallized plagioclase crystals with fine grained polygonal quartz aggregates. Local footwall units are the most common clast types, although exotic fragments are also present (Plates 3-5a and b).

Although Footwall Breccia matrix is variable in colour throughout the study area, a pink hue is commonly developed in patches within $10 \mathrm{~m}$ of the contact with the nearest "Epidote Zone" patch. This is attributed to the micrographic intergrowth of quartz and pink K-feldspar that now displays strong alteration to clays, and is the result of metasomatic processes related to intrusion of the Sudbury Igneous Complex. The rest of the matrix is dominated 
by plagioclase that has been almost completely obliterated by clay alteration and interstitial quartz. Few vestiges of unaltered plagioclase remain. Amphibole is the dominant mafic mineral in the matrix, occurring in masses of several $\mathrm{mm}$ sized grains with chlorite, biotite, and less commonly, magnetite and pyrrhotite. Magnetite is replaced by ilmenite along exsolution planes in incipiently-altered Footwall Breccia near Epidote Zone alteration development due to reaction with remobilizing fluids (Plates 3-6a and b). Apatite occurs as an accessory mineral. Intensive epidotization began with the development of patchy epidotization of the matrix, especially around small mafic clasts or disseminated sulphides such as chalcopyrite, pyrrhotite and pyrite (LGBXepdz). Mediumgrained quartz aggregates adjacent to epidote-rich patches and mafic clasts also appear at this stage in the alteration progression. Clast margins are common sites for an increase in the amount of disseminated sulphides. Also associated with the weakly altered Epidote Zone margins are veinlets of fine- to mediumgrained epidote and quartz up to $5 \mathrm{~mm}$ wide. Occasionally these veinlets also contain disseminated chalcopyrite, pyrrhotite and pyrite. Rare, similarly sized veinlets of chalcopyrite also occur. The veinlets tend to envelop the breccia matrix amphibole and plagioclase, resulting in their recrystallization. Plagioclase enveloped by the sulphides is fresh and quartz from the matrix is consumed and does not occur within the chalcopyrite veinlet, whereas epidote is a common inclusion. Saussuritization of plagioclase in the breccia matrix is more pervasive with decreasing distance from the margin of the Epidote Zone, imparting a 
greenish tint to the rock. In thin section, some vestiges of more weakly altered Footwall Breccia remain.

The margin of the main part of the Epidote Zone is relatively sharp, $<1 \mathrm{~cm}$ thick, and is commonly marked by an increase in quartz content, intergrown with fine- to coarse-grained epidote as a band or vein $<40 \mathrm{~cm}$ thick. The contact itself is defined by $>50 \%$ pervasive epidote alteration of the Footwall Breccia matrix (EPDZ). Quartz disappears with increasing proximity to the centre of the zone and massive epidote with accessory titanite is the dominant rock type (Plates 3-7a and b). At this point relict Footwall Breccia matrix textures have been modified, although clasts $>2 \mathrm{~cm}$ in diameter are identifiable as rounded masses of amphibole and less commonly epidote. Sulphides that occur in this part of the alteration progression are typically associated with the relict amphibole-rich clasts as blebs and disseminations or as concentrations along clast margins.

Toward the centre of the alteration zone elongate blades of actinolite are more abundant (EPDZact). Actinolite increases in abundance as bands that envelop the amphibole-rich clasts or as contorted layers within the dominantly medium-grained epidote. Although rare, optically continuous quartz surrounds epidote and amphibole, much like it surrounds stubby plagioclase laths in Footwall Breccia. As actinolite content increases, there is a concomitant increase in sulphide content. Sulphide growth is largely confined to grain boundaries and actinolite cleavage. Amphibole content increases with 
increasing alteration until it becomes the dominant mineral in the rock matrix (ACTZ). The rounded Footwall Breccia clast-like shapes are rarely visible at this degree of alteration and the sulphides occur as blebs, stringers and veinlets of pentlandite with minor pyrite up to $3 \mathrm{~cm}$ wide that form complex intergrowths with actinolite (Plates 3-8a and b). In general, timing relationships between epidote and amphibole are difficult to determine. However, in EPDZact and ACTZ, epidote appears to be later than amphibole and overgrows it. Sulphides are the latest phases in these facies.

The most intense alteration associated with the "Epidote Zone" patches is the development of magnetite-rich patches within their central parts. The magnetite initially occurs as fine-grained disseminations and aggregates $<1 \mathrm{~cm}$ in diameter within epidote- and actinolite-rich parts of the centre of the zone and may form 2 to $3 \mathrm{~mm}$ wide selvages on large (>1 $\mathrm{cm}$ wide) pentlandite blebs (EPDZmag and ACTZmag). Magnetite content increases sharply as patches and irregularly oriented stringers until it comprises between 20 and $60 \%$ of the rock within $1 \mathrm{~m}$ of its initial occurrence as disseminations (MAGZ). Magnetite forms at the expense of both epidote and actinolite until, at its maximum development, it forms up to $80 \%$ of the rock (Plates 3-9a and b). Pentlandite is retained as the main sulphide in the assemblage, forming $3 \mathrm{~cm}$ wide blebs and stringers, that comprise most of the rest of the rock.

Calcite is the last mineral to join the alteration assemblage. Calcite-rich parts of the Epidote Zone show resorbed magnetite and a late generation of 
euhedral to subhedral amphibole growth. The introduction of calcite to the assemblages represents a major change in fluid composition and its ability to carry metals.

Trace minerals identified in the Epidote Zone are baddelyite, monazite, barite and $\mathrm{Cr}$-bearing epidote. The implications from their occurrence are the mobility of elements such as $\mathrm{Zr}$ and REE, traditionally considered to be relatively immobile.

An idealized section through an "Epidote Zone" patch is shown in Figure 3-1. Exceptions to the idealized zonation pattern are common as revealed in the underground exposures of Epidote Zone (e.g. Figure 1-5), where the zones are not always present although magnetite-rich central facies do exist. Of interest is the control large mafic (MGN) clasts within the Footwall Breccia have had on the degree and location of alteration. This is displayed on the $S$ wall of exposed Epidote Zone shown in Figure 1-5. Three large clasts form a barrier between relatively unaltered to weakly altered Footwall Breccia and EPDZ. Within the zone an elongate clast of MGN outlines the contact between EPDZ and more intensely altered ACTZ. A parallel may be drawn between this and, on a larger scale, the concentration of mafic and ultramafic rocks in the footwall at the base of the Epidote Zone-bearing Footwall Breccia. In addition, surface mapping and drilling have shown that the contact between the footwall and Footwall Breccia is locally marked by mafic and ultramafic units (Chapter 2 ). 
Further evidence to the limited permeability of these mafic-ultramafic units occurs in drill core, where adjacent well developed Epidote Zone alteration extends no more than $75 \mathrm{~cm}$ into mafic gneiss or metagabbro. Optically continuous quartz has also been identified as enclosing epidote grains in altered metagabbro (MGABepdz). Epidote Zone alteration is also weakly developed where in contact with more mafic, Sublayer-like, breccia.

\section{3-3b. ORE MINERALOGY}

A trend to a decrease in chalcopyrite content and the development of a $\mathrm{Ni}$-rich, pyrite- and pentlandite-dominated sulphide mineral assemblage is characteristic of Epidote Zone development with increased alteration. This trend is disrupted with the addition of large amounts (>20\%) of magnetite to the alteration assemblage.

Sulphide minerals in the Epidote Zone occur as disseminations, blebs, stringers and veinlets of pentlandite with less common, later-formed pyrite. Chalcopyrite is rare within the Epidote Zone, although it occurs in Footwall Breccia ore throughout the North Range as part of the main sulphide assemblage with pyrrhotite, and in barren Footwall Breccia as veinlets. However, even in incipiently altered Footwall Breccia pyrite may replace chalcopyrite. In magnetite-rich Epidote Zone, chalcopyrite, although still rare, occurs more commonly than in the actinolite-dominated facies. Chalcopyrite is typically only found within Epidote Zone alteration as inclusions from 0.1 to 2 $\mathrm{mm}$ in diameter within pyrite (Plate 3-10a). Pentlandite masses overgrow both 
epidote and amphibole, commonly along cleavage planes in amphibole and along grain boundaries. It also occurs as inclusions in alteration minerals. Pentlandite and pyrrhotite are ubiquitously unstable with subhedral pyrite recrystallization. In clots dominated by sulphide minerals, silicates include masses and anhedral individual grains of epidote and elongate amphibole. Pyrite is the latest sulphide mineral in the assemblage, forming mm-sized subhedral to euhedral grains. It commonly overgrows pentlandite and chalcopyrite. Although minute Se-bearing galena inclusions are common in pyrite, they also occur in magnetite in one sample (Plate 3-10b). Pb and $\mathrm{Se}$ may have been liberated by the breakdown of pentlandite. These trace metals were subsequently incorporated as inclusions into pyrite.

\section{3-3c. MINERAL CHEMISTRY}

\section{i. Epidote}

Most electron microprobe analyses of epidote from samples displaying EPDZ alteration levels or more have Pistacite contents of $>30 \%$, which are greater than those displayed by epidote from Cu-rich vein alteration (Table 3-7). The two EPDZ samples show different characteristics, one with low Ps (28.2) and the other high (31.9). The variable nature of EPDZ epidote mimics the differing geochemical characteristics of the EPDZ (see Chapter 4). Except for sample F46-4Ei, epidote tends to have cores enriched in Fe and Ti. Rim compositions are enriched in Si. Only one sample (F46-3C1) from all analyzed 
epidote, including epidote from $\mathrm{Cu}$-rich vein alteration, contained $\mathrm{Ni}$. Both $\mathrm{F}$ and

$\mathrm{Cl}$ contents are commonly below detection limits.

ii. Amphibole

Amphibole from both relatively unaltered Footwall Breccia and Epidote Zone is dominantly actinolite (Table 3-9). Amphibole from the most intensely altered Epidote Zone (>EPDZ) is ferro-actinolitic and actinolitic with lower $\mathrm{X}_{\mathrm{Mg}}$. Epidote Zone amphibole has a much more limited range of composition compared to those in alteration associated with $\mathrm{Cu}$-rich veins, reflecting a more limited range of original rock composition (all Footwall Breccia) and fluid composition. For example, amphibole from an unusual occurrence of altered ultramafic rock within Epidote Zone alteration (sample FR46-150-13) is tremolitic to actinolitic $\left(X_{M g}=0.93 \pm 0.03\right)$. However, second generation amphibole with calcite (sample FR46-287-7) is compositionally similar to other amphibole in the Epidote Zone, but contains slightly more $\mathrm{K}$ and is strongly zoned. Several samples from different degrees of alteration show $\mathrm{Mg}$ - and Fe-rich compositional domains. Amphibole is Ni-bearing in every alteration facies, but there is no detectable $\mathrm{Ni}$ in amphibole from the altered ultramafic rock.

\section{iii. Less Common Alteration Minerals}

Chlorite in the Epidote Zone is dominantly brunsvigite (Table 3-10a). $\mathrm{X}_{\mathrm{Mg}}$ of chlorite in the ACTZ facies is lower $(0.09$ to 0.14$)$ than those in Footwall Breccia (0.49). However, chlorite developed in mafic and ultramafic footwall units at the base of the Epidote Zone is penninite and has very different overall 
composition than chlorite from the Epidote Zone (Appendix IV). This suggests that these chlorites are the result of different host rock lithologies interacting with the Epidote Zone-forming fluids or that they are the result of retrograde metamorphism. The first possibility is unlikely in light of the fact that the rest of the rock, including plagioclase, does not appear to have been affected by the Epidote Zone-related fluids. Halogen contents are relatively low in all analyzed chlorites.

Titanite analyses do not show compositional variations with changes in alteration intensity (Table 3-10b). Halogen contents are seldom above detection limits.

Although pristine, completely unaltered Footwall Breccia has not been encountered during the course of this study, composition of plagioclase of unaltered breccias is between $A n_{32}$ to $A n_{45}$ (Greenman, 1970; Coats \& Snajdr, 1984). Since feldspars are not part of the alteration assemblage within the well developed Epidote Zone, analyses are limited to altered Footwall Breccia along Epidote Zone margins. All analyzed feldspars are albitic (approximately $\mathrm{Ab}_{99}$; Table 3-10c).

Magnetite from the Epidote Zone is stable and very pure when compared to the resorbed magnetite analyzed from Cu-rich footwall deposits (Table 3-10d). By comparison, McCreedy West magnetite contains significant amounts of $\mathrm{Si}$, $\mathrm{Ti}$, $\mathrm{Cr}, \mathrm{Al}, \mathrm{Mn}$ and $\mathrm{Mg}$, and those from Strathcona's Copper Zone contain considerable Al. 
Stilpnomelane commonly occurs in sulphide-rich parts of the Epidote Zone. The higher Fe content for the ACTZ sample than that of the EPDZact sample mimics the epidote trend to higher $\mathrm{Fe}^{3+}$ content with increased degree of alteration (Table 3-10e).

Only one sample from the Epidote Zone was found to contain garnet (Table 3-10f). However, garnets have also been identified at Lindsley Mine (Watkinson, 1994) and in ore contacts at McCreedy East (Jago et al., 1994). Not surprisingly, the Epidote Zone garnet is dominantly andradite. In contrast, those from the Lindsley Mine and McCreedy East are spessartine garnets.

\section{3-4. DISCUSSION}

\section{3-4a. MINERAL CHEMISTRY}

Epidote, amphibole and chlorite compositions from alteration associated with $\mathrm{Cu}$-rich sulphide veins vary between and within individual deposits. However, epidote does show $\mathrm{Fe}^{3+}$-content variations reflective of alteration intensity in the Epidote Zone. Amphibole compositions do not mimic this trend. 3-4b. NATURE OF THE FLUID: PETROGRAPHIC IMPLICATIONS

\section{i. Cu-rich Veins}

Watkinson (1990) suggested that PGM- and Cu-rich mineralization in some North American deposits was formed as the result of the reaction of metaltransporting saline fluids with primary minerals to produce the hydrated and slightly oxidized phases such as Fe-rich epidote. The alteration and $\mathrm{Cl}$-bearing phases associated with Cu-rich veins in the North Range investigated as part of 
this study, and those of Li and Naldrett (1993d) and Jago et al. (1994), support this hypothesis. Zonation within epidote and distinct compositional domains within amphibole suggests a sequence of pulsing alteration, resorption and precipitation.

\section{ii. Epidote Zone}

The breakdown of magnetite marginal to the well developed alteration patches in weakly altered Footwall Breccia suggests that the original fluid that reacted with pristine Footwall Breccia may have been reducing, perhaps buffered by the existing sulphides. However, the increase in $\mathrm{Fe}^{3+}$-content in the Epidote Zone with increased alteration suggests that the fluids involved in Epidote Zone formation became more oxidized as they reacted with the Footwall Breccia. The oxidized fluids apparently carried metals, such as $\mathrm{Cu}$, out of the Epidote Zone. This trend continued until the development of magnetite-rich zones. The precipitation of calcite signalled a reduction and possible $\mathrm{pH}$ increase of the fluid, causing $\mathrm{Cu}$ solubility to drop. This explains the slight increase in chalcopyrite content in very magnetite-rich zones where calcite precipitation was in its incipient stages.

Figure 3-6 is an inferred phase diagram of $\log \mathrm{fO}_{2}$ vs. the $\log$ of the sum of the activities of the sulphur species $\left(\log \sum \mathrm{S}\right)$ for the system $\mathrm{Fe}-\mathrm{Ni}-\mathrm{S}-\mathrm{O}-\mathrm{H}$ for $200 \mathrm{MPa}$ and $300^{\circ} \mathrm{C}$ from Frost (1985). Due to the lack of thermochemical data for pentlandite, Frost (1985) showed its stability field schematically, as determined from a variety of petrologic information. Because of the possible 
recrystallization of sulphides, and the fact that the stability field of pentlandite was determined using information from serpentinite development, the absolute fugacity values are not reliable, although the fluid gradients will still be valid.

Petrographic observations about the sulphide assemblages in the Epidote Zone have been projected onto a $\log \mathrm{fO}_{2}$ vs. $\log \sum \mathrm{S}$ phase diagram in figure 3-6. The trend is similar to the path followed by fluids involved in the metamorphism of ultramafic rocks. The early sulphide assemblage included pyrrhotite and pentlandite (field 1 in figure 3-6). The instability of these phases with the development of magnetite and pyrite suggests an increase in $\mathrm{fO}_{2}$ and possibly of $\mathrm{S}_{2}$ (field 2). The discovery of sulphate accidental inclusions in fluid inclusions (Chapter 6) in the Epidote Zone suggests that the fluid extended from the field of pyrite stability above the sulphate - sulphide fence (field 2+). With the appearance of calcite, magnetite became unstable and pyrite was established as the dominant sulphide mineral. A variety of fluid compositional changes may be responsible for the move into the pyrite stability field. These include a decrease in $\mathrm{fO}_{2}(3 a)$, or a decrease in $\mathrm{fO}_{2}$ with an increase in $\sum \mathrm{S}(3 \mathrm{~b})$. Petrographic observations suggest that either is possible.

Similar observations from the Epidote Zone have been plotted onto a log $\mathrm{fO}_{2}$ vs. $\mathrm{pH}$ diagram showing sulphide and oxide stabilities in the system $\mathrm{Fe}-\mathrm{S}-\mathrm{O}$ $\mathrm{H}$. It shows that the early stable sulphide assemblage of pentlandite and pyrrhotite (field 1) was consumed by the development of stable pyrite and magnetite, suggesting an increase in $\mathrm{fO}_{2}$ and little change or a decrease in $\mathrm{pH}$ 
(field 2). The higher PGE content of magnetite-bearing facies in the Epidote Zone indicates that a decrease in $\mathrm{pH}$ to as low as 3 or 4 is likely to have occurred (see Discussion, Chapter 4). With the appearance of calcite, magnetite became unstable and pyrite remained as the dominant sulphide. Three possible changes in fluid composition, including a decrease in $\mathrm{fO}_{2}$ (field $3 a)$, decrease in $\mathrm{pH}(3 \mathrm{~b})$, and a combination of both a decrease in $\mathrm{fO}_{2}$ and in increase in $\mathrm{pH}(3 \mathrm{c})$ are superimposed on the diagram. The stability of calcite and the fluid compositional trends shown in Figure $3-6$ suggest that $3 c$ is the most likely of these possibilities.

The numerous inclusions of trace metal minerals such as Se-bearing galena and PGM in pyrite is the result of their precipitation in response to chemical changes in the fluid (Chapter 5). These trace metals may have been released into the fluid during the destruction of pyrrhotite and pentlandite. 


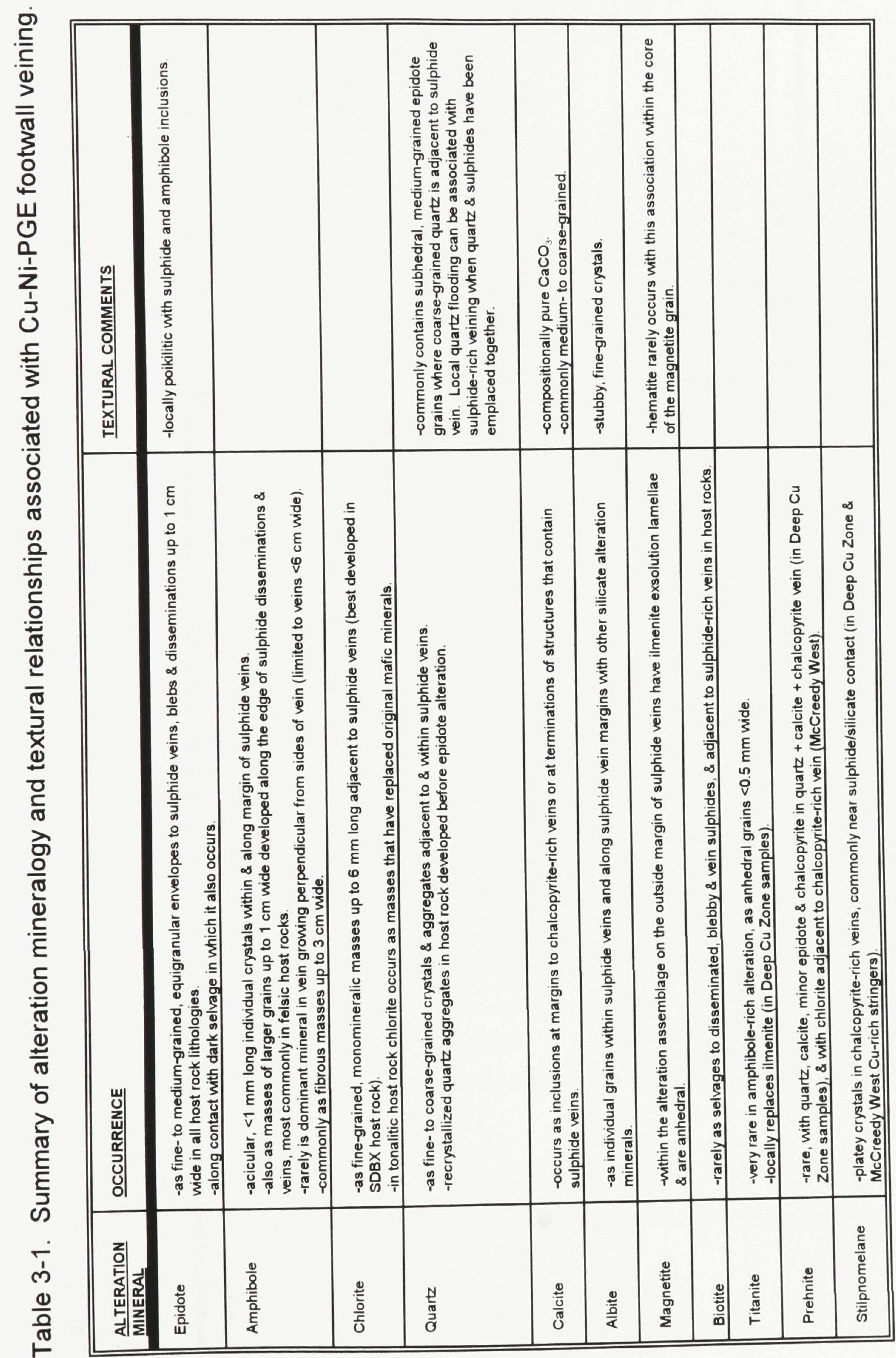




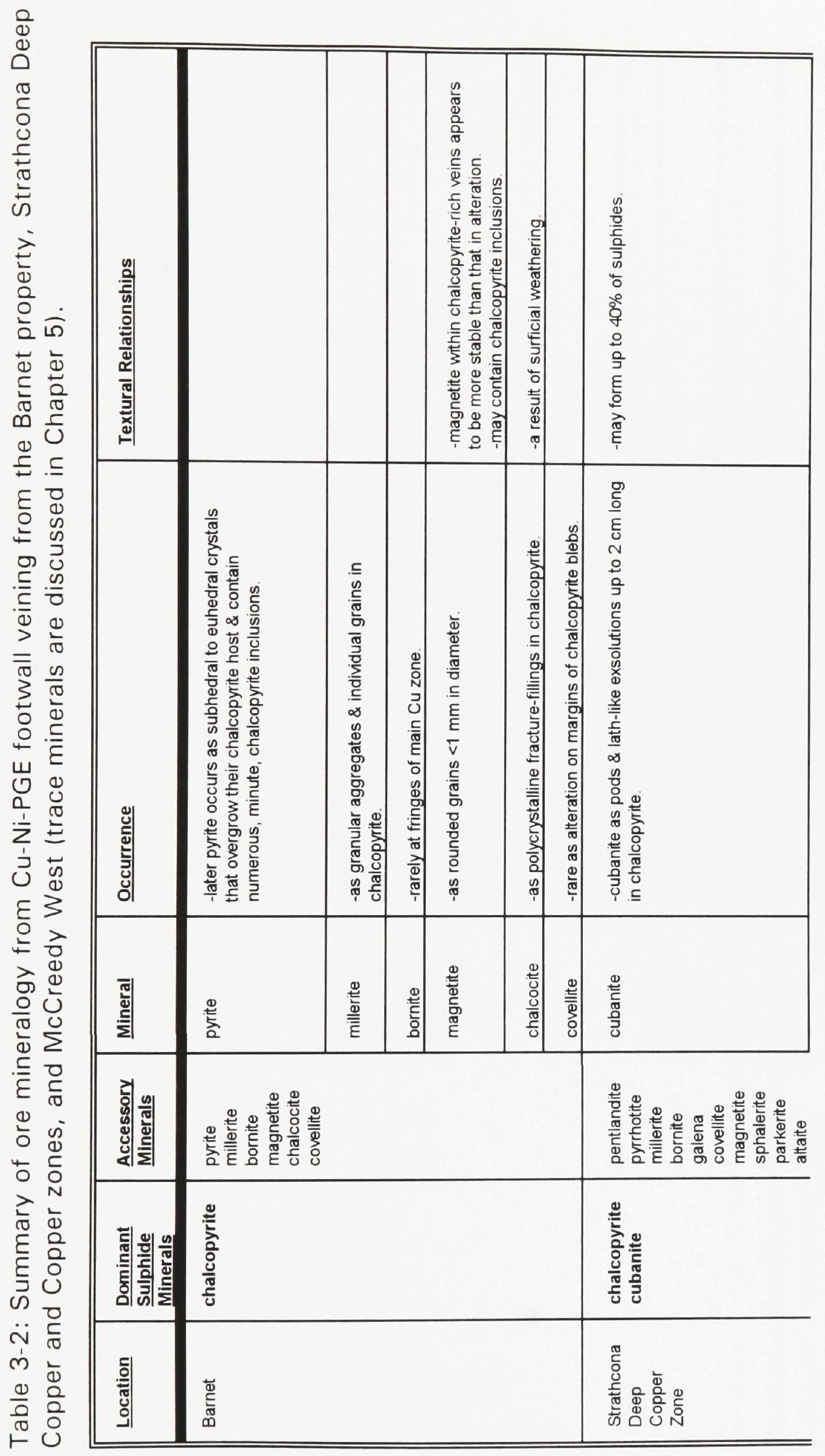

ำ 


\begin{tabular}{|c|c|c|c|c|c|c|c|c|c|}
\hline 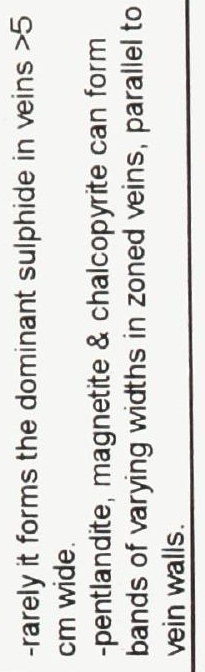 & 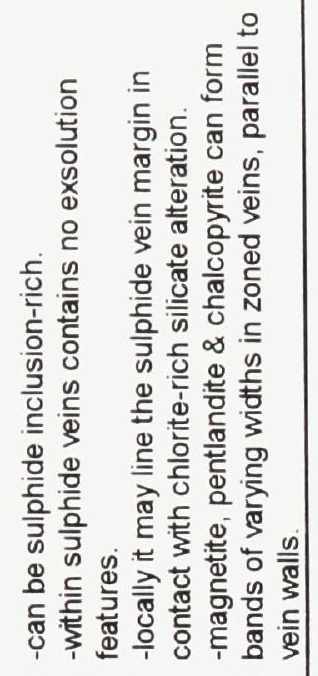 & & 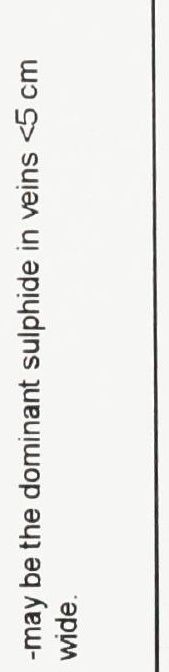 & 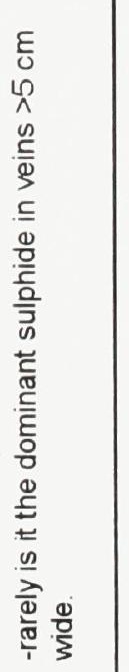 & & & & & \\
\hline 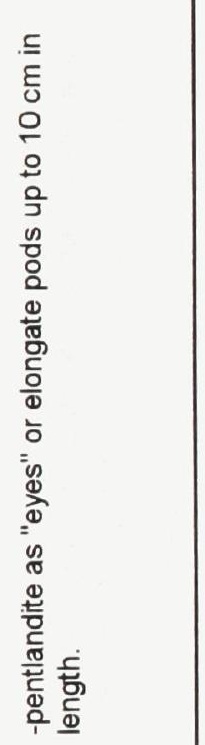 & 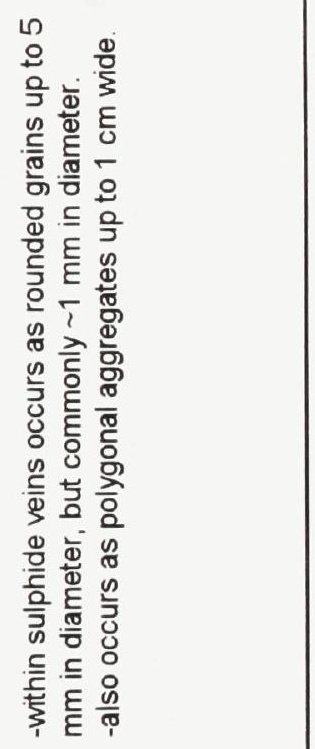 & 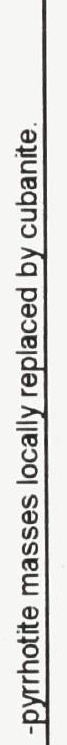 & 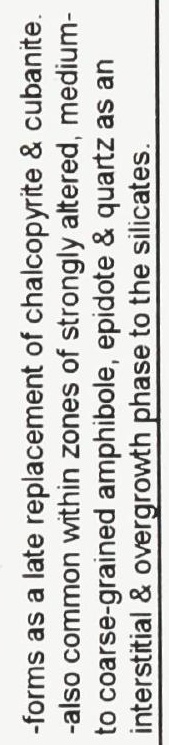 & 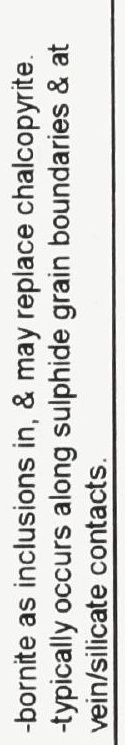 & 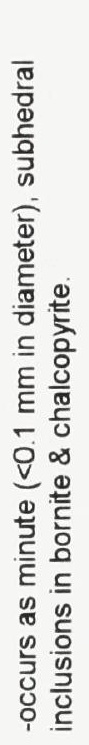 & 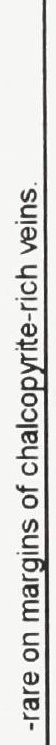 & 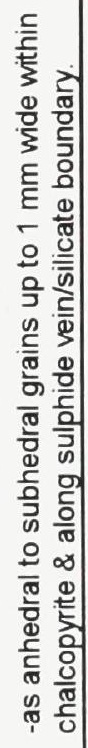 & 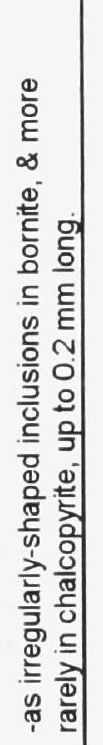 & 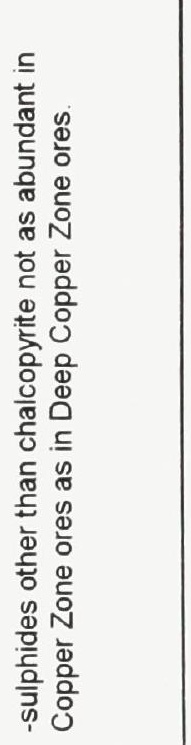 \\
\hline \multirow[t]{4}{*}{ 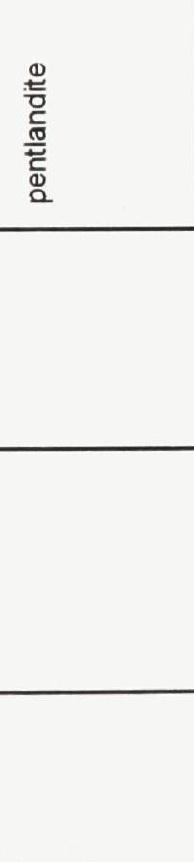 } & 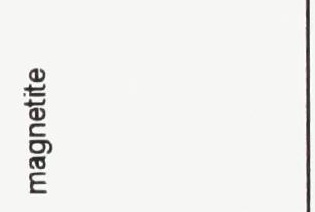 & 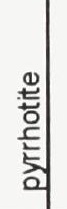 & 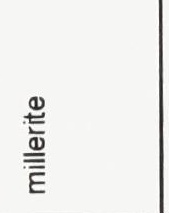 & 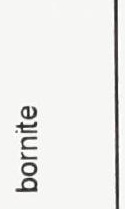 & 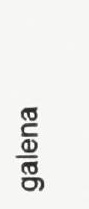 & 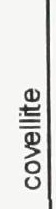 & $\begin{array}{l}\frac{0}{5} \\
\frac{0}{\frac{0}{\pi}} \\
\frac{5}{0} \\
\frac{0}{0}\end{array}$ & 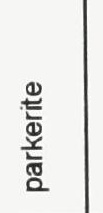 & 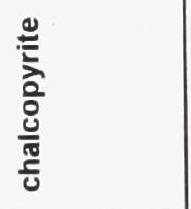 \\
\hline & & & & & & & & & 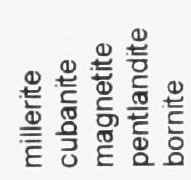 \\
\hline & & & & & & & & & 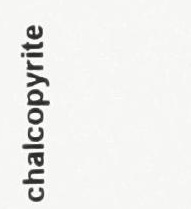 \\
\hline & & & & & & & & & 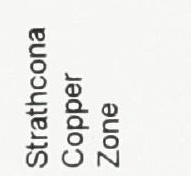 \\
\hline
\end{tabular}

으 


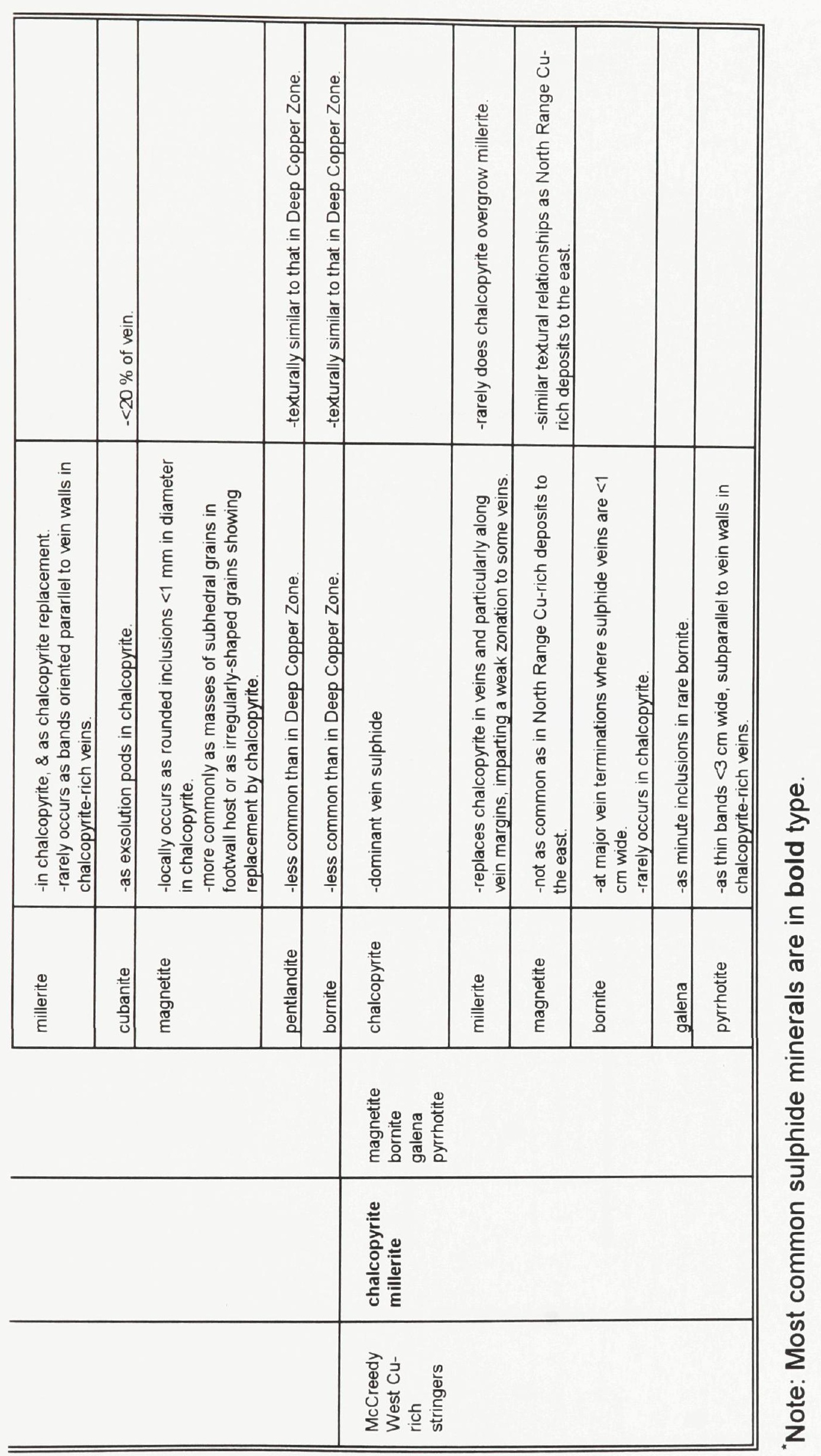


Table 3-3: Sulphide mineral paragenetic sequence in Cu-rich sulphide veins.

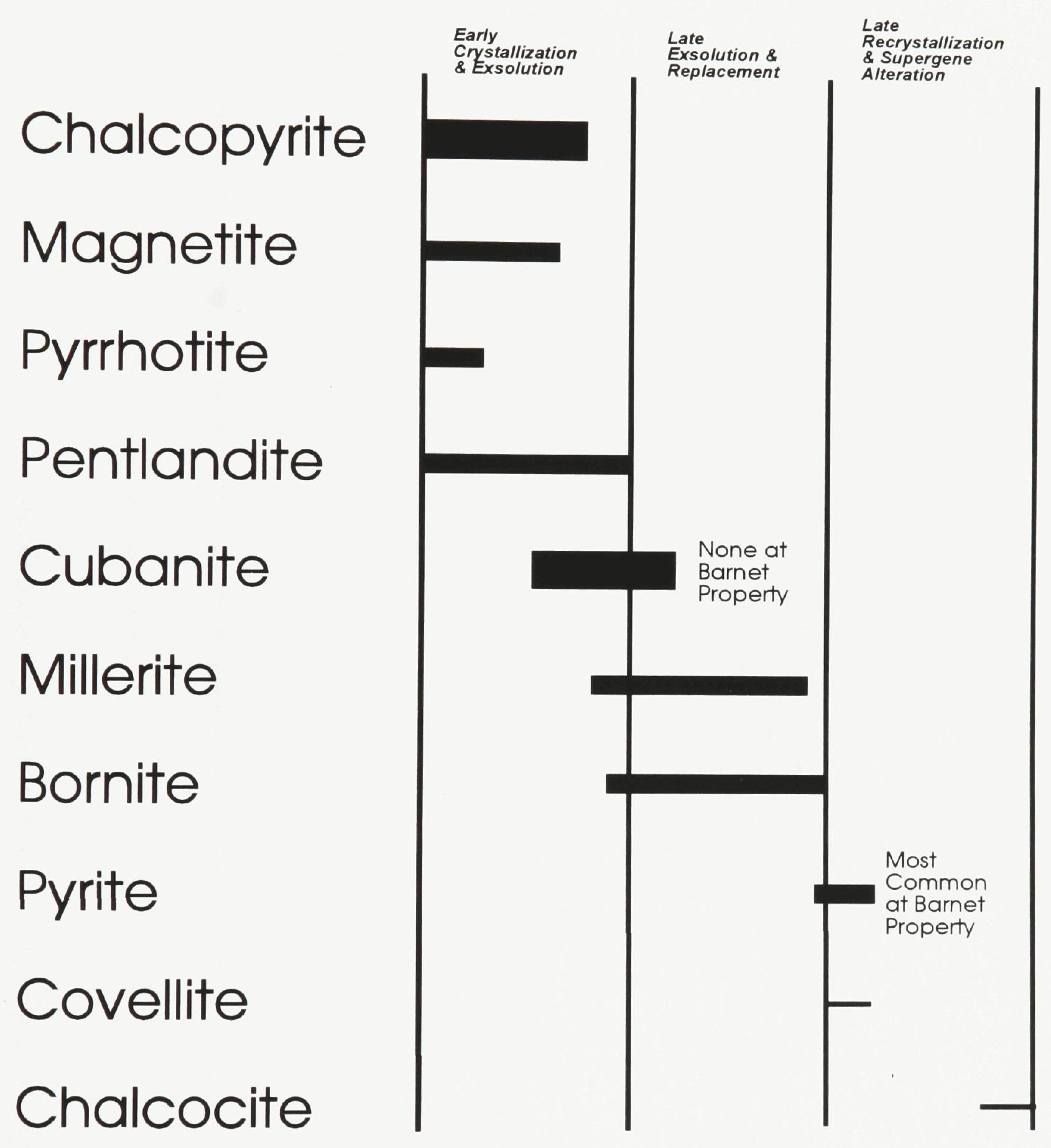

Note: Bar thickness corresponds to mineral abundance. 


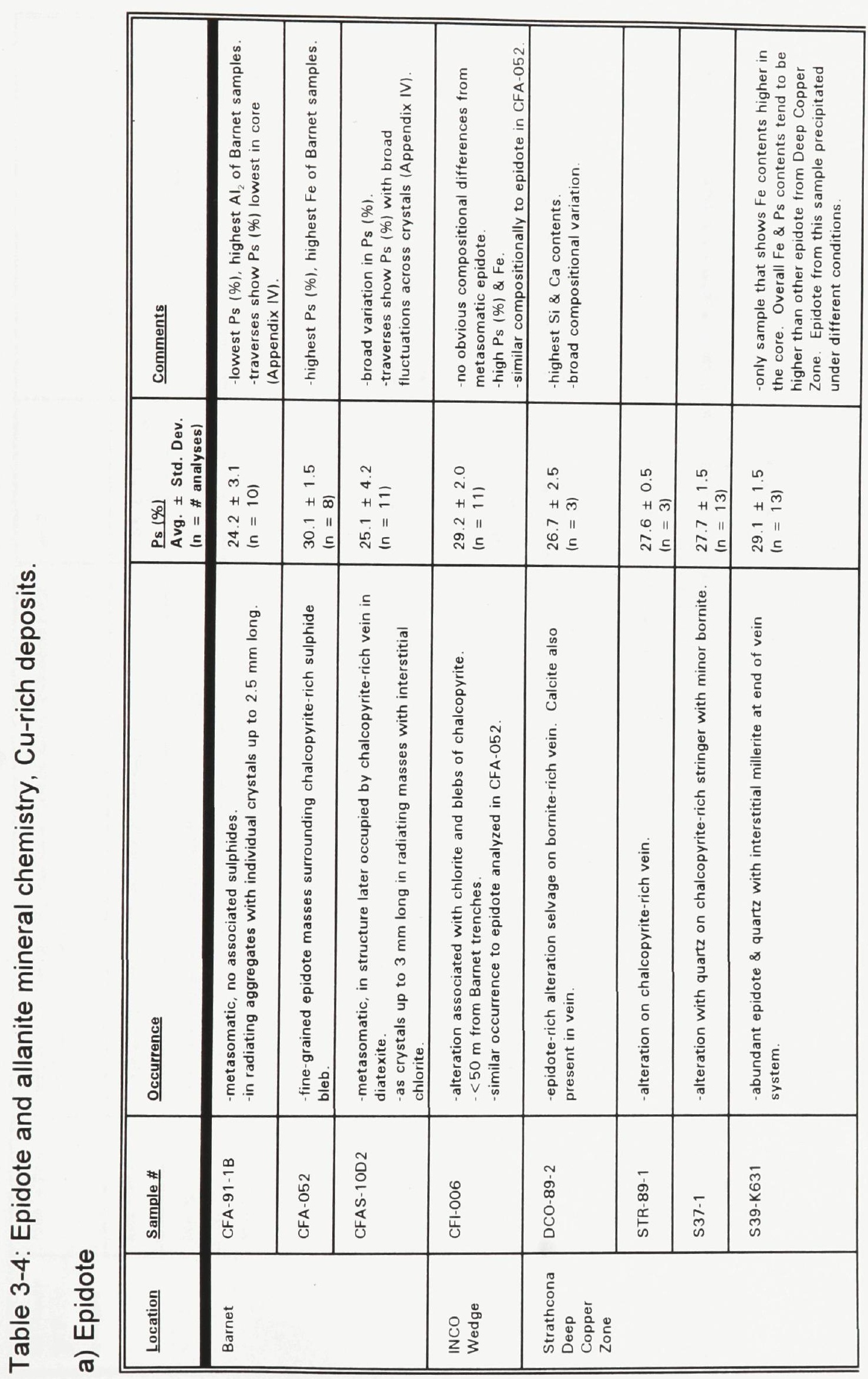



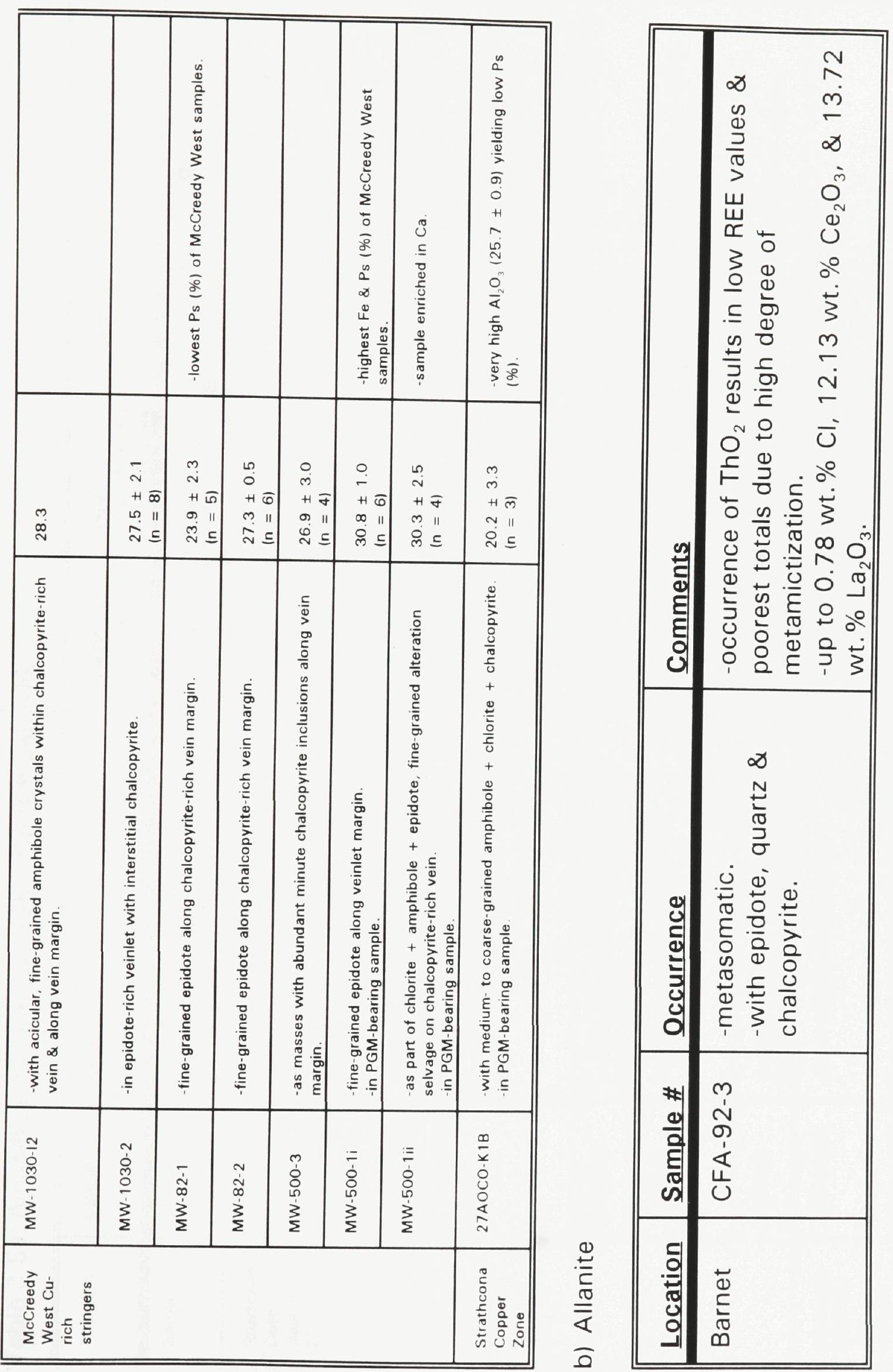


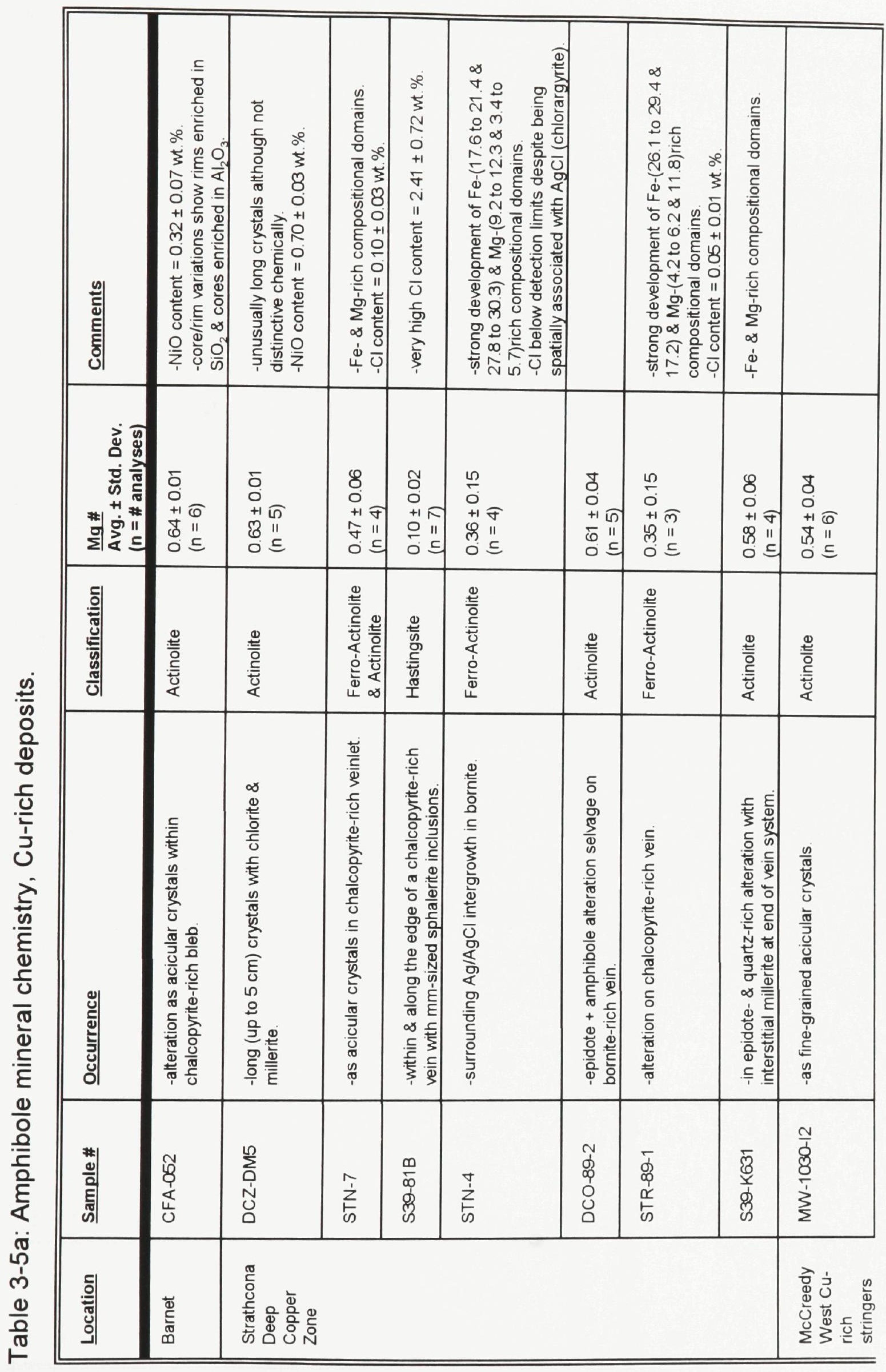




\begin{tabular}{|c|c|c|c|c|c|}
\hline 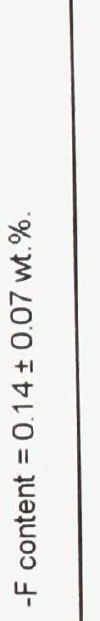 & 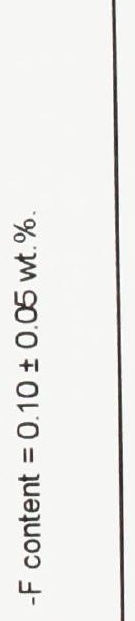 & & & & 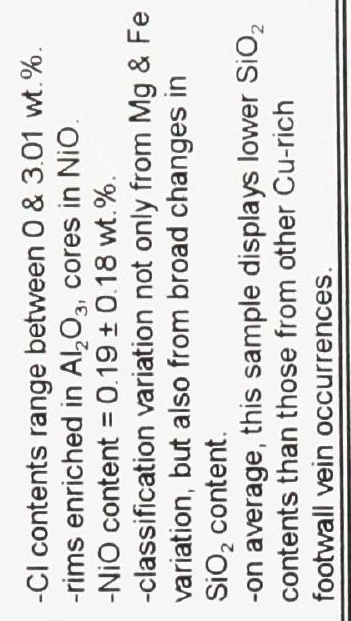 \\
\hline $\begin{array}{l}8 \\
0 \\
+1 \\
+1 \\
10 \\
0 \\
0\end{array}$ & $\begin{array}{l}8 \\
0 \\
0 \\
+1 \\
8 \\
8 \\
0 \leq\end{array}$ & 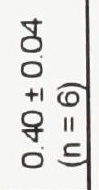 & 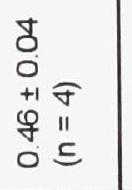 & $\begin{array}{l}8 \\
0 \\
0 \\
+11 \\
03 \\
0.11 \\
0.5\end{array}$ & 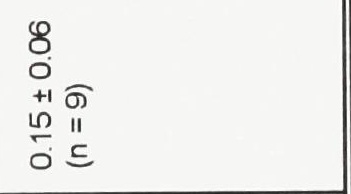 \\
\hline 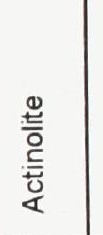 & 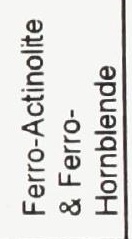 & 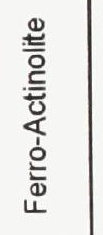 & 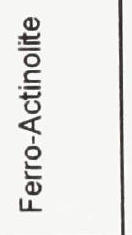 & 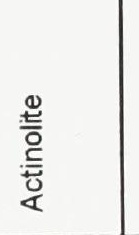 & 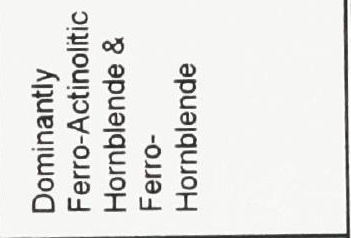 \\
\hline 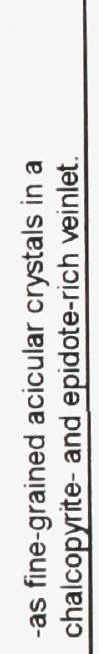 & 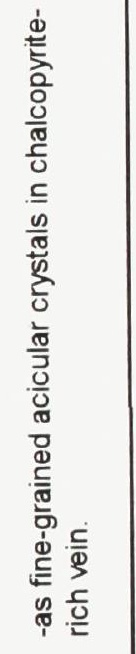 & 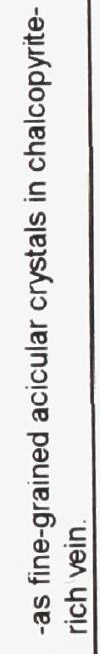 & 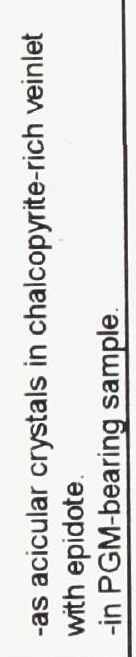 & 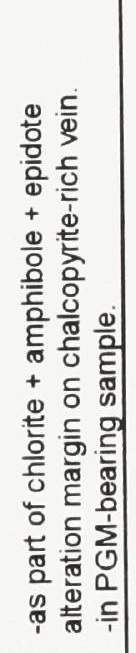 & 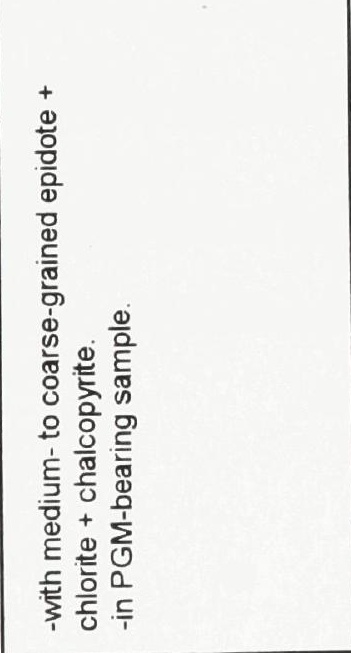 \\
\hline$\frac{\text { Nे }}{8}$ & $\begin{array}{l}N \\
\sim \\
\infty \\
\infty \\
\vdots \\
\sum\end{array}$ & 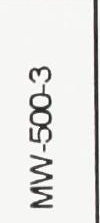 & $\begin{array}{l}\overline{\overline{8}} \\
8 \\
\sum_{\Sigma}^{1} \\
\sum\end{array}$ & $\begin{array}{l}: \overline{1} \\
8 \\
0 \\
\vdots \\
\sum\end{array}$ & 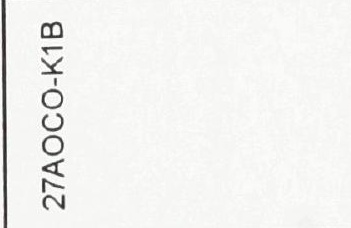 \\
\hline & & & & & 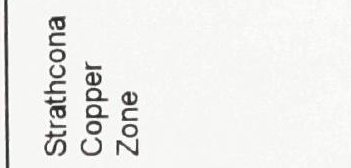 \\
\hline
\end{tabular}

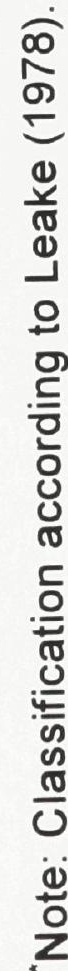


Table 3-5b: Hastingsitic and actinolitic amphibole mineral chemistry from Strathcona Deep Copper Zone alteration compared to coexisting hastingsitic and actinolitic amphibole from hydrothermal alteration in the Salton Sea geothermal system.

\begin{tabular}{|c|c|c|c|c|}
\hline & $\begin{array}{l}\text { Salton Sea } \\
\text { Hastingsitic } \\
\text { Amphibole }\end{array}$ & $\begin{array}{l}\text { Salton Sea } \\
\text { Actinolitic } \\
\text { Amphibole }\end{array}$ & $\begin{array}{l}\text { Deep Copper } \\
\text { Zone } \\
\text { Hastingsitic } \\
\text { Amphibole }\end{array}$ & $\begin{array}{l}\text { Deep Copper } \\
\text { Zone } \\
\text { Actinolitic } \\
\text { Amphibole }\end{array}$ \\
\hline $\mathrm{TiO}_{2}$ & $0.3-0.7$ wt. $\%$ & & $0-0.07$ wt. $\%$ & \\
\hline K & $0.3-0.6$ p.f.u. & & $0.3-0.6$ p.f.u. & \\
\hline $\mathrm{Na}$ & $\begin{array}{l}0.27 \pm 0.03 \\
\text { p.f.u. }\end{array}$ & & $\begin{array}{l}0.28 \pm 0.05 \\
\text { p.f.u. }\end{array}$ & \\
\hline${ }^{[4]} \mathbf{A l}$ & $1.42-1.79$ p.f.u. & $\begin{array}{l}0.22-0.54 \\
\text { p.f.u. }\end{array}$ & $\begin{array}{l}1.90-2.05 \\
\text { p.f.u. }\end{array}$ & $0-0.25$ p.f.u. \\
\hline${ }^{[\mathrm{A}]}(\mathrm{Na}+\mathrm{K})$ & $0.47-0.73$ p.f.u. & $\begin{array}{l}0.02-0.13 \\
\text { p.f.u. }\end{array}$ & $\begin{array}{l}0.61-0.84 \\
\text { p.f.u. }\end{array}$ & $\begin{array}{l}0.01-0.27 \\
\text { p.f.u. }\end{array}$ \\
\hline Cl-content & up to $2.65 w t . \%$ & $<0.5 w t . \%$ & $\begin{array}{l}1.53-3.56 \\
\text { wt. } \%\end{array}$ & $0-0.18 w t . \%$ \\
\hline $\mathrm{T}\left({ }^{\circ} \mathrm{C}\right)$ & 350 & 350 & $\begin{array}{l}250-400(\text { see } \\
\text { Chapters } 6 \& 7)\end{array}$ & $\begin{array}{l}250-400(\text { see } \\
\text { Chapters } 6 \& \text { \% })\end{array}$ \\
\hline $\mathrm{P}(\mathrm{MPa})$ & $\sim 90$ & $\sim 90$ & $>90$ & $>90$ \\
\hline
\end{tabular}

"T data from this study from Chapters 6 \& 7 .

" $P$ data from estimated depth of ore formation in the North Range of 3 to $8 \mathrm{~km}$ (Souch et al., 1969; Hoffman et al., 1979).

"'Salton Sea geothermal system data from Enami et al. (1992). 


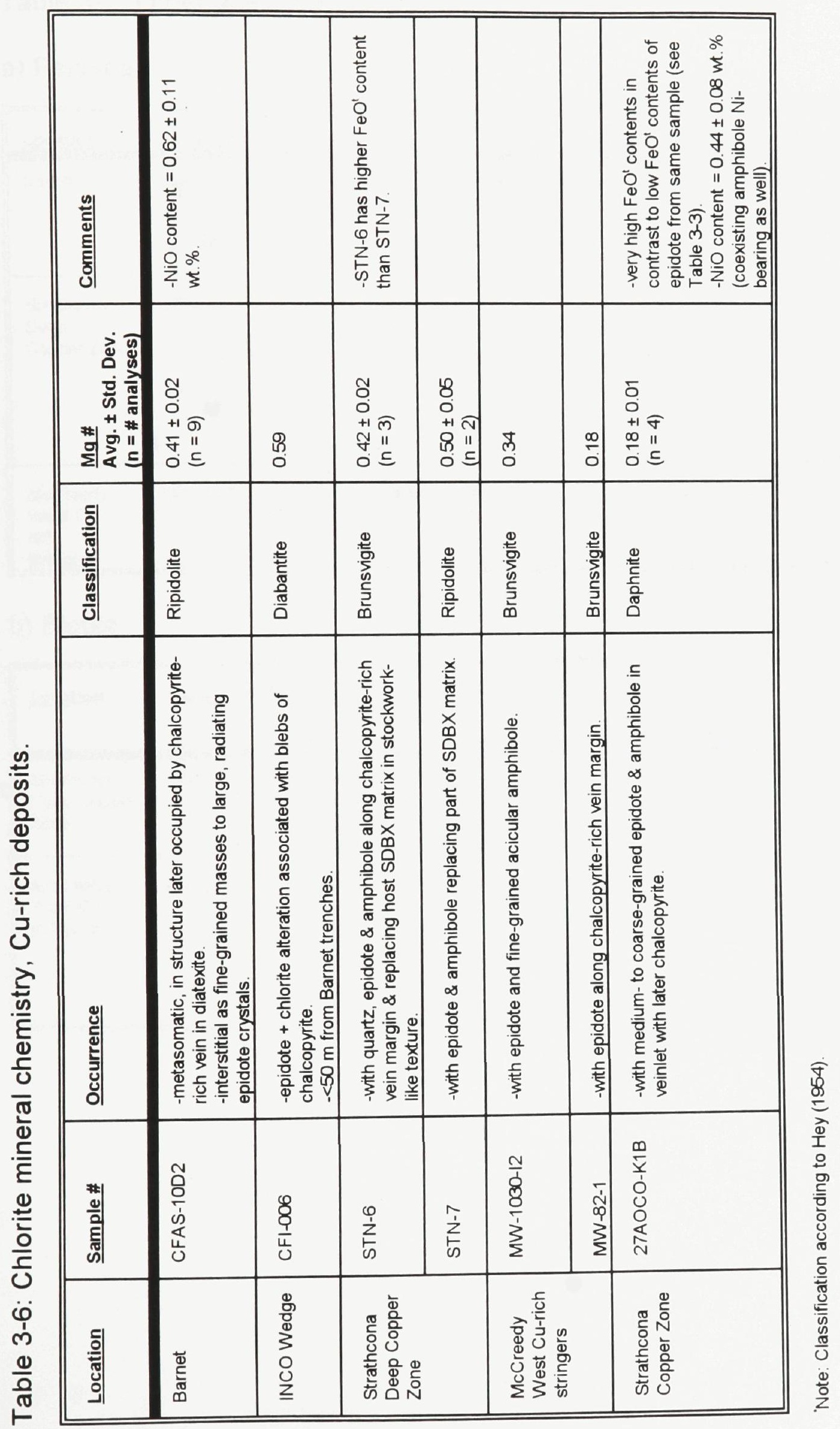


Table 3-7: Other alteration mineral chemistry, Cu-rich deposits.

\section{a) Feldspar}

\begin{tabular}{|c|c|c|c|c|}
\hline Location & Sample \# & Occurrence & Classification & Comments \\
\hline \multirow[t]{2}{*}{ Barnet } & CFA-91-1B & $\begin{array}{l}\text {-metasomatic, no associated sulphides. } \\
\text {-in micrographic intergrowth with quartz. }\end{array}$ & $\mathrm{Or}_{100}$ & \\
\hline & CFA-052 & $\begin{array}{l}\text {-metasomatic, sulphide bleb overprint. } \\
\text {-with quartz \& epidote. }\end{array}$ & Or $_{100}$ & \\
\hline \multirow{2}{*}{$\begin{array}{l}\text { Strathcona } \\
\text { Deep } \\
\text { Copper Zone }\end{array}$} & STN-7 & -in K-feldspar-rich area. & $\mathrm{Or}_{89}$ & \\
\hline & 539-c3 & $\begin{array}{l}\text {-K-feldspar. } \\
\text {-oligoclase }\end{array}$ & $\begin{array}{l}\mathrm{Or}_{72-77} \\
\mathrm{An}_{26}\end{array}$ & $\begin{array}{l}\text {-more Ab-Or solid } \\
\text { solution in Deep } \\
\text { Copper Zone K- } \\
\text { feldspars. }\end{array}$ \\
\hline $\begin{array}{l}\text { McCreedy } \\
\text { West Cu- } \\
\text { rich } \\
\text { stringers }\end{array}$ & MW-82-1 & $-0.5 \mathrm{~mm}$ in diameter grain. & $\mathrm{Or}_{\infty}$ & \\
\hline
\end{tabular}

\section{b) Biotite}

\begin{tabular}{|c|c|c|c|c|}
\hline Location & Sample \# & Occurrence & $\begin{array}{l}\frac{M g \#}{\text { Avg. } \pm \text { Std. Dev. }} \\
\text { (n=\# analyses) }\end{array}$ & Comments \\
\hline $\begin{array}{l}\text { Strathcona } \\
\text { Deep Copper } \\
\text { Zone }\end{array}$ & s39-c3 & $\begin{array}{l}\text {-metasomatic origin. } \\
\text {-in Sudbury Breccia host to } \\
\text { chalcopyrite-rich vein. } \\
\text {-with numerous sulphide inclusions. }\end{array}$ & $\begin{array}{l}0.31 \pm 0.05 \\
(n=3)\end{array}$ & $-\mathrm{Cl}=0.93 \pm 0.06$ wt. $\%$ \\
\hline $\begin{array}{l}\text { McCreedy } \\
\text { West Cu-rich } \\
\text { stringers }\end{array}$ & MW-82-2 & -inclusions in chalcopyrite vein. & $\begin{array}{l}0.18 \pm 0.02 \\
(n=3)\end{array}$ & $\begin{array}{l}\text {-higher FeO' than Deep } \\
\text { Copper Zone biotite, } \\
\text { possibly due to ore- } \\
\text { related alteration rather } \\
\text { than pre-ore } \\
\text { metasomatism. } \\
-\mathrm{Cl}=0.59 \pm 0.11 \text { wt. } \% \text {. }\end{array}$ \\
\hline
\end{tabular}


Table 3-7: (con't)

c) Magnetite (\& Ilmenite)

\begin{tabular}{||l|l|l|l||}
\hline Location & Sample \# & Occurrence & Comments \\
\hline $\begin{array}{l}\text { McCreedy West } \\
\text { Cu-rich stringers }\end{array}$ & $\mathrm{MW}-500-1 \mathrm{i}$ & $\begin{array}{l}\text {-ilmenite occurring with altered } \\
\text { magnetite }\end{array}$ & $\begin{array}{l}\text {-alteration of magnetite includes } \\
\text { increase in } \mathrm{SiO}_{2}, \mathrm{TiO}_{2}, \mathrm{Cr}_{2} \mathrm{O}_{3} \& \\
\mathrm{MgO} \text { compared to Copper } \mathrm{Zone} \\
\text { magnetite. }\end{array}$ \\
\hline $\begin{array}{l}\text { Strathcona Copper } \\
\text { Zone }\end{array}$ & 27AOCO-H1 & $\begin{array}{l}\text {-large magnetite in chalcopyrite- } \\
\text { rich vein with growth zones of } \\
\text { silicates (Cl-rich biotite, chlorite \& } \\
\text { quartz) \& chalcopyrite. }\end{array}$ & $\begin{array}{l}\text {-traverse across grain shows } \mathrm{TiO}_{2} \\
\text { \&nO increase together, } \\
\text { whereas } \mathrm{Al}_{2} \mathrm{O}_{3} \text { shows a } \\
\text { concomitant decrease. }\end{array}$ \\
\hline
\end{tabular}

\section{d) Prehnite}

\begin{tabular}{||l|l|l|l||}
\hline Location & Sample \# & Occurrence & Comments \\
\hline $\begin{array}{l}\text { McCreedy West Cu-rich } \\
\text { stringers }\end{array}$ & MW-82-1 & $\begin{array}{l}\text {-with chlorite adjacent } \\
\text { chalcopyrite-rich vein. }\end{array}$ & \\
\hline
\end{tabular}

e) Pyroxene (not part of the alteration assemblage)

\begin{tabular}{|c|c|c|c|c|}
\hline Location & Sample \# & Occurrence & $\begin{array}{l}\text { Composition } \\
\text { Avg. } \pm \text { Std. } \\
\text { Dev. } \\
\text { ( } n=\# \\
\text { analyses) }\end{array}$ & Comments \\
\hline $\begin{array}{l}\text { Strathcona Deep } \\
\text { Copper Zone }\end{array}$ & S39-c3 & $\begin{array}{l}\text {-individual grains in } \\
\text { SDBX (contact } \\
\text { metamorphic origin?). }\end{array}$ & $\begin{array}{l}\mathrm{En}_{45.5 \pm 0.7} \\
\mathrm{FS}_{51.7 \pm 0.7} \\
\mathrm{Wo}_{2.8 \pm 0.1} \\
(\mathrm{n}=2)\end{array}$ & $\begin{array}{l}\text {-low Ca contents of } \\
\text { pyroxene characteristic } \\
\text { of Strathcona sublayer } \\
\text { inclusions. }\end{array}$ \\
\hline $\begin{array}{l}\text { McCreedy West Cu- } \\
\text { rich stringers }\end{array}$ & $M W-1030-12$ & $\begin{array}{l}\text {-in host to } \\
\text { chalcopyrite-rich vein. }\end{array}$ & $\begin{array}{l}\mathrm{En}_{40.2 \pm 0.7} \\
\mathrm{Fs}_{18.4 \pm 0.6} \\
\mathrm{Wo}_{41.4 \pm 0.7} \\
(\mathrm{n}=4)\end{array}$ & $\begin{array}{l}\text {-possible remnant of } \\
\text { granulite grade } \\
\text { metamorphism with } \\
\text { high } \mathrm{Mg} \text { and } \mathrm{Ca} \\
\text { contents. }\end{array}$ \\
\hline
\end{tabular}




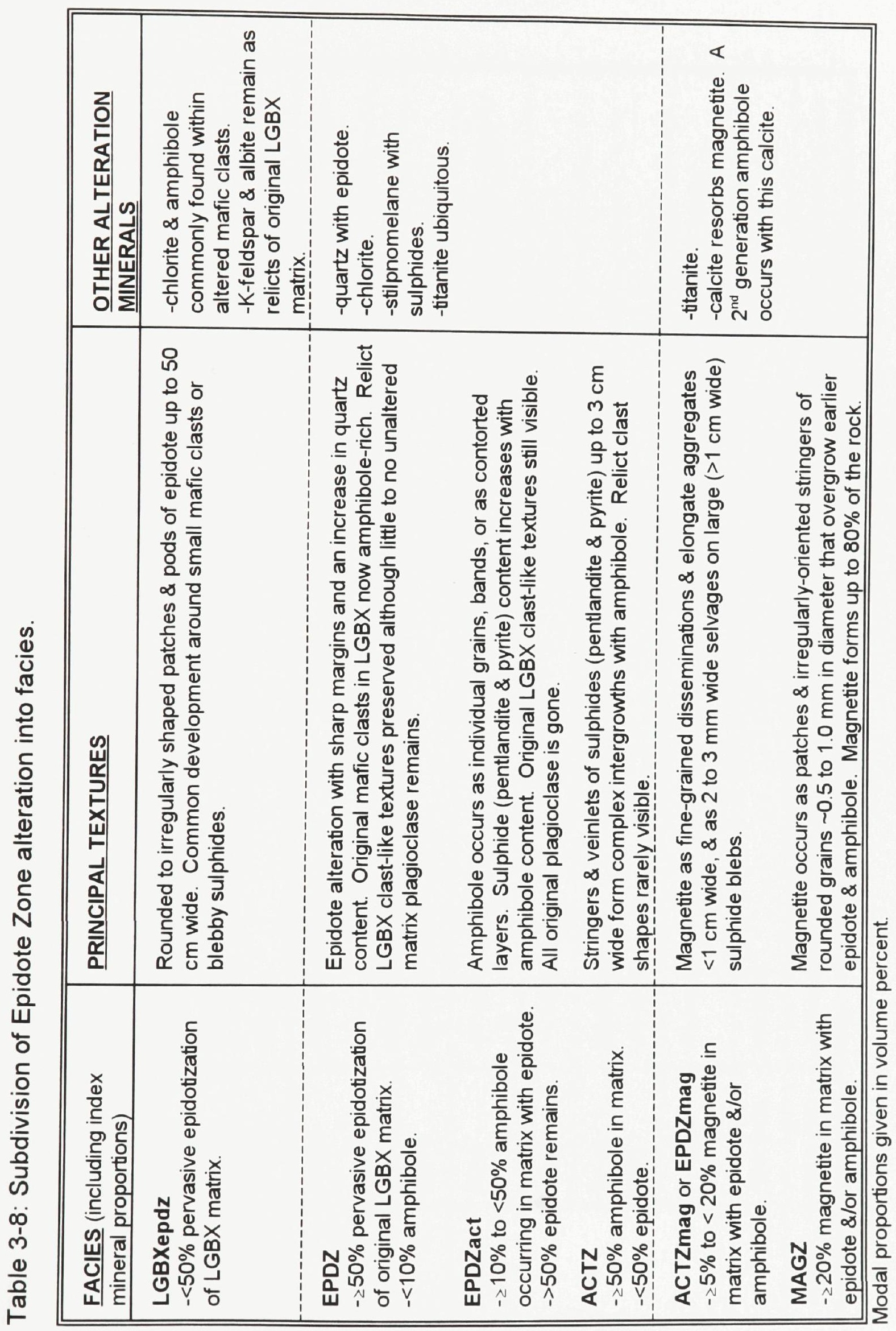




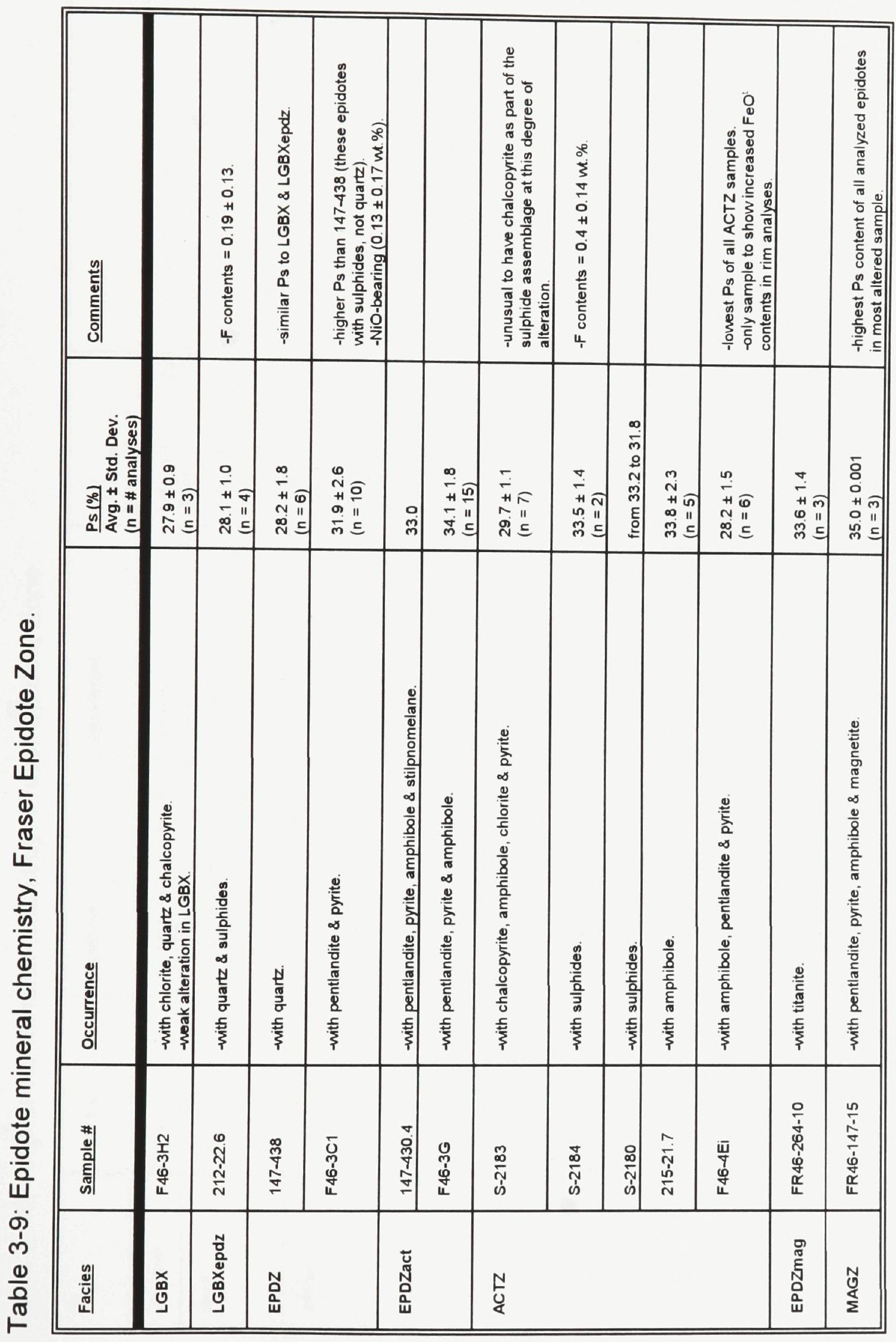




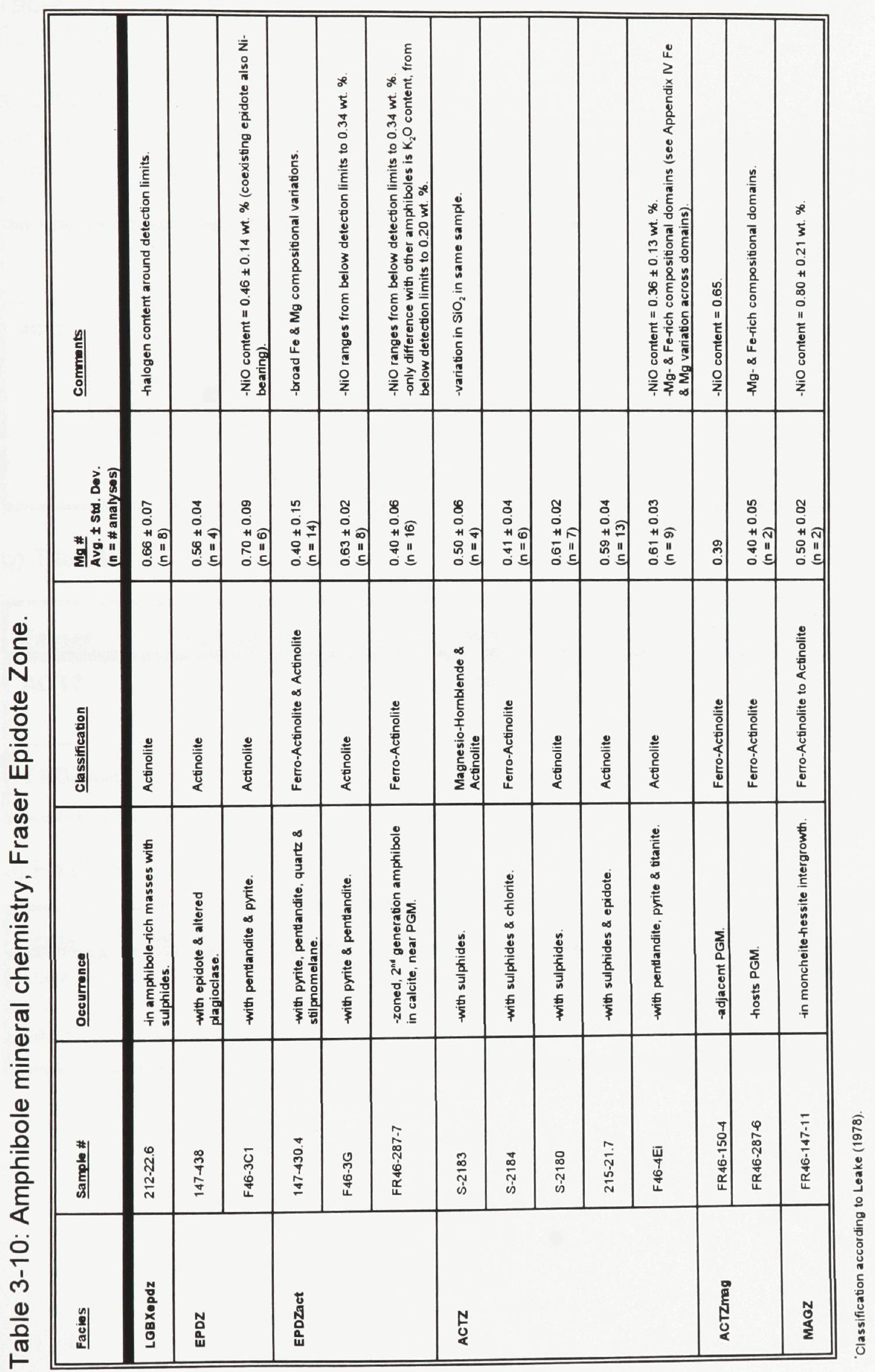


Table 3-11: Mineral chemistry of less common alteration minerals, Fraser Epidote Zone.

\section{a) Chlorite}

\begin{tabular}{|c|c|c|c|c|c|}
\hline Facies & Sample \# & Occurrence & Classification & $\begin{array}{l}\frac{M g \#}{\text { Avg. } \pm \text { Std. Dev. }} \\
\text { (n=\# analyses) }\end{array}$ & Comments \\
\hline LGBX & $\mathrm{F} 46-3 \mathrm{H} 2$ & $\begin{array}{l}\text {-with quartz. } \\
\text {-weak alteration in } \\
\text { LGBX. }\end{array}$ & $\begin{array}{l}\text { Ripidolite \& } \\
\text { Brunsvigite }\end{array}$ & $\begin{array}{l}0.49 \pm 0.01 \\
(n=3)\end{array}$ & $-\mathrm{Cl}=0.03 \pm 0.01$ wt. \% \\
\hline \multirow[t]{2}{*}{ ACTZ } & S-2183 & $\begin{array}{l}\text {-with epidote, quartz, } \\
\text { stilpnomelane \& } \\
\text { sulphides. }\end{array}$ & Brunsvigite & $\begin{array}{l}0.09 \pm 0.02 \\
(n=5)\end{array}$ & $-\mathrm{Cl}=0.10 \pm 0.02$ wt. $\%$ \\
\hline & S-2184 & $\begin{array}{l}\text {-with quartz \& } \\
\text { amphibole. }\end{array}$ & Brunsvigite & 0.14 & $\begin{array}{l}\text {-chlorite from ACTZ } \\
\text { has much higher Fe } \\
\text { contents than chlorite } \\
\text { from alteration in } \\
\text { LGBX. }\end{array}$ \\
\hline
\end{tabular}

b) Titanite

\begin{tabular}{||l|l|l|l||}
\hline \hline Facies & Sample \# & Occurrence & Comments \\
\hline \multirow{2}{*}{ ACTZ } & S-2183 & -with epidote. & \\
\cline { 2 - 4 } & F46-4Ei & -with amphibole. & -up to 0.07 wt.\% Cl. \\
\hline \multirow{2}{*}{ EPDZmag } & FR46-264-10 & -with epidote \& pentlandite. & $\begin{array}{l}\text {-up to } 1.67 \text { wt. } \% \\
\text { BaO. }\end{array}$ \\
\hline
\end{tabular}

\section{c) Feldspar}

\begin{tabular}{||l|l|l|l|l||}
\hline Facies & Sample \# & \multicolumn{1}{|l|}{ Occurrence } & Classification & Comments \\
\hline LGBXepdz & $212-22.6$ & $\begin{array}{l}\text {-with saussuritized plagioclase \& } \\
\text { amphibole. }\end{array}$ & $\mathrm{Ab}_{9-100}$ & -contains $0.60 \mathrm{wt} \% \mathrm{~F}$. \\
\hline EPDZ & $147-438$ & -with saussuritized plagioclase. & $A b_{9 \vartheta}$ & $\begin{array}{l}\text {-original plagioclase Ca- } \\
\text { depleted. }\end{array}$ \\
\hline
\end{tabular}


Table 3-11: (con't)

d) Magnetite

\begin{tabular}{|c|c|c|c|}
\hline Facies & Sample \# & Occurrence & Comments \\
\hline EPDZact & $147-430.4$ & -in sulphides. & \\
\hline MAGZ & FR46-147-11 & $\begin{array}{l}\text {-in most magnetite-rich rock } \\
\text { encountered in the Epidote } \\
\text { Zone ( } 80 \% \text { magnetite). }\end{array}$ & $\begin{array}{l}\text {-Epidote Zone magnetite is pure in comparison } \\
\text { to magnetite from } \mathrm{McCreedy} \text { West }\left(\mathrm{SiO}_{2}, \mathrm{TiO}_{2} \text {, }\right. \\
\left.\mathrm{Cr}_{2} \mathrm{O}_{3}, \mathrm{Al}_{2} \mathrm{O}_{3}, \mathrm{MnO} \& \mathrm{MgO}\right) \text { or Strathcona's } \\
\text { Copper Zone }\left(\mathrm{Al}_{2} \mathrm{O}_{3}\right) \text {. }\end{array}$ \\
\hline
\end{tabular}

\section{e) Stilpnomelane}

\begin{tabular}{||l|l|l|l||}
\hline Facies & Sample \# & \multicolumn{1}{|c||}{ Occurrence } & Comments \\
\hline EPDZact & $147-430.4$ & $\begin{array}{l}\text {-intergrown with chalcopyrite \& } \\
\text { with pyrite, epidote \& } \\
\text { amphibole. }\end{array}$ & -higher Mg than ACTZ sample. \\
\hline ACTZ & S-2183 & $\begin{array}{l}\text {-with pyrite, pentlandite \& } \\
\text { amphibole. }\end{array}$ & $\begin{array}{l}\text {-higher Fe than EPDZact sample (mimics epidote } \\
\text { trends to higher Fe }{ }^{3+} \text { content with increased degree of } \\
\text { alteration). } \\
\text {-halogen contents approximately equal to detection } \\
\text { limits for both samples. }\end{array}$ \\
\hline
\end{tabular}

\section{f) Garnet}

\begin{tabular}{|c|c|c|c|c|}
\hline Facies & Sample \# & Occurrence & Classification & Comments \\
\hline EPDZact & $147-430.4$ & -with quartz. & $\begin{array}{l}\text { Andradite }=\varpi 3.7 \pm 1.4 \\
\text { Grossular }=35.9 \pm 1.5 \\
(n=4)\end{array}$ & $\begin{array}{l}\text {-only Epidote Zone sample containing } \\
\text { garnet. }\end{array}$ \\
\hline
\end{tabular}


Figure 3-1: Schematic diagram of a Cu-rich vein and surrounding alteration.

$\square$ Host Rock

- Sulphide vein \& blebs Amphibole
18 Epidote

$\square$ Quartz

포모 Calcite

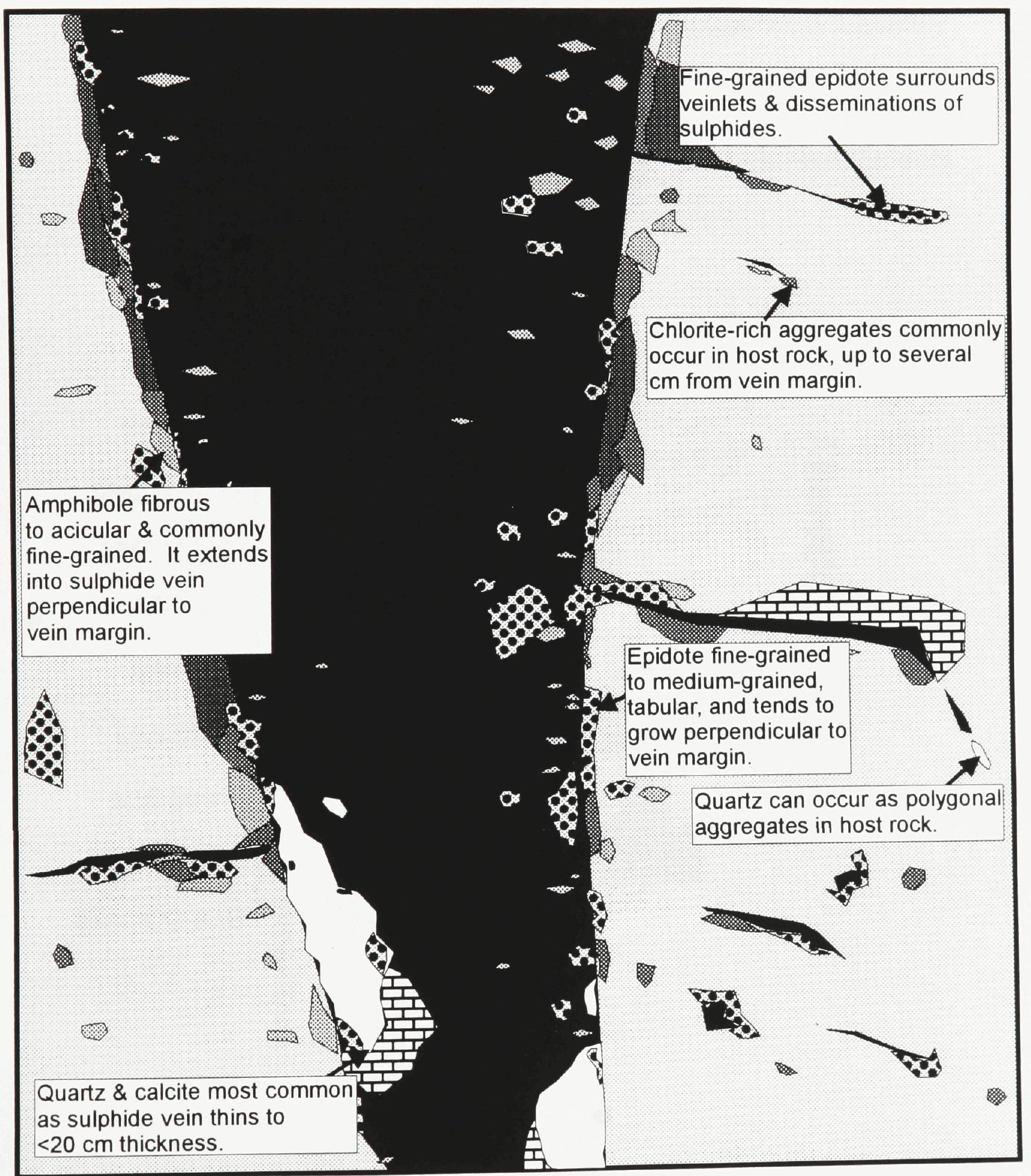




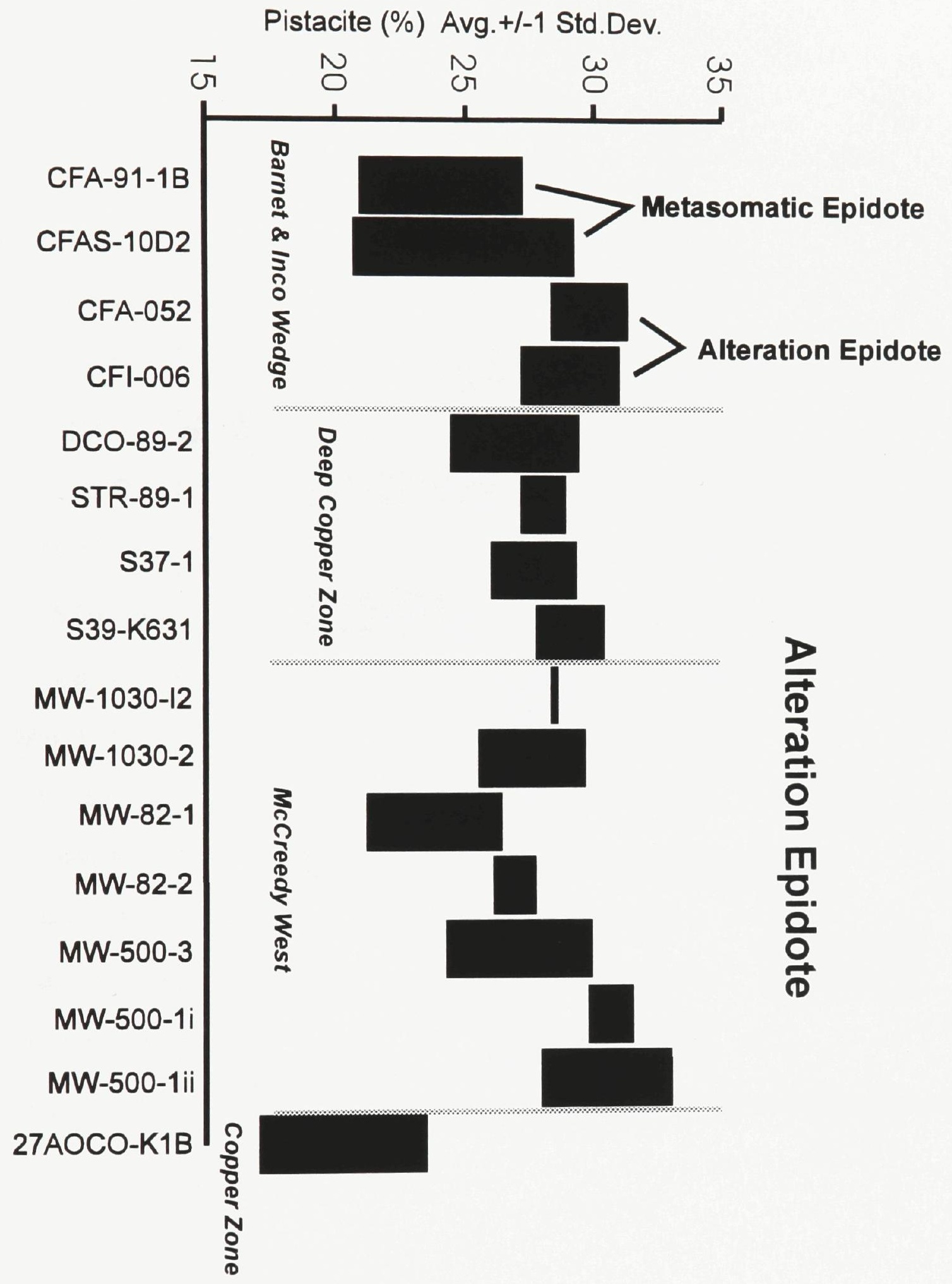

Figure 3-2: Epidote compositional (Pistacite \%) variation in Cu-rich vein settings. Note the compositional variation between epidote of metasomatic origin and $\mathrm{Cu}$ rich vein-associated epidote alteration at Barnet. 
Mg\# Avg.+/-1 Std.Dev.

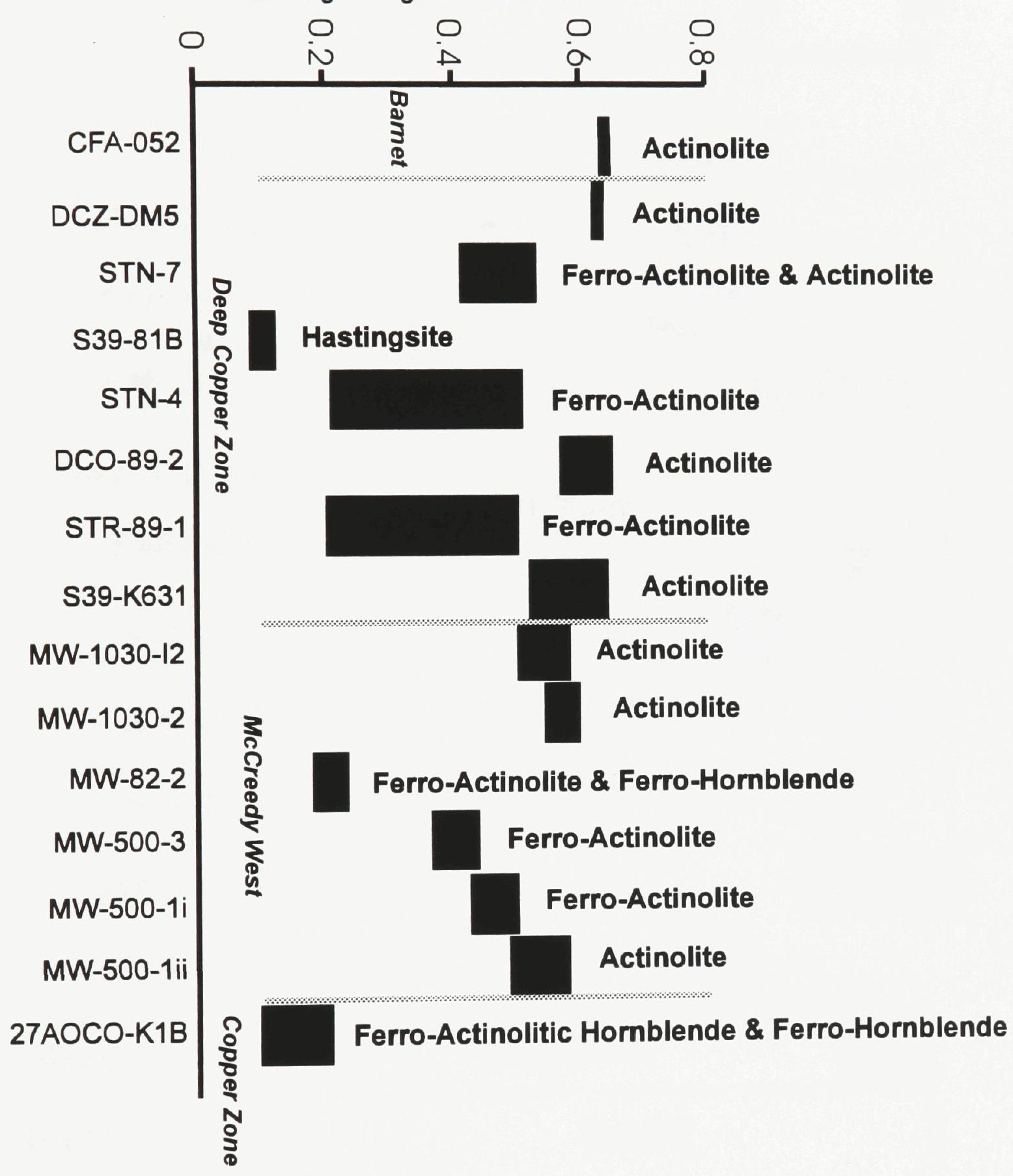

Figure 3-3: Amphibole compositional ( $\mathrm{Mg} \#)$ variation in $\mathrm{Cu}$-rich vein settings. Variations are not deposit specific. 


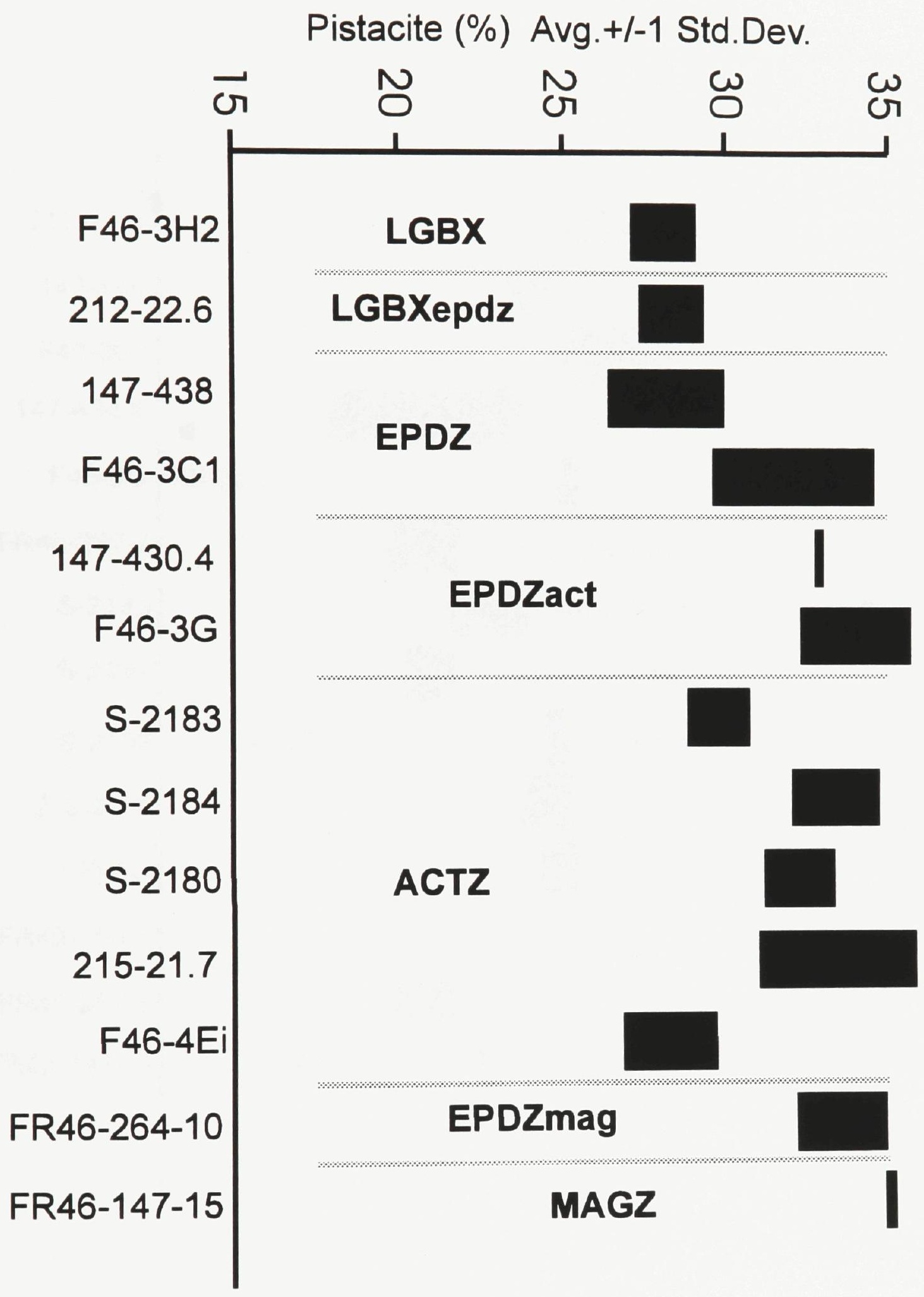

Figure 3-4: Epidote compositional (Pistacite \%) variation in different alteration facies of the Epidote Zone. 


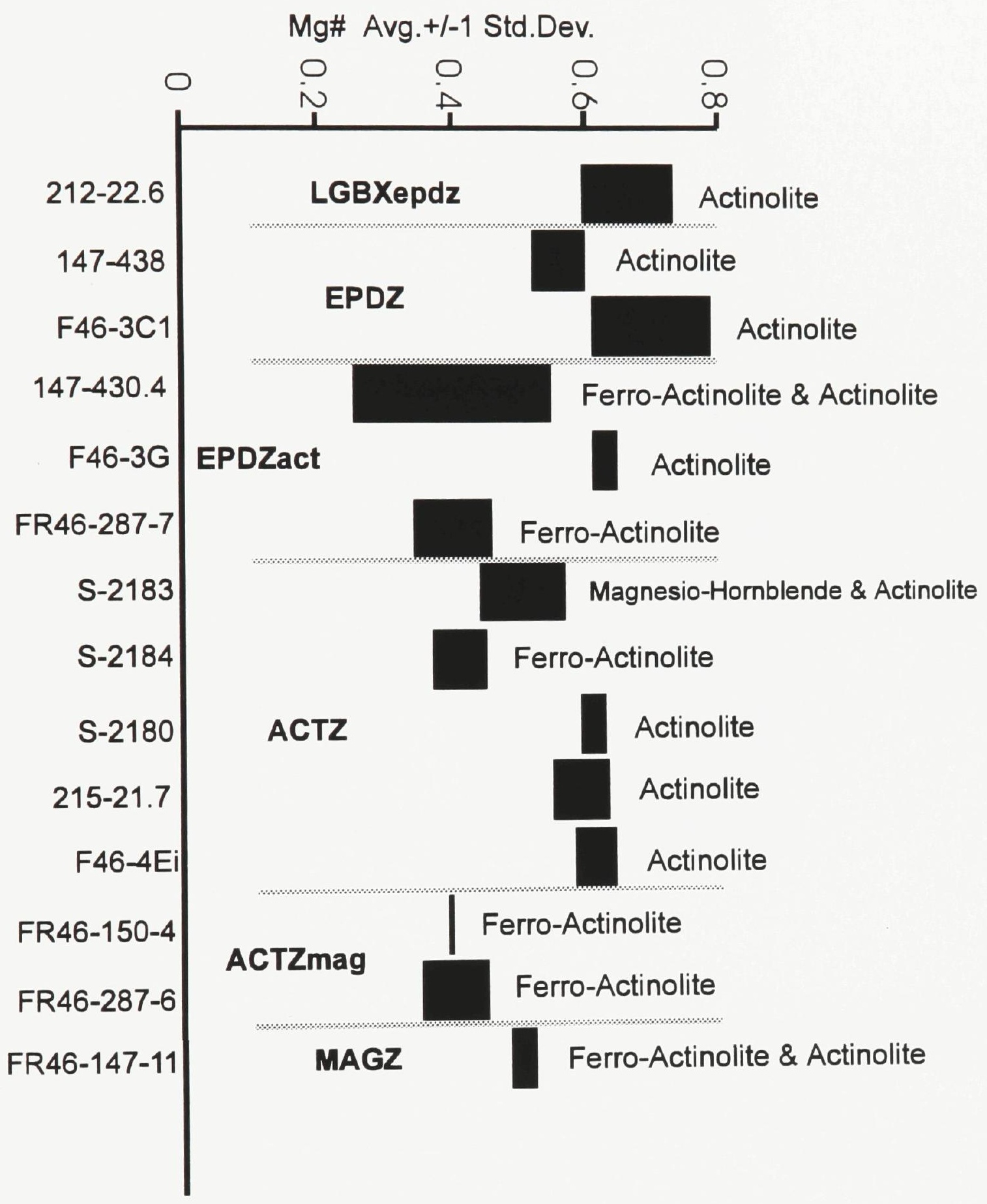

Figure 3-5: Amphibole compositional ( $\mathrm{Mg} \#)$ variation in different alteration facies of the Epidote Zone. Amphibole Fe contents tend to be highest in the most intensely altered facies. 


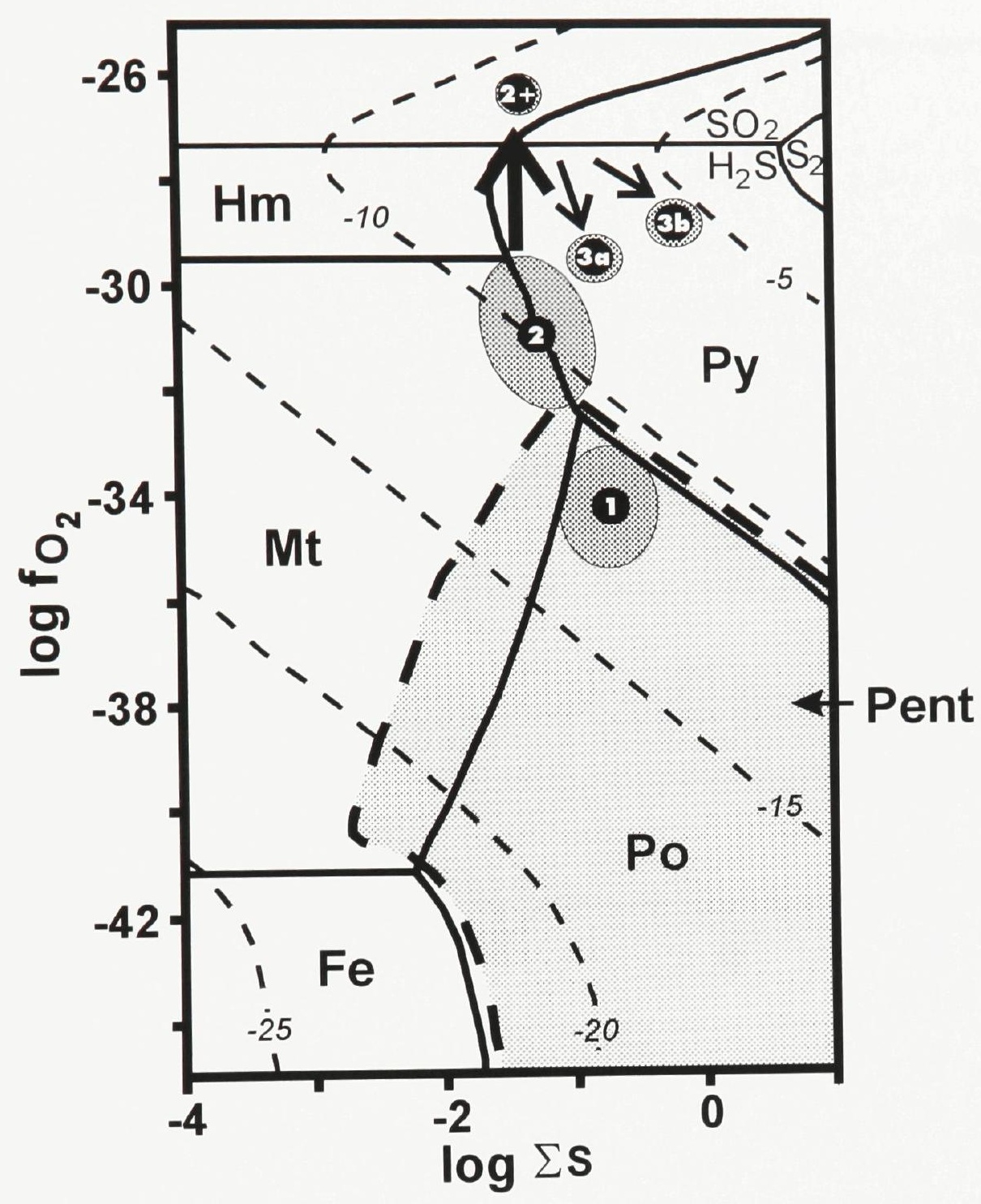

Figure 3-6: $\log \mathrm{fO}_{2}$ vs. $\log \Sigma \mathrm{S}$ diagram showing sulphide and oxide stabilities at $300{ }^{\circ} \mathrm{C}$ and $2 \mathrm{~kb}$. Heavy solid lines represent reactions between solid phases from Frost (1985) for the system $\mathrm{H}-\mathrm{O}-\mathrm{S}-\mathrm{Fe}-\mathrm{Ni}$, calculated from thermodynamic data. The light solid lines mark boundaries between fields where specific sulphur species dominate. The light dashed lines are contours for log fS in the fluid. The heavy dashed line and lightly shaded field is the stability field for pentlandite. See text for discussion of numbered fields. Modified from Frost (1985). Mineral abbreviations: $\mathrm{Hm}=$ hematite; $\mathrm{Py}=$ pyrite; $\mathrm{Mt}=$ magnetite $\mathrm{Po}=$ pyrrhotite $;$ Pent $=$ pentlandite $; \mathrm{Fe}=$ iron .

Sulphate - Sulphide fence:

$2 \mathrm{H}_{2} \mathrm{~S}+3 \mathrm{O}_{2}=2 \mathrm{H}_{2} \mathrm{O}+2 \mathrm{SO}_{2}$ 


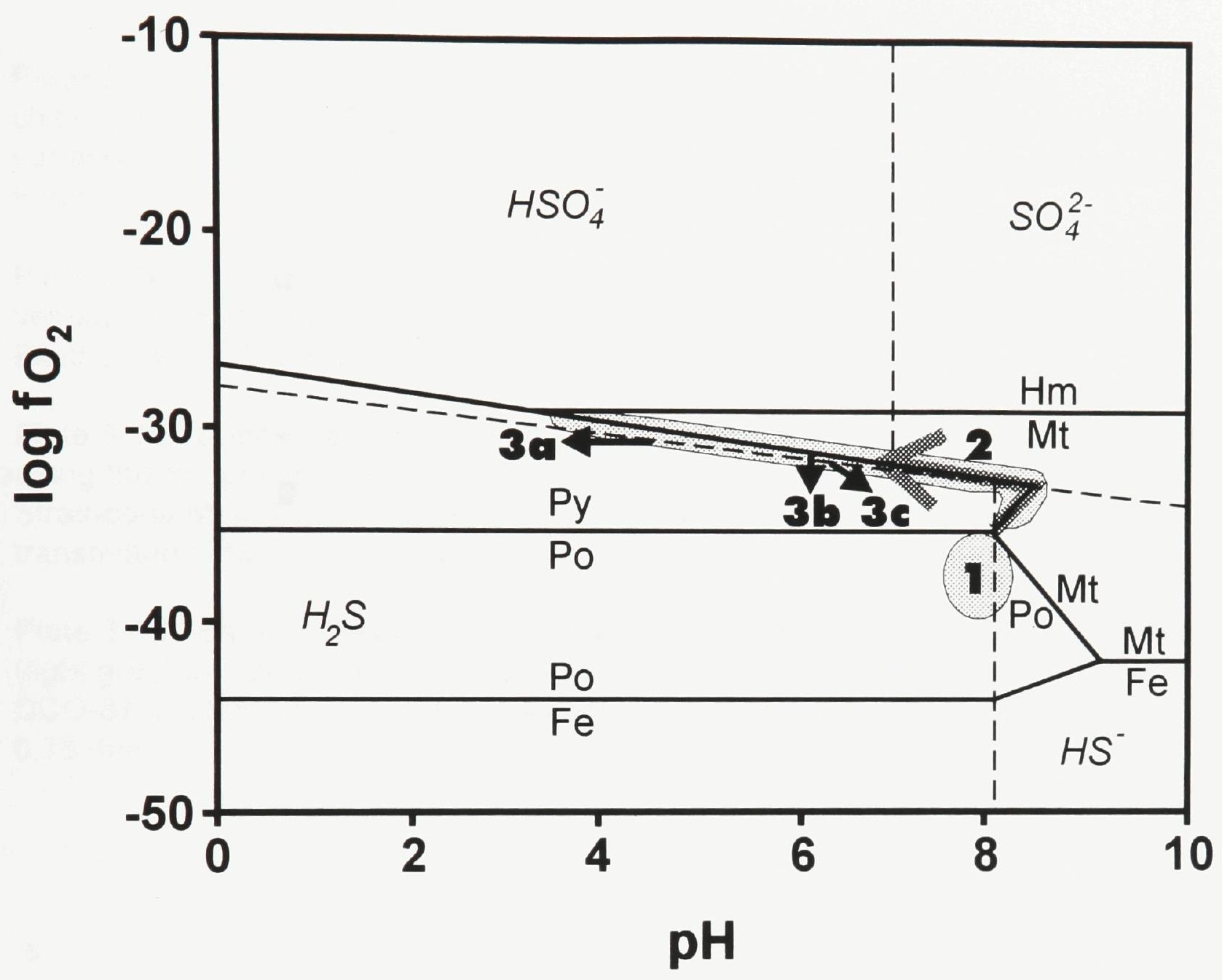

Figure 3-7: $\log \mathrm{fO}_{2}$ vs. pH diagram showing sulphide and oxide stabilities at $300{ }^{\circ} \mathrm{C}$ and $\Sigma \mathrm{S}=0.05 \mathrm{~m}$ in the system $\mathrm{Fe}-\mathrm{S}-\mathrm{O}-\mathrm{H}$. Dashed lines represent boundaries between predominant dissolved sulphur species. Solid lines separate fields of Fe-sulphide and oxide minerals. See text for discussion of numbered fields. Modified from Mountain and Wood (1988a). Mineral abbreviations: $\mathrm{Hm}=$ hematite; $\mathrm{Mt}=$ magnetite; $\mathrm{Py}=$ pyrite; $\mathrm{Po}=$ pyrrhotite; $\mathrm{Fe}=$ iron. 


\section{PLATE CAPTIONS}

Plate 3-1a: Zoned epidote inclusions within and along the margin of a chalcopyrite-rich vein (black). Epidote zonation is the result of slight $\mathrm{Fe}$ content variations: Sample S42-D5, 4200 Level, Strathcona Mine Deep Copper Zone. Field of view $=2.5 \mathrm{~mm}$, cross-polarized, transmitted light.

Plate 3-1b: Quartz and calcite with a later, cross-cutting chalcopyrite-rich veinlet. Sample S42-D13, 4200 Level, Strathcona Mine Deep Copper Zone. Field of view $=2.5 \mathrm{~mm}$, cross-polarized, transmitted light.

Plate 3-1c: Subhedral epidote in quartz with abundant trails of fluid inclusions along the margin of a chalcopyrite-rich stringer. Sample S37-1, 3700 Level, Strathcona Mine Deep Copper Zone. Field of view $=2.5 \mathrm{~mm}$, cross-polarized, transmitted light.

Plate 3-1d: Backscattered electron image of a remnant of a zoned allanite grain (light grey) in a zoned epidote crystal within chalcopyrite (light grey). Sample DCO-87-2, 3900 Level, Strathcona Mine Deep Copper Zone. Field of view $0.75 \mathrm{~mm}$. 

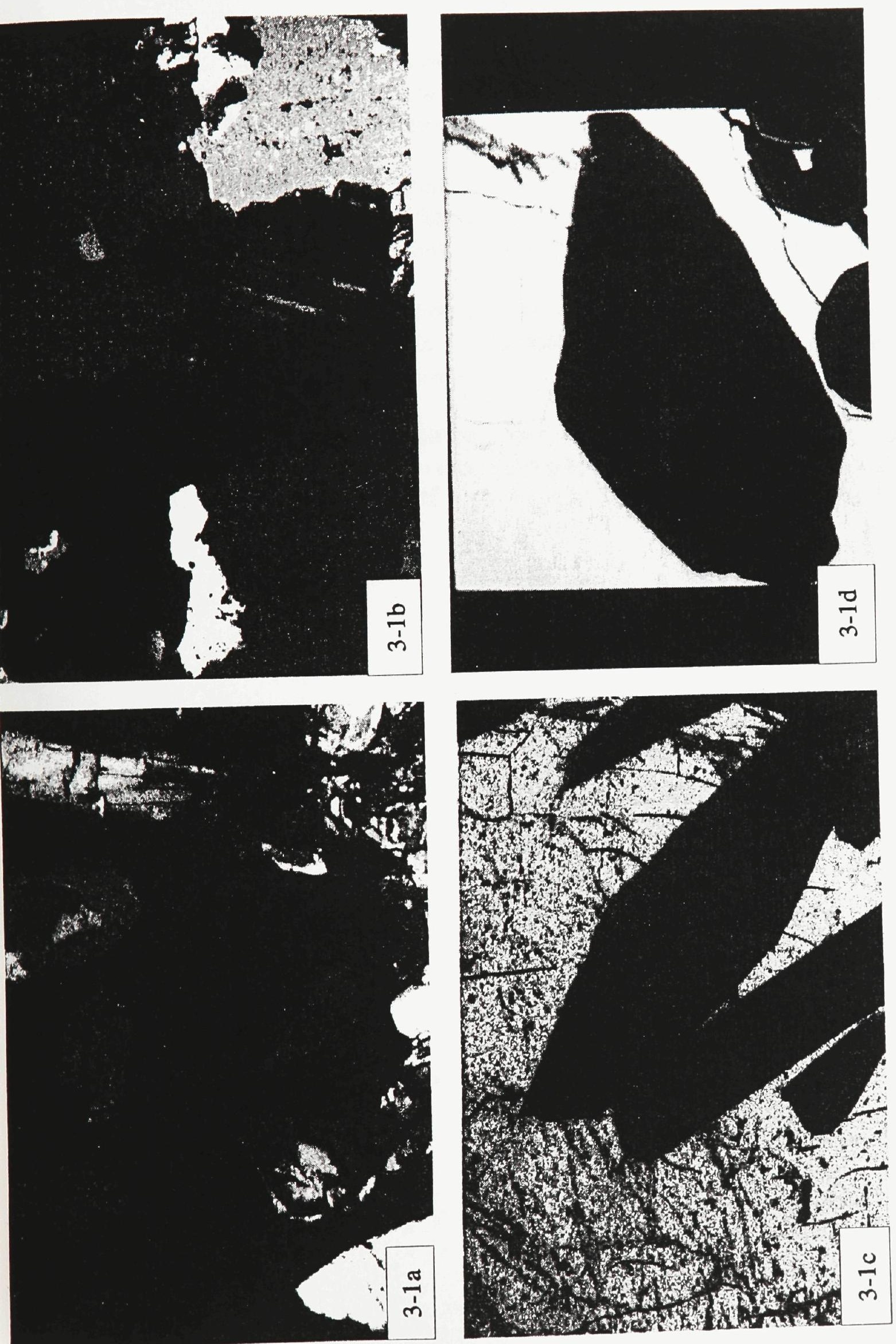


\section{PLATE CAPTIONS}

Plate 3-2: Comb-textured vein with actinolite crystals up to $1 \mathrm{~cm}$ long along the vein margin and chalcopyrite in the vein core. Minor quartz and calcite. Sample S37-A23, 3700 Level, Strathcona Mine Deep Copper Zone.

Plate 3-3a: Bornite after chalcopyrite (white) extending into quartz and epidote on margin of Cu-rich vein. Minor covellite. Sample S37-1, 3700 Level, Strathcona Deep Copper Zone. Field of view $=2.5 \mathrm{~mm}$, reflected light.

Plate 3-3b: Chalcopyrite and millerite -rich bleb (light grey) with acicular to subhedral actinolite inclusions. Sample CFA-052, Barnet Trench \#4. Field of view $=2.5 \mathrm{~mm}$, reflected light.

Plate 3-4: Sphalerite inclusions (orange-brown) with hastingsite (dark green) at margin of chalcopyrite-rich vein. Sample S37-8B, 3700 Level, Strathcona Mine Deep Copper Zone. Field of view $=1.25 \mathrm{~mm}$, plane-polarized light. 

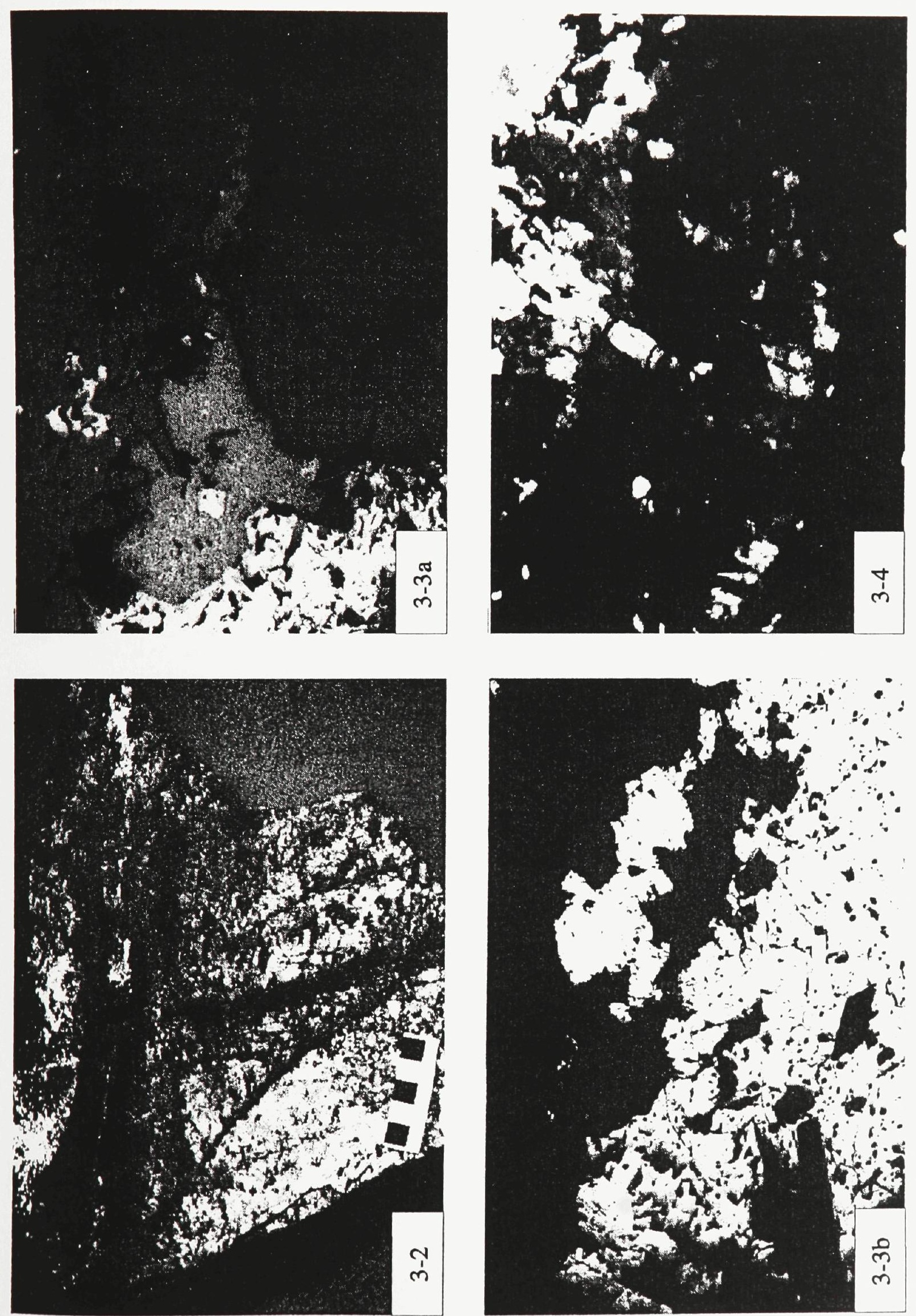


\section{PLATE CAPTIONS}

Plate 3-5a: Footwall Breccia with angular mafic clasts $<25 \mathrm{~m}$ from a welldeveloped Epidote Zone patch. 46-190 Exploration Drift, Fraser Mine.

Plate 3-5b: Weakly altered Footwall Breccia (LGBXepdz) from near an Epidote Zone patch. Sample F46-4A, 46-190 Exploration Drift, Fraser Mine.

Plates 3-6a and 3-6b: Colour-enhanced backscattered electron images showing unstable magnetite (light bronze) being replaced by ilmenite (orange) in weakly altered Footwall Breccia (LGBXepdz). Sample FR46-147-6. 

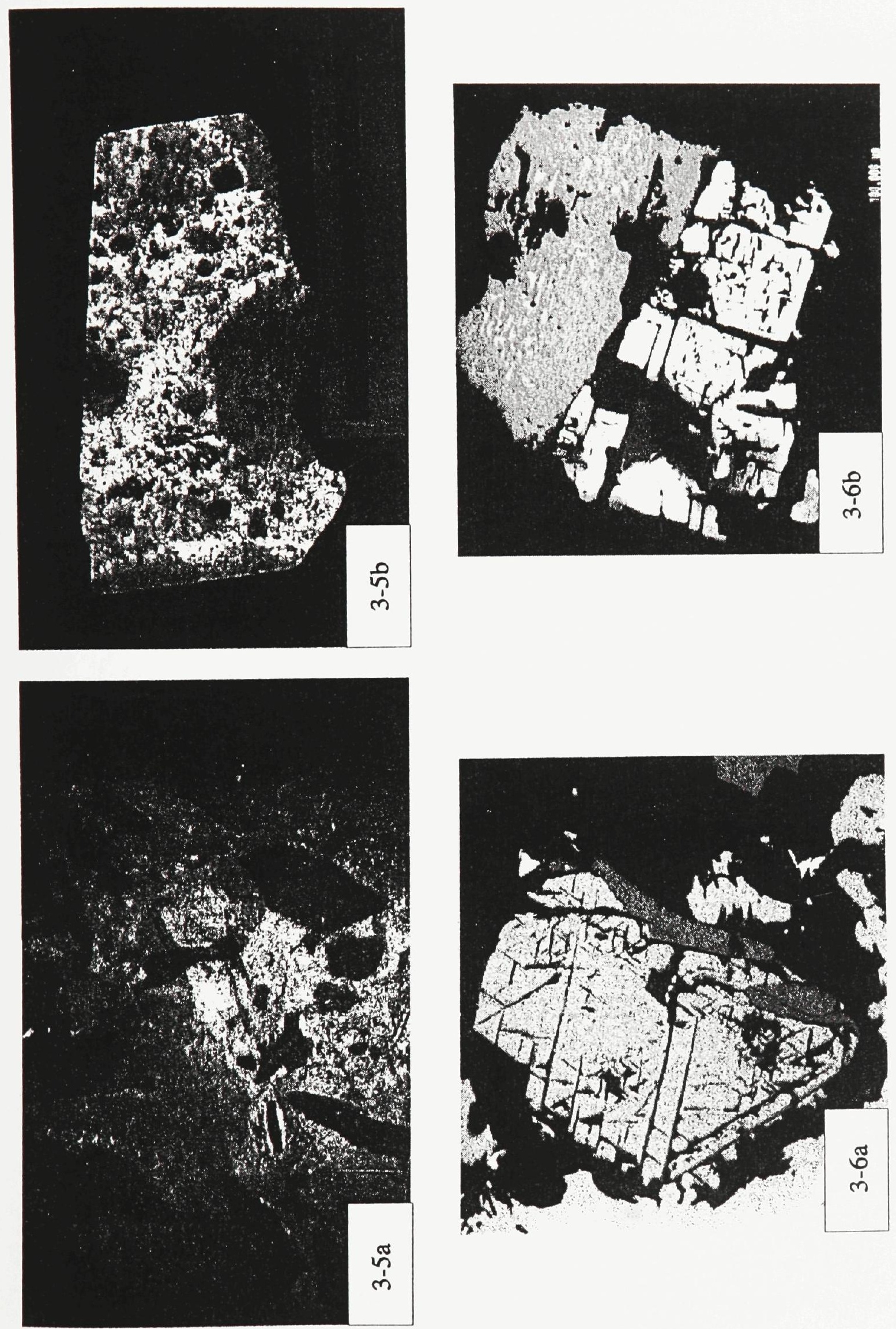


\section{PLATE CAPTIONS}

Plate 3-7a: EPDZ facies. Footwall Breccia clast-like textures remain at this degree of alteration, although the matrix has been pervasively epidotized. Sample F46-4C, Exploration Drift 46-190, Fraser Mine.

Plate 3-7b: EPDZact facies. Epidote content is greater than amphibole content. Sample FR46-287-2. Field of view $=2.5 \mathrm{~mm}$, cross-polarized, transmitted light.

Plate 3-8a: ACTZ facies. Original Footwall Breccia matrix is almost entirely actinolite. Sample F46-4E, Exploration Drift 46-190, Fraser Mine.

Plate 3-8b: ACTZ facies. Backscattered electron image of abundant titanite (grey) grains in pentlandite (white) and amphibole. Sample F46-4E, Exploration Drift 46-190, Fraser Mine. 

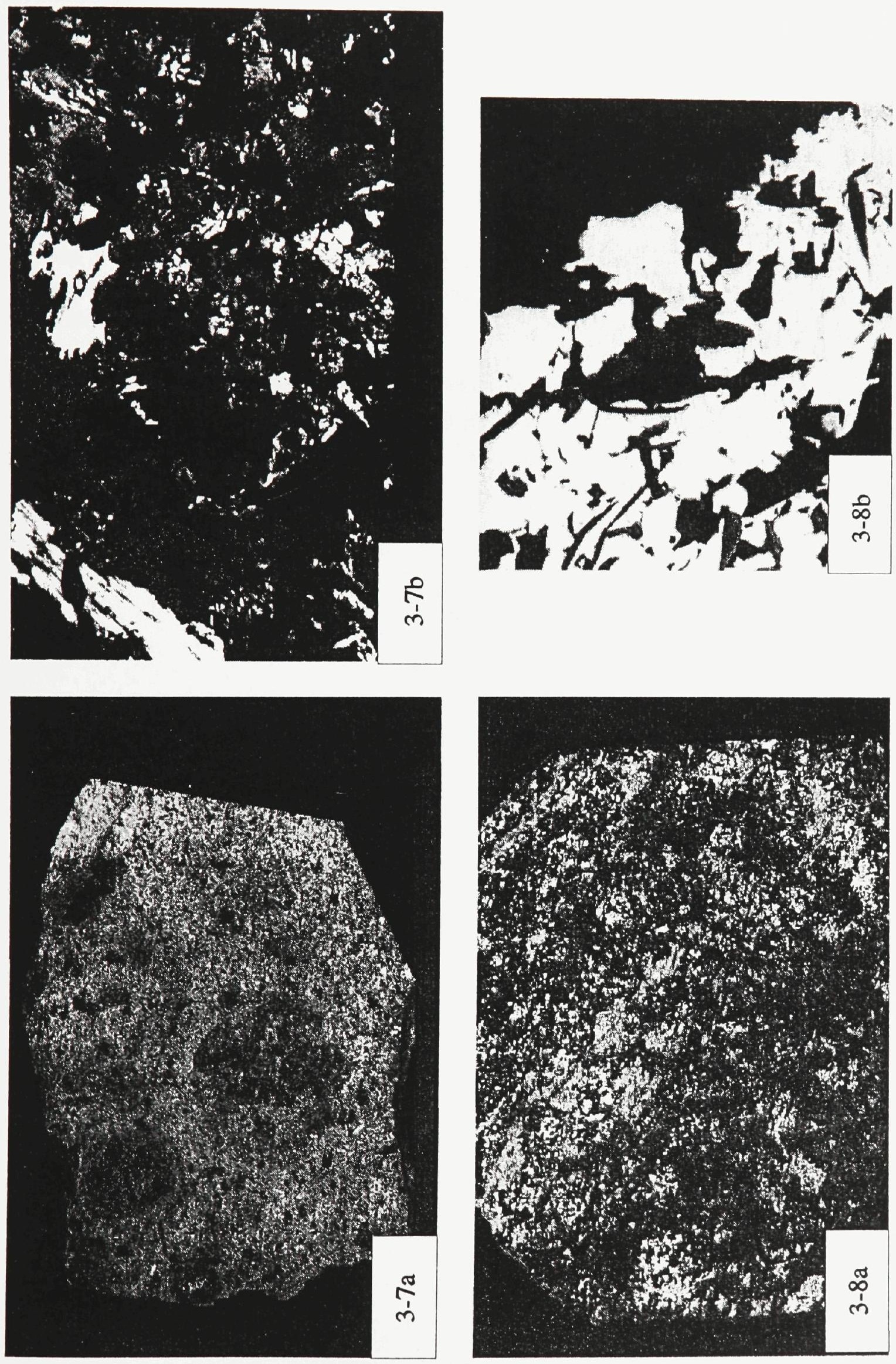


\section{PLATE CAPTIONS}

Plate 3-9a: MAGZ facies. Magnetite occurs as equant grey grains with interstitial pentlandite (white). Epidote and actinolite are the silicate minerals (dark grey). Sample FR46-147-10. Field of view $=2.5 \mathrm{~mm}$, reflected light.

Plate 3-9b: MAGZ facies. As above in cross-polarized, transmitted light.

Plate 3-10a: EPDZact facies. Backscattered electron image of pyrite (dark grey) with galena (white) and chalcopyrite (light grey) inclusions. The galena contains trace amounts of Ag. Sample FR46-287-7.

Plate 3-10b: ACTZ facies. Backscattered electron image of subhedral pyrite with Se-bearing galena inclusions adjacent to unstable pentlandite. Sample F46-4E, Exploration Drift 46-190, Fraser Mine. 

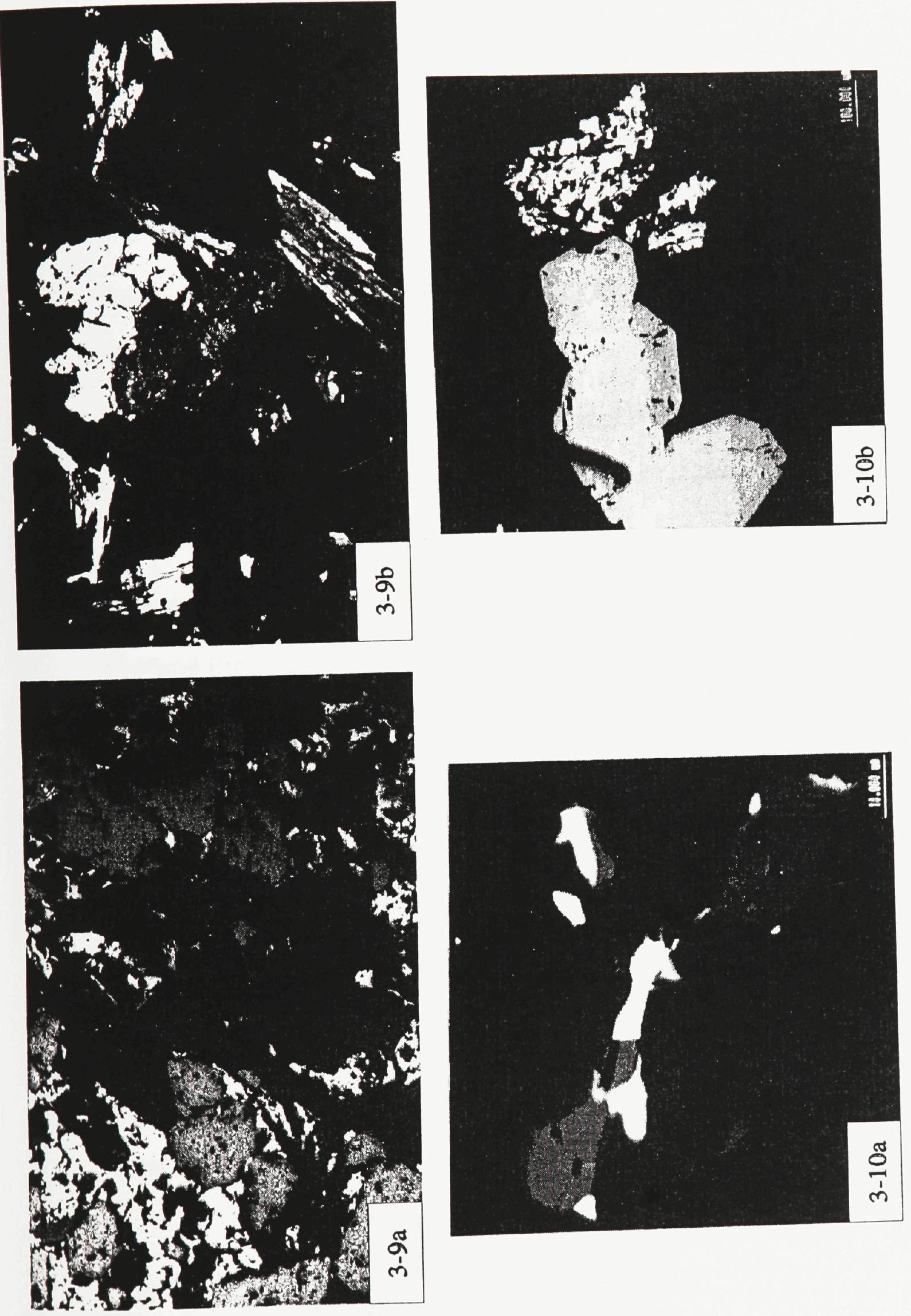


\section{CHAPTER 4: METAL GEOCHEMISTRY}

\section{4-1. INTRODUCTION}

The Barnet Property showing and the Fraser Mine Epidote Zone have been selected as examples of two different types of Cu-Ni-PGE mineralization, one $\mathrm{Cu}$-rich, the other $\mathrm{Ni}$-rich, deposited or extensively modified by hydrothermal fluids. The metal geochemical characteristics of the Barnet Property are identified and compared to those of other Cu-rich footwall deposits, including the Strathcona Mine Deep Copper Zone (Li et al., 1992; Money, 1992) and Copper Zone (Li et al., 1992), and the McCreedy West Cu-rich stringers (Hoffman et al., 1979). Although the Epidote Zone is unique and analogues for comparison do not exist in the literature, an attempt has been made to compare this deposit to Footwall Breccia deposits in the Sudbury area to better understand its genesis.

\section{4-2. FOOTWALL CU-Ni-PGE VEIN DEPOSITS}

A strong metal zonation has been documented at both Strathcona and McCreedy West. There is a consistent increase in Pt and Pd with increasing distance from the footwall contact, and a concomitant depletion in Os, Ru, Ir and Rh (Keays and Crocket, 1970; Chyi and Crocket, 1976; Hoffman et al., 1979; Naldrett et al., 1982; Li et al., 1992). At Strathcona this trend is complicated by the fact that there are two separate Cu-rich zones; the Deep Copper Zone is richer in PGE than is the Copper Zone. 


\section{4-2a. BARNET PROPERTY}

Eight samples, 4 from veins in the Barnet Trench Extension and 4 from Cu-rich stringer occurrences elsewhere on the property were analyzed for $\mathrm{Cu}$, Ni, Co, S, Ir, Rh, Pt, Pd and Au (Table 4-1; Appendix V). These data have been used to compare Barnet property metal geochemistry with that from well documented occurrences of Cu-rich veining in the North Range, and has been combined with a metal geochemical database of 417 samples collected from drill core sampling, channel sampling and grab sampling, provided by Falconbridge Limited (Exploration).

\section{i. Metal Abundances}

The low total PGE content of the Barnet property sulphides has lead previous workers to suggest that they are analagous to Strathcona's Copper Zone (Barnett and Tirschmann, 1989; Farrow and Sweeney, 1990). However, comparison of Copper Zone analyses (Li et al., 1992) and Barnet analyses of equivalent $\mathrm{S}$ content shows that Barnet has higher $\mathrm{Co}$, Ir and Rh, and lower Pt and $\mathrm{Pd}$ abundances than Copper Zone. This implies that Barnet sulphide mineralization is not related to that of the Copper Zone. This possibility will be further explored in later sections.

\section{ii. Element Ratios}

Because more sulphide-rich rocks tend to have higher metal contents, element ratio trends allow for more direct comparison of elements concentrated in sulphides. 
Comparison of $\mathrm{Pt} /(\mathrm{Pt}+\mathrm{Pd})$ ratio frequency plots from Barnet, Copper Zone, Deep Copper Zone and McCreedy West Cu-rich stringers shows that the Barnet property samples have higher $\mathrm{Pt} /(\mathrm{Pt}+\mathrm{Pd})$ ratios than any of the other locations, averaging 0.55 (Figs. 4-1a, b, c and d). Samples with Pt and Pd contents below detection limits are not included on these plots. Although different sampling procedures and analytical techniques have been used in this comparison, the high number of data points renders their comparison possible. Deep Copper Zone samples have much lower $\mathrm{Pt} /(\mathrm{Pt}+\mathrm{Pd})$ ratios $(\sim 0.4)$ but the frequency pattern is skewed to higher values. The Barnet $\mathrm{Pt} /(\mathrm{Pt}+\mathrm{Pd})$ ratios are most similar to those from the Copper Zone. A comparison of $\mathrm{Pt} /(\mathrm{Pt}+\mathrm{Pd})$ vs. $\mathrm{Cu} /(\mathrm{Cu}+\mathrm{Ni})$ diagrams from Barnet and Deep Copper Zone highlights the geochemical differences between the two deposits (Figs. 4-2a and b). The abundance of low $\mathrm{Cu} /(\mathrm{Cu}+\mathrm{Ni})$ values at Deep Copper Zone is the result of sampling bias in the data of Li et al., (1992). Samples with high Ni (millerite and pentlandite) contents tend to contain higher $\mathrm{Pt}$ values but are not representative of the deposit as a whole. For this reason, these values will not be used for further comparison with the Barnet Cu zone.

Further comparison with other $\mathrm{Cu}$-rich vein deposits shows that the Barnet $\mathrm{Cu}$ zone has considerably lower $(\mathrm{Pt}+\mathrm{Pd}) / \mathrm{Ir}$ ratios $\left(3.0 \times 10^{3}\right)$ than both Deep Copper Zone $\left(9.0 \times 10^{4}\right)$, Copper Zone $\left(11 \times 10^{4}\right)$ and McCreedy West Curich stringers due to its lower Pt and Pd abundances. 
$\mathrm{Ni} / \mathrm{Cu}$ ratios for Barnet average 0.03 , similar to those from Copper Zone (0.01), but less than those from Deep Copper Zone and McCreedy West Cu-rich stringers. This is supported by the abundance of pentlandite and millerite, respectively, in the chalcopyrite-rich vein systems of these orebodies (Chapter 3). Barnet $\mathrm{Pd} / \mathrm{Ir}$ ratios (1900) are similar to those from McCreedy West, but are slightly lower than those reported for either of Strathcona's Cu-rich orebodies. In Figure 4-3 the data are plotted on a Pd/Ir vs. Ni/Cu diagram (Barnes et al., 1985). Because of their low Ni/Cu ratios, Barnet analyses fall to the left of the "Cu-rich sulphide vein" field of Barnes et al. (1988). Deep Copper and Copper zone ores fall in the low $\mathrm{Ni} / \mathrm{Cu}$ section, or outside this field. McCreedy West analyses fall predominantly within the "Cu-rich sulphide vein" field, but extend into the overlapping "Flood basalt" and "Layered intrusions" fields, and appear to form a geochemical continuum with Footwall Breccia ore from the same deposit.

Although $\mathrm{Cu} / \mathrm{Ir}$ ratios for Barnet $\left(10^{8}\right)$ are slightly lower than those for the Strathcona Cu-rich orebodies, all fall within the field of "Cu-rich sulphide veins" of Barnes et al. (1988) on a plot of Ni/Pd vs. Cu/lr (Figure 4-4). McCreedy West Cu-rich stringers extend from this field into the "Flood basalts" and "Layered intrusions" fields due to their wide range of $\mathrm{Cu} / \mathrm{lr}$ ratios.

\section{iii. Correlation Coefficients}

A Pearson correlation matrix was calculated for the Barnet metal geochemical data (Table 4-2). The most obvious relationship was the positive 
correlation of 0.99 between $\mathrm{Cu}$ and $\mathrm{S}$. However, also strongly positively associated with both $\mathrm{Cu}$ and $\mathrm{S}$ was $\mathrm{Rh}$, probably because it occurs as a trace element in the chalcopyrite, and not as a distinct Rh-bearing mineral.

Chalcopyrite has been found to contain up to $24 \mathrm{ppm}$ Rh in some Cu-Ni-PGE deposits (L.J. Cabri, pers. comm., 1992). The strong positive correlation between Ir and $\mathrm{Au}$ is not as easily understood. Pt and Pd show similar behaviour but are not associated with $\mathrm{Cu}$ or $\mathrm{S}$ because they tend to form discrete minerals (Chapter 5). This may be the explanation for the behaviour of $\mathrm{Au}$ as well, although no Au minerals have been identified in Barnet samples to date.

\section{iv. Chondrite-Normalized Abundances}

A chondrite-normalized plot of Barnet analyses and those from Deep Copper and Copper zones, and both disseminated and massive sulphide vein ore in SDBX from McCreedy West is shown in Figure 4-5. The profiles are all highly fractionated, yet slightly variable. However, Copper and Deep Copper zone profiles show enrichment in $\mathrm{Ni}$, Pt and $\mathrm{Pd}$. Although Copper Zone total PGE are lower than those for Deep Copper Zone, they are not nearly as low as those for Barnet. Disseminated Cu-rich sulphides from McCreedy West display a similar profile but lower values.

\section{4-2b. SUMMARY}

Metal geochemical differences among different $\mathrm{Cu}$-rich vein orebodies in the North Range suggest that each was deposited as the result of differences in 
metal sources and/or depositional processes. Furthermore, the sulphides of the Barnet Property showing and the Copper Zone are not geochemically similar.

\section{4-3. Cu-Ni-PGE MINERALIZATION IN THE FOOTWALL BRECCIA}

\section{4-3a. FRASER MINE EPIDOTE ZONE}

A total of forty samples from four exploration diamond drill cores (FR46147, 150, 264 and 287; Appendix II) of "Epidote Zone" and surrounding lithologies from the Fraser Mine were sampled for petrographic and metal geochemical study (Table 4-4; Appendix V). This was combined with PGE analyses from 5 samples from the only exposed "Epidote Zone" occurrence in exploration drift FR46-190 (Samples F46-4A to E) and a sample of ore-bearing LGBX (F46-6) from the $46-570$ cross-cut. Sample F46-6 is not associated with "Epidote Zone" development. Analytical methods and detection limits are summarized in Appendix V. Data was synthesized from fifteen other diamond drill hole logs (Appendix II) in addition to those examined in detail for this study. Data from ACTZ and EPDZmag facies are difficult to interpret due to paucity of data.

\section{i. Metal Abundances}

Depth versus abundance sections have been plotted for each of the four detailed holes and the following trends are apparent:

1) Fe increase corresponds to an increase in alteration and the development of MAGZ. 
2) $\mathrm{Ni}$, and less clearly, S, Co and Se, also mimic this trend as do most other metals.

3) Overall $\mathrm{Cu}$ and $\mathrm{Ag}$ abundances are low and both elements behave similarly. Most of these increases correspond to at least the EPDZact alteration facies.

\section{ii. Element Ratios}

Selected ratios for Fraser Epidote Zone metal geochemistry are listed in Table 4-5.

The Footwall Breccia $\mathrm{Cu} /(\mathrm{Cu}+\mathrm{Ni})$ average is 0.26 . All the more altered facies have $\mathrm{Cu} /(\mathrm{Cu}+\mathrm{Ni})$ ratios at least an order of magnitude lower. At the EPDZact facies and higher degrees of alteration, $\mathrm{Cu} /(\mathrm{Cu}+\mathrm{Ni})$ ratios are commonly $<0.01$ (Figure 4-6). EPDZ facies rocks display variable geochemical signatures. $\mathrm{Pt} /(\mathrm{Pt}+\mathrm{Pd})$ averages for all analyzed lithologies are similar and range between 0.43 and 0.60 . By comparison, Footwall Breccia sulphides from McCreedy West disseminated ore and massive ore have similar $\mathrm{Pt} /(\mathrm{Pt}+\mathrm{Pd})$ ratios to the rocks of this study, and $\mathrm{Cu} /(\mathrm{Cu}+\mathrm{Ni})>0.01$. Fraser Depth Footwall Breccia ore has slightly lower average $\mathrm{Pt} /(\mathrm{Pt}+\mathrm{Pd})$ ratios, and all but two samples have $\mathrm{Cu} /(\mathrm{Cu}+\mathrm{Ni})<0.01$.

Figure 4-7 highlights two different trends for $\mathrm{Pt} / \mathrm{Pd}$ and Ir/Pd ratios with respect to alteration intensity. Most of the pristine to moderately altered rocks follow the Footwall Breccia trend of little change in Pt/Pd ratio and variation of almost 2 orders of magnitude for Ir/Pd ratios. On the other hand, more intensely 
altered rocks, outlined by the ACTZ and ACTZmag trend, show a decoupling of $\mathrm{Pt}$ and $\mathrm{Pd}$ abundances and higher, yet more restricted in range, Ir/Pd ratios.

Similar trends to those shown by $\mathrm{Pd} / \mathrm{Ir}$ are displayed by the $(\mathrm{Pt}+\mathrm{Pd}) /(\mathrm{Ru}+\mathrm{Ir}+\mathrm{Os})$ ratios. Footwall Breccia associated with Epidote Zone development has an average ratio of 249 with wide variation among different locations. All the more altered rocks have $(\mathrm{Pt}+\mathrm{Pd}) /(\mathrm{Ru}+\mid \mathrm{r}+\mathrm{Os})$ ratios $<100$, similar to the average Footwall Breccia ore from McCreedy West and Strathcona (Naldrett, 1984), except for EPDZact with an average of 133.

Ni vs. S plots display a strong linear trend (slope $\sim 0.15$ ) for sulphidebearing Sublayer (DNBX or Dark Norite Breccia in mine terminology) and Footwall Breccia. The slope increases to $\sim 0.4$ with increasing alteration. The low levels of $\mathrm{Ni}$ in amphibole and chlorite are not significant enough to have an effect when compared to the amount of $\mathrm{Ni}$ in sulphides.

Footwall Breccia and LGBXepdz Ni/Cu ratio averages are 11 and 20 respectively. They are 159 for the EPDZ facies and show a dramatic increase to 734 in EPDZact. The rest of the altered rocks have $\mathrm{Ni} / \mathrm{Cu}$ ratio averages of $>200$. Ni abundances are not significantly different for each of the alteration facies and their increased $\mathrm{Ni} / \mathrm{Cu}$ ratio can be attributed to lower $\mathrm{Cu}$ contents than the pristine Footwall Breccia, although there is typically a slight increase in Ni content. ACTZ, ACTZmag and MAGZ have Pd/Ir ratios similar to the DNBX average (28), which is consistent with the increase in Ir content displayed by these facies in the mantle-normalized plots when compared to mineralized 
Footwall Breccia (see below). The highest Pd/Ir average occurs in Footwall Breccia (369). In Figure 4-8a the data are plotted on a Pd/Ir vs. Ni/Cu diagram. It shows how a subdivision between Footwall Breccia and low degrees of alteration, and more highly altered Epidote Zone (EPDZact and higher) can be drawn at a $\mathrm{Ni} / \mathrm{Cu}$ ratio of 10 , although $\mathrm{Pd} / \mathrm{Ir}$ values are more variable. Data from other Footwall Breccia sulphides from McCreedy West (Hoffman et al., 1979) and Fraser Depth (Naldrett and Pessaran, 1992) follow this trend. When compared to the fields for magmatic-associated Ni-Cu-PGE deposits as defined by Barnes et al. (1988; 1993), Epidote Zone rocks have high Pd/Ir ratios with repect to their high $\mathrm{Ni} / \mathrm{Cu}$ ratios (Figure 4-8b); this is presumably due to their modification by hydrothermal fluids. Relatively unaltered Sublayer and Footwall Breccia samples correspond to the "Layered Intrusions" field of Barnes et al. (1988; 1993).

Figure 4-9a is a plot of $\mathrm{Ni} / \mathrm{Pd}$ vs. Cu/lr and shows that Ni/Pd ratios are between $10^{4}$ and $10^{6}$, and that all of the most altered Epidote Zone rocks (EPDZact and higher) have Cu/lr ratios of $<10^{6}$. Data from relatively pristine Footwall Breccia from McCreedy West (Hoffman et al., 1979) and Fraser Depth (Naldrett and Pessaran, 1992) show relatively low Ni/Pd ratios, even in comparison to Footwall Breccia sampled for this study. Figure 4-9b shows that most of the Footwall Breccia analyses overlap with the "Layered Intrusions" and "PGE Reefs" fields of Barnes et al. (1988; 1993). 
With respect to these fields, Epidote Zone analyses are variable and cover a broad range of $\mathrm{Ni} / \mathrm{Pd}$ and $\mathrm{Cu} / \mathrm{lr}$ ratios because of their hydrothermal modification. This suggests that the fields of Barnes et al. $(1988 ; 1993)$ are not useful for hydrothermally modified deposits but only for strictly magmatic deposits (see discussion at end of chapter).

\section{iii. Correlation Coefficients}

A Pearson correlation matrix for all the Epidote Zone data shows strong positive correlations between $\mathrm{Ni}$ and $\mathrm{Co}, \mathrm{Cu}$ and $\mathrm{Au}$ and among $\mathrm{Ir}, \mathrm{Os}, \mathrm{Ru}$ and $\mathrm{Rh}$ (Table 4-6; $\mathrm{n}=39$ ). The relatively strong correlations of $\mathrm{Zn}$ with Os, Ir and Pt are more difficult to understand. It is suggested that since they all have a moderately positive correlation with $\mathrm{S}$ that they exist as trace elements within the sulphides.

Correlation matrices were also calculated for selected Epidote Zone facies (Tables 4-7a, $b$ and $c$ ). They support most of the correlations shown by all the data and have helped to identify other trends. Ni is not only positively correlated with $\mathrm{Co}$, but also $\mathrm{S}$ and $\mathrm{Ag}$, possibly the result of traces of $\mathrm{Ag}$ in pentlandite. $\mathrm{Cu}$ is strongly positively correlated with both $\mathrm{Au}$ and $\mathrm{Ag}$. $\mathrm{Fe}$ is strongly positively correlated with S in LGBX, EPDZ and EPDZact where $\mathrm{Fe}$ is in sulphides and silicates. The same relationship does not exist in the ACTZmag and MAGZ facies, where magnetite is strongly developed. In the ACTZmag facies, Se shows a strong relationship with $S$ and all the PGE. Re is most 
commonly associated with $\mathrm{Cu}$ and $\mathrm{Ag}$. $\mathrm{Pb}$ does not show any particular affinity for any of the other elements.

\section{iv. Chondrite-Normalized Abundances}

Chondrite-normalized plots have been completed and interpreted according to both hole and lithology (Table 4-8). Within each hole there is an trend similarity among various alteration facies. Altered rocks tend to mimic the chondrite-normalized trend of their host Footwall Breccia when all lithologies are plotted together. Trends are slightly fractionated to flat, with the dominant alteration patterns being low $\mathrm{Au}$ and $\mathrm{Cu}$ contents in the most altered rocks. On a smaller scale lithological trends are visible within each hole. These include an overall increase in all plotted metals except $\mathrm{Au}$ and $\mathrm{Cu}$ for the most altered samples. Both $\mathrm{Au}$ and $\mathrm{Cu}$ decrease in abundance with respect to pristine Footwall Breccia. Sublayer samples have higher abundances of all metals in the chondrite-normalized plots than Footwall Breccia.

To facilitate comparison among alteration facies, for each facies chondrite-normalized plots of average values \pm 1 standard deviation have been made (Figures $4-10 a$ to $\mathrm{i}$ ). Within the altered rocks a change in profile shape is not evident until the EPDZact degree of alteration is reached. There is a considerable flattening of the profile as $\mathrm{Au}$ and $\mathrm{Cu}$ contents drop and $\mathrm{Ni}$ abundance increases slightly. PGE abundances are high in both analyzed ACTZ samples. This is difficult to interpret due to the low number of analyzed samples of the ACTZ facies, and because both are from different areas in the 
mine. Interpretation of the low PGE contents of the EPDZmag facies suffers from a similar limitation, although both samples are from the same drill hole. ACTZmag and MAGZ samples display high PGE abundances. The low abundances in EPDZmag may be the result of differences in local fluid composition to form this unusual facies; these fluids were capable of transporting PGE and other metals out of it. It could also be the result of specific compositional characteristics of the hole because this facies has not been recognized elsewhere. From the EPDZact to MAGZ facies chondrite-normalized profiles are relatively flat and enriched in $\mathrm{Os}, \mathrm{Ir}, \mathrm{Ru}$ and $\mathrm{Rh}$ compared to their Footwall Breccia host rocks, but not when compared to sulphide-bearing Sublayer. For all elements except $\mathrm{Pd}, \mathrm{Au}$ and $\mathrm{Cu}$, the most highly altered rocks (EPDZact, ACTZ, EPDZmag, ACTZmag and MAGZ) show the greatest range of abundances.

Samples of epidotized metagabbro, gneiss and mafic gneiss, and an ultramafic rock from Epidote Zone bounding units display a variety of profiles (Figure 4-10j). It is unlikely that they were a significant source for metals for the alteration fluids during Epidote Zone development because alteration seldom extends more than $1 \mathrm{~m}$ into the footwall lithologies from the LGBX contact.

A compilation of all chondrite-normalized values for samples from EPDZact through to MAGZ is shown in Figures 4-11a and $b$. The most altered rocks of the Epidote Zone show a profile very similar to those for both DNBX and LGBX from this study, although it is slightly less fractionated (Figure 4-11a). 
Conversely, the relatively flat profile of the most altered Epidote Zone rocks is very different than those displayed by Barnet Cu-rich sulphides, in addition to Strathcona's Deep Copper and Copper zones. Os, Ir, Ru and Rh values are higher, whereas $\mathrm{Pt}, \mathrm{Pd}, \mathrm{Au}$ and $\mathrm{Cu}$ are lower. In Figure 4-11b they are also compared with the profiles for massive and disseminated sulphides in Footwall Breccia from McCreedy West. Here the profiles are similar, with the Epidote Zone profile being slightly less fractionated, and variations due to absolute PGE abundances.

v. Relative Element Gains and Losses: Application of the Isocon Method to Metal Geochemistry

\section{Introduction}

The "isocon method" (Grant, 1986) is a graphical method of solution of Gresens' (1967) method of analysis of changes in concentrations during metasomatism. Grant's method of solution involved rearrangement of Gresen's equations into a linear relationship between the concentration of a component in hydrothermally altered rock and the original. In traditional applications, the "isocon method" is a convenient and simple way to show changes in mass, volume and element concentration, caused by pervasive metasomatism within equivalent, commonly metavolcanic, units. A straight line, or isocon, typically through the origin, and corresponding to zero concentration change is determined, by inspection, as the best fit of the line to the chemical data. The isocon may be established on the basis of a group of components, the immobility of components (i.e., $\mathrm{Al}, \mathrm{Ti}, \mathrm{Zr}$, etc.), or on mass or volume. The deviation of a 
data point from the isocon represents its concentration change. Components plotting above the isocon are gained, those plotting below are lost.

This study has attempted to test the applicability of the "isocon method" to another type of metasomatic problem that includes the compositional variation between metal concentrations in pristine Footwall Breccia and the various facies of the Epidote Zone. The altered rocks were only compared to relatively unaltered Footwall Breccia from the same hole or area in the case of sampling in Exploration Drift 46-190, because previous geochemical tests, including the mantle-normalized plots, showed that there are subtle geochemical trends specific to the original rocks in each area. The reference isocon was that of the best fit to all the data, since it was previously determined that none of the analyzed elements was immobile during the hydrothermal processes that formed the Epidote Zone.

A summary of the approach and its sources of error are presented in Appendix $V$. Because the main rock-forming components of the rock are not being compared it is not possible to compare rock volume changes. Thus, the compositional changes reported in this study are relative, although trends verified by other geochemical tests and by petrography and observation are supported, suggesting that the method is useful for comparing metal concentrations modified by pervasive hydrothermal processes. 


\section{$\underline{\text { Results }}$}

Plots of element gains and losses have been constructed for each of the analyzed elements to graphically show the concentration changes calculated from the "isocon method" (Figs. 4-12a-q). All samples from each alteration facies have been compared to relatively unaltered Footwall Breccia (LGBX) from the same area. Pristine Footwall Breccia was not found in hole FR46-287, so alteration facies were compared to the least altered rock type available (EPDZ). Thus, these results cannot be interpreted with as much confidence as the results from the other drill core locations.

In general, the Epidote Zone is characterized by low sulphide content by comparison with unaltered Footwall Breccia-hosted ore and high Ni/S ratios (Chapter 2). Figure 4-12a shows that $S$ behaviour is erratic, but for comparison of Footwall Breccia with EPDZ and EPDZact there is considerable loss of sulphur. Hole FR46-287, where EPDZ was compared to more altered equivalents, shows a strong loss of $S$ in higher intensity alteration facies that may be specific to the hole.

Fe concentration is variable in EPDZ and EPDZact, but is lower in ACTZ (Figure 4-12b). However, with the onset of magnetite development (ACTZmag and MAGZ) Fe increases. This trend is not apparent in EPDZmag due to its lack of sulphides.

Ni concentrations increase in EPDZact, ACTZ and MAGZ compared to relatively unaltered Footwall Breccia (Figure 4-12c). This supports the trend to 
higher $\mathrm{Ni}$ concentrations in higher intensity alteration facies shown in the mantlenormalized plots. Ni decrease in EPDZact and MAGZ compared to EPDZ in hole FR46-287.

There is an almost ubiquitous loss of $\mathrm{Cu}$, except in one comparison from hole FR46-264 of EPDZ and Footwall Breccia (Figure 4-12d). Slight increases in chalcopyrite content have been observed elsewhere at the epidote + quartz contact of Epidote Zone alteration and host Footwall Breccia. These trends to loss of $\mathrm{Cu}$ have also been shown in mantle-normalized and $\mathrm{Pd} / \mathrm{lr}$ vs. Ni/Cu plots.

$\mathrm{Zn}$, like $\mathrm{Cu}$, is lost in almost all facies, suggesting that $\mathrm{Zn}$ exists as a trace element in chalcopyrite or that it moved with $\mathrm{Cu}$ in the fluid (Figure 4-12e).

Pearson correlation matrices for EPDZ and ACTZmag facies also show a strong positive relationship between $\mathrm{Cu}$ and $\mathrm{Zn}$.

$\mathrm{Pb}$ concentrations increase in EPDZ, ACTZ and EPDZmag when compared to pristine Footwall Breccia (Figure 4-12f). The only Pb-mineral in the Epidote Zone that could partially control its abundance are minute, Se-bearing galena inclusions in pyrite (Chapter 3 ).

Co increases in concentration in all facies, possibly due to its occurrence as a trace element in pentlandite (Figure 4-12g). However, comparisons from hole FR46-287 display the opposite trend.

Se concentrations tend to increase with increased alteration (Figure 412h). However, due to its low abundance, results are difficult to interpret. Se may occur as a trace element in pentlandite. 
$\mathrm{Ag}$, like $\mathrm{Cu}$, is depleted with respect to unaltered LGBX (Figure 4-12i). Its low abundance and possible "nugget effect" with hessite occurring as a common precious metal mineral within the Epidote Zone (Chapter 5), makes it difficult to quantify. However, correlation coefficients for $\mathrm{Ag}$ and $\mathrm{Cu}$ are strongly positive, indicating that they were both carried out of the zone by hydrothermal fluids. Au is similarly strongly related to $\mathrm{Cu}$ and tends to be depleted when compared to its concentration in relatively unaltered Footwall Breccia (Figure 4-12j). Its low concentration in the Epidote Zone makes its behaviour appear more erratic than that of $\mathrm{Ag}$.

Low abundances of $\mathrm{Re}$ and Os render their trends difficult to interpret (Figs. 4-12k and I). However, Os only occurs in amounts greater than detection limits in the most altered rocks.

Concentrations of Ir, Ru and Rh almost ubiquitously increase (Figs. 4$12 \mathrm{~m}, \mathrm{n}$ and $\mathrm{o})$. This trend is supported by mantle-normalized plots and their strong correlation in calculated Pearson correlation plots.

The behaviour of $\mathrm{Pt}$ and $\mathrm{Pd}$ is variable and slightly decoupled. $\mathrm{Pt}$ increases in concentration in EPDZmag, ACTZmag and MAGZ (Figs. 4-12p and q). This trend is similar to that displayed by the occurrence of PGM. Moncheite, $\left[(\mathrm{Pt}, \mathrm{Pd})(\mathrm{Te}, \mathrm{Bi})_{2}\right]$, platinian melonite $\left[(\mathrm{Ni}, \mathrm{Pt})(\mathrm{Te}, \mathrm{Bi})_{2}\right]$ and palladian melonite $\left[(\mathrm{Ni}, \mathrm{Pd})(\mathrm{Te}, \mathrm{Bi})_{2}\right]$ have only been found in the most altered facies of the Epidote Zone (Chapter 5). 


\section{4-3b. SUMMARY}

Major metal geochemical changes in the Epidote Zone are related to alteration of greater intensity than the EPDZ facies. At this degree of alteration, geochemical behaviour is varied and difficult to interpret. Epidote Zone chondrite-normalized profiles are most consistent with profiles for sulphide mineralization in Sublayer and Footwall Breccia.

Despite the apparent lack of quantitative certainty in using the isocon method to show gains and losses in metals in pervasively altered rock, the trends highlighted by it support those identified by more conventional methods (i.e. mantle-normalized diagrams) and by observation and petrography.

\section{4-4. DISCUSSION}

\section{4-4a. Cu-RICH SULPHIDE VEINS}

This comparative study has shown that each $\mathrm{Cu}$-rich footwall vein deposit has its own metallic element geochemical signature, suggesting that each was part of individual hydrothermal cells developed in the footwall. Each deposit inherited characteristics from the original source magmatic sulphides. The source sulphides supplied the $\mathrm{Cu}, \mathrm{Ni}$ and PGE to the remobilizing fluids, for later deposition in the footwall.

Field and experimental PGE geochemical studies have traditionally suggested that $\mathrm{Pt}$ and $\mathrm{Pd}$ are the most mobile of the PGE in hydrothermal environments (Mountain and Wood, 1988a; 1988b). The $\mathrm{Cu}^{+}$ion has the same affinity towards soft ligands as $\mathrm{Pt}^{2+}$ and $\mathrm{Pd}^{2+}$. This affinity may explain the 
common associated of $\mathrm{Cu}$ with $\mathrm{Pt}$ and $\mathrm{Pd}$ in many hydrothermal deposits (Mountain and Wood, 1988a; 1988b; Wood et al., 1990) and of the footwall veins of the North Range. The thermodynamically predicted order of PGE solubility as chlorides at $25^{\circ} \mathrm{C}$ is $\mathrm{Pd}>\mathrm{Pt}>\mathrm{Os}>\mathrm{Ir}$, Au (Mountain and Wood, 1988a). Extrapolated to higher temperatures, significant Pt and Pd solubility is attained only in highly acidic and oxidizing solutions (Wood, 1987; Mountain and Wood, 1988a; Wood et al., 1989; Gammons et al., 1992).

\section{4-4b. EPIDOTE ZONE}

In the Epidote Zone, PGE typically considered to be relatively immobile (i.e., Ir, Os) tend to increase in abundance with an increase in degree of alteration. In magmatic systems these elements are considered to be, with $\mathrm{Ni}$, relatively compatible with mono-sulphide solid solution. However, Ir and Os content increases with respect to unaltered LGBX equivalents suggest that they are mobile and that they have been transported into the Epidote Zone. Typically $\mathrm{Cu}$ and $\mathrm{Ag}$ abundances are low, probably because they have been transported out by a fluid containing "hard" ligands, such as chlorine, which bond strongly to Ag and Cu (Seward, 1973; Phillips and Groves, 1983; Mountain and Wood,

1988a; 1988b; Wood et al., 1989). There is, however, a significant decoupling of $\mathrm{Pt}$ and $\mathrm{Pd}$ from their characteristic behaviour of following $\mathrm{Cu}$ in hydrothermal systems. Previously documented behaviour during hydrothermal remobilization of $\mathrm{Pt}$ and $\mathrm{Pd}$ with $\mathrm{Cu}$ and $\mathrm{Au}$ without affecting the other PGE has been suggested as important in Ni-Cu deposits in Western Australia and in Wyoming 
(McCallum et al., 1976; Keays et al., 1981; 1982). Comparisons within diamond drill holes indicate that even if the alteration formed only where original mineralized Footwall Breccia existed, any original metal abundances have been strongly modified by the alteration.

The decoupled behaviour of $\mathrm{Pt}$ and $\mathrm{Pd}$ could be the result of a drop in the salinity of the fluid in the most highly altered facies or by variation in $\mathrm{pH}$. Experimental data given by Gammons et al. (1992) showed that Pd is more mobile as a chloride complex at slightly higher $\mathrm{pH}$ than $\mathrm{Pt}$ in highly oxidized fluids. As a result, some Pd could have continued out of the Epidote Zone in solution.

4-4c. ASSESSMENT OF DEPOSIT CLASSIFICATION OF BARNES ET AL. (1988; 1993)

The broad variation of the various Epidote Zone alteration facies in $\mathrm{Pd} / \mathrm{Ir}$, $\mathrm{Ni} / \mathrm{Cu}, \mathrm{Ni} / \mathrm{Pd}$ and $\mathrm{Cu} / \mathrm{lr}$ ratios reveals that the classifications of Barnes et al. $(1988 ; 1993)$ is ineffective for comparisons between non-magmatic and magmatic $\mathrm{Cu}-\mathrm{Ni}-\mathrm{PGE}$ deposits. Even the Barnet and Copper Zone vein systems plot outside the "Cu-rich sulphide veins" field of Barnes et al. (1988) on a Pd//r vs. Ni/Cu diagram. North Range Sublayer and Footwall Breccia ores fall outside of or within many different fields. The classification is based on magmatic sulphide models (i.e., fractionation of a sulphide magma that had previously segregated from a silicate liquid). There are no examples from remobilized (tectonic or hydrothermal) sulphide deposits. This, as shown by Epidote Zone 
alteration, has resulted in samples being well out of the range of known magmatic trends. However, these plots provide useful comparisons of ratios among samples that have not suffered added bias by recalculation to $100 \%$ sulphide. In addition, it is not necessary to have $S$ analyses to compare, model and interpret the genesis of various deposit types.

\section{4-4d. COMPARISON OF EPIDOTE ZONE AND CU-RICH SULPHIDE VEIN}

\section{FLUIDS}

In Chapter 3 , values of $\mathrm{fO}_{2}, \mathrm{fS}_{2}$ and $\mathrm{pH}$ of the fluids associated with Epidote Zone development were estimated from the evolution of the dominant sulphide and oxide phases with increased degree of alteration. $\log \mathrm{fO}_{2}$ as high as -27 and $\mathrm{pH}$ values of between 3 to 8 were estimated for fluids associated with Epidote Zone development. Several investigators have shown that at low to intermediate temperatures $\left(25\right.$ to $300^{\circ} \mathrm{C}$ ) only very acidic, $\mathrm{Cl}$-rich aqueous fluids with high $\mathrm{fO}_{2}$ can transport Pt and Pd (Mountain and Wood, 1988a; 1988b;

Wood et al., 1989; Gammons et al., 1992). According to Gammons et al. (1992), the fluid conditions estimated for Epidote Zone development in Chapter 3 would transport $\mathrm{Pt}$ and $\mathrm{Pd}$ as aqueous $\mathrm{PtS}_{2}$ and $\mathrm{PdS}$.

Silicate alteration assemblages are similar (dominated by epidote, actinolite, etc.) for both Cu-rich vein alteration and the Epidote Zone, but their metallic element geochemistry is very different. The similarity of Fe-bearing, silicate alteration assemblages suggests that $\mathrm{fO}_{2}$ of the fluid associated with $\mathrm{Cu}$ rich veining was close to that estimated for Epidote Zone development. 
Sulphate accidental minerals in both $\mathrm{Cu}$-rich footwall veins and in the Epidote Zone suggest high $\mathrm{fO}_{2}$ of the fluid (see Discussion, Chapter 3 ). In addition, similar changes in the evolution of the hydrothermal system that resulted in the instability of magnetite, and in calcite stability, is characteristic of both deposit styles. As a result, differences in fluid composition must be related either to $\mathrm{pH}$ and/or $\mathrm{fS}_{2}$ variations. Although total $\mathrm{S}$ content of the fluid is difficult to compare, it is possible that differences in acidity could partially explain the metal geochemical variations between the $\mathrm{Cu}$-rich and Ni-rich deposits. Higher acidity in the $\mathrm{Cl}$-rich aqueous solution could explain the increased mobility of $\mathrm{Pt}$ and $\mathrm{Pd}$ to produce the $\mathrm{Cu}$-rich veins. The relative lack of experimental data on the mobility of PGE such as Ir and Os in aqueous solution is a limitation to further estimates of fluid composition in this study. However, the fluid conditions in the evolving Epidote Zone were still able to take $\mathrm{Cu}, \mathrm{Au}, \mathrm{Ag}$, and possibly $\mathrm{Zn}$ and $\mathrm{Re}$, into solution, while $\mathrm{Ni}, \mathrm{Co}, \mathrm{Pt}$ and $\mathrm{Pd}$ remained relatively immobile. The reduction and increased $\mathrm{pH}$ of the fluid marked the end of MAGZ development and the precipitation of calcite in both the Epidote Zone and in Cu-rich vein systems. The control of temperature changes on element mobility will be discussed in chapters 6 and 7. 
Table 4-1: Barnet property Ni, Cu, Co, S, Ir, Rh, Pt, Pd and Au geochemical data and selected ratios from this study.

\begin{tabular}{|c|c|c|c|c|c|c|c|}
\hline Sample \# & Ni(wt.\%) & Cu(wt.\%) & Co(wt.\%) & S(wt.\%) & $\operatorname{Ir}(p p b)$ & $R h(p p b)$ & $\mathrm{Pt}(\mathrm{ppb})$ \\
\hline CFAS-5 & 0.09 & 15.00 & 0.006 & 15.30 & 1.48 & 59.41 & 142 \\
\hline CFAS-7 & 0.13 & 30.00 & 0.007 & 31.50 & 0.13 & 48.69 & 45 \\
\hline CFAS-8 & 0.07 & 27.40 & 0.005 & 27.60 & 0.47 & 98.79 & 149 \\
\hline CFAS-10 & 0.06 & 7.90 & 0.052 & 12.10 & 0.22 & 2.93 & 144 \\
\hline CFA-92-1 & 0.05 & 0.61 & 0.014 & 2.80 & 0.14 & 1.62 & 164 \\
\hline CFA-92-3 & 0.04 & 23.30 & 0.016 & 25.20 & 0.06 & 123.75 & 76 \\
\hline CFA-92-4 & 0.10 & 0.92 & 0.011 & 1.18 & 0.16 & 1.90 & 689 \\
\hline CFA-92-6 & 0.11 & 14.30 & 0.015 & 15.90 & 0.22 & 88.86 & 173 \\
\hline Average & 0.08 & 14.93 & 0.016 & 16.45 & 0.36 & 53.24 & 198 \\
\hline Std. Dev. & \pm 0.03 & \pm 10.63 & \pm 0.014 & \pm 10.41 & $\begin{array}{r}+0.44 \\
-0.36\end{array}$ & \pm 45.01 & 190 \\
\hline Sample \# & $\operatorname{Pd}(p p b)$ & $A u(p p b)$ & $\mathrm{Cu} / \mathrm{Cu}+\mathrm{Ni}$ & $P t / P t+P d$ & Pd/lr & $\mathrm{Ni} / \mathrm{Cu}$ & Ni/Pd \\
\hline CFAS-5 & 76 & 205.41 & 0.994 & 0.65 & 51 & 0.006 & 1184 \\
\hline CFAS-7 & 107 & 22.25 & 0.996 & 0.82 & 823 & 0.004 & 1215 \\
\hline CFAS-8 & 242 & 67.68 & 0.997 & 0.60 & 515 & 0.003 & 289 \\
\hline CFAS-10 & 31 & 50.44 & 0.992 & 0.50 & 141 & 0.008 & 1935 \\
\hline CFA-92-1 & 34 & 27.86 & 0.924 & 0.83 & 243 & 0.082 & 1471 \\
\hline CFA-92-3 & 397 & 82.05 & 0.998 & 0.16 & 6617 & 0.002 & 101 \\
\hline CFA-92-4 & 876 & 96.67 & 0.902 & 0.44 & 5475 & 0.109 & 114 \\
\hline CFA-92-6 & 254 & 60.94 & 0.992 & 0.41 & 1155 & 0.008 & 433 \\
\hline Average & 252 & 76.66 & 0.975 & 0.55 & 1877 & 0.028 & 843 \\
\hline Std. Dev. & $\begin{array}{r}+264 \\
-252\end{array}$ & \pm 54.04 & \pm 0.036 & 0.21 & $\begin{array}{r}+2447 \\
-1877\end{array}$ & $\begin{array}{r}+0.040 \\
-0.028\end{array}$ & 652 \\
\hline
\end{tabular}

$\begin{array}{lcc}\text { Sample \# } & \text { Cu/lr } & \text { Pt+Pd/lr } \\ \text { CFAS-5 } & 1.01 \times 10^{7} & 147 \\ \text { CFAS-7 } & 2.31 \times 10^{8} & 1169 \\ \text { CFAS-8 } & 5.83 \times 10^{7} & 832 \\ \text { CFAS-10 } & 3.59 \times 10^{7} & 795 \\ \text { CFA-92-1 } & 4.36 \times 10^{6} & 1414 \\ \text { CFA-92-3 } & 3.88 \times 10^{8} & 7883 \\ \text { CFA-92-4 } & 5.75 \times 10^{6} & 9781 \\ \text { CFA-92-6 } & 6.50 \times 10^{7} & 1941 \\ \text { Average } & 9.98 \times 10^{7} & 2995 \\ \text { Std. Dev. } & +1.29 \times 10^{8} & +3437 \\ & -9.98 \times 10^{7} & -2995\end{array}$


ర్

$\frac{8}{2}$

$\frac{\mathrm{c}}{\sigma}$

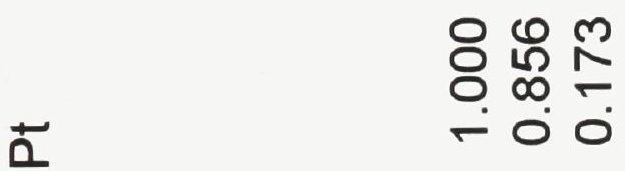

$\frac{\overline{1}}{\alpha}$

용 용 용

츰

은

๘

$\frac{5}{\pi}$

m

는

즌

$\omega$

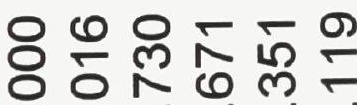

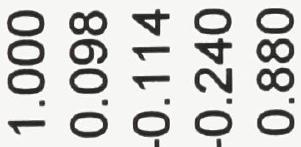

= $\quad-0$ i

苑

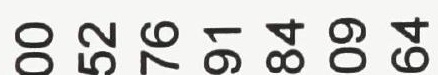

- N N M N

든

짐

능

ธุำ

กับ

(1)

ชิ

$\frac{1}{\frac{1}{6}}$ 


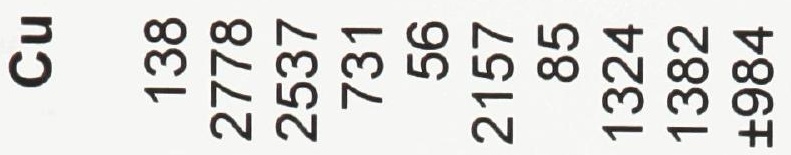

mㄴำ

उ

으 음

ग

ס之z

0.

$+\infty$

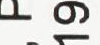

ब

=

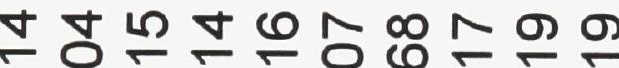

-

乏̄

종

表

응 흥

흐

$\pm z$

동

西

인

믄

है

잉

믐

$\stackrel{d}{ \pm}$

후

임

ป $\frac{1}{\sqrt{0}}$

भं

ช

응 등

ए ह

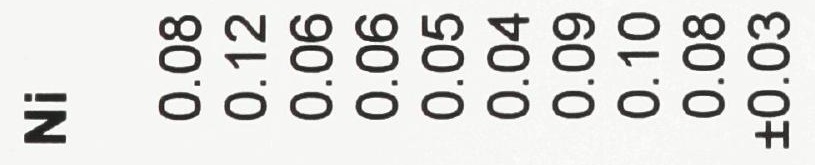

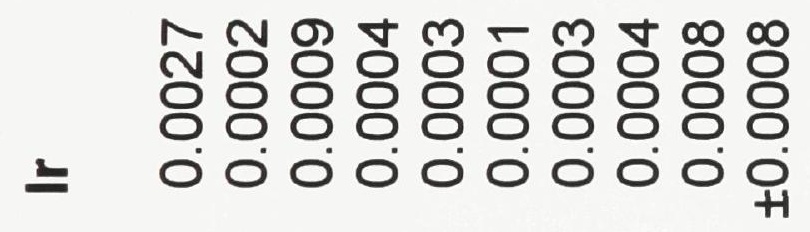

육ำ

스 0000000000

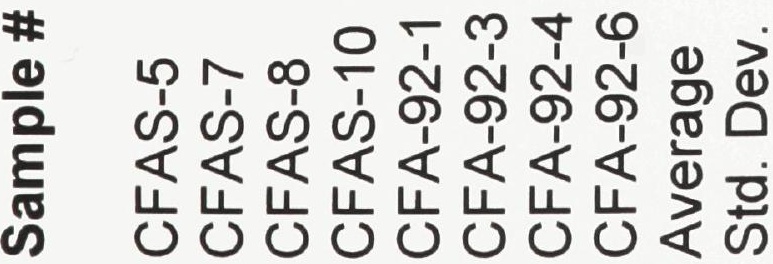


Table 4-4: Fraser Epidote Zone metal geochemistry showing averages and standard deviations for each facies.

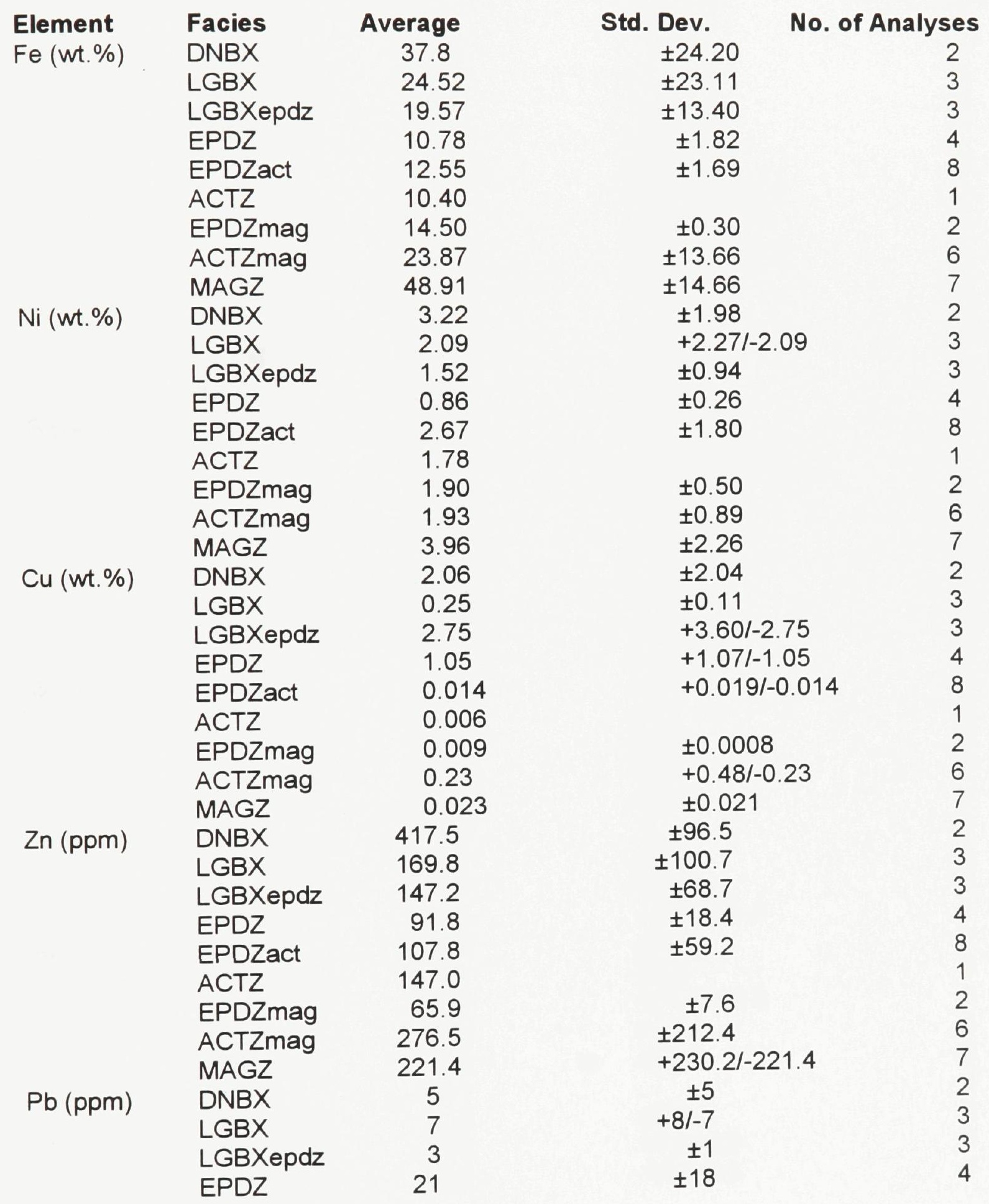


Table4-4: (con't)

\begin{tabular}{|c|c|c|c|c|}
\hline \multirow[t]{6}{*}{ Element } & Facies & Average & Std. Dev. & No. of Analyses \\
\hline & EPDZact & 12 & $+14 /-12$ & 8 \\
\hline & ACTZ & 9 & & 1 \\
\hline & EPDZmag & 3 & \pm 1 & 2 \\
\hline & ACTZmag & 18 & $+23 /-18$ & 6 \\
\hline & MAGZ & 18 & $+27 /-18$ & 7 \\
\hline \multirow[t]{9}{*}{ Co (ppm) } & DNBX & 860.5 & \pm 569.5 & 2 \\
\hline & LGBX & 367.7 & $+371.8 /-367.7$ & 3 \\
\hline & LGBXepdz & 374.7 & \pm 235.5 & 3 \\
\hline & EPDZ & 351.2 & $+377.0 /-351.2$ & 4 \\
\hline & EPDZact & 484.1 & \pm 354.0 & 8 \\
\hline & ACTZ & 326 & & 1 \\
\hline & EPDZmag & 394.5 & \pm 180.5 & 2 \\
\hline & ACTZmag & 414.2 & \pm 319.7 & 6 \\
\hline & MAGZ & 643.9 & \pm 238.1 & 7 \\
\hline \multirow[t]{9}{*}{ S (wt. \%) } & DNBX & 28.00 & \pm 11.50 & 2 \\
\hline & LGBX & 13.28 & $+15.80 /-13.28$ & 3 \\
\hline & LGBXepdz & 15.19 & \pm 11.10 & 3 \\
\hline & EPDZ & 5.35 & \pm 4.87 & 4 \\
\hline & EPDZact & 4.42 & \pm 2.75 & 8 \\
\hline & ACTZ & 2.85 & & 1 \\
\hline & EPDZmag & 4.86 & \pm 1.60 & 2 \\
\hline & ACTZmag & 5.82 & \pm 4.89 & 6 \\
\hline & MAGZ & 10.07 & \pm 3.66 & 7 \\
\hline \multirow[t]{9}{*}{ Se (ppm) } & DNBX & 24.4 & \pm 8.4 & 2 \\
\hline & LGBX & 4.9 & \pm 1.7 & 3 \\
\hline & LGBXepdz & 25.1 & \pm 19.9 & 3 \\
\hline & EPDZ & 8.7 & \pm 3.7 & 4 \\
\hline & EPDZact & 27.2 & \pm 23.8 & 8 \\
\hline & ACTZ & 32.4 & & 1 \\
\hline & EPDZmag & 15.6 & \pm 5.9 & 2 \\
\hline & ACTZmag & 14.3 & \pm 8.6 & 6 \\
\hline & MAGZ & 23.9 & $+26.1 /-23.9$ & 7 \\
\hline \multirow[t]{9}{*}{$\mathrm{Ag}(\mathrm{ppm})$} & DNBX & 7.7 & \pm 7.7 & 2 \\
\hline & LGBX & 2.1 & \pm 1.6 & 3 \\
\hline & LGBXepdz & 10.6 & $+11.8 /-10.6$ & 3 \\
\hline & EPDZ & 5.8 & \pm 4.1 & 4 \\
\hline & EPDZact & 1.9 & \pm 0.6 & 8 \\
\hline & ACTZ & 2.1 & & 1 \\
\hline & EPDZmag & 1.2 & \pm 0.2 & 2 \\
\hline & ACTZmag & 2.9 & $+4.3 /-2.9$ & 6 \\
\hline & MAGZ & 0.3 & $+0.7 /-0.3$ & 7 \\
\hline
\end{tabular}


Table 4-4: (con't)

\begin{tabular}{|c|c|c|c|c|}
\hline \multirow{10}{*}{$\begin{array}{l}\text { Element } \\
\operatorname{Re}(p p b)\end{array}$} & Facies & Average & Std. Dev. & No. of Analyses \\
\hline & DNBX & 41.0 & \pm 16.02 & \\
\hline & LGBX & 3.0 & $+3.5 /-3.0$ & 6 \\
\hline & LGBXepdz & 5.0 & $+5.7 /-5.0$ & 3 \\
\hline & EPDZ & 5.0 & $+5.2 /-5.0$ & 5 \\
\hline & EPDZact & 1.0 & $+1.2 /-1.0$ & 9 \\
\hline & ACTZ & 6.5 & \pm 4.5 & 2 \\
\hline & EPDZmag & 0.5 & \pm 0.5 & 2 \\
\hline & ACTZmag & 4.3 & $+9.2 /-4.3$ & 6 \\
\hline & MAGZ & 0.4 & $+0.7 /-0.4$ & 7 \\
\hline \multirow[t]{9}{*}{ Os (ppb) } & DNBX & 9 & \pm 3 & 2 \\
\hline & LGBX & $<3$ & & 6 \\
\hline & LGBXepdz & 1 & $+2 /-1$ & 3 \\
\hline & EPDZ & 1 & $+2 /-1$ & 5 \\
\hline & EPDZact & 1 & $+2 /-1$ & 9 \\
\hline & ACTZ & 26 & \pm 8 & 2 \\
\hline & EPDZmag & $<3$ & & 2 \\
\hline & ACTZmag & 7 & \pm 7 & 6 \\
\hline & MAGZ & 6 & $+8 /-6$ & 7 \\
\hline \multirow[t]{9}{*}{ Ir (ppb) } & DNBX & 32.0 & \pm 1.2 & 2 \\
\hline & LGBX & 1.6 & \pm 1.6 & 6 \\
\hline & LGBXepdz & 8.6 & $+12.0 /-8.6$ & 3 \\
\hline & EPDZ & 4.1 & $+4.6 /-4.1$ & 5 \\
\hline & EPDZact & 4.7 & $+4.9 /-4.7$ & 9 \\
\hline & ACTZ & 121.4 & \pm 64.6 & 2 \\
\hline & EPDZmag & 0.2 & \pm 0.2 & 2 \\
\hline & ACTZmag & 24.8 & \pm 20.5 & 6 \\
\hline & MAGZ & 17.3 & $+18.2 /-17.3$ & 7 \\
\hline \multirow[t]{9}{*}{ Ru (ppb) } & DNBX & 42 & \pm 4 & 2 \\
\hline & LGBX & 6 & \pm 4 & 3 \\
\hline & LGBXepdz & 11 & \pm 11 & 3 \\
\hline & EPDZ & 7 & \pm 4 & 4 \\
\hline & EPDZact & 12 & $+13 /-12$ & 8 \\
\hline & ACTZ & 105 & & 1 \\
\hline & EPDZmag & 6 & \pm 2 & 2 \\
\hline & ACTZmag & 29 & \pm 26 & $\overline{6}$ \\
\hline & MAGZ & 17 & \pm 15 & 7 \\
\hline \multirow{5}{*}{$\mathrm{Rh}(\mathrm{ppb})$} & DNBX & 150 & \pm 82 & 2 \\
\hline & LGBX & 5 & \pm 4 & 3 \\
\hline & LGBXepdz & 22 & $+31 /-22$ & 3 \\
\hline & EPDZ & 14 & $+16 /-14$ & 4 \\
\hline & EPDZact & 15 & \pm 13 & 8 \\
\hline
\end{tabular}


Table 4-4: (con't)

\begin{tabular}{|c|c|c|c|c|}
\hline \multirow{5}{*}{$\begin{array}{l}\text { Element } \\
\text { Rh (ppb) }\end{array}$} & Facies & Average & Std. Dev. & No. of Analyses \\
\hline & ACTZ & 136 & & 1 \\
\hline & EPDZmag & 2 & \pm 1 & 2 \\
\hline & ACTZmag & 89 & \pm 67 & 6 \\
\hline & MAGZ & 65 & $+66 /-65$ & 7 \\
\hline \multirow[t]{9}{*}{$\mathrm{Pt}(\mathrm{ppb})$} & DNBX & 840 & \pm 260 & 2 \\
\hline & LGBX & 366 & $+404 /-366$ & 6 \\
\hline & LGBXepdz & 60 & \pm 17 & 3 \\
\hline & EPDZ & 191 & \pm 167 & 5 \\
\hline & EPDZact & 175 & \pm 87 & 9 \\
\hline & ACTZ & 1170 & \pm 880 & 2 \\
\hline & EPDZmag & 87 & \pm 33 & 2 \\
\hline & ACTZmag & 412 & \pm 335 & 6 \\
\hline & MAGZ & 342 & $+369 /-342$ & 7 \\
\hline \multirow[t]{9}{*}{$P d(p p b)$} & DNBX & 735 & \pm 125 & 2 \\
\hline & LGBX & 324 & $+361 /-324$ & 6 \\
\hline & LGBXepdz & 92 & \pm 57 & 3 \\
\hline & EPDZ & 139 & \pm 55 & 5 \\
\hline & EPDZact & 136 & \pm 48 & 9 \\
\hline & ACTZ & 1070 & \pm 630 & 2 \\
\hline & EPDZmag & 82 & \pm 28 & 2 \\
\hline & ACTZmag & 241 & \pm 155 & 6 \\
\hline & MAGZ & 377 & \pm 370 & 7 \\
\hline \multirow[t]{9}{*}{$A u(p p b)$} & DNBX & 88 & \pm 72 & 2 \\
\hline & LGBX & 23 & \pm 19 & 6 \\
\hline & LGBXepdz & 231 & $+303 /-231$ & 3 \\
\hline & EPDZ & 40 & $+70 /-40$ & 5 \\
\hline & EPDZact & 7 & \pm 7 & 9 \\
\hline & ACTZ & 20 & \pm 14 & 2 \\
\hline & EPDZmag & 15 & \pm 5 & 2 \\
\hline & ACTZmag & 6 & $+9 /-6$ & 6 \\
\hline & MAGZ & 9 & \pm 7 & 7 \\
\hline
\end{tabular}


Table 4-5: Selected ratios for Fraser Epidote Zone metal geochemistry showing averages and standard deviations for each facies.

\begin{tabular}{|c|c|c|c|c|}
\hline Ratio & Facies & Average & Std. Dev. & $\begin{array}{l}\text { No. of } \\
\text { Analyses }\end{array}$ \\
\hline \multirow[t]{9}{*}{$\mathrm{Cu} /(\mathrm{Cu}+\mathrm{Ni})$} & DNBX & 0.39 & \pm 0.38 & 2 \\
\hline & LGBX & 0.26 & \pm 0.16 & 3 \\
\hline & LGBXepdz & 0.32 & $+0.33 /-0.32$ & 3 \\
\hline & EPDZ & 0.33 & \pm 0.33 & 4 \\
\hline & EPDZact & 0.01 & $+0.03 /-0.01$ & 8 \\
\hline & ACTZ & 0.004 & & 1 \\
\hline & EPDZmag & 0.005 & \pm 0.002 & 2 \\
\hline & ACTZmag & 0.07 & $+0.14 /-0.07$ & 6 \\
\hline & MAGZ & 0.01 & \pm 0.01 & 7 \\
\hline \multirow[t]{9}{*}{$\mathrm{Ni} / \mathrm{Cu}$} & DNBX & 118 & \pm 117 & 2 \\
\hline & LGBX & 11 & $+13 /-11$ & 3 \\
\hline & LGBXepdz & 20 & $+24 /-20$ & 3 \\
\hline & EPDZ & 159 & $+167 /-159$ & 4 \\
\hline & EPDZact & 734 & \pm 624 & 8 \\
\hline & ACTZ & 283 & & 1 \\
\hline & EPDZmag & 222 & \pm 77 & 2 \\
\hline & ACTZmag & 364 & $+463 /-364$ & 6 \\
\hline & MAGZ & 668 & $+914 /-668$ & 7 \\
\hline \multirow[t]{9}{*}{$\mathrm{Ni} / \mathrm{Co}$} & DNBX & 39 & \pm 3 & 2 \\
\hline & LGBX & 49 & \pm 13 & 3 \\
\hline & LGBXepdz & 42 & \pm 2 & 3 \\
\hline & EPDZ & 50 & $\pm \overline{31}$ & 4 \\
\hline & EPDZact & 58 & \pm 14 & 8 \\
\hline & ACTZ & 55 & & 1 \\
\hline & EPDZmag & 53 & \pm 12 & 2 \\
\hline & ACTZmag & 61 & \pm 28 & 6 \\
\hline & MAGZ & 59 & \pm 23 & 7 \\
\hline \multirow[t]{9}{*}{$\mathrm{Pt} /(\mathrm{Pt}+\mathrm{Pd})$} & DNBX & 0.52 & \pm 0.04 & 2 \\
\hline & LGBX & 0.57 & \pm 0.06 & 6 \\
\hline & LGBXepdz & 0.44 & \pm 0.10 & 3 \\
\hline & EPDZ & 0.49 & \pm 0.20 & 4 \\
\hline & EPDZact & 0.53 & \pm 0.11 & 9 \\
\hline & ACTZ & 0.47 & \pm 0.07 & 2 \\
\hline & EPDZmag & 0.51 & \pm 0.01 & 2 \\
\hline & ACTZmag & 0.60 & \pm 0.09 & 6 \\
\hline & MAGZ & 0.47 & \pm 0.14 & 7 \\
\hline \multirow[t]{2}{*}{$\mathrm{Pt} / \mathrm{Pd}$} & DNBX & 1.1 & \pm 0.2 & 2 \\
\hline & LGBX & 1.3 & \pm 0.3 & 6 \\
\hline
\end{tabular}


Table 4-5: (con't)

\begin{tabular}{|c|c|c|c|c|}
\hline Ratio & Facies & Average & Std. Dev. & $\begin{array}{l}\text { No. of } \\
\text { Analyses }\end{array}$ \\
\hline \multirow[t]{7}{*}{$\mathrm{Pt} / \mathrm{Pd}$} & LGBXepdz & 0.8 & \pm 0.3 & 3 \\
\hline & EPDZ & 1.2 & \pm 0.7 & 5 \\
\hline & EPDZact & 1.3 & \pm 0.5 & 9 \\
\hline & ACTZ & 0.9 & \pm 0.3 & 2 \\
\hline & EPDZmag & 1.0 & \pm 0.04 & 2 \\
\hline & ACTZmag & 1.6 & \pm 0.6 & 6 \\
\hline & MAGZ & 1.0 & \pm 0.4 & 7 \\
\hline$(P t+P d) /$ & DNBX & 20 & \pm 7 & 2 \\
\hline \multirow[t]{8}{*}{ (Ru+|r+Os) } & LGBX & 249 & $+325 /-249$ & 6 \\
\hline & LGBXepdz & 34 & \pm 27 & 3 \\
\hline & EPDZ & 70 & $+82 /-70$ & 5 \\
\hline & EPDZact & 133 & $+253 /-133$ & 9 \\
\hline & ACTZ & 11 & \pm 6 & 2 \\
\hline & EPDZmag & 28 & \pm 15 & 2 \\
\hline & ACTZmag & 27 & \pm 22 & 6 \\
\hline & MAGZ & 36 & \pm 24 & 7 \\
\hline \multirow[t]{9}{*}{$\mathrm{Pd} / \mathrm{lr}$} & DNBX & 23 & \pm 5 & 2 \\
\hline & LGBX & 369 & $+504 /-369$ & 6 \\
\hline & LGBXepdz & 123 & \pm 117 & 3 \\
\hline & EPDZ & 77 & \pm 54 & 5 \\
\hline & EPDZact & 130 & $+152 /-130$ & 9 \\
\hline & ACTZ & 8.4 & \pm 0.7 & 2 \\
\hline & EPDZmag & 367 & & 1 \\
\hline & ACTZmag & 16 & \pm 8 & 6 \\
\hline & MAGZ & 55 & $+71 /-55$ & 7 \\
\hline \multirow[t]{9}{*}{$\mathrm{Ni} / \mathrm{Pd}$} & DNBX & $4.0 \times 10^{4}$ & $3^{4} \quad \pm 2.0 \times 10^{4}$ & 2 \\
\hline & LGBX & $5.5 \times 10^{4}$ & $\pm 1.6 \times 10^{4}$ & 3 \\
\hline & LGBXepdz & $1.6 \times 10^{5}$ & $\pm 1.0 \times 10^{5}$ & 3 \\
\hline & EPDZ & $8.3 \times 10^{4}$ & $\pm 4.6 \times 10^{4}$ & 4 \\
\hline & EPDZact & $1.9 \times 10^{5}$ & $\pm 1.2 \times 10^{5}$ & 8 \\
\hline & ACTZ & $4.0 \times 10^{4}$ & & 1 \\
\hline & EPDZmag & $2.4 \times 10^{5}$ & $\pm 2.1 \times 10^{4}$ & 2 \\
\hline & ACTZmag & $1.8 \times 10^{5}$ & $\pm 1.6 \times 10^{5}$ & 6 \\
\hline & MAGZ & $2.1 \times 10^{5}$ & $\pm 1.8 \times 10^{5}$ & 7 \\
\hline \multirow[t]{5}{*}{$\mathrm{Cu} / \mathrm{lr}$} & DNBX & $6.2 \times 10^{5}$ & $\pm 6.2 \times 10^{5}$ & 2 \\
\hline & LGBX & $1.2 \times 10^{5}$ & $\pm 7.2 \times 10^{4}$ & 3 \\
\hline & LGBXepdz & $1.3 \times 10^{7}$ & $\pm 3.1 \times 10^{6}$ & 2 \\
\hline & EPDZ & $1.8 \times 10^{6}$ & $+2.3 \times 10^{6} /-1.8 \times 10^{6}$ & 4 \\
\hline & EPDZact & $6.7 \times 10^{4}$ & $+8.6 \times 10^{4} /-6.7 \times 10^{4}$ & 8 \\
\hline
\end{tabular}


Table 4-5: (con't)

\begin{tabular}{|c|c|c|c|c|}
\hline Ratio & Facies & Average & Std. Dev. & $\begin{array}{l}\text { No. of } \\
\text { Analyses }\end{array}$ \\
\hline \multirow[t]{4}{*}{$\mathrm{Cu} / \mathrm{Ir}$} & ACTZ & $1.1 \times 10^{3}$ & & 1 \\
\hline & EPDZmag & $2.7 \times 10^{5}$ & & 1 \\
\hline & ACTZmag & $1.1 \times 10^{5}$ & $+1.6 \times 10^{5}$ & $\times 10^{5} 6$ \\
\hline & MAGZ & $8.5 \times 10^{4}$ & $+1.7 \times 10^{5} /-\varepsilon$ & $\times 10^{4} 6$ \\
\hline
\end{tabular}


Table 4-6: Pearson correlation matrix for all Fraser Epidote Zone geochemical analyses.

\begin{tabular}{lrrrlllll} 
& \multicolumn{1}{l}{$\mathrm{Fe}$} & $\mathrm{Ni}$ & $\mathrm{Cu}$ & $\mathrm{Zn}$ & $\mathrm{Pb}$ & $\mathrm{Co}$ & $\mathrm{S}$ & $\mathrm{Se}$ \\
$\mathrm{Fe}$ & 1.000 & & & & & & & \\
$\mathrm{Ni}$ & 0.677 & 1.000 & & & & & & \\
$\mathrm{Cu}$ & -0.147 & -0.106 & 1.000 & & & & & \\
$\mathrm{Zn}$ & 0.391 & 0.198 & 0.215 & 1.000 & & & & \\
$\mathrm{~Pb}$ & 0.117 & -0.029 & -0.146 & 0.449 & 1.000 & & & \\
$\mathrm{Co}$ & 0.483 & 0.764 & 0.056 & 0.335 & -0.134 & 1.000 & & \\
$\mathrm{~S}$ & 0.585 & 0.544 & 0.388 & 0.380 & -0.255 & 0.688 & 1.000 & \\
$\mathrm{Se}$ & 0.107 & 0.608 & 0.181 & 0.007 & -0.119 & 0.533 & 0.295 & 1.000 \\
$\mathrm{Ag}$ & 0.089 & 0.119 & 0.153 & 0.231 & -0.237 & 0.304 & 0.512 & 0.000 \\
$\mathrm{Re}$ & 0.190 & 0.167 & 0.331 & 0.407 & -0.165 & 0.539 & 0.696 & 0.141 \\
$\mathrm{Os}$ & 0.233 & 0.003 & 0.131 & 0.727 & 0.389 & 0.148 & 0.092 & 0.053 \\
$\mathrm{Ir}$ & 0.206 & 0.041 & 0.218 & 0.759 & 0.367 & 0.210 & 0.193 & 0.149 \\
$\mathrm{Ru}$ & 0.059 & -0.035 & 0.161 & 0.608 & 0.230 & 0.115 & 0.128 & 0.113 \\
$\mathrm{Rh}$ & 0.300 & 0.142 & 0.086 & 0.677 & 0.263 & 0.386 & 0.356 & 0.212 \\
$\mathrm{Pt}$ & 0.474 & 0.362 & -0.009 & 0.774 & 0.339 & 0.556 & 0.558 & 0.030 \\
$\mathrm{Pd}$ & 0.276 & 0.274 & 0.008 & 0.423 & 0.081 & 0.452 & 0.452 & 0.173 \\
$\mathrm{Au}$ & -0.123 & -0.053 & 0.920 & 0.083 & -0.112 & 0.110 & 0.365 & 0.213
\end{tabular}

\begin{tabular}{lrlllllll} 
& \multicolumn{1}{l}{$\mathrm{Ag}$} & $\mathrm{Re}$ & $\mathrm{Os}$ & $\mathrm{Ir}$ & $\mathrm{Ru}$ & $\mathrm{Rh}$ & $\mathrm{Pt}$ & $\mathrm{Pd}$ \\
$\mathrm{Ag}$ & 1.000 & & & & & & & \\
$\mathrm{Re}$ & 0.258 & 1.000 & & & & & & \\
$\mathrm{Os}$ & 0.067 & 0.248 & 1.000 & & & & & \\
$\mathrm{Ir}$ & 0.117 & 0.380 & 0.929 & 1.000 & & & & \\
$\mathrm{Ru}$ & 0.123 & 0.344 & 0.805 & 0.923 & 1.000 & & & \\
$\mathrm{Rh}$ & 0.200 & 0.574 & 0.767 & 0.880 & 0.770 & 1.000 & & \\
$\mathrm{Pt}$ & 0.442 & 0.529 & 0.524 & 0.559 & 0.455 & 0.672 & 1.000 & \\
$\mathrm{Pd}$ & 0.378 & 0.375 & 0.318 & 0.356 & 0.329 & 0.526 & 0.683 & 1.000 \\
$\mathrm{Au}$ & 0.144 & 0.252 & 0.045 & 0.131 & 0.072 & 0.038 & -0.030 & -0.007
\end{tabular}

Au $\quad \begin{array}{ll}\text { Au } \\ 1.000\end{array}$

Number of observations $=39$. 
Table 4-7a: Pearson correlation matrix for EPDZact facies geochemical analyses.

\begin{tabular}{|c|c|c|c|c|c|c|c|c|}
\hline & $\mathrm{Fe}$ & $\mathrm{Ni}$ & $\mathrm{Cu}$ & $\mathrm{Zn}$ & $\mathrm{Pb}$ & Co & $S$ & $\mathrm{Se}$ \\
\hline ee & 1.000 & & & & & & & \\
\hline 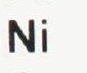 & 0.738 & 1.000 & & & & & & \\
\hline $\mathrm{Cu}$ & -0.212 & -0.447 & 1.000 & & & & & \\
\hline $7 n$ & -0.621 & -0.646 & -0.067 & 1.000 & & & & \\
\hline $\mathrm{Pb}$ & -0.744 & -0.479 & -0.265 & 0.762 & 1.000 & & & \\
\hline$C_{0}$ & 0.768 & 0.944 & -0.418 & -0.642 & -0.494 & 1.000 & & \\
\hline S & 0.918 & 0.841 & -0.312 & -0.818 & -0.682 & 0.856 & 1.000 & \\
\hline $\mathrm{Se}$ & 0.801 & 0.813 & -0.389 & -0.543 & -0.508 & 0.886 & 0.814 & 1.0 \\
\hline $\mathrm{Ag}$ & 0.404 & 0.801 & -0.211 & -0.621 & -0.343 & 0.584 & 0.585 & 0.4 \\
\hline $\operatorname{Re}$ & 0.599 & 0.715 & -0.421 & -0.138 & -0.251 & 0.687 & 0.507 & 0.4 \\
\hline Os & -0.369 & -0.437 & 0.919 & 0.142 & -0.101 & -0.403 & -0.492 & -0.3 \\
\hline Ir & -0.348 & -0.657 & 0.348 & 0.700 & 0.141 & -0.710 & -0.667 & -0.52 \\
\hline $\mathrm{Ru}$ & -0.248 & -0.510 & 0.149 & 0.713 & 0.182 & -0.610 & -0.566 & -0.51 \\
\hline $\mathrm{Rh}$ & -0.210 & -0.579 & 0.366 & 0.560 & -0.056 & -0.615 & -0.541 & -0.426 \\
\hline $\mathrm{Pt}$ & 0.217 & 0.216 & -0.064 & 0.428 & 0.047 & 0.208 & -0.063 & 0.13 \\
\hline $\mathrm{Pd}$ & 0.603 & 0.673 & -0.359 & -0.117 & -0.214 & 0.700 & 0.502 & 0.4 \\
\hline 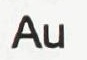 & 0.538 & 0.914 & -0.441 & -0.744 & -0.368 & 0.874 & 0.780 & 0 \\
\hline
\end{tabular}

\begin{tabular}{|c|c|c|c|c|c|c|c|}
\hline $\mathrm{Ag}$ & $\operatorname{Re}$ & Os & Ir & $\mathrm{Ru}$ & $\mathrm{Rh}$ & $\mathrm{Pt}$ & $\mathrm{Pd}$ \\
\hline 1.000 & & & & & & & \\
\hline 0.427 & 1.000 & & & & & & \\
\hline-0.242 & -0.365 & 1.000 & & & & & \\
\hline-0.538 & -0.217 & 0.437 & 1.000 & & & & \\
\hline-0.399 & 0.045 & 0.219 & 0.940 & 1.000 & & & \\
\hline-0.513 & -0.172 & 0.427 & 0.977 & 0.907 & 1.000 & & \\
\hline-0.005 & 0.726 & 0.128 & 0.367 & 0.510 & 0.340 & 1.000 & \\
\hline 0.323 & 0.978 & -0.307 & -0.255 & -0.017 & -0.219 & 0.746 & 1.000 \\
\hline 0.801 & 0.423 & -0.442 & -0.849 & -0.771 & -0.787 & -0.142 & 0.38 \\
\hline
\end{tabular}

Au $\quad \begin{array}{ll}\mathrm{Au} \\ 1.000\end{array}$

Number of observations $=8$. 
Table 4-7b: Pearson correlation matrix for ACTZmag facies geochemical analyses.

\begin{tabular}{lrrllllll} 
& \multicolumn{1}{l}{$\mathrm{Fe}$} & $\mathrm{Ni}$ & $\mathrm{Cu}$ & $\mathrm{Zn}$ & $\mathrm{Pb}$ & $\mathrm{Co}$ & $\mathrm{S}$ & $\mathrm{Se}$ \\
$\mathrm{Fe}$ & 1.000 & & & & & & & \\
$\mathrm{Ni}$ & 0.676 & 1.000 & & & & & & \\
$\mathrm{Cu}$ & -0.257 & 0.077 & 1.000 & & & & & \\
$\mathrm{Zn}$ & 0.421 & 0.492 & 0.747 & 1.000 & & & & \\
$\mathrm{~Pb}$ & 0.919 & 0.571 & -0.283 & 0.419 & 1.000 & & & \\
$\mathrm{Co}$ & -0.181 & 0.377 & 0.915 & 0.725 & -0.200 & 1.000 & & \\
$\mathrm{~S}$ & -0.013 & 0.083 & 0.943 & 0.865 & -0.043 & 0.787 & 1.000 & \\
$\mathrm{Se}$ & 0.332 & 0.331 & 0.490 & 0.800 & 0.509 & 0.526 & 0.593 & 1.000 \\
$\mathrm{Ag}$ & -0.425 & -0.020 & 0.983 & 0.618 & -0.442 & 0.907 & 0.873 & 0.392 \\
$\mathrm{Re}$ & -0.277 & 0.062 & 0.999 & 0.734 & -0.304 & 0.915 & 0.937 & 0.492 \\
$\mathrm{Os}$ & 0.442 & 0.402 & 0.527 & 0.891 & 0.609 & 0.530 & 0.667 & 0.930 \\
$\mathrm{Ir}$ & 0.383 & 0.409 & 0.708 & 0.971 & 0.433 & 0.685 & 0.830 & 0.911 \\
$\mathrm{Ru}$ & 0.359 & 0.400 & 0.766 & 0.975 & 0.338 & 0.719 & 0.884 & 0.825 \\
$\mathrm{Rh}$ & 0.216 & 0.206 & 0.618 & 0.812 & 0.326 & 0.590 & 0.715 & 0.956 \\
$\mathrm{Pt}$ & 0.535 & 0.449 & 0.435 & 0.868 & 0.684 & 0.457 & 0.595 & 0.955 \\
$\mathrm{Pd}$ & 0.497 & 0.309 & 0.145 & 0.583 & 0.632 & 0.193 & 0.302 & 0.900 \\
$\mathrm{Au}$ & -0.318 & 0.167 & 0.972 & 0.664 & -0.376 & 0.963 & 0.851 & 0.402
\end{tabular}

\begin{tabular}{lrlllllll} 
& \multicolumn{1}{l}{$\mathrm{Ag}$} & $\mathrm{Re}$ & $\mathrm{Os}$ & $\mathrm{Ir}$ & $\mathrm{Ru}$ & $\mathrm{Rh}$ & $\mathrm{Pt}$ & $\mathrm{Pd}$ \\
$\mathrm{Ag}$ & 1.000 & & & & & & & \\
$\mathrm{Re}$ & 0.986 & 1.000 & & & & & & \\
$\mathrm{Os}$ & 0.400 & 0.512 & 1.000 & & & & & \\
$\mathrm{Ir}$ & 0.586 & 0.702 & 0.928 & 1.000 & & & & \\
$\mathrm{Ru}$ & 0.647 & 0.763 & 0.845 & 0.981 & 1.00 & & & \\
$\mathrm{Rh}$ & 0.532 & 0.628 & 0.846 & 0.927 & 0.888 & 1.000 & & \\
$\mathrm{Pt}$ & 0.299 & 0.424 & 0.984 & 0.926 & 0.843 & 0.874 & 1.000 & \\
$\mathrm{Pd}$ & 0.040 & 0.157 & 0.748 & 0.739 & 0.656 & 0.864 & 0.846 & 1.000 \\
$\mathrm{Au}$ & 0.980 & 0.975 & 0.411 & 0.614 & 0.683 & 0.528 & 0.324 & 0.062
\end{tabular}

$\mathrm{Au}$

$\mathrm{Au} \quad 1.000$

Number of observations $=6$. 
Table 4-7c: Pearson correlation matrix for MAGZ facies geochemical analyses.

\begin{tabular}{lrrrrrrrr} 
& \multicolumn{1}{l}{$\mathrm{Fe}$} & $\mathrm{Ni}$ & $\mathrm{Cu}$ & $\mathrm{Zn}$ & $\mathrm{Pb}$ & \multicolumn{1}{l}{$\mathrm{Co}$} & \multicolumn{1}{l}{$\mathrm{S}$} & $\mathrm{Se}$ \\
$\mathrm{Fe}$ & 1.000 & & & & & & & \\
$\mathrm{Ni}$ & 0.486 & 1.000 & & & & & & \\
$\mathrm{Cu}$ & -0.767 & -0.502 & 1.000 & & & & & \\
$\mathrm{Zn}$ & 0.126 & 0.018 & 0.083 & 1.000 & & & & \\
$\mathrm{~Pb}$ & 0.187 & 0.141 & -0.048 & 0.979 & 1.000 & & & \\
$\mathrm{Co}$ & 0.068 & 0.766 & 0.011 & 0.345 & 0.368 & 1.000 & & \\
$\mathrm{~S}$ & 0.432 & 0.727 & -0.123 & -0.270 & -0.231 & 0.508 & 1.000 & \\
$\mathrm{Se}$ & -0.202 & 0.335 & 0.155 & 0.184 & 0.277 & 0.375 & 0.058 & 1.000 \\
$\mathrm{Ag}$ & -0.925 & -0.441 & 0.829 & -0.160 & -0.214 & -0.103 & -0.203 & 0.132 \\
$\mathrm{Re}$ & -0.799 & -0.323 & 0.841 & 0.310 & 0.251 & 0.154 & -0.206 & 0.226 \\
$\mathrm{Os}$ & -0.122 & -0.414 & -0.006 & 0.736 & 0.744 & -0.223 & -0.800 & 0.121 \\
$\mathrm{Ir}$ & -0.200 & -0.326 & 0.135 & 0.820 & 0.829 & -0.069 & -0.671 & 0.200 \\
$\mathrm{Ru}$ & -0.412 & -0.475 & 0.387 & 0.763 & 0.727 & -0.086 & -0.687 & 0.120 \\
$\mathrm{Rh}$ & -0.532 & -0.373 & 0.516 & 0.708 & 0.684 & 0.042 & -0.547 & 0.257 \\
$\mathrm{Pt}$ & -0.024 & 0.052 & 0.336 & 0.905 & 0.853 & 0.469 & -0.030 & 0.087 \\
$\mathrm{Pd}$ & -0.707 & -0.240 & 0.817 & 0.422 & 0.355 & 0.271 & -0.134 & 0.198 \\
$\mathrm{Au}$ & 0.105 & 0.559 & -0.151 & -0.116 & -0.151 & 0.718 & 0.443 & -0.207
\end{tabular}

\begin{tabular}{lrlllllll} 
& \multicolumn{1}{l}{ Ag } & \multicolumn{1}{l}{ Re } & \multicolumn{1}{l}{ Os } & Ir & Ru & Rh & Pt & Pd \\
$\mathrm{Ag}$ & 1.000 & & & & & & & \\
$\mathrm{Re}$ & 0.881 & 1.000 & & & & & & \\
$\mathrm{Os}$ & -0.007 & 0.256 & 1.000 & & & & & \\
$\mathrm{Ir}$ & 0.133 & 0.453 & 0.962 & 1.000 & & & & \\
$\mathrm{Ru}$ & 0.363 & 0.651 & 0.891 & 0.958 & 1.000 & & & \\
$\mathrm{Rh}$ & 0.527 & 0.804 & 0.769 & 0.894 & 0.965 & 1.000 & & \\
$\mathrm{Pt}$ & 0.097 & 0.549 & 0.489 & 0.661 & 0.697 & 0.722 & 1.000 & \\
$\mathrm{Pd}$ & 0.797 & 0.984 & 0.258 & 0.472 & 0.662 & 0.810 & 0.673 & 1.000 \\
$\mathrm{Au}$ & -0.205 & -0.180 & -0.513 & -0.485 & -0.447 & -0.410 & 0.021 & -0.090
\end{tabular}

Au $\quad \begin{array}{ll}\text { Au } \\ 1.000\end{array}$

Number of observations $=7$. 
Table 4-8: Chondrite-normalized Fraser Epidote Zone geochemistry showing averages and standard deviations for each facies ( $\mathrm{C} 1$ chondrite values for PGE and $\mathrm{Au}$ after Naldrett and Duke, 1981; Ni, Cu and Co after Naldrett, 1981).

\begin{tabular}{|c|c|c|c|c|}
\hline Element & Facies & Average & Std. Dev. & $\begin{array}{l}\text { No. of } \\
\text { Analyses }\end{array}$ \\
\hline \multirow[t]{9}{*}{$\mathrm{Ni}$} & DNBX & 3 & \pm 2 & 2 \\
\hline & LGBX & 2 & \pm 2 & 3 \\
\hline & LGBXepdz & 1 & \pm 1 & 3 \\
\hline & EPDZ & 0.8 & \pm 0.2 & 4 \\
\hline & EPDZact & 2 & \pm 2 & 8 \\
\hline & ACTZ & 2 & & 1 \\
\hline & EPDZmag & 2 & \pm 0.5 & 2 \\
\hline & ACTZmag & 2 & \pm 0.8 & 6 \\
\hline & MAGZ & 4 & \pm 2 & 7 \\
\hline \multirow[t]{9}{*}{ Os } & DNBX & 0.02 & \pm 0.006 & 2 \\
\hline & LGBX & $<0.006$ & & 6 \\
\hline & LGBXepdz & 0.003 & \pm 0.004 & 3 \\
\hline & EPDZ & 0.002 & \pm 0.004 & 5 \\
\hline & EPDZact & 0.001 & \pm 0.004 & 9 \\
\hline & ACTZ & 0.05 & \pm 0.02 & 2 \\
\hline & EPDZmag & $<0.006$ & & 2 \\
\hline & ACTZmag & 0.01 & \pm 0.02 & 6 \\
\hline & MAGZ & 0.01 & \pm 0.02 & 7 \\
\hline \multirow[t]{9}{*}{ Ir } & DNBX & 0.06 & \pm 0.002 & 2 \\
\hline & LGBX & 0.003 & \pm 0.003 & 6 \\
\hline & LGBXepdz & 0.02 & \pm 0.02 & 3 \\
\hline & EPDZ & 0.008 & \pm 0.008 & 5 \\
\hline & EPDZact & 0.009 & \pm 0.009 & 9 \\
\hline & ACTZ & 0.2 & \pm 0.1 & 2 \\
\hline & EPDZmag & 0.0003 & \pm 0.0003 & 2 \\
\hline & ACTZmag & 0.05 & \pm 0.04 & 6 \\
\hline & MAGZ & 0.03 & \pm 0.03 & 7 \\
\hline \multirow[t]{9}{*}{$\mathrm{Ru}$} & DNBX & 0.06 & \pm 0.007 & 2 \\
\hline & LGBX & 0.009 & \pm 0.005 & 6 \\
\hline & LGBXepdz & 0.02 & \pm 0.02 & 3 \\
\hline & EPDZ & 0.01 & \pm 0.01 & 4 \\
\hline & EPDZact & 0.02 & \pm 0.02 & 8 \\
\hline & ACTZ & 0.2 & & 1 \\
\hline & EPDZmag & 0.009 & \pm 0.002 & 2 \\
\hline & ACTZmag & 0.04 & \pm 0.04 & 6 \\
\hline & MAGZ & 0.03 & \pm 0.02 & 7 \\
\hline $\mathrm{Rh}$ & DNBX & 0.7 & \pm 0.4 & 2 \\
\hline
\end{tabular}


Table 4-8: (con't)

Element Facies

$\mathrm{Rh}$

$\mathrm{Pt}$

$$
\begin{aligned}
& \text { LGBX } \\
& \text { LGBXepdz } \\
& \text { EPDZ } \\
& \text { EPDZact } \\
& \text { ACTZ } \\
& \text { EPDZmag } \\
& \text { ACTZmag } \\
& \text { MAGZ }
\end{aligned}
$$

DNBX

LGBX

LGBXepdz

EPDZ

EPDZact

ACTZ

EPDZmag

ACTZmag

MAGZ

Pd

DNBX

LGBX

LGBXepdz

EPDZ

EPDZact

ACTZ

EPDZmag

ACTZmag

MAGZ

$\mathrm{Au}$

DNBX

LGBX

LGBXepdz

EPDZ

EPDZact

ACTZ

EPDZmag

ACTZmag

MAGZ

$\mathrm{Cu}$
Average

0.02

0.1

0.06

0.07

0.7

0.01

0.4

0.3

0.8

0.4

0.06

0.2

0.2

1

0.09

0.4

0.3

1.3

0.6

0.2

0.3

0.2

2

0.2

0.4

0.7

0.6

0.2

2

0.3

0.05

0.1

0.1

0.04

0.06

191

23

254

77
Std. Dev.

$\pm 0.02$

$\pm 0.2$

$\pm 0.08$

$\pm 0.07$

$\pm 0.005$

$\pm 0.3$

$\pm 0.3$

$\pm 0.3$

$\pm 0.4$

$\pm 0.02$

$\pm 0.2$

$\pm 0.09$

$\pm 1$

$\pm 0.03$

$\pm 0.3$

$\pm 0.4$

$\pm 0.2$

$\pm 0.7$

$\pm 0.1$

$\pm 0.1$

$\pm 0.09$

$\pm 1$

$\pm 0.05$

$\pm 0.3$

$\pm 0.7$

$\pm 0.5$

$\pm 0.1$

$\pm 2$

$\pm 0.5$

$\pm 0.05$

$\pm 0.1$

$\pm 0.03$

$\pm 0.06$

$\pm 0.05$

$\pm 189$

$\pm 10$

$\pm 334$

$\pm 97$
No. of

Analyses

3

3

4

8

1

2

6

7

2

6

3

5

9

2

2

6

7

2

6

3

5

9

2

2

6

7

2

6

3

5

9

2

2

6

7

2

3

3

4 
Table 4-8: (con't)

$\begin{array}{llccc}\text { Element } & \text { Facies } & \text { Average } & \text { Std. Dev. } & \begin{array}{c}\text { No. of } \\ \text { Analyses }\end{array} \\ \mathrm{Cu} & \text { EPDZact } & 1 & & 8 \\ & \text { ACTZ } & 0.6 & & 1 \\ & \text { EPDZmag } & 0.8 & \pm 0.08 & 2 \\ & \text { ACTZmag } & 21 & \pm 44 & 6 \\ & \text { MAGZ } & 2 & \pm 2 & 7\end{array}$



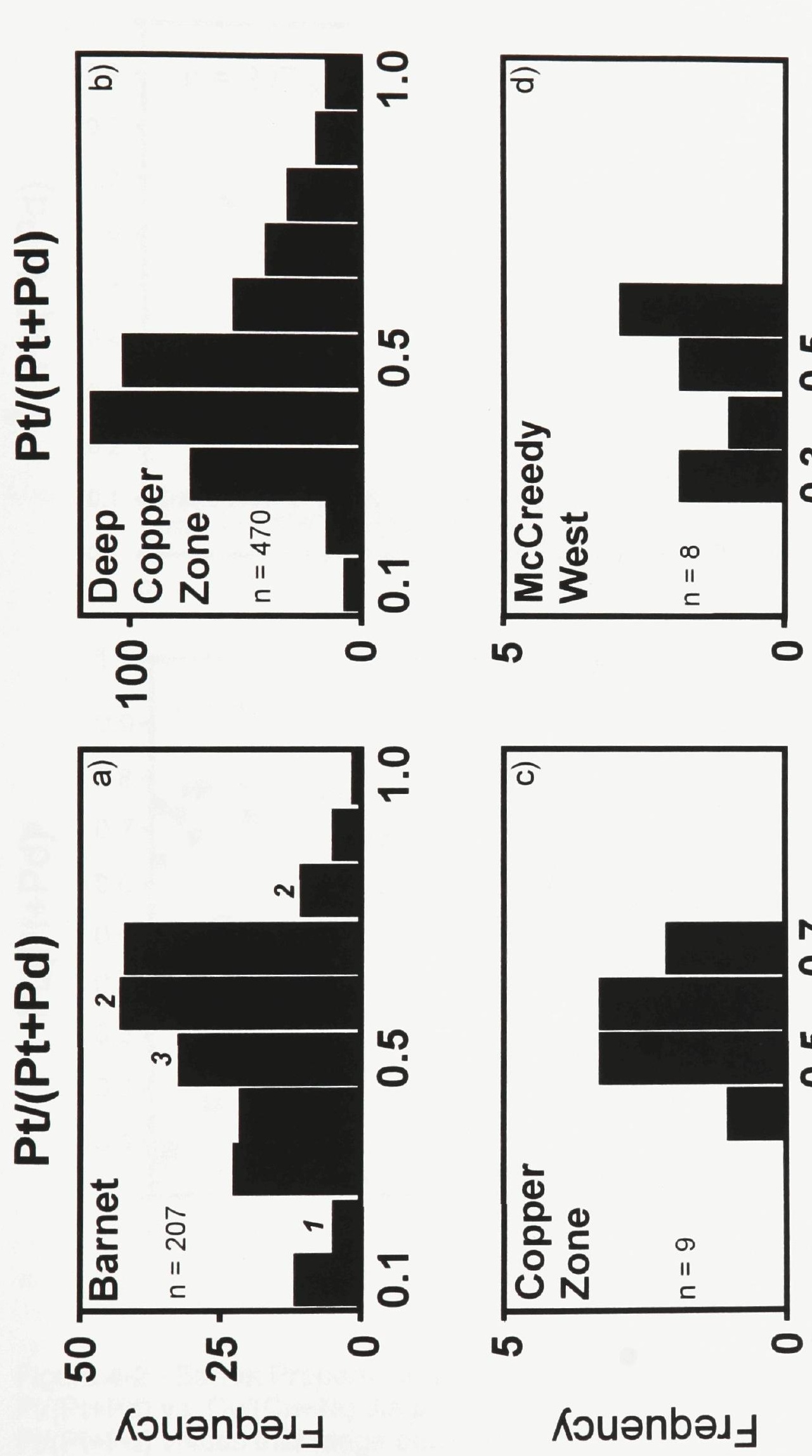

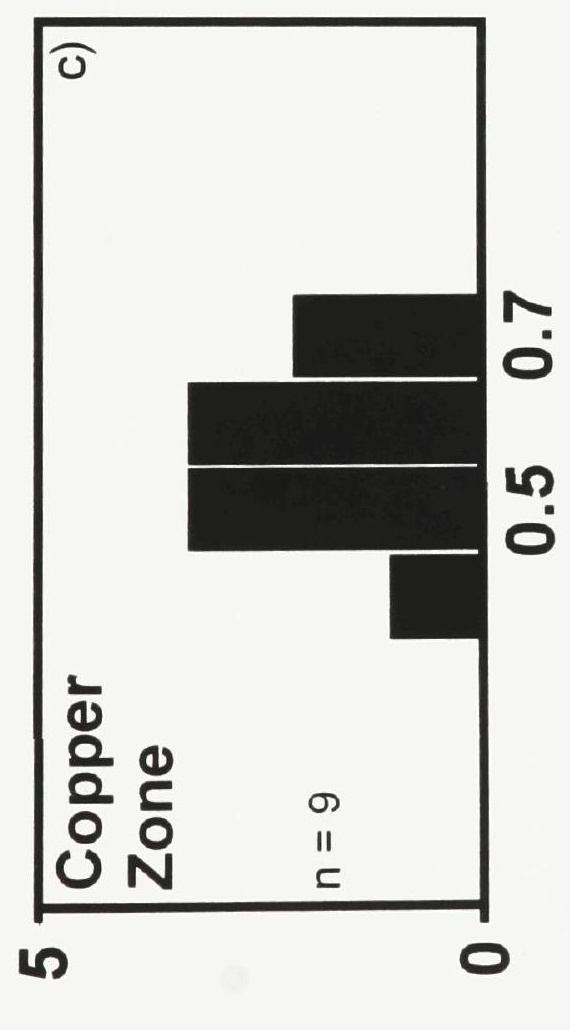

ペuənbəد」

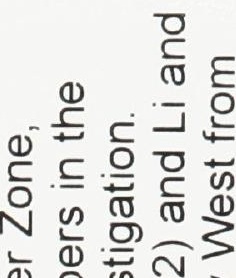

बं जै

응 है

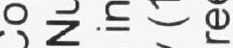

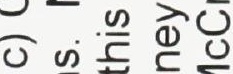

- ᄃ

ब응 $\Sigma$

유요

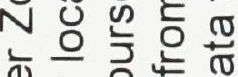

屯े

용

نㅎํ용

잉요

든 응

๑ 뜽 융

ล

뇽요

\pm 은

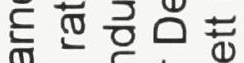

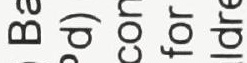

สำ

$\varepsilon$ 西

인?

क口 을

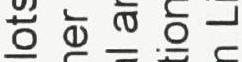

응등 정

으를 흔

웜

전

성

近 ว을 듕ㅇㅇ

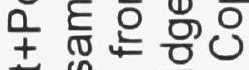

起先

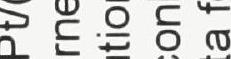

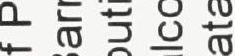

미은 은

ᄃ. ㄴ.

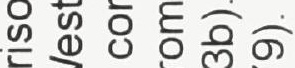

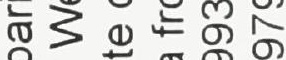

은

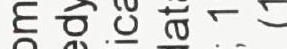

U \&

บ넹

$\because 0$ 든헝

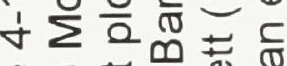

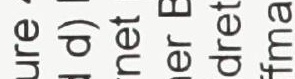

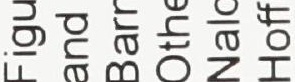



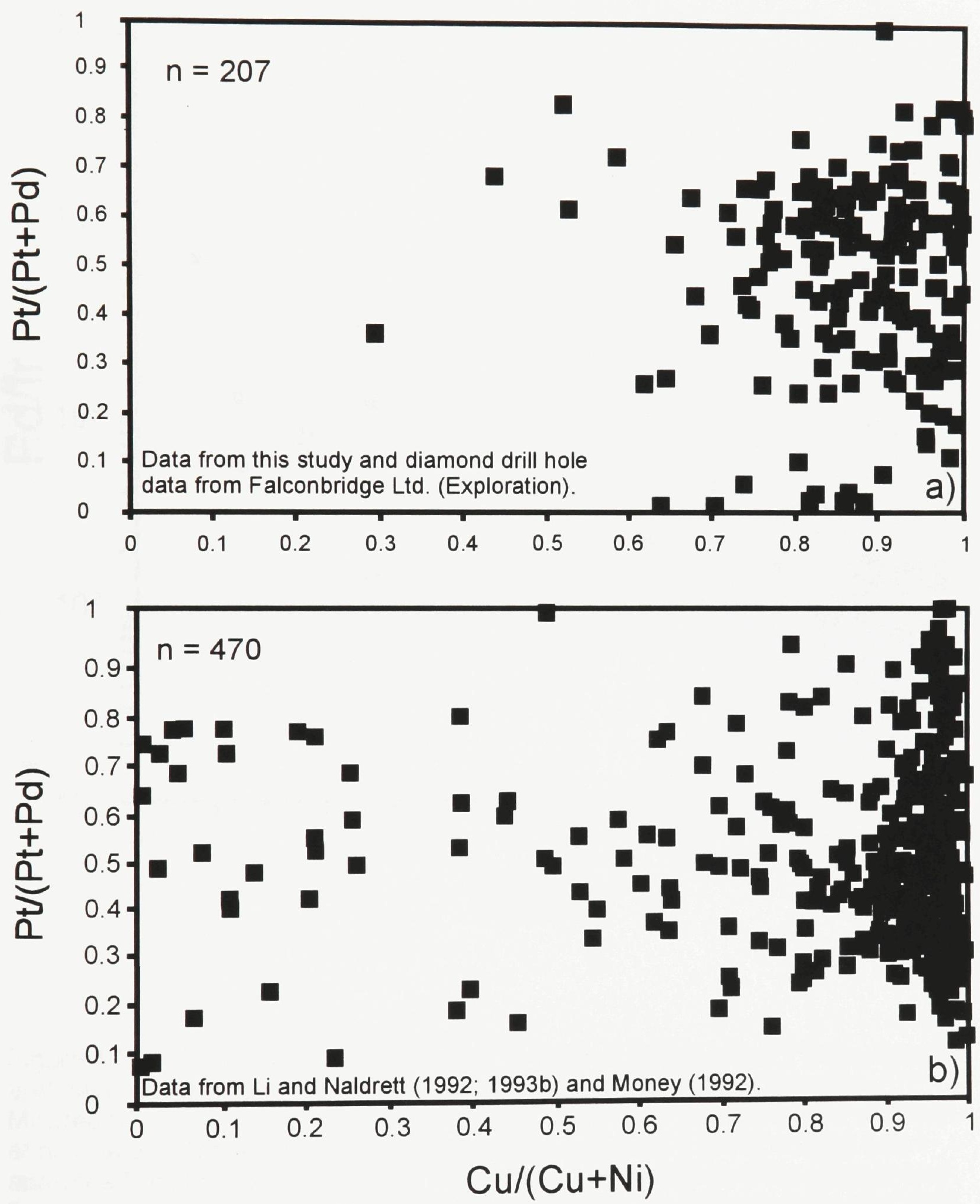

Figure 4-2: Barnet Property (a) and Strathcona Deep Copper Zone (b) $\mathrm{Pt} /(\mathrm{Pt}+\mathrm{Pd})$ vs. $\mathrm{Cu} /(\mathrm{Cu}+\mathrm{Ni})$ diagrams. The $\mathrm{Cu}$-rich veins show slight variations in $\mathrm{Pt} /(\mathrm{Pt}+\mathrm{Pd})$ values that range between 0.4 and 0.7 at Barnet, and 0.2 to 0.6 at Deep Copper Zone. 


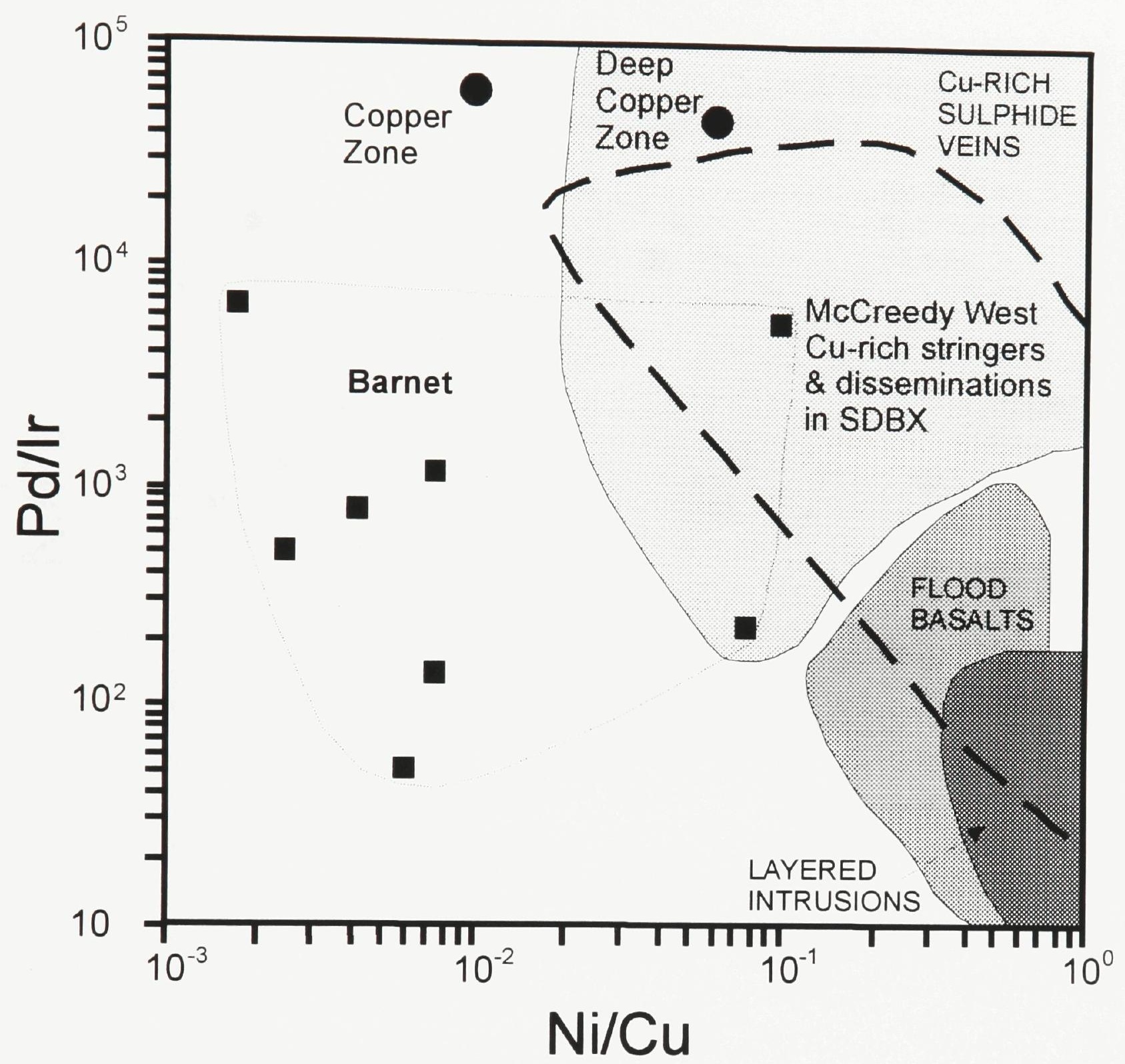

Figure 4-3: Pd/lr vs. Ni/Cu diagram with "Cu-rich sulphide veins", "flood basalts" and "layered intrusions" fields from Barnes et al. (1988; 1993). Data for McCreedy West stringers and disseminations in Sudbury Breccia from Hoffman et al. (1979). Copper and Deep Copper zone data from Li et al. (1992). All analyses from the Barnet Property and those representative of the Copper and Deep Copper zones are in the low Ni/Cu part of the "Cu-rich sulphide vein" field. By comparison, the McCreedy West data extend from the "Cu-rich sulphide veins" field into the "flood basalts" and "layered intrusions" fields. 


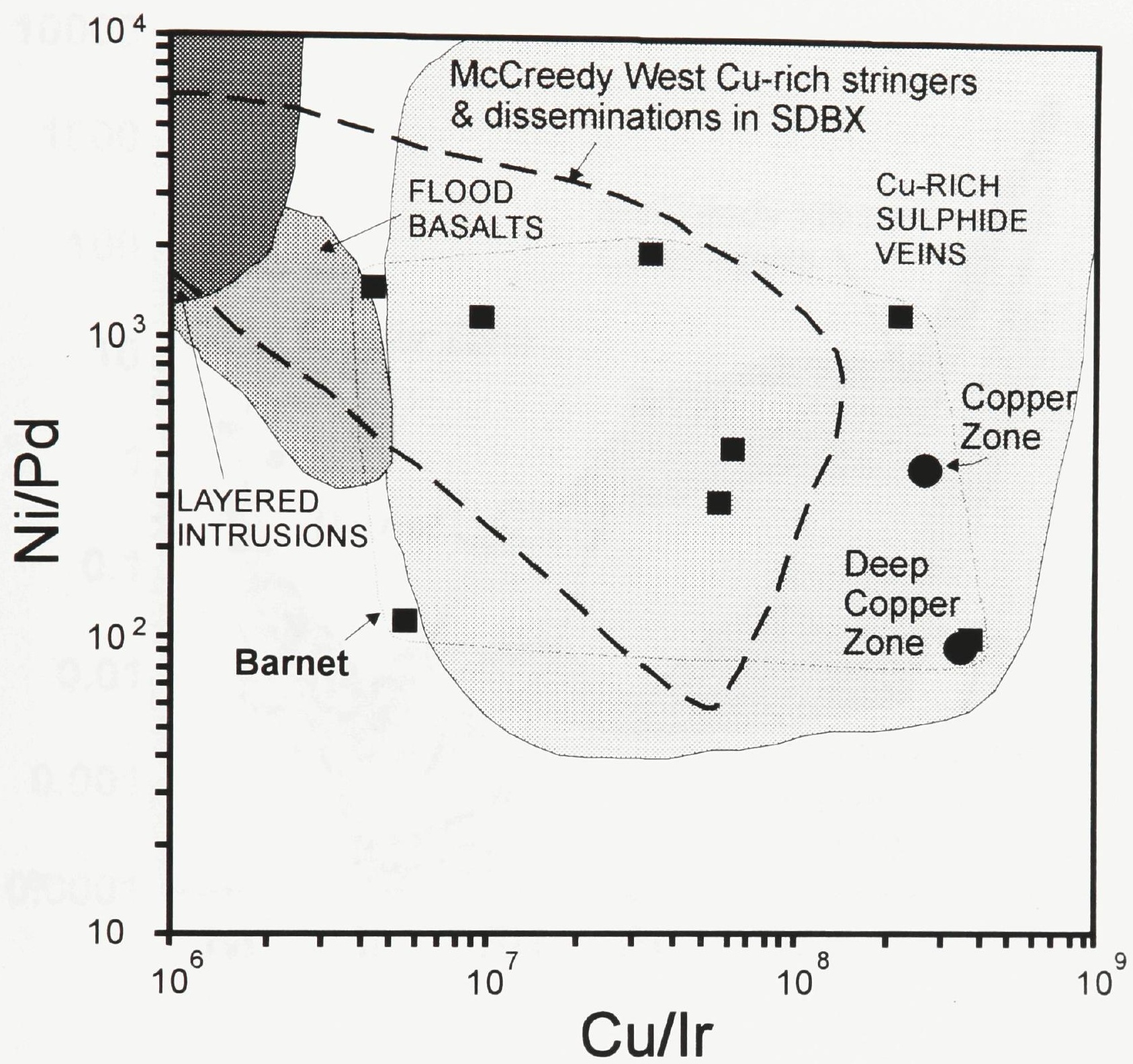

Figure 4-4: Ni/Pd vs. Cu/lr diagram with "Cu-rich sulphide veins", "flood basalts" and "layered intrusions" fields from Barnes et al. (1988; 1993). Data for McCreedy West stringers and disseminations in Sudbury Breccia from Hoffman et al. (1979). Copper and Deep Copper zone data from Li et al. (1992). Almost all analyses from the Barnet Property and those representative of the Copper and Deep Copper zones are in the "Cu-rich sulphide vein" field. By comparison the McCreedy West data extend from the "Cu-rich sulphide veins" field into the "flood basalts" and "layered intrusions" fields. 


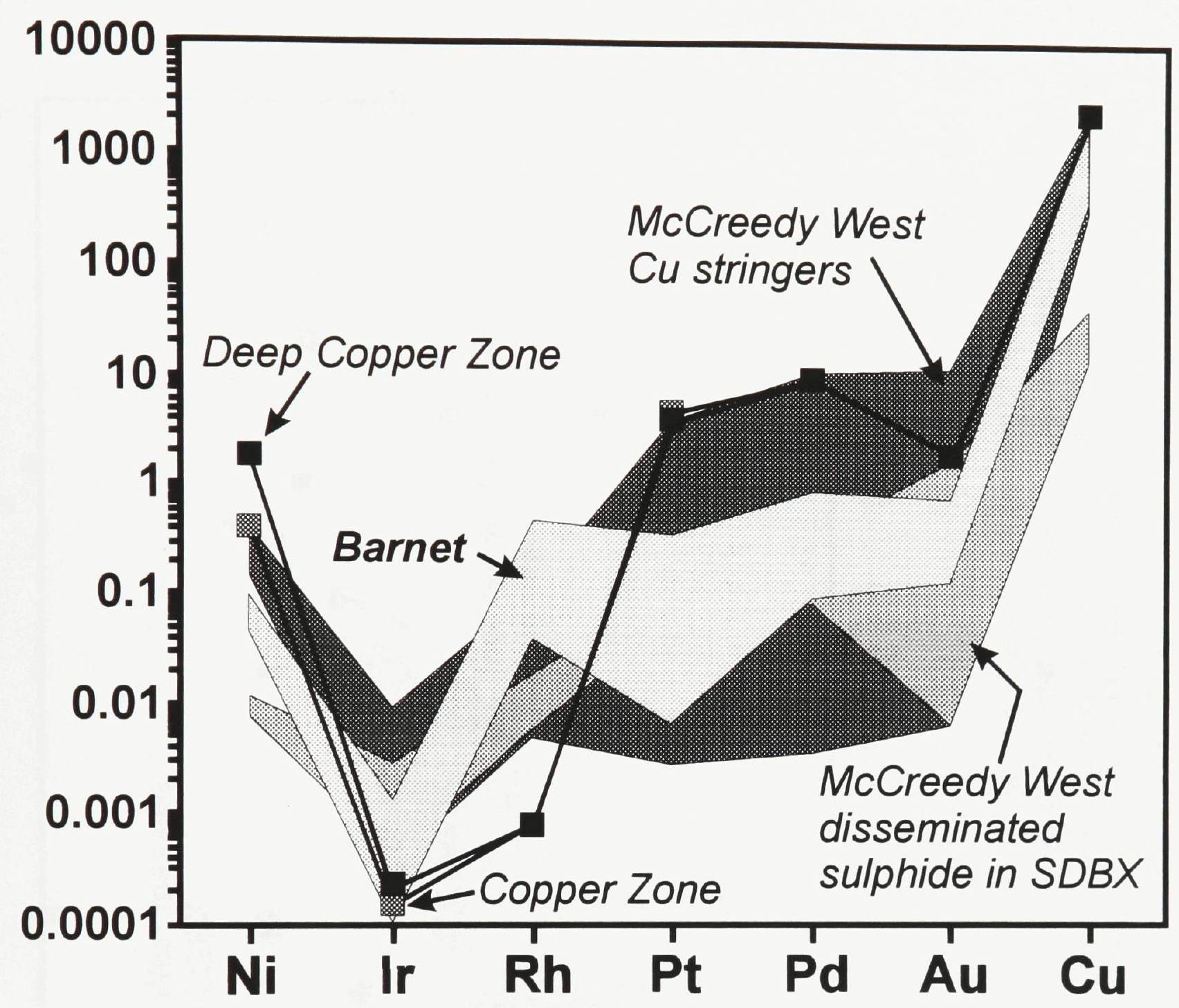

Figure 4-5: Chondrite-normalized plot of Barnet analyses compared to those from the Strathcona Deep Copper and Copper zones, and disseminated and massive sulphide vein ores in Sudbury Breccia from McCreedy West. Deep Copper and Copper zone data from Li and Naldrett (1992; 1993b). McCreedy West data from Hoffman et al. (1979). 


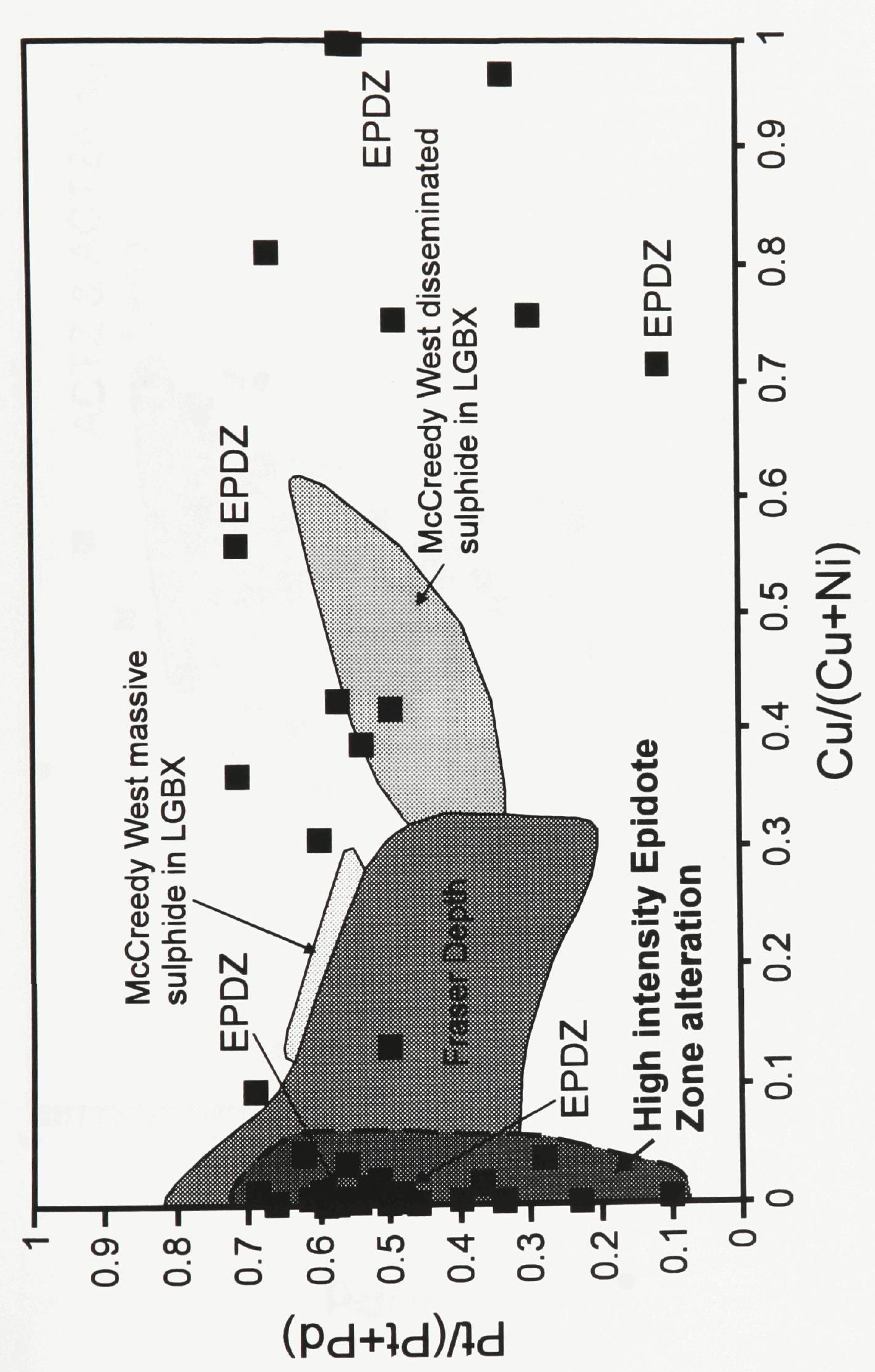

สั

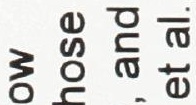

을 के

\⿻

त

w $\overline{\bar{E}}$ 호오

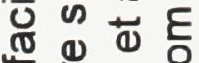

N交 $\frac{5}{6}$

물 욤

虫它毞

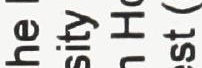

ᄃ

元昰农

도 드 중

응 중

은

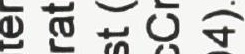

-

条宁了合

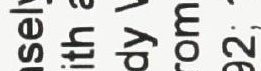

ఖ

든ㄷㅇㅇㄴㅇ

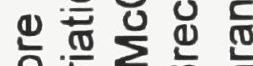

은 这㐫 㐫

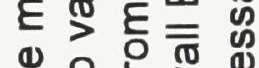

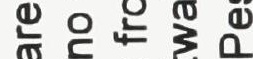

궁 $\frac{\pi}{0}$ 잉

조 언이 두

() ज 들

똥ำ 뜬

N克 $\overline{\bar{\sigma}}$ 음

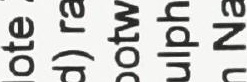

음으난 느농인 10 준

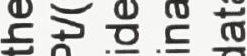
E 등 은 $\dot{5} \frac{2}{3}$ 严 ㅇํㅇ क 응

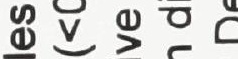
응 的宛这 토음

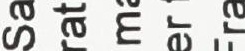
ติ 寸我的

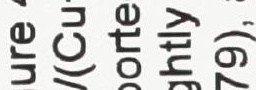

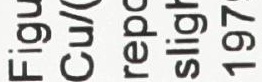




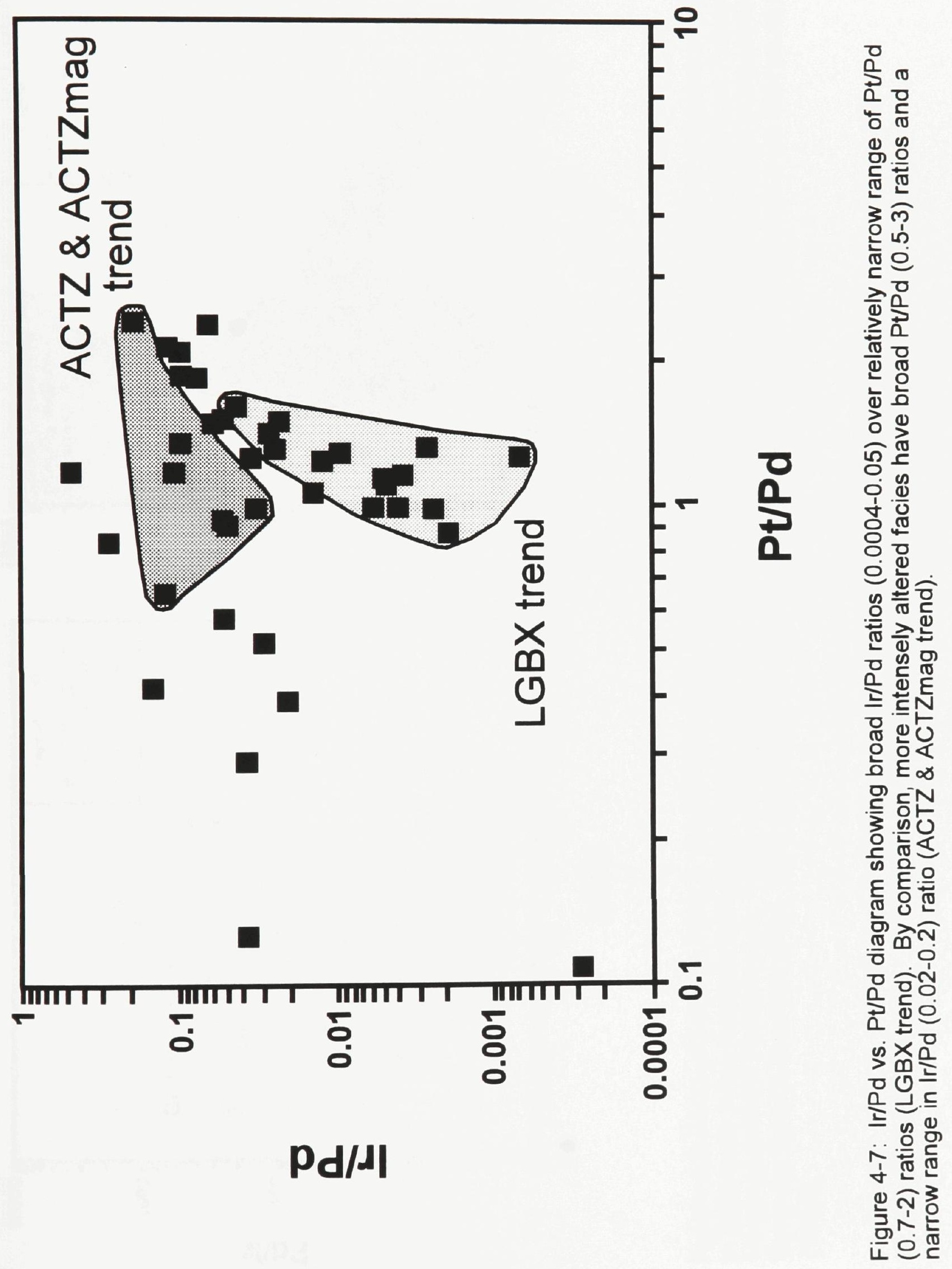




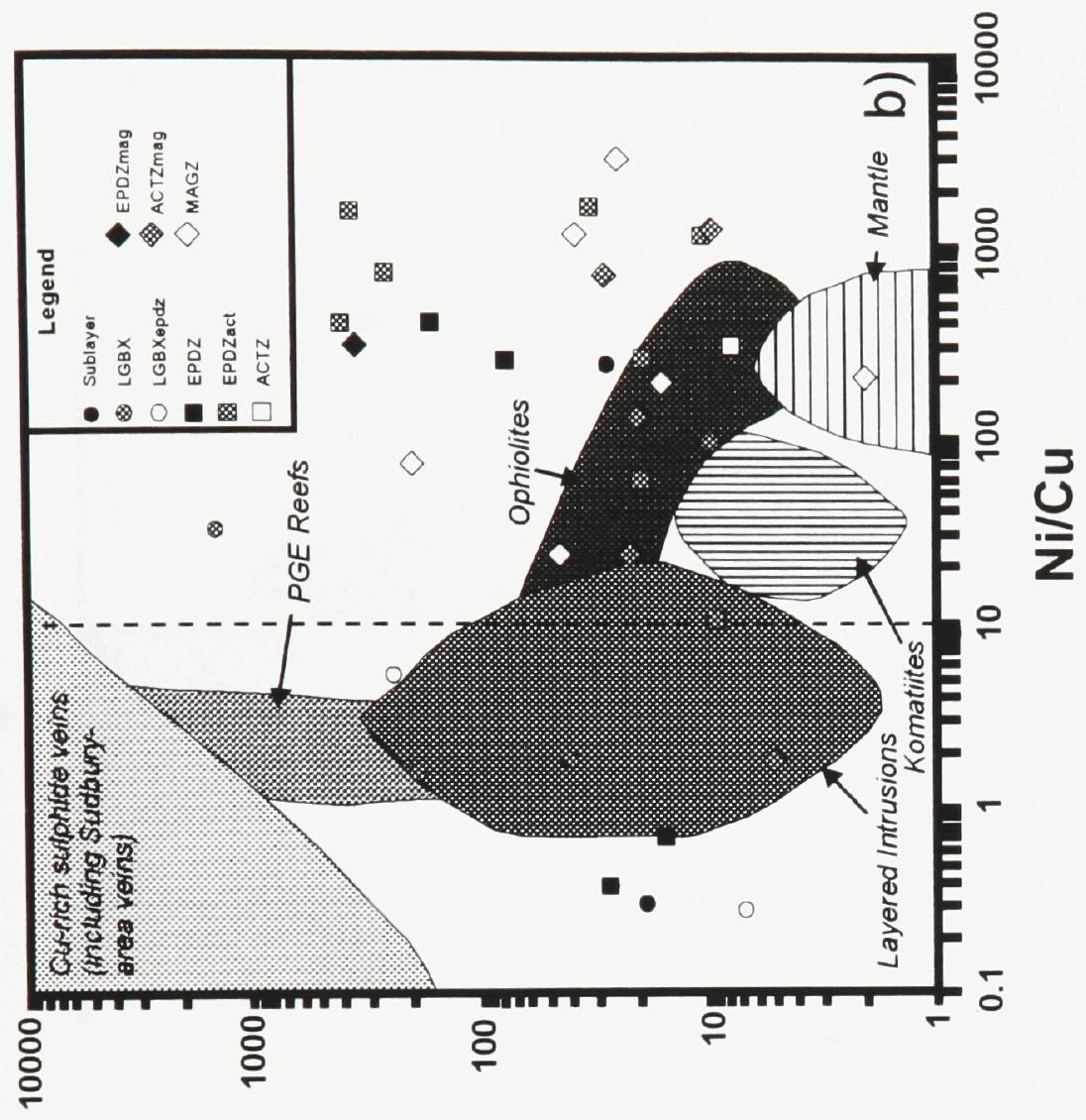

을 孚

윽

๘

ญ

ज은 잉

है

은은

สั

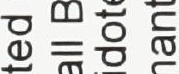

진흔

.

हิ잉

比的

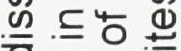

O d w

돔을 은 은

으는 응

在的垴

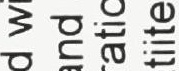

ర

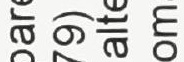

읕의 오

든흐

入宁

월

的宁至

론등

틍우

응 ส

팅

은

(1) ฮิ

$\checkmark$ 苋

สㅇㅎㅂ

; 증

गु 으

之这宁

i $\overline{\overline{0}} \stackrel{0}{>}$

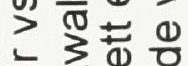

흥ㅎㅇ흐늠

눈든

ठ फ

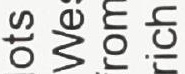

व

○ 엉

广่

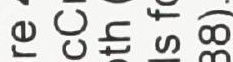

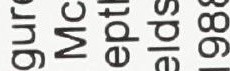

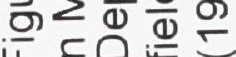



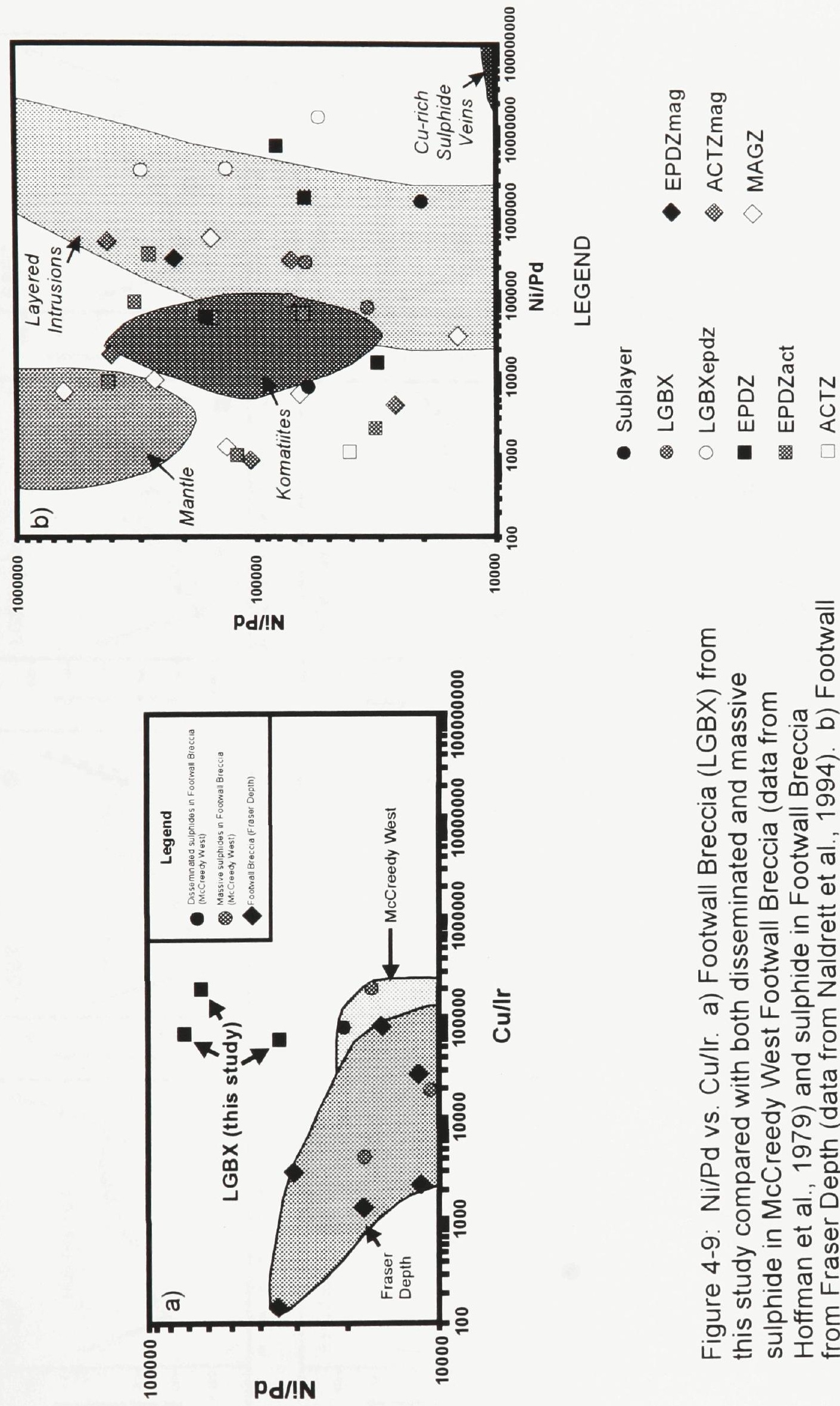

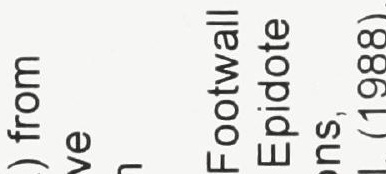

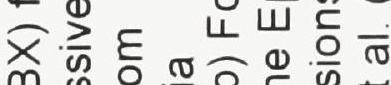

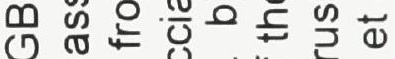

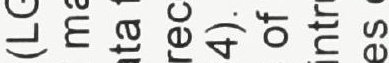
ธ믐 प त ब $0 . \frac{0}{2}=\pi$

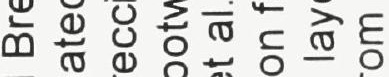

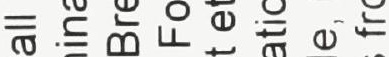

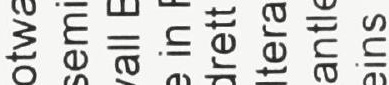

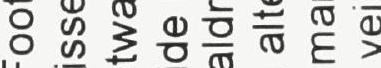

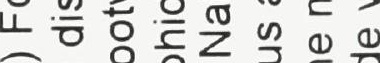

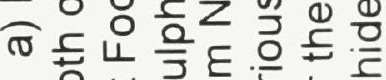

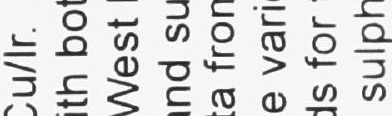

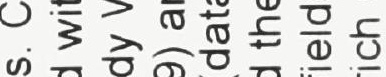

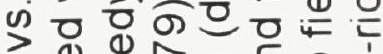

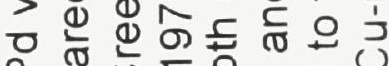
은 응 之 ह ช क $\subseteq$ ब

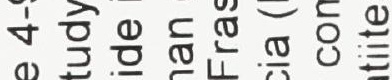

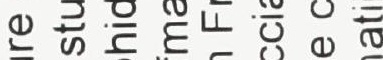

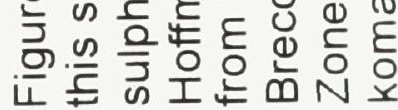



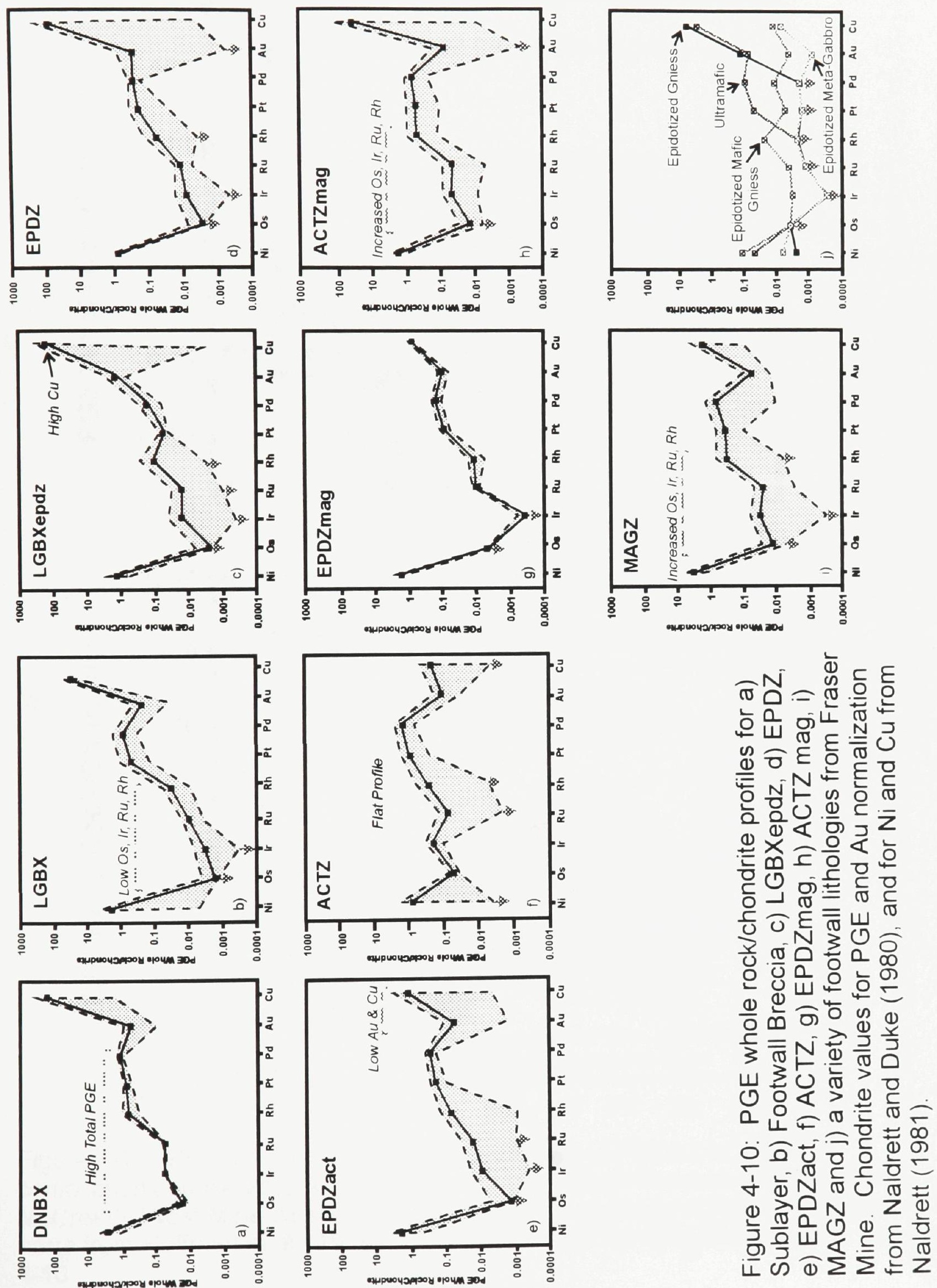

넌

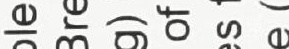

产

山类宁

0 (1)

둥ㅎㅁ

으응 응 은

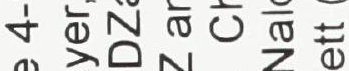

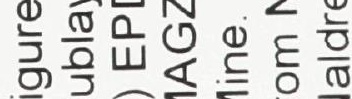

レ心 (1) $\sum \sum \Sigma$ 

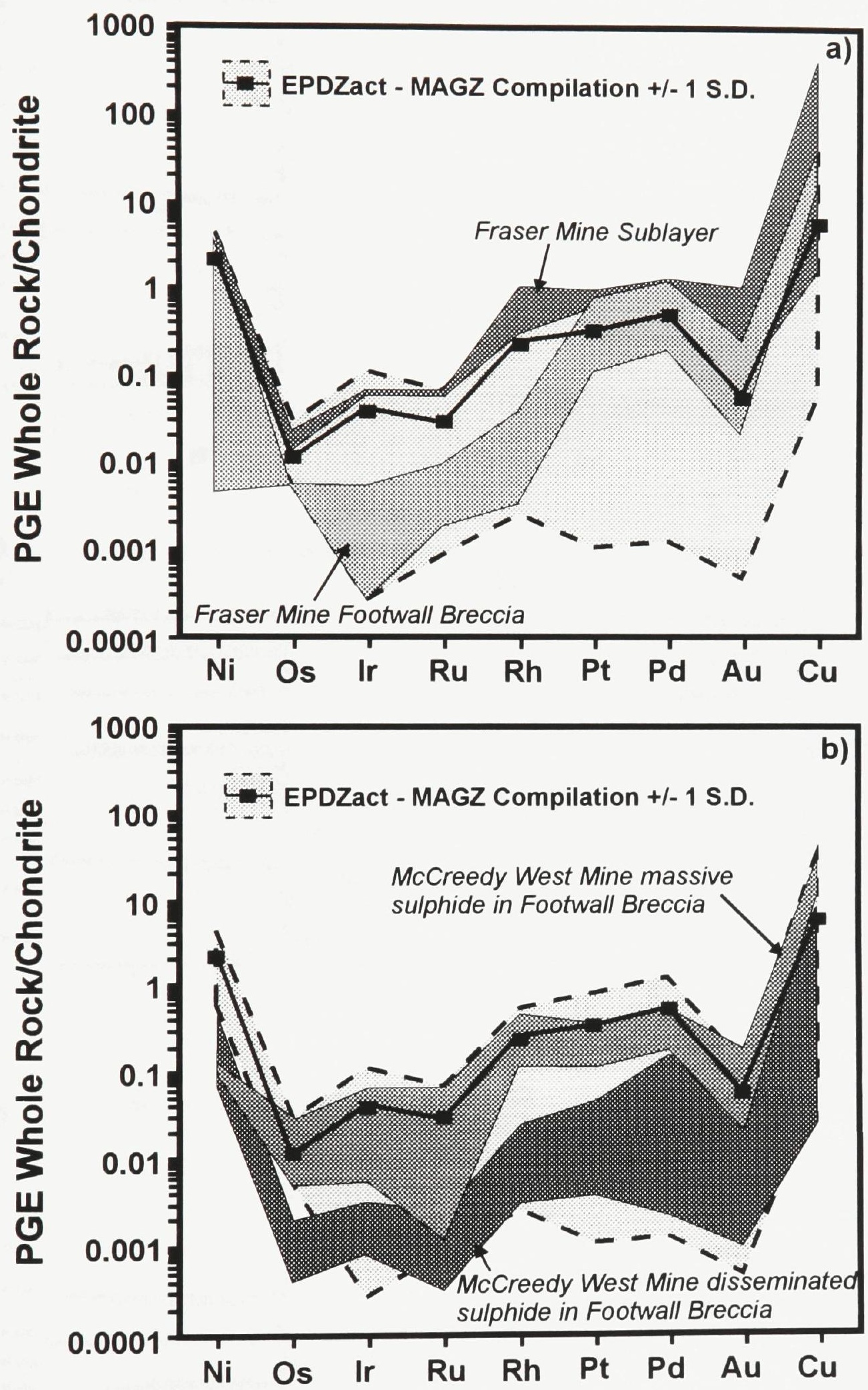

Figure 4-11: PGE whole rock/chondrite profiles for EPDZact to MAGZ compilation compared to a) Fraser Mine Sublayer and Footwall Breccia, and b) McCreedy West Mine disseminated and massive sulphide in Footwall Breccia (data from Hoffman et al., 1979). Chondrite values for normalization as in Figure 4-10. 

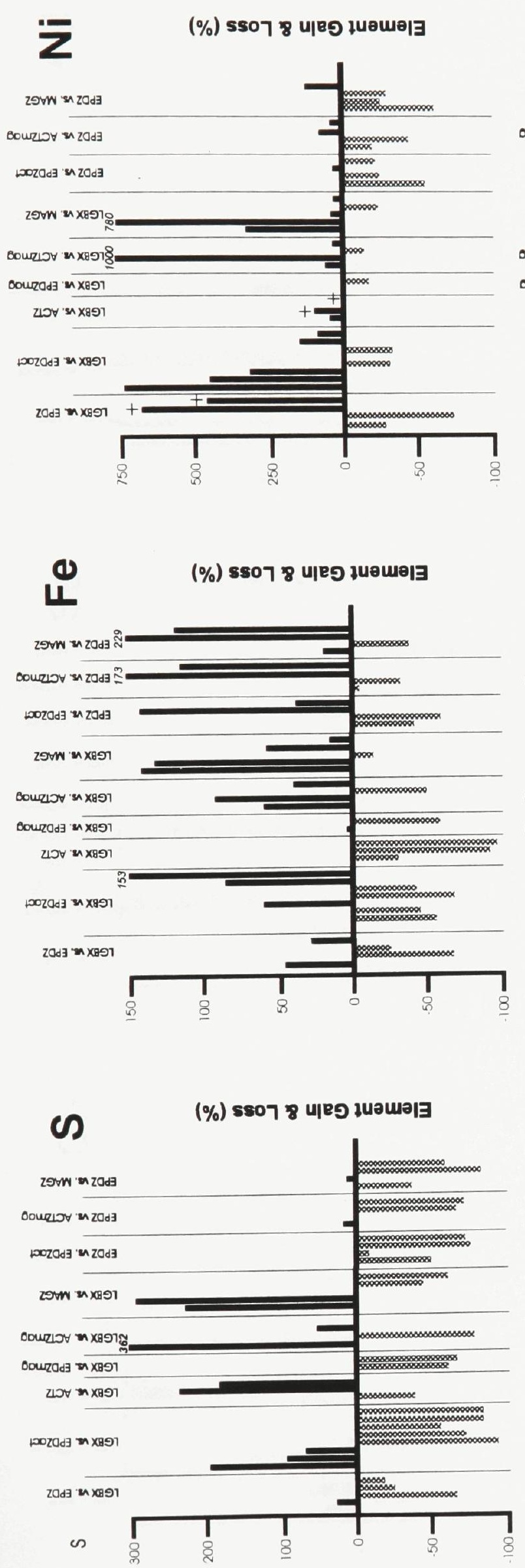
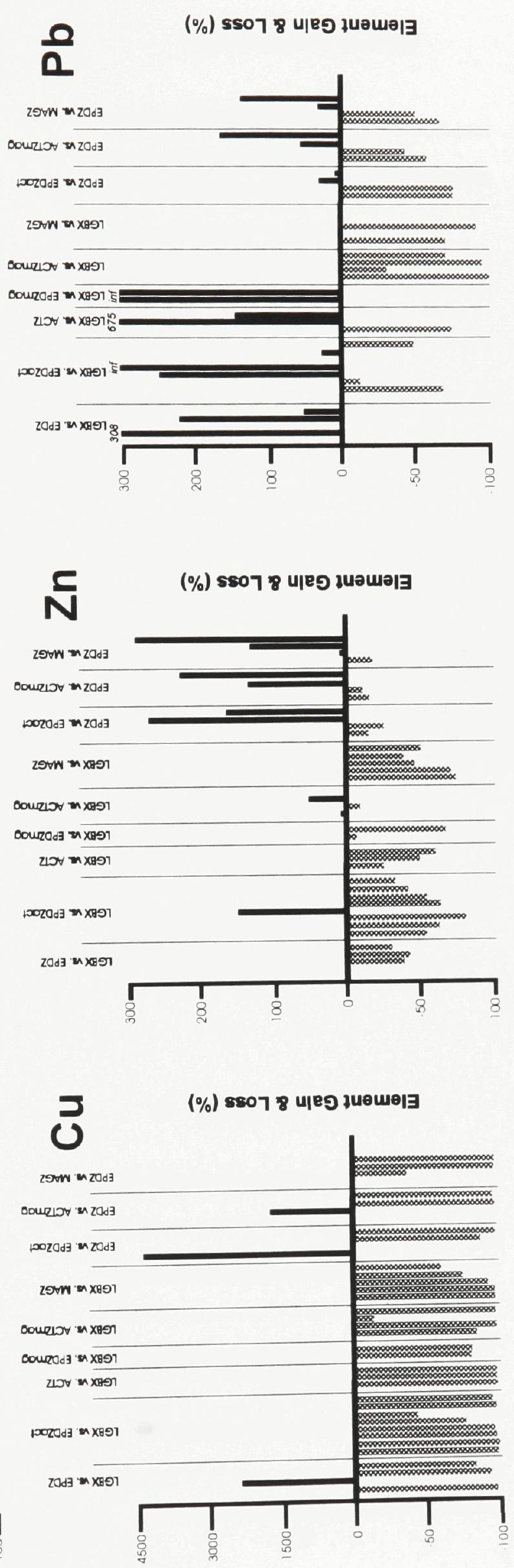

N

כ

Z

(1)

ㄴ

(5)

ธั่

$\stackrel{\varrho}{\frac{1}{0}}$

N

$+$

응

Ш

$\stackrel{\emptyset}{=}$

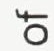

包

तั

을

으

믐

$\stackrel{\frac{1}{\sigma}}{\frac{1}{6}}$

ธี

Е

(1)

E

$\underline{1}$

Ш

เั่

V

寸

(1) 음

(1)음

디이

느 

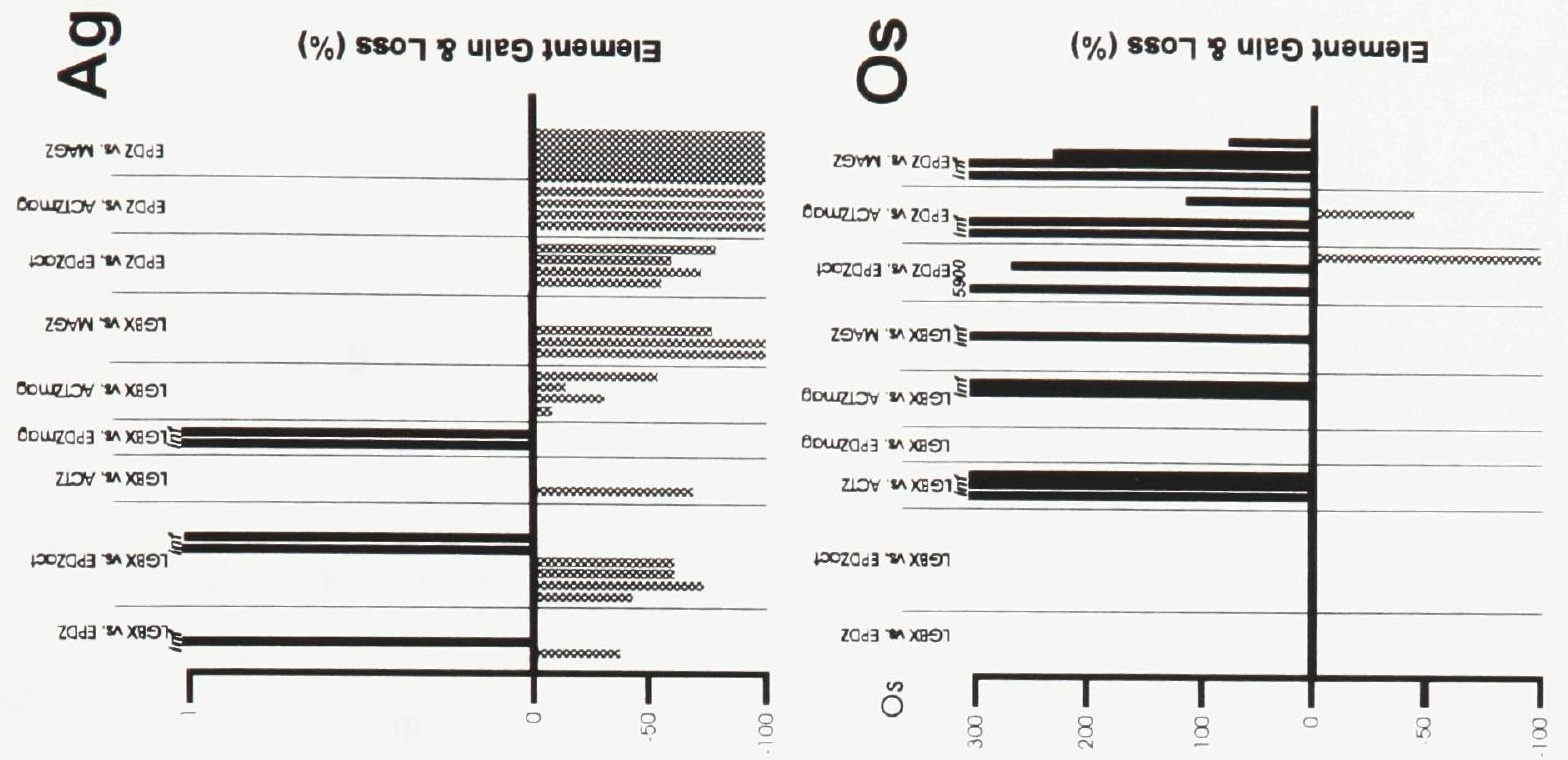

(1)
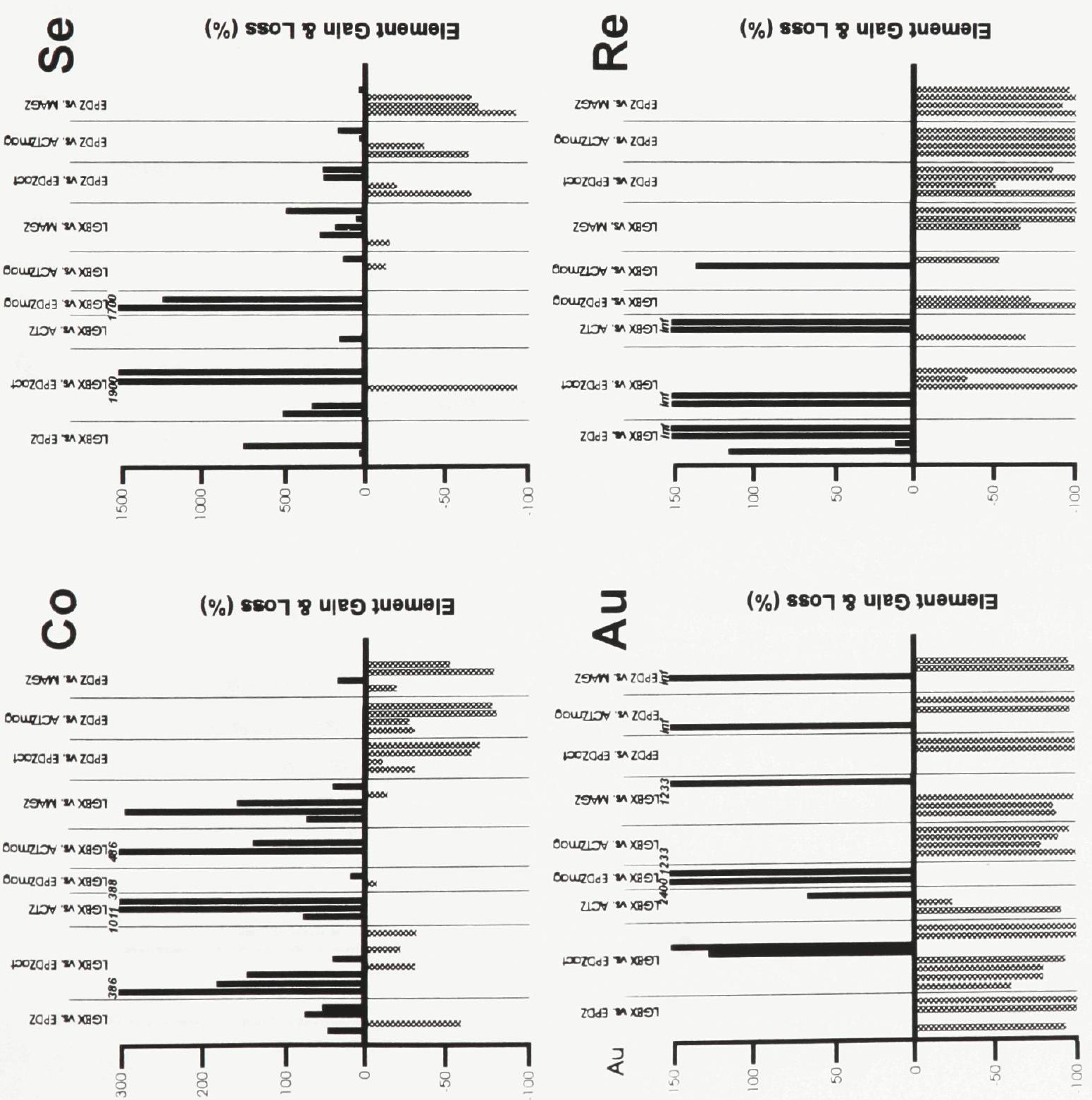

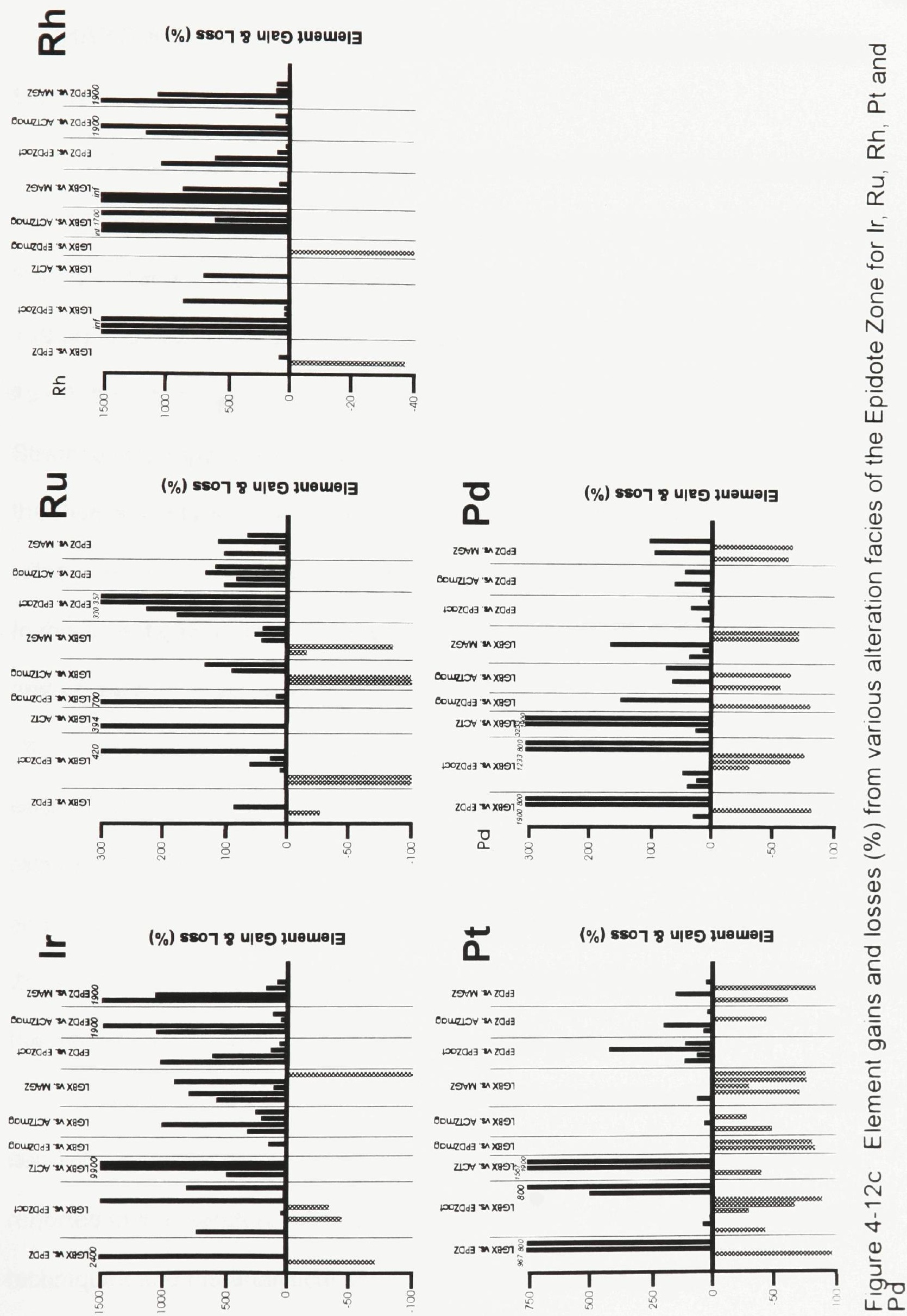


\section{CHAPTER 5: PLATINUM-GROUP AND OTHER UNCOMMON MINERALS}

\section{5-1. INTRODUCTION}

Although information exists on the PGM and other minor minerals for the Strathcona Mine Deep Copper Zone (Springer and Collins, 1982; Snajdr, 1985; Springer, 1985; 1989; Springer and Lalonde, 1987; Li and Naldrett, 1992; 1993a) and McCreedy West (Hawley and Berry, 1958; Cabri and Laflamme, 1976), this study presents the first report of PGM from the Barnet property, Strathcona Copper Zone, and the Fraser Mine Epidote Zone. In many studies of the PGE and PGM, whole-rock chemical or mineral chemical data are presented without much consideration of where and how the PGE-bearing minerals occur. In this investigation, the relationship is made between the occurrence of PGM and whole-rock PGE data.

This study examines the occurrence of PGM and other trace minerals for each location, and documents their mode of occurrence and textural relationships with the sulphides and alteration minerals of the ores. Most emphasis is placed on those minerals from the Barnet property and the Epidote Zone, where the most detailed work was completed. PGM-bearing samples from the other deposits were studied for comparative purposes.

A summary of PGM and other trace minerals identified for all the studied deposits, including their occurrence in other deposits in the Sudbury area as reported in the literature, is presented in Table 5-1. A synopsis of the analytical techniques and the analytical data are reported in Appendix VI. 


\section{5-2. PGM AND OTHER TRACE MINERALS IN FOOTWALL CU-Ni-PGE VEIN DEPOSITS}

\section{5-2a. PETROGRAPHY}

\section{i. Barnet Property}

All the precious metal minerals from the Barnet property are small (commonly $<5 \mu \mathrm{m}$ in diameter), individual telluride and selenide grains, hessite being most common (Table 5-2). Merenskyite is the only PGM, and naummanite the only selenide (Plate 5-1a). Palladian melonite was identified in one sample (Plate 5-1b). Chalcopyrite is the most common host for hessite and merenskyite (Plates 5-1c and d). However, other host minerals are epidote (merenskyite), pyrite (naummanite and merenskyite), quartz (palladian melonite) and amphibole (naummanite). Very fine intergrowths of hessite and merenskyite are common, but are too small to resolve quantitatively with the SEM. In one naumannite occurrence, numerous naumannite grains exist with abundant chalcopyrite inclusions in pyrite, suggesting that one or more of the $\mathrm{Ag}$ and Se may have existed as trace elements within the chalcopyrite before it was overgrown by subhedral pyrite.

The small size of Barnet PGM (commonly $<5 \mu \mathrm{m}$ in diameter) has precluded their accurate quantitative analysis.

\section{ii. Strathcona Mine Deep Copper Zone}

PGM from two samples from the Deep Copper Zone include sobolevskite, moncheite and froodite, and are commonly associated with hessite (Table 5-3). 
One grain of platinian melonite was also identified. This partial assemblage, richer in $\mathrm{Bi}$ than the precious metal mineral assemblage at Barnet, compares favourably with the phases identified in recent studies of PGM in the Deep Copper Zone (Table 5-1). Only platinian melonite had not been identified previously in Deep Copper Zone or in any other Sudbury area deposits. Platinian melonite has also been identified in the Fraser Mine Epidote Zone (this chapter). Although moncheite was not identified by Li and Naldrett (1992; 1993a) in their detailed study of Deep Copper Zone PGM, it has been identified in this study and that of Springer (1989). Likewise, Li and Naldrett (1992; 1993a) identified one grain of sobolevskite, whereas Springer (1989) reported none.

The nature of the host mineralogy for precious metal minerals at Deep Copper Zone is also very different from that at Barnet. Except for the two sobolevskite grains in chalcopyrite, all others are in quartz and epidote, most commonly at grain boundaries. Because both of the studied sections are of well developed alteration selvages adjacent to veins, and because of the relatively small number of studied samples this dominance of alteration silicate hosts may not be representative. In their study, Li and Naldrett (1992; 1993a) determined that most of the PGM occurred at the margins of sulphides.

None of the grains was zoned although in two cases (sobolevskite/hessite and moncheite/hessite) two precious metal minerals occurred in contact.

Chlorine-bearing PGM were reported by Li and Naldrett (1993a) and 
include an unnamed $\mathrm{Pd}-\mathrm{Bi}$ chloride and an unnamed $\mathrm{Cl}$-bearing $\mathrm{Pd}-\mathrm{Bi}$ sulphide. Another $\mathrm{Cl}$-bearing rare phase associated with these minerals is bismoclite (BiOCl; Li and Naldrett; 1993a).

\section{iii. Strathcona Mine Copper Zone}

Precious metal minerals were studied in 3 samples from the Strathcona Mine Copper Zone (Table 5-4). Froodite is the most common PGM and is found as part of large composite grains also composed of michenerite, sobolevskite, hessite and parkerite (Plates 5-2a and b). Other precious metal minerals from the Copper Zone are Au-Ag alloy, niggliite, sperrylite, native $\mathrm{Ag}$ and unnamed $(\mathrm{Pt}, \mathrm{Pd})(\mathrm{Bi}, \mathrm{Te})_{2}$ that chemically resembles $(\mathrm{Pt}, \mathrm{Pd})(\mathrm{Bi}, \mathrm{Te}, \mathrm{Sn})_{2}$ reported by $\mathrm{Li}$ and Naldrett (1992) from the Deep Copper Zone. An unnamed $\mathrm{BiTe}_{2} \mathrm{~S}_{2}$ phase is also present. Most of the PGM occur at the contact between chalcopyrite and silicates (epidote or amphibole; Plate 5-2c).

The PGM assemblage represented by these samples, with abundant froodite and sobolevskite, resembles that of Deep Copper Zone and not that from the Barnet property, suggesting that the Copper Zone and Barnet deposit are not part of the same deposit.

\section{iv. McCreedy West Mine Cu-rich Stringers}

PGM investigated from McCreedy West Cu-rich stringers commonly occur as large composite grains that include michenerite, platinian michenerite, hessite, tellurohauchecornite, moncheite and unnamed bismuth-tellurides (Table 5-5; Plate 5-3a). Moncheite / hessite composite grains are most common. The 
close relationship between moncheite and hessite was also found by Cabri and Laflamme (1976) in their study of McCreedy West and Creighton PGM. One free grain of argentian gold was identified at a chalcopyrite / chlorite margin (Plate 5-3b). However, the most common PGM host mineral is chalcopyrite, with some grains within amphibole.

\section{v. Longvack Property Cu-rich Veinlets}

Two Cu-rich samples from the Longvack property were found to contain small, individual precious metal minerals (Table 5-6). Merenskyite, hessite and a variety of $\mathrm{Pb}$-bearing bismuth-tellurides were identified. Although data is limited, the similarity of precious metal mineral assemblage of these rocks to those from the Barnet property suggest that they may have formed from the same hydrothermal system. The predominant host minerals are chalcopyrite, pyrite and epidote.

\section{5-3. PGM AND OTHER TRACE MINERALS IN FRASER MINE EPIDOTE ZONE}

\section{5-3a. INTRODUCTION}

The data for this study of precious metal minerals in the Epidote Zone was obtained from exploration diamond drill cores FR46-147, FR46-150, FR46264 and FR46-287 that were also sampled for petrographic and metal geochemical study (Chapter 4). Because of the low (<1000 ppb) levels of Pt and Pd in the analyzed samples, the discovery of PGM in the Epidote Zone was unexpected. 


\section{5-3b. PETROGRAPHY}

All the precious metal minerals described in this study are tellurides or bismuth tellurides, dominated by the platinum telluride, moncheite (Plate 5-4a, b, $c$ and d). Other phases are hessite, tsumoite (Plate 5-4e), merenskyite (Plate 54f), palladian melonite and platinian melonite. None is visibly zoned and the dominant host minerals are pyrite, pentlandite and amphibole. Other common characteristics of PGM-bearing samples are the occurrence of magnetite adjacent to the precious metal host and small ( $<10 \mu \mathrm{m}$ in diameter) Se-bearing galena inclusions in pyrite. Traces of seleniferous galena have also been identified in the Cu-rich Victor Deep and McCreedy East orebodies (Jago et al., 1994). The characteristics of individual mineral grains are summarized in Table 5-7.

Moncheite and merenskyite were also encountered in altered samples of UMAF and DNBX surrounded by Epidote Zone in FR46-150. This is an unusual hole in that there are abundant sulphides in DNBX on the footwall side of the Footwall Breccia (F. Twilley, pers. comm., 1991). Because specimens in the other holes investigated during the course of this study (without this LGBX / Epidote Zone / DNBX / UMAF / Epidote Zone / LGBX association) contain moncheite it is proposed that the fluids altering the DNBX and UMAF were similar to those that caused the development of Epidote Zone in the adjacent Footwall Breccia. However, the alteration of DNBX and UMAF acted as the source for the Pd-bearing fluids that precipitated merenskyite only in rocks of 
this hole.

Hessite is limited to two occurrences in FR46-147. The fact that it was not encountered elsewhere again indicates that some of the precious metal abundances are features peculiar to a particular Epidote Zone patch and may be controlled by either the original characteristics of the area before Epidote Zone development or the fluid characteristics specific to that area of alteration.

\section{5-3c. SUMMARY}

This study has shown that the occurrence of precious metal minerals is most common in magnetite-bearing Epidote Zone. Five of six Epidote Zone samples with PGM and Ag-bearing phases display this affinity.

It is uncertain as to why a Pt-rich phase dominates the precious metal mineral assemblage, although whole-rock PGE geochemistry shows that Pt and Pd abundances are subequal throughout the Epidote Zone and that they show a positive correlation (Chapter 4). Figure 5-1 shows that the PGM-bearing samples exist in the top $50 \%$ of analyzed samples for total $\mathrm{Pt}$ and $\mathrm{Pd}$, although these totals are low compared to other PGM-bearing deposits. For example, moncheite has been identified in a sample (FR46-287-7) with only $210 \mathrm{ppb} \mathrm{Pt}$.

\section{5-4. MINERAL CHEMISTRY}

\section{5-4a. FROODITE, $\mathrm{PdBi}_{2}$}

Froodite was only encountered in samples from the Strathcona Copper Zone. It ranges from pure $\mathrm{PdBi}_{2}$ to compositions with minor substitution of $\mathrm{Pt}$ for $\mathrm{Pd}$, and $\mathrm{Te}$ for $\mathrm{Bi}$. Figure $5-2$ is a $\mathrm{Bi}-(\mathrm{Pd}+\mathrm{Pt}+\mathrm{Ni})-(\mathrm{Te}+\mathrm{Se})$ ternary plot showing 
that Copper Zone froodite is similar in composition to that reported from the nearby Deep Copper Zone (Li and Naldrett, 1992; 1993a) and Coleman (Cabri and Laflamme, 1976) deposits, and several South Range mines (Cabri and Laflamme, 1976).

\section{5-4b. SOBOLEVSKITE, PdBi}

Sobolevskite was found in both the Deep Copper Zone and the Copper Zone. The only two other reports of sobolevskite in the Sudbury area was one grain from the Deep Copper Zone intergrown with froodite, native bismuth and bismoclite (BiOCl; Li and Naldrett, 1992; 1993a), and occurrences in the Victor Deep and McCreedy East orebodies (Jago et al., 1994). Their analysis showed no substitution of either $\mathrm{Pd}$ or $\mathrm{Bi}$. However, analyses from this study show up to 11 at. \% replacement of $\mathrm{Bi}$ by $\mathrm{Te}$. One analysis from the Deep Copper Zone yielded considerable $\mathrm{Sb}(1.3$ at.\%) and $\mathrm{Pb}(3.6$ at. \%).

5-4c. MICHENERITE, PdBiTe, AND PLATINIAN MICHENERITE, (Pd,Pt)BiTe Michenerite from the Copper Zone contains no Pt. However, all but one analysis from McCreedy West show significant Pt substitution for Pd (range 4.5 to $13.6 \mathrm{wt} . \%)$. The range of $\mathrm{Pt}$ substitution for platinian michenerite from this study is much higher than that reported by Li and Naldrett (1992; 1993a) for Deep Copper Zone Pt-bearing michenerites, but is similar to that from platinian michenerites from McCreedy West (Cabri and Laflamme, 1976). Cabri and Laflamme (1976) reported the presence of $\mathrm{Pt}$, with less frequent and smaller quantities of $\mathrm{Sb}$, as characteristic of North Range michenerites in comparison to 
those from South Range deposits. However, michenerite compositions from the Lindsley Mine in the South Range (D.H. Watkinson, unpub. data) shows ubiquitous $\mathrm{Pt}$ substitution for $\mathrm{Pd}$, ranging from 0.62 to $7.78 \mathrm{wt}$ \%, suggesting that Pt-rich michenerites are not solely characteristic of North Range deposits. Conversely, ubiquitous Sb substitution in the Lindsley michenerites (range 0.21 to 3.16 wt.\%) supports the statement made by Cabri and Laflamme (1976) that South Range michenerites are more Sb-rich than those from North Range deposits.

On a $\mathrm{Bi}-(\mathrm{Te}+\mathrm{Se})-(\mathrm{Pd}+\mathrm{Pt}+\mathrm{Ni})$ projection (Figure 5-3), the fields for Copper Zone and McCreedy West michenerite and platinian michenerite from this study overlap with that for michenerite from Deep Copper Zone ( $\mathrm{Li}$ and Naldrett, 1992; 1993a). However, michenerite and platinian michenerite reported by Cabri and Laflamme (1976) and those from Lindsley (D.H. Watkinson, unpub. data) are more depleted in $\mathrm{Bi}$ and enriched in $\mathrm{Te}$ than those from this study. Hoffman and MacLean (1976) determined that michenerite forms an extensive solid-solution field by substitution between $\mathrm{Bi}$ and $\mathrm{Te}$ from $\mathrm{Pd}_{0.99} \mathrm{Bi}_{0.79} \mathrm{Te}_{1.22}$ to $\mathrm{Pd}_{0.95} \mathrm{Bi}_{1.11} \mathrm{Te}_{0.94}$ below $489{ }^{\circ} \mathrm{C}$, the start of melting of Bi-rich michenerite.

Figure 5-4 shows that only michenerite from the Copper Zone have considerable Ni substitution, compared to other michenerite and merenskyite from this study, from Cabri and Laflamme (1976) and from the Lindsley Mine (D.H. Watkinson, unpub. data). 
5-4d. MERENSKYITE, $(\mathrm{Pd}, \mathrm{Pt})(\mathrm{Te}, \mathrm{Bi})_{2}$, AND MONCHEITE, $(\mathrm{Pt}, \mathrm{Pd})(\mathrm{Te}, \mathrm{Bi})_{2}$

Merenskyite has been identified in samples from the Barnet and Longvack properties, whereas moncheite occurs in the Epidote and Deep Copper zones, and in McCreedy West Cu-rich stringers. Sample FR46-150-11 (altered Sublayer) from the Epidote Zone appears to contain a separate phase containing approximately equal proportions of Pd and Pt. Almost complete solid solution between moncheite and merenskyite exists in the analyses from this study (Figure 5-5).

All merenskyite analyzed as part of this study contained Pt; the lowest concentration was found in sample CFA-046 (2.5 to 3.4 wt.\%). However, within the same deposit, sample CFA-006 contained between 8.1 and $8.5 \mathrm{wt} \% \mathrm{Pt}$, suggesting that merenskyite composition is controlled on a sample- rather than deposit-scale. Similarly, Bi contents vary widely among analyzed samples. At Barnet, Bi content ranges from 11.1 to $11.6 \mathrm{wt} \%$ in sample CFA-006, and from 2.6 to 8.2 wt. \% in sample CFA-046. Bi contents from the Epidote Zone are higher, ranging from 20.3 to 23.3 wt. \%. Ni content in Barnet merenskyite is negligible, although those from the Epidote Zone contained between 1.7 and 2.2 wt.\% Ni. Of interest is the fact that the more Pt-rich phases from sample FR46150-11 contain less $\mathrm{Ni}$ (between 1.4 and $1.6 \mathrm{wt} . \%$ ).

Figure 5-5 shows that the most variation in merenskyite content from Barnet, Longvack and the Epidote Zone is in $\mathrm{Pt}$. By comparison, merenskyite from Lindsley has much broader variations in both Pt and Bi (D.H. Watkinson, 
unpub. data), although the fields for both overlap.

Like merenskyite, moncheite compositional variations are controlled on a sample-scale, especially variations in $\mathrm{Pd}$ and $\mathrm{Bi}$ content. In the Epidote Zone this is even shown by samples from the same drill core, with FR46-287-6 containing between 1.7 and $2.6 \mathrm{wt} . \% \mathrm{Bi}$, and FR46-287-7 containing between 6.2 and $9.1 \mathrm{wt} . \% \mathrm{Bi}$. On the other hand, deposit-scale variations are best shown by differences in $\mathrm{Bi}$ and $\mathrm{Ni}$ content. Figure 5-6 shows that except for the unusual merenskyite / moncheite grains from Epidote Zone sample FR46-15011, Epidote Zone samples tend to contain much less Bi (1.7 to 17.2 wt.\%), than moncheite from McCreedy West (18.0 to 23.2 wt.\%) or Deep Copper Zone (19.2 to 23.4 wt.\%). Although one sample (FR46-150-13, altered ultramafic) contained moncheite with no $\mathrm{Ni}$, it was ubiquitous in all other Epidote Zone moncheite in abundances up to $2.0 \mathrm{wt}$ \% (Figure 5-4). Moncheite from McCreedy West and Deep Copper Zone contain very little to no $\mathrm{Ni}$ (up to 0.53 wt.\%). McCreedy West moncheite analyzed in this study are compositionally similar to those analyzed by Cabri and Laflamme (1976).

5-4e. INSIZWAITE, (Pt,Pd)(Bi,Te $)_{2}$

One grain of $(\mathrm{Pt}, \mathrm{Pd})(\mathrm{Bi}, \mathrm{Te})_{2}$ phase was found adjacent to froodite in the Copper Zone near hessite, sperrylite, niggliite and argentian gold grains. Small grain size has limited the determination of its optical characteristics. It is similar to the $(\mathrm{Pt}, \mathrm{Pd})(\mathrm{Bi}, \mathrm{Te}, \mathrm{Sn})_{2}$ phase identified by Li and Naldrett (1992) in the Deep Copper Zone, although it does not contain $\mathrm{Sn}$. A Pt(Bi, Te, Sn $)_{2}$ phase was also 
identified by Springer (1989) from the Deep Copper Zone, but he identified it as niggliite. According to Li and Naldrett (1992), this unnamed phase was also associated with froodite and hessite. The grain analyzed in this study is also similar to insizwaite $\left[\mathrm{Pt}(\mathrm{Bi}, \mathrm{Sb})_{2}\right]$ although it does not contain $\mathrm{Sb}$. The "moncheite" identified by Springer (1989) in the Deep Copper Zone bears considerable resemblance to the phase analyzed here, and may have been incorrectly identified by Springer (1989). The lack of other occurrences precludes the positive identification of this phase.

\section{5-4f. NIGGLIITE, PtSn}

Niggliite was identified as part of a composite grain with electrum and froodite in the Copper Zone. It displays similar Pd substitution ( 0.80 to 0.94 wt.\%) as niggliite reported from the Deep Copper Zone (Li and Naldrett, 1992; 1993a). Sb contents in the same grain range from 0 to $2.3 \mathrm{wt} . \%$, consistent with those from the nearby Deep Copper Zone (Li and Naldrett, 1992; 1993a) and Coleman deposits (Cabri and Laflamme, 1976).

5-4g. SPERRYLITE, PtAs ${ }_{2}$

One grain of sperrylite was found in amphibole with chalcopyrite, froodite, niggliite, electrum, hessite and possible insizwaite in a sample from the Copper Zone. Sb substitution (1.7 to 2.5 wt.\%) was higher in this grain than sperrylite from the Deep Copper Zone (Li and Naldrett, 1992), from a variety of South Range deposits and the Coleman Mine (Cabri and Laflamme, 1976), and from the Lindsley Mine (D.H. Watkinson, unpub. data). In one analysis Au was found 
to replace Pt. Au was not encountered in any other analyses of sperrylite from the Sudbury area.

5-4h. PALLADIAN MELONITE, $(\mathrm{Ni}, \mathrm{Pd})(\mathrm{Te}, \mathrm{Bi})_{2}$, AND PLATINIAN MELONITE, $(\mathrm{Ni}, \mathrm{Pt})(\mathrm{Te}, \mathrm{Bi})_{2}$

Palladian melonite has previously been reported from the Sudbury area. In this study it was identified in samples from the Epidote Zone and the Barnet property. In general, palladian melonite compositions analyzed in this study are similar to those reported by Cabri and Laflamme (1976). However, Bi contents that range from 5.6 to $16.5 \mathrm{wt} . \%$ in other Sudbury-area occurrences are considerably lower in palladian melonite from the Epidote Zone (4.0 to $4.1 \mathrm{wt} . \%$ ) and Barnet (1.3 to 1.4 wt.\%). Although there is no $\mathrm{Pt}$ in palladian melonite from the Epidote Zone, Pt contents range from 3.9 to 5.1 at Barnet. This is higher than in any other Sudbury palladian melonite.

Another telluride, with approximately equal proportions of $\mathrm{Ni}$ and $\mathrm{Pt}$ has been encountered in samples from the Epidote and Deep Copper zones, and has been identified as platinian melonite.

Rucklidge (1969) and Cabri and Laflamme (1976) have reported that a solid solution exists between melonite and merenskyite. Although the sampling is limited, it is suggested as a result of these analyses that a solid solution exists between Pd-melonite and moncheite. Figure 5-7 shows the linear relationship between increased $\mathrm{Ni}$ content and decreased $\mathrm{Pd}+\mathrm{Pt}$ from high-Ni palladian melonite from the Epidote Zone (FR46-150-4) to a lower Ni, moncheite-like mineral (S37-1). Although one of the high Ni samples is from a high $\mathrm{Ni}$ 
environment of altered DNBX and ultramafic rock (FR46-150), the other is from a relatively low $\mathrm{Ni}$, Cu-rich vein from the Barnet property (CFAS-5C). On a Pd - $\mathrm{Ni}$ - Pt ternary diagram, Ni-bearing moncheite from the Epidote Zone has been included. Despite the Pd substitution in these analyses, a trend can be identified from the Pt apex to palladian melonite with a Ni:Pd ratio of approximately $3: 1$ (Figure 5-8). Similarly, a trend from palladian melonite with a $\mathrm{Pd}:(\mathrm{Te}+\mathrm{Bi})$ ratio of approximately $1: 9$ to ideal moncheite exists on a $\mathrm{Pd}-(\mathrm{Te}+\mathrm{Bi})$ - Pt projection (Figure 5-9).

5-4i. Ag-Au AlloY, (Ag,Au)

Because of the small size of the grains, there was considerable contamination of the analyses by the host sulphides in the 3 grains analyzed from the Copper Zone. However, compositions ranged from $\mathrm{Ag}_{72-86}$. This $\mathrm{Ag}$ content is much higher than those reported by Money (1992) for Ag-Au alloy from the nearby Deep Copper Zone $\left(\mathrm{Ag}_{53-68}\right)$ and by Jago et al. (1994) for McCreedy East $\left(\sim \mathrm{Ag}_{50}\right)$. Au-Ag alloy from McCreedy West is much more Au-rich $\left(\mathrm{Au}_{59-61}\right)$.

Native $\mathrm{Ag}$ with an $\mathrm{AgCl}$ rim was identified in bornite from the Deep Copper Zone and is discussed further in chapter 6 . Hessite was identified in the same sample at the contact between bornite and calcite. Native $\mathrm{Ag}$ identified in a sample from the Copper Zone is in a mass of epidote and amphibole.

\section{5-4j. HESSITE, $\mathrm{Ag}_{2} \mathrm{Te}$}

Hessite is the most common precious metal mineral identified in all the 
study locations. It occurs alone or with PGM. It is typically composed only of its ideal elements, with little substitution. However, Se contents in hessite from the Deep Copper Zone range from 0 to 0.84 wt.\%. Although data is limited, Se substitution in hessite from Longvack ranges from 0.71 to 0.88 wt.\%.

5-4k. NAUMANNITE, $\mathrm{Ag}_{2} \mathrm{Se}$

Naumannite was only identified at Barnet, both in polished thin section, and as an accidental phase in fluid inclusions in chalcopyrite (Chapter 6). It shows only very limited substitution of Se by $\mathrm{Te}$ and $\mathrm{As}$.

5-4I. TELLUROHAUCHECORNITE, $\mathrm{Ni}_{9} \mathrm{BiTeS}_{8}$

Although hauchecornite has been previously identified in the Deep Copper Zone (Snajdr, 1985; Springer, 1985; Springer and Collins, 1982), the hauchecornite-group mineral analyzed from McCreedy West contains no Sb, but sub-equal proportions of $\mathrm{Bi}$ and $\mathrm{Te}$, and has therefore been identified as tellurohauchecornite. There is minor substitution of $\mathrm{Co}$ for $\mathrm{Ni}(0.88$ to $1.1 \mathrm{wt} . \%)$ and of $\mathrm{Pb}$ for $\mathrm{Bi}(0$ to 2.6 wt.\%). Tellurohauchecornite has also been reported in the Victor Deep and McCreedy East orebodies, although no analyses are available (Jago et al., 1994).

5-4m. BISMUTHINITE, $\mathrm{Bi}_{2} \mathrm{~S}_{3}$

One grain of bismuthinite was identified in a sample from McCreedy West, but it has also been reported as occurring in the Deep Copper Zone (Springer, 1989). It shows no unusual compositional characteristics. 
Interpretation of the analytical results of the variety of bismuth tellurides is tenuous because of the small size of all the analyzed phases. A detailed computer search was completed in order to match these analyses with known phases but it yielded inconclusive results. A more detailed study of these phases by electron microprobe is required for more specific identification.

\section{i. Strathcona Mine Copper Zone}

An unknown, previously unidentified $\mathrm{BiTe}_{2} \mathrm{Se}_{2}$ phase was found in chalcopyrite from the Copper Zone. There has been minor contamination of the analyses by the host chalcopyrite.

\section{ii. McCreedy West Mine Cu-rich Stringers}

Two different phases were identified in a sample from McCreedy West. One is possibly related to pilsenite $\left(\mathrm{Bi}_{4} \mathrm{Te}_{3}\right)$, and shows limited Se substitution (2.2 to 2.9 at.\%). The other may be related to unnamed mineral \#489 $\left[\mathrm{Bi}_{3}(\mathrm{Se}, \mathrm{Te}, \mathrm{S})_{4}\right]$

\section{iii. Longvack Property Cu-rich Stringers}

Analyses of a sample from the Longvack property were made on very small grains, resulting in considerable contamination by associated sulphides. Common chemical characteristics include approximately equal atomic proportions of $\mathrm{Bi}$ and Te with limited Se substitution (2.0 to 4.4 at.\%), giving it a tsumoite-like composition. $\mathrm{Pb}$ appears to locally replace $\mathrm{Bi}$. The amount of $\mathrm{S}$ in these phases is unknown due to the contamination in the analyses. An unnamed $\mathrm{Bi}_{2} \mathrm{Te}_{2} \mathrm{~S}$ phase was also found in chalcopyrite from the Longvack 
property.

\section{iv. Fraser Mine Epidote Zone}

One grain of a tsumoite-like (BiTe) mineral has been identified with pentlandite. Tsumoite has not previously been identified in the Sudbury area. However, the small size of the grain has resulted in contamination of the analyses by the pentlandite host $(\mathrm{Ni}, \mathrm{Fe}$, and $\mathrm{S})$. The large amount of $\mathrm{Se}$ (7.7 to $8.2 \mathrm{wt. \% )}$ indicates that this mineral does not conform to ideal tsumoite stoichiometry, although it contains equal atomic proportions of $\mathrm{Bi}$ and $\mathrm{Te}$.

\section{5-5. DISCUSSION}

\section{5-5a. CU-RICH FOOTWALL VEIN DEPOSITS}

Precious metal minerals in Cu-rich footwall vein deposits occur most commonly in chalcopyrite near, or at, the contact with silicate alteration minerals. Li and Naldrett (1993a) indicated that chlorite was typically associated with PGM. However, this study has shown that the most common silicate hosts are actinolite, quartz and epidote. In fact, PGM have been identified in quartzbearing veinlets (Sample S37-1), contrary to the findings of Li et al. (1992) and Li and Naldrett (1993a). Pyrite is a rare PGM host. In all studied deposits hessite is the most common precious metal mineral and is associated with both tellurides (merenskyite and moncheite) and bismuthides (froodite and hauchecornite). However, there are no specific PGM assemblages specific to either sulphide or silicate hosts. The close spatial association of PGM with silicate alteration and $\mathrm{Cl}$-bearing PGM and other rare phases, is compatible with 
the influence of a $\mathrm{H}-\mathrm{O}-\mathrm{Cl}-\mathrm{S}-\mathrm{Te}-\mathrm{Se}-\mathrm{Bi}-\mathrm{As}$-bearing fluid in $\mathrm{PGM}$ deposition.

Precious metal minerals that have been investigated here are consistent with previously published data (i.e., Deep Copper Zone and McCreedy West). However, each deposit has its own dominant precious metal mineral assemblage. For example, the Barnet property assemblage is characterized by merenskyite, hessite and naumannite. At McCreedy West, moncheite, michenerite and hessite are the dominant phases. Although Deep Copper and Copper zones both contain abundant froodite, there are other differences in their assemblages. Despite the limited data from the Longvack Property, the assemblage is merenskyite and hessite, similar to that from Barnet. This supports evidence from surface mapping that indicates that Cu-rich sulphides at Longvack are related to those at Barnet. Thus, as with the geochemical data (Chapter 4), it may be said that the composition of each Cu-rich footwall deposit is a function of the original mineralization and the fluids that interacted with and deposited them.

\section{5-5b. EPIDOTE ZONE}

The Epidote Zone precious metal mineral assemblage consists of a moncheite-rich assemblage. However, as the geochemical analysis showed, rocks from different locations have particular characteristics (i.e., merenskyite in altered DNBX and UMAF that is not recognized elsewhere). Although wholerock PGE totals are relatively low in comparison to other PGM-bearing deposits, Pt and Pd -bearing PGM have been identified within the Epidote Zone. This 
suggests that most of the Pt and Pd is not in solid solution in base metal sulphides, but that Pt and Pd occurs in discrete PGM and Ni-rich tellurides. It was shown in Chapter 4 that Os and Ir were moderately enriched in the Epidote Zone compared to other ore types. No Os or Ir -bearing PGM were identified, so the possibility that these elements occur in solid solution with pentlandite, pyrrhotite, pyrite or magnetite still exists.

Precious metal minerals tend to occur in magnetite-bearing alteration facies, with individual PGM near magnetite grain contacts. Sulphide host minerals include pyrite (dominant), pyrrhotite and pentlandite. Actinolite is the only silicate host mineral. Fluid composition consistent with magnetite development appears to have resulted in the development of discrete PGM.

Common to the development of all Epidote Zone patches was an aqueous, $\mathrm{Cl}$-rich fluid that contained significant amounts of $\mathrm{Te}$ and $\mathrm{Bi}$ (Chapter 6). The change of mineralogy with alteration type indicates that the fluid evolved and became more oxidized with time (Chapter 3 ). Previous studies have shown that an oxidized, saline fluid may well be significant in transporting significant quantities of PGE (Mountain and Wood, 1988b; Watkinson, 1990). The precipitation of magnetite may have reduced the fluid such that PGE solubility decreased, and $\mathrm{Pt}$-, $\mathrm{Pd}$-, as well as $\mathrm{Ag}$ - and $\mathrm{Cu}$ - bearing phases subsequently precipitated (chapters 3 and 4).

\section{5-5c. IMPLICATIONS FOR FLUID COMPOSITION}

End-member PGM compositions are rare in any of the deposit types in the 
Sudbury area (Figures 5-4, 5-5, 5-6, 5-7, 5-8 and 5-9). Where sample abundance is great enough, PGM compositions were found to be depositspecific, and in the case of the Epidote Zone, location specific. This is the result of different fluid compositions (i.e., metallic element contents) and conditions (i.e., $\mathrm{fO}_{2}, \mathrm{fS}_{2}, \mathrm{pH}$, and temperature). Although there is overlap in PGM assemblages between deposits (i.e., Deep Copper Zone and Copper Zone), there are mineral chemical characteristics typical of each location. Similarly, whole-rock geochemical characteristics are location specific (Chapter 4). 
TABLE 5-1. Summary of platinum-group minerals and other trace minerals identified as part of this study.

\begin{tabular}{|c|c|c|c|c|}
\hline $\begin{array}{l}\text { Important } \\
\text { Element }\end{array}$ & Mineral Name & Mineral Formula & Location & $\begin{array}{l}\text { Other Sudbury Occurrences (with } \\
\text { references) }\end{array}$ \\
\hline \multirow[t]{4}{*}{$\mathrm{Ag}$} & $\mathrm{Ag}$ & $\mathrm{Ag}$ & $\begin{array}{l}\text { Deep Copper Zone, } \\
\text { Copper Zone, Barnet (in } \\
\text { fluid inclusion in } \\
\text { chalcopyrite). }\end{array}$ & $\begin{array}{l}\text { Frood }^{1}, \text { Victor Deep } \\
\text { East }^{13}, \text { McCreedy }^{3}, \text { Deep Copper Zone } \\
\end{array}$ \\
\hline & Chlorargyrite & $\mathrm{AgCl}$ & $\begin{array}{l}\text { Barnet (in fluid inclusion } \\
\text { in chalcopyrite). }\end{array}$ & None. \\
\hline & Hessite & $\mathrm{Ag}_{2} \mathrm{Te}$ & $\begin{array}{l}\text { McCreedy West Cu- } \\
\text { stringers, Epidote Zone, } \\
\text { Deep Copper Zone, } \\
\text { Copper Zone, Longvack, } \\
\text { Barnet. }\end{array}$ & $\begin{array}{l}\text { Victor Deep }{ }^{13}, \text { McCreedy East }{ }^{13} \text {, } \\
\text { Deep Copper Zone }{ }^{256} \text {. }\end{array}$ \\
\hline & Naumannite & $\mathrm{Ag}_{2} \mathrm{Se}$ & Barnet. & None. \\
\hline $\mathrm{Au}$ & Au-Ag Alloy & $(\mathrm{Au}, \mathrm{Ag})$ & $\begin{array}{l}\text { McCreedy West Cu- } \\
\text { stringers, Copper Zone. }\end{array}$ & $\begin{array}{l}\text { Lockerby }^{12} \text {, Victor Deep }{ }^{13}, \text { McCreedy } \\
\text { East }^{13} \text {, Deep Copper Zone }\left(\mathrm{Ag}_{53-084}\right. \\
\left.\mathrm{Au}_{32-436}\right)^{2.4 .6} \text {. }\end{array}$ \\
\hline \multirow[t]{7}{*}{ Bi } & $\mathrm{Bi}$ & $\mathrm{Bi}$ & $\begin{array}{l}\text { Deep Copper Zone } \\
\text { (also in fluid inclusion in } \\
\text { bornite). }\end{array}$ & Frood', Deep Copper Zone ${ }^{2,311}$. \\
\hline & Bismuthinite & $\mathrm{Bi}_{2} \mathrm{~S}_{3}$ & $\begin{array}{l}\text { McCreedy West Cu- } \\
\text { stringers. }\end{array}$ & Deep Copper Zone ${ }^{\theta}$. \\
\hline & Tsumoite & $\mathrm{BiTe}$ & $\begin{array}{l}\text { Epidote Zone, } \\
\text { Longvack. }\end{array}$ & None. \\
\hline & unnamed & $\mathrm{BiTe}_{2} \mathrm{~S}_{2}$ & Copper Zone. & None. \\
\hline & Pilsenite(?) & $\mathrm{Bi}_{4} \mathrm{Te}_{3}$ & McCreedy West. & None. \\
\hline & Unnamed Mineral \#489 & $\mathrm{Bi}_{3}(\mathrm{Se}, \mathrm{Te}, \mathrm{S})_{4}$ & McCreedy West. & None. \\
\hline & unnamed & $\mathrm{Bi}_{2} \mathrm{Te}_{2} \mathrm{~S}$ & Longvack. & None. \\
\hline $\mathrm{Ni}$ & Tellurohauchecornite & $\mathrm{Ni}_{8}(\mathrm{Bi}, \mathrm{Te})_{2} \mathrm{~S}_{8}$ & $\begin{array}{l}\text { McCreedy West Cu- } \\
\text { stringers. }\end{array}$ & Victor Deep ${ }^{13}$. \\
\hline \multirow[t]{6}{*}{$\mathrm{Pd}$} & Froodite & $\mathrm{PdBi}_{2}$ & Copper Zone. & $\begin{array}{l}\text { Frood, Vermillion, Creighton, Victor } \\
\text { Deep }{ }^{13}, \text { McCreedy East }{ }^{13}, \text { Levack } \\
\text { (McCreedy) West, Coleman }^{78} \text {. Deep } \\
\text { Copper Zone } \text { S }^{23.11} \text {. }\end{array}$ \\
\hline & Merenskyite & $(\mathrm{Pd}, \mathrm{Pt})(\mathrm{Te}, \mathrm{Bi})_{2}$ & $\begin{array}{l}\text { Epidote Zone, } \\
\text { Longvack, Barnet. }\end{array}$ & $\begin{array}{l}\text { Creighton, Crean Hill, Lockerby' } \\
\text { Victor Deep } \\
\text { Levack (McCreedy) West }^{13}, \text { Meed } \\
\text { Copper Zone } \\
\text { Cop.11, Lindsley }\end{array}$ \\
\hline & Michenerite & PdBiTe & $\begin{array}{l}\text { McCreedy West Cu- } \\
\text { stringers, Copper Zone. }\end{array}$ & $\begin{array}{l}\text { Occurs in most deposits } \\
\text { Lindsley } \\
\text { Lin }\end{array}$ \\
\hline & Platinian Michenerite & $(\mathrm{Pd}, \mathrm{Pt}) \mathrm{BiTe}$ & $\begin{array}{l}\text { McCreedy West Cu- } \\
\text { stringers. }\end{array}$ & $\begin{array}{l}\text { Levack (McCreedy) West }{ }^{8} \text {, } \\
\text { Coleman }^{8} \text {. }\end{array}$ \\
\hline & Palladian Melonite & $(\mathrm{Ni}, \mathrm{Pd})(\mathrm{Te}, \mathrm{Bi})_{2}$ & Epidote Zone, Barnet. & $\begin{array}{l}\text { Falconbridge, Strathcona, Crean } \\
\text { Hill, Creighton }{ }^{8} \text {, Lockerby }\end{array}$ \\
\hline & Sobolevskite & $\mathrm{PdBi}$ & $\begin{array}{l}\text { Deep Copper Zone, } \\
\text { Copper Zone. }\end{array}$ & $\begin{array}{l}\text { Victor Deep }{ }^{13}, \text { McCreedy East }^{\prime} \\
\text { Deep Copper Zone } \\
\end{array}$ \\
\hline Pt & Moncheite & $(\mathrm{Pt}, \mathrm{Pd})(\mathrm{Te}, \mathrm{Bi})_{2}$ & $\begin{array}{l}\text { McCreedy West Cu- } \\
\text { stringers, Epidote Zone, } \\
\text { Deep Copper Zone. }\end{array}$ & $\begin{array}{l}\text { Creighton, Victor Deep }{ }^{13}, \text { McCreedy } \\
\text { East }^{13} \text {, Levack (McCreedy) West } \\
\text { Deep Copper Zone }{ }^{2 \theta} \text {. }\end{array}$ \\
\hline
\end{tabular}




\begin{tabular}{|c|c|c|c|}
\hline Niggliite & PtSn & Copper Zone. & $\begin{array}{l}\text { Victor Deep }{ }^{13}, \text { McCreedy East }{ }^{13}, \\
\text { Coleman }^{8} \text {, Deep Copper Zone }{ }^{235}\end{array}$ \\
\hline Platinian Melonite & $(\mathrm{Ni}, \mathrm{Pt})(\mathrm{Te}, \mathrm{Bi})_{2}$ & $\begin{array}{l}\text { Epidote Zone, Deep } \\
\text { Copper Zone. }\end{array}$ & None. \\
\hline Sperrylite & $\mathrm{PtAs}_{2}$ & Copper Zone. & $\begin{array}{l}\text { Most common Pt mineral of the } \\
\text { South Range }{ }^{1810}, \text { Lindsley } \\
\text { Deep }{ }^{13}, \text { McCreedy }^{9} \text {. East }{ }^{13}, \text { Deep } \\
\text { Copper Zone } \\
\text { 235.11. }\end{array}$ \\
\hline Insizwaite & $(\mathrm{Pt}, \mathrm{Pd})(\mathrm{Bi}, \mathrm{Te})_{2}$ & Copper Zone. & Deep Copper Zones. \\
\hline
\end{tabular}

REFERENCES: 1 = Hawley and Stanton, 1962; $2=$ Snajdr, 1985; $3=$ Springer, 1985; $4=$ Springer and Lalonde, $1987 ; 5=\mathrm{Li}$ and Naldrett, 1992 \& 1993a; $6=$ Springer, $1989 ; 7=$ Hawley and Berry, 1958; $8=$ Cabri and Laflamme, $1976 ; 9=$ Watkinson (unpubl. data); $10=$ Naldrett, 1984; 11 = Springer and Collins, 1982, 12 = Chen, 1993, 13 = Jago et al., 1994 
Table 5-2: Summary of precious metal minerals from the Barnet property.

\begin{tabular}{|c|c|c|c|}
\hline Sample \# & $\begin{array}{l}\text { Precious Metal } \\
\text { Mineral }\end{array}$ & Size $\&$ Shape & Host Mineralogy \& Textures \\
\hline \multirow[t]{3}{*}{ CFA-006 } & $\begin{array}{l}\text { Merenskyite } \\
(\mathrm{Pd}, \mathrm{Pt})(\mathrm{Te}, \mathrm{Bi})_{2}\end{array}$ & 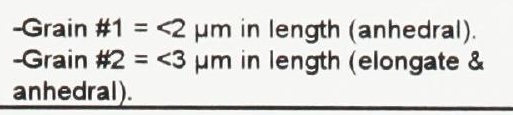 & $\begin{array}{l}\text { In epidote } 5 \mu \mathrm{m} \text { from contact with } \\
\text { chalcopyrite. }\end{array}$ \\
\hline & $\begin{array}{l}\text { Hessite } \\
\mathrm{Ag}_{2} \mathrm{Te}\end{array}$ & $\begin{array}{l}\text {-Grain \#1 = <5 } \mu \mathrm{m} \text { wide (anhedral). } \\
\text {-Grain \#2 }=<5 \mu \mathrm{m} \text { long (anhedral). } \\
\text {-Numerous other hessite grains }<3 \mu \mathrm{m} \\
\text { wide. }\end{array}$ & $\begin{array}{l}\text {-Both Grain \#1 \& Grain \#2 in chalcopyrite. } \\
-\mathrm{PbCl}_{2} \text { inclusions near hessite in chalcopyrite. } \\
\text {-All other hessite grains also in chalcopyrite } \\
\text { but too small for accurate quantitative } \\
\text { analyses. }\end{array}$ \\
\hline & Merenskyite/Hessite & $\begin{array}{l}\text {-Numerous grains }<5 \mu \mathrm{m} \text { wide } \\
\text { (anhedral). }\end{array}$ & $\begin{array}{l}\text {-Fine intergrouths of merenskyite \& hessite } \\
\text { too small to resolve quantitatively with SEM. } \\
\text {-All in chalcopyrite. }\end{array}$ \\
\hline CFA-016B & $\begin{array}{l}\text { Naumannite } \\
\mathrm{Ag}_{2} \mathrm{Se}\end{array}$ & $\begin{array}{l}\text {-Area characterized by several large } \\
\text { grains (the largest } 20 \mu \mathrm{m} \times 7 \mu \mathrm{m} \text {, } \\
\text { anhedral) with abundant minute }(<5 \mu \mathrm{m}) \\
\text { grains of irregular shape. }\end{array}$ & $\begin{array}{l}\text { In pyrite, closely associated with \& locally } \\
\text { intergrown with chalcopyrite inclusions. } \\
\text {-Nearby silicates include K-feldspar \& epidote. }\end{array}$ \\
\hline CFA-046 & $\begin{array}{l}\text { Merenskyite } \\
(\mathrm{Pd}, \mathrm{Pt})(\mathrm{Te}, \mathrm{Bi})_{2}\end{array}$ & $\begin{array}{l}\text { Several small anhedral grains }<5 \mu \mathrm{m} \text { in } \\
\text { diameter. }\end{array}$ & $\begin{array}{l}\text {-All but } 1 \text { grain in chalcopyrite. The other in } \\
\text { pyrite. }\end{array}$ \\
\hline \multirow[t]{3}{*}{ CFA-052 } & $\begin{array}{l}\text { Merenskyite } \\
(\mathrm{Pd}, \mathrm{Pt})(\mathrm{Te}, \mathrm{Bi})_{2}\end{array}$ & $\begin{array}{l}\text {-Several small ( }<5 \mu \mathrm{m} \text { long) \& anhedral. } \\
\text { Small size limits quantitative analyses. }\end{array}$ & $\begin{array}{l}\text {-All in chalcopyrite. } 1 \text { adjacent to hole in slide } \\
\& \text { surrounded by chalcopyrite. }\end{array}$ \\
\hline & $\begin{array}{l}\text { Hessite } \\
\mathrm{Ag}_{2} \mathrm{Te}\end{array}$ & $\begin{array}{l}\text { Several small ( }<5 \mu \mathrm{m} \text { long) \& anhedral. } \\
\text { Small size limits quantitative analyses. }\end{array}$ & $\begin{array}{l}\text {-All in chalcopyrite. Merenskyite/hessite } \\
\text { intergrowths, merenskyite \& galena inclusions } \\
\text { nearby in chalcopyrite. }\end{array}$ \\
\hline & Merenskyite/Hessite & $\begin{array}{l}\text {-The largest of these fine intergrounths } 5 \\
\mu \mathrm{m} \times 3 \mu \mathrm{m} \text { \& irregularly-shaped. }\end{array}$ & $\begin{array}{l}\text {-All in chalcopyrite. Merenskyite, hessite \& } \\
\text { galena inclusions nearby in chalcopyrite. }\end{array}$ \\
\hline \multirow[t]{3}{*}{ CFAS-5C1 } & $\begin{array}{l}\text { Palladian Melonite } \\
(\mathrm{Ni}, \mathrm{Pd})(\mathrm{Te}, \mathrm{Bi})_{2}\end{array}$ & $\sim 7 \mu \mathrm{m}$ in diameter (anhedral). & In quartz. \\
\hline & $\begin{array}{l}\text { Naumannite } \\
\mathrm{Ag}_{2} \mathrm{Se}\end{array}$ & $\sim 7 \mu \mathrm{m}$ long (anhedral). & $\begin{array}{l}\text { Inclusion along cleavage trace in euhedral } \\
\text { amphibole crystal in chalcopyrite. }\end{array}$ \\
\hline & $\begin{array}{l}\text { Hessite } \\
\mathrm{Ag}_{2} \mathrm{Te}\end{array}$ & $\sim 1 \mu \mathrm{m}$ in diameter (anhedral). & $\begin{array}{l}\text {-In chalcopyrite adjacent to hole in slide. } \\
\text {-No quantitative analysis due to small size. }\end{array}$ \\
\hline \multirow[t]{3}{*}{ CFA-91-2 } & $\begin{array}{l}\text { Hessite } \\
\mathrm{Ag}_{2} \mathrm{Te}\end{array}$ & $\begin{array}{l}\text {-Numerous small ( }<5 \mu \mathrm{m} \text { in diameter), } \\
\text { anhedral hessite grains. } \\
\text {-Locally up to } 10 \mu \mathrm{m} \text { long. }\end{array}$ & -All in chalcopyrite. \\
\hline & $\begin{array}{l}\text { Merenskyite } \\
(\mathrm{Pd}, \mathrm{Pt})(\mathrm{Te}, \mathrm{Bi})_{2}\end{array}$ & Small, rounded grain $<5 \mu \mathrm{m}$ in diameter. & In chalcopyrite. \\
\hline & Merenskyite/Hessite & $-<3 \mu \mathrm{m}$ in diameter. & $\begin{array}{l}\text { In chalcopyrite. Fine intergroukhs of } \\
\text { merenskyite \& hessite. Numerous small } \\
\text { hessite grains nearby. }\end{array}$ \\
\hline
\end{tabular}


Table 5-3: Summary of precious metal and platinum-group minerals from the Strathcona Mine Deep Copper Zone.

\begin{tabular}{|c|c|c|c|}
\hline Sample \# & $\begin{array}{l}\text { Precious Metal } \\
\text { Mineral }\end{array}$ & Size \& Shape & Host Mineralogy \& Texture \\
\hline \multirow[t]{4}{*}{ S37-1 } & $\begin{array}{l}\text { Sobolevskite } \\
\text { PdBi }\end{array}$ & $\begin{array}{l}-G r a i n \# 1=50 \mu \mathrm{m} \times 30 \\
\mu \mathrm{m} \text { rounded grain with } \\
25 \mu \mathrm{m} \text { long tail of } \\
\text { hessite. } \\
\text {-Grain \#2=50 } \mu \mathrm{m} \times 25 \\
\mu \mathrm{m} \text { oval-shaped grain. }\end{array}$ & $\begin{array}{l}\text {-Grain \#1 in chalcopyrite } \\
\text { with abundant nearby } \\
\text { hessite \& parkerite } \\
\text { inclusions. No zoning. } \\
\text {-Grain \#2 with chalcopyrite } \\
\text { at quartz-epidote contact. }\end{array}$ \\
\hline & $\begin{array}{l}\text { Platinian Melonite } \\
(\mathrm{Ni}, \mathrm{Pt})(\mathrm{Te}, \mathrm{Bi})_{2}\end{array}$ & $\begin{array}{l}-<10 \mu \mathrm{m} \text { in diameter, } \\
\text { anhedral. }\end{array}$ & -In quartz. \\
\hline & $\begin{array}{l}\text { Moncheite } \\
(\mathrm{Pt}, \mathrm{Pd})(\mathrm{Te}, \mathrm{Bi})_{2}\end{array}$ & $\begin{array}{l}- \text { Grain \#1 = anhedral, }<5 \\
\mu \mathrm{m} \text { in diameter. } \\
- \text { Grain } \# 2=9 \mu \mathrm{m} \times 8 \\
\mu \mathrm{m}, \text { triangular shape. }\end{array}$ & $\begin{array}{l}\text {-Grain \#1 in epidote with } \\
\text { nearby hessite. } \\
\text {-Grain \#2 in quartz with } \\
\text { adjacent anhedral hessite } \\
\text { grain. }\end{array}$ \\
\hline & $\begin{array}{l}\text { Hessite } \\
\mathrm{Ag}_{2} \mathrm{Te}\end{array}$ & $\begin{array}{l}\text {-Grain \#1 = anhedral, }<5 \\
\mu \mathrm{m} \text { in diameter. } \\
\text {-Grain \#2= anhedral, } 8 \\
\mu \mathrm{m} \times 6 \mu \mathrm{m} .\end{array}$ & $\begin{array}{l}\text {-Grain \#1 in epidote with } \\
\text { nearby moncheite. } \\
\text {-Grain \#2 at quartz/epidote } \\
\text { contact, adjacent to } \\
\text { moncheite. }\end{array}$ \\
\hline \multirow{2}{*}{$\begin{array}{l}\text { S39-K631 } \\
\text { (No } \\
\text { quantitative } \\
\text { analyses, but } \\
\text { compositions } \\
\text { verified by } \\
\text { SEM-EDS). }\end{array}$} & $\begin{array}{l}\text { Hessite } \\
\mathrm{Ag}_{2} \mathrm{Te}\end{array}$ & $\begin{array}{l}-15 \mu \mathrm{m} \times 18 \mu \mathrm{m}, \\
\text { triangular shape. }\end{array}$ & $\begin{array}{l}\text {-At junction of several } \\
\text { epidote grains. } \\
-45 \mu \mathrm{m} \text { from froodite grain. }\end{array}$ \\
\hline & $\begin{array}{l}\text { Froodite } \\
\mathrm{PdBi}_{2}\end{array}$ & $\begin{array}{l}-5 \mu \mathrm{m} \times 5 \mu \mathrm{m} \text {, } \\
\text { subhedral. }\end{array}$ & $\begin{array}{l}\text {-At contact of } 2 \text { epidote } \\
\text { grains. } \\
-45 \mu \mathrm{m} \text { from hessite grain. }\end{array}$ \\
\hline \multirow[t]{2}{*}{ STN-4 } & Native Ag & $\begin{array}{l}-1 \mathrm{~mm} \text { in diameter, } \\
\text { subhedral. }\end{array}$ & $\begin{array}{l}\text {-with rim of } \mathrm{AgCl} \text { in bornite } \\
\text { host. }\end{array}$ \\
\hline & $\begin{array}{l}\text { Hessite } \\
\mathrm{Ag}_{2} \mathrm{Te}\end{array}$ & $\begin{array}{l}\text {-grains up to } 100 \mu \mathrm{m} \text { in } \\
\text { diameter, subhedral. }\end{array}$ & $\begin{array}{l}\text {-at contact between bornite } \\
\& \text { calcite, in bornite. }\end{array}$ \\
\hline
\end{tabular}


Table 5-4: Summary of precious metal and platinum-group mineralogy from the Strathcona Mine Copper Zone.

\begin{tabular}{|c|c|c|c|}
\hline Sample \# & Precious Metal Mineral & Size \& Shape & Host Mineralogy \& Texture \\
\hline \multirow[t]{6}{*}{ 27AOCO-H1 } & $\begin{array}{l}\text { Hessite } \\
\mathrm{Ag}_{2} \mathrm{Te}\end{array}$ & $\begin{array}{l}-40 \mu \mathrm{m} \times 30 \mu \mathrm{m} \text {, subhedral. } \\
\text { - Numerous small ( }<5 \mu \mathrm{m} \text { wide) } \\
\text { grains scattered in amphibole in } \\
\text { vicinity of large grain. } \\
\text { - Elsewhere many other small } \\
\text { grains ( }<3 \mu \mathrm{m} \text { wide), anhedral. }\end{array}$ & $\begin{array}{l}\text {-At margin of chalcopyrite with amphibole. Many other } \\
\text { phases within } 50 \mu \mathrm{m} \text { in amphibole, including spermlite, } \\
\text { froodite, niggliite, electrum and insizwaite. } \\
\text {-Elsewhere associated with froodite. }\end{array}$ \\
\hline & $\begin{array}{l}\text { Insizwaite } \\
(\mathrm{Pt}, \mathrm{Pd})(\mathrm{Bi}, \mathrm{Te})_{2}\end{array}$ & $-7 \mu \mathrm{m} \times 5 \mu \mathrm{m}$, subhedral. & $\begin{array}{l}\text {-Adjacent subhedral froodite. } \\
\text {-In vicinity of many other phases as described above. }\end{array}$ \\
\hline & $\begin{array}{l}A g-A u \text { alloy } \\
(A g, A u)\end{array}$ & $\begin{array}{l}- \text { Grain \#1 }=11 \mu \mathrm{m} \times 4 \mu \mathrm{m}, \\
\text { anhedral, elongate. } \\
\text {-Grain } \# 2=3 \mu \mathrm{m} \times 3 \mu \mathrm{m}, \\
\text { subhedral. } \\
\text {-Grain } \# 3=10 \mu \mathrm{m} \times 10 \mu \mathrm{m}, \\
\text { irregularly-shaped. } \\
\text {-Elsewhere, other small grains ( }<3 \\
\mu \mathrm{m} \text { wide), anhedral. }\end{array}$ & $\begin{array}{l}\text {-Grain \#1 = separate grain in vicinity of many other } \\
\text { phases as described above. } \\
\text {-Grain } \# 2=\text { adjacent hessite in vicinity of other phases } \\
\text { as described above. } \\
\text {-Grain } \# 3=\text { part of composite grain } 20 \mu \mathrm{m} \text { long with } \\
\text { froodite \& nigglitite in vicinity of many other phases as } \\
\text { described above. } \\
\text {-Elsewhere associated with froodite. }\end{array}$ \\
\hline & $\begin{array}{l}\text { Froodite } \\
\mathrm{PdBi}_{2}\end{array}$ & 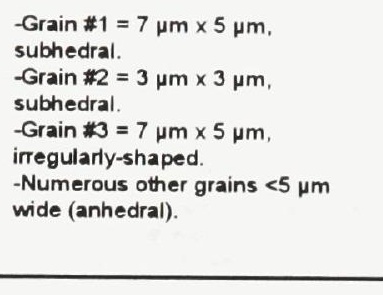 & $\begin{array}{l}\text {-Grain \#1 = adjacent subhedral unknown } \\
{[(P+, P d)(B i, T e)] \text {, in vicinity of many other phases as }} \\
\text { described above. } \\
\text {-Grain } \# 2=\text { in vicinity of many other phases as } \\
\text { described above. } \\
\text {-Grain } \# 3=\text { part of composite grain } 20 \mu m \text { long with } \\
\text { electrum \& nigglite in vicinity of many other phases as } \\
\text { described above. } \\
\text {-Froodite most common PGM of this sample. As } \\
\text { individual grains or associated with hessite \& electrum. }\end{array}$ \\
\hline & $\begin{array}{l}\text { Niggliite } \\
\text { PtSn }\end{array}$ & $-5 \mu \mathrm{m} \times 5 \mu \mathrm{m}$, subhedral. & $\begin{array}{l}\text {-Part of composite grain } 20 \mu \mathrm{m} \text { long with electrum \& } \\
\text { froodite in vicinity of many other phases as described } \\
\text { above. }\end{array}$ \\
\hline & $\begin{array}{l}\text { Sperrylite } \\
\text { PtAs, }\end{array}$ & $-4 \mu \mathrm{m} \times 4 \mu \mathrm{m}$, irregularly-shaped. & $\begin{array}{l}\text {-Individual grain with chalcopyrite in amphibole. } \\
\text {-In vicinity of many other phases as described above. }\end{array}$ \\
\hline \multirow[t]{3}{*}{ 23AOCO-INCOB } & $\begin{array}{l}\text { Hessite } \\
\mathrm{Ag}_{2} \mathrm{Te}\end{array}$ & $\begin{array}{l}\text {-Grain \#1 }=10 \mu \mathrm{m} \times 10 \mu \mathrm{m}, \\
\text { rounded. } \\
\text {-Grain } \# 2=5 \mu \mathrm{m} \times 3 \mu \mathrm{m} \text {, anhedral. } \\
\text {-Grain \#3=small }(<3 \mu \mathrm{m} \text { wide }) \\
\text { grain, anhedral. }\end{array}$ & $\begin{array}{l}\text {-Grain } \# 1=\text { in chalcopyrite, near unknown Bi-Te-S } \\
\text { phase } \& \text { a galena veinlet. } \\
\text {-Grain } \# 2=\text { isolated grain in chalcopyrite. } \\
\text {-Grain } \# 3=\text { adjacent Se-bearing galena in quartz with } \\
\text { nearby altaite ( } \mathrm{PbTe} \text { ). }\end{array}$ \\
\hline & $\begin{array}{l}\text { Unknown } \\
\text { BiTe, } S_{2}\end{array}$ & $\begin{array}{l}-15 \mu \mathrm{m} \times 15 \mu \mathrm{m} \text {, irregularly- } \\
\text { shaped. }\end{array}$ & -adjacent galena veinlet. \\
\hline & Native $\mathbf{A g}$ & $\begin{array}{l}-4 \text { grains, } 5 \mu \mathrm{m} \text { to } 10 \mu \mathrm{m} \text { long, in } \\
\text { cluster } 20 \mu \mathrm{m} \text { in diameter. }\end{array}$ & $\begin{array}{l}\text {-In epidote } \& \text { amphibole mass. } \\
\text {-Nearby galena. }\end{array}$ \\
\hline \multirow[t]{4}{*}{ 27AOCO-K1B } & $\begin{array}{l}\text { Composite Grain \#1 } \\
\text { (froodite + michenerite + } \\
\text { hessite + parkerite) }\end{array}$ & $-100 \mu \mathrm{m} \times 50 \mu \mathrm{m}$, rectangular. & $\begin{array}{l}\text {-At contact between blebby chalcopyrite } \& \text { epidote. } \\
\text {-Froodite most abundant phase, with michenerite } \& \\
\text { hessite. Parkerite is dominant rim phase. }\end{array}$ \\
\hline & $\begin{array}{l}\text { Composite Grain } \# 2 \\
\text { (froodite + sobolevskite + } \\
\text { hessite) }\end{array}$ & $\begin{array}{l}-100 \mu \mathrm{m} \times 80 \mu \mathrm{m} \text {, irregularly- } \\
\text { shaped. }\end{array}$ & $\begin{array}{l}\text {-In amphibole. } \\
\text { Sobolevskite most abundant phase with froodite \& } \\
\text { hessite. }\end{array}$ \\
\hline & $\begin{array}{l}\text { Froodite } \\
\mathrm{PdBi}_{2}\end{array}$ & $\begin{array}{l}\text {-Many grains, largest } 20 \mu \mathrm{m} \times 10 \\
\mu \mathrm{m}, \text { anhedral. }\end{array}$ & $\begin{array}{l}\text { Most commonly at contact between blebby } \\
\text { chalcopyrite \& amphibole. Rarely as part of thin veinlet } \\
\text { with hessite. }\end{array}$ \\
\hline & $\begin{array}{l}\text { Hessite } \\
\mathrm{Ag}_{2} \mathrm{Te}\end{array}$ & $\begin{array}{l}\text {-Numerous small ( }<5 \mu \mathrm{m} \text { wide), } \\
\text { anhedral grains. }\end{array}$ & $\begin{array}{l}\text {-at contact between blebby chalcopyrite } \& \text { amphibole, } \\
\text { or in amphibole. More rarely as part of thin veinlet with } \\
\text { froodite. }\end{array}$ \\
\hline
\end{tabular}


Table 5-5: Summary of precious metal and platinum-group mineralogy from McCreedy West Cu-rich stringers.

\begin{tabular}{|c|c|c|c|}
\hline Sample \# & Precious Metal Mineral & Size \& Shape & Host Mineralogy \& Texture \\
\hline \multirow[t]{3}{*}{ MWV-500-1 } & $\begin{array}{l}\text { Moncheite } \\
(\mathrm{Pt}, \mathrm{Pd})(\mathrm{Te}, \mathrm{Bi})_{2}\end{array}$ & $\begin{array}{l}\text {-Grain \#1=75 } \mu \mathrm{m} \times 70 \mu \mathrm{m} \text {, irregularly- } \\
\text { shaped. } \\
\text {-Grain } \# 2=10 \mu \mathrm{m} \times 12 \mu \mathrm{m} \text {, irregularly- } \\
\text { shaped. }\end{array}$ & $\begin{array}{l}\text {-Grain \#1 = in chalcopyrite. Partially } \\
\text { surrounded by, \& associated with, hessite. } \\
\text {-Grain } \# 2=\text { interstitial to surrounding epidote } \\
\text { grains. Nearby chalcopyrite \& hessite. }\end{array}$ \\
\hline & $\begin{array}{l}\text { Hessite } \\
\mathrm{Ag}_{2} \mathrm{Te}^{-}\end{array}$ & $\begin{array}{l}-100 \mu \mathrm{m} \text { long is largest, irregularly-shaped } \\
\text { grain. } \\
\text {-Numerous other smaller inclusions in } \\
\text { chalcopyrite, ranging from }<10 \mu \mathrm{m} \text { to } 100 \\
\mu \mathrm{m} \text { wide. }\end{array}$ & $\begin{array}{l}\text {-Most hessite in chalcopyrite, but may also } \\
\text { be hosted by epidote at edge of sulphide } \\
\text { blebs or veins. Where it occurs with } \\
\text { epidote, it is interstitial to rounded epidote } \\
\text { grains. }\end{array}$ \\
\hline & $\begin{array}{l}\text { Composite Grain } \\
\text { (michenerite + platinian } \\
\text { michenerite + hessite + } \\
\text { tellurohauchecornite) } \\
\end{array}$ & $\begin{array}{l}-350 \mu \mathrm{m} \times 150 \mu \mathrm{m} \text { (core is } 50 \mu \mathrm{m} \times 40 \mu \mathrm{m} \text {, } \\
\text { anhedral michenerite). }\end{array}$ & $\begin{array}{l}\text {-Core of composite grain is michenerite, } \\
\text { partially rimmed by platinian michenerite, } \\
\text { hessite \& tellurohauchecornite. }\end{array}$ \\
\hline \multirow[t]{8}{*}{ MW-600-1 } & $\begin{array}{l}\text { Composite Grain \#1 } \\
\text { (moncheite + hessite) }\end{array}$ & $-40 \mu \mathrm{m} \times 35 \mu \mathrm{m}$, rounded. & $\begin{array}{l}\text {-In chalcopyrite, with small, triangular } \\
\text { hessite grain attached. }\end{array}$ \\
\hline & $\begin{array}{l}\text { Composite Grain \#2 } \\
\text { (moncheite + hessite) }\end{array}$ & $-27 \mu \mathrm{m} \times 8 \mu \mathrm{m}$, elongate. & -In chalcopyrite. \\
\hline & $\begin{array}{l}\text { Composite Grain } \\
\text { (moncheite + hessite) }\end{array}$ & $\begin{array}{l}-45 \mu \mathrm{m} \times 30 \mu \mathrm{m} \text {, both moncheite \& hessite } \\
\text { subhedral. }\end{array}$ & -In chalcopyrite. \\
\hline & $\begin{array}{l}\text { Composite Grain } 4 \\
\text { (michenerite + moncheite + } \\
\mathrm{Bi}_{3}(\mathrm{Se}, \mathrm{Te}, \mathrm{S})_{4}\end{array}$ & $\begin{array}{l}\text {-composite grain }=140 \mu \mathrm{m} \times 55 \mu \mathrm{m} \text {, } \\
\text { irregularly-shaped. } \\
\text {-individual moncheite \& michenerite grains } \\
\text { up to } 50 \mu \mathrm{m} \times 50 \mu \mathrm{m} \text { in vicinity of composite } \\
\text { grain. }\end{array}$ & $\begin{array}{l}\text {-In mass of chlorite } \& \text { epidote with } \\
\text { chalcopyrite in vicinity. At edge of major } \\
\text { chalcopyrite-rich vein. }\end{array}$ \\
\hline & $\begin{array}{l}\text { Composite Grain } 45 \\
\text { (moncheite + hessite) }\end{array}$ & $-300 \mu \mathrm{m} \times 200 \mu \mathrm{m}$, irregularly-shaped. & $\begin{array}{l}\text {-Hosted by chalcopyrite, chlorite \& epidote. } \\
\text {-Moncheite more or less core of grain. } \\
\text { surrounded by hessite. }\end{array}$ \\
\hline & $\begin{array}{l}\text { Moncheite } \\
(\mathrm{Pt}, \mathrm{Pd})(\mathrm{Te}, \mathrm{Bi})_{2}\end{array}$ & $-22 \mu \mathrm{m} \times 8 \mu \mathrm{m}$, subhedral. & $\begin{array}{l}\text {-In chalcopyrite with nearby composite grain } \\
\text { of moncheite \& hessite. }\end{array}$ \\
\hline & $\begin{array}{l}\text { Hessite } \\
\mathrm{Ag}_{2} \mathrm{Te}\end{array}$ & -small grain ( $<5 \mu \mathrm{m}$ wide). & -In chalcopyrite. \\
\hline & $\begin{array}{l}\mathrm{Au}-\mathrm{Ag} \text { alloy } \\
(\mathrm{Au}, \mathrm{Ag})\end{array}$ & $-17 \mu \mathrm{m} \times 10 \mu \mathrm{m}$, irregularly-shaped. & $\begin{array}{l}\text {-Hosted mainly by chalcopyrite, at contact } \\
\text { with chlorite. }\end{array}$ \\
\hline \multirow[t]{4}{*}{ MW-950-LCu } & $\begin{array}{l}\text { Platinian michenerite } \\
\text { (Pd,Pt)BiTe }\end{array}$ & $\begin{array}{l}\text {-Numerous small ( }<5 \mu \mathrm{m} \text { wide) grains, } \\
\text { euhedral to rounded in shape. } \\
\text {-Grain } 1=\text { largest individual grain, } 8 \mu \mathrm{m} \times 3 \\
\mu \mathrm{m} \text {, anhedral. } \\
\text {-Grain } 2=45 \mu \mathrm{m} \times 30 \mu \mathrm{m} \text {, irregularly- } \\
\text { shaped, many small ( }<10 \mu \mathrm{m} \text { wide) grains } \\
\text { nearby. }\end{array}$ & $\begin{array}{l}\text {-Most small grains in chalcopyrite. } \\
\text {-Grain \#1 = hosted predominantly by } \\
\text { amphibole with chalcopyrite. Near } \\
\text { composite grain. } \\
\text {-Grain } \# 2 \text { = in chalcopyrite. }\end{array}$ \\
\hline & $\begin{array}{l}\text { Bismuthinite } \\
\mathrm{Bi}_{2} \mathrm{~S}_{3}\end{array}$ & Small grain $\sim 10 \mu \mathrm{m}$ wide, anhedral. & -In chalcopyrite. \\
\hline & $\begin{array}{l}\text { Pilsenite } \\
\mathrm{Bi}_{4} \mathrm{Te}\end{array}$ & $-49 \mu \mathrm{m} \times 14 \mu \mathrm{m}$, elongate. & -In chalcopyrite. \\
\hline & $\begin{array}{l}\text { Composite Grain } \\
\text { (platinian michenerite + unknown } \\
{\left[\mathrm{Bi},(\mathrm{Te}, \mathrm{Se})_{\theta} \mathrm{S}\right] \text { ?) }}\end{array}$ & $\begin{array}{l}-33 \mu \mathrm{m} \times 28 \mu \mathrm{m} . \\
- \text { Very small }(<3 \mu \mathrm{m} \text { wide) platinian } \\
\text { michenerite grains in vicinity, irregularly- } \\
\text { shaped. }\end{array}$ & $\begin{array}{l}\text {-Hosted by chalcopyrite \& amphibole. Grain } \\
\text { dominantly composed of platinian } \\
\text { michenerite with wedge-shaped unknown on } \\
1 \text { edge. } \\
\text { Small platinian michenerite grains in vannty } \\
\text { hosted by amphibole. }\end{array}$ \\
\hline
\end{tabular}


Table 5-6: Summary of precious metal and platinum-group mineralogy from the Longvack property.

\begin{tabular}{|c|c|c|c|}
\hline Sample \# & $\begin{array}{l}\text { Precious Metal } \\
\text { Mineral }\end{array}$ & Size \& Shape & 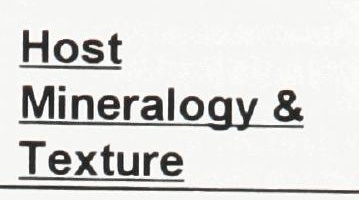 \\
\hline $\begin{array}{l}\text { CFL-012B } \\
\text { (No quantitative } \\
\text { analyses, but } \\
\text { compositions } \\
\text { verified by SEM- } \\
\text { EDS). }\end{array}$ & $\begin{array}{l}\text { Hessite } \\
\mathrm{Ag}_{2} \mathrm{Te}\end{array}$ & $\begin{array}{l}\text {-Small }(<5 \mu \mathrm{m} \\
\text { wide). }\end{array}$ & -In chalcopyrite. \\
\hline \multirow[t]{7}{*}{ CFL-048 } & $\begin{array}{l}\text { Unknown } \\
\mathrm{Bi}_{2} \mathrm{Te}_{2} \mathrm{~S}\end{array}$ & $\begin{array}{l}-8 \mu \mathrm{m} \times 4 \mu \mathrm{m}, \\
\text { anhedral. }\end{array}$ & -In pyrite. \\
\hline & Tsumoite-like & $\begin{array}{l}-12 \mu \mathrm{m} \times 3 \mu \mathrm{m}, \\
\text { elongate. }\end{array}$ & -In pyrite. \\
\hline & $\begin{array}{l}\text { Merenskyite } \\
(\mathrm{Pd}, \mathrm{Pt})(\mathrm{Te}, \mathrm{Bi})_{2}\end{array}$ & $\begin{array}{l}\text {-Grain \#1 = } 3 \mu \mathrm{m} \\
\times 1 \mu \mathrm{m} \text {, anhedral. } \\
\text {-Grain \#2=6 } 6 \mathrm{~m} \\
\times 3 \mu \mathrm{m} \text {, anhedral. }\end{array}$ & $\begin{array}{l}\text {-Grain \#1 = in } \\
\text { epidote at pyrite } \\
\text { grain margin. } \\
\text {-Grain \#2 = in } \\
\text { epidote. }\end{array}$ \\
\hline & Tsumoite-like & $\begin{array}{l}- \text { Small }(<3 \mu \mathrm{m} \\
\text { wide). }\end{array}$ & -In pyrite. \\
\hline & $\begin{array}{l}\text { Hessite } \\
\mathrm{Ag}_{2} \mathrm{Te}\end{array}$ & $\begin{array}{l}- \text { Small }(<5 \mu \mathrm{m} \\
\text { wide). }\end{array}$ & -In chalcopyrite. \\
\hline & Tsumoite-like & $\begin{array}{l}- \text { Small }(<3 \mu \mathrm{m} \\
\text { wide). }\end{array}$ & -In epidote. \\
\hline & Tsumoite-like & $\begin{array}{l}-8 \mu \mathrm{m} \times 3 \mu \mathrm{m} \text {, } \\
\text { irregularly- } \\
\text { shaped. }\end{array}$ & $\begin{array}{l}\text {-In epidote with } \\
\text { nearby millerite, } \\
\text { Ni-bearing pyrite } \\
\& \text { amphibole. }\end{array}$ \\
\hline
\end{tabular}


Table 5-7: Summary of precious metal and platinum-group mineralogy from the Fraser Mine Epidote Zone.

\begin{tabular}{|c|c|c|c|c|c|}
\hline$\underline{\mathrm{DDH} \#}$ & Sample & $\begin{array}{l}\text { Host } \\
\text { Lithology }\end{array}$ & Precious Metal Mineral & Size \& Shape & Host Mineralogy \& Texture \\
\hline \multirow[t]{2}{*}{ FR46-147 } & \multirow[t]{2}{*}{11} & \multirow[t]{2}{*}{ MAGZ } & $\begin{array}{l}\text { Hessite } \\
\mathrm{Ag}_{2} \mathrm{Te}\end{array}$ & $\begin{array}{l}- \text { Numerous small grains }(<10 \\
\mu \mathrm{m} \text { long). }\end{array}$ & $\begin{array}{l}\text {-In pyrite. May be associated } \\
\text { with unknown bismuth-tellurides } \\
\& \text { moncheite. }\end{array}$ \\
\hline & & & $\begin{array}{l}\text { Composite Grain } \\
\text { (moncheite + hessite) }\end{array}$ & $\begin{array}{l}\text { - Largest area of irregularly- } \\
\text { shaped moncheite \& hessite } \\
\text { intergrowth }=150 \mu \mathrm{m} \times 100 \\
\mu \mathrm{m} \text {. } \\
\text { - Largest hessite grain near } \\
\text { composite grain }=75 \mu \mathrm{m} \times 50 \\
\mu \mathrm{m} \text {. } \\
\text { - Numerous small grains ( }<10 \\
\mu \mathrm{m} \text { in diameter) of hessite with } \\
\text { minor bismuth-tellurides (not } \\
\text { quantitatively analyzed), \& rare } \\
\text { moncheite within } 300 \mu \mathrm{m} \text { of } \\
\text { composite grain. }\end{array}$ & $\begin{array}{l}\text {-Composite grain largely within } \\
\text { pyrite, along pyrite / magnetite } \\
\text { grain boundaries. Associated } \\
\text { hessite, moncheite \& Bi-Te } \\
\text { mineralization along pyrite / } \\
\text { pyrite, pyrite / magnetite \& pyrite } \\
\text { / pentlandite grain boundaries. } \\
\text {-Composite grain composed of } \\
\text { hessite host with elongate } \\
\text { intergrowths of moncheite. }\end{array}$ \\
\hline FR46-147 & 15 & MAGZ & $\begin{array}{l}\text { Hessite } \\
\mathrm{Ag}_{2} \mathrm{Te}\end{array}$ & $-5 \mu \mathrm{m} \times 4 \mu \mathrm{m}$, anhedral. & $\begin{array}{l}\text {-In pyrite. } \\
\text {-Other inclusions in pyrite include } \\
\text { pentlandite \& Se-bearing galena. }\end{array}$ \\
\hline FR46-150 & 4 & ACTZmag & $\begin{array}{l}\text { Palladian melonite } \\
(\mathrm{Ni}, \mathrm{Pd})(\mathrm{Te}, \mathrm{Bi})_{2}\end{array}$ & $-3 \mu \mathrm{m} \times 2 \mu \mathrm{m}$, subhedral. & $\begin{array}{l}\text {-At tip of extension of pentlandite } \\
\text { into mass of amphibole. }\end{array}$ \\
\hline \multirow[t]{2}{*}{ FR46-150 } & \multirow[t]{2}{*}{11} & \multirow[t]{2}{*}{ altered DNBX } & $\begin{array}{l}\text { Moncheite } \\
(\mathrm{Pt}, \mathrm{Pd})(\mathrm{Te}, \mathrm{Bi})_{2}\end{array}$ & $\begin{array}{l}\text {-Grain \#1 }=5.5 \mu \mathrm{m} \times 6 \mu \mathrm{m} \text {, } \\
\text { sub- to euhedral. } \\
\text {-Grain } \# 2=8 \mu \mathrm{m} \times 5 \mu \mathrm{m}, \\
\text { anhedral. }\end{array}$ & $\begin{array}{l}\text {-Grain } \# 1 \text { = at tip of extension of } \\
\text { pyrrhotite into mass of quartz. } \\
\text {-Grain } \# 2=\text { within pyrmotite at } \\
\text { contact with magnetite. }\end{array}$ \\
\hline & & & $\begin{array}{l}\text { Merenskyite } \\
(\mathrm{Pd}, \mathrm{Pt})(\mathrm{Te}, \mathrm{Bi})_{2}\end{array}$ & $\begin{array}{l}\text {-Grain \#1 }=5.5 \mu \mathrm{m} \times 5 \mu \mathrm{m} \text {, } \\
\text { anhedral. } \\
\text {-Grain \#2 }=3.5 \mu \mathrm{m} \times 3.5 \mu \mathrm{m} \text {, } \\
\text { subhedral. }\end{array}$ & $\begin{array}{l}\text {-Grain } \# 1 \text { = within pyrrhotite at } \\
\text { contact with magnetite. } \\
\text {-Grain } \# 2=\text { within pentlandite at } \\
\text { edge of hole in slide. }\end{array}$ \\
\hline \multirow[t]{2}{*}{ FR46-150 } & \multirow[t]{2}{*}{13} & \multirow[t]{2}{*}{ altered UMAF } & $\begin{array}{l}\text { Moncheite } \\
(\mathrm{Pt}, \mathrm{Pd})(\mathrm{Te}, \mathrm{Bi})_{2}\end{array}$ & $\begin{array}{l}\text {-cluster of grains, the largest } \\
\text { being } 32 \mu \mathrm{m} \times 15 \mu \mathrm{m} \text {, all } \\
\text { anhedral. }\end{array}$ & $\begin{array}{l}\text {-Grains commonly within } \\
\text { patches of irregularly-shaped } \\
\text { magnetite intergrown with } \\
\text { serpentine. A small number of } \\
\text { these grains are entirely within } \\
\text { serpentine. }\end{array}$ \\
\hline & & & $\begin{array}{l}\text { Merenskyite } \\
(\mathrm{Pd}, \mathrm{Pt})(\mathrm{Te}, \mathrm{Bi})_{2}\end{array}$ & $\begin{array}{l}-3 \text { elongate grains up to } 25 \mu \mathrm{m} \\
\text { long. }\end{array}$ & $\begin{array}{l}\text {-Grains within amphibole along } \\
\text { cleavage planes. Two of them } \\
\text { are at amphibole / pyrite contact. }\end{array}$ \\
\hline FR46-264 & 10 & EPDZmag & $\begin{array}{l}\text { Tsumoite } \\
\text { BiTe }\end{array}$ & $-8 \mu \mathrm{m} \times 3 \mu \mathrm{m}$, anhedral. & $\begin{array}{l}\text {-Horseshoe-shaped grain largely } \\
\text { within pentlandite at contact with } \\
\text { titanite. }\end{array}$ \\
\hline FR 46-287 & 6 & ACTZmag & $\begin{array}{l}\text { Moncheite } \\
(\mathrm{Pt}, \mathrm{Pd})(\mathrm{Te}, \mathrm{Bi})_{2}\end{array}$ & $\begin{array}{l}-15 \mu \mathrm{m} \times 7 \mu \mathrm{m} \text {, euhedral. } \\
\text { Several small ( }<3 \mu \mathrm{m} \text { in } \\
\text { diameter) moncheite grains } \\
\text { within } 35 \mu \mathrm{m} \text { of large euhedral } \\
\text { grain. }\end{array}$ & $\begin{array}{l}\text {-All grains are inclusions in } \\
\text { amphibole. Pentlandite } \& \text { pyrite } \\
\text { are the } 2 \text { nearest sulphides. }\end{array}$ \\
\hline \multirow[t]{2}{*}{ FR46-287 } & \multirow[t]{2}{*}{7} & \multirow[t]{2}{*}{$\begin{array}{l}\text { EPDZact to } \\
\text { ACTZ }\end{array}$} & $\begin{array}{l}\text { Moncheite } \\
(\mathrm{Pt}, \mathrm{Pd})(\mathrm{Te}, \mathrm{Bi})_{2}\end{array}$ & $\begin{array}{l}\text {-Grain } 1=15 \mu \mathrm{m} \times 10 \mu \mathrm{m}, \\
\text { irregularly-shaped. } \\
\text {-Grain } 2=10 \mu \mathrm{m} \times 10 \mu \mathrm{m}, \\
\text { subhedral. } \\
\text {-Grain } 3=10 \mu \mathrm{m} \times 10 \mu \mathrm{m}, \\
\text { sub- to euhedral. }\end{array}$ & $\begin{array}{l}\text {-Grain \#1 = at contact between } \\
\text { pyrite \& adjacent intergrowths of } \\
\text { calcite \& zoned amphibole. } \\
\text {-Grain } \# 2 \& \text { \& = inclusions } \\
\text { within subhedral pyrite with } \\
\text { abundant inclusions of Se- } \\
\text { bearing } \mathrm{PbS} \text { up to } 15 \mu \mathrm{m} \text { long. }\end{array}$ \\
\hline & & & $\begin{array}{l}\text { Platinian melonite } \\
(\mathrm{Ni}, \mathrm{Pt})(\mathrm{Te}, \mathrm{Bi})_{2}\end{array}$ & $<3 \mu \mathrm{m}$ wide, subhedral. & in pyrite. \\
\hline
\end{tabular}


Table 5-8: Epidote Zone alteration facies and associated sulphide, precious, trace, and alteration minerals.

\begin{tabular}{|c|c|c|}
\hline FACIES & $\begin{array}{l}\text { SULPHIDE \& } \\
\text { PRECIOUS METAL } \\
\text { MINERALS }\end{array}$ & $\begin{array}{l}\text { OTHER MINOR } \\
\text { ALTERATION } \\
\text { MINERALS }\end{array}$ \\
\hline $\begin{array}{l}\text { LGBXepdz }-<50 \% \\
\text { pervasive epidotization } \\
\text { of LGBX matrix. }\end{array}$ & $\begin{array}{l}\text { pyrrhotite } \\
\text { pyrite } \\
\text { chalcopyrite } \\
\text { pentlandite }\end{array}$ & $\begin{array}{l}\text { chlorite } \\
\text { amphibole } \\
\text { K-feldspar } \\
\text { albite }\end{array}$ \\
\hline $\begin{array}{l}\text { EPDZ - } 250 \% \text { pervasive } \\
\text { epidotization of original } \\
\text { LGBX matrix. }<10 \% \\
\text { amphibole. }\end{array}$ & $\begin{array}{l}\text { pyrite } \\
\text { pentlandite } \\
\text { rare chalcopyrite } \\
\text { rare moncheite } \\
\text { galena (inclusions in } \\
\text { pyrite) }\end{array}$ & $\begin{array}{l}\text { quartz } \\
\text { chlorite } \\
\text { stilpnomelane } \\
\text { titanite }\end{array}$ \\
\hline $\begin{array}{l}\text { EPDZact }-\geq 10 \% \text { to } \\
<50 \% \text { amphibole } \\
\text { occurring in matrix with } \\
\text { epidote. }>50 \% \text { epidote } \\
\text { remains. }\end{array}$ & rare platinian melonite & \\
\hline $\begin{array}{l}\text { ACTZ - } \geq 50 \% \\
\text { amphibole in matrix. } \\
<50 \% \text { epidote. }\end{array}$ & & \\
\hline $\begin{array}{l}\text { ACTZmag or } \\
\text { EPDZmag - } \geq 5 \% \text { to } \\
<20 \% \text { magnetite in } \\
\text { matrix with epidote \&/or } \\
\text { amphibole. }\end{array}$ & $\begin{array}{l}\text { pyrite (rare galena } \\
\text { inclusions) } \\
\text { pentlandite } \\
\text { moncheite } \\
\text { hessite } \\
\text { chalcopyrite } \\
\text { tsumoite }\end{array}$ & $\begin{array}{l}\text { titanite } \\
\text { calcite }\end{array}$ \\
\hline $\begin{array}{l}\text { MAGZ - } \geq 20 \% \\
\text { magnetite in matrix with } \\
\text { epidote \&/or amphibole. }\end{array}$ & palladian melonite & \\
\hline
\end{tabular}

* Modal proportions given in volume percent.

** Sulphide and precious metal minerals in bold type indicates most common (sulphides and precious metal minerals treated separately). 


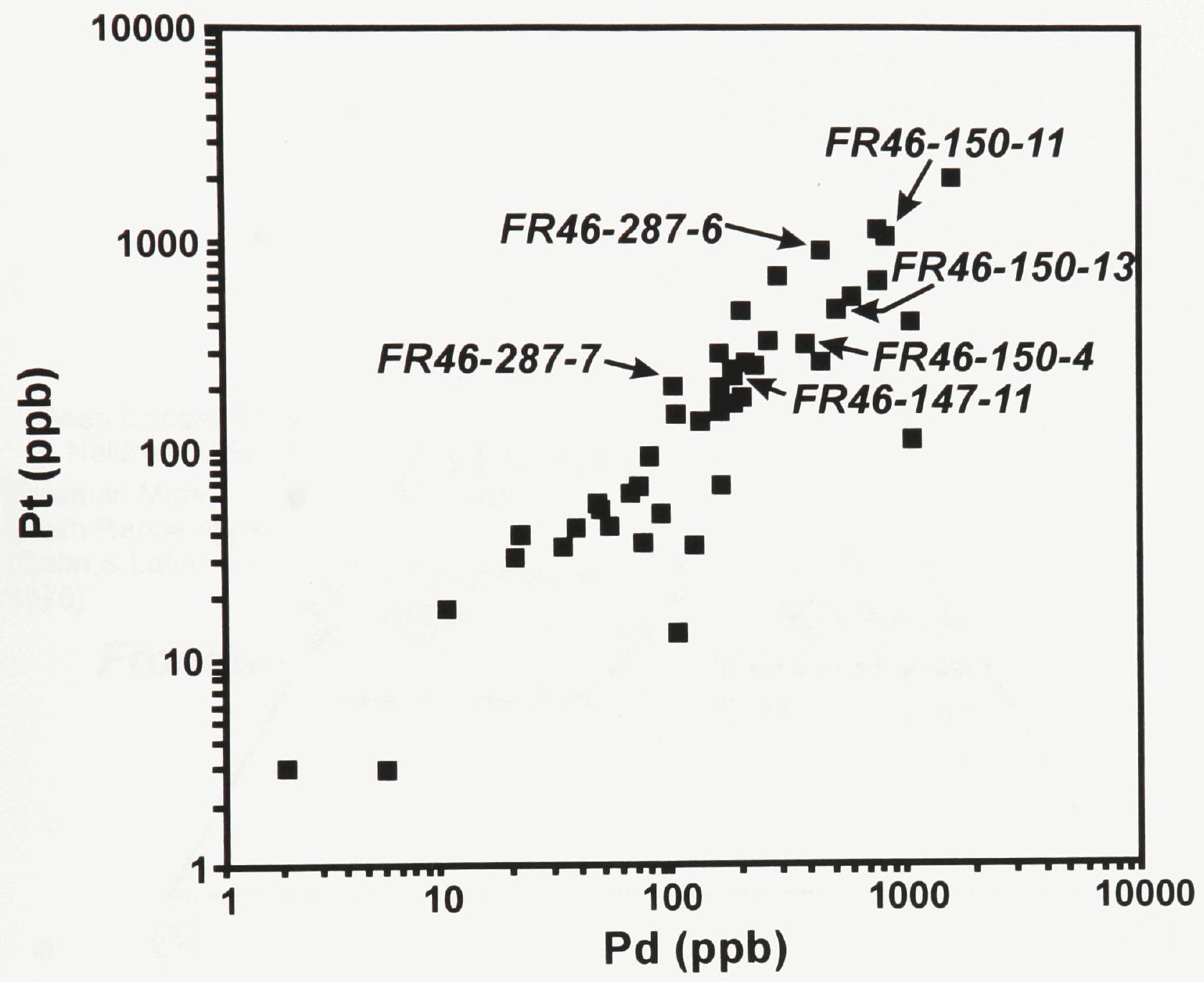

Figure 5-1: Pt vs. Pd plot for analyzed samples from the Epidote Zone. PGMbearing samples are identified and tend to occur in the top $50 \%$ of analyzed samples for total Pt and $\mathrm{Pd}$. 


\section{$\mathbf{P d}+\mathbf{P t}+\mathbf{N i}$}

Deep Copper Zone ( $\mathrm{Li}$ \& Naldrett, 1992; 1993a)

Coleman Mine, South Range mines (Cabri \& Laflamme, 1976)

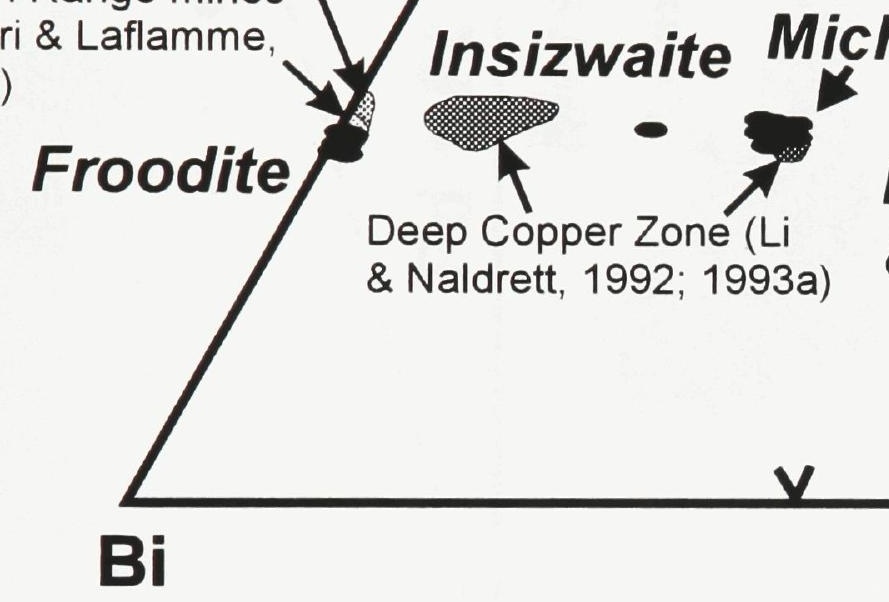

\section{Sobolevskite}

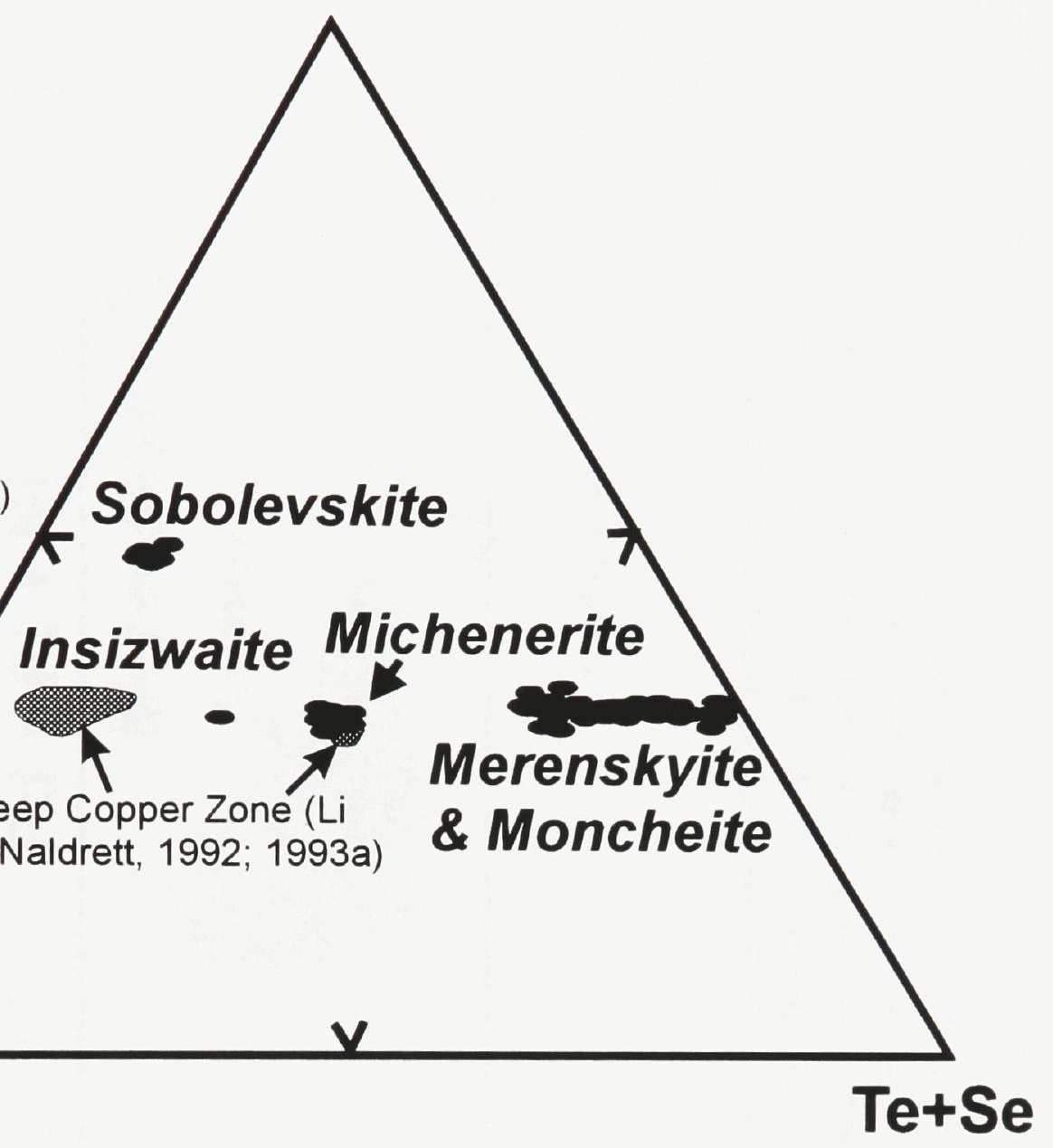

Figure 5-2: This $\mathrm{Bi}-(\mathrm{Pd}+\mathrm{Pd}+\mathrm{Ni})-(\mathrm{Te}+\mathrm{Se})$ ternary plot shows that froodite analyzed in this study is similar in composition to that reported from Deep Copper Zone (Li \& Naldrett, 1992; 1993a), Coleman Mine and several South Range mines (Cabri \& Laflamme, 1976). Copper Zone michenerite compositions are also similar to michenerite compositions reported from the Deep Copper Zone by Li \& Naldrett (1992; 1993a). Also shown are sobolevskite, merenskyite and moncheite compositions from this study. Plotted abundances are in atomic proportions. 


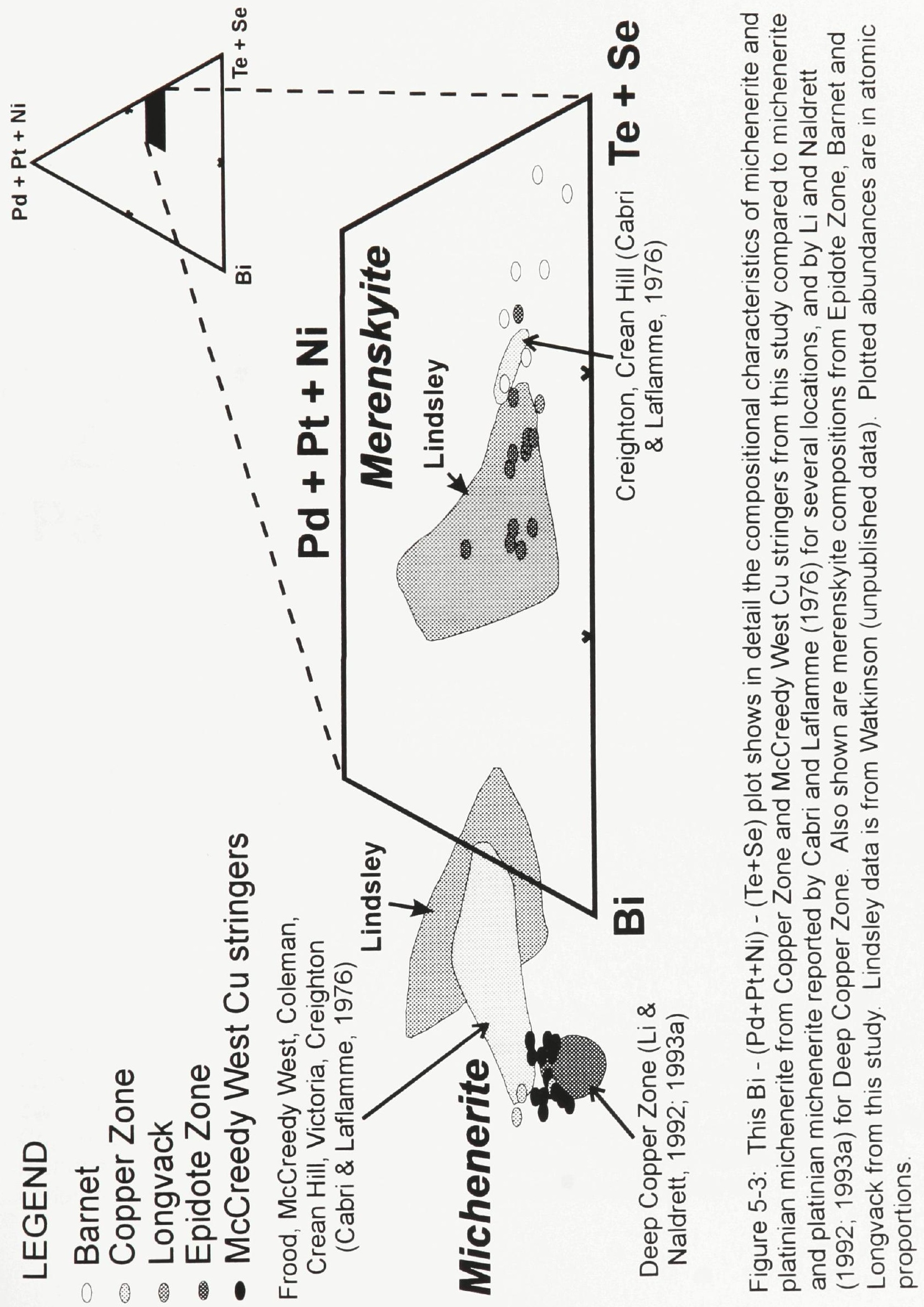




\section{$\mathrm{Ni}$}

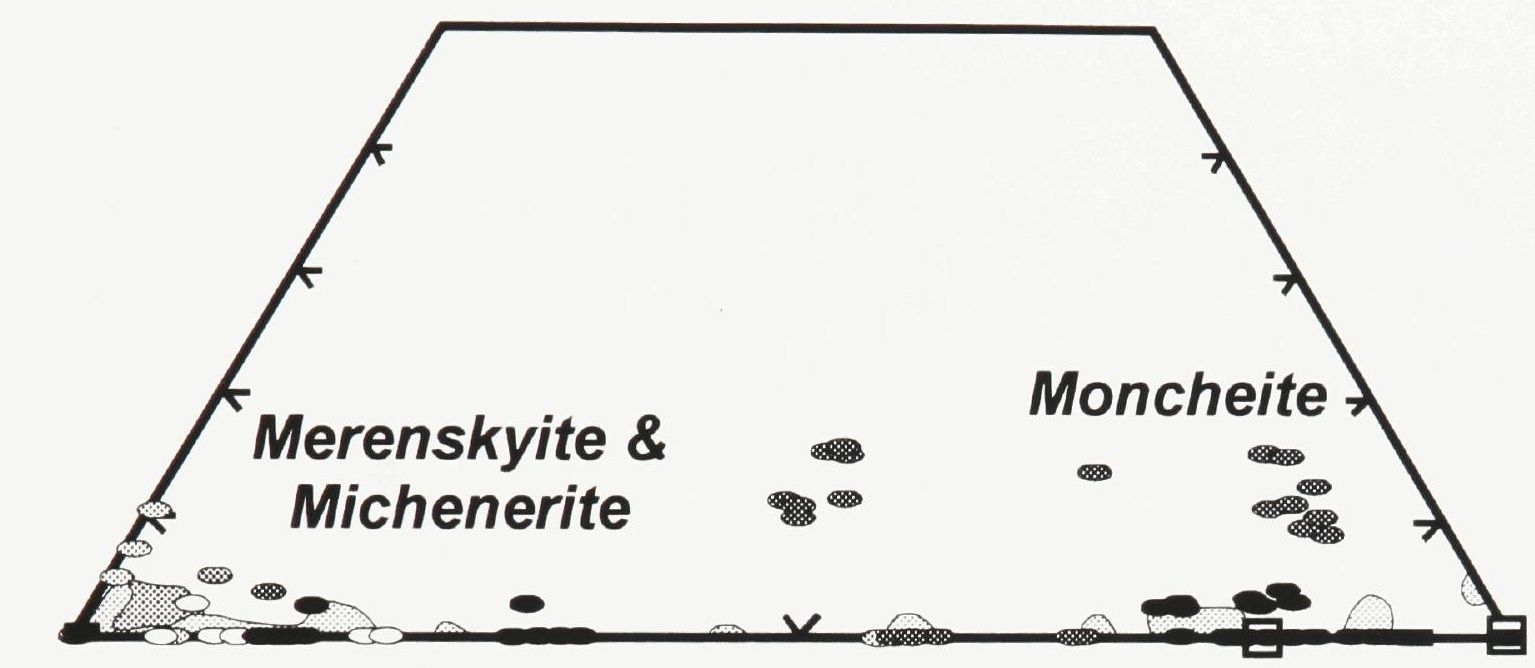

Pd

Pt

- Barnet

- Strathcona Mine Copper Zone

- Longvack

- Epidote Zone

- McCreedy West Cu-rich stringers

- Strathcona Mine Deep Copper Zone

$\square$ Springer (1989)

Cabri \& Laflamme (1976)

Lindsley

Figure 5-4: $\mathrm{Ni}-\mathrm{Pd}$ - Pt plot showing michenerite, merenskyite and moncheite compositions from this study compared to michenerite and merenskyite compositions from the Lindsley Mine (Watkinson, unpublished data), Deep Copper Zone "Moncheite" (Springer, 1989), and michenerite, merenskyite and moncheite compositions from a variety of Sudbury locations (Cabri and Laflamme, 1976). Plotted abundances are in atomic proportions. 


\section{LEGEND}

Strathcona Mine Deep

Copper Zone

Barnet

Longrack

Lindsley Mine

Creighton \& McCreedy West mines

(Cabri \& Laflamme, 1976)

- Epidote Zone

Strathcona Mine Deep

Copper Zone Moncheite

(Springer, 1989)

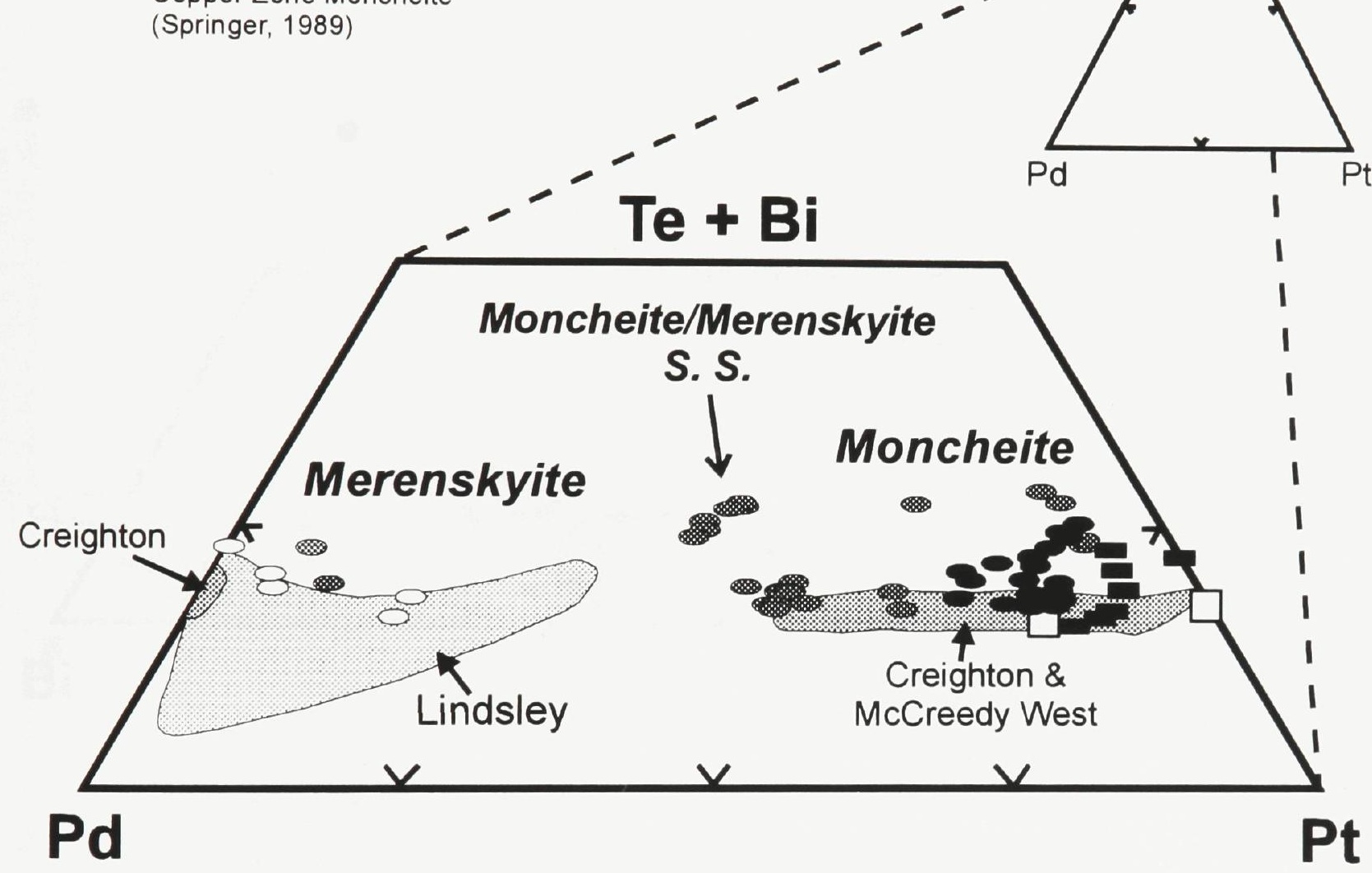

Figure 5-5: $\mathrm{Te}+\mathrm{Bi}-\mathrm{Pd}-\mathrm{Pt}$ ternary diagram of merenskyite, moncheite and merenskyite/moncheite solid solution compositions from this study compared to those from other Sudbury locations. Additional Strathcona Mine Deep Copper Zone "Moncheite" data from Springer (1989). Creighton Mine and additional McCreedy West Mine data from Cabri and Laflamme (1976). Lindsley Mine data from Watkinson (unpublished data). Plotted abundances are in atomic proportions. 


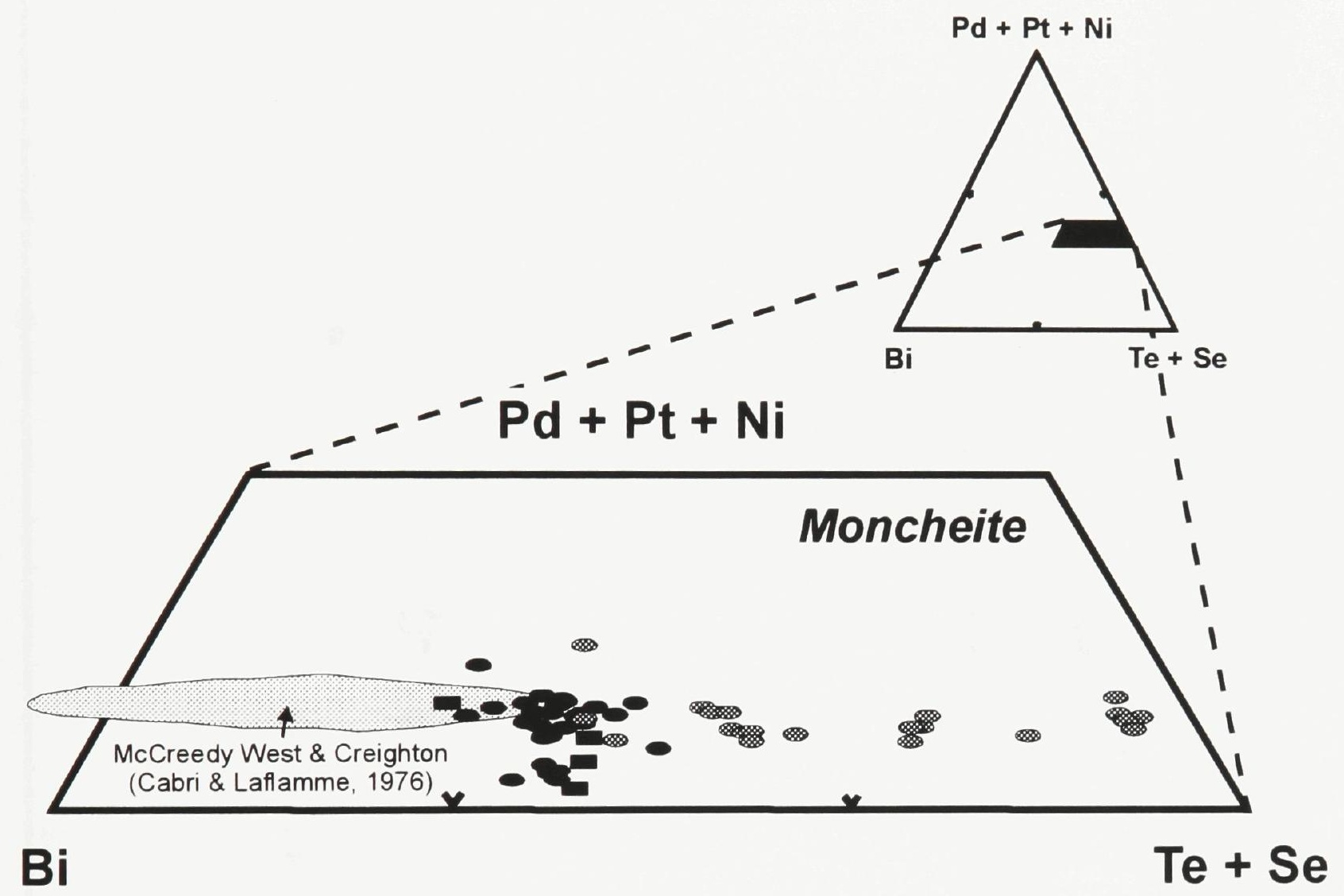

- Epidote Zone

- McCreedy West Cu-rich stringers

- Strathcona Mine Deep Copper Zone

Figure 5-6: $\mathrm{Bi}-\mathrm{Pd}+\mathrm{Pt}+\mathrm{Ni}-\mathrm{Te}+\mathrm{Se}$ diagram showing moncheite compositions from the Epidote Zone, McCreedy West Mine Cu-rich stringers and Strathcona Mine Deep Copper Zone compared to those from McCreedy West and Creighton mines reported by Cabri and Laflamme (1976). All data is in atomic proportions. 


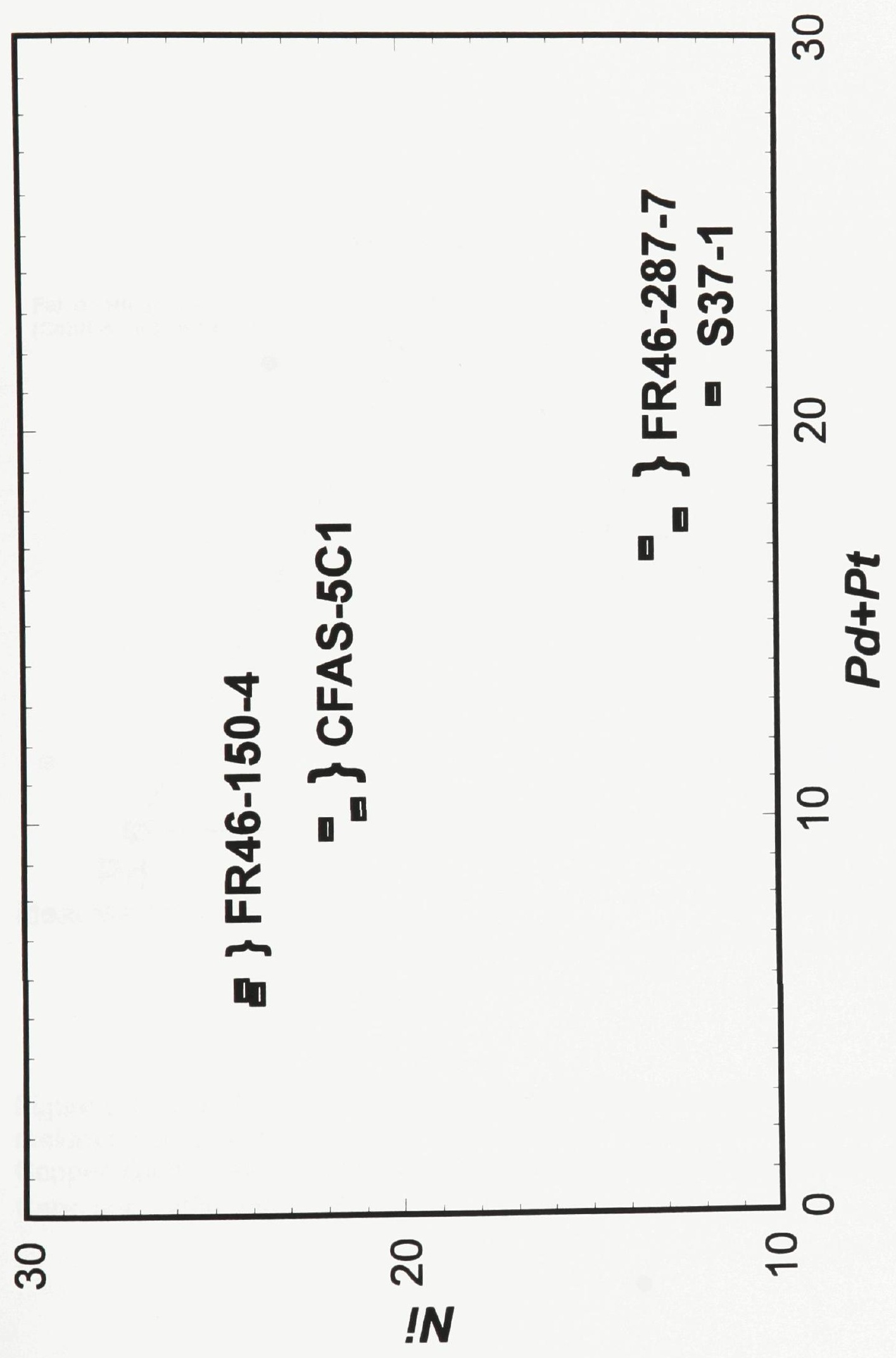

룽다

은

-

ธิ

듀

(亠)

둥로

등 둥

导吉吉

\%응

는 믐

물

$\Phi$ 는다

$\sum_{0} 0$

우

을 운

하은

으음

ธัธ

ब잉

市

品㝴

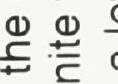

ज 은다

ठठ

क $\frac{1}{\sigma}$ क

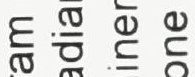

б을

뜸 ญำ

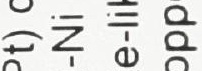

京亩

늘 웡

( हो 웡

$>$ 는

之吉的

w

ᄃ西

더웡

内



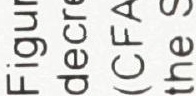




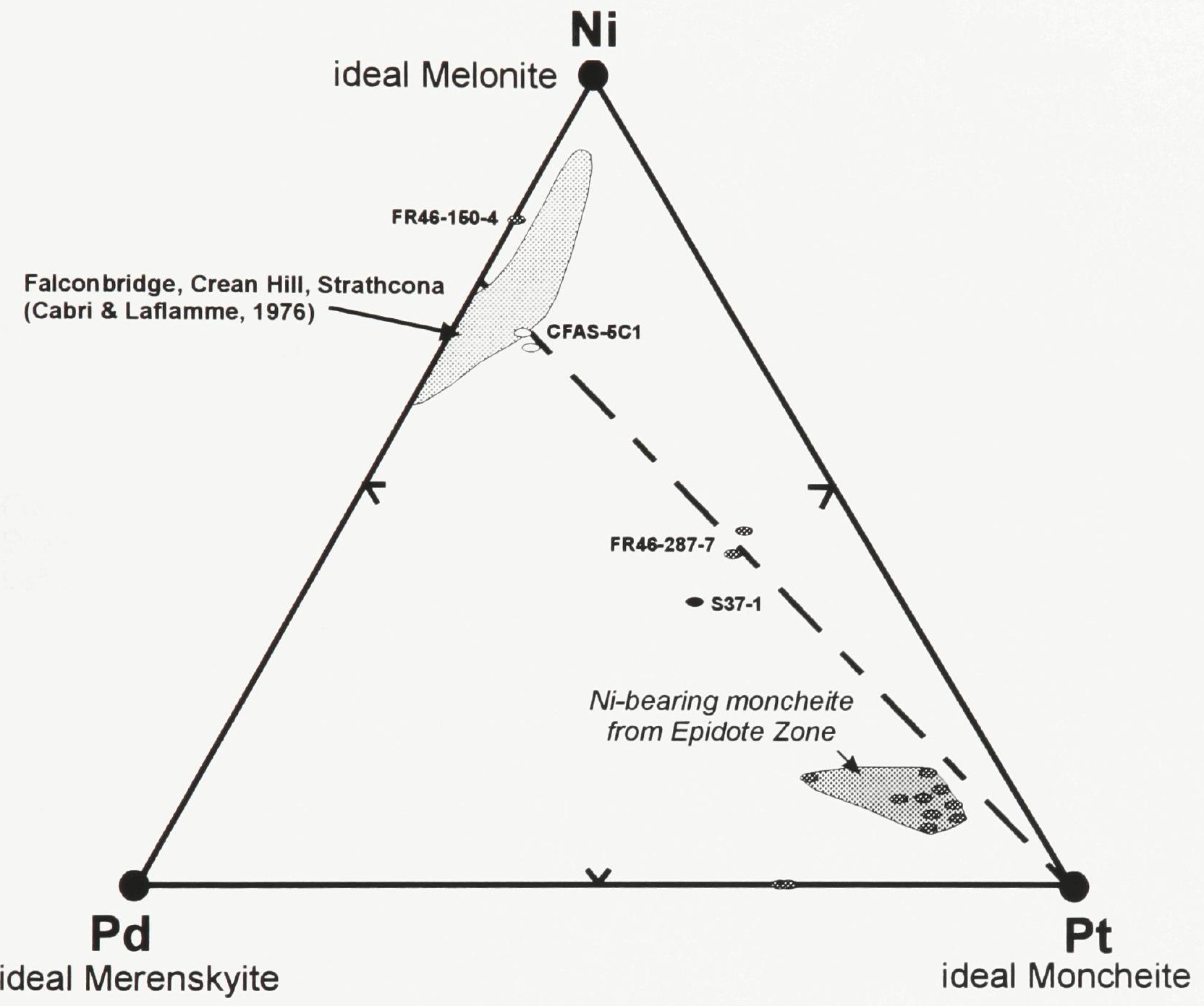

Figure 5-8: $\mathrm{Pd}-\mathrm{Ni}$ - Pt ternary diagram showing moncheite and palladian melonite compositions from the Epidote Zone, Barnet and Strathcona Mine Deep Copper Zone. Falconbridge, Crean Hill and additional Strathcona mine data from Cabri and Laflamme (1976). 


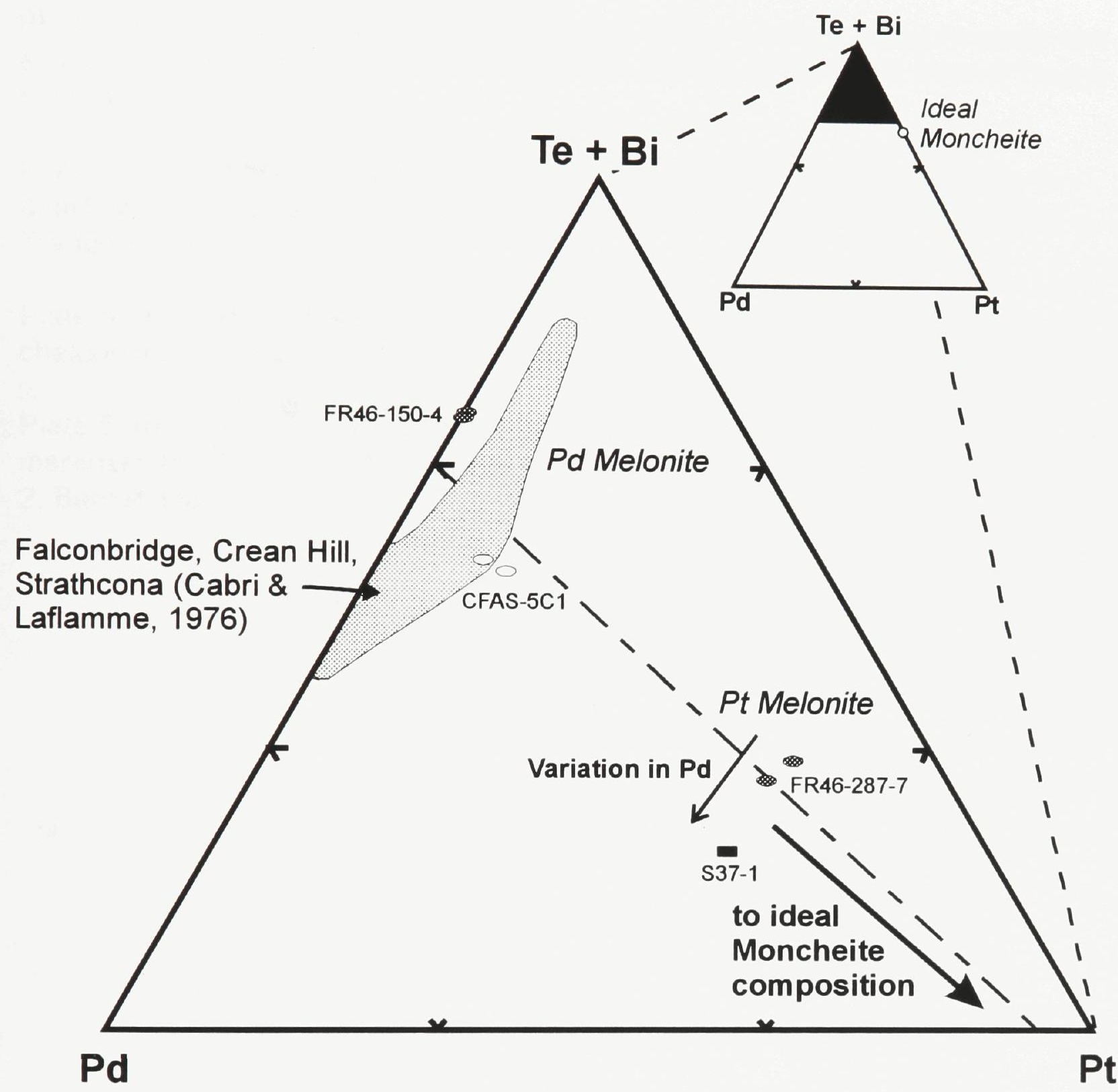

Figure 5-9: $\mathrm{Pd}-\mathrm{Te}+\mathrm{Bi}-\mathrm{Pt}$ ternary diagram showing palladian melonite and platinian melonite compositions from the Epidote Zone, Barnet and Strathcona Mine Deep Copper Zone. Falconbridge, Crean Hill and additional Strathcona mine data from Cabri and Laflamme (1976). 


\section{PLATE CAPTIONS}

Plate 5-1a: Colour-enhanced backscattered electron image of naumannite and associated chalcopyrite inclusions in pyrite. Sample CFA-016B, Barnet Trench Extension:

Plate 5-1b: Backscattered electron image of euhedral palladian melonite in quartz with nearby chalcopyrite and amphibole. Sample CFAS-5C1, Barnet Trench Extension.

Plate 5-1c: Backscattered electron image of euhedral merenskyite in chalcopyrite. Sample CFA-046, Barnet Trench Extension.

Plate 5-1d: Colour-enhanced backscattered electron image of hessite (left) and merenskyite (right) on either side of void space in chalcopyrite. Sample CFA-912, Barnet Trench \#2. 

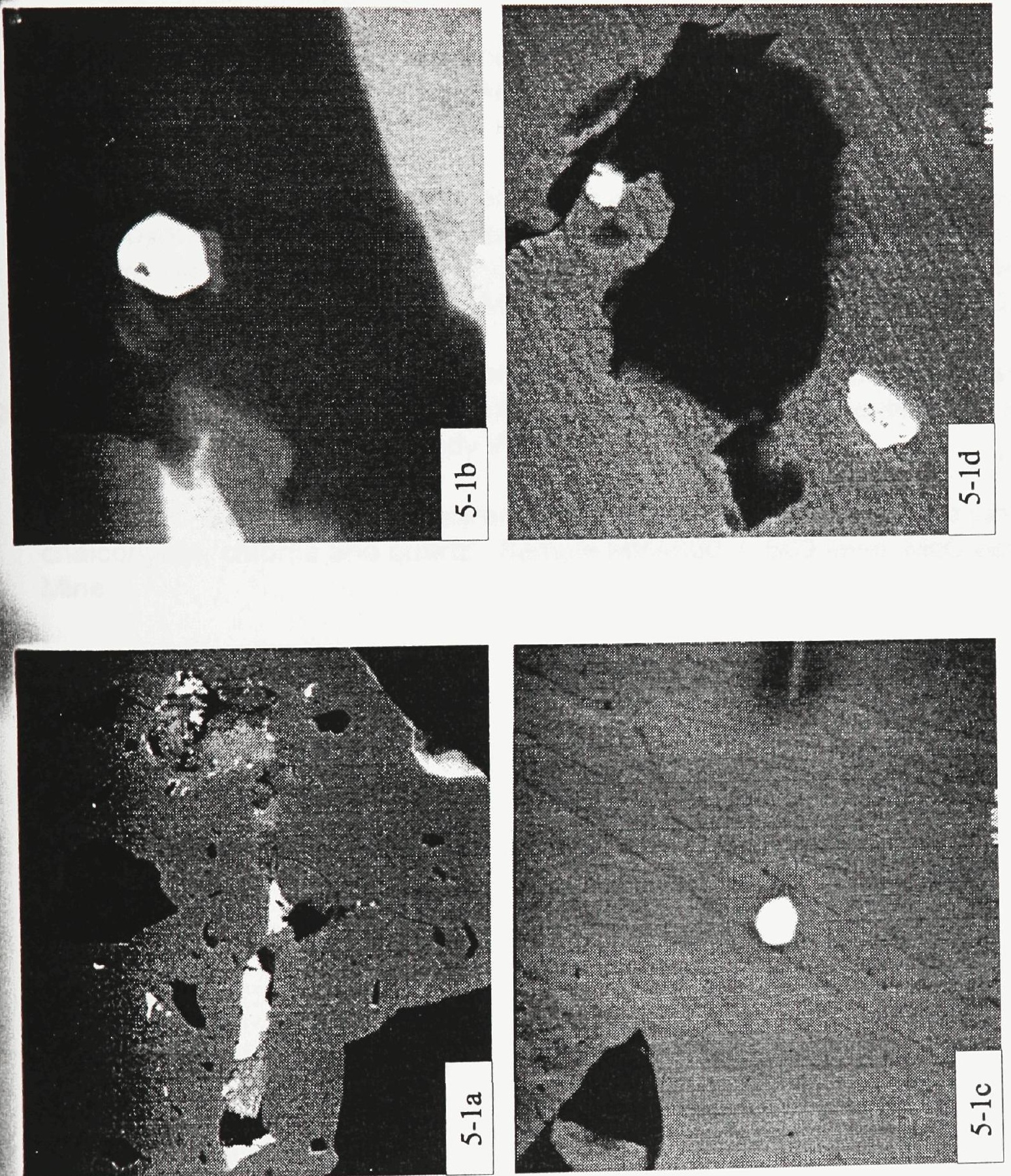


\section{PLATE CAPTIONS}

Plate 5-2a: Backscattered electron image of a large composite grain of froodite, michenerite, parkerite and hessite. Sample 27AOCO-K1B, 27AOCO stope, Strathcona Mine Copper Zone.

Plate 5-2b: Backscattered electron image of a composite grain of sobolevskite, froodite and hessite. Sample 27AOCO-K1B, K vein, 27AOCO stope, Strathcona Mine Copper Zone.

Plate 5-2c: Backscattered electron image of a concentration of PGM hosted by chalcopyrite, amphibole and epidote. Precious metal minerals include hessite, froodite, electrum, niggliite, sperrylite and an unknown insizwaite-like mineral. Sample 27AOCO-H1, H vein, 27AOCO stope, Strathcona Mine Copper Zone.

Plate 5-3a: Backscattered electron image of a composite grain of michenerite partially rimmed by hessite and tellurohauchecornite in a millerite host. Sample MW-500-1, 500 level, McCreedy West Mine.

Plate 5-3b: Backscattered electron image of an electrum grain at the junction of chalcopyrite, chlorite and quartz. Sample MW-600-1, 600 level, McCreedy West Mine. 

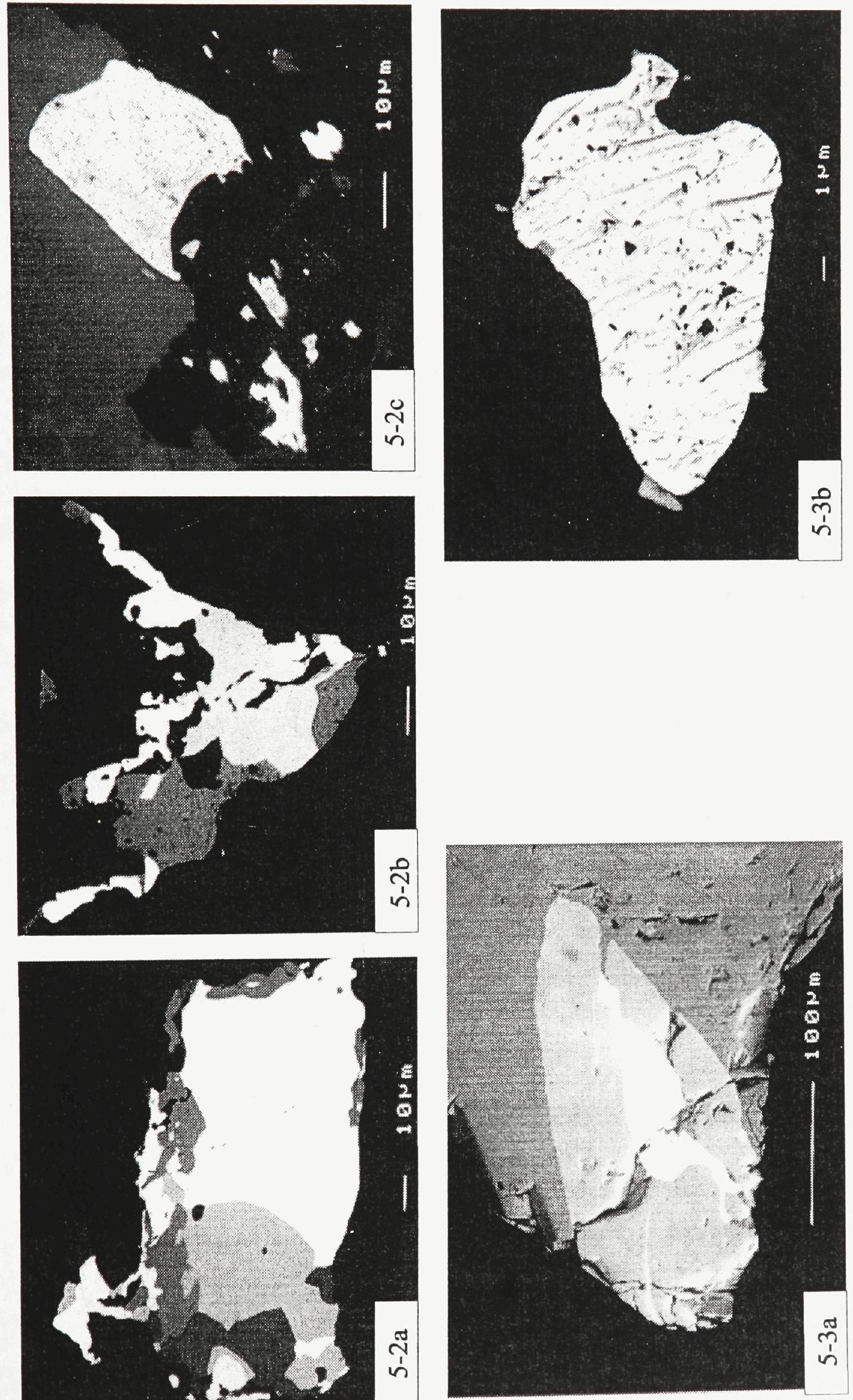


\section{PLATE CAPTIONS}

Plate 5-4a: Backscattered electron image of a moncheite and hessite intergrowth in host pyrite at contact with magnetite and pentlandite. MAGZ facies. Sample FR46-147-11, Fraser Mine Epidote Zone.

Plate 5-4b: Backscattered electron image of three moncheite grains in pyrite. EPDZact facies. Sample FR46-287-7, Fraser Mine Epidote Zone.

Plate 5-4c: Backscattered electron image of euhedral moncheite in amphibole with several smaller inclusions. Compositional domains in amphibole are visible. Pentlandite and pyrite are nearby sulphides. ACTZmag facies. Sample FR46287-6, Fraser Mine Epidote Zone.

Plate 5-4d: Backscattered electron image of a concentration of moncheite grains within irregularly-shaped magnetite and serpentine. Host rock is altered ultramafic. Sample FR46-150-13, Fraser Mine.

Plate 5-4e: Backscattered electron image of horseshoe-shaped tsumoite in pentlandite with titanite inclusions (black). EPDZmag facies. Sample FR46264-10, Fraser Mine Epidote Zone.

Plate 5-4f: Elongate merenskyite in amphibole along cleavage planes.

Surrounding sulphide is pyrite. Host rock is altered ultramafic. Sample FR46150-13, Fraser Mine Epidote Zone. 

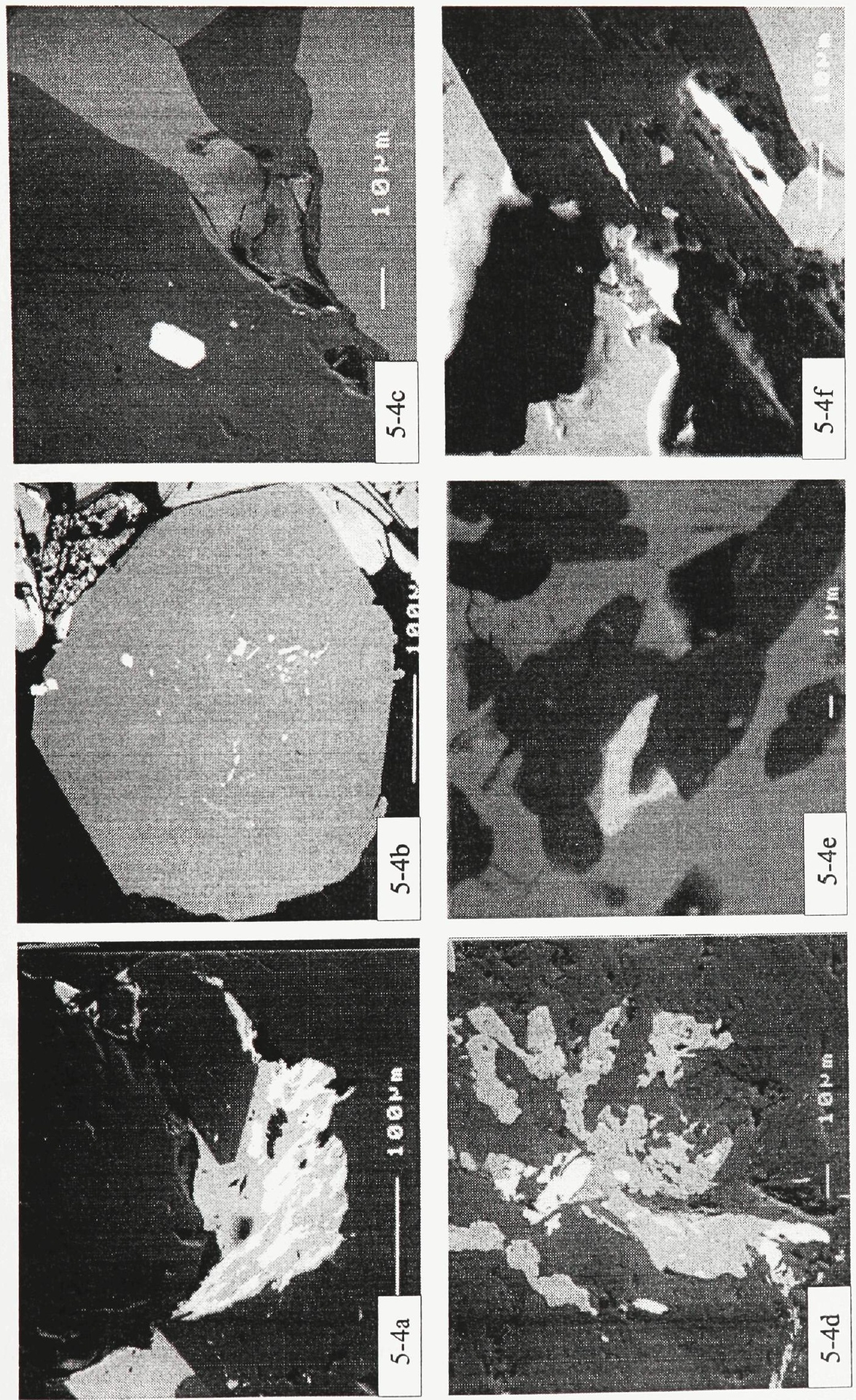


\section{CHAPTER 6: FLUID-INCLUSION STUDY}

\section{6-1. INTRODUCTION}

The origin of the contact deposits of the Sudbury area through liquid immiscibility of sulphide and silicate magmas is well established. Footwall Curich veining has been ascribed to fractionation of the original sulphide magma and segregation of a Cu-rich residuum into fractures in the footwall near the contact or as far away as hundreds of metres. However, part of the research for this thesis (Farrow and Watkinson;1992) sparked a new round of controversy surrounding the role of fluids in footwall orebody genesis by suggesting that $\mathrm{Ca}$ $\mathrm{Na}-\mathrm{Cl}-\mathrm{H}_{2} \mathrm{O}$ fluids were associated with footwall $\mathrm{Cu}-\mathrm{Ni}-\mathrm{PGE}$ mineralization. Several papers have since suggested that a residue of $\mathrm{Cu}$-rich magma was saturated with a relatively small amount of $\mathrm{Cl}$-rich, aqueous fluid that remobilized and refined precious metal abundances in discrete zones, most commonly at vein terminations (Li and Naldrett, 1993a; 1993d; Jago et al., 1994).

The close association of vein sulphides and alteration assemblages involving amphibole, chlorite and epidote with quartz and calcite suggests that the fluid inclusions within the quartz, other silicate minerals and calcite represent fluids similar to those that participated in CU-Ni-PGE transport and deposition. This study combines conventional, transparent mineral fluid inclusion techniques, including microthermometry and Raman spectrometry, with the development of a new technique for obtaining quantitative SEM-EDS analyses from daughter minerals and accidental phases in fluid inclusions in opaque 
sulphide minerals. It represents the first study of fluid inclusions associated with footwall Cu-Ni-PGE deposits by conventional techniques in the Sudbury area, and the first detailed study of fluid- inclusion daughter minerals in sulphides by SEM-EDS analysis anywhere.

Part of this study provided the data for two publications, Farrow and Watkinson (1992) and Farrow et al. (1994).

\section{6-2. PETROGRAPHY OF TRANSPARENT MINERALS}

Traditional fluid-inclusion techniques were confined to quartz occurring adjacent to Cu-rich sulphide veins in the Deep Copper Zone (Plate 6-1a), and Quartz \#2 in the centres of metasomatic, epidote-rich pods at Barnet (quartz, if present, is too small for traditional fluid-inclusion study on Cu-rich sulphide veins at Barnet). One sample from the Deep Copper Zone displays microstructures in quartz that indicate that it was deposited during or before minor deformation associated with nearby diabase dyke emplacement (i.e., sample S37-4) or movement along minor, localized faults.

The study of fluid inclusions from the "Epidote Zone" alteration is more limited since fluid inclusion-bearing quartz is not a significant part of the alteration assemblage in the most well developed alteration. Therefore, fluid inclusion analyses are limited to the margins of the epidote-rich parts of the alteration and epidote-rich veining.

The small size of fluid inclusions in amphibole and feldspar limited microthermometric measurements using these minerals. Only one measurement 
was made on a fluid inclusion in epidote. In quartz primary fluid inclusions occur individually, as clusters, or in variably developed planes of inclusions. In general it was impossible to distinguish between primary and pseudosecondary inclusions because the primary inclusion paragenesis is obscured by the large number of pseudosecondary inclusions trails. Because the optical extinction of crystal domains between fracture planes is sharp it is assumed that the later episodes of fracturing have not altered the previously-formed fluid inclusions away from the fracture planes. Secondary inclusions in later healed fractures or those showing obvious signs of necking-down were not measured and have been identified by their textural associations and unusual proportions of phase volumes.

Most examined fluid inclusions are saline and composed of two (liquid + vapour) and three phases (liquid + vapour + salt cube) at room temperature, although polyphase inclusions also occur (Table 6-1; Plates 6-1b, c and d). Some of these solid inclusions have been identified by laser Raman spectrometry as titanite (Appendix VII) and calcite, and others as amphibole and epidote by optical properties. Opaque phases are hematite and possibly sulphides. They are accidental inclusions rather than daughter minerals according to the criteria of Roedder (1984).

In most samples, fluid-inclusion size ranged from submicroscopic to approximately $30 \mu \mathrm{m}$ in their long dimensions, with most studied inclusions considerably less than $15 \mu \mathrm{m}$ in diameter. However, in one sample from the 
Deep Copper Zone (S37-1) rare individual fluid inclusions were $>80 \mu \mathrm{m}$ in length. Filling volumes in all samples are very consistent, with vapour volume ranging between 10 and $25 \%$ in both 2 and 3 phase inclusions, and salt cube volume ranging between 10 and $30 \%$. Single phase inclusions were analyzed by laser Raman spectroscopy and did not show spectra indicative of common gas phases, such as $\mathrm{CO}_{2}, \mathrm{CH}_{4}$, etc. In multi-phase inclusions, gas phases, such as $\mathrm{CO}_{2}$, have been sought by petrographic and microthermometric (clathrate formation) analyses in addition to laser Raman spectroscopy but have not been found.

Similar types of fluid inclusions to those described above exist in alteration minerals at McCreedy West and in both Epidote Zone (Plate 6-1e) and other "Epidote Zone"-like occurrences, including the intense epidote-rich alteration associated with sulphides on the East Range (Falconbridge's Capre Lake Property).

One sample from the Deep Copper Zone (S37-D5) contained 2 distinct fluid inclusion populations in separate trails, one typical of those saline, two and three phase, inclusions described above, and the other containing a round to elongate, non-birefringent solid (Plate 6-1f). Filling volumes of these unknown solids were commonly similar to those typical of salt cubes. SEM analyses have shown that these solids are indeed chlorides, commonly dominated by $\mathrm{NaCl}$ with less abundant $\mathrm{CaCl}_{2}$ (see section 6-4).

\section{6-3. MICROTHERMOMETRY}


Homogenization, eutectic and melting temperatures, and calculated total salinities in $\mathrm{NaCl}$ wt.\% equivalencies are summarized in Table 6-2.

Low temperature measurements were made by cooling the sample to -195 ${ }^{\circ} \mathrm{C}$. For typical saline fluid inclusions of this study observations of the onset of ice melting, identified by the rounding of euhedral ice crystals, dominantly range between -65 and $-18{ }^{\circ} \mathrm{C}$ (Figure 6-1). Final ice-melting temperatures are characteristically between -48 to $-1{ }^{\circ} \mathrm{C}$. Individual inclusions from all three deposits contain a phase, possibly hydrohalite or nahcolite, that exists metastably from 13 to $26{ }^{\circ} \mathrm{C}$. Marshall (1990) reported temperatures of approximately $15{ }^{\circ} \mathrm{C}$ for the disappearance of a metastable solid phase in threephase $\left(\mathrm{L}+\mathrm{V}+\mathrm{X}_{\text {Salt Cube }}\right), \mathrm{CaCl}_{2}$-bearing fluid inclusions from the Cobalt, Ontario area. The fact that both two and three phase inclusions display comparable freezing temperatures suggest that salt cubes have simply not nucleated in the two phase inclusions at room temperature as a result of their metastable behaviour.

Where possible, salinities were calculated from the temperature of disappearance of the salt cube. It was not possible to use freezing point depressions relative to the $\mathrm{NaCl}-\mathrm{H}_{2} \mathrm{O}$ eutectic for many of the studied inclusions because they were below $-20.8^{\circ} \mathrm{C}$.

Similarly, low ice-melting temperatures suggest that the fluid inclusions from each location may be modeled in the $\mathrm{H}_{2} \mathrm{O}-\mathrm{NaCl}-\mathrm{CaCl}_{2}$ system (Crawford, 1981; Vanko et al., 1988; Oakes et al., 1990), although metastable behaviour in 
the system $\mathrm{H}_{2} \mathrm{O}-\mathrm{NaCl}-\mathrm{MgCl}_{2}$ in inclusions $<30$ um in diameter can also account for these low temperatures (Davis et al., 1990). This is less likely responsible for the observed trends due to the Ca-rich nature of the fluids as exhibited by the nature of the alteration assemblages associated with the mineralization, and has been proven by SEM-EDS analyses of daughter mineral chlorides. However, the relatively small size of most of the inclusions studied ( $<15 \mu \mathrm{m}$ in diameter) probably was very important in contributing to the metastability of these inclusions, especially in light of the fact that the salt system was very $\mathrm{Cl}$-rich and $\mathrm{CaCl}_{2}$-bearing. Metastability, common in the $\mathrm{H}_{2} \mathrm{O}-\mathrm{NaCl}-\mathrm{CaCl}_{2}$ system (Vanko et al., 1988; Roedder, 1984), rendered the acquisition of low-temperature microthermometric data difficult to impossible in this study. Similar low temperature metastability of Deep Copper Zone fluid inclusions has been reported by Li and Naldrett (1993d). Upon heating to approximately -80 to $-65^{\circ} \mathrm{C}$ the fluid inclusions that do display phase changes at low temperatures turn brownish. Marshall (1990) attributed this behaviour to either the onset of melting just below the $\mathrm{H}_{2} \mathrm{O}-\mathrm{NaCl}-\mathrm{CaCl}_{2}$ eutectic or to the refraction of light from cracks in the ice, antarcticite $\left(\mathrm{CaCl}_{2} \cdot 6 \mathrm{H}_{2} \mathrm{O}\right)$, hydrohalite $\left(\mathrm{NaCl} \cdot 2 \mathrm{H}_{2} \mathrm{O}\right)$ and metastable halite within the fluid inclusion that result from the differing thermal expansions of the variety of salt minerals within the fluid inclusion.

Although daughter mineral studies in both quartz and sulphide minerals (Section 6-4) indicate that although $\mathrm{CaCl}_{2}$ and $\mathrm{NaCl}$ are the dominant chlorides, modelling in the system $\mathrm{CaCl}_{2}-\mathrm{NaCl}-\mathrm{H}_{2} \mathrm{O}$ may be simplistic because the fluids 
also contained abundant $\mathrm{Fe}, \mathrm{Pb}, \mathrm{Ba}$, etc. No experimental data exist to provide phase relationship information on such a wide range of components in an aqueous system.

Upon heating, final homogenization for both vapour- and salt cubebearing inclusions was to liquid. In $>65 \%$ of the inclusions the homogenization of the vapour to liquid preceded the melting of halite. Higher vapour homogenization temperatures may result from post-trapping volume changes that are difficult to recognize petrographically or from phase ratios at room temperature. For each of the deposits, data from inclusions with salt cubes and those without has been analyzed separately, despite the fact that the range of vapour homogenization temperatures overlap (Figures 6-2, 6-3 and 6-4).

Farrow and Watkinson (1992) suggested, on the basis of fluid inclusion microthermometric data, that a temperature gradient existed from the Epidote Zone through Barnet to the Deep Copper Zone. It corresponded to the distance from the SIC contact, with the lowest temperatures, and correspondingly lowest isochore temperatures (between 175 and $280^{\circ} \mathrm{C}$ ) being associated with the Deep Copper Zone. However, additional data from the Deep Copper Zone have shown that homogenization temperatures vary widely from sample to sample, with representatives from high temperature $\left(240\right.$ to $\left.410^{\circ} \mathrm{C}\right)$ and low temperature (100 to $250^{\circ} \mathrm{C}$ ) vapour homogenization and salt cube melting temperatures (Figures $6-2 a$ and $b$ ). This suggests that different periods of quartz deposition from different fluids existed. The high temperature samples are petrographically 
different from the low temperature samples. One (S39-K64B) is fine- to mediumgrained quartz in weakly altered host SDBX adjacent to a chalcopyrite vein. The studied quartz appears to be part of a period of pre-ore alteration. The other (S37-D5) is quartz that is contemporaneous with chalcopyrite, but is part of a much later quartz + amphibole + chalcopyrite remobilization along a post-ore structure. The range in vapour homogenization temperatures in this sample (up to $511^{\circ} \mathrm{C}$ ) is likely the result of post-entrapment leakage due to late movement along the structure. The lower-temperature samples (S37-1 and S42-B2) are subhedral quartz hosted by chalcopyrite and millerite, and are most closely related to the sulphide-deposition event. An even lower temperature, liquid-rich, secondary population (G-2; Tables 6-1 and 6-2) has also been identified in sample S37-1, with vapour homogenization temperatures of less than $130^{\circ} \mathrm{C}$. Another sample (S37-4), adjacent to the NW-trending diabase dyke that cuts 3700 level, displays vapour homogenization temperatures of between 197.7 and $309.4^{\circ} \mathrm{C}$.

Vapour phase homogenization temperatures from the Barnet Property cluster between 155 and $220^{\circ} \mathrm{C}$ (Figure 6-3). The studied quartz from Barnet is part of the pre-ore metasomatic event, since no adequate alteration quartz associated directly with chalcopyrite mineralization was available for study. This quartz was not associated with K-feldspar as granophyric intergrowths, but was a much later stage, and probably lower temperature, infilling of epidote-rich structures. 
Vapour homogenization temperatures for Epidote Zone fluid inclusions cluster between 160 and $270{ }^{\circ} \mathrm{C}$ (Figure 6-4).

\section{6-3a. ISOCHORES}

Isochores for the fluid have been established using average values and standard deviations from each deposit in conjunction with the data of Zhang \& Frantz (1987). A rough estimation of the depth of ore formation in the North Range at 3 to $8 \mathrm{~km}$ was proposed by Souch et al. (1969) and Hoffman et al. (1979). Assuming rock density to be approximately $3.0 \mathrm{~g} / \mathrm{cm}^{3}$, lithostatic pressures are calculated as being in the range of 90 to $240 \mathrm{MPa}$. The resulting range in calculated temperatures is 206 to $352{ }^{\circ} \mathrm{C}$ for the Epidote Zone, 163 to $320^{\circ} \mathrm{C}$ for the Barnet property, 154 to $435^{\circ} \mathrm{C}$ for the high temperature Deep Copper Zone samples, and 130 to $294^{\circ} \mathrm{C}$ for the low temperature Deep Copper Zone samples.

Although Barnet property fluid inclusions cannot be used to establish the temperature gradient of Farrow and Watkinson (1992), the low temperature Deep Copper Zone population and those from the Epidote Zone still define it.

Salinities calculated using the same data are similar for each deposit and range from 21 to $40 \mathrm{NaCl}$ wt. \% equivalent. However, these calculated salinities are minimums due to the uncertainty of numerous components in addition to the $\mathrm{NaCl}-\mathrm{CaCl}_{2}-\mathrm{H}_{2} \mathrm{O}$. Li and Naldrett (1993d) have reported calculated salinities, based on the same system, of fluid inclusions from the Deep Copper Zone of up to $60 \mathrm{NaCl}$ wt. \% equivalent. 


\section{6-3b. DISCUSSION OF TRADITIONAL METHODS}

Temperatures estimated using the data of Zhang and Frantz (1987) for the system $\mathrm{H}_{2} \mathrm{O}-\mathrm{NaCl}-\mathrm{CaCl}_{2}$ appear to be low in light of the range of temperatures of formation suggested by the alteration mineral assemblage for both $\mathrm{Cu}$-rich vein and Epidote Zone alteration. This is a result of the fact that the Zhang and Frantz (1987) equation of state has been optimized to fluid densities in the range 0.5 to $0.9 \mathrm{~g} / \mathrm{cm}^{3}$; calculated densities for the fluids of this study are greater than $1.1 \mathrm{~g} / \mathrm{cm}^{3}$.

The estimated temperature of formation of the Epidote Zone and Cu-rich vein alteration is approximately $300{ }^{\circ} \mathrm{C}$. This coincides with the intermediatetemperature $\left(200\right.$ to $\left.700{ }^{\circ} \mathrm{C}\right)$ PGE deposit subdivision proposed by Nyman et al. (1990); however, the structural settings at Sudbury are not related to the suggested example of shearing and metamorphism of mafic and ultramafic rocks at the New Rambler (Loucks, 1976; McCallum et al., 1976; Nyman et al., 1990). and Rathbun Lake (Rowell and Edgar, 1986) deposits. Table 6-3 provides a summary of some of the available data on fluid inclusions from a variety of $\mathrm{Cu}$ Ni-PGE deposits. The Sudbury North Range deposits of this study contain fluid inclusions of similar to more saline composition than many of these examples. The high-temperature deposits such as the Bushveld and Lac-des-Iles are considered to be the result of transport of PGE and associated metals by $\mathrm{Cl}$-rich fluids during late-stage magmatic-hydrothermal processes (Ballhaus and Stumpfl, 1986; Johan and Watkinson, 1987; Tellier et al., 1991). Because of the 
lack of New Rambler-type shearing and metamorphism and the relationship of the North Range alteration to the cooling Sudbury Igneous Complex hydrothermal system, the deposits of this study are likely the result of late-stage hydrothermal activity similar to the middle stage veins of the Bushveld hydrothermal system (Schiffries and Skinner, 1987).

\section{6-4. SEM-EDS ANALYSES}

A new technique for studying and comparing daughter minerals and accidental phases in fluid inclusions in opaque ore minerals has been developed as part of this study and form the basis for a publication (Farrow et al., 1994).

The details of the analytical techniques and technique development are outlined in Appendix VII.

\section{6-4a. INTRODUCTION}

Because most of the data pertinent to the hydrothermal aspects of Sudbury footwall genesis have been collected from silicate and carbonate alteration minerals, it was decided to search for evidence of the nature of fluid inclusions within the sulphide minerals themselves using the scanning electron microscope (SEM). The identification of fluid inclusions within footwall sulphides and the knowledge of distinguishing features of fluid inclusions in sulphide minerals from different deposits is especially instructive where transparent alteration minerals do not exist, where the origin of the transparent minerals is equivocal, or where they cannot be used for conventional fluid inclusion study. Furthermore, infrared fluid inclusion microthermometry on coexisting wolframite, 
cassiterite and quartz has shown that coexisting gangue and opaque ore minerals do not always give the same thermometric measurements (Moore and Moore, 1979; Campbell and Robinson-Cook, 1987). Methods of SEM study were similar to those used for transparent fluid inclusion minerals (cf. Metzger et al., 1975; 1977; LeBel, 1976; 1980; Nesbitt and Kelly, 1977; Hallbauer and Kable, 1982; London et al., 1982; Anthony et al., 1983; 1984; Roedder, 1984; Reynolds and Beane, 1985; Marshall, 1990) with adaptations made for the cryosystem equipment available (Kelly and Burgio, 1983; Ayora and Fontarnau, 1990; Griffin, 1990).

This study is the first description of primary fluid inclusions in sulphide minerals with quantitative analyses of daughter phases, and further illustrates the importance of $\mathrm{Cl}$-rich fluids on Cu-Ni-PGE deposition in some deposits of the Sudbury area (Plates 6-2a, b, c, d, e and f). Assemblages of fluid inclusion daughter minerals and accidental inclusions are identified as characteristic of host mineral composition and of specific deposits. South Range deposits (Lindsley and Little Stobie) are included in the comparison to highlight these results. They suggest that fluids of chemically complex salt solutions existed at the time of formation of these footwall deposits.

\section{6-4b. SEMI-QUANTITATIVE AND QUANTITATIVE SEM-EDS RESULTS}

Due to the small size of the inclusions and their associated daughter minerals, spectra of complex chloride mixtures were obtained. However, 
whether they represent adjacent individual minerals or complicated substitutions, the detected elements existed in the fluid during deposition of the host mineral.

Quantitative SEM-EDS analytical results are tabled in Appendix VII, and show that in almost all cases the $\Sigma$ cation/Cl ratio was slightly greater than the stoichiometric value (1.0 or 0.5$)$, a result of $\mathrm{Cl}$ volatility that occurs even at very low $\left(<180^{\circ} \mathrm{C}\right)$ temperature (Marshall, 1977; Quinton, 1978; Ayora and Fontarnau, 1990). Ayora and Fontarnau (1990) recommended that areas of $>4$ $\mu \mathrm{m}^{2}$ be rastered with the electron beam to more safely preserve the concentrations of most elements. The best $\sum$ cation $/ \mathrm{Cl}$ ratio for $\mathrm{CaCl}_{2}$ was obtained by rastering on an area of precipitate adjacent to an open fluid inclusion in quartz from the Deep Copper Zone (sample S37-1), although the analytical total was poor (21.21 wt.\%). However, because of the small size of the fluid inclusions $(<20 \mu \mathrm{m})$ and their daughter minerals $(<5 \mu \mathrm{m})$, rastering was seldom possible. Because $\mathrm{NaCl}$ cubes, where they existed, commonly were the largest daughter minerals, results were the most reproducible due to low levels of interference from adjacent or host minerals. The lowest $\Sigma$ cation $/ \mathrm{Cl}$ ratios for $\mathrm{CaCl}_{2}, \mathrm{PbCl}_{2}$ and $\mathrm{BaCl}_{2}$ (Lindsley) using a stationary beam were $0.60,0.54$ and 0.61 respectively. The analysis of some very large $(>10 \mu \mathrm{m})$ cotunnite $\left(\mathrm{PbCl}_{2}\right)$ crystals from the Barnet property exhibit excellent ratios. Possible contaminants or substitutions that are commonly included in cotunnite are $\mathrm{K}, \mathrm{Fe}, \mathrm{Mn}, \mathrm{Cu}$ and Na. Common contaminants in $\mathrm{BaCl}_{2}$ are $\mathrm{Na}, \mathrm{Ca}$ and $\mathrm{K}$, and in $\mathrm{CaCl}_{2}$ are $\mathrm{Na}, \mathrm{K}$ and more rarely a broad variety of other elements. Potassium-dominated 
chloride analyses reveal complex mixtures that commonly contain $\mathrm{Pb}, \mathrm{Mn}$ and Ba. These contaminant elements may be contributions from adjacent crystals, the host mineral, or attached phases too small to be resolved in the SEM image. However, the strong association of $\mathrm{Pb}$ - and $\mathrm{K}$ - chlorides in chalcopyrite from Barnet and Deep Copper Zone suggest that there may be some solid solution between them.

The volatility of $\mathrm{Cl}$ precludes the precise determination of the formula of Fe-chloride daughter minerals of this study. However, the presence of $\mathrm{O}$ in their EDS spectra suggests that they may be hydroxy chlorides such as $(\mathrm{Fe}, \mathrm{Mn})(\mathrm{OH}) \mathrm{Cl}(\mathrm{LeBel}, 1980)$. Fe-chlorides of this formula were reported to occur as acicular inclusions in chalcopyrite and cubanite at Deep Copper Zone (Springer, 1989). The $\Sigma$ cations/Cl ratios are best from the Barnet Property analyses, where they range from 1.03 to 1.52 . Despite $\mathrm{Cl}$-loss during analysis, Fe/Mn ratios ranged consistently between 9.8 and 12.9. By comparison, microprobe analyses of Fe-chloride by Springer (1989) yielded Fe/Mn ratios of 6.1. The variation in Fe/Mn ratios is likely the result of the analyses being from different deposits.

Upon fracturing at room temperature, many of the inclusions developed a rim of mosaic-textured $\mathrm{NaCl}$ and $\mathrm{CaCl}_{2}$ precipitate (Plates $6-2 \mathrm{~g}$, h and i). EDS spectra have also shown that various amounts of $\mathrm{K}, \mathrm{Fe}$ and $\mathrm{Mn}$ may also be present. Smooth-textured rims are characteristic of $\mathrm{CaCl}_{2}$-rich precipitate. 
However, some inclusions in chalcopyrite from Lindsley displayed smooth rims composed of $\mathrm{NaCl}$ and $\mathrm{BaCl}_{2}$, with traces of $\mathrm{Ca}$ and $\mathrm{K}$.

Table 6-4 represents a summary of the composition of daughter and accidental minerals from fluid inclusions in quartz, chalcopyrite, bornite, millerite, pentlandite and pyrrhotite from the Sudbury area. In addition to a wide variety of chloride compositions, the suite of accidental inclusions consists of native metals (Ag in Deep Copper Zone, Barnet and Lindsley; Bi in Deep Copper Zone), sulphates (Deep Copper Zone, Barnet, Epidote Zone and Lindsley), silicates (quartz, titanite, K-feldspar and chlorite), oxides (cassiterite), sulphides (sphalerite and chalcopyrite) and carbonates (calcite and dolomite). Plates 6-2a to j show a variety of opened fluid inclusions and their daughter minerals in quartz and sulphides.

\section{6-4c. DISCUSSION}

\section{i. Comparison of Daughter Mineral Populations from Quartz- and Sulphide- hosted Fluid Inclusions}

The native metals, naumannite and cassiterite are found only in inclusions in chalcopyrite and bornite. Otherwise, inclusion mineralogy, and therefore quartz- and sulphide- saturated fluids, are similar in bulk composition and are interpreted as being from the same fluid system. The exception to this is the Barnet deposit, where $\mathrm{Na}$ - and $\mathrm{Ca}$ - chlorides in fluid inclusions in quartz contain no trace of metals or accidental solid phases. These differences may be attributed to the fact that the studied quartz was part of the earlier quartz $+\mathrm{K}$ feldspar + epidote metasomatic event and not directly associated with the 
sulphide mineralizing fluids. Cassiterite has also been identified in sulphides and magnetite from the Victor Deep orebody, and is most abundant in samples with chlorine-rich phases.

The largest variation in fluid composition within deposits is represented by variations in $\mathrm{Ca}-, \mathrm{Na}-, \mathrm{Fe}-$ and $\mathrm{Pb}$ - chloride abundances in chalcopyrite. On the North Range, these variations are best shown in the Deep Copper Zone and at Barnet.

Native $\mathrm{Ag}, \mathrm{Bi}$ and selenide minerals occur in saline fluid inclusions in chalcopyrite and bornite from Deep Copper Zone and the Barnet Property (Plates 6-3a, b, c and d). This is direct evidence that Ag and possibly other precious metals are transported by $\mathrm{Cl}$-rich fluids and is supported by the discovery of a $\mathrm{Cl}$-bearing, $\mathrm{Pd}-\mathrm{Bi}$ compound in association with magnetite, chalcopyrite, insizwaite, sperrylite, electrum, michenerite, hessite and chlorite in Deep Copper Zone ores by Li and Naldrett (1992). Springer (1989) identified numerous $\mathrm{Cl}$-bearing minerals, such as $\mathrm{Fe}-\mathrm{Mn}$-chlorides, pyrosmalite, phlogopite, an Fe-rich analogue of sepiolite, and a ferric iron-rich amphibole, in PGM-rich Deep Copper Zone veins. In addition, $\mathrm{PbCl}_{2}$ (with hessite and merenskyite) has been found as inclusions in a chalcopyrite-rich sample from Barnet (sample CFA-046).

\section{ii. Inferences About Fluid Composition}

In many cases where grains have been fractured either under vacuum conditions or in air, with ejection and quenching of the fluid, there remains a halo 
surrounding the cavities with or without daughter minerals. These halos are the result of pressure quenching and evaporation of the aqueous phase upon breakage of the fluid inclusion volume. The coating may be composed of thin to hopper-like halite crystals or an irregular mosaic of $\mathrm{NaCl}$ and $\mathrm{CaCl}_{2}$ with minor $\mathrm{K}$, $\mathrm{Fe}$ and $\mathrm{Mn}$. This kind of brine condensation halo on sample surfaces is visible in SEM images shown by Metzger et al. (1977), LeBel (1980), and Kelly and Burgio (1983). Anthony et al. (1984) referred to these coatings as "splatter marks". Identification of these coatings is important because they precipitate directly from the fluid upon fracturing the inclusion volume and yield information about fluid composition complimenting the daughter mineral analysis.

Precipitates with smooth surfaces are composed predominantly of $\mathrm{CaCl}_{2}$ because $\mathrm{Ca}$-rich fluids in inclusions are notoriously difficult to nucleate (Vanko et al., 1988; Marshall, 1990). The decomposition that occurred when the SEM beam was focused on $\mathrm{CaCl}_{2}$-rich inclusions opened in air may be attributed to the metastable existence of antarcticite $\left(\mathrm{CaCl}_{2} \cdot 6 \mathrm{H}_{2} \mathrm{O}\right)$ as hydrate daughter minerals at room temperature as suggested by Schiffries (1988) for fluid inclusions from the Bushveld Complex. The electron beam heated the inclusion, thereby driving off the water, leaving only solid $\mathrm{CaCl}_{2}$ with minor amounts of $\mathrm{NaCl}$ and $\mathrm{KCl}$ (Plate 6-2j).

Variation within each deposit (i.e., from a $\mathrm{Na}$ - to an $\mathrm{Fe}$ - and $\mathrm{Pb}$ - chloride dominated system at Barnet) indicates that either the fluids involved in $\mathrm{Cu}-\mathrm{Ni}$ - 
PGE mineralization were poorly mixed or that there were pulses of fluid activity of slightly different composition.

\section{iii. Comparison of North and South Range Daughter Mineral Populations}

The daughter minerals in fluid inclusions from veins and alteration of the North Range deposits (Deep Copper Zone, Barnet Property, McCreedy West and East, Epidote Zone) are similar to those of the South Range (Lindsley and Little Stobie). In the former, "primary" fluid inclusions contain Na-, Ca-, Fe- and $\mathrm{Pb}$ - chlorides whereas those from Lindsley contain greater proportions of $\mathrm{BaCl}_{2}$. This implies that the fluids trapped within quartz and sulfides in the Sudbury footwall were compositionally similar, their differences being attributable to the partial control of composition by their host rocks. It is likely that the Lindsley inclusions contain more Ba because of fluid interaction with enveloping Sudbury Breccua developed in granite of the Murray Pluton (Binney et al., 1992). The Little Stobie Mine is close to Lindsley, but inclusions in quartz and chalcopyrite of similar geological setting are particularly $\mathrm{Pb}$-rich and $\mathrm{Ba}$-poor. This may be attributed to the fact that only a small part of the Little Stobie Number 1 orebody is in contact with unbrecciated Murray Pluton, thereby precluding extensive fluid interaction with granite. North Range veins occur in plagioclase-rich gneisses and migmatites of the Levack Gneiss complex; thus, fluid-rock interaction would have enriched the fluid in $\mathrm{Ca}$ by albitization reactions such as:

$$
2 \mathrm{Na}^{+}+\mathrm{CaAl}_{2} \mathrm{Si}_{2} \mathrm{O}_{8}+4 \mathrm{SiO}_{2}--->2 \mathrm{NaAlSi}_{3} \mathrm{O}_{8}+\mathrm{Ca}^{2+}
$$

\section{iv. Comparison with Present-day Groundwaters}


Studies of present-day, deep (>650 m), saline groundwaters at locations (including Sudbury) in the Precambrian Shield have shown that the geochemical evolution of these waters favours the development of $\mathrm{Ca}, \mathrm{Na}$ and $\mathrm{Cl}$-rich brines of indeterminate origin (Rittenhouse, 1967; Frape et al., 1984). In addition, although a high $\mathrm{Ca}$ concentration in these fluids is ubiquitous, local lithology has an influence on the abundance of more minor cations in the groundwaters (Frape et al., 1984). These characteristics have also been shown during this study of fluid inclusions from a variety of locations in the Sudbury area. This suggests that deep-seated, evolved formational waters existed at the time of the Sudbury event and were a possible source of fluid included in hydrothermal activity generated in the footwall.

However, it has been postulated that the leaching of intergranular salts or fluid inclusions by present-day, deep groundwaters could explain the elevated salinities of these brines (Fuge, 1979; Moore et al., 1983; Frape et al., 1984). These groundwaters may represent fossil marine waters (Frape and Fritz, 1982; Frape et al., 1984) that have been enriched in $\mathrm{Cl}$, or they may even have a mantle origin (Frape et al., 1984). However, intense geochemical exchange with host lithologies has obscured their exact origin.

\section{6-5. SUMMARY AND DISCUSSION}

Fluid inclusions in quartz associated with $\mathrm{Cu}$-rich footwall vein deposits and the Epidote Zone in this study suggests that the $\mathrm{Cl}$-rich brines were important in this type of metal deposition. Recent preliminary data on $\mathrm{Cl}$ 
contents in "thermally metamorphosed" Sudbury Breccia reported by Jago et al. (1994) also support this conclusion. They indicate that Sudbury Breccia that hosts $\mathrm{Cu}$-rich footwall veining is anomalously enriched in $\mathrm{Cl}$ (300 to $4000 \mathrm{ppm}$ ), whereas barren Sudbury Breccia contains $<300 \mathrm{ppm} \mathrm{Cl}$.

The occurrence of primary fluid inclusions in sulphide minerals is direct evidence of the important role of fluids in sulphide deposition in footwall deposits of the Sudbury Structure, and is complemented by information gained from fluid inclusion studies on transparent alteration minerals associated with sulphides. Semi-quantitative energy-dispersion spectrometry (EDS) was performed using the scanning electron microscope (SEM) to study the morphology and the composition of chloride solids in fluid inclusions in quartz and sulphide minerals. This investigation confirmed conventional fluid inclusion studies on transparent minerals that their compositions were dominated by $\mathrm{CaCl}_{2}$ and $\mathrm{NaCl}$. Perfect cubic solids were almost entirely $\mathrm{NaCl}$, while mixtures of other salts existed as rounded to subrounded, elongate forms. Individual $\mathrm{CaCl}_{2}: \mathrm{NaCl}: \mathrm{KCl}$ proportions varied at different locations on the surface of the same solid.

Chlorine-rich precipitates were also identified in microfractures of drillcore samples from the Victor Deep and McCreedy East orebodies by Jago et al. (1994). However, their observations were made on polished rock faces. It is likely that the fluids and pastes used in the polishing procedure disrupted the original compositions and textures of chloride minerals that may have existed in the microfractures. Likewise, their descriptions of "bleeding fractures" on these 
polished surfaces tend to occur in porous sulphides, at sulphide-silicate, and sulphide-oxide boundaries, suggesting that fluids involved in the polishing process have been trapped along microfractures and grain boundaries. Semiquantitative analyses from such precipitates would not be representative or accurate.

Although there are slightly different solid phase assemblages from quartzand sulphide- hosted inclusions, the quartz- and sulphide- saturated fluids are similar in bulk composition in all deposits but the Barnet Property. This may reflect the different stage of quartz that was studied at Barnet. Precious metals were transported with the base metals in the $\mathrm{Cl}$-rich fluids, and thus were not carried far from the massive sulphide veins.

Variation of daughter mineral compositions within individual deposits suggests that the fluids were poorly mixed or that there were pulses of fluid activity of slightly differing composition. The significant influence of footwall rocks during the evolution of the fluids in the North Range inferred from isotopic studies (Chapter 7) is compatible with the differing salt assemblages in fluid inclusions of this study. This is similar to the broad geochemical behaviour of present-day, deep, saline groundwaters, and suggests that if formational waters of similar composition existed during the Sudbury Event they are a potential fluid source for some of the hydrothermal activity associated with footwall orebody generation. 
Table 6-1: Summary of fluid inclusion petrography from each study location.

a) Deep Copper Zone

\begin{tabular}{|c|c|c|c|c|c|c|c|}
\hline \multirow[t]{3}{*}{ SAMPLE } & \multirow[t]{3}{*}{ HOST MINERALOOY } & \multirow[t]{3}{*}{ INCLUSION TYPE } & \multirow[t]{3}{*}{$\underline{\mathbf{n}}$} & \multicolumn{3}{|l|}{$\frac{\text { FILLING }}{\text { VOLUMES }}$} & \multirow[t]{3}{*}{ GENERATION } \\
\hline & & & & $\mathbf{v}$ & sc & OTHER & \\
\hline & & & & Avg $\pm 1 S . D$. & Avg土S.D. & PHASES & \\
\hline \multirow[t]{5}{*}{ S42-B2 } & \multirow{5}{*}{$\begin{array}{l}\text {-quartz (medium- } \\
\text { grained) \& calcite with } \\
\text { chalcopyrite \& millerite. } \\
\text { Subhedral quartz locally } \\
\text { included in chalcopyrite. }\end{array}$} & $L+V$ & 19 & $18 \pm 8.5$ & & & P/Ps \\
\hline & & $L+V+S C$ & 17 & $13 \pm 3.9$ & $13 \pm 4.8$ & & P/Ps \\
\hline & & $L+V+S C+X$ & 5 & $13 \pm 3.8$ & $13 \pm 3.7$ & $2.8 \pm 2.4$ & P/Ps \\
\hline & & $L+V+X$ & 1 & 7 & & 1 & P/Ps \\
\hline & & $L+V+X_{1}+X_{2}$ & 1 & 9 & & $\begin{array}{l}X_{1}=1 \\
X_{2}=2 \\
\end{array}$ & P/Ps \\
\hline \multirow[t]{6}{*}{ S37-D5 } & \multirow{6}{*}{$\begin{array}{l}\text {-quartz with chlorite \& } \\
\text { chalcopyrite inclusions } \\
\text { along edge of sulphide } \\
\text { vein. Coarse-grained. } \\
\text { Appears } \\
\text { contemporaneous with } \\
\text { chalcopyrite, deposited } \\
\text { along late structure. }\end{array}$} & $L+V+S$ & 13 & $22 \pm 7.5$ & $18 \pm 5.3$ & & P/Ps \\
\hline & & $\mathrm{L}+\mathrm{V}$ & 8 & $26 \pm 6.3$ & & & P/Ps \\
\hline & & $L+V+S+X_{1}+X_{2}$ & 6 & $28 \pm 4.4$ & $20 \pm 8.2$ & $\begin{array}{l}x_{1}= \\
3.7 \pm 2.6 \\
x_{2}=3 \pm 3\end{array}$ & P/Ps \\
\hline & & $L+V+S+X_{1}$ & 3 & $19 \pm 4.3$ & $28 \pm 5.3$ & $2 \pm 0.8$ & P/Ps \\
\hline & & $L+V+S+X_{1}+X_{2}+X_{3}$ & 1 & 10 & 14 & $\begin{array}{l}x_{1}=2 \\
x_{2}=2 \\
x_{3}=1\end{array}$ & P/Ps \\
\hline & & $L+V+S$ & 1 & 25 & & 1 & P/Ps \\
\hline \multirow[t]{7}{*}{ S37-1 } & \multirow{7}{*}{$\begin{array}{l}\text {-quartz adjacent to } \\
\text { chalcopyrite-rich } \\
\text { sulphides with epidote } \\
\text { inclusions. Coarse- } \\
\text { grained quartz between } \\
\text { sulphides \& medium- } \\
\text { grained epidote. }\end{array}$} & $\mathrm{L}+\mathrm{V}+\mathrm{SC}$ & 11 & $11 \pm 3.4$ & $16 \pm 6.3$ & & P/Ps \\
\hline & & $\mathrm{L}+\mathrm{V}+\mathrm{SC}$ & 1 & 5 & 9 & & $\mathrm{G}-2$ \\
\hline & & $L+V$ & 9 & $12 \pm 4.3$ & & & P/Ps \\
\hline & & $L+V$ & 3 & $6.7 \pm 1.2$ & & & G-2 \\
\hline & & $L+V+S C+X$ & 2 & $10 \pm 0$ & $12 \pm 2.5$ & $1.5 \pm 0.5$ & P/Ps \\
\hline & & $L+V+X$ & 2 & $16 \pm 0$ & & $3.0 \pm 1$ & P/Ps \\
\hline & & $L+V+X_{1}+X_{2}$ & 2 & $13 \pm 5.0$ & & $\begin{array}{l}x_{1}= \\
5.5 \pm 0.5 \\
x_{2}=1.0 \pm 0\end{array}$ & P/Ps \\
\hline \multirow[t]{2}{*}{ S-epDCZ } & \multirow{2}{*}{$\begin{array}{l}\text {-medium- to coarse- } \\
\text { grained quartz } \\
\text { intergrown with } \\
\text { medium-grained } \\
\text { epidote along } \\
\text { chalcopyrite veinlet. }\end{array}$} & $L+V$ & 6 & $28 \pm 8.5$ & & & P/Ps \\
\hline & & $L+V+S C$ & 2 & $17 \pm 1.0$ & $17 \pm 2.0$ & & P/Ps \\
\hline \multirow[t]{3}{*}{$537-4$} & \multirow{3}{*}{$\begin{array}{l}\text {-quartz vein with minor } \\
\text { chalcopyrite. Quartz } \\
\text { coarse-grained. }\end{array}$} & $\mathrm{L}+\mathrm{V}$ & 5 & $15 \pm 6.8$ & & & $\mathrm{P} / \mathrm{P}_{5}$ \\
\hline & & $L+V+S C$ & 4 & $14 \pm 2.1$ & $25 \pm 13$ & & P/Ps \\
\hline & & $L+V+S C+X$ & 1 & 12 & 13 & 10 & P/Ps \\
\hline \multirow[t]{2}{*}{ S39-K64B } & \multirow{2}{*}{$\begin{array}{l}\text {-early quartz, fine to } \\
\text { medium-grained on } \\
\text { host rock side of vein. }\end{array}$} & $L+V$ & 13 & $27 \pm 6.8$ & & & P/Ps \\
\hline & & $L+V+S C$ & 9 & $22 \pm 8.1$ & $17 \pm 5.4$ & & P/Ps \\
\hline
\end{tabular}


Table 6-1: (con't)

b) Barnet Property

\begin{tabular}{|c|c|c|c|c|c|c|c|}
\hline \multirow[t]{3}{*}{ SAMPLE } & \multirow[t]{3}{*}{ HOST MINERALOOY } & \multirow[t]{3}{*}{$\frac{\text { INCLUSION }}{\text { IYPE }}$} & \multirow[t]{3}{*}{$\underline{n}$} & \multicolumn{3}{|l|}{$\begin{array}{l}\text { FILLING } \\
\text { VOLUMES }\end{array}$} & \multirow[t]{3}{*}{ GENERATION } \\
\hline & & & & v & sc & \multirow[t]{2}{*}{ OTHER } & \\
\hline & & & & Avot1s.D. & Ava土1S.D. & & \\
\hline CFAS- $10 \mathrm{C} 2$ & $\begin{array}{l}\text {-metasomatic medium- } \\
\text { grained quartz with } \\
\text { radiating epidote in } \\
\text { structure later occupied } \\
\text { by chalcopyrite vein. }\end{array}$ & $L+V$ & 9 & $17 \pm 4.1$ & & & P/Ps \\
\hline \multirow[t]{6}{*}{ CFAS-3 } & \multirow{6}{*}{$\begin{array}{l}\text {-metasomatic, coarse- } \\
\text { grained with epidote in } \\
\text { core of quart + epidote } \\
+ \text { K-feldspar pod. }\end{array}$} & $L+V$ & 13 & $19 \pm 9.5$ & & & P/Ps \\
\hline & & $L+V+S C$ & 4 & $14 \pm 2.2$ & $12 \pm 2.5$ & & $\mathrm{P} / \mathrm{Ps}_{\mathbf{s}}$ \\
\hline & & $L+V+X$ & 4 & $18 \pm 7.1$ & $4.8 \pm 4.3$ & & $\mathrm{P} / \mathrm{Ps}_{\mathrm{s}}$ \\
\hline & & $L+V+S C+X$ & 2 & $14 \pm 3.5$ & $15 \pm 5.0$ & $10 \pm 5.0$ & P/Ps \\
\hline & & $L+V+S C+X_{1}+X_{2}$ & 1 & 15 & 9 & $\begin{array}{l}X_{1}=1 \\
X_{2}=1\end{array}$ & P/Ps \\
\hline & & $L+V+X_{1}+X_{2}+X_{3}+X$ & 1 & 10 & & $\begin{array}{l}X_{1}=10 \\
X_{2}=6 \\
X_{3}=4 \\
X_{1}=2\end{array}$ & P/Ps \\
\hline
\end{tabular}

\section{c) Fraser Epidote Zone}

\begin{tabular}{|c|c|c|c|c|c|c|c|}
\hline \multirow[t]{3}{*}{ SAMPLE } & \multirow[t]{3}{*}{$\begin{array}{l}\text { HOST } \\
\text { MINERALOOY }\end{array}$} & \multirow[t]{3}{*}{$\frac{\text { INCLUSION }}{\text { TYPE }}$} & \multirow[t]{3}{*}{$\underline{n}$} & \multicolumn{3}{|l|}{$\frac{\text { FILLINO }}{\text { VOLUMES }}$} & \multirow[t]{3}{*}{ GENERATION } \\
\hline & & & & $\mathbf{v}$ & sc & OTHER & \\
\hline & & & & Avq土1S.D. & Avg土1S.D. & & \\
\hline \multirow[t]{3}{*}{ FR46-209-12.8 } & \multirow{3}{*}{$\begin{array}{l}\text {-fine- to medium- } \\
\text { grained quartz } \\
\text { intergrown with } \\
\text { epidote in Epidote } \\
\text { Zone. }\end{array}$} & $L+V$ & 19 & $17 \pm 4.3$ & & & P/Ps \\
\hline & & $L+V+S C$ & 5 & $12 \pm 3.3$ & $19 \pm 8.5$ & & P/Ps \\
\hline & & $L+V+X$ & 1 & 6 & & 9 & P/Ps \\
\hline \multirow[t]{4}{*}{$F 46-4 C$} & \multirow{4}{*}{$\begin{array}{l}\text {-fine- to medium- } \\
\text { grained quartz in } \\
\text { EPDZ. Relict } \\
\text { Footwall Breccia } \\
\text { textures still } \\
\text { visible. }\end{array}$} & $L+V$ & 17 & $25 \pm 8.4$ & & & P/Ps \\
\hline & & $L+V+S C$ & 8 & $18 \pm 6.5$ & $19 \pm 5.9$ & & P/Ps \\
\hline & & $L+V+S C+X$ & 1 & 14 & 13 & 1 & P/Ps \\
\hline & & $L+V+X$ & 1 & 15 & & 2 & P/Ps \\
\hline \multirow[t]{4}{*}{ F 46-31 } & \multirow{4}{*}{$\begin{array}{l}\text {-quartz intergrown } \\
\text { with epidote in } \\
\text { vein in Footwall } \\
\text { Breccia near } \\
\text { Epidote Zone } \\
\text { patch. }\end{array}$} & $L+V+S C$ & 8 & $18 \pm 6.5$ & $19 \pm 5.5$ & & P/Ps \\
\hline & & $L+V+S C+X$ & 5 & $20 \pm 5.2$ & $20 \pm 5.4$ & $2.8 \pm 1.8$ & P/Ps \\
\hline & & $L+V+S C+X_{1}+X_{2}$ & 2 & $16 \pm 4.0$ & $20 \pm 5.0$ & $\begin{array}{l}X_{1}=2 \pm 1 \\
X_{2}=3 \pm 0\end{array}$ & P/Ps \\
\hline & & $L+V$ & 2 & $20 \pm 6.5$ & & & P/Ps \\
\hline
\end{tabular}


Table 6-2: Summary of fluid inclusion microthermometry from each study location.

\section{a) Deep Copper Zone}

\begin{tabular}{|c|c|c|c|c|c|c|c|}
\hline SAMPLE & INCLUSION TYPE & $\begin{array}{l}\text { Thuxi } \\
\text { Avg } \pm 1 S . D .\end{array}$ & $\underline{T h}_{30}$ & $\underline{T h} x$ & I.(ice) & $I_{a}$ (ice- $>$ L) & $\begin{array}{l}\text { NaCl (wt. \% } \\
\text { eq) } \\
\text { Avg士1S.D. }\end{array}$ \\
\hline \multirow[t]{5}{*}{$S 42-B 2$} & $L+V$ & $182 \pm 92.2$ & & & $\mathrm{~m}$ & $\mathrm{~m}$ & \\
\hline & $L+V+S C$ & $144 \pm 20.2$ & $183 \pm 22.9$ & & $-18 \pm 11$ & $-4.1 \pm 5.1$ & $31.1 \pm 1.1$ \\
\hline & $L+V+S C+X$ & $136 \pm 28.5$ & $164 \pm 32.4$ & & $\mathrm{~m}$ & $m$ & $30.2 \pm 1.5$ \\
\hline & $L+V+X$ & 106.7 & & & & & \\
\hline & $L+V+X_{1}+X_{2}$ & 121.2 & & & & & \\
\hline \multirow[t]{5}{*}{ S37-D5 } & $L+V+S C$ & $312 \pm 99.5$ & $290 \pm 32.7$ & & $m$ & $\mathrm{~m}$ & \\
\hline & $L+V$ & $325 \pm 73.8$ & & & $-29.6 \pm 5.9$ & $22.4 \pm 3.4$ & \\
\hline & $L+V+S C+X_{1}+X_{2}$ & $393 \pm 77.0$ & $296 \pm 27.0$ & $\begin{array}{l}X_{1}=139 \pm 46.7 \\
X_{2}=182 \pm 16.4\end{array}$ & -1.3 & 20.2 & $37.6 \pm 2.0$ \\
\hline & $L+V+S C+X_{1}$ & $273 \pm 17.2$ & $280 \pm 33.8$ & $X_{1}=140$ & -27.5 & 25.8 & $36.5 \pm 2.4$ \\
\hline & $L+V+S C+X_{1}+X_{2}+X_{3}$ & 183.4 & 307 & $\begin{array}{l}X_{1}=93.8 \\
X_{3}=65\end{array}$ & -28.7 & 15.7 & 38.4 \\
\hline \multirow[t]{7}{*}{ s37-1 } & $L+V+S C$ & $148 \pm 15.5$ & $206 \pm 13.6$ & & $-46.4 \pm 18.3$ & $-27.2 \pm 25.8$ & $32.2 \pm 0.7$ \\
\hline & $L+V+S C(G-2)$ & 129.3 & 155 & & $m$ & $m$ & 30.0 \\
\hline & $L+V$ & $179 \pm 44.9$ & & & -53.6 & -17.5 & 20.6 \\
\hline & $L+V(G-2)$ & $105 \pm 22.7$ & & & m & $m$ & \\
\hline & $L+V+S C+X$ & 142.9 & 200 & & m & $m$ & 31.9 \\
\hline & $L+V+X$ & $159 \pm 8.4$ & & & $m$ & $m$ & \\
\hline & $L+V+X_{1}+X_{2}$ & $177 \pm 16.1$ & & $X_{1}=108$ & $m$ & $m$ & \\
\hline \multirow[t]{2}{*}{ S-epDCZ } & $L+V$ & $179 \pm 16.5$ & & & m & $m$ & \\
\hline & $L+V+S C$ & 171.3 & 165 & & m & $m$ & 30.3 \\
\hline \multirow[t]{2}{*}{ S37-4 } & $L+V$ & $280 \pm 32.9$ & & & $\mathrm{~m}$ & $m$ & \\
\hline & $L+V+S C$ & $262 \pm 37.1$ & $253 \pm 24.7$ & & $m$ & $\mathrm{~m}$ & $34.8 \pm 1.6$ \\
\hline \multirow[t]{2}{*}{ S39-K64B } & $L+V$ & $303 \pm 54.6$ & & & $-59 \pm 6.4$ & $-23 \pm 8.4$ & \\
\hline & $L+V+S C$ & $303 \pm 55.4$ & $232 \pm 24.0$ & & $\mathrm{~m}$ & $\mathrm{~m}$ & 33.6 \\
\hline
\end{tabular}


Table 6-2: (con't)

b) Barnet Property

\begin{tabular}{|c|c|c|c|c|c|c|c|}
\hline SAMPLE & INCLUSION TYPE & $\begin{array}{l}T h_{\text {wat }} \\
\text { Avg } \pm 1 \text { S.D. }\end{array}$ & $\underline{T h}_{s o}$ & $\underline{T h}$ & I.(ice) & $\underline{T_{e}(\text { ice } \rightarrow L)}$ & $\begin{array}{l}\mathrm{NaCl}(\mathrm{wt} \% \\
\text { Avg) } \\
\text { Avg士1S.D. }\end{array}$ \\
\hline CFAS-10C2 & $\mathrm{L}+\mathrm{V}$ & $177 \pm 40.7$ & & & $-52 \pm 6.8$ & $-18.8 \pm 9.8$ & \\
\hline \multirow[t]{5}{*}{ CFAS-3 } & $\mathrm{L}+\mathrm{V}$ & $200 \pm 28.0$ & & & $-52.6 \pm 7.0$ & $-25.0 \pm 15.4$ & \\
\hline & $L+V+S C$ & $185 \pm 17.8$ & $193 \pm 13.9$ & & $m$ & $\mathrm{~m}$ & $31.6 \pm 0.7$ \\
\hline & $L+V+X$ & $176 \pm 12.9$ & & & $-56.5 \pm 4.5$ & $-26.2 \pm 7.8$ & \\
\hline & $\mathrm{L}+\mathrm{V}+\mathrm{SC}+\mathrm{X}_{1}+\mathrm{X}_{2}$ & 175.7 & 156.9 & $x_{1}=65$ & -46.4 & -33.5 & 30.0 \\
\hline & $L+V+S C+X_{1}+X_{2}+X_{3}+X_{1}$ & 185.1 & & & -54.1 & 12.7 & \\
\hline
\end{tabular}

\section{c) Fraser Epidote Zone}

\begin{tabular}{|c|c|c|c|c|c|c|c|}
\hline SAMPLE & INCLUSION TYPE & $\begin{array}{l}\text { Thuat } \\
\text { Avg士1S.D. }\end{array}$ & $\underline{T h}_{20}$ & $\underline{T h} x$ & I.(ice) & $I_{\text {a (ice- } \rightarrow L)}$ & $\begin{array}{l}\text { NaCl (wt\% } \\
\text { oq) } \\
\text { Avg士15.D. }\end{array}$ \\
\hline \multirow[t]{2}{*}{ FR46-209-12.8 } & $L+V$ & $214 \pm 19.7$ & & & $-46 \pm 2.6$ & $-37 \pm 4.4$ & \\
\hline & $L+V+X$ & 165.4 & & & m & $m$ & \\
\hline \multirow[t]{4}{*}{$F 46-4 C$} & $L+V$ & $272 \pm 96.4$ & & & $-55.1 \pm 12.8$ & $-28.4 \pm 8.1$ & \\
\hline & $L+V+S C$ & $210 \pm 25.5$ & $261 \pm 48.6$ & & $\mathrm{~m}$ & m & $35.3 \pm 3.3$ \\
\hline & $L+V+S C+X$ & 206.4 & 188 & & & & 31.3 \\
\hline & $L+V+X$ & 249 & & & & & \\
\hline \multirow[t]{4}{*}{ F46-31 } & $L+V+S C$ & $217 \pm 16.3$ & $265 \pm 31.5$ & & -42.3 & -25 & $35.6 \pm 2.1$ \\
\hline & $L+V+S C+X$ & $227 \pm 0.2$ & $294 \pm 3.8$ & & $-33.4 \pm 2.8$ & $-11.3 \pm 2.8$ & $37.5 \pm 0.3$ \\
\hline & $L+V+S C+X_{1}+X_{2}$ & 189 & 272.2 & $x_{1}=65$ & -30.3 & -15.1 & 36.0 \\
\hline & $L+V$ & 214.9 & & & & & \\
\hline
\end{tabular}

$m=$ metastable behaviour during freezing (i.e., unable to freeze, etc.) 


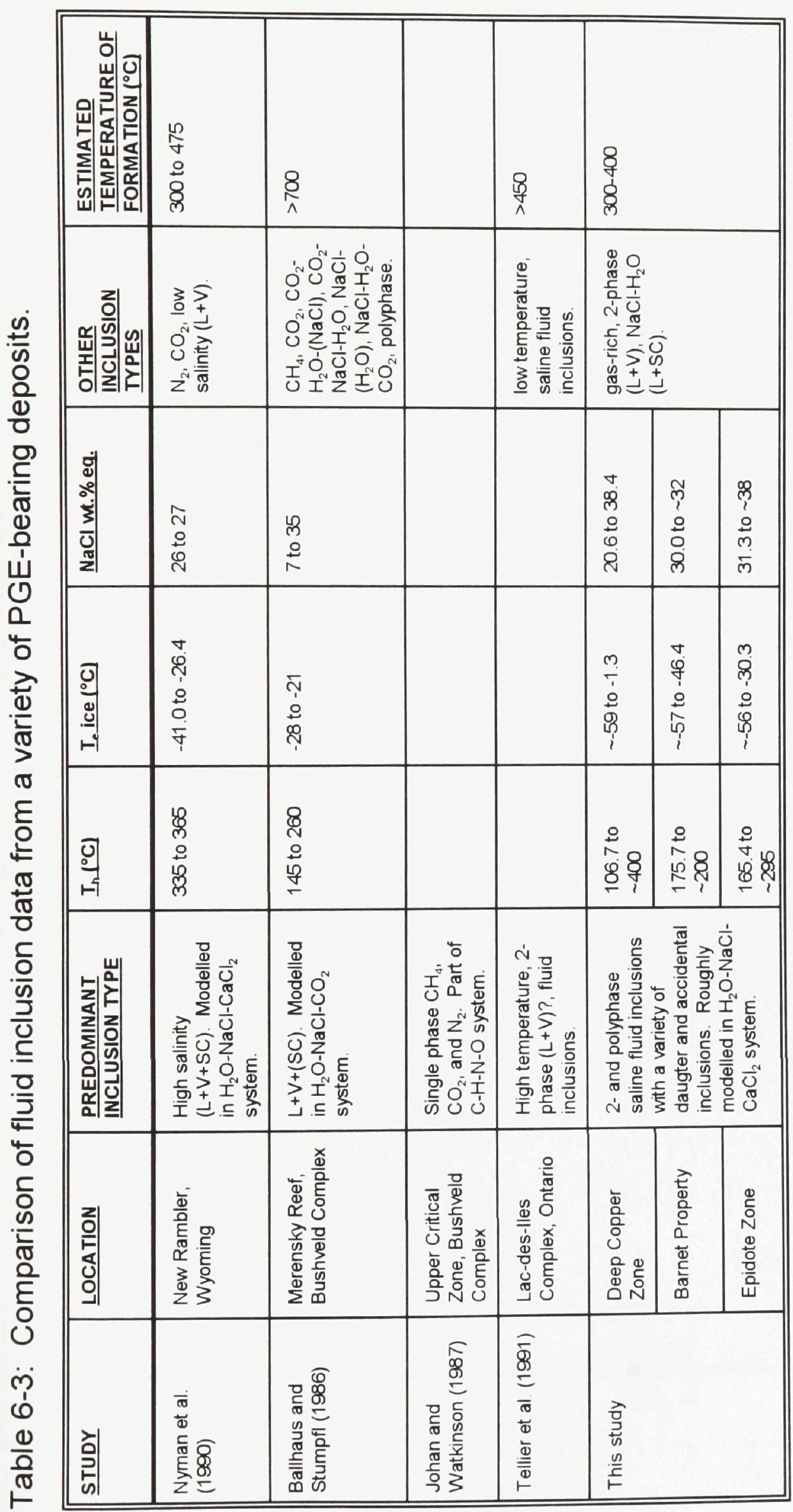

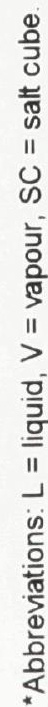


Table 6-4: Summary of data on solid phases in fluid inclusions analyzed by SEM-EDS from the Sudbury area.

\begin{tabular}{|c|c|c|c|c|}
\hline DEPOSIT & $\begin{array}{l}\text { HOST } \\
\text { MINERAL }\end{array}$ & $\begin{array}{l}\text { DOMINANT } \\
\text { CHLORIDES }\end{array}$ & $\begin{array}{l}\text { OTHER } \\
\text { ELEMENTS } \\
\text { DETECTED IN } \\
\text { CHLORIDES }\end{array}$ & $\begin{array}{l}\text { ACCIDENTAL } \\
\text { INCLUSIONS }\end{array}$ \\
\hline $\begin{array}{l}\text { Strathcona Mine Deep } \\
\text { Copper Zone }\end{array}$ & \begin{tabular}{|l} 
quartz \\
----- \\
chalcopyrite \\
----- \\
bornite \\
----- \\
millerite
\end{tabular} & $\begin{array}{l}\mathrm{Ca}, \mathrm{Na}, \mathrm{Fe} \\
----- \\
\mathrm{Ca}, \mathrm{Na}, \mathrm{Pb} \\
----- \\
\mathrm{Ca}, \mathrm{Na} \\
----- \\
\mathrm{Na}\end{array}$ & $\begin{array}{l}\mathrm{K}, \mathrm{Mn}, \mathrm{Al}, \mathrm{Ba} \\
\mathrm{Mg}, \mathrm{Ni}, \mathrm{Pb}, \mathrm{Zn}, \\
\mathrm{Se} \\
\mathrm{K}, \mathrm{Fe}, \mathrm{Mn}, \mathrm{Ba} \\
\mathrm{Zn}, \mathrm{Al}, \mathrm{Mg}, \mathrm{Se} \\
\mathrm{K} \\
\mathrm{K}---- \\
\mathrm{Fe}, \mathrm{Pb}, \mathrm{Se}\end{array}$ & $\begin{array}{l}\text { Ca-sulphate } \\
\text { K-sulphate } \\
\text { calcite } \\
--\ldots \text { native } \mathrm{Ag} \\
\text { quartz } \\
\text { sphalerite } \\
\text { native } \mathrm{Ag} \\
\text { native } \mathrm{Bi} \\
\text { chalcopyrite }\end{array}$ \\
\hline Barnet Property & $\begin{array}{l}\text { quartz } \\
\text { chalcopyrite }\end{array}$ & $\begin{array}{l}\mathrm{Na}, \mathrm{Ca}, \mathrm{K} \\
\mathrm{Na}, \mathrm{Fe}, \mathrm{Pb}\end{array}$ & $\begin{array}{l}\mathrm{Ca}, \mathrm{Mn}, \mathrm{Mg}, \mathrm{K} \\
\mathrm{Zn}, \mathrm{Al}, \mathrm{Ag}, \mathrm{Cu} \\
\mathrm{Se}\end{array}$ & $\begin{array}{l}\text { sphalerite } \\
\text { native } \mathrm{Ag} \\
\mathrm{Ag}_{2} \mathrm{Se} \\
\text { cassiterite } \\
\mathrm{Fe}-\mathrm{Mn} \text {-sulphate }\end{array}$ \\
\hline McCreedy West Mine & $\begin{array}{l}\text { quartz } \\
----- \\
\text { chalcopyrite }\end{array}$ & $\begin{array}{l}\mathrm{Ca}, \mathrm{Na} \\
----- \\
\mathrm{Ca}, \mathrm{Na}\end{array}$ & $\begin{array}{l}\mathrm{K}, \mathrm{Fe}, \mathrm{Mn}, \mathrm{Ti}, \\
\mathrm{Ba} \\
\mathrm{K}, \mathrm{Mn}, \mathrm{Zn}\end{array}$ & -- \\
\hline McCreedy East Mine & chalcopyrite & $\mathrm{Ca}, \mathrm{Na}$ & & $\begin{array}{l}\text { quartz } \\
\text { calcite }\end{array}$ \\
\hline $\begin{array}{l}\text { Fraser Mine Epidote } \\
\text { Zone }\end{array}$ & $\begin{array}{l}\text { quartz } \\
\\
----- \\
\text { pentlandite } \\
---\ldots-- \\
\text { chalcopyrite } \\
\text { pyrite }\end{array}$ & $\begin{array}{l}\mathrm{Na}, \mathrm{Ca} \\
\\
\mathrm{Ca}, \mathrm{Na} \\
------ \\
\mathrm{Na}, \mathrm{Ca}--- \\
\mathrm{Na}\end{array}$ & $\begin{array}{l}\mathrm{K}, \mathrm{Mg}, \mathrm{Fe} \\
----- \\
\mathrm{K}----- \\
\mathrm{Fe}, \mathrm{K}\end{array}$ & $\begin{array}{l}\text { hematite or } \\
\text { magnetite } \\
\text { titanite } \\
\text { dolomite } \\
\mathrm{Ti} \& \mathrm{Mg} \text {-sulphate } \\
\text { apatite } \\
\text { K-feldspar } \\
\text { biotite(?) } \\
\text { calcite } \\
\text { titanite } \\
- \text { titanite }--\ldots \\
\text { chlorite }\end{array}$ \\
\hline Lindsley Mine & quartz & $\begin{array}{l}\mathrm{Na}, \mathrm{Ca}, \mathrm{Ba}, \\
\mathrm{Fe}\end{array}$ & $\mathrm{Mn}, \mathrm{K}$ & \\
\hline
\end{tabular}




\begin{tabular}{|c|c|c|c|c|}
\hline & $\begin{array}{l}\text { chalcopyrite } \\
----- \\
\text { pyrrhotite }\end{array}$ & $\begin{array}{l}\mathrm{Na}, \mathrm{Ca}, \mathrm{Ba} \\
\mathrm{Na}, \mathrm{Ca}, \mathrm{Ba}\end{array}$ & $\begin{array}{l}\mathrm{Fe}, \mathrm{Mn}, \mathrm{K}, \mathrm{Zn}, \\
\mathrm{Al} \\
\mathrm{K}\end{array}$ & $\begin{array}{l}\text { native } \mathrm{Ag} \\
\text { sphalerite } \\
\text { Cu-sulphate }\end{array}$ \\
\hline \multirow[t]{2}{*}{ Little Stobie Mine } & quartz & $\mathrm{Na}, \mathrm{Pb}, \mathrm{Ca}$ & $\mathrm{K}, \mathrm{Mg}, \mathrm{Cu}$ & chalcopyrite \\
\hline & chalcopyrite & $\mathrm{Pb}, \mathrm{Na}$ & $\begin{array}{l}\mathrm{Mg}, \mathrm{Ca}, \mathrm{Cu}, \mathrm{K} \\
\mathrm{Zn}, \mathrm{Fe}\end{array}$ & \\
\hline
\end{tabular}

" = reported in decreasing order of abundance. 


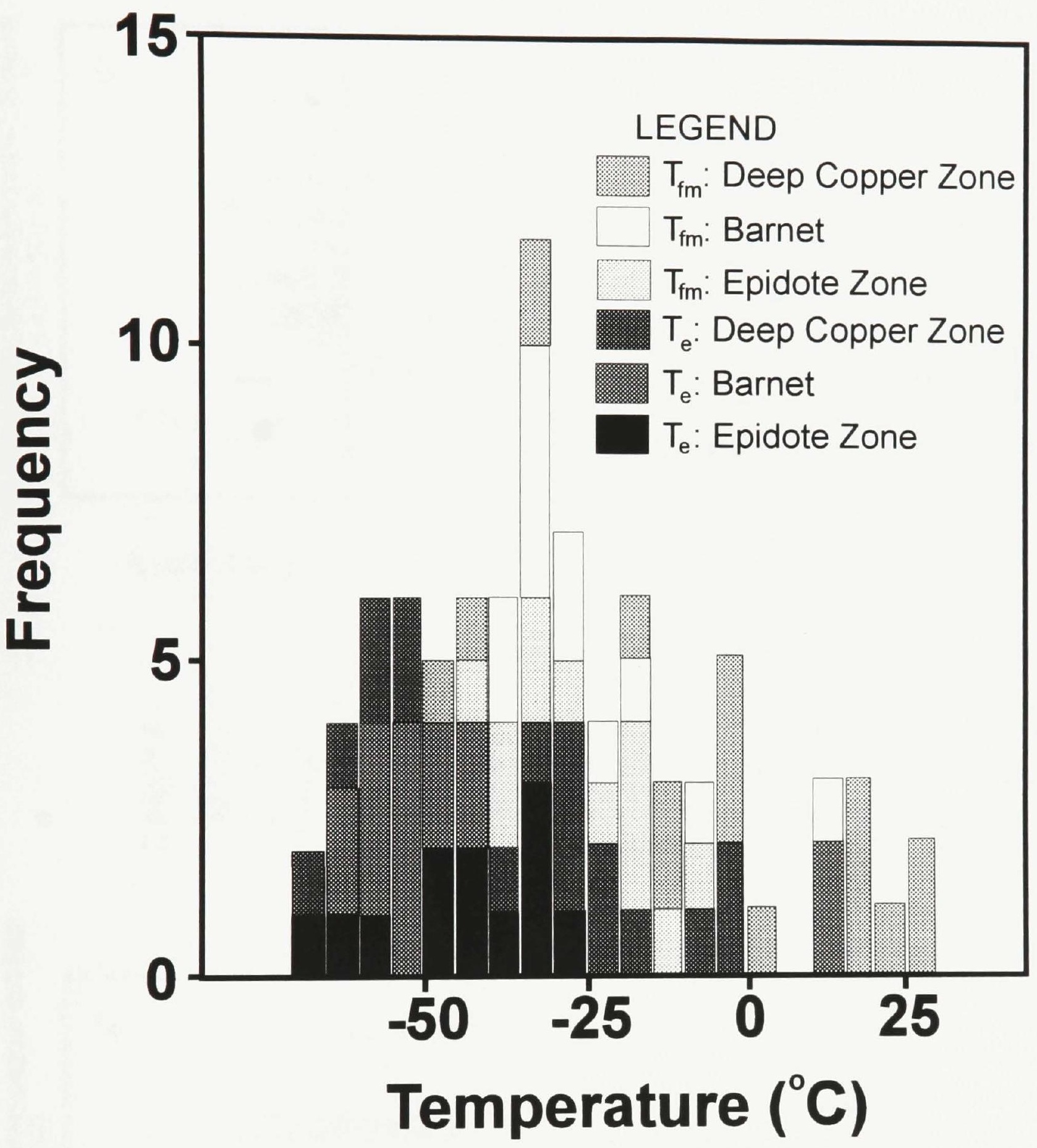

Figure 6-1: Eutectic $\left(T_{e}\right)$ and final melting $\left(T_{f m}\right)$ temperatures for fluid inclusions from the Deep Copper Zone, Barnet and the Epidote Zone. 

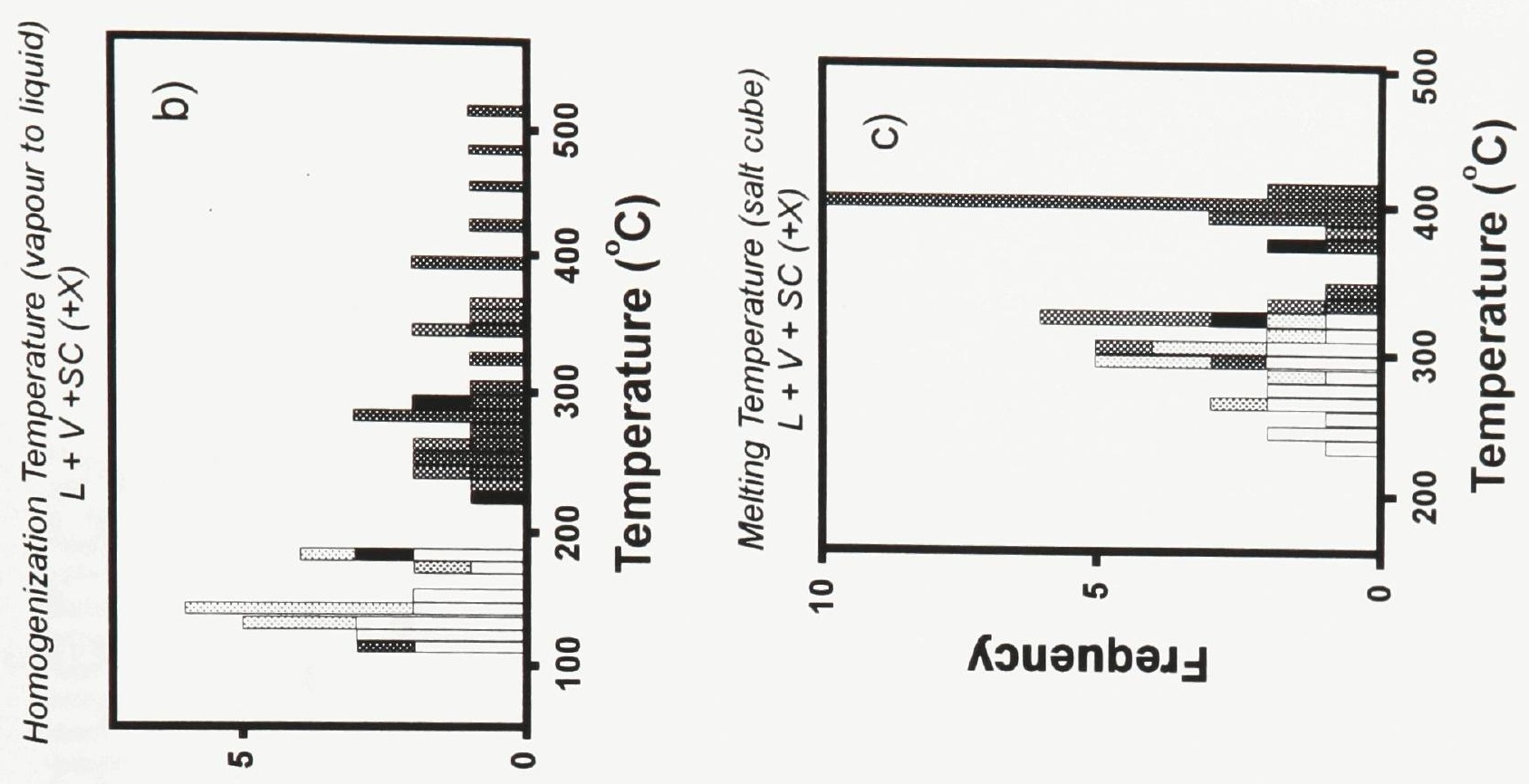

\section{אכuanbad}
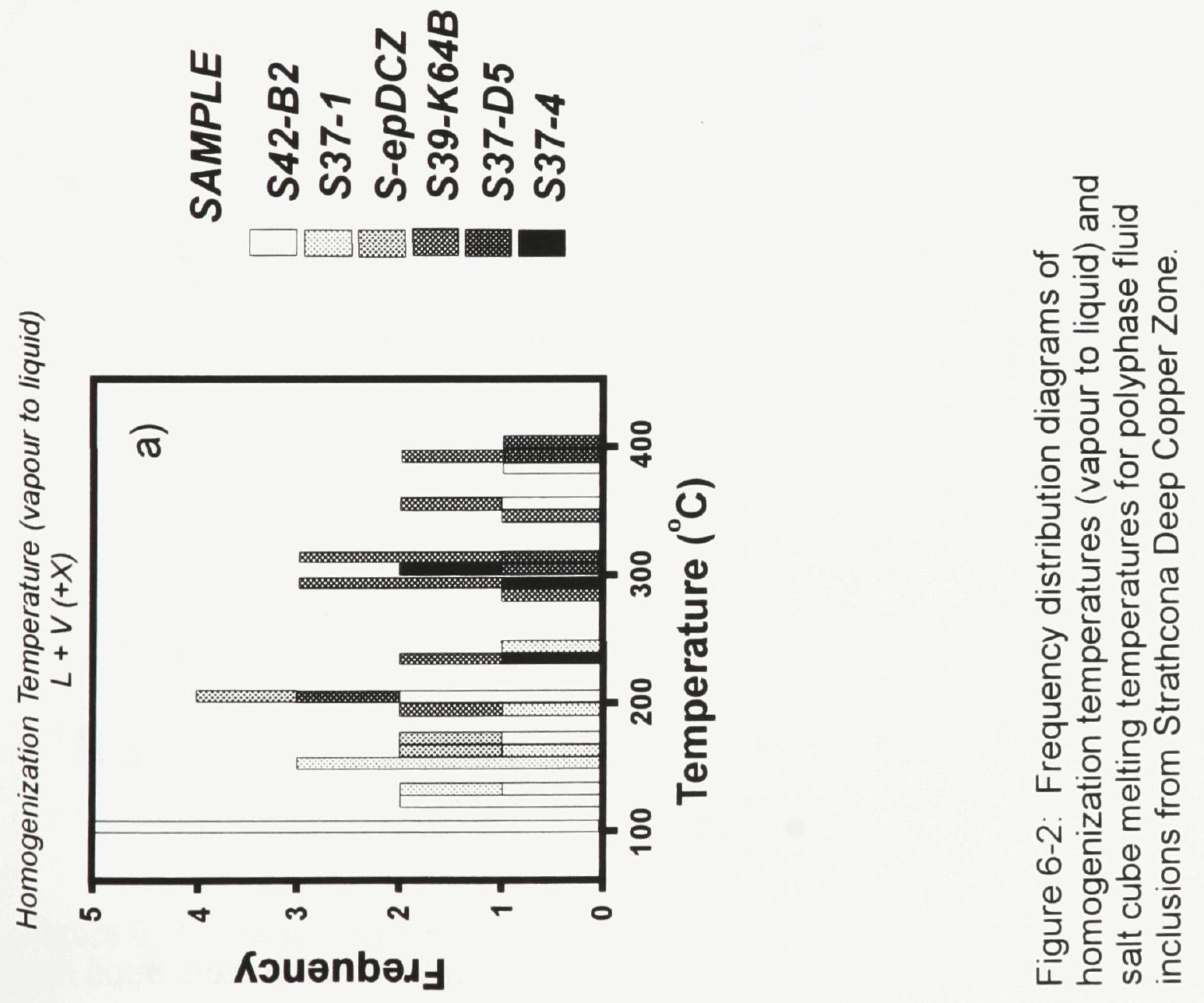


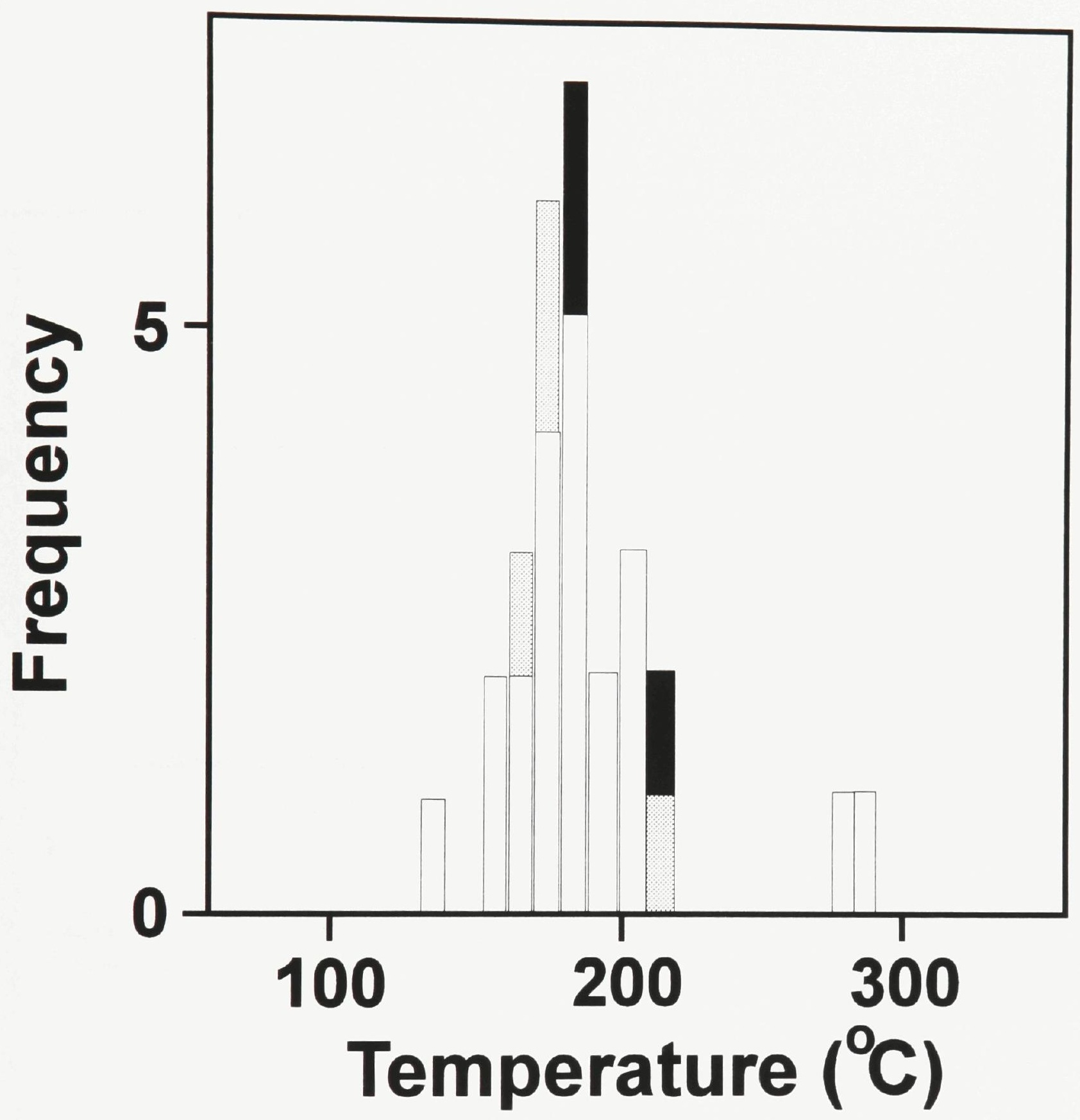

\section{LEGEND}

Homogenization temperature (liquid to vapour, no salt cube) Homogenization temperature (liquid to vapour, salt cube)

Salt cube melting temperature

Figure 6-3: Frequency distribution diagram of homogenization temperatures and salt cube melting temperatures for fluid inclusions from the Barnet Property. 


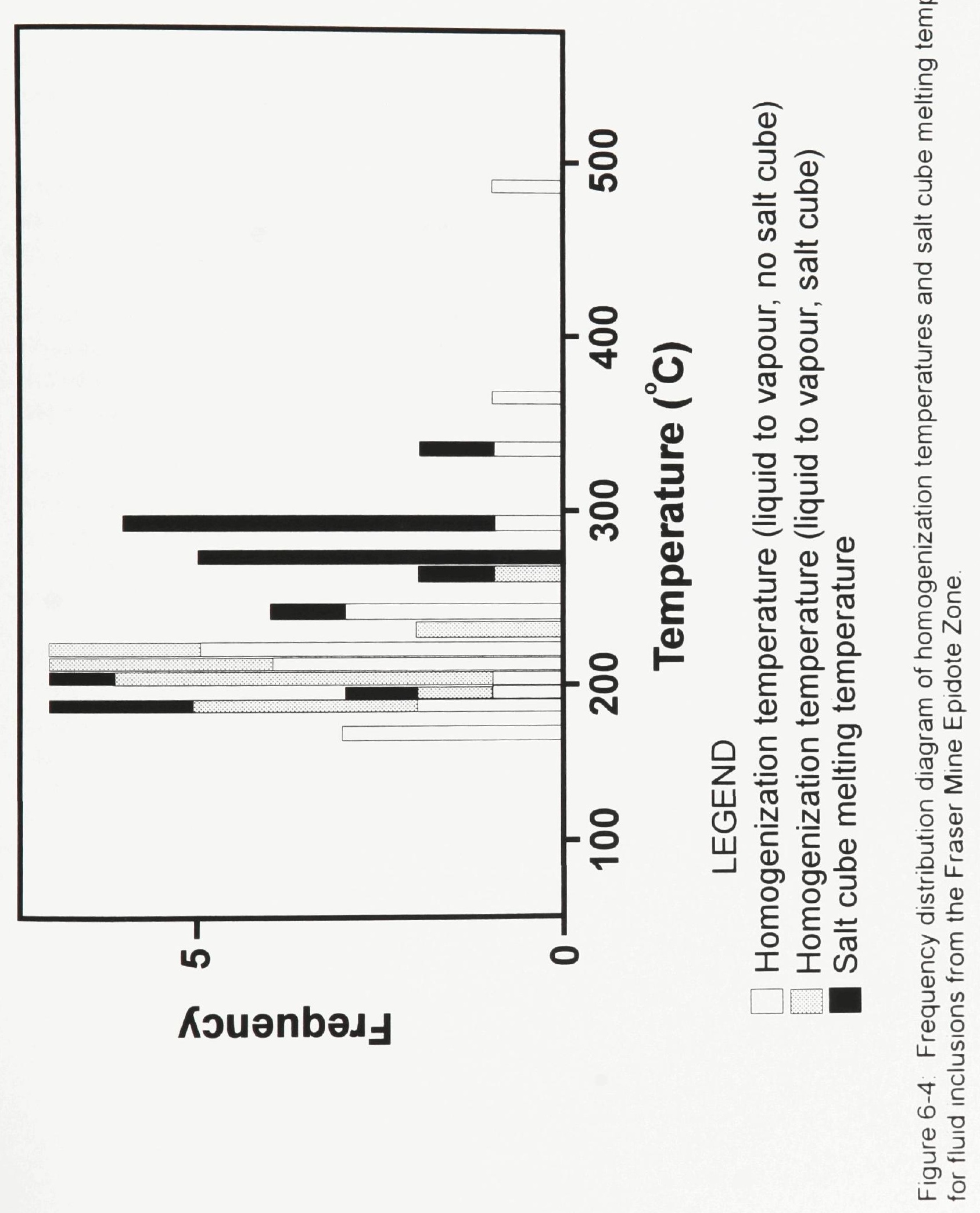




\section{PLATE CAPTIONS}

Plate 6-1a: Three phase (liquid + vapour + salt cube) fluid inclusion in quartz with nearby chalcopyrite. Fluid inclusion length is approximately $10 \mu \mathrm{m}$. Sample S37-1iii, 3700 level, Strathcona Mine Deep Copper Zone. Regular transmitted light.

Plate 6-1b: Two phase (liquid + vapour) fluid inclusion with a negative crystal shape in quartz. Fluid inclusion length is approximately $8 \mu \mathrm{m}$. Sample S37-1, 3700 level, Strathcona Mine Deep Copper Zone. Regular transmitted light.

Plate 6-1c: Three phase (liquid + vapour + salt cube) fluid inclusion in quartz. Fluid inclusion length is approximately $15 \mu \mathrm{m}$. Sample S37-1, 3700 level, Strathcona Mine Deep Copper Zone. Regular transmitted light.

Plate 6-1d: Polyphase (liquid + vapour + salt cube +3 non-birefringent solid phases) fluid inclusion in quartz. The non-birefringent solids are salts. Fluid inclusion length is approximately $10 \mu \mathrm{m}$. Sample S37-1, 3700 level, Strathcona Mine Deep Copper Zone. Regular transmitted light.

Plate 6-1e: Polyphase fluid inclusions with several solids including a round, non-birefringent phase in quartz. SEM-EDS analyses suggest that these are $\mathrm{Ca}$ and $\mathrm{Na}$ chlorides. The length of the largest fluid inclusion is approximately 27 $\mu \mathrm{m}$. Sample S37-D5, 3700 level, Strathcona Mine Deep Copper Zone. Regular transmitted light.

Plate 6-1f: Polyphase (liquid + vapour + 2 high relief, non-birefringent phases + 1 low relief, non-birefringent phase) fluid inclusion in quartz. Sample is from a quartz + epidote vein that cross-cuts relatively unaltered Footwall Breccia near a well-developed Epidote Zone patch. The length of the fluid inclusion in the centre of the photomicrograph is approximately $9 \mu \mathrm{m}$. Sample F46-31, Exploration Drift 46-190, Fraser Mine. Regular transmitted light. 

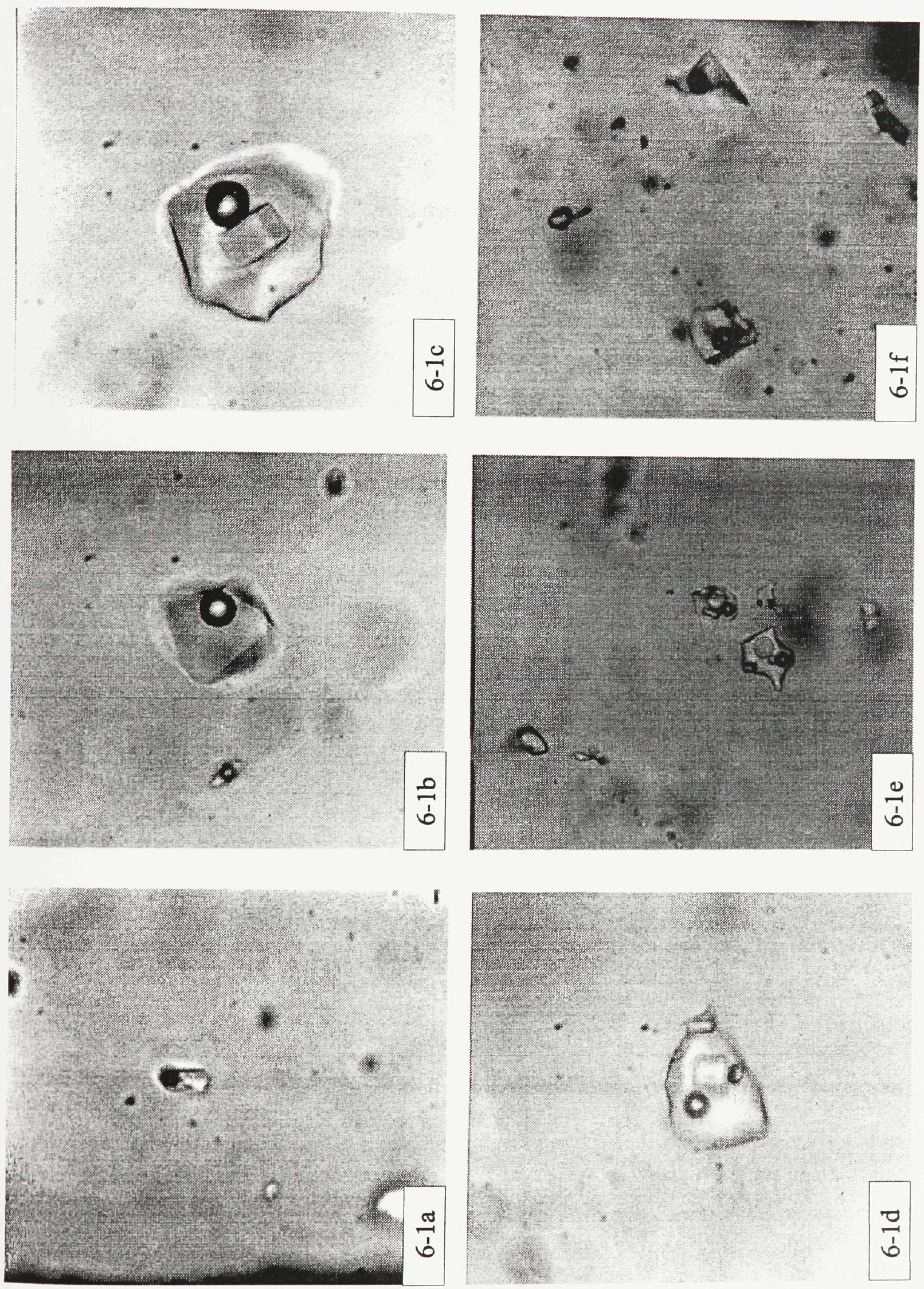


\section{PLATE CAPTIONS}

Plate 6-2a: Colour-enhanced secondary electron image of a broken surface in quartz showing three opened fluid inclusions. All three contain a large halite solid phase. Smaller daughter minerals are $\mathrm{CaCl}_{2}$. Minor $\mathrm{Fe}, \mathrm{Mn}$ and $\mathrm{K}$ peaks appear on the $\mathrm{CaCl}_{2}$ spectra. Sample S37-1, 3700 level, Strathcona Mine Deep Copper Zone.

Plate 6-2b: Secondary electron image of a broken surface in pyrite showing two large, $\mathrm{NaCl}$-bearing fluid inclusions. Sample F48-92-5, 4800 level, Fraser Mine Epidote Zone.

Plate 6-2c: Secondary electron image of a large $\mathrm{NaCl}$ cube in a fluid inclusion with a negative crystal shape in bornite. Sample STN-4, 3900 level, Strathcona Mine Deep Copper Zone.

Plate 6-2d: Secondary electron image of a large $\mathrm{NaCl}$ cube in a fluid inclusion in pyrite. Sample F48-92-2, 4800 level, Fraser Mine Epidote Zone.

Plate 6-2e: Secondary electron image of two $\mathrm{NaCl}$ and two $\mathrm{PbCl}_{2}$ daughter solids with an accidental cassiterite rod in an opened fluid inclusion in chalcopyrite. Sample CFA-92-3, Barnet property.

Plate 6-2f: Secondary electron image of an opened fluid inclusion in quartz with three daughter phases. The central phase in an Fe-rich chloride with minor $\mathrm{Mn}$ in the spectra. To the left is $\mathrm{NaCl}$, although analysis shows contamination by $\mathrm{Fe}$ and $\mathrm{Mn}$ from the adjacent phase. The phase to the right is a $\mathrm{Ca}$-rich chloride with abundant K. Sample S42-B23, 4200 level, Strathcona Mine Deep Copper Zone. 

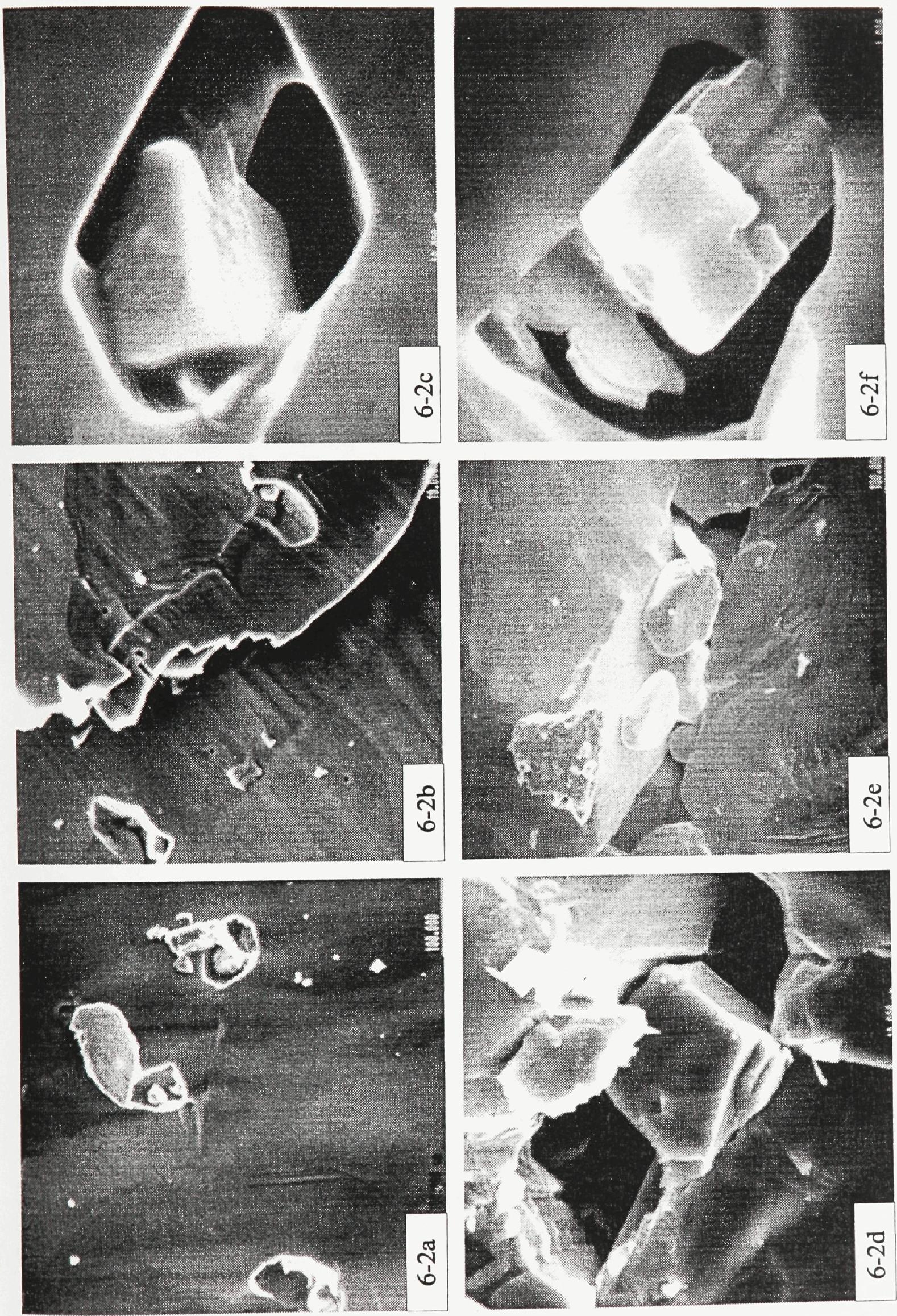


\section{PLATE CAPTIONS}

Plate 6-2g: Secondary electron image of an opened fluid inclusion in quartz with an adjacent halite cube. The small solid is $\mathrm{CaCl}_{2}$. The chloride precipitate is $\mathrm{Na}$-rich with considerable $\mathrm{Ca}$. The fluid inclusion was opened in a vacuum and therefore the precipitate has a regular outline.

Plate 6-2h: Secondary electron image of an opened fluid inclusion in chalcopyrite. A large $\mathrm{NaCl}$ solid and a sphalerite accidental inclusion are attached to the fluid inclusion wall. The precipitate is a $\mathrm{Ca}$ and $\mathrm{Na}$-rich chloride. The irregular pattern of the precipitate is the result of it having been opened in air.

Plate 6-2i: Secondary electron image of an empty opened fluid inclusion in quartz. The mottled precipitate is composed of approximately equal proportions of $\mathrm{Ca}$ and $\mathrm{Na}$-chloride with minor $\mathrm{K}$. The sample was opened in a vacuum. Sample MW-600-1, 600 level, McCreedy West Mine.

Plate 6-2j: Secondary electron image of "boiled" Ca-rich chloride in quartz. See text for detailed discussion. Sample S37-1, 3700 level, Strathcona Deep Copper Zone. 


\section{PLATE CAPTIONS}

Plates 6-3a and b: Backscattered electron image of native $\mathrm{Ag}$ (white) with a mottled rim of $\mathrm{AgCl}_{2}$ (chlorargyrite). The host minerals are bornite (dark grey) and calcite (black). Sample STN-4, Strathcona Mine Deep Copper Zone.

Plates $6-3 \mathrm{c}$ and $\mathrm{d}$ : Secondary electron image of a native $\mathrm{Ag}$ grain in an opened fluid inclusion in chalcopyrite from the Barnet property. The mottled surface of the grain is composed of $\mathrm{AgCl}_{2}$. 


\section{CHAPTER 7: ISOTOPE GEOCHEMISTRY}

\section{7-1. INTRODUCTION}

Previous stable isotope investigations in the Sudbury area are limited to groundwaters within and around the Sudbury Structure (Frape and Fritz, 1982; Frape et al., 1984), O isotopic compositions of various lithologies in the Sudbury area (Ding and Schwarcz, 1984), and alteration associated with Proterozoic base-metal deposits within the Basin (Davies et al., 1990).

This stable isotope study of alteration associated with Ni-Cu-PGE mineralization in the North Range of the Sudbury Structure was undertaken to characterize the isotopic signature of the alteration minerals, further identify their temperature of formation and determine possible source fluids. Analyzed alteration mineral separates from the Barnet Property, Strathcona Deep Copper and Copper zones and the Fraser Epidote Zone include amphibole, magnetite, epidote, K-feldspar, quartz, titanite and calcite. This is the first study of its kind in the Sudbury area.

Previous stable isotope geochemical studies of layered mafic intrusions have shown that some, like the Stillwater Complex (Dingwall and Dunn, 1982; Dunn, 1986) and the Kiglapait Intrusion (Kalamarides, 1982; 1984), have retained their magmatic isotopic signatures, whereas the Skaergaard Intrusion (Taylor and Epstein, 1963; Taylor, 1968; Norton and Taylor, 1979; Taylor and Forester, 1979) the Cuillins Complex, Isle of Skye (Forester and Taylor, 1977) and the Kap Edvard Holm Complex, East Greenland (Fehlhaber and Bird, 1991) 
have modified isotopic values caused by the circulation of meteoric water (Taylor and Epstein, 1963; Taylor, 1968; Taylor and Forester, 1979). Rocks of the Muskox Intrusion reacted with magmatic water during cooling (Taylor, 1968).

Previous $\mathrm{Rb}-\mathrm{Sr}$ and $\mathrm{Nd}-\mathrm{Sm}$ isotope studies of North Range footwall rocks include those of Basu et al. (1985), Naldrett et al. (1985) and Deutsch et al. (1989). These studies focused on the origin of the Sudbury Structure and the Sudbury Igneous Complex. McNutt et al. (1990) reported ${ }^{87} \mathrm{Sr} /{ }^{86} \mathrm{Sr}$ values of Sudbury area groundwaters as part of their study of Canadian Shield groundwater isotopic compositions. This investigation represents a preliminary study of the $\mathrm{Rb}-\mathrm{Sr}$ and $\mathrm{Nd}-\mathrm{Sm}$ signatures of the alteration minerals associated with Ni-Cu-PGE mineralization in the North Range footwall.

\section{7-2. STABLE ISOTOPE STUDY}

\section{7-2a. INTRODUCTION}

In order to identify the stable isotope composition and fluid source, mineral separates were analysed for $\delta^{18} \mathrm{O}, \delta \mathrm{D}$ and $\delta^{13} \mathrm{C}$ compositions. Stable isotopic ratios are reported in the standard \%o notation and are compared to SMOW (Standard Mean Ocean Water) except where otherwise indicated. Sample preparation and analytical techniques are summarized in Appendix VIII. For mineral pairs it was attempted on petrographic bases to establish if the minerals were in equilibrium; except for sample F46-37 this was the case. Stable isotope values for individual mineral separates are listed in Table 7-1 and illustrated in Figures 7-1 and 7-2. 


\section{7-2b. OXYGEN ISOTOPES}

$\delta^{18} \mathrm{O}$ ranges for individual mineral separates from the Barnet Property, Deep Copper Zone and the Epidote Zone are similar, but some subtle differences exist. For example, $\delta^{18} \mathrm{O}$ values for epidote from the Epidote Zone are slightly lower (range from -2.3 to $0.9 \%$ ) than those from the Barnet Property and the Deep Copper Zone (range from 0.2 to $4.8 \%$ ). A similar trend is displayed by Epidote Zone quartz ( 4.3 to $6.4 \%$ ) when compared to Barnet Property and Deep Copper Zone quartz (8.2 to 10.7\%o). Calcite from the Epidote Zone has lower $\delta^{18} \mathrm{O}(7.1$ to $8.5 \%$ ) than calcite from the Deep Copper Zone $(8.3$ to $10.3 \%)$.

\section{7-2c. HYDROGEN ISOTOPES}

Hydrogen-isotope trends are not as easily defined as those for oxygen isotopes due to limited data (Figure 7-3). However, the only amphibole analyzed from the Copper Zone has a $\delta D$ value of -47 compared to -65 to $-72 \%$ of the Deep Copper and Epidote zones, although its $\delta^{18} \mathrm{O}$ value is similar to those from amphiboles from the Deep Copper and Epidote zones. The epidote $\delta D$ values range between -23 and $-4 \%$ and vary by $16 \%$ among Epidote Zone samples alone. However, because of the strong dependency of $\delta \mathrm{D}$ values on Fe content in epidote and the poor experimental characterization of this relationship, the epidote $\delta D$ values determined as part of this study are enigmatic. The role of fluid composition on isotopic fractionation is discussed below.

Graham and Sheppard (1980) showed that hydrogen isotope 
fractionations between epidote, and, by analogy, other hydrous minerals, and aqueous solutions are dependent on the chemical composition of the solution at temperatures less than $550^{\circ} \mathrm{C}$. This brings the effect on solution chemistry into question with reference to oxygen isotope fractionations. Fluid inclusion investigations have shown the fluids involved in the alteration mineralization to be extremely saline (Chapter 6; Farrow and Watkinson, 1992; Li and Naldrett, 1993d).

\section{7-2d. CARBON ISOTOPES}

Carbon isotopic analyses of calcite from both the Deep Copper Zone and the Epidote Zone show two distinct populations (Figure 7-4). Deep Copper Zone $\delta^{13} \mathrm{C}$ of calcite range between -2.5 and -2.8 , whereas Epidote Zone calcite has $\delta^{13} \mathrm{C}$ values of -5.8 and $-6.2 \%$. This suggests that the fluids involved in Deep Copper and Epidote zone development were compositionally different.

\section{7-2e. OXYGEN VS. HYDROGEN ISOTOPES}

Figure 7-5 shows that a two-stage evolution model is suggested by $\delta D$ and $\delta^{18} \mathrm{O}$ values of amphibole and epidote. Amphibole formed under specific $\delta^{18} \mathrm{O}$ conditions and a narrower range of $\delta \mathrm{D}$ compositions than did epidote. This indicates that the fluids responsible for epidote formation were poorly mixed, reflecting various $\delta^{18} \mathrm{O}$ and $\delta \mathrm{D}$ fluid compositions.

Variations between $\delta^{18} \mathrm{O}$ and $\delta \mathrm{D}$, and the Ps (\%) composition of epidote, and $\mathrm{Mg}$ \# of amphibole are shown in Figures 7-6a, b, c and d. Limited data precludes a meaningful interpretation of the effect of mineral chemistry on the 
stable isotopic composition of each mineral.

\section{7-2f. FLUID COMPOSITION}

It is possible to calculate the isotopic composition of the fluid in equilibrium with each of these minerals using applicable fractionation curves and the approximate formation temperatures derived from fluid inclusion measurements. Experimental determinations of fractionation curves for titanite are not available in the literature.

Calculated fluid $\delta^{18} \mathrm{O}$ compositions from Deep Copper Zone and Barnet quartz $\delta^{18} \mathrm{O}$ values (calculated range -3.3 to $3.3 \%$ using a variety of fractionation equations for quartz-epidote pairs) are more enriched in $\delta^{18} \mathrm{O}$ than calculated fluid values for the Epidote Zone (-6.4 to $-4.4 \%$; Table $7-2)$. This implies that the fluids involved in Epidote Zone development had lower $\delta^{18} \mathrm{O}$ values and/or were higher temperature than those from the footwall $\mathrm{Cu}$-vein deposits. The first possibility suggests that fluids reacted with the relatively $\delta^{18} \mathrm{O}$ -rich host gneisses/migmatites during the development of the Deep Copper Zone and thus, became isotopically heavier. Ding and Schwarz (1984) showed that the footwall gneisses in the Hwy. 144 area have whole rock $\delta^{18} \mathrm{O}$ values of between 6.3 and $9.0 \%$. The latter possibility supports the temperature gradient indicated by fluid inclusion microthermometric data presented in Chapter 6 . By comparison, Davies et al. (1990) reported calculated $\delta^{18} \mathrm{O}$ values of modified seawater responsible for the deposition of $\mathrm{Cu}-\mathrm{Pb}-\mathrm{Zn}$ deposits in the Sudbury Basin of approximately $-1 \%$ at temperatures $>100{ }^{\circ} \mathrm{C}$, but lower than those from 
Deep Copper Zone.

Hydrogen isotopic composition of the fluids from Cu-rich vein, and Epidote Zone epidote and amphibole alteration were calculated using the fractionation equations of Graham and Sheppard (1980) for epidote, and Suzuoki and Epstein (1976) and Graham et al. (1984) for amphibole. All calculated hydrogen isotopic contents of fluid are enriched in D. Calculations using amphibole result in lower $\delta D$ values than epidote-based calculations and tend to be $>0$. However, unlike $\delta^{18} \mathrm{O}$ values that were different for $\mathrm{Cu}$-rich and Epidote Zone alteration, $\delta D$ values are similar for both. Because of the limited experimental information on the effect of both hypersaline brines, and the uncertain effect of variable amphibole compositions and structures on hydrogen isotope fractionation, the calculated $\delta D$ values of the fluid are presented with limited confidence and are used to illustrate a trend toward extreme $\delta \mathrm{D}$ enrichment.

This enrichment has also been shown for Sudbury area groundwaters (Frape and Fritz, 1982; Figure 7-7). In their groundwater study, Frape and Fritz (1982) showed that the greatest $\delta D$ enrichment was associated with the highest salinity brines. It is possible that the hypersaline fluids associated with footwall orebody development lie along this trend. In addition, previous studies have shown that the formation of hydrated salts may result in a shift to more positive $\delta D$ values in the fluid (Sofer and Gat, 1975; Grabczak et al., 1986). SEM-EDS study of daughter minerals in fluid inclusions associated with Cu-Ni-PGE 
deposition has shown that hydrated salts were formed from the mineralizing fluid.

No estimations were made of temperature of formation from fluid inclusions for the magnetite-rich facies of the Epidote Zone. Fluid compositions for this style of alteration will be discussed below.

\section{7-2g. GEOTHERMOMETRY}

Table 7-3 represents a summary of oxygen isotope fractionations for mineral pairs, calculated temperatures and fluid compositions. Temperatures of formation of quartz-epidote Cu-vein alteration associations in the Deep Copper Zone and Barnet were estimated between $196^{\circ}$ and $241^{\circ} \mathrm{C}$ from the empirically estimated epidote- $\mathrm{H}_{2} \mathrm{O}$ fractionations of Matthews et al. (1983a). The range of temperatures is within that indicated by fluid inclusion data. One epidote-quartz pair (sample F46-209-12.8) from the Epidote Zone gave an estimated temperature of formation of approximately $213^{\circ} \mathrm{C}$. This temperature is slightly lower than those from fluid inclusion microthermometric data. An explanation for this is that the experimental data of Matthews et al. (1983a) was optimized in the range 400 to $700^{\circ} \mathrm{C}$. The extrapolations necessary for using this equation at temperatures well below $400^{\circ} \mathrm{C}$ could cause some inaccuracies, especially since the ${ }^{18} \mathrm{O}$ fractionation behaviour of epidote has not been experimentally calibrated.

One quartz-magnetite pair from an Epidote Zone occurrence at the base of the ramp on 4800 level of Fraser Mine has yielded temperatures of $473^{\circ} \mathrm{C}$ 
using the empirical method of Bottinga and Javoy (1975) and $509^{\circ} \mathrm{C}$ using the method of Matthews et al. (1983b). However, these represent very steep trends on a $\Delta_{\mathrm{Qtz}-\mathrm{Mag}}$ vs. $10^{6} / \mathrm{T}^{2}$ plot and, therefore, are not very accurate geothermometers. Nevertheless, these temperatures are considerably higher than those determined for quartz + epidote + actinolite assemblages from both Cu-rich vein alteration and the Epidote Zone as determined by fluid inclusion and stable isotopes. Although data is limited, and quartz coexisting with magnetite is uncommon in the Epidote Zone, petrographic study suggests that magnetite-rich parts of the Epidote Zone have grown at the expense of epidote + actinolite alteration assemblages. As a result, it is possible that a pulse of higher temperature hydrothermal activity is responsible for its unique mineralogy of oxide, sulphide, and precious metal minerals.

Other mineral pairs, such as quartz-calcite and epidote-calcite could not be used for geothermometry due to a lack of equilibrium. Overgrowth textures of calcite on quartz and epidote suggest that calcite formed later, and possibly at a lower temperature than the other analyzed phases.

\section{7-2h. DISCUSSION}

The limited $\delta^{18} \mathrm{O}$ and $\delta \mathrm{D}$ values of this study preclude the interpretation of the relationship between mineral chemistry and isotopic composition. Only medium- to coarse-grained minerals that could be separated by conventional methods were analysed; it is possible that they reflect a slightly different isotopic composition than fine-grained equivalents. Other problems in stable isotope 
calculations and interpretations of these rocks include the very saline nature of the fluids as determined by fluid inclusion study (Chapter 6).

i. Composition and origin of altering fluids.

Slight variations in $\delta^{18} \mathrm{O}$ and $\delta^{13} \mathrm{C}$ values for mineral separates from the Deep Copper and Epidote zones suggest that fluid compositions and/or temperatures involved in their development were different. Lower $\delta^{18} \mathrm{O}$ values displayed by Epidote Zone mineral separates would support the suggestion in Chapter 6 that higher temperature fluids were involved in Epidote Zone development. However, fluid compositional changes are possible in that $\mathrm{Cu}$ vein fluids reacted with higher $\delta^{18} \mathrm{O}$ host rocks.

At this point it is difficult to estimate the water-rock ratio of the reacting hydrothermal fluids in the footwall of the Sudbury Igneous Complex. However, the limited amount of pervasive alteration away from sulphide mineralization indicates that it was relatively low, with fluid movement being structurally controlled by dilation fractures in the case of footwall Cu-rich veining, and that the hypersalinity of the fluid resulted in a low $\mathrm{a}_{\mathrm{H} 2 \mathrm{O}}$. The veins and alteration patches of the Epidote Zone contained fluids that had exhibited the greatest degree of chemical and isotopic exchange with their host rocks.

\section{7-3. RADIOGENIC ISOTOPE STUDY}

\section{7-3a. RUBIDIUM/STRONTIUM AND SAMARIUM/NEODYMIUM}

Alteration mineral separates analysed for all three deposits are epidote. Because epidote has a very low $\mathrm{Rb} / \mathrm{Sr}$ ratio, its $\mathrm{Sr}$ isotopic ratio will not change 
significantly over time. Variations in ${ }^{87} \mathrm{Sr} /{ }^{86} \mathrm{Sr}$ with increasing distance from the SIC to the left (Figure 7-7) are strong among and within deposits, suggesting that the fluids were not well mixed, SIC magmatic fluids. This is especially evident in the Deep Copper Zone and Barnet Property, where ${ }^{87} \mathrm{Sr} /{ }^{86} \mathrm{Sr}$ ratios range between 0.703 and 0.706 . The overall range of ${ }^{87} \mathrm{Sr} /{ }^{86} \mathrm{Sr}$ values for North Range alteration epidote is 0.703 to 0.707 . This is slightly lower than that of 0.710 to 0.713 for footwall rocks east of the Bob's Lake Fault (North Mine) reported by Frape et al., 1984.

A plot (Figure 7-8) of $\epsilon \mathrm{Nd}(1.85 \mathrm{Ga})$ vs. $€ \mathrm{Sr}(1.85 \mathrm{Ga})$ shows that epidote alteration associated with Cu-rich veining at the Deep Copper Zone has a strong overprint from the host Levack Gneiss. The only analysed sample plots very close to the field for Levack Gneiss of Naldrett et al., 1985.

\section{7-4. DISCUSSION}

The information presented in Chapter 6, and the isotopic data presented in this chapter suggest that the fluid involved in $\mathrm{Cu}-\mathrm{Ni}$-PGE mineralization in the North Range footwall was predominantly composed of deep formation waters, and that it was not compatible with the interpretation that sulphide-rich veins in the footwall precipitated from differentiated sulphide magma, or that the hydrothermal fluids were the result of melt-fluid phase separation during the crystallization of the sulphide liquid. The calculated $\delta^{18} \mathrm{O}$ values of water in equilibrium with quartz and calcite from alteration associated with $\mathrm{Cu}-\mathrm{Ni}$-PGE mineralization varies from -3 to $+3 \% 0_{\mathrm{SMOW}}$. $\epsilon_{\mathrm{Nd}}(1.85 \mathrm{Ga})$ and $\epsilon_{\mathrm{Sr}}(1.85 \mathrm{Ga})$ 
values from epidote alteration from Deep Copper Zone veining in Sudbury Breccia developed in the Levack Gneiss Complex are close to the $\epsilon_{\mathrm{Nd}} v s . \epsilon_{\mathrm{Sr}}$ field for the Levack Gneiss Complex defined by Naldrett et al. (1985). By comparison, the most saline deep groundwaters from the North Mine (near Fraser Mine) yielded ${ }^{87} \mathrm{Sr} /{ }^{86} \mathrm{Sr}$ ratios of 0.7155 (McNutt et al., 1990). This is considerably higher than the values for alteration epidote from other locations in the North Range.

\section{7-4a. COMPARISON WITH SUDBURY-AREA GROUNDWATERS}

Present-day, deep (>650 m), saline formational waters and brines in Shield areas are either enriched in deuterium or depleted in ${ }^{18} \mathrm{O}$ when compared to present day meteoric waters (Fig. 7-9, Frape et al., 1984). More specifically, Sudbury area brines tend to be more enriched in deuterium and ${ }^{18} \mathrm{O}$ than other Shield locations, including Yellowknife and Thompson (Frape et al., 1984). Although the origin of these fluids is not well constrained, Frape and Fritz (1982) suggested that they may have a fossil marine origin.

Although calculated fluid compositions from alteration mineral separates are more enriched in ${ }^{18} \mathrm{O}$ and $\mathrm{D}$ than present day deep Sudbury brines, equivalent formational waters during the Sudbury Event could still be considered as possible fluid sources during the development of the footwall orebodies. Reaction with ${ }^{18} \mathrm{O}$ enriched footwall gneisses and migmatites at elevated temperatures may have been responsible for the higher $\delta^{18} \mathrm{O}$ values calculated for the ore-forming fluids. In addition, calculated fluid $\delta^{18} \mathrm{O}$ values for fluids 
associated with $\mathrm{Cu}$-rich vein deposition overlap with present-day seawater $\delta^{18} \mathrm{O}$ values. Estimates of oxygen isotope composition of seawater during the Sudbury Event range between 0 and $-6 \%$ (Karhu and Epstein, 1986), and 0 and $-3 \%$ (Sheppard, 1986). By comparison, the Epidote Zone fluid is depleted in $\delta^{18} \mathrm{O}$ relative to present-day seawater, but may have been similar to fossil seawater or formational brines at the time of the Sudbury Event. Abundant seawater is likely to have been available for incorporation into hydrothermal systems associated with CU-Ni-PGE deposition since it has been proposed that the Sudbury Event took place in a continental shelf environment (Morrison et al., 1994). Therefore, rocks of the Sudbury Structure may have had extensive interaction with these heated fluids. 
Table 7-1: Stable isotope data from the Barnet Property, Strathcona Mine Deep Copper and Copper zones, and Fraser Mine Epidote Zone.

\begin{tabular}{|c|c|c|c|c|c|c|c|c|c|c|c|}
\hline Deposit & Sample \# & $\begin{array}{l}\delta^{18} \mathrm{O} \\
\text { Amph }\end{array}$ & $\begin{array}{l}\delta^{18} \mathrm{O} \\
\mathrm{Mag}\end{array}$ & $\begin{array}{l}\delta^{18} \mathrm{O} \\
\mathrm{Ep}\end{array}$ & $\begin{array}{l}\delta^{18} \mathrm{O} \\
\mathrm{Kf}\end{array}$ & $\begin{array}{l}\delta^{18} \mathrm{O} \\
\text { Qtz }\end{array}$ & $\begin{array}{l}\delta^{18} \mathrm{O} \\
\text { Tnt }\end{array}$ & $\begin{array}{l}\delta^{18} \mathrm{O} \\
\mathrm{Cc}\end{array}$ & $\begin{array}{l}\delta^{13} C_{P D B} \\
C C\end{array}$ & $\begin{array}{l}\text { SD } \\
\text { Amph }\end{array}$ & $\begin{array}{l}\delta D \\
E p\end{array}$ \\
\hline \multirow[t]{3}{*}{ Barnet } & CFA-052 & & & & 7.4 & 8.2 & & & & & \\
\hline & CFA-91-1A & & & 1.6 & & $\begin{array}{l}8.0 \& \\
8.7\end{array}$ & & & & & -16 \\
\hline & CFAS-3 & & & 2.3 & 9.0 & 8.9 & & & & & -23 \\
\hline \multirow{7}{*}{$\begin{array}{l}\text { Deep } \\
\text { Copper } \\
\text { Zone }\end{array}$} & S37-D5A & & & & & 10.3 & & & & & \\
\hline & DCZ-DM5 & 2.8 & & & & & & & & -72 & \\
\hline & S39-K63!vi & & & 0.2 & & & & & & & -10 \\
\hline & S42-D5 & & & & & 10.1 & & $\begin{array}{l}8.8 \& \\
8.6\end{array}$ & $\begin{array}{l}-2.6 \& \\
-2.6\end{array}$ & & \\
\hline & S39-1620 & & & 4.8 & & 10.7 & & $\begin{array}{l}10.6 \& \\
10.3\end{array}$ & $\begin{array}{l}-2.6 \& \\
-2.8\end{array}$ & & -10 \\
\hline & S37-1 & & & & & 8.7 & & & & & \\
\hline & S42-D13 & & & & & & & $\begin{array}{l}8.4 \& \\
8.3\end{array}$ & $\begin{array}{l}-2.6 \& \\
-2.5\end{array}$ & & \\
\hline $\begin{array}{l}\text { Copper } \\
\text { Zone }\end{array}$ & $\begin{array}{l}\text { 27AOCO- } \\
\text { K13viii }\end{array}$ & 2.9 & & & & & & & & -47 & \\
\hline \multirow{8}{*}{$\begin{array}{l}\text { Epidote } \\
\text { Zone }\end{array}$} & F46-4Eii & 2.5 & & & & & & & & -69 & \\
\hline & $\begin{array}{l}\text { F46-209- } \\
12.8\end{array}$ & & & -2.3 & & 4.3 & & & & & -5 \\
\hline & F46-3G & 2.9 & & & & & & & & -66 & \\
\hline & F46-3A & 2.5 & & 0.9 & & & & & & -65 & -20 \\
\hline & $\begin{array}{l}\text { FR46-147- } \\
11\end{array}$ & & $\begin{array}{l}-3.9 \& \\
-3.5\end{array}$ & & & & & & & & \\
\hline & F46-37 & & 2.1 & & & & & $\begin{array}{l}7.3 \& \\
7.1\end{array}$ & $\begin{array}{l}-5.8 \& \\
-5.8\end{array}$ & & \\
\hline & F48-92-2 & & -3.6 & & & 6.4 & -4.4 & 8.5 & -6.2 & & \\
\hline & $\begin{array}{l}\text { FR46-147- } \\
9\end{array}$ & & & -1.5 & & & & & & & -4 \\
\hline
\end{tabular}

Abbreviations: Amph = amphibole $; \mathrm{Cc}=$ calcite $; \mathrm{Ep}=$ epidote $\mathrm{Kf}=\mathrm{K}$-feldspar $;$ Mag = magnetite $\mathrm{Qtz}=$ quartz; Tnt $=$ titanite .

Note: Calcite values were obtained from the University of Ottawa stable isotope laboratory, Ottawa, Ontario. Other values were obtained by conventional methods from the BRGM-CNRS, Orléans, France. Values in bold type were obtained by laser ablation methods at the BRGM-CNRS. All $\delta^{18} \mathrm{O}$ and $\delta \mathrm{D}$ values reported in $\%_{\text {SMOW }}$. 
Table 7-2: Calculated fluid isotopic compositions using various fractionation equations and temperatures.

Table 7-2a: Calculated fluid isotopic compositions using quartz.

\begin{tabular}{|c|c|c|c|c|c|c|}
\hline \multirow[t]{2}{*}{ Location } & \multirow[t]{2}{*}{ Sample } & \multirow[t]{2}{*}{$\begin{array}{l}\delta^{180} \\
\text { Sample }\end{array}$} & \multirow[t]{2}{*}{$\begin{array}{l}\text { Temperature } \\
\left({ }^{\circ} \mathrm{C}\right)\end{array}$} & \multicolumn{3}{|c|}{ Calculated $\delta^{18} O_{\text {H2O }}$ (\& Equations) } \\
\hline & & & & $\begin{array}{l}\text { Clayton et } \\
\text { al. (1972) }\end{array}$ & $\begin{array}{l}\text { Clayton et } \\
\text { al. (1989) }\end{array}$ & $\begin{array}{l}\text { Matsuhisa et } \\
\text { al. } \\
\text { (1978;1979) }\end{array}$ \\
\hline \multirow[t]{6}{*}{ Barnet } & \multirow[t]{2}{*}{ CFA-052 } & \multirow[t]{2}{*}{8.2} & 250 & -0.8 & 1.2 & -0.7 \\
\hline & & & 300 & 1.3 & 3.0 & 1.4 \\
\hline & \multirow[t]{2}{*}{ CFA-91-1A } & \multirow[t]{2}{*}{8.0} & 250 & -1.0 & 1.0 & -0.9 \\
\hline & & & 300 & 1.1 & 2.8 & 1.2 \\
\hline & \multirow[t]{2}{*}{ CFAS-3 } & \multirow[t]{2}{*}{8.9} & 250 & -0.1 & 1.9 & 0 \\
\hline & & & 300 & 2.0 & 3.7 & 2.1 \\
\hline \multirow[t]{8}{*}{$\mathrm{DCZ}$} & \multirow[t]{2}{*}{ S37-D5A } & \multirow[t]{2}{*}{10.3} & 250 & 1.3 & 3.3 & 1.4 \\
\hline & & & 300 & 3.4 & 5.1 & 3.4 \\
\hline & \multirow[t]{2}{*}{ S42-D5 } & \multirow[t]{2}{*}{10.1} & 250 & 1.1 & 3.1 & 1.2 \\
\hline & & & 300 & 3.2 & 4.9 & 3.2 \\
\hline & \multirow[t]{2}{*}{ S39-1620 } & \multirow[t]{2}{*}{10.7} & 250 & 1.7 & 3.7 & 1.8 \\
\hline & & & 300 & 3.8 & 5.5 & 3.8 \\
\hline & \multirow[t]{2}{*}{ s37-1 } & \multirow[t]{2}{*}{8.7} & 250 & -0.3 & 1.7 & -0.2 \\
\hline & & & 300 & 1.8 & 3.5 & 1.9 \\
\hline \multirow[t]{2}{*}{ EPDZ } & \multirow[t]{2}{*}{ F46-209-12.8 } & 4.3 & 300 & -2.6 & -0.9 & -2.5 \\
\hline & & 6.4 & 300 & -0.5 & 1.2 & -0.4 \\
\hline
\end{tabular}


Table 7-2b: Calculated fluid isotopic compositions using calcite.

\begin{tabular}{|c|c|c|c|c|c|}
\hline \multirow[t]{2}{*}{ Location } & \multirow[t]{2}{*}{ Sample } & \multirow[t]{2}{*}{$\delta^{18} \mathrm{O}$ Sample } & \multirow{2}{*}{$\begin{array}{l}\text { Temperature } \\
\left({ }^{\circ} \mathrm{C}\right)\end{array}$} & \multicolumn{2}{|c|}{ Calculated $\delta^{18} \mathrm{O}_{\mathrm{H} 2 \mathrm{O}}$ (\& Equations) } \\
\hline & & & & $\begin{array}{l}\text { Friedmann \& } \\
\text { O'Meil (1977) }\end{array}$ & $\begin{array}{l}\text { O'Weil et al. } \\
\text { (1969) }\end{array}$ \\
\hline \multirow[t]{3}{*}{ DCZ } & S42-D5 & 8.6 & 250 & 1.3 & 1.8 \\
\hline & S39-1620 & 10.3 & 250 & 3.0 & 3.5 \\
\hline & $S 42-D 13$ & 8.3 & 250 & 1.0 & 1.5 \\
\hline \multirow[t]{4}{*}{ EPDZ } & \multirow[t]{2}{*}{$F 46-37$} & \multirow[t]{2}{*}{7.1} & 250 & -0.2 & 0.3 \\
\hline & & & 300 & 1.5 & 2.0 \\
\hline & \multirow[t]{2}{*}{ F48-92-2 } & \multirow[t]{2}{*}{8.5} & 250 & 1.2 & 1.7 \\
\hline & & & 300 & 2.9 & 3.4 \\
\hline
\end{tabular}




\begin{tabular}{|c|c|c|c|c|c|c|c|c|c|c|}
\hline \multicolumn{11}{|c|}{ 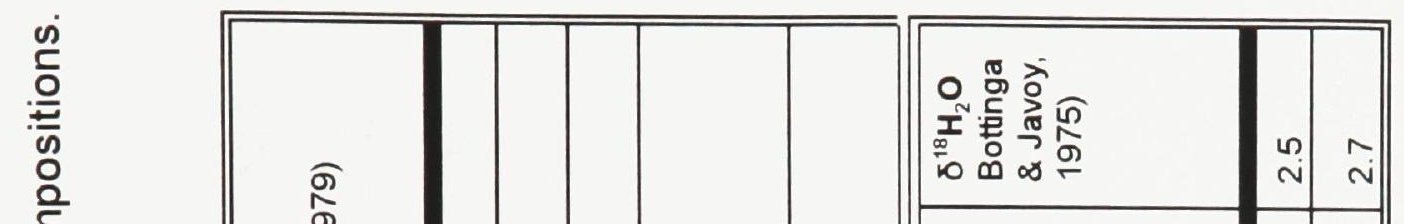 } \\
\hline$\frac{0}{0}$ & 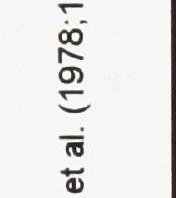 & & & & & & 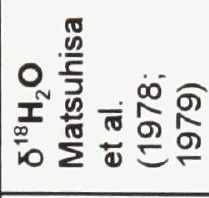 & & $\stackrel{m}{\sim}$ & $\hat{m}$ \\
\hline 点 & 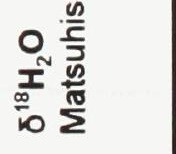 & $\stackrel{m}{\sim}$ & $\bar{r}$ & مִ & $\stackrel{+}{\sim}$ & 它 & 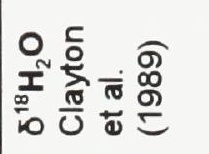 & & ఫे & $\stackrel{\sigma}{\forall}$ \\
\hline ֻัญ & 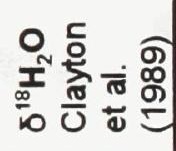 & on & $\begin{array}{l}0 \\
\stackrel{9}{i}\end{array}$ & $\stackrel{N}{o}$ & $\stackrel{m}{m}$ & $\underset{\dot{T}}{\dot{T}}$ & 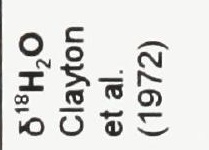 & & $\mid \begin{array}{l}m \\
\dot{v}\end{array}$ & $\hat{m}$ \\
\hline$\frac{\frac{\pi}{3}}{\frac{0}{\pi}}$ & 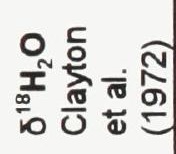 & 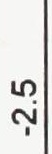 & $\stackrel{m}{p}$ & $\Upsilon$ & $\stackrel{m}{r}$ & $\begin{array}{l}n \\
\varphi \\
\varphi\end{array}$ & 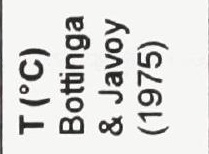 & $\stackrel{?}{\stackrel{?}{*}}$ & $\begin{array}{l}\text { : } \\
\text { 员 } \\
\text { () }\end{array}$ & $\stackrel{?}{\stackrel{9}{5}}$ \\
\hline 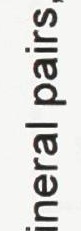 & 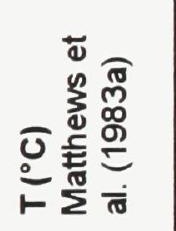 & $\overline{\mathrm{N}}$ & $\stackrel{\mathscr{\varrho}}{\leftarrow}$ & $\stackrel{m}{\sim}$ & $\underset{\mathbf{N}}{\bar{J}}$ & $\stackrel{m}{\sim}$ & 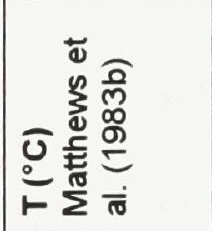 & 옹 & & \\
\hline$\frac{5}{2}$ & 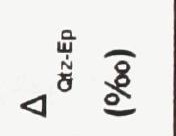 & $\begin{array}{l}\nabla \\
0\end{array}$ & $\therefore$ & $\begin{array}{l}0 \\
\dot{0}\end{array}$ & م) & $\ddot{\varphi}$ & 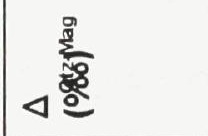 & 으 & & \\
\hline $\begin{array}{l}\dot{j} \\
0 \\
\frac{0}{0} \\
\frac{1}{0}\end{array}$ & $\begin{array}{l}\frac{8}{0} \\
\text { 음 } 0 \\
\text { 욤 }\end{array}$ & $\stackrel{\varphi}{-}$ & $\stackrel{\varphi}{-}$ & $\stackrel{m}{\mathrm{i}}$ & $\stackrel{\infty}{\forall}$ & $\stackrel{m}{\sim}$ & 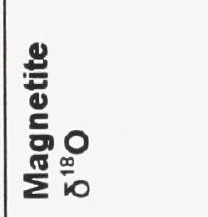 & $\stackrel{\varphi}{\dddot{P}}$ & & \\
\hline 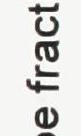 & 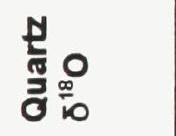 & $\infty$ & $\hat{\infty}$ & $\begin{array}{l}\infty \\
\infty \\
\infty\end{array}$ & 응 & $\stackrel{m}{\dot{q}}$ & 量 & $\ddot{\theta}$ & & \\
\hline 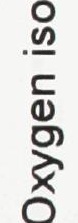 & $\begin{array}{l}\text { \# } \\
\text { है } \\
\text { हूँ }\end{array}$ & $\frac{\frac{5}{1}}{\frac{5}{9}}$ & & 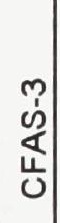 & 苂 & 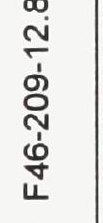 & $\begin{array}{l}\text { \# } \\
\frac{0}{0} \\
\text { है } \\
\text { ल }\end{array}$ & 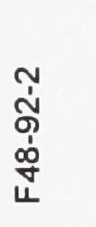 & & \\
\hline $\begin{array}{l}\dot{p} \\
\frac{1}{0}\end{array}$ & 음 & 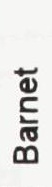 & & & 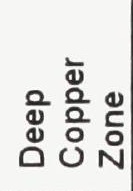 & 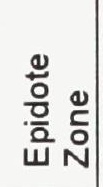 & בְ & 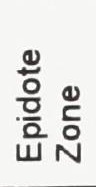 & & \\
\hline
\end{tabular}




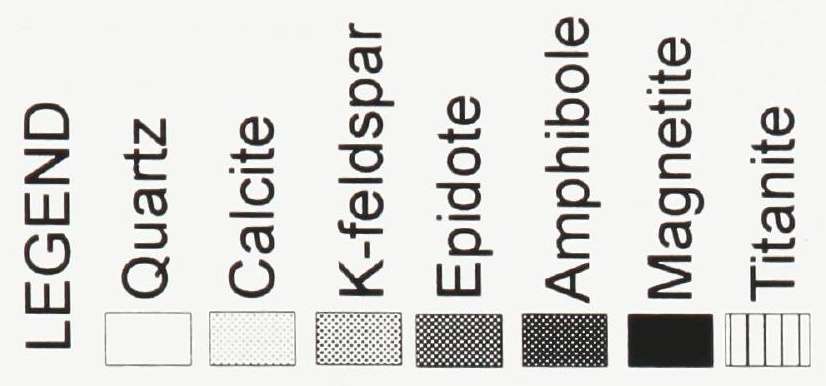

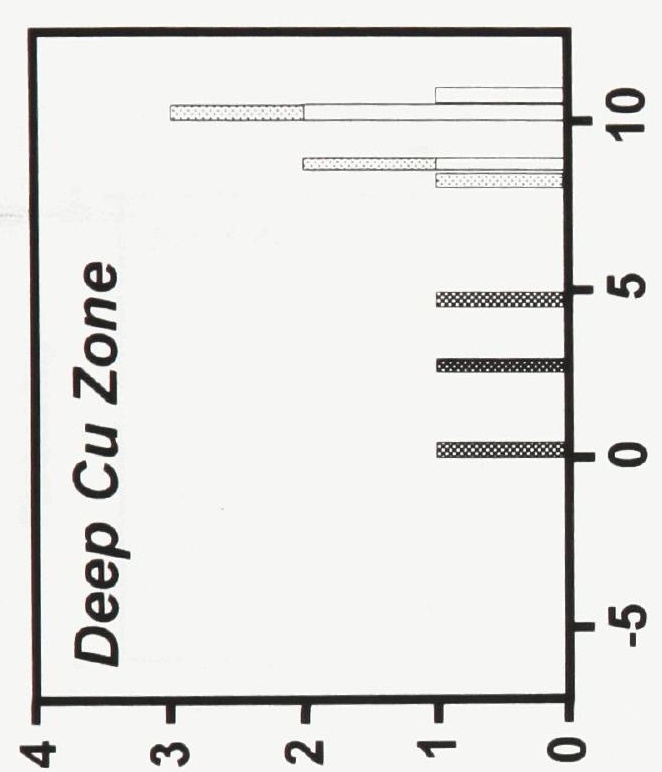

Кวuәnbəد

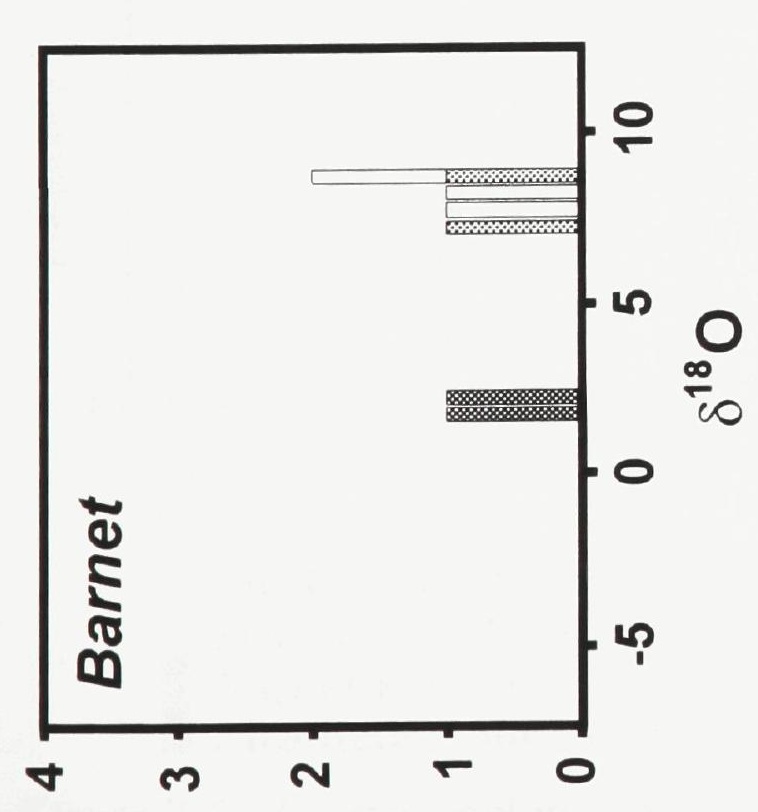

Кэuәnbอม

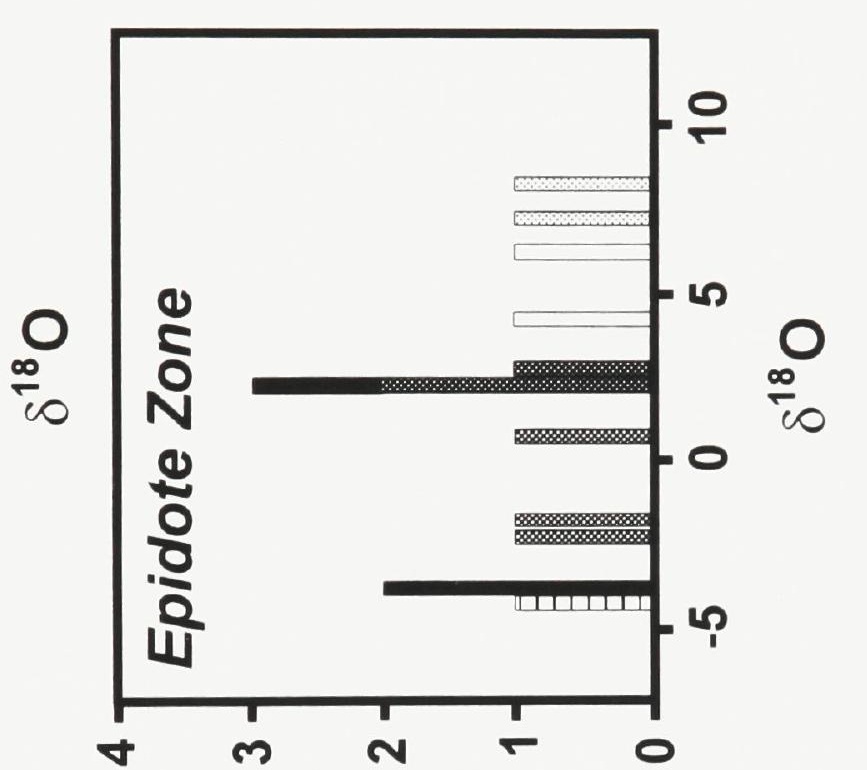

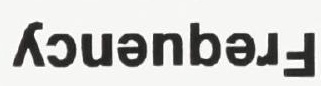

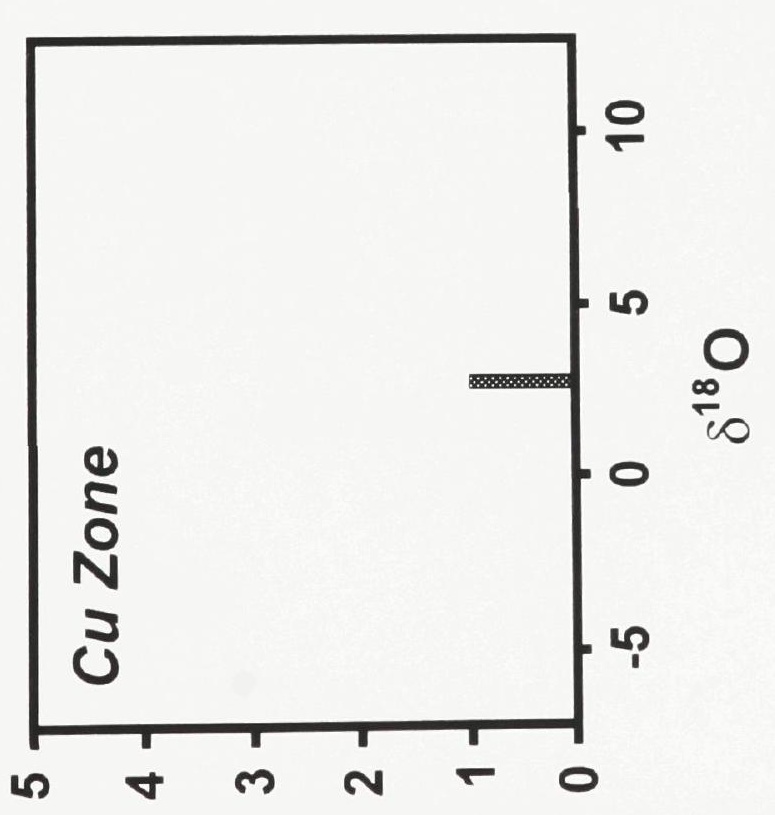

Кวuənbəد」 

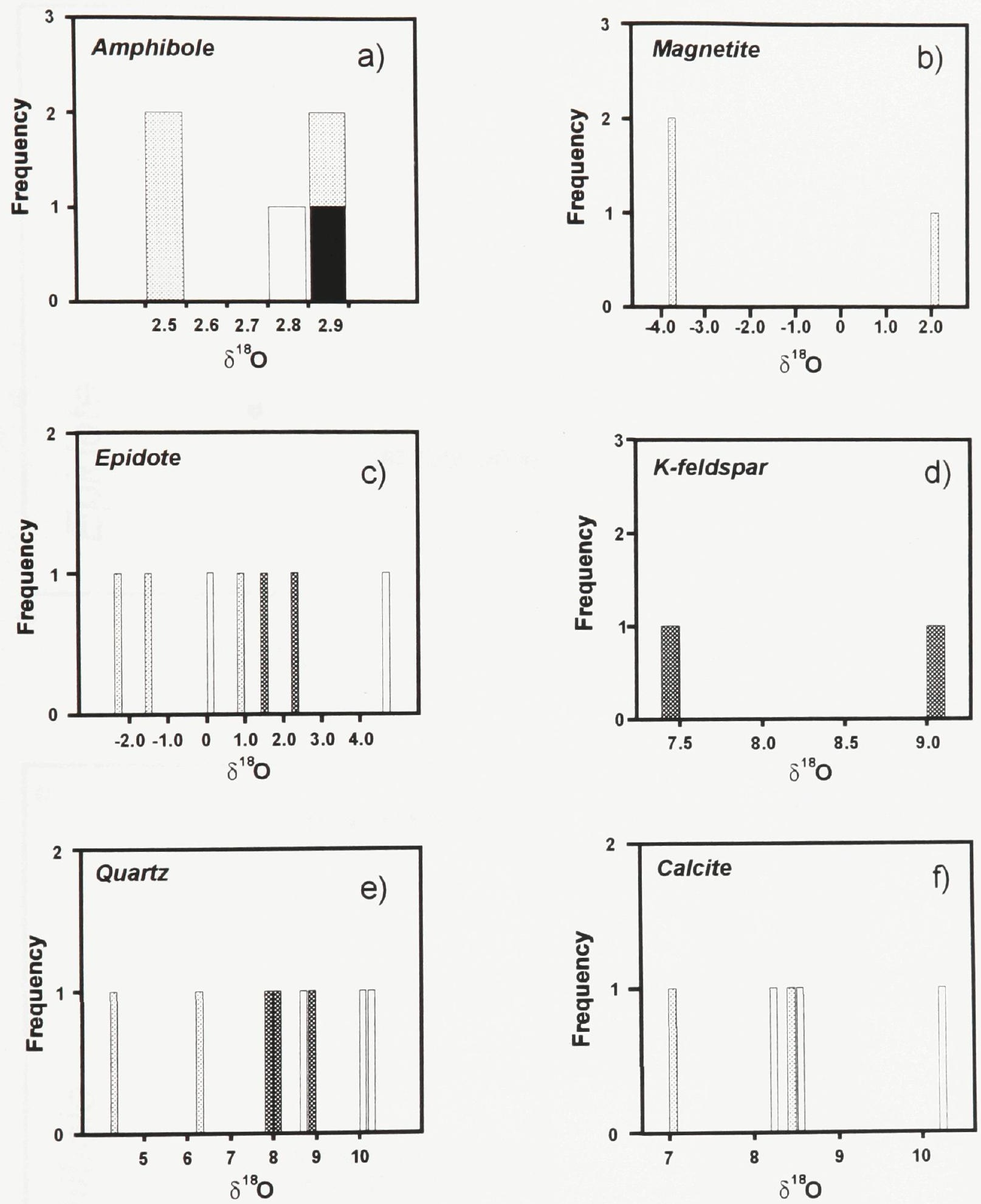

Strathcona Mine Deep Copper Zone Fraser Mine Epidote Zone Barnet Property Strathcona Mine Copper Zone

Figure 7-2: Oxygen isotope values for mineral separates from Barnet, Deep Copper Zone, Copper Zone and the Epidote Zone. 

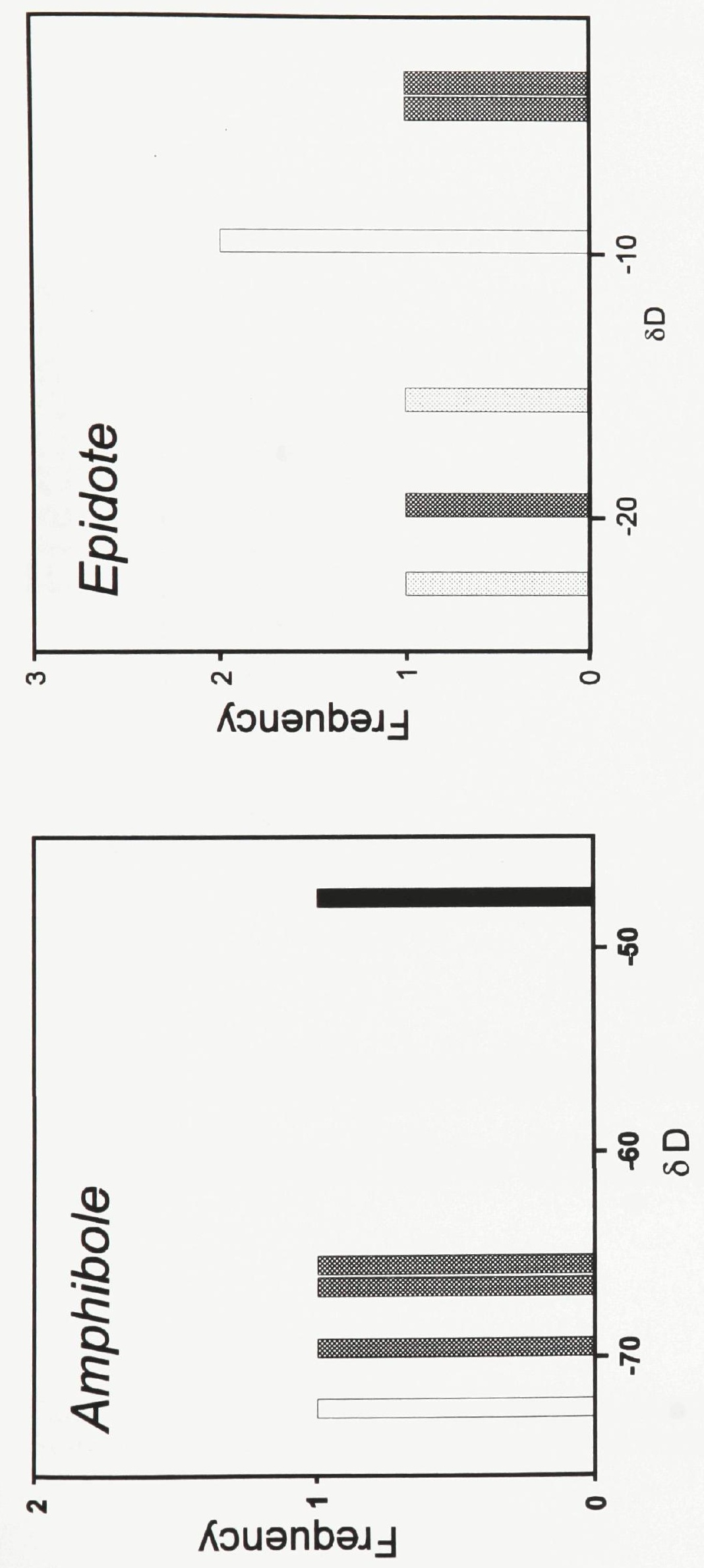

ํㅗㅇ

ㅎํํํํ음

응

ง ธุ่

인 응

ญ ㅎํㅇํํ

() 긍

를네을

즌 은 뜬

으는동

뻔

तั 든

ஸ市立芯 


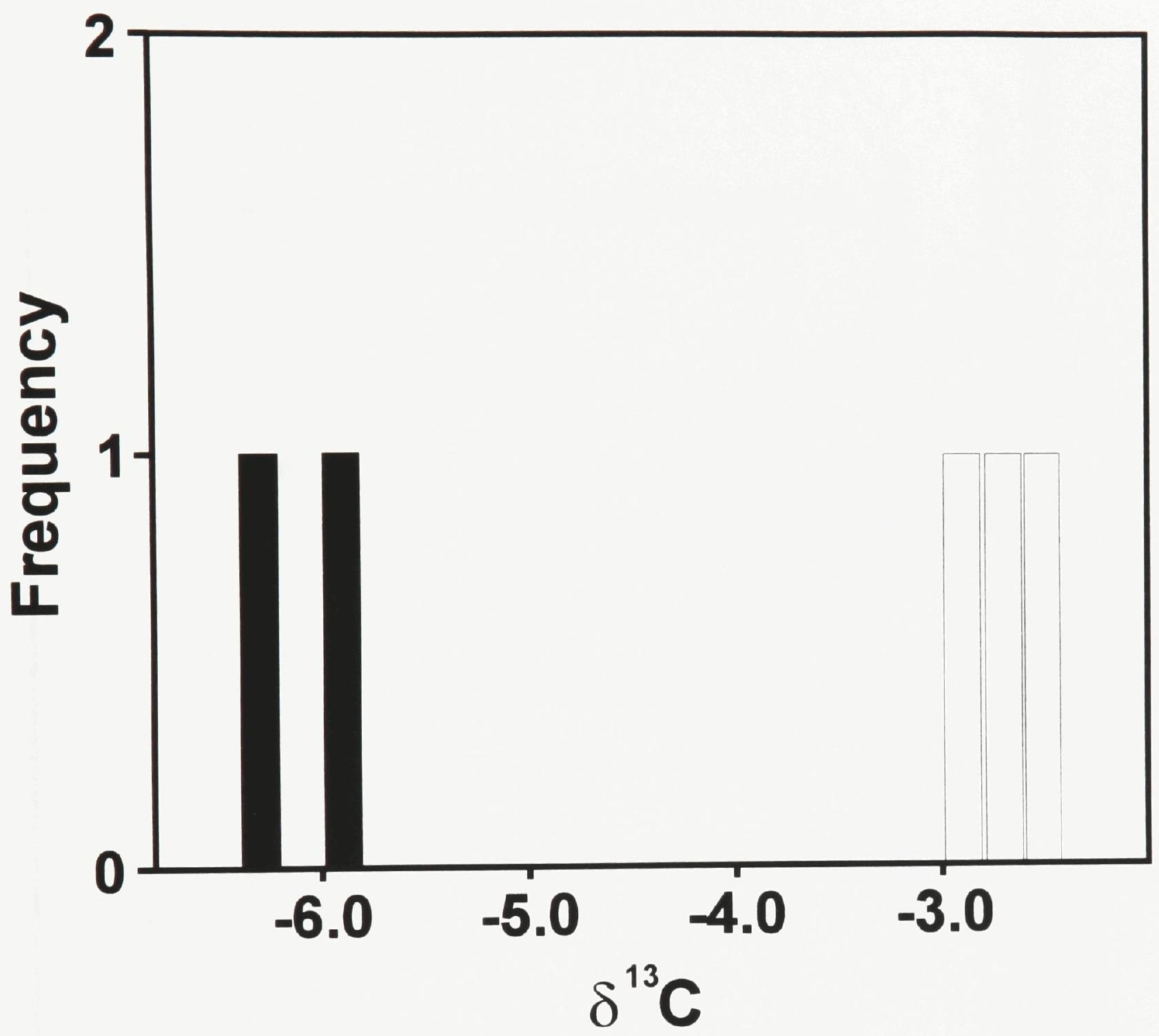

\section{Strathcona Mine Deep Copper Zone} Fraser Mine Epidote Zone

Figure 7-4: Carbon isotope values from calcite mineral separates from the Strathcona Mine Deep Copper Zone and the Fraser Mine Epidote Zone. 


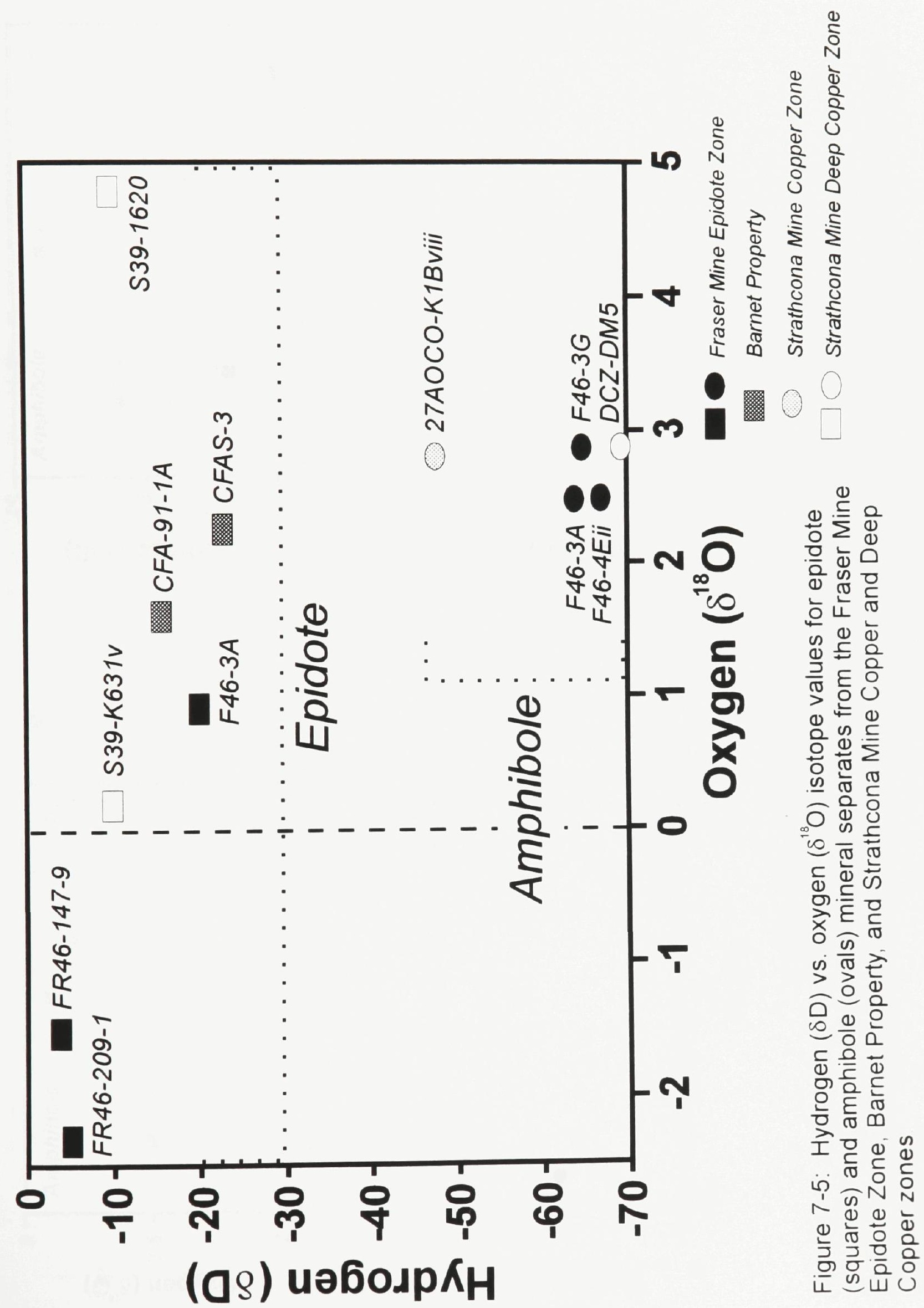




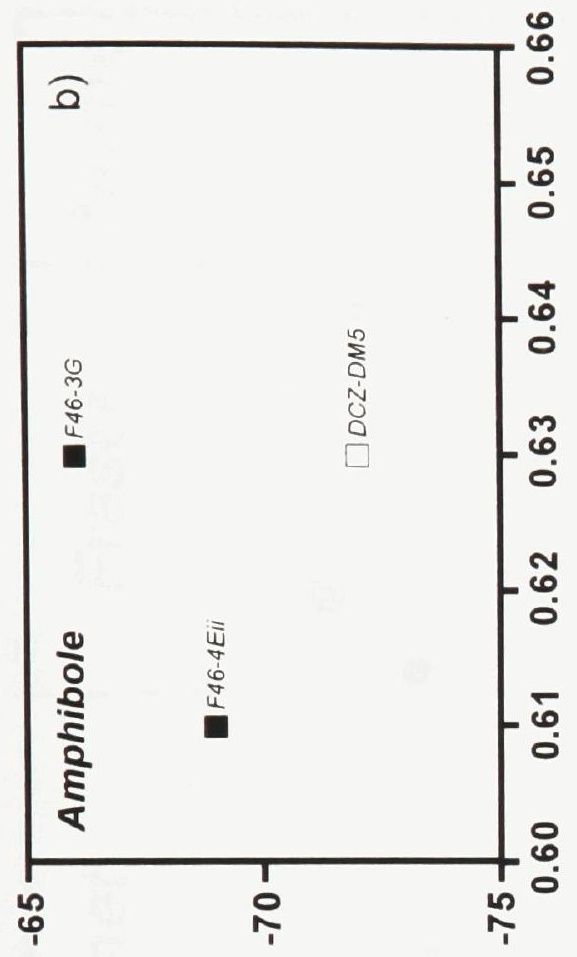

(as) uә6олpКH

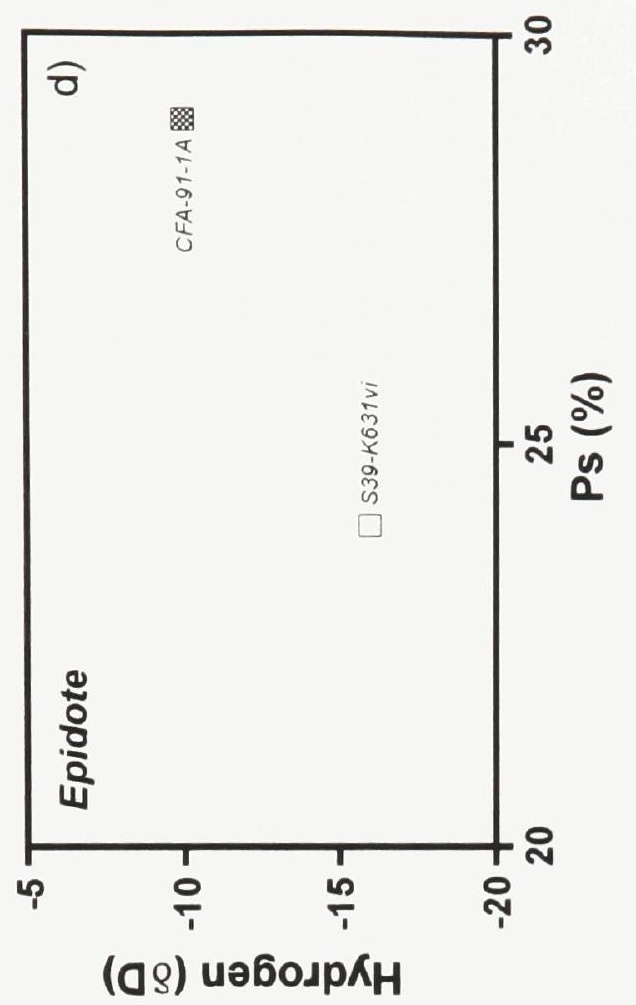

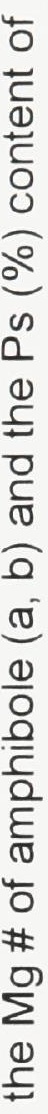

응

잉 웡

$N$ 京

응 ญे है

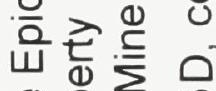

(1) $\sum_{0}$

든든 당 뭉

닝

ब兵 0

त

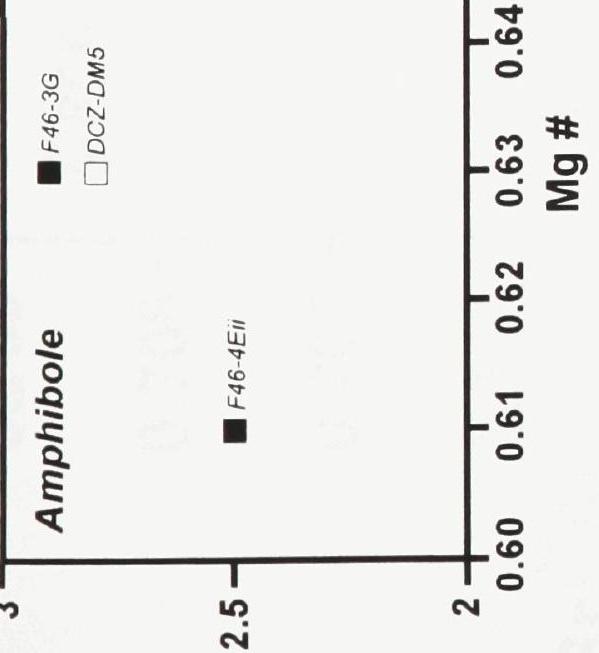

$\left(\mathrm{O}_{8 \mathrm{~L}} \mathrm{~g}\right)$ uə6/xO

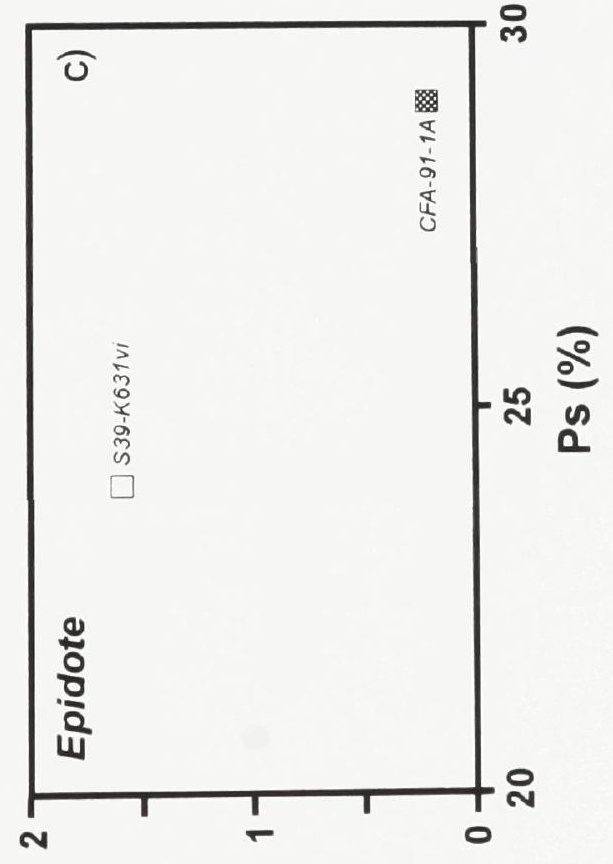

$\left(\mathrm{O}_{81} \mathrm{~S}\right)$ uә6Кх0

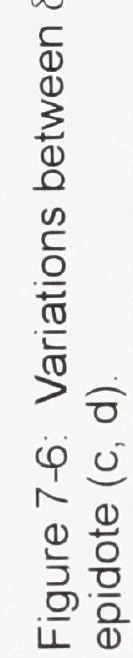



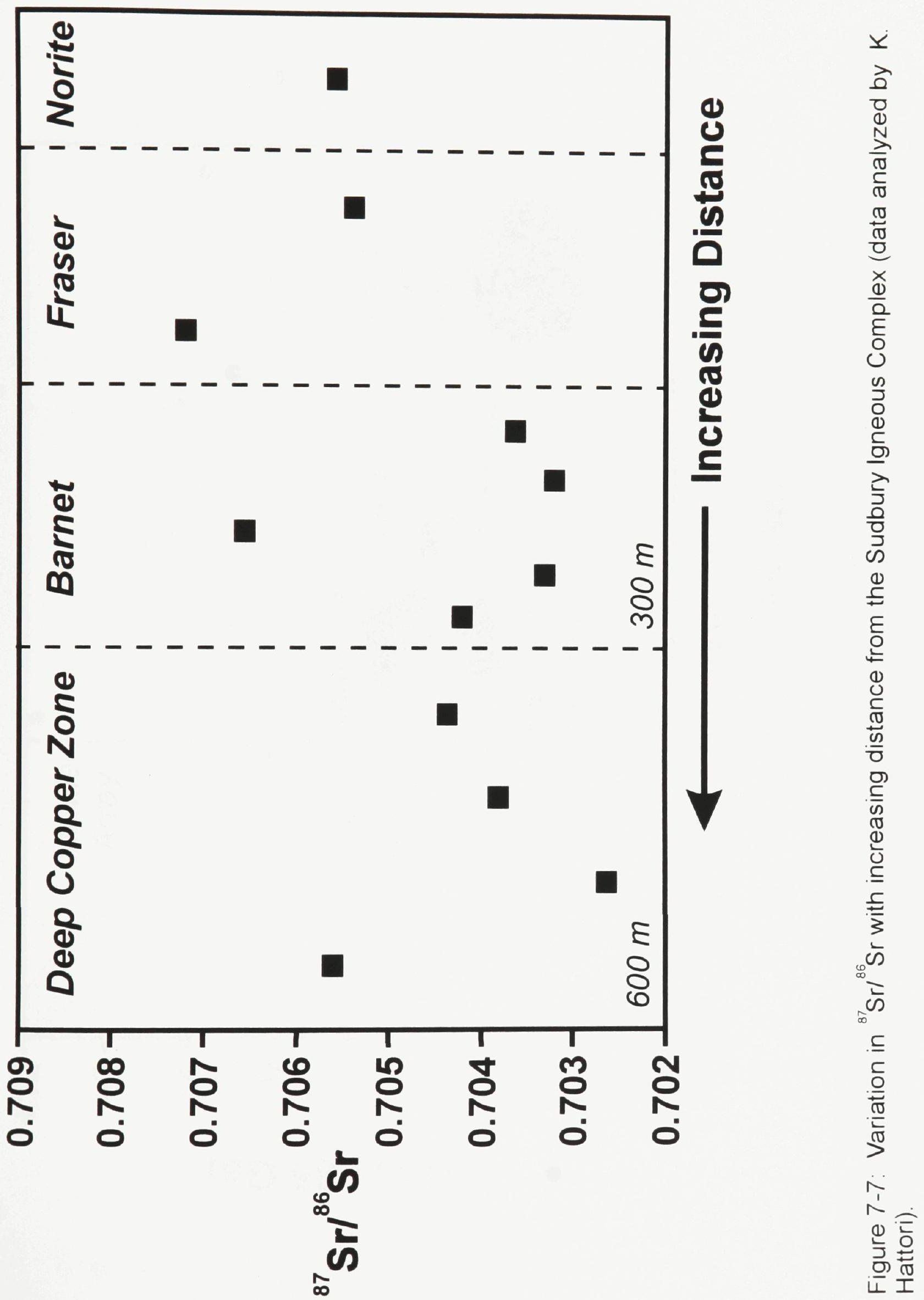


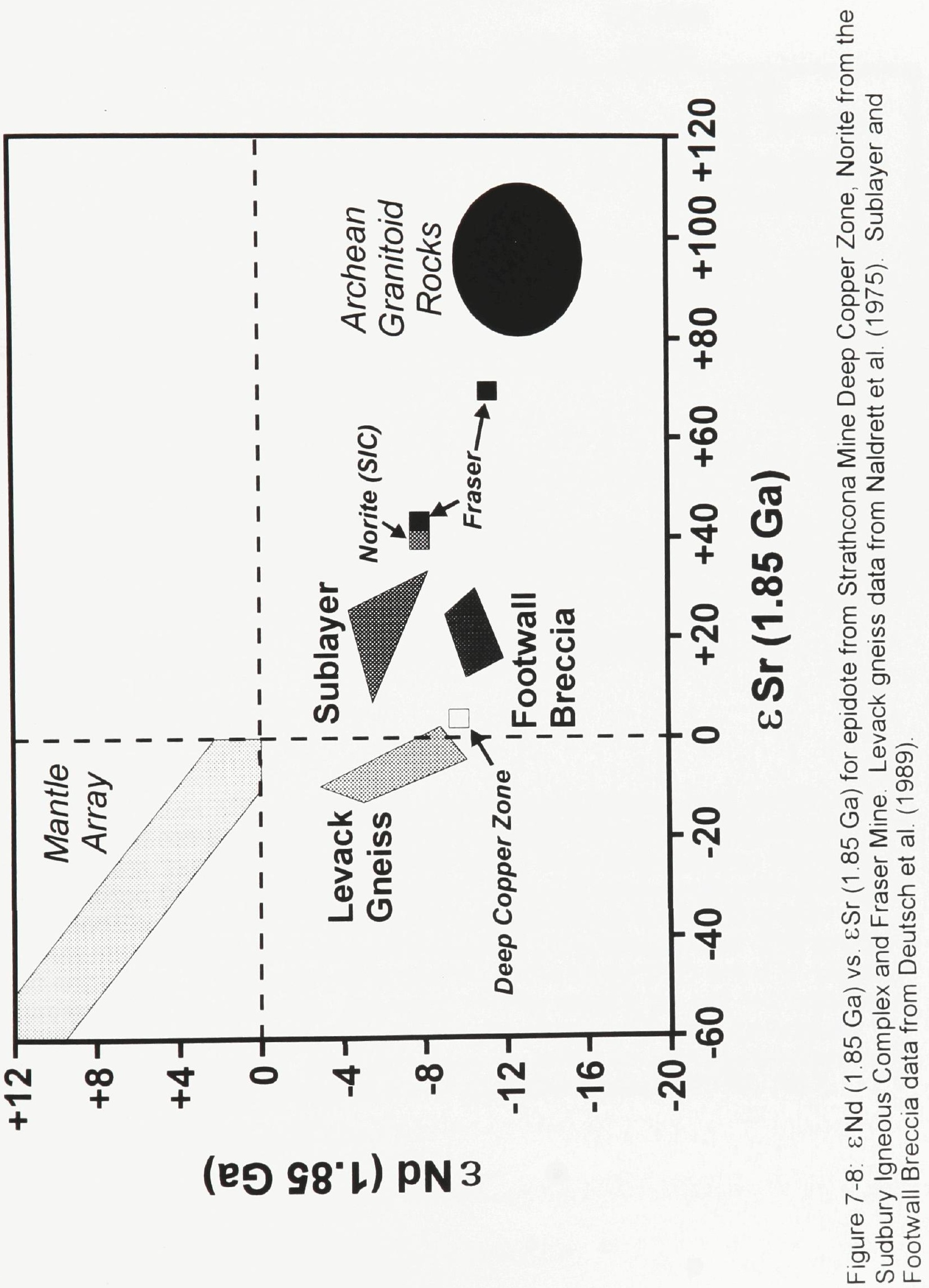




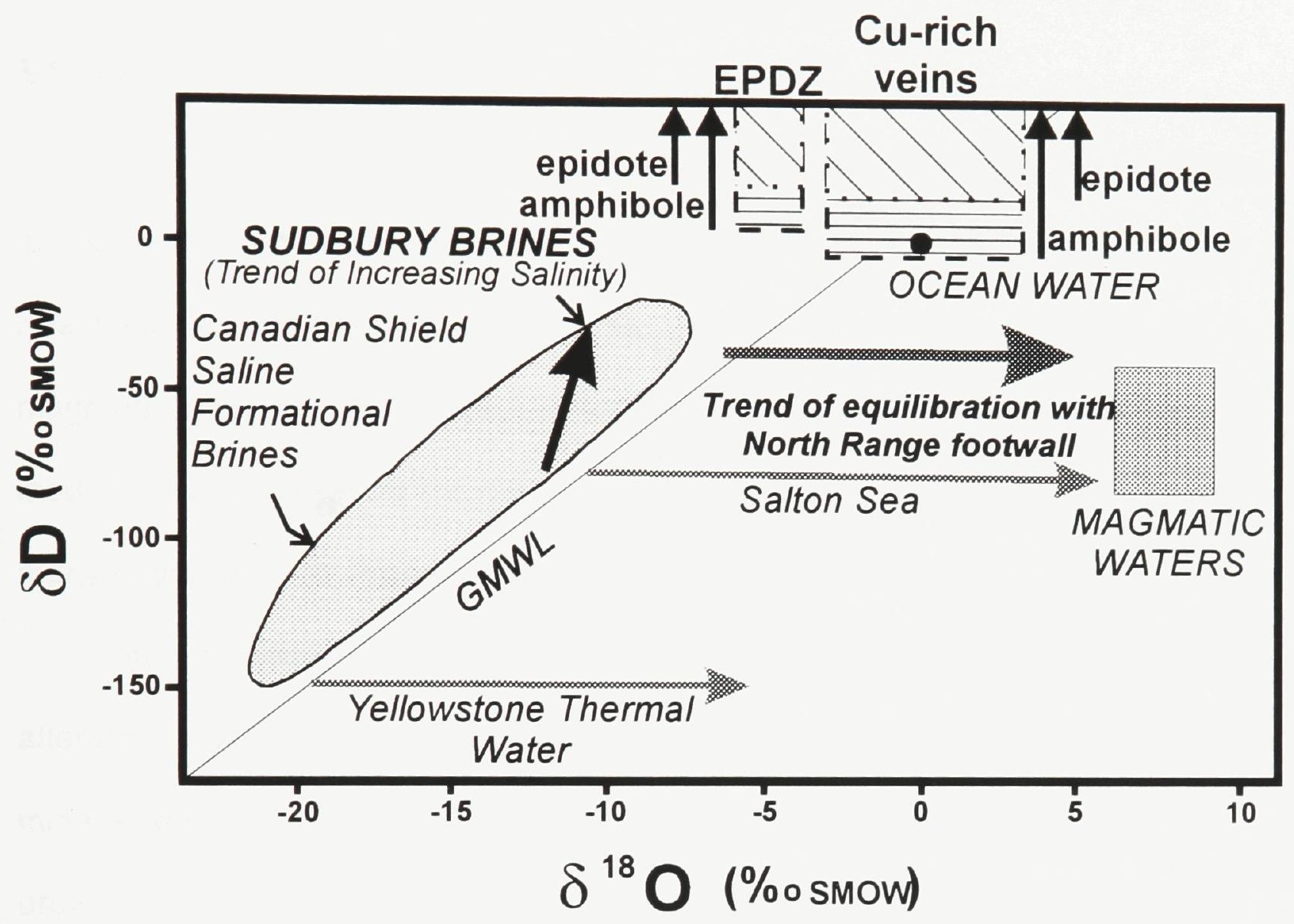

Figure 7-9: $\delta \mathrm{D}$ vs. $\delta^{18} \mathrm{O}$ diagram showing calculated Epidote Zone (EPDZ) \& Curich vein fluid compositions compared to Canadian Shield formational brine compositions, including Sudbury Brines; ocean water (present-day); magmatic water; Salton Sea and Yellowstone saline waters. O isotope values for Epidote Zone and $\mathrm{Cu}$-rich vein fluids have been calculated from coexisting quartzepidote mineral pairs. The range of calculated $\delta D$ values are from both epidote and amphibole $D$ contents and extend out of the range of $\delta D$ and $\delta^{18} O$ values represented by this diagram. The higher $\delta^{18} \mathrm{O}$ contents of $\mathrm{Cu}$-rich vein fluids may be due to the attempted equilibration of the fluids with $\delta^{18} \mathrm{O}$ enriched footwall gneisses and migmatites. Fluid $\delta D$ values are similar for both Epidote Zone and $\mathrm{Cu}$-rich veins with little change in $\delta \mathrm{D}$. (Figure after Frape and Fritz, 1982). 


\section{CHAPTER 8: DISCUSSION}

\section{8-1. INTRODUCTION}

The association of hydrothermal alteration and $\mathrm{Ni}-\mathrm{Cu}-\mathrm{PGE}$ mineralization in the Sudbury footwall orebodies has resulted in a controversy concerning the relative importance of magmatic and hydrothermal processes. Although the magmatic origin for most of the contact orebodies is well established, traditional models of sulphide-liquid fractionation have not as successfully been applied to many of the footwall deposits.

In this chapter, the origin of the footwall orebodies associated with alteration is discussed in light of their spatial distribution, temporal relationships, mineralogy, geochemistry and isotopic signature. The data presented in previous chapters will be synthesized and used to develop a model to explain the development of the orebodies.

\section{8-2. DISCUSSION}

The Sudbury Igneous Complex and its associated orebodies were emplaced during a period of great exogenic and/or endogenic crustal instability. resulting in Sudbury Breccia (pseudotachylite) development.

Contact breccias (Sublayer and leucocratic Footwall Breccia) occur at the base of the norite and host most of the ore in the North Range. Although Sublayer ore is dominantly magmatic, Footwall Breccia-hosted ore reveals magmatic, with tectonic and hydrothermal modifications, that culminated in the development of large epidote-rich alteration zones. 
The alteration mineral assemblages from all study locations are similar to those formed during regional greenschist facies metamorphism or hightemperature hydrothermal sea-floor alteration. The zonal nature of the assemblages and spatial association with footwall mineral deposits suggest that they are associated with ore-forming processes but were not strongly disturbed by subsequent regional, lower-greenschist-facies metamorphism.

A period of pre-footwall ore K-feldspar + quartz + epidote metasomatism (patches and veins) followed emplacement of the Sudbury Igneous Complex and affected Footwall Breccia, Archean footwall gneiss and migmatite, and Sudbury Breccia.

Alteration associated with $\mathrm{Cu}-\mathrm{Ni}-\mathrm{PGE}$ mineralization in the footwall may be subdivided into two major types:

1) dark green alteration selvages to $\mathrm{Cu}$-rich veining (Barnet Property, Strathcona Mine Copper and Deep Copper zones, McCreedy West Mine copper stringers), and

2) Epidote Zone-style alteration dominated by the development of epidote, actinolite and magnetite alteration facies within Footwall Breccia (Fraser Mine).

Although there are distinct differences in host rock lithology, texture and structure of altered rocks, and associated economic mineralization between $\mathrm{Cu}$ rich footwall veining and the Epidote Zone, there are more subtle variations among individual $\mathrm{Cu}$-rich vein deposits. However, overall alteration 
assemblages are similar in that they are predominantly $\mathrm{Ca}$ - and $\mathrm{Fe}$ - bearing silicates such as epidote and actinolite.

Individual Cu-rich vein deposits show distinct geochemical variations. Although $\mathrm{Cu} /(\mathrm{Cu}+\mathrm{Ni})$ ratios are similar (commonly $>0.7)$ except in distal parts of vein systems, $\mathrm{Pt} /(\mathrm{Pt}+\mathrm{Pd})$ ratios are varied among deposits. $\mathrm{Pt} /(\mathrm{Pt}+\mathrm{Pd})$ ratios from the Barnet Property are most frequently between 0.6 and 0.7 , whereas those from the Deep Copper Zone are approximately 0.4 (Chapter 4). Although the database is more limited and therefore less reliable for the Copper Zone and McCreedy West Cu-stringers, variations in $\mathrm{Pt} /(\mathrm{Pt}+\mathrm{Pd})$ ratios are evident.

Similar variations are shown among all the footwall orebodies with respect to precious metal mineral assemblages (Chapter 5). At Barnet the precious metal mineral assemblage is characterized by tellurides including hessite, merenskyite and palladian melonite. However, naummanite is the only selenide to commonly occur in any of the studied deposits. The precious metal mineral assemblages in the Deep Copper and Copper zones are very similar according to this investigation and to previously published data. They are characterized by much more complex mineral chemical variation than the other deposits; the minerals are tellurides (hessite, platinian melonite and moncheite), bismuthides (sobolevskite and froodite), Sn-bearing niggliite, and an arsenide (sperrylite). The precious metal mineral assemblage at McCreedy West copper stringer is also composed of tellurides and bismuth tellurides, as is the precious metal mineral assemblage in the Epidote Zone, with both Pt- and Pd- bearing PGM. 
Temperatures of formation of the alteration assemblage associated with Cu-rich sulphide veins and the Epidote Zone may be estimated from assemblage and mineral chemical characteristics. The assemblage actinolite + albite + epidote + chlorite + quartz + titanite described by Schiffries and Skinner (1987) for middle stage veins of the Bushveld hydrothermal system is similar to that associated with $\mathrm{Cu}$-rich veins in the North Range footwall. They estimated temperatures of formation between 300 and $600{ }^{\circ} \mathrm{C}$ for the Bushveld veins. Coexisting $\mathrm{Cl}$-rich hastingsite and actinolite from the Salton Sea geothermal system was estimated to have formed at temperatures of approximately $350^{\circ} \mathrm{C}$ and at pressures of $90 \mathrm{MPa}$. On the other hand, slightly lower temperatures (200 to $300{ }^{\circ} \mathrm{C}$ ) of formation for prehnite were estimated from the Kamikita area, Japan (Inoue and Utada, 1991). Because prehnite in this study appears to be late in the paragenetic sequence, similarly low fluid temperatures may be responsible for its formation in the North Range. In support of these temperatures, the fluid inclusion study of Chapter 6 shows that fluid temperatures of approximately 300 ${ }^{\circ} \mathrm{C}$ are responsible for alteration associated with $\mathrm{Cu}$-rich veins and slightly higher temperatures $\left(<400^{\circ} \mathrm{C}\right)$ for the Epidote Zone.

Fluid-inclusion microthermometric analyses and interpretation suggest that the hydrothermal fluids were very saline, multicomponent solutions, and that there existed a thermal gradient with temperatures being the highest in the Epidote Zone, and lower temperatures in the footwall copper-rich veins. This suggests that there was a thermal gradient from the SIC contact into the footwall, 
with the heat source driving the hydrothermal activity being the intrusion. This proposal of a thermal gradient is supported by thermometric calculations using stable isotope values of alteration mineral separates. Table $8-1$ is a summary of microthermometric temperatures, calculated $\mathrm{O}$ isotopic temperatures from coexisting mineral pairs, and related sample information for the deposits studied in detail. Since temperatures that resulted in the formation of the distal Deep Copper Zone were $\geq 300^{\circ} \mathrm{C}$, it is unlikely that similar Cu-PGE -rich deposits could exist at distances much further from the SIC contact unless another heat source is possible. Morrison et al. (1994) have suggested that footwall Cu-rich deposits potentially exist thousands of metres into the footwall from the SIC contact. However, temperature restrictions suggest that the Deep Copper Zone represents the most distal footwall deposit. Hydrothermal fluids similar to those involved in Deep Copper Zone generation at lower temperatures would not likely transport enough PGE and other metals to form vein deposits. The heat generated by the cooling SIC at its base was not great enough to maintain an effective hydrothermal system at distances $>1000 \mathrm{~m}$ into the footwall.

Semi-quantitative analyses of fluid-inclusion daughter minerals and accidental phases show that the deposits have characteristic daughter mineral assemblages, dominated by $\mathrm{Ca}-\mathrm{Na}$ chlorides. For example, the Barnet property fluid inclusions have the highest proportion of Fe hydroxy chloride daughter minerals. Daughter minerals at the Lindsley Mine include barium chloride $\left(\mathrm{BaCl}_{2}\right)$, a reflection of the reaction of local hydrothermal fluids with the host 
brecciated granite (Watkinson, 1994). The Lindsley example suggests that the availability of specific elements, such as $\mathrm{Ba}$, is strongly influenced by the local lithology. Studies of Precambrian Shield deep, saline groundwaters have also shown that the concentration of elements other than $\mathrm{Ca}$ and $\mathrm{Na}$ is dominantly controlled by the local lithology(Frape et al., 1984). The more Fe-rich composition of daughter mineral populations from the Barnet Property is more difficult to explain, although there are ample sources for Fe within mafic minerals of the host diatexites, gneissses and Sudbury Breccia at Barnet. Figure 8-1 shows a comparison of present-day Sudbury saline groundwaters and brines, and present-day ocean water, with estimated compositions of the fluids associated with Cu-Ni-PGE deposition at several locations in the Sudbury area on a $\mathrm{Na}-\mathrm{Ca}-(\mathrm{Mg}+\mathrm{Fe}+\mathrm{Pb}+\mathrm{K}+\mathrm{Ba})$ ternary diagram. The trend to higher $\mathrm{Na}$ abundances in the Sudbury Cu-Ni-PGE -bearing fluids represents a mixing line between present-day Sudbury deep brines and ocean water; however, ocean water is more $\mathrm{Mg}$-rich.

The individual hydrothermal cells that have inherited characteristics from original magmatic sulphides are interpreted from detailed mapping and petrography, and show distinctive geochemical signatures, PGM assemblages and daughter mineral populations in silicate- and sulphide-hosted fluid inclusions from each footwall $\mathrm{Cu}-\mathrm{Ni}$-PGE deposit. The isotopic and chemical compositions of present-day, deep, saline brines in the Canadian shield and in the Sudbury area suggest that they occur in hydrologically isolated "pockets" 
(Frape et al., 1984). If these pockets existed during the emplacement of the SIC they may have been subjected to high temperatures and developed into individual hydrothermal cells. Heat from the cooling Sudbury Igneous Complex drove the circulation of the hydrothermal fluids. Previous studies have found that very saline brines dominated by $\mathrm{Ca}-\mathrm{Na}-\mathrm{Cl}$ occur within major faults and shear zones at depths below $650 \mathrm{~m}$ (Frape and Fritz, 1982; Frape et al., 1984).

The origin of the hydrothermal fluids may be either of marine or deep groundwater origin, or a combination of both; their isotopic and chemical compositional signature may be overprinted as they approached equilibrium with their host rocks. The influence of marine water is possible because postulated depths of ore formation are $\geq 3 \mathrm{~km}$ (Souch et al., 1969; Hoffman et al., 1979); the continental shelf environment that existed during the Sudbury Event (Morrison et al., 1994) indicates that there could have been an abundant supply of seawater that may have percolated downward and mixed with the deep crustal brines.

Figure $8-1$ is a ternary plot for $\mathrm{Na}-\mathrm{Ca}-(\mathrm{Mg}+\mathrm{Fe}+\mathrm{Pb}+\mathrm{K}+\mathrm{Ba})$ of a variety of fluids. It shows that the Sudbury ore-bearing fluids may define a mixing line between the composition of present-day Sudbury brines, and present-day ocean water. Crustal instabilities developed as a result of the Sudbury Event provided permeability for fluid movement.

The deposit-scale (and locally smaller) similarities of individual products of hydrothermal activity suggest that individual hydrothermal cells were developed within the footwall that reacted with their host rocks. Thus, even if the 
$\mathrm{Ca}, \mathrm{Na}$ and $\mathrm{Cl}$-rich deep groundwaters that existed during the Sudbury Event $(1.85 \mathrm{Ga})$ were not as geochemically "evolved" as those represented by recent groundwater investigations, their reaction with plagioclase-rich, tonalitic gneisses and migmatites in the North Range footwall could have provided the necessary dominant $\mathrm{Ca}$ and $\mathrm{Na}$ cations.

The hydrothermal cells extended into the ore-bearing Footwall Breccia and possibly Sublayer and scavenged metals. Mafic and ultramafic Sublayer inclusion and matrix lithologies are commonly locally hydrothermally altered in both the North and South ranges (P.C. Lightfoot, Ontario Geological Survey, pers. comm.), compatible with the extension of post-emplacement hydrothermal cells into the Sublayer. The metals were carried into the footwall where they were deposited as Cu-Ni-PGE veins in dilation fractures developed in a tectonically unstable crust. As a result, footwall rocks adjacent to altered Sublayer and Footwall Breccia (i.e., Epidote Zone) would be reasonable targets for further exploration, in addition to structurally compatible zones to deposit $\mathrm{Cu}$ rich veins.

A model for the development of footwall Cu-Ni-PGE deposits is illustrated in Figures $8-2 a-d$. The figures portray the relative timing of events such as footwall ground preparation associated with the formation of Sudbury Breccia (a), the intrusion of the Sudbury Igneous Complex, Sublayer, Footwall Breccia and contact ore deposits (b), heating of deep formational brines by the Sudbury Igneous Complex and the development of metal scavenging footwall 
hydrothermal cells (c), and the focusing of hydrothermal fluids during the formation of the Epidote Zone (d). 
Table 8-1: Summary of microthermometric temperatures, calculated $O$ isotopic temperatures from coexisting mineral pairs, and related sample information for the deposits studied in detail.

\begin{tabular}{|c|c|c|c|c|}
\hline DEPOSIT & $\begin{array}{l}\text { SAMPLE } \\
\#\end{array}$ & $\begin{array}{l}\text { ANALYZED } \\
\text { MINERALS }\end{array}$ & $\begin{array}{l}\text { TEXTURAL } \\
\text { RELATIONS }\end{array}$ & COMMENTS \\
\hline \multirow[t]{4}{*}{$\begin{array}{l}\text { Fraser } \\
\text { Mine } \\
\text { Epidote } \\
\text { Zone }\end{array}$} & $\begin{array}{l}\text { F46-4Eii } \\
\text { (ACTZ } \\
\text { facies) }\end{array}$ & $\begin{array}{l}\text { Amphibole } \\
\delta^{18} O=2.5 \\
\delta D=-69\end{array}$ & $\begin{array}{l}-65 \% \text { fibrous } \\
\text { amphibole. Patches } \\
\text { of fine-grained, } \\
\text { equigranular epidote. } \\
\text { Sulphides } \\
\text { concentrated along } \\
\text { contacts between } \\
\text { amphibole-rich \& } \\
\text { epidote-rich areas. } \\
\text { Sulphides are } \\
\text { unstable pentlandite } \\
\& \text { later subhedral } \\
\text { pyrite. }\end{array}$ & $\begin{array}{l}\text {-Amphibole is } \\
\text { actinolite, } \mathrm{Mg \#}= \\
0.61, \mathrm{Ni} \text {-bearing. } \\
\text {-Epidote } \mathrm{Ps}(\%)=28 \text {. } \\
\text {-Daughter minerals in } \\
\text { fluid inclusions: } \\
\text { pentlandite }=\mathrm{CaCl}_{2} .\end{array}$ \\
\hline & $\begin{array}{l}\text { FR46-209- } \\
12.8 \text { (EPDZ } \\
\text { facies) }\end{array}$ & $\begin{array}{l}\text { Quartz } \\
\delta^{18} O=4.3 \\
\text { Epidote } \\
\delta^{18} O=-2.3 \\
\delta D=-5\end{array}$ & $\begin{array}{l}\text {-medium to coarse - } \\
\text { grained epidote \& } \\
\text { less common } \\
\text { amphibole with } \\
\text { quartz-rich patches. }\end{array}$ & $\begin{array}{l}\text {-Daughter minerals in } \\
\text { fluid inclusions : } \\
\text { quartz }=\mathrm{Ca}>\mathrm{Na} \\
\text { chlorides. } \\
\text {-Isochore } \mathrm{T} \text { range = } \\
206^{\circ} \text { to } 368^{\circ} \mathrm{C} \text { (from } \\
90 \text { to } 230 \mathrm{MPa} \text { ). } \\
\text {-Calculated isotopic } \\
\delta^{18} \mathrm{O} \text { temperatures } \\
\text { from quartz-epidote } \\
\text { pair }=213^{\circ} \mathrm{C} \text {. }\end{array}$ \\
\hline & $\begin{array}{l}\text { F46-3G } \\
\text { (EPDZact } \\
\text { facies) }\end{array}$ & $\begin{array}{l}\text { Amphibole } \\
\delta^{18} O=2.9 \\
\delta D=-66\end{array}$ & $\begin{array}{l}-55 \text { to } 60 \% \text { epidote, } \\
40 \% \text { amphibole, } 5 \% \\
\text { calcite. Calcite } \\
\text { interstitial to epidote } \\
\& \text { amphibole. } \\
\text { Epidote is fine- } \\
\text { grained. Amphibole } \\
\text { is medium-grained. } \\
\text { Disseminated } \\
\text { pentlandite in matrix } \\
\text { with later subhedral } \\
\text { pyrite. }\end{array}$ & $\begin{array}{l}\text {-Amphibole is } \\
\text { actinolite, } \mathrm{Mg \#}= \\
0 . \mathrm{W}_{3} \text { minor } \mathrm{Ni} \\
\text {-Epidote } \mathrm{Ps}(\%)=34\end{array}$ \\
\hline & $\begin{array}{l}\text { F46-3A } \\
\text { (EPDZact } \\
\text { facies) }\end{array}$ & $\begin{array}{l}\text { Amphibole } \\
\delta^{18} O=2.5 \\
\delta D=-65 \\
\text { Epidote } \\
\delta^{18} O=0.9 \\
\delta D=-20\end{array}$ & $\begin{array}{l}\text {-medium-grained } \\
\text { epidote + amphibole. }\end{array}$ & \\
\hline
\end{tabular}




\begin{tabular}{|c|c|c|c|c|}
\hline & $\begin{array}{l}\text { FR46-147- } \\
11 \text { (MAGZ } \\
\text { facies) }\end{array}$ & $\begin{array}{l}\text { Magnetite } \\
\delta^{18} O=-3.9 \& \\
-3.5\end{array}$ & $\begin{array}{l}-65 \text { to } 80 \% \\
\text { magnetite. } 1 \% \\
\text { interstitial epidote. } \\
\text { Magnetite rounded } \\
\text { with few visible } \\
\text { crystal faces. } \\
\text { Pentlandite (10 to } \\
20 \% \text { ) interstitial to } \\
\text { magnetite. Pyrite } \\
\text { later. }\end{array}$ & $\begin{array}{l}\text {-Amphibole is } \\
\text { actinolite, Mg\# = } \\
0.50, \text { Ni-bearing. } \\
\text { - Magnetite is pure, } \mathrm{Ti} \\
\text { < detection limits to } \\
0.50 \text { wt. \%. } \\
\text { - Daughter minerals in } \\
\text { fluid inclusions: pyrite } \\
=\mathrm{NaCl} \text { pentlandite = } \\
\mathrm{CaCl}_{2} \text {. } \\
-\mathrm{Sample} \text { contains } \\
\mathrm{PGM} \text { (Moncheite, } \\
\mathrm{PtTe}_{2} \text { ). }\end{array}$ \\
\hline & $\begin{array}{l}\text { F46-37 } \\
\text { (MAGZ } \\
\text { facies) }\end{array}$ & $\begin{array}{l}\text { Magnetite } \\
\delta^{18} \mathrm{O}=-2.1 \\
\text { Calcite } \\
\delta^{18} \mathrm{O}_{\text {SMOW }}=7.3 \\
\& 7.1 \\
\delta^{18} O_{\mathrm{PDB}}=-22.9 \\
\delta^{13} \mathrm{C}_{\mathrm{PDB}}=-5.8 \\
\&-5.8\end{array}$ & $\begin{array}{l}-1 \mathrm{~mm} \text { in diameter } \\
\text { resorbed magnetite \& } \\
\text { pentlandite replaced } \\
\text { by calcite \& second } \\
\text { generation, locally } \\
\text { coarse-grained, } \\
\text { amphibole. }\end{array}$ & \\
\hline & $\begin{array}{l}\text { F48-92-2 } \\
\text { (MAGZ } \\
\text { facies) }\end{array}$ & $\begin{array}{l}\text { Magnetite } \\
\delta^{18} \mathrm{O}=-3.6 \\
\text { Calcite } \\
\delta^{18} O_{\text {SMOw }}=8.5 \\
\delta^{18} O_{\text {PDB }}=-6.2 \\
\text { Quartz } \\
\delta^{18} O=6.4 \\
\text { Titanite } \\
\delta^{18} O=-4.4\end{array}$ & $\begin{array}{l}\text {-magnetite-rich } \\
\text { alteration with patchy } \\
\text { development of } \\
\text { intergrown quartz \& } \\
\text { calcite. Titanite } \\
\text { occurs in magnetite, } \\
\text { at the edge of } \\
\text { sulphide (pentlandite } \\
+ \text { pyrite) \& calcite + } \\
\text { quartz patches. }\end{array}$ & $\begin{array}{l}\text {-Daughter minerals in } \\
\text { fluid inclusions: } \\
\text { quartz }=\mathrm{NaCl} \text {. } \\
- \text { Calculated isotopic } \\
\delta^{18} \mathrm{O} \text { temperatures } \\
\text { from quartz- } \\
\text { magnetite pair }=473- \\
509^{\circ} \mathrm{C} \text {. }\end{array}$ \\
\hline & $\begin{array}{l}\text { FR46-147- } \\
9 \text { (EPDZact } \\
\text { facies) }\end{array}$ & $\begin{array}{l}\text { Epidote } \\
\delta^{18} O=-1.5 \\
\delta D=-4\end{array}$ & $\begin{array}{l}\text {-Patchy, fine to } \\
\text { medium -grained } \\
\text { epidote development } \\
\text { in large, poikilitic, } \\
\text { optically continuous } \\
\text { quartz. } 30 \% \text { fibrous } \\
\text { amphibole. } \\
\text { Disseminated blebs } \\
\text { of pentlandite \& later, } \\
\text { subhedral pyrite. }\end{array}$ & \\
\hline $\begin{array}{l}\text { Strathcona } \\
\text { Mine Deep } \\
\text { Copper } \\
\text { Zone }\end{array}$ & S37-D5A & $\begin{array}{l}\text { Quartz } \\
\delta^{18} \mathrm{O}=10.3\end{array}$ & $\begin{array}{l}\text {-Large (some }>5 \mathrm{~mm} \\
\text { long) anhedral to } \\
\text { subhedral quartz } \\
\text { grains replacing } \\
\text { earlier, coarse- } \\
\text { grained calcite. } \\
\text { Calcite has replaced } \\
\text { epidote. Minor } \\
\text { chlorite. Quartz is } \\
\text { the last mineral to } \\
\text { form. Chalcopyrite } \\
\text { has replaced epidote } \\
\text { in calcite. }\end{array}$ & $\begin{array}{l}\text {-Daughter minerals in } \\
\text { fluid inclusions: } \\
\text { quartz }=\mathrm{Ca}>\mathrm{Na} \\
\text { chloride; chalcopyrite } \\
=\mathrm{Ca}>\mathrm{Pb}>\mathrm{K} \\
\text { chloride. } \\
\text {-Isochore } \\
\text { temperature range }= \\
154^{\circ} \text { to } 435^{\circ} \mathrm{C} \text { (from } \\
90 \text { to } 230 \mathrm{MPa} \text { ). }\end{array}$ \\
\hline
\end{tabular}




\begin{tabular}{|c|c|c|c|}
\hline DCZ-DM5 & $\begin{array}{l}\text { Amphibole } \\
\delta^{18} O=2.8 \\
\delta D=-72\end{array}$ & $\begin{array}{l}\text {-large (locally }>5 \mathrm{~cm} \\
\text { long) amphibole with } \\
\text { interstitial chlorite. } \\
5 \% \text { epidote. } \\
\text { Dominant sulphide } \\
\text { mineral is millerite } \\
\text { replacing } \\
\text { chalcopyrite. Millerite } \\
\text { late with inclusions of } \\
\text { chlorite \& amphibole. }\end{array}$ & $\begin{array}{l}\text {-Amphibole is } \\
\text { actinolite, Mg\# = } \\
0 . \widetilde{3}, \text { Ni-bearing }\end{array}$ \\
\hline S39-K631vi & $\begin{array}{l}\text { Epidote } \\
\delta^{18} O=0.2 \\
\delta D=-10\end{array}$ & $\begin{array}{l}-40 \% \text { medium- } \\
\text { grained, anhedral to } \\
\text { subhedral epidote. } \\
\text { Amphibole fibrous, } \\
\text { being replaced by } \\
\text { chalcopyrite (+ trace } \\
\text { bornite) along } \\
\text { cleavage planes. } 5 \% \\
\text { later, coarse-grained } \\
\text { quartz. }\end{array}$ & $\begin{array}{l}\text {-Amphibole is } \\
\text { actinolite, Mg\# = } \\
0.58, \text { Ni-bearing. } \\
\text {-Epidote Ps }(\%)=29 \text {. }\end{array}$ \\
\hline S42-D5 & $\begin{array}{l}\text { Calcite } \\
\delta^{18} O_{\text {SMOW }}= \\
8.76 \& 8.6 \\
\delta^{18} O_{\text {PDB }}= \\
-21.49 \\
\delta^{13} C_{\text {PDB }}=-2.6 \\
\&-2.6 \\
\text { Quartz } \\
\delta^{18} O=10.1\end{array}$ & $\begin{array}{l}\text { - Clasts of quartz \& } \\
\text { calcite in chalcopyrite } \\
\text { matrix. Trace } \\
\text { euhedral epidote in } \\
\text { chalcopyrite. Host } \\
\text { rock is epidotized } \\
\text { Sudbury Breccia } \\
\text { matrix. }\end{array}$ & \\
\hline S39-1620 & $\begin{array}{l}\text { Calcite } \\
\delta^{18} O_{\text {SMOW }}= \\
10.58 \& 10.3 \\
\delta^{18} O_{\text {PDB }}= \\
-19.72 \\
\delta^{13} C_{\text {PDB }}=-2.55 \\
\&-2.8 \\
\text { Quartz } \\
\delta^{18} O=10.7 \\
\text { Epidote } \\
\delta^{18} O=4.8 \\
\delta D=-10\end{array}$ & $\begin{array}{l}\text {-Zoned chalcopyrite, } \\
\text { calcite, quartz \& } \\
\text { epidote vein. Silicate } \\
\text { minerals \& calcite are } \\
\text { coarse-grained. } \\
\text { Euhedral epidote also } \\
\text { occurs in the } \\
\text { chalcopyrite. }\end{array}$ & $\begin{array}{l}\text {-Daughter minerals in } \\
\text { fluid inclusions: } \\
\text { quartz }=\mathrm{Na}>\mathrm{Fe}> \\
\mathrm{Ca} \text { chloride; } \\
\text { chalcopyrite }=\mathrm{Ca}> \\
\text { Na chloride. } \\
- \text { Calculated isotopic } \\
\delta^{18} \mathrm{O} \text { temperatures } \\
\text { from quartz - epidote } \\
\text { pair }=241^{\circ} \mathrm{C} \text {. }\end{array}$ \\
\hline S42-D13 & $\begin{array}{l}\text { Calcite } \\
\delta^{18} O_{\text {SMOW }}= \\
8.37 \& 8.3 \\
\delta^{18} O_{\text {PDB }}= \\
-21.49 \\
\delta^{13} C_{\text {PDB }}=-2.63 \\
\&-2.5\end{array}$ & $\begin{array}{l}\text {-Calcite, quartz \& } \\
\text { chalcopyrite vein in } \\
\text { Sudbury Breccia. } \\
\text { Calcite \& quartz are } \\
\text { coarse-grained. }\end{array}$ & \\
\hline
\end{tabular}




\begin{tabular}{|c|c|c|c|c|}
\hline & S37-1 & $\begin{array}{l}\text { Quartz } \\
\delta^{18} O=8.7\end{array}$ & $\begin{array}{l}\text {-Quartz (coarse- } \\
\text { grained, up to } 3 \mathrm{~mm} \\
\text { long) \& epidote } \\
\text { envelope chalcopyrite } \\
\text { (+ bornite + trace } \\
\text { covellite) -rich vein in } \\
\text { Sudbury Breccia. } \\
\text { Relative ages with } \\
\text { oldest first = epidote - } \\
\text { quartz - chalcopyrite. } \\
\text { Epidote alteration } \\
\text { locally extends into } \\
\text { Sudbury Breccia } \\
\text { matrix. }\end{array}$ & 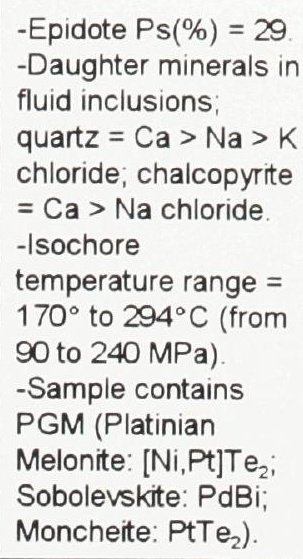 \\
\hline \multirow[t]{3}{*}{$\begin{array}{l}\text { Barnet } \\
\text { Property }\end{array}$} & CFA-052 & $\begin{array}{l}\text { K-feldspar } \\
\delta^{18} \mathrm{O}=7.4 \\
\text { Quartz } \\
\delta^{18} \mathrm{O}=8.2\end{array}$ & $\begin{array}{l}\text {-Micrographic } \\
\text { intergrowths of quartz } \\
\text { \& K-feldspar are the } \\
\text { result of "pre-ore" } \\
\text { metasomatism. }\end{array}$ & $\begin{array}{l}\text {-Amphibole is } \\
\text { actinolite, Mg\# = } \\
0.64, \text { Ni-bearing. } \\
\text {-Epidote } \mathrm{Ps}(\%)=30 \text {. }\end{array}$ \\
\hline & CFA-91-1A & $\begin{array}{l}\text { Quartz } \\
\delta^{18} O=8.0 \& \\
8.7 \\
\text { Epidote } \\
\delta^{18} O=1.6 \\
\delta D=-16\end{array}$ & $\begin{array}{l}\text {-Intergrown epidote, } \\
\text { K-feldspar \& quartz. }\end{array}$ & $\begin{array}{l}\text { - Epidote } \mathrm{Ps}(\%)=24 . \\
\text {-Calculated isotopic } \\
\delta^{18} \mathrm{O} \text { temperatures } \\
\text { from quartz }- \text { epidote } \\
\text { pair }=196-221^{\circ} \mathrm{C} .\end{array}$ \\
\hline & CFAS-3 & $\begin{array}{l}\text { Quartz } \\
\delta^{18} O=8.9 \\
\text { Epidote } \\
\delta^{18} O=2.3 \\
\delta D=-23 \\
K-\text { feldspar } \\
\delta^{18} O=9.0\end{array}$ & $\begin{array}{l}\text {-Intergrown epidote, } \\
\text { K-feldspar \& quartz. }\end{array}$ & $\begin{array}{l}\text {-Daughter minerals in } \\
\text { fluid inclusions: } \\
\text { quartz }=\mathrm{Na}>\mathrm{Ca} \\
\text { chloride. } \\
\text {-Isochore } \\
\text { temperature range = } \\
190^{\circ} \text { to } 320^{\circ} \mathrm{C} \text { (from } \\
90 \text { to } 230 \mathrm{MPa} \text { ). } \\
\text {-Calculated isotopic } \\
\delta^{18} \mathrm{O} \text { temperatures } \\
\text { from quartz }- \text { epidote } \\
\text { pair }=213^{\circ} \mathrm{C} \text {. }\end{array}$ \\
\hline
\end{tabular}

Note: All stable isotope values in bold print were obtained by laser ablation methods at the BRGMCNRS, Orléans, France. All other values were obtained by convential methods from the BRGMCNRS or for calcite from the University of Ottawa stable isotope laboratory, Ottawa, Ontario. 


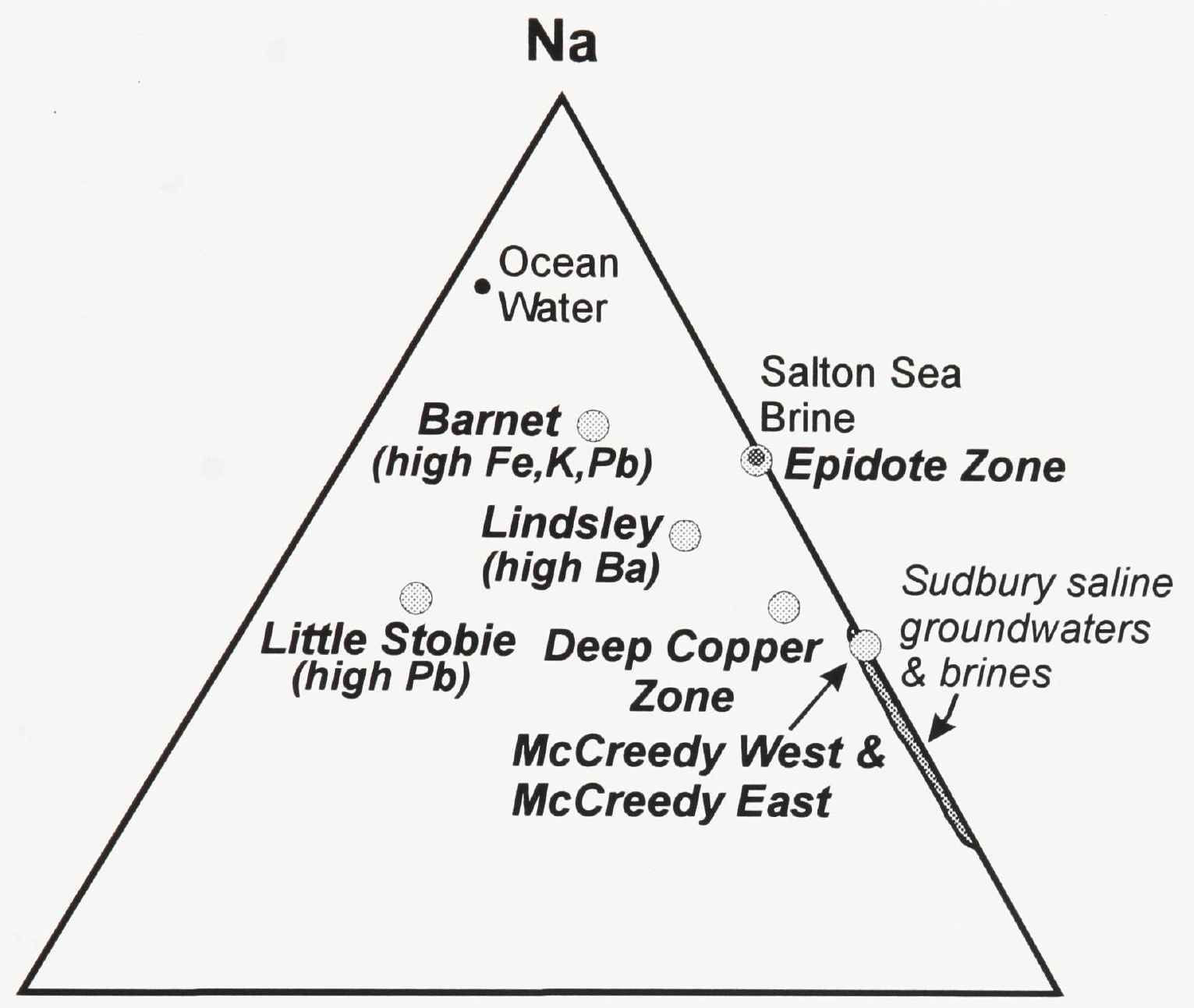

\section{Other cations (Mg,Fe,Pb,K,Ba)}

Figure 8-1: Ternary plot for $\mathrm{Na}-\mathrm{Ca}-(\mathrm{Mg}+\mathrm{Fe}+\mathrm{Pb}+\mathrm{K}+\mathrm{Ba})$ of highly saline waters or brines from present-day Sudbury deep groundwaters, ocean water, Salton Sea geothermal brines, and Sudbury area fluids associated with Cu-Ni-PGE mineralization. Compositions for Sudbury Cu-Ni-PGE deposits are from calculations of weighted abundances of individual chloride daughter mineral abundances from each location and are an estimation of the composition of the original fluids. The trend to higher $\mathrm{Na}$ abundances in the Sudbury Cu-Ni-PGE fluids represents a mixing line between present-day Sudbury saline groundwaters and brines, and present-day ocean water (modified from Frape and Fritz, 1982). 


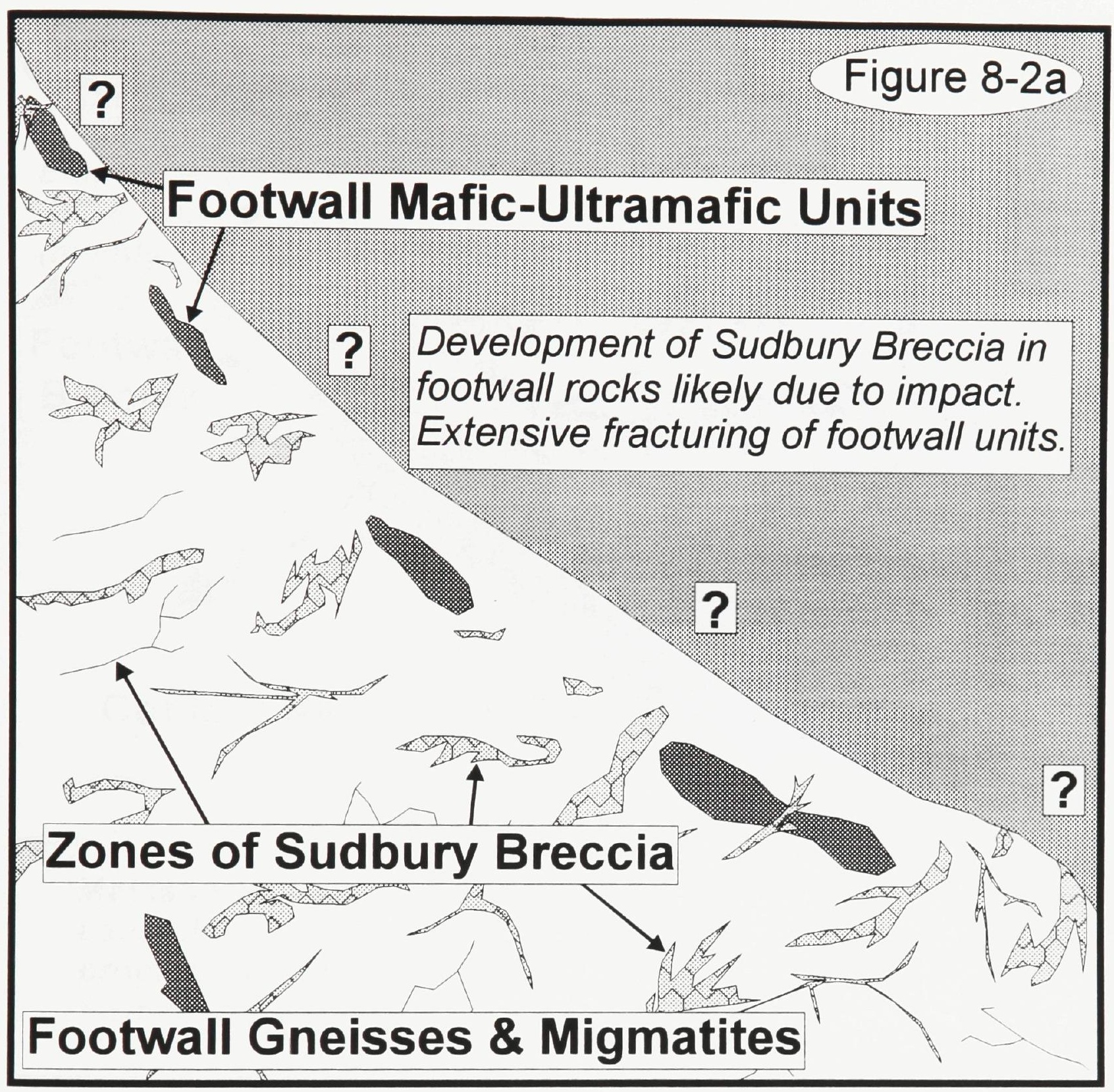

Figure 8-2: Model of sequence of events (illustrated in figures $8-2 a$ to $8-2 d$ ) that contributed to the development of footwall ores in the North Range of the Sudbury Structure. 


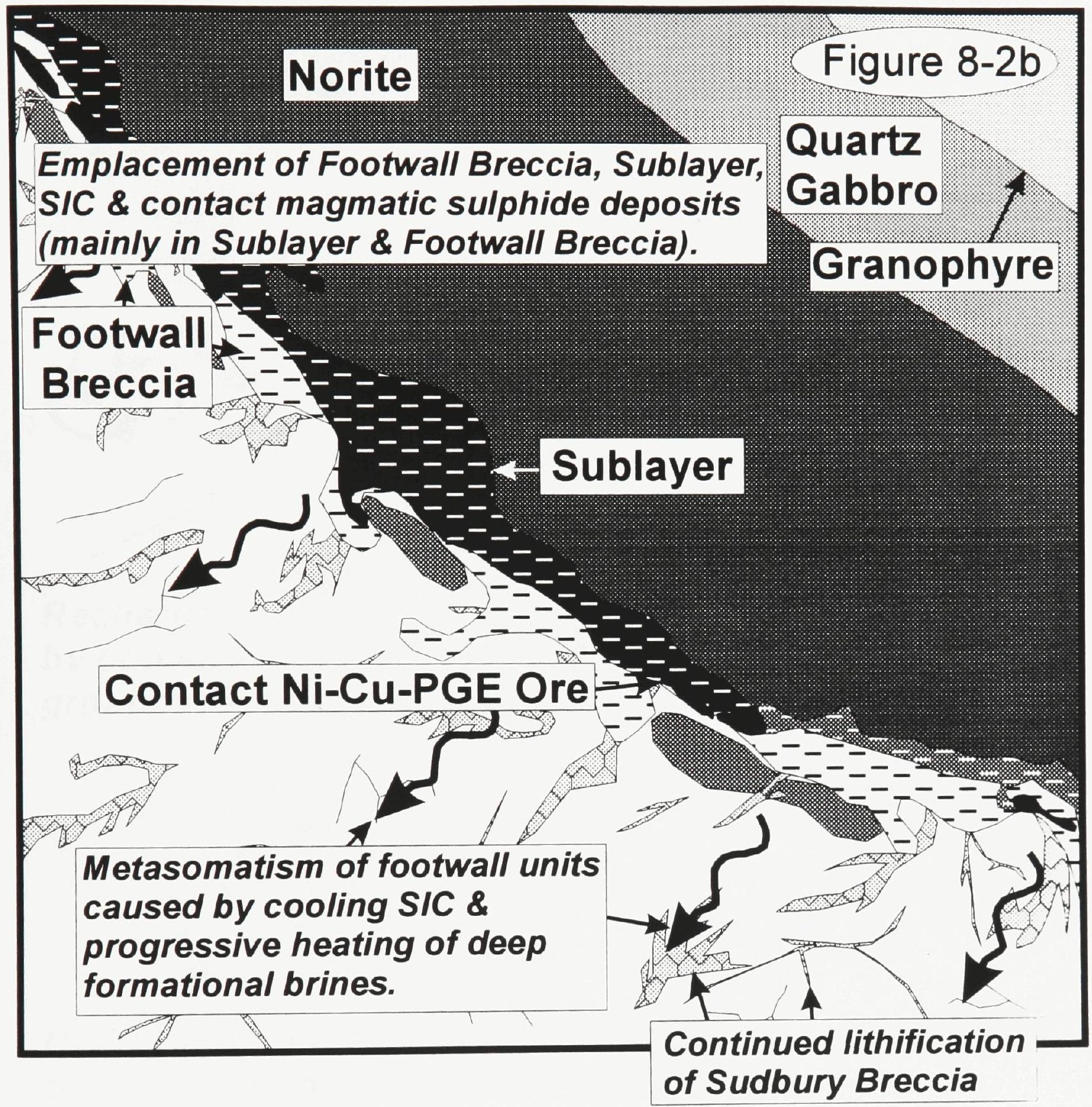

Figure 8-2: (con't) 


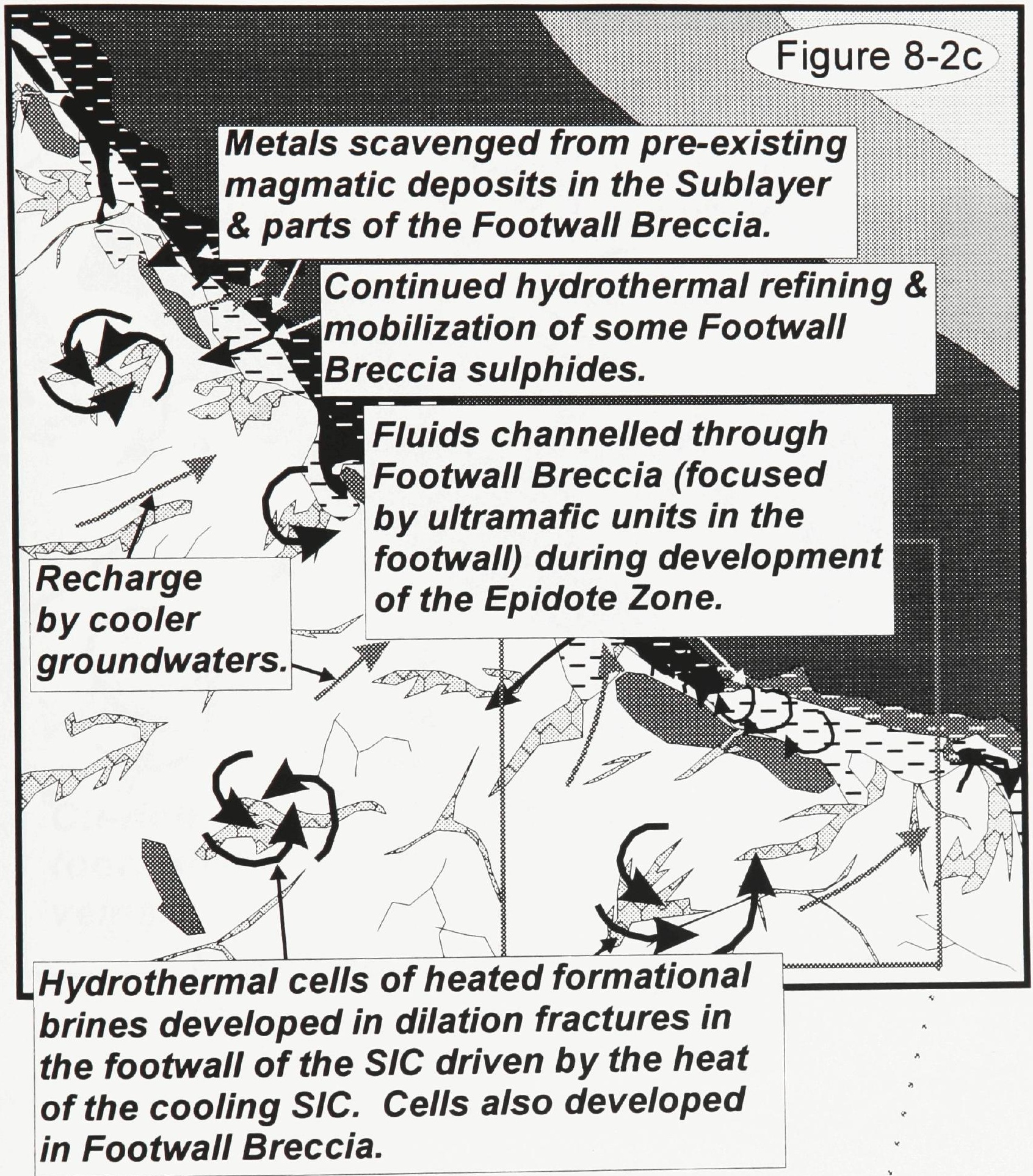

Figure 8-2d

Figure 8-2: (con't) 


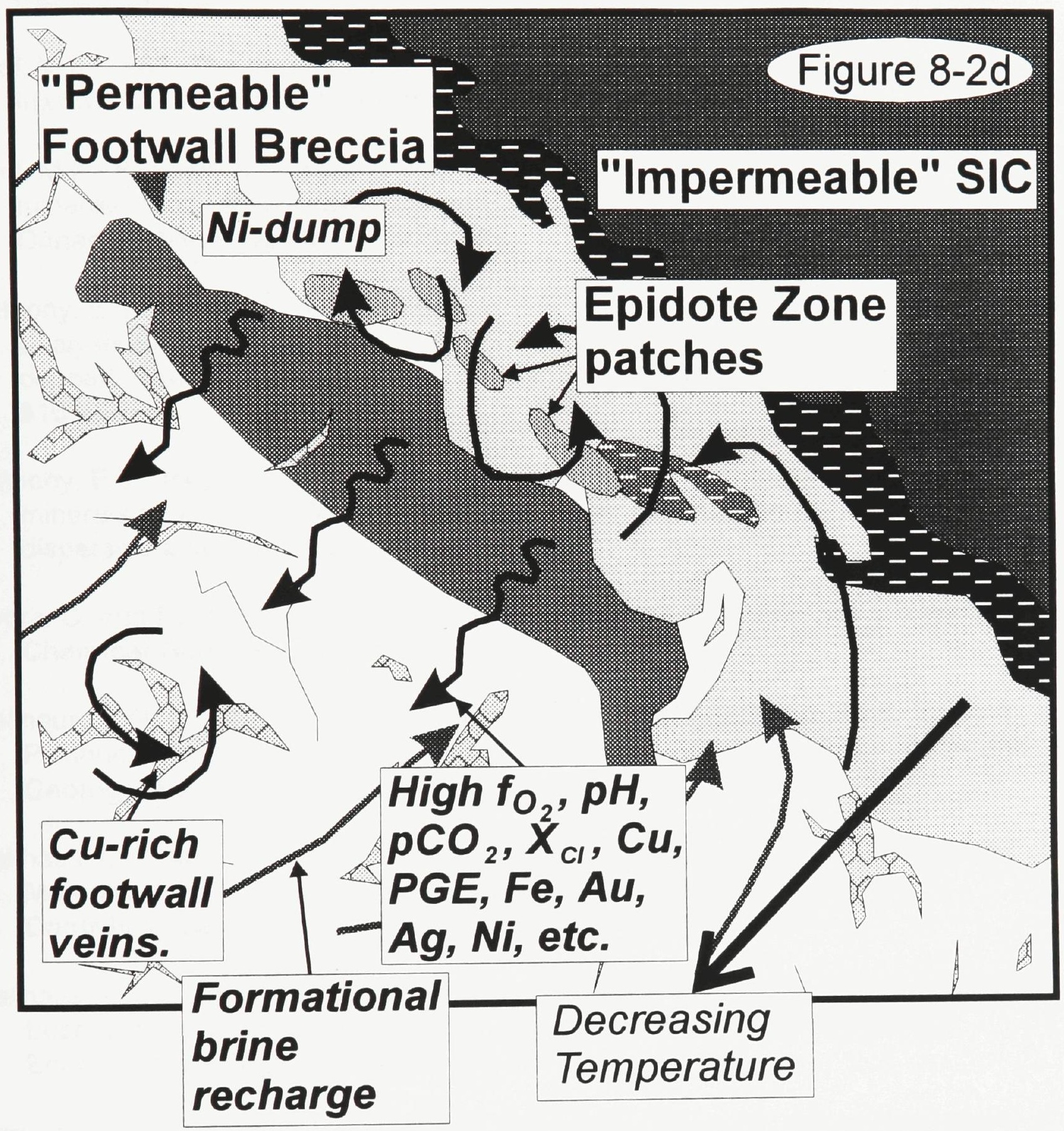

Figure 8-2: (con't) 


\section{REFERENCES}

Abel, M.K. 1981. The structure of the Strathcona Mine copper zone. Canadian Institute of Mining and Metallurgy Bulletin, 74: 89-97.

Abel, M.K., Buchan, R., Coats, C.J.A. and Penstone, M.E. 1979. Copper mineralization in the footwall complex, Strathcona mine, Sudbury, Ontario. Canadian Mineralogist, 17: 275-286.

Anthony, E.Y., Reynolds, T.J. and Beane, R.E. 1983. The use of energy dispersive analysis to identify daughter minerals from the Santa Rita porphyry copper deposit, New Mexico. Geological Society of America Abstracts \& Programs, 15: 516.

Anthony, E.Y., Reynolds, T.J. and Beane, R.E. 1984. Identification of daughter minerals in fluid inclusions using scanning electron microscopy and energy dispersive analysis. American Mineralogist, 69: 1053-1057.

Ayora, C. and Fontarnau, R. 1990. X-ray microanalysis of frozen fluid inclusions. Chemical Geology, 89: 135-148.

Ballhaus, C.G. 1988. Potholes of the Merensky Reef at Brakspruit Shaft, Rustenburg Platinum Mines: primary disturbances in the magmatic stratigraphy. Economic Geology, 83: 1140-1158.

Ballhaus, C.G. and Stumpfl, E.F. 1986. Sulfide and platinum mineralization in the Merensky Reef: evidence from hydrous silicates and fluid inclusions. Contributions to Mineralogy and Petrology, 94: 193-204.

Ballhaus, C.G., Cornelius, M. and Stumpfl, E.F. 1988. The Upper Critical Zone of the Bushveld Complex and the origin of Merensky-type ores--A Discussion. Economic Geology, 83: 1082-1085.

Barnes, S.-J., Naldrett, A.J. and Gorton, M.P. 1985. The origin of the fractionation of platinum-group elements in terrestrial magmas. Chemical Geology, 53: 303323.

Barnes, S.-J., Boyd, R., Korneliussen, A., Nilsson, L.-P., Often, M., Pedersen, R.B. and Robins, B. 1988. The use of mantle normalization and metal ratios in discriminating between the effects of partial melting, crystal fractionation and sulfide segregation on platinum-group elements, gold, nickel and copper: examples from Norway. In Prichard, H.M., Potts, P.J., Bowles, J.F.W. and Cribb, S.J. (eds). Geo-Platinum '87. pp. 113-143, Elsevier Applied Science. 
Barnes, S.-J., Couture, J.-F., Sawyer, E.W. and Bouchaib, C. 1993. Nickel-copper occurrences in the Belleterre-Angliers belt of the Pontiac Subprovince and the use of $\mathrm{Cu}-\mathrm{Pd}$ ratios in interpretting platinum-group element distributions. Economic Geology, 88: 1402-1418.

Barnett, E.S. and Tirschmann, P.A. 1989. Barnet Project Diamond Drill Summary Report. Falconbridge Limited Exploration Internal Report, 44p.

Binney, W.P., Foy, R.A., Halladay, S.H., Poulin, R.Y. and Sweeny, J.M. 1992. The Lindsley Ni-Cu-PGE deposit and its geological setting (abstr.). Canadian Mineralogist, 30: 485-486.

Bleeker, W. 1992. Structural controls on the Strathcona Deep Copper mineralization. Falconbridge Limited Exploration Internal Report, 11p.

Bottinga, Y. and Javoy, M. 1975. Oxygen isotope partitioning among the minerals in igneous and metamorphic rocks. Reviews in Geophysics and Space Physics, 13: $401-418$.

Boudreau, A.E., Mathez, E.A. and McCallum, I.S. 1986. Halogen geochemistry of the Stillwater and Bushveld Complexes: evidence for transport of the platinum-group elements by $\mathrm{Cl}$-rich fluids. Journal of Petrology, 27: 967-986.

Boudreau, A.E. and McCallum, I.S. 1986. Investigations of the Stillwater Complex: III. The Picket Pin Pt/Pd deposit. Economic Geology, 81: 1953-1975.

Boudreau, A.E. and Kruger, F.J. 1990. Variation in the composition of apatite through the Merensky Cyclic Unit in the Western Bushveld Complex. Economic Geology, 85: 737-745.

Brockmeyer, P. 1986. Geologische Kartierung der Sultana Property, Sudbury Distrikt (Ontario, Kanada), Und die petrographische Untersuchung der Sudbury-Breccie. MSc thesis, University of Munster, Germany.

Brown, M. 1973. The definition of metatexis, diatexis and migmatite. Proceedings of the Geological Association, 84(4): 371-382.

Cabri, L.J. and Laflamme, J.H.G. 1976. The mineralogy of the platinum-group elements from some copper-nickel deposits of the Sudbury area, Ontario. Economic Geology, 71: 1159-1195.

Campbell, A.R. and Robinson-Cook, S. 1987. Infrared fluid inclusionm microthemometry on coexisting wolframite and quartz. Economic Geology, 82 : 
1640-1645.

Cavarretta, G., Gianelli, G. and Puxeddu, M. 1982. Formation of authigenic minerals and their use as indicators of the physicochemical parameters of the fluid in the Larderello-Travale geothermal field. Economic Geology, 77: 1071-1084.

Chen, Y. 1993. Precious-metal mineralization and sulfide-silicate relationships in some Canadian Ni-Cu sulfide deposits: Thompson Mine, Manitoba; Sudbury, Ontario; Dundonald Beach, Ontario. PhD Thesis, University of Western Ontario, London, Ontario, $292 \mathrm{p}$.

Chivas, A.R. 1981. Geochemical evidence for magmatic fluids in prophyry copper mineralization. Part I. Mafic silicates from the Koloula Igneous Complex. Contributions to Mineralogy and Petrology, 78: 389-403.

Chyi, L.L. and Crocket, J.H. 1976. Partition of platinum, palladium, iridium, and gold among coexisting minerals from the Deep Ore Zone, Strathcona Mine, Sudbury, Ontario. Economic Geology, 71: 1196-1205.

Clayton, R.N., O'Neil, J. and Mayeda, T.K. 1972. Oxygen isotope exchange between quartz and water. Journal of Geophysical Research, 77: 3057-3067.

Clayton, R.N., Goldsmith, J.R. and Mayeda, T.K. 1989. Oxygen isotope fractionation in quartz, albite, anorthite and calcite. Geochimica et Cosmochimica Acta, 53: 725-733.

Cluff, G. 1969. Morgan Township Geology Review. Falconbridge Limited Internal Report.

Coats, C.J.A. and Snajdr, P. 1984. Ore deposits of the North Range, OnapingLevack area, Sudbury. In Pye, E.G., Naldrett, A.J., and Giblin, P.E. (eds). The Geology and Ore Deposits of the Sudbury Structure, Ontario Geological Survey Special Volume 1, pp. 328-346.

Cooper, A.F. and Lovering, J.F. 1970. Greenschist amphiboles from Haast River, New Zealand. Contributions to Mineralogy and Petrology, 27: 11-24.

Cowan, J.C. 1968. Geology of the Strathcona ore deposit. Canadian Institute of Mining and Metallurgy Bulletin, 61:38-54.

Craig, H. 1961. Standard for reporting concentrations of deuterium and oxygen-18 in natural waters. Geochimica et Cosmochimica Acta, 33: 833-834. 
Crawford, M.L. 1981. Phase equilibria in aqueous fluid inclusions. In Hollister, L.S. and Crawford, M.L. (eds). Fluid Inclusions: Applications to Petrology, Mineralogical Association of Canada, Short Course Handbook, 6, pp. 41-63.

Davies, J.F., Leroux, M.V., Whitehead, R.E., and Goodfellow, W.D. 1990. Oxygenisotope composition and temperature of fluids involved in deposition of Proterozoic Sedex deposits, Sudbury Basin, Ontario. Canadian Journal of Earth Sciences, 27: 1299-1303.

Davis, D.W., Lowenstein, T.K. and Spencer, R.J. 1990. Melting behaviour of fluid inclusions in laboratory-grown halite crystals in the systems $\mathrm{NaCl}-\mathrm{H}_{2} \mathrm{O}, \mathrm{NaCl}-$ $\mathrm{KCl}-\mathrm{H}_{2} \mathrm{O}, \mathrm{NaCl}-\mathrm{MgCl}_{2}-\mathrm{H}_{2} \mathrm{O}$ and $\mathrm{NaCl}-\mathrm{CaCl}_{2}-\mathrm{H}_{2} \mathrm{O}$. Geochimica et Cosmochimica Acta, 54: 591-601.

Deer, W.A., Howie, R.A. and Zussman, J. 1985. An Introduction to the Rock-forming Minerals. Longman Group Limited, Essex, 528 p.

Deitz, R.S. 1964. Sudbury structure as an astrobleme. Journal of Geology, 72: 412434.

Ding, T.P. and Schwarz, H.P. 1984. Oxygen isotopic and chemical compositions of rocks of the Sudbury Basin, Ontario. Canadian Journal of Earth Sciences, 21: 305-318.

Dingwell, D.B. and Dunn, T. 1982. Oxygen isotopic investigation of the Precambrian Stillwater intrusion, Montana. Geological Association of Canada Annual Meeting Programme with Abstracts, 7: 45.

Dressler, B.O. 1984a. General geology of the Sudbury area. In Pye, E.G., Naldrett, A.J., and Giblin, P.E. (eds). The Geology and Ore Deposits of the Sudbury Structure, Ontario Geological Survey Special Volume 1, pp.57-72.

Dressler, B.O. 1984b. The effects of the Sudbury Event and the intrusion of the Sudbury Igneous Complex on the footwall rocks of the Sudbury Structure. In Pye, E.G., Naldrett, A.J. and Giblin, P.E. (eds). The Geology and Ore Deposits of the Sudbury Structure, Ontario Geological Survey Special Volume 1, pp.97136.

Dressler, B.O. 1984c. Sudbury geological compilation. Ontario Geological Survey, Map 2491.

Dressler, B.O., Gupta, V.K. and Muir, T.L. 1991. The Sudbury Structure. In Thurston, P.C. (ed). Geology of Ontario, Ontario Geological Survey Special Volume 4(1), 
pp.593-625.

Dressler, B.O., Peredery, W.V. and Muir, T.L. 1992. Geology and mineral deposits of the Sudbury Structure. Ontario Geological Survey, Guidebook 8, 33p.

Dunn, T. 1986. An investigation of the oxygen isotope geochemistry of the Stillwater Complex. Journal of Petrology, 27: 987-997.

Dupuis, L. 1979. The nature and origin of Sudbury Breccia near Lake Laurentian. Unpublished M.Sc. thesis, Laurentian University, Sudbury, Ontario.

Dupuis, L., Whitehead, R.E.S. and Davies, J.F. 1982. Evidence for a genetic link between Sudbury Breccias and fenite breccias. Canadian Journal of Earth Sciences, 19: 1174-1184.

Elders, W.A., Haagland, J.R. and Williams, A.E. 1981. Distribution of hydrothermal mineral zones in the Cerro Pricto geothermal field of Baja California, Mexico. Geothermics, 10: 245-253.

Enami, M., Liou, J.G. and Bird, D.K. 1992. Cl-bearing amphibole in the Salton Sea geothermal system, California. Canadian Mineralogist, 30: 1077-1092.

Faggart, B.E., Basu, A.R. and Tatsumoto, Y. 1985. Origin of the Sudbury Complex by meteorite impact: Neodymium isotopic evidence. Science, 230: 436-439.

Fairbairn, H.W. and Robson, G.M. 1942. Breccia at Sudbury, Ontario. Journal of Geology, 50: 1-33.

Fairbairn, H.W. and Robson, G.M. 1943. Breccia at Sudbury. Ontario Department of Mines, Annual Report for 1941, 50(6): 18-33.

Fairbairn, H.W., Hurley, P.M., Card, K.D. and Knight, C.J. 1969. Correlation of radiometric ages of Nipissing Diabase and Huronian metasediments with Proterozoic orogenic events in Ontario. Canadian Journal of Earth Sciences, 6: $489-497$.

Farrow, C.E.G. and Sweeny, J.M. 1990. Barnet Trench Extension Geology Report. Falconbridge Limited Exploration Internal Report, $33 \mathrm{p}$.

Farrow, C.E.G. and Watkinson, D.H. 1992. Alteration and the role of fluids in $\mathrm{Ni}, \mathrm{Cu}$ and platinum-group element deposition, Sudbury Igneous Complex contact, Onaping-Levack area, Ontario. Mineralogy and Petrology, 46: 67-83. 
Farrow, C.E.G., Watkinson, D.H., Hattori, K. and Fouillac, A.M. 1992a. Mineralogical and isotopic characteristics of alteration associated with $\mathrm{Ni}, \mathrm{Cu}$ and PGE deposition in the North Range of the Sudbury Structure. Geological Association of Canada/Mineralogical Association of Canada Joint Annual Meeting Program with Abstracts, 17: A32-A33.

Farrow, C.E.G., Hattori, K., Watkinson, D.H. and Fouillac, A.M. 1992b. Isotopic study of alteration minerals associated with $\mathrm{Ni}, \mathrm{Cu}$ and PGE mineralization in the North Range of the Sudbury Intrusive Complex. American Geophysical Union/Canadian Geophysical Union/Mineralogical Society of America Spring Meeting Abstracts, p. 345.

Farrow, C.E.G., Watkinson, D.H., Tirschmann, P.A. and Chai, G. 1992c. The Barnet Property Cu mineralization, North Range, Sudbury Structure: Ministry of Northern Development and Mines, Ontario Mines and Minerals Symposium 1992, p. 31.

Farrow, C.E.G., Watkinson, D.H. and Jones, P.C. 1994. Fluid inclusions in sulfides from North and South range Cu-Ni-PGE deposits, Sudbury Structure, Ontario. Economic Geology, 89: 647-655.

Fehlhaber, K. and Bird, D.K. 1991. Oxygen isotope exchange and mineral alteration in gabbros of the Lower Layered Series, Kap Edvard Holm Complex, East Greenland. Geology, 19: 819-822.

Fleet, M.E. 1977. Origin of disseminated copper-nickel sulfide ore at Frood, Sudbury, Ontario. Economic Geology, 72: 1449-1456.

Fleet, M.E. 1979. Partitioning of $\mathrm{Fe}, \mathrm{Co}, \mathrm{Ni}$, and $\mathrm{Cu}$ between sulfide liquid and basaltic melts and the composition of $\mathrm{Ni}-\mathrm{Cu}$ sulfide deposits--a discussion. Economic Geology, 74: 1517-1519.

Forester, R.W. and Taylor, H.P. Jr. $1977 .{ }^{18} \mathrm{O} /{ }^{16} \mathrm{O}, \mathrm{D} / \mathrm{H}$ and ${ }^{13} \mathrm{C} /{ }^{12} \mathrm{C}$ studies of the Tertiary Igneous Complex of Skye, Scotland. American Journal of Science, 277: 136-177.

Foy, R. 1989. Longvack Diamond Drill Report. Falconbridge Limited Exploration Internal Report, $30 \mathrm{p}$.

Frape, S.K. and Fritz, P. 1982. The chemistry and isotopic composition of saline groundwaters from the Sudbury Basin, Ontario. Canadian Journal of Earth Sciences, 19: 645-661. 
Frape, S.K., Fritz, P. and McNutt, R.H. 1984. Water-rock interaction and chemistry of groundwaters from the Canadian Shield. Geochimica et Cosmochimica Acta, 48: 1617-1627.

Friedmann, I. and O'Neil, J.R. 1977. Compilation of stable isotope fractionation factors of geochemical interest. In Fleischer, M. (ed). Data of Geochemistry, $6^{\text {th }}$ edition, Chapter KK, U.S. Geological Survey Paper 440-KK, 12 p.

Frost, B.R. 1985. On the stability of sulfides, oxides and native metals in serpentinite. Journal of Petrology, 26: 1-33.

Fuge, R. 1979. Water-soluble chlorine in granitic rocks. Chemical Geology, 25: 169-174.

Gammons, C.H., Bloom, M.S. and Yu, Y. 1992. Experimental investigation of the hydrothermal geochemistry of platinum and palladium: I. Solubility of platinum and palladium sulphide minerals in $\mathrm{NaCl} / \mathrm{H}_{2} \mathrm{SO}_{4}$ solutions at $300^{\circ} \mathrm{C}$. Geochimica et Cosmochimica Acta, 56: 3881-3894.

Good, D.J. and Crocket, J.H. 1989. PGE study of the Geordie Lake and Marathon Cu-Ni-precious metal deposits, Coldwell Alkalic Complex. Ontario Geological Survey Miscellaneous Paper 143: 186-198.

Grabczak, J., Rozanski, K. and Zuber, A. 1986. Comments on "Water-rock interaction and chemistry of groundwaters from the Canadian Shield by Frape, Fritz and McNutt". Geochimica et Cosmochimica Acta, 50: 1559-1560.

Graham, C.M. and Sheppard, S.M.F. 1980. Experimental hydrogen isotope studies, II. Fractionations in the systems epidote- $\mathrm{NaCl}-\mathrm{H}_{2} \mathrm{O}$, epidote- $-\mathrm{CaCl}_{2}-\mathrm{H}_{2} \mathrm{O}$ and epidote-seawater, and the hydrogen isotope composition of natural epidotes. Earth and Planetary Science Letters, 49: 237-251.

Graham, C.M., Harmon, R.S. and Sheppard, S.M.F. 1984. Experimental hydrogen isotope studies: hydrogen isotope exchange between amphibole and water. American Mineralogist, 69: 128-138.

Grant, J.A. 1986. The isocon diagram - a simple solution to Gresens' equation for metasomatic alteration. Economic Geology, 81: 1976-1982.

Greenman, L. 1970. The petrology of the footwall breccias in the vicinity of the Strathcona Mine, Levack, Ontario. PhD Thesis, University of Toronto, Toronto, Canada. 
Gresens, R.L. 1967. Composition-volume relationships of metasomatism. Chemical Geology, 2: 47-55.

Griffin, B.J. 1990. In situ analysis of natural fluid inclusions in minerals by a cryostage and thin window EDS. In Michael, J.R. and Ingram, P. (eds). Microbeam Analysis, Proceedings of the $25^{\text {th }}$ Annual Conference of the Microbeam Analysis Society, Seattle, Washington, 12-18 August, 1990, p. 203-205.

Hallbauer, D.K. and Kable, E.J.D. 1982. Fluid inclusions and trace element content of quartz and pyrite pebbles from Witwatersrand conglomerates: Their significance with respect to the genesis of primary deposits. In Amstutz, G.C. et al. (eds). Ore Genesis - The State of the Art, Springer-Verlag, Berlin, p. 742-752.

Harney, D.M., Merkle, R.K.W. and Von Gruenewaldt, G. 1990. Platinum-group element behaviour in the lower part of the Upper Zone, Eastern Bushveld Complex--implications for the formation of the Main Magnetite Layer. Economic Geology, 85: 1777-1789.

Hawley, J.E. 1962. The Sudbury ores: their mineralogy and origin. Canadian Mineralogist, 7: 207p.

Hawley, J.E. and Berry, L.G. 1958. Michenerite and Froodite, palladium bismuthide minerals. Canadian Mineralogist, 6: 200-209.

Hawley, J.E. and Stanton, R.L. 1962. The facts, the ores, their minerals, metals and distribution. In The Sudbury Ores: Their Mineralogy and Their Origin. Canadian Mineralogist, 7: 30-145.

Hendry, D.A.F., Chivas, A.R., Long, J.V.P. and Reed, S.J.B. 1985. Chemical differences between minerals from mineralizing and barren intrusions from some North American porphyry copper deposits. Contributions to Mineralogy and Petrology, 89: 317-329.

Hey, M.H. 1954. A new review of the chlorites. Mineralogical Magazine, 30: 271279.

Hoffman, E.L and MacLean, W.H. 1976. Phase relations of michenerite and merenskyite in the Pd-Bi-Te system. Economic Geology, 71: 1461-1468.

Hoffman, E.L., Naldrett, A.J., Alcock, R.A. and Hancock, R.G.V. 1979. The noble metal content of ore in the Levack West and Little Stobie mines, Ontario.

Canadian Mineralogist, 17: 437-451. 
Inoue, A. and Utada, M. 1991. Pumpellyite and related minerals from hydrothermally altered rocks at the Kamikita area, Northern Honshu, Japan. Canadian Mineralogist, 29: 255-270.

Irvine, T.N. 1975. Crystallization sequences of the Muskox intrusion and other layered intrusions-II. Origin of chromitite layers and similar deposits of other magmatic ores. Geochimica et Cosmochimica Acta, 39: 991-1020.

Ishizuka, H. 1985. Prograde metamorphism of the Horokanai ophiolite in the Kamuikotan zone, Hokkaido, Japan. Journal of Petrology, 26: 391-417.

Ito, E. and Anderson, A.T., Jr. 1983. Submarine metamorphism of gabbros from the Mid-Cayman Rise: petrographic and mineralogical constraints on hydrothermal processes at slow-spreading ridges. Contributions to Mineralogy and Petrology, 82: 371-388.

Jago, B.C., Morrison, G.G. and Little, T.L. 1994. Metal zonation patterns and microtextural and micromineralogical evidence for alkali- and halogen-rich fluids in the genesis of the Victor Deep and McCreedy East footwall copper orebodies, Sudbury Igneous Complex. In Lightfoot, P.C. and Naldrett, A.J. (eds). Proceedings of the Sudbury-Noril'sk Symposium, p. 65-75.

James, R., Peredery, W. and Sweeny, J.M. 1991. Geothermobarometry of Levack Gneisses - Footwall rocks on the North Range of the Sudbury Igneous Complex (SIC). abstr.

Johan, Z. and Watkinson, D.H. 1987. Phase fluide riche en $\mathrm{Na}-\mathrm{Cl}-\mathrm{H}-\mathrm{O}-\mathrm{N}$ et son role dans le concentration des elements groupe de platine et de la chromite: "Upper Critical Zone", complexe de Bushveld, In Guides de prospection pour les gisements de platinoides dans les complexes ophiolitiques et stratifies. Rapport final: Commission des Communautes Europeennes, pp. 61-85.

Kalamarides, R.I. 1982. ${ }^{18} \mathrm{O}$ fractionation among phases and evaluation of the contamination of the Kiglapait layered intrusion. Transcripts of the American Geophysical Union EOS, 45: 1151.

Kalamarides, R.I. 1984. Kiglapait geochemistry VI: Oxygen isotopes. Geochimica et Cosmochimica Acta, 48: 1827-1836.

Karhu, J. and Epstein, S. 1986. The implication of the oxygen isotope records in coexisting cherts and phosphates. Geochimica et Cosmochimica Acta, 50: $1745-1756$. 
Keays, R.R. and Crocket, J.H. 1970. A study of precious metals in the Sudbury Nickel Irruptive ores. Economic Geology, 65: 438-450.

Keays, R.R., Ross, J.R. and Woolrich, P. 1981. Precious metals in volcanic peridotite-associated nickel sulfide deposits in Western Australia II: distribution within the ores and host rocks at Kambalda. Economic Geology, 76: 16451674.

Keays, R.R., Nickel, I.H., Groves, D.I. and McGoldrick, P.J. 1982. Iridium and palladium as discriminants of volcanic-exhalative hydrothermal and magmatic nickel sulphide mineralization. Economic Geology, 77: 1535-1547.

Kelly, W.C. and Burgio, P.A. 1983. Cryogenic scanning electron microscopy of fluid inclusions in ore and gangue minerals. Economic Geology, 78: 1262-1267.

Kostopoulos, D. 1984. The trace element geochemistry of the Strathcona coppernickel deposit, Sudbury, Ontario. MSc thesis, Laurentian University, Ontario, $90 \mathrm{p}$.

Krogh, T.E., Davis, D.W., and Corfu, F. 1984. Precise U-Pb zircon and baddeleyite ages for the Sudbury area. In Pye, E.G., Naldrett, A.J., and Giblin, P.E. (eds). The Geology and Ore Deposits of the Sudbury Structure, Ontario Geological Survey Special Volume 1, $603 \mathrm{p}$.

Lafleur, J. and Dressler, B.O. 1985. Geology of Cascaden, Dowling, Levack and Trill Townships, District of Sudbury. Ontario Geological Survey Open File Report $5533,135 p$.

Lakomey, R. 1990. Implications for cratering mechanics from a study of the Footwall Breccia of the Sudbury impact structure. Meteoritics, 25: 195-207.

Langford, F.F. 1960. Geology of Levack Township and the northern part of Dowling Township, District of Sudbury. Ontario Department of Mines Preliminary Report 1960-5, 78p.

Lausen, C. 1930. Graphic intergrowth of niccolite and chalcopyrite, Worthington Mine, Sudbury. Economic Geology, 25: 356-364.

Leake, B.E. 1978. Nomenclature of amphiboles. Canadian Mineralogist, 16: 501520.

LeBel, L. 1976. Preliminary note on the mineralogy of solid phases in quartz phenocryst inclusions in the porphyry copper from Cerro Verde-Santa Rosa, S. 
Peru. Bulletin Societe Vaudoise Science Nationale, 73(350): 201-208.

LeBel, L. 1980. Caractéristiques de la phase fluide associé à la minéralisation de Cerro Verde-Santa Rosa. In Johan, Z. (ed.). Minéralisations lieés aux granitoids. Mémoire du Bureau de Réchèrches Geologique Minières, 99: 129-139.

Lee, J.E. 1987. Some structural relationships in the northern part of the Sudbury Structure. Falconbridge Limited Internal Report.

Li, C. and Naldrett, A.J. 1989. PGE study in the footwall at Sudbury. In Milne, V.G. (ed.). Ontario Geological Survey Miscellaneous Paper 143:104-113.

Li, C. and Naldrett, A.J. 1990. PGE study at Sudbury: their concentration by sulfideliquid fractionation. In Milne, V.G. (ed.). Ontario Geological Survey Miscellaneous Paper 150:37-46.

Li, C. and Naldrett, A.J. 1992. PGE studies in the footwall at Sudbury. Ontario geoscience research grant program, grant no. 326; Ontario Geological Survey Open File Report 5830, 118p.

Li, C., Naldrett, A.J., Coats, C.J.A., and Johannssen, P. 1992. Platinum, palladium, gold and copper-rich stringers at the Strathcona Mine, Sudbury: Their enrichment by fractionation of a sulfide liquid. Economic Geology, 87:15841598.

Li, C. and Naldrett, A.J. 1993a. Platinum-group minerals from the Deep Copper Zone of the Strathcona deposit, Sudbury, Ontario. Canadian Mineralogist, 31: 631644.

Li, C. and Naldrett, A.J. 1993b. Concentrations of platinum-group elements and gold in sulfides from the Strathcona deposit, Sudbury, Ontario. Canadian Mineralogist, 31: 523-532.

Li, C. and Naldrett, A.J. 1993c. Sulfide capacity of magma: a quantitative model and its application to the formation of sulfide ores at Sudbury, Ontario. Economic Geology, 88: 1253-1260.

Li, C. and Naldrett, A.J. 1993d. High chlorine alteration minerals and calcium-rich brines in fluid inclusions from the Strathcona Deep Copper Zone, Sudbury, Ontario. Economic Geology, 88: 1780-1796.

Lochhead, D.R. 1955. The Falconbridge ore deposit. Economic Geology, 50: 4250 . 
London, D., Spooner, E.T.C. and Roedder, E. 1982. Fluid-solid inclusions in spodumene from the Tanco pegmatite, Bernic Lake, Manitoba. Carnegie Institution of Washington Year Book, 81:334-339.

Loucks, R.R. 1976. Platinum-gold-copper mineralization, central Medicine Bow Mountains, Wyoming. Unpublished M.Sc. thesis, Colorado State University.

Macdonald, A.J. 1988. Platinum-group element mineralization and the relative importance of magmatic and deuteric processes: Field evidence from the Lacdes-lles Deposit, Ontario, Canada. In Prichard, H.M., Potts, P.J., Bowles, J.F.W. and Cribb, S.J., (eds). Geo-Platinum '87. Elsevier Applied Science, pp.215-236.

Maruyama, S., Suzuki, K. and Liou, J.G. 1983. Greenschist-amphibole transition equilibria at low pressures. Journal of Petrology, 24: 583-604.

Marshall, A.T. 1977. Iso-atomic droplets as models for the investigation of parameters affecting $x$-ray microanalysis of biological specimens. Micron, 8 : 193-200.

Marshall, D.D. 1990. Pressure, temperature, composition and state of the fluid during silver arsenide vein formation, Cobalt, Ontario. Unpublished M.Sc. thesis, Carleton University, Ottawa, Ontario, 92p.

Matsuhisa, Y., Goldsmith, J.R. and Clayton, R.N. 1978. Mechanism of hydrothermal crystallization of quartz at $250^{\circ} \mathrm{C}$ and $15 \mathrm{kbar}$. Geochimica et Cosmochimica Acta, 42: 173-182.

Matsuhisa, Y., Goldsmith, J.R. and Clayton, R.N. 1979. Oxygen isotopic fractionation in the system quartz-albite-anorthite-water. Geochimica et Cosmochimica Acta, 43: 1131-1140.

Matthews, A., Goldsmith, J.R. and Clayton, R.N. 1983a. Oxygen isotope fractionation between zoisite and water. Geochimica et Cosmochimica Acta, 47:645-654.

Matthews, A., Goldsmith, J.R. and Clayton, R.N. 1983b. Oxygen isotope fractionations involving pyroxenes: the calibration of mineral-pair geothermometers. Geochimica et Cosmochimica Acta, 47: 631-644.

McCallum, M.E., Loucks, R.R., Carlson, R.R., Cooley, E.F. and Doerge, T.A. 1976. Platinum metals associated with hydrothermal copper ores of the New Rambler Mine, Medicine Bow Mountains, Wyoming. Economic Geology, 71: 1429-1450. 
McKibben, M.A., Williams, A.E. and Hall, G.E.M. 1990. Solubility and transport of platinum-group elements and $\mathrm{Au}$ in saline hydrothermal fluids: constraints from geothermal brine data. Economic Geology, 85: 1926-1934.

McNutt, R.H., Frape, S.K., Fritz, P., Jones, M.G. and MacDonald, I.M. 1990. The ${ }^{87} \mathrm{Sr} /{ }^{86} \mathrm{Sr}$ values of Canadian Shield brines and fracture minerals with applications to groundwater mixing, fracture history, and geochronology. Geochimica et Cosmochimica Acta, 54: 205-215.

Mehnert, K.R. 1968. Migmatites and the origin of granitic rocks. Elsevier, 393p.

Metzger, F.W., Nesbitt, B.E. and Kelly, W.C. 1975. Scanning electron microscopy of daughter minerals in fluid inclusions. Geological Association of America Abstracts and Programs, 7: 1199.

Metzger, F.W., Kelly, W.C., Nesbitt, B.E. and Essene, E.J. 1977. Scanning electron microscopy of daughter minerals in fluid inclusions. Economic Geology, 72: $141-152$.

Mitchell, G.P. and Mutch, A.D. 1956. Geology of the Hardy Mine, Sudbury District, Ontario. Canadian Institute of Mining and Metallurgy Bulletin, February 1956: 75-81.

Money, D.P. 1992. Ni, Cu, Au, Pt, Pd and Ag distribution within the 37-1620 stope, Deep Copper Zone, Strathcona Mine, Onaping, Ontario, Canada. MSc thesis, Queen's University, Kingston, Ontario, 85p.

Moore, F. and Moore, D.J. 1979. Fluid inclusion study of mineralization at St. Michael's Mount, Cornwall, England. Institute of Mining and Metallurgy Transactions, 88: 57-60.

Moore, D.E., Morrow, C.A. and Byerlee, J.D. 1983. Chemical reactions accompanying fluid flow through granite held in a temperature gradient. Geochimica et Cosmochimica Acta, 47: 445-453.

Morrison, G.G., Jago, B.C. and Little, T.L. 1992. Sudbury footwall mineralization, with particular reference to the McCreedy East and Victor deposits (abstr.). Canadian Mineralogist, 30: 483-484.

Morrison, G.G., Jago, B.C. and White, T.L. 1994. Footwall mineralization of the Sudbury Igneous Complex. In Lightfoot, P.C. and Naldrett, A.J. (eds).

Proceedings of the Sudbury Noril'sk Symposium. Ontario Geological Survey Special Volume 5, p.57-64. 
Mountain, B.W. and Wood, S.A. 1988a. Chemical controls on the solubility, transport, and deposition of platinum and palladium in hydrothermal solutions: a thermodynamic approach. Economic Geology, 83: 492-510.

Mountain, B.W. and Wood, S.A. 1988b. Solubility and transport of platinum-group elements in hydrothermal solutions: thermodynamic and physical chemical constraints. In Prichard, H.M., Potts, P.J., Bowles, J.F.W. and Cribb, S.J. (eds.) Geo-Platinum '87. pp. 57-82, Elsevier Applied Science.

Muir, T. 1983. Geology of the Morgan Lake-Nelson Lake area, District of Sudbury. Ontario Geological Survey Open File Report 5426.

Mulja, T., and Mitchell, R. 1989. Platinum-group minerals from the Geordie Lake intrusion, Coldwell Alkaline Complex, Ontario. Geological Association of Canada/Mineralogical Association of Canada Joint Annual Meeting Programme with Abstracts, 14: A70.

Muller-Mohr, V. 1988. Geologische Kartierung im Zentralen Teil von Levack Township, Sudbury-Distrikt (Ontario, Kanada), und die Untersuchung der Sudbury-Strucktur; Petrographie und Verbreitung entlang eines Profils in der North Range der Struktur. MSc thesis, University of Munster, Germany.

Naldrett, A.J. 1979. Partitioning of $\mathrm{Fe}, \mathrm{Co}, \mathrm{Ni}$ and $\mathrm{Cu}$ between sulfide liquid and basaltic melts and the composition of $\mathrm{Ni}$-Cu sulfide deposits--a reply and further discussion. Economic Geology, 74: 1520-1528.

Naldrett, A.J. 1981. Nickel sulfide deposits: Classification, composition and genesis Economic Geology, 75: 628-685.

Naldrett, A.J. 1984. Mineralogy and composition of the Sudbury ores. In Pye, E.G., Naldrett, A.J. and Giblin, P.E. (eds). The Geology and Ore Deposits of the Sudbury Structure. Ontario Geological Survey Special Volume 1, p.309-326.

Naldrett, A.J. 1989. Magmatic Sulfide Deposits. Oxford Monographs on Geology and Geophysics No.14, Clarendon Press, New York, 186p.

Naldrett, A.J. and Kullerud, G. 1967. A study of the Strathcona mine and its bearing on the origin of the nickel-copper ores of the Sudbury district, Ontario. Journal of Petrology, 8: 453-531.

Naldrett, A.J. and Duke, J.M. 1980. Platinum metals in magmatic sulfide ores. Science, 208: 1417-1428. 
Naldrett, A.J. and MacDonald, A.J. 1980. Tectonic setting of some Ni-Cu sulfide ores: their importance in genesis and exploration. Geological Association of Canada Special Paper 20: 633-657.

Naldrett, A.J., Innes, D.G., Sowa, J., and Gorton, M.P. 1982. Compositional variations within and between five Sudbury ore deposits. Economic Geology, 77: 1519-1534.

Naldrett, A.J., Hewins, R.H., Dressler, B.O. and Rao, B.V. 1984. The contact Sublayer of the Sudbury Igneous Complex. In Pye, E.G., Naldrett, A.J. and Giblin, P.E. (eds). The Geology and Ore Deposits of the Sudbury Structure. Ontario Geological Survey Special Volume 1, p.253-274.

Naldrett, A.J., Rao, B.V., Evensen, N.M. and Dressler, B.O. 1985. Major and trace element and isotopic studies at Sudbury - a model for the structure and its ores. Ontario Geological Survey Miscellaneous Paper 127, p.30-44.

Naldrett, A.J., Rao, B.V. and Evenson, N.M. 1986. Contamination at Sudbury and its role in ore formation. In Gallagher, M.J., Ixer, R.A., Neary, C.R. and Pritchard, H.M. (eds). Metallogeny of basic and ultrabasic rocks. London Institution of Mining and Metallogeny, p. 75-91.

Naldrett, A.J., Pessaran, R. and Li, C. 1992. Variation in the Ni, Cu and PGE content of ore on the North Range at Sudbury, between the Hardy and Longvack mines (abstr.). Canadian Mineralogist, 30: 495-496.

Naldrett, A.J., Pessaran, R., Asif, M., and Li, C. 1994. Compositional variation in the Sudbury ores and prediction of the proximity of footwall copper-PGE orebodies.

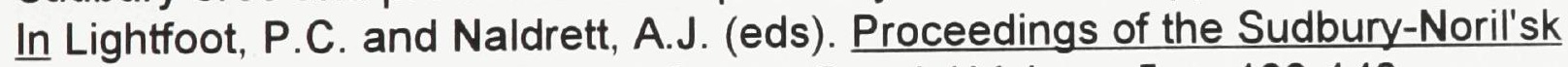
Symposium. Ontario Geological Survey Special Volume 5, p. 133-146.

Nesbitt, B.E. and Kelly, W.C. 1977. Magmatic and hydrothermal inclusions in carbonatite of the Magnet Cove Complex, Arkansas. Contributions to Mineralogy and Petrology, 63: 271-294.

Norton,D. and Taylor, H.P., Jr. 1979. Quantitative simulation of the hydrothermal systems of crystallizing magmas on the basis of transport theory and oxygen stable isotope data: An analysis of the Skaergaard intrusion. Journal of Petrology, 20: 421-486.

Nyman, M.W., Sheets, R.W. and Bodnar, R.J. 1990. Fluid-inclusion evidence for the physical and chemical conditions associated with intermediate-temperature PGE mineralization at the New Rambler deposit, southeastern Wyoming. Canadian 
Mineralogist, 28: 629-638.

Oakes, C.S., Bodnar, R.J. and Simonson, J.M. 1990. The system $\mathrm{NaCl}-\mathrm{CaCl}_{2}-\mathrm{H}_{2} \mathrm{O}$. I. The ice liquidus at $1 \mathrm{~atm}$. total pressure. Geochimica et Cosmochimica Acta, 54: 603-610.

O'Neil, J.R., Clayton, R.N. and Mayeda, T.K. 1969. Oxygen isotope fractionation in divalent metal carbonates. Journal of Chemical Physics, 51: 5547-5558.

Pattison, E.F. 1979. The Sudbury Sublayer. Canadian Mineralogist, 17: 257-274.

Peredery, W.V. 1972. The origin of rocks at the base of the Onaping Formation, Sudbury, Ontario. PhD thesis, University of Toronto, Toronto, Ontario, 366p.

Peredery, W.V. and Morrison, G.G. 1984. Discussion of the origin of the Sudbury Structure. In Pye, E.G., Naldrett, A.J., and Giblin, P.E. (eds). The Geology and Ore Deposits of the Sudbury Structure, Ontario Geological Survey Special Volume 1, pp. 491-512.

Phillips, G.N. and Groves, D.I. 1983. The nature of Archean gold-bearing fluids as deduced from gold deposits of Western Australia. Journal of the Geological Society of Australia, 30: 25-39.

Pye, E.G., Naldrett, A.J. and Giblin, P.E. (eds). 1984. The Geology and Ore Deposits of the Sudbury Structure. Ontario Geological Survey Special Volume 1, 603p.

Quinton, P.M. 1978. Ultramicroanalysis of biological fluids with energy dispersive $x-$ ray spectrometry. Micron, 9: 57-69.

Reynolds, T.J. and Beane, R.E. 1985. Evolution of hydrothermal fluid characteristics at the Santa Rita, New Mexico, porphyry copper deposit. Economic Geology, 80: $1328-1347$.

Rittenhouse, G. 1967. Bromine in oil-field waters and its use in determining possibilities of origin of these waters. American Association of Petroleum Geologists Bulletin, 51: 2430-2440.

Roedder, E. 1984. Fluid Inclusions. Mineralogical Society of America Reviews in Mineralogy, 12, 644p.

Rowell, W.F. and Edgar, A.D. 1986. Platinum-group element mineralization in a hydrothermal $\mathrm{Cu}-\mathrm{Ni}$ sulfide occurrence, Rathbun Lake, northeastern Ontario. Economic Geology, 81: 1272-1277. 
Rucklidge, J. 1969. Electron microprobe investigations of platinum metal minerals from Ontario. Canadian Mineralogist, 9: 617-628.

Sassini, D.C. and Shock, E.L. 1990. Speciation and solubility of palladium in aqueous magmatic-hydrothermal solutions. Geology, 18: 925-928.

Schiffries, C.M. 1982. The petrogenesis of a platiniferous dunite pipe in the Bushveld Complex: infiltration metasomatism by a chloride solution. Economic Geology, 77: 1439-1453.

Schiffries, C.M. and Skinner, B.J. 1987. The Bushveld hydrothermal system: field and petrologic evidence. American Journal of Science, 287: 566-595.

Seward, T.M. 1973. Thiocomplexes of gold and the transport of gold in hydrothermal ore solutions. Geochimica et Cosmochimica Acta, 37: 379-399.

Shand, S.J. 1916. The pseudotachylite of Parijs (Orange Free State). Geological Society of London Quarterly Journal, 72: 198-221.

Sheppard, S.M.F. 1986. Characterization and isotopic variations in natural waters. In Valley, J.W., Taylor, H.P., Jr., and O'Neil, J.R. (eds). Stable Isotopes in High Temperature Geological Processes, Mineralogical Society of America, Reviews in Mineralogy, 16: 165-183.

Snajdr, P. 1985. Mineralogy and petrology of the Strathcona Deep Copper Zone. Petrographic Report No. 141, Falconbridge Limited Report.

Sofer, Z. and Gat, J.R. 1975. The isotopic composition of evaporating brines: effect of the isotopic activity ratio in saline solutions. Earth and Planetary Science Letters, 26: 179-186.

Souch, B.E., Podolsky, T., and Geological Staff. 1969. The sulfide ores of Sudbury: their particular relationship to a distinctive inclusion-bearing facies of the Nickel Irruptive. In Wilson H.D.B. (ed.) Magmatic Ore Deposits, Economic Geology Monograph, 4: 252-261.

Speers, E.C. 1957. The age relation and origin of common Sudbury Breccia. Journal of Geology, 65: 497-514.

Springer, G. 1985. Ore minerals in the Deep Copper Zone. Falconbridge Limited Report, 4p.

Springer, G. 1989. Chlorine-bearing and other uncommon minerals in the Strathcona 
Deep Copper Zone, Sudbury District, Ontario. Canadian Mineralogist, 27: 311 313.

Springer, G. and Collins, D.A. 1982. Electron probe results on the Strathcona Deep Copper Zone. Falconbridge Limited Report, 8p.

Springer, G. and Lalonde, S. 1987. Gold in the Deep Copper Zone, Falconbridge Limited Report, 1p.

Streckeisen, A.L. 1976. To each plutonic rock its proper name. Earth Science Review, 12: 1-34

Stumpfl, E.F. 1992. Volatiles: the decisive factor in platinum mineralization. In Foster, R.P. (ed). Mineral deposit modelling in relation to crustal reservoirs of ore-forming elements, Abstracts volume, Keyworth, United Kingdom, April 22-23, 1992, p9.

Sweeny, J.M., and Farrow, C.E.G. 1990. Morgan West Project Geology Report, Morgan and Levack Townships. Falconbridge Limited Exploration Internal Report, $35 \mathrm{p}$.

Sweeny, J.M., Meecham, R., Spark, R. and Farrow, C.E.G. 1990. Geology of the Pike Lake-Longvack properties. Falconbridge Limited Exploration Internal Report, $14 \mathrm{p}$.

Tagiri, M. 1977. Fe-Mg partition and miscibility gap between coexisting calcic amphiboles from the southern Abukuma Plateau, Japan. Contributions to Mineralogy and Petrology, 62: 271-281.

Taylor, H.P. 1968. The oxygen isotope geochemistry of igneous rocks. Contributions to Mineralogy and Petrology, 19: 1-71.

Taylor, H.P. 1974. The application of oxygen and hydrogen isotopic studies to problems of hydrothermal alteration and ore deposition. Economic Geology, 69: 843-883.

Taylor, H.P. and Epstein, S. 1963. $\mathrm{O}^{18} / \mathrm{O}^{16}$ ratios in rocks and coexisting minerals of the Skaergaard intrusion, East Greenland. Journal of Petrology, 4: 51-74.

Taylor, H.P. and Forester, R.W. 1979. An oxygen and hydrogen isotope study of the Skaergaard intrusion and its country rocks; a description of a 55-m.y. old fossil hydrothermal system. Journal of Petrology, 20: 355-419. 
Tellier, M.L., Brugmann, G.E. and Naldrett, A.J. 1991. Gabbro-hosted PGE mineralization in the Lac-des-lles Complex: A geochemistry and fluid inclusion study. Geological Association of Canada/Mineralogical Association of Canada/Society of Economic Geologists Joint Annual Meeting Programme with Abstracts, 16:A123.

Tirschmann, P.A. 1989. Barnet Project Geology Report, Levack Township. Falconbridge Limited Exploration Internal Report, $24 \mathrm{p}$.

Twilley, F.T. 1993. Preliminary Report on Status of Epidote Zone Exploration. Falconbridge Limited Internal Report, $8 \mathrm{p}$.

Vanko, D.A. 1986. High chlorine amphiboles from oceanic rocks: product of highly saline hydrothermal fluids? American Mineralogist, 71: 51-59.

Vanko, D.A., Bodnar, R.J. and Sterner, S.M. 1988. Synthetic fluid inclusions: VIII. Vapor-saturated halite solubility in part of the system $\mathrm{NaCl}-\mathrm{CaCl}_{2}-\mathrm{H}_{2} \mathrm{O}$, with application to fluid inclusions from oceanic hydrothermal systems. Geochimica et Cosmochimica Acta, 52: 2451-2456.

Volfinger, M., Robert, J.L., Vielzeuf, D. and Neiva, A.M.R. 1985. Structural control of the chlorine content of $\mathrm{OH}$-bearing silicates (micas and amphiboles).

Geochimica et Cosmochimica Acta, 49: 37-49.

Wandke, A. and Hoffman, R. 1924. A study of Sudbury ore deposits. Economic Geology, 19: 169-204.

Watkinson, D.H. 1990. Platinum-group minerals in Cu-rich sulfides from some North American mafic-ultramafic rock complexes. Second Symposium on Modern Mineralogy, Mineralogical Society of Korea, pp. 37-51.

Watkinson, D.H. 1994. Fluid-rock interaction at contact of Lindsley 4b Ni-Cu-PGE orebody and enclosing granitic rocks, Sudbury, Canada. Transactions of the Institution of Mining and Metallurgy, 103: B121-128.

Watkinson, D.H. and Dunning, G. 1979. Geology and platinum-group mineralization, Lac-des-Iles complex, northwestern Ontario. Canadian Mineralogist, 17: 435462.

Watkinson, D.H., Whittaker, P.J. and Jones, P.C. 1983. Platinum-group elements in the Eastern Gabbro, Coldwell Complex, northwestern Ontario. Ontario Geological Survey Miscellaneous Paper 113: 183-191. 
Watkinson, D.H. and Dahl, R. 1988. Platinum-group mineral precipitation from fluids in pegmatitic gabbro: Two Duck Lake intrusion, Coldwell Complex, Ontario. In Prichard, H.M., Potts, P.J., Bowles, J.F.W. and Cribb, S.J. (eds). Geo-Platinum '87. Elsevier Applied Science, p.237.

Watkinson, D.H., Melling, D.R. and Farrow, C.E.G. 1991. Origin of platinum-group mineralization in low-temperature copper-sulfide assemblages, Salt Chuck intrusion, Alaska. Sixth International Platinum Symposium Abstracts, Perth, Australia, p.52.

Watkinson, D.H. and Ohnenstetter, D. 1991. Hydrothermal origin of platinum-group mineralization in the Two Duck Lake intrusion, Coldwell Complex, northwestern Ontario. Canadian Mineralogist, 30 (in press).

Watkinson, D.H. and Melling, D.R. 1992. Hydrothermal origin of platinum-group mineralization in low-temperature copper sulfide-rich assemblages, Salt Chuck intrusion, Alaska. Economic Geology, 87: 47-57.

Watkinson, D.H., Farrow, C.E.G. and Jones, P.C. 1993. Quantitative analysis of daughter minerals in fluid inclusions from sulfides; implications for PGE enrichment from saline fluids in some $\mathrm{Ni}$-Cu sulfide deposits. European Union of Geosciences Annual Meeting, EUG VII, Terra Abstracts, 5: 301.

Westendorp, R.W. 1992. Magnetite zones at the Ansil Copper-Zinc deposit, RouynNoranda, Quebec. Unpublished M.Sc. thesis, Carleton University, Ottawa, Ontario, $80 \mathrm{p}$.

Wood, S.A. 1987. Thermodynamic calculations of the volatility of the platinum-group elements (PGE): the PGE content of fluids at magmatic temperatures.

Geochimica et Cosmochimica Acta, 51: 3041-3050.

Wood, S.A., Mountain, B.W. and Fenlon, B. 1989. Thermodynamic constraints on the solubility, transport and deposition of platinum and palladium in hydrothermal solutions: reassessment of hydroxide, bisulfide and ammonia complexing.

Economic Geology, 84: 2020-2028.

Yates, A.B. 1948. Properties of the International Nickel Company of Canada. In Structural Geology of Canadian Ore Deposits, Canadian Institute of Mining and Metallurgy, pp.598-617. 


\section{APPENDIX I: BARNET PROPERTY TRENCH REPORT}

\section{I-1. INTRODUCTION}

Mineralization on the Barnet property occurs in the main Cu zone and is spatially associated with a NE-SW -trending zone of Sudbury Breccia southwest of Longvack Lake. The main zone was stripped and mapped by P.A. Tirschmann in the spring of 1989. Mechanical stripping was extended from the main Cu showing southwest to the INCO property boundary in the fall of 1989 . This trench extension was the focus of 1:100 scale mapping during May and June of 1990 (Figure 1-1). The original trenches were remapped to include alteration and structural characteristics in September, 1990.

The zone of mineralized SDBX was traced from the Barnet trenches across the INCO wedge to a Cu-rich showing on the Longvack property. Although the majority of the mineralization is restricted to the zone of Sudbury Breccia, minor chalcopyrite-rich veins were observed in the surrounding tonalitic footwall rocks.

Previous work has suggested that footwall-hosted CU-PGE sulphides located on the Barnet property are analogous to those in the Deep Copper Zone at the Strathcona Mine and are characterized by massive chalcopyrite veins, blebs, stringers and disseminations in SDBX (Barnett and Tirschmann, 1989; Tirschmann, 1989). It was also suggested that the Barnet Cu occurrences represented the up-plunge extension of Strathcona's Copper Zone due to the low PGE values in the Barnet main Cu zone (E.S. Barnett, pers. comm., 1990). 
Although previous work showed the main $\mathrm{Cu}$ zone at Barnet as consisting of narrow (maximum $30 \mathrm{~cm}$ ) chalcopyrite-rich veins (Barnett and Tirschmann, 1989; Tirschman, 1989), mapping in the trench extension has shown a preferred orientation of the largest veins of between $033^{\circ}$ and $074^{\circ}$, with steep dips. These orientations are similar to those of the main $\mathrm{Cu}$ zone identified by diamond drilling in $1988-89\left(035^{\circ}-040^{\circ}\right.$, dipping subvertically; Barnett and Tirschmann, 1989). Mapping and diamond drill core analysis has highlighted the close relationship between alteration and chalcopyrite-rich mineralization.

\section{I-2. TRENCH GEOLOGY}

The dominant trench lithologies include Sudbury Breccia (SDBX) and foliated tonalitic diatexite with rafts of felsic gneiss and anorthosite, the contact between them being well-defined in a NE-SW to E-W trend through the middle of the trench extension. Mineralization decreases in abundance in the southern half of the trench extension and corresponds to the contact between the SDBX and the diatexite.

The SDBX matrix is characteristically aphanitic and grey to dark grey on fresh surfaces. Locally it displays a "fluidal" texture typified by wispy, elongate felsic fragments $<2 \mathrm{~cm}$ in length. These elongate fragments are oriented subparallel to large fragment ( $>30 \mathrm{~cm}$ in diameter) and SDBX vein boundaries. A wide variety of clast types including, in decreasing order of abundance, tonalitic diatexite, felsic gneiss, intermediate gneiss, metatexite, mafic gneiss, anorthosite, diorite, melanocratic gabbro, pyroxenite and Matachewan diabase, 
occur in the SDBX. Xenoliths in the tonalitic diatexite are largely restricted to dioritic or gabbroic lithologies.

Two samples, one of tonalitic diatexite and one of felsic gneiss, have similar REE patterns (Sweeny and Farrow, 1990). Both show a LREE enrichment, weak negative Eu anomalies and a relatively fractionated trend typical of crustally derived granitoids.

\section{I-3. METASOMATISM}

A period of metasomatic activity, related to the intrusion of the SIC, predates $\mathrm{Cu}$-rich mineralization in the footwall at Barnet. It is similar to that observed at Strathcona Mine Copper Zone, although it is absent at Deep Copper Zone. It post-dates LGBX intrusion and is ubiquitously developed in Footwall Breccia in the southeast corner of the Pike Lake property on the hill overlooking Strathcona Mine.

The most common type of metasomatism occurs in the most mineralized northern section of the trench extension. It consists of patches of quartz, epidote and K-feldspar. Quartz crystals up to $1 \mathrm{~cm}$ long core the patches and occur with a thin $(<1-3 \mathrm{~cm})$ rind of epidote and a K-feldspar or granophyric (quartz $+\mathrm{K}$-feldspar) halo up to $30 \mathrm{~cm}$ wide. These patches tend to be rounded or irregularly-shaped, from 1 to $50 \mathrm{~cm}$ in diameter, and show no preferred orientation. They may cross-cut SDBX matrix and clasts, although they are commonly located within one or the other. Contacts with the host rock can be relatively sharp to diffuse, extending over 1 to $3 \mathrm{~cm}$ widths. Veins containing 
similar quartz, epidote and K-feldspar zonation occur throughout the trenches but are widest (up to $30 \mathrm{~cm}$ ) and most spectacular in and around a metatexite clast near L1E in the northeast part of the trench extension. Quartz crystals forming the centre of the patches and veins locally show well-developed crystal terminations. Where epidote does not occur, quartz and pink K-feldspar display granophyric textures. Thin stringers of quartz + epidote + K-feldspar metasomatism up to $1 \mathrm{~cm}$ wide locally mark the contact between SDBX and its associated felsic clasts.

Fine-grained and rarely coarse-grained K-feldspar metasomatism occupies the same structural feature of three of the major veins in the trench extension. Fine-grained to "colloform"-textured K-feldspar metasomatism is more characteristic of the large chalcopyrite veins than of smaller stringers and veins. This relationship is best developed where K-feldspar, chlorite, epidote and quartz are intergrown adjacent to the most southerly large vein.

Within foliated tonalitic diatexite, elongate, xenolith-like, pods of epidote and quartz up to $40 \mathrm{~cm}$ in length occur and are oriented subparallel to the overall foliation. However, epidote metasomatism is best developed in mafic clasts/xenoliths within both the SDBX and tonalitic diatexite.

\section{1-4. ALTERATION}

Dark, fine-grained alteration selvages on chalcopyrite-rich mineralization in SDBX, similar to those associated with footwall Cu-rich veining in Strathcona and $\mathrm{McC}$ reedy West, are most common in the main $\mathrm{Cu} z o n e$ at Barnet. These 
are composed of intergrowths of actinolite, epidote, chlorite and minor finegrained quartz.

In the northern part of the trench extension, epidote selvages commonly rim small ( $<1 \mathrm{~cm}$ in diameter) chalcopyrite blebs and disseminations.

Elsewhere, quartz-, epidote- and chlorite- bearing alteration veins can contain pyrite and chalcopyrite disseminations, especially where they cross-cut host rock fabric orientations. Such veins may also occur as extensions of chalcopyrite-rich veins and tend to be located along lithologic boundaries. Pervasive hematite alteration commonly extends from several centimetres into the host rock from vein margins. Thin $(<1 \mathrm{~cm})$ stringers of chlorite are seldom associated with mineralization.

Chloritization of mafic minerals is common in tonalitic diatexite; fracturecontrolled and vein-hosted chlorite is less important. However, within the tonalitic diatexite disseminated chalcopyrite occurs in chloritized mafic minerals.

Hematitization is locally fracture controlled and occurs as veins in felsic clasts within the main SDBX zone. It may also occur as a light dusting on feldspars, along grain boundaries or, where intense, as a pervasive, deep salmon pink colouration. Felsic and intermediate clasts commonly display incipient to weak and moderate pervasive hematitization and epidotization. Intense, pervasive hematitization is rare in SDBX clasts. Pervasive hematitization and more commonly pervasive, vein and fracture-controlled epidotization of various intensities occurs in the SDBX matrix. More intense 
hematitization in tonalitic diatexite adjacent to mafic xenoliths is evidence of fluid transport along lithological boundaries, whereas the massive to foliated tonalitic diatexite footwall rocks display more limited alteration.

Malachite is developed as surface alteration in strongly mineralized zones.

\section{I-5. SULPHIDE MINERALIZATION}

Sulphide mineralization includes chalcopyrite-rich veins, stringers, blebs and disseminations, and disseminations of pyrite. The occurrence of chalcopyrite in SDBX clasts is not limited by clast lithology. Mafic, intermediate and felsic clasts may display variable amounts of $\mathrm{Cu}$-rich mineralization.

Similarly, adjacent SDBX matrix and contained clasts can be differently mineralized. Thus, prediction of host lithology/Cu-rich mineralization associations are difficult. Veins, stringers and blebs are commonly located along large ( $>50 \mathrm{~cm}$ in diameter) clast margins with the SDBX matrix. However, mineralization may or may not transect clast boundaries. Chalcopyrite stringers in foliated and gneissic SDBX clasts and in tonalitic diatexite are dominantly oriented subparallel to these fabrics, although locally they may cross-cut major fabric trends as part of a conjugate set of veins and stringers. Chalcopyrite-rich mineralization is more common in SDBX matrix and its associated clasts than in the tonalitic diatexite, although the styles of mineralization are similar. Chalcopyrite stringers and veins tend to occur oblique to "fluidal" texture orientations in SDBX matrix, suggesting a later, post-SDBX-consolidation 
emplacement. Locally, contacts between xenoliths in the tonalitic diatexite are also sites for blebby to disseminated chalcopyrite mineralization.

Commonly associated with large chalcopyrite veins are surrounding areas of semi-massive to disseminated chalcopyrite and thin splays from the main veins. The large veins, the longest being over $5 \mathrm{~m}$ in length, vary in thickness from $>30 \mathrm{~cm}$ and rapidly thin to a few millimetres. Only one of the major veins is located within the tonalitic diatexite. Major lithologic contacts (tonalitic diatexite/SDBX, SDBX/felsic clasts) are the dominant sites for the four largest veins in the Barnet trench extension. However, these patterns of vein development are consistent in the main zone of Cu-rich mineralization in Trench \#3.

Within the two most recent fracture zones, disseminated to blebby chalcopyrite and pyrite mineralization has locally been preserved and displays similar textures to that in more pristine rocks.

Mafic and intermediate clasts and xenoliths within the SDBX and tonalitic diatexite contain minor amounts of disseminated pyrite.

Quartz, epidote and K-feldspar metasomatism may or may not contain rounded to irregularly-shaped blebs of chalcopyrite up to $3 \mathrm{~cm}$ long, regardless of host rock lithology, although such metasomatic patches are more frequently devoid of sulphide mineralization.

\section{I-6. STRUCTURAL GEOLOGY}

Foliations and gneissosities measured from tonalitic diatexite, felsic 
gneiss and intermediate gneiss clasts within the SDBX have random orientations as a result of rotation during the SDBX brecciation event. Foliations and gneissosities measured from the tonalitic diatexite in the south end of the trench trend $083^{\circ}$ to $118^{\circ}$ and have moderate southerly dips between $43^{\circ}$ and $70^{\circ}$. These trends are similar to those measured for the rest of the Barnet property (Tirschmann, 1989) and the Inco Wedge (Fig. 2-5).

Three of the large chalcopyrite veins trend between $062^{\circ}$ and $074^{\circ}$. The large vein that extends along the SDBX/tonalitic diatexite contact trends at $033^{\circ}$, its orientation controlled by the lithological contact (Fig. 1-1). Similar NE-SW to E-W trends are common for smaller chalcopyrite stringers and veins in the SDBX zone (Fig. I-1). In the diatexitic and gneissic rocks, chalcopyrite-rich stringers may occur at a slight angle to the foliation or gneissosity of the host rock. A limited number of stringers are more conformable to previously-formed rock fabrics. Elsewhere in the SDBX zone, chalcopyrite stringers and veins may be subparallel or less commonly oblique to foliations and gneissosities of intermediate and felsic clasts in which they occur. The conformity of many of these to previously developed fabrics suggests that the mineralizing fluids were preferentially focused along these passive surfaces, in a similar sense to those channelled along SDBX and tonalitic diatexite lithologic contacts.

Chalcopyrite-rich veins from the Barnet area are very steeply dipping. Their E-W trend is similar to that of veins in the Deep Copper Zone, although the latter have shallower dips, suggesting a slightly different stress regime during 
emplacement of these two footwall vein deposits. Deep Copper Zone veins $\leq 20$ $\mathrm{cm}$ wide show a slightly different trend, with an E-NE to W-SW orientation (Fig. I-2a). This may be in response to the tendency of smaller veins to follow preexisting rock fabrics and textures more readily than the larger (>20 cm wide) veins (Fig. I-2b).

There is a suggestion of two dominant orthogonal directions of steeply dipping metasomatic veins and stringers (Fig. I-3). One orientation is similar to that for both large and small chalcopyrite veins and stringers, commonly between $040^{\circ}$ and $050^{\circ}$. The other dominant trend for alteration and metasomatic veins is between $137^{\circ}$ and $152^{\circ}$. Such metasomatism characteristically cross-cuts previously developed fabrics, although it tends to show local lithological controls.

Sudbury Breccia veins in tonalitic diatexite tend to trend between $31^{\circ}$ and $55^{\circ}$ with very steep dips (Fig. I-4). These orientations correspond to trends displayed by one orientation of metasomatic veins and stringers and indicates the existence of a similar stress regime during emplacement of SDBX and metasomatizing fluids.

Poor development of mineralized joints and lack of any similarity between jointing and chalcopyrite vein orientation precludes presently exposed jointing as a structural control on Cu-rich mineralization. Joints display a dominant trend at approximately $240^{\circ}$ to $270^{\circ}$. There is a more weakly developed orthogonal set. These orientations correspond to regional structural trends (Sweeny et al., 
1990), and are related to later, post-chalcopyrite mineralization, brittle events.

The most recent structural event is represented by two major zones of fracturing up to $4 \mathrm{~m}$ wide, characterized by moderate to intense hematitization and epidotization. Fluid movement that has caused the late alteration along these zones has not been intense enough to remobilize the disseminated sulphides within each zone. The north fracture zone trends $280^{\circ}-289^{\circ}$ and dips $71^{\circ}-74^{\circ}$, whereas the south zone trends approximately $304^{\circ} / 76^{\circ}$. They contain well-developed conjugate joint sets at $284^{\circ}-291^{\circ}$ and $000^{\circ}-014^{\circ}$, both displaying relatively steep dips $\left(69^{\circ}-77^{\circ}\right)$. Joint orientations within the fracture zones are slightly different than regional trends and are representative of a different stress regime. These features may be small splays off the Longvack fault to the southwest.

\section{I-7. DISCUSSION}

Until recently (Barnett and Tirschmann, 1989), silicate alteration had been overlooked as an important feature associated with Cu-rich mineralization. Phenomena such as altered rock hosting this mineralization, and epidote-rich selvages on chalcopyrite blebs and stringers are common in the Barnet trenches. However, the amount and style of alteration in non-mineralized footwall rocks in surrounding properties remains complicated in that there is more than one generation of alteration superimposed on post-SIC intrusion metasomatism. This suggestion is supported by the fact that there is a strong increase in alteration intensity (i.e. pervasive hematitization and epidotization) in 
fracture zones that are much younger than the Cu mineralizing event.

Nevertheless, the obvious spatial association between specific styles of alteration and metasomatism cannot be overlooked.

A summary of the controls of chalcopyrite-rich mineralization in the Barnet trenches is presented in Table I-1. A dominant orientation $\left(033^{\circ}-074^{\circ}\right)$ of large chalcopyrite veins has been defined. Smaller chalcopyrite veins and stringers show similar trends due to the same fluid-focusing mechanisms. The significant numbers of metasomatic veins and stringers, and of SDBX veins in tonalitic diatexite which follow a consistent trend suggests the existence of a similar stress regime during their emplacement. The development of SDBX and metasomatism may have provided the ground preparation necessary for Cu-rich mineralizing fluids. Relatively passive surfaces such as those at previously developed fabric and lithologic contacts have also provided for preferential fluid movement. A further, well-documented lithologic control on chalcopyrite mineralization is that chalcopyrite is more abundant within SDBX zones than within relatively non-brecciated footwall units, suggesting that the fine-grained SDBX matrix was a better trap for fluids.

Higher PGE values to the north of the main zone in Trench \#2 (Barnett and Tirschmann, 1989) and on the east shore of Longvack Lake (Tirschmann, 1989) may be PGE-enriched fringes of the main Cu-rich zone (Tirschmann, 1989).

Supporters of the sulphide magma fractionation hypothesis for footwall 
Cu-rich vein genesis (Naldrett et al., 1982; Kostopoulos, 1984; Naldrett, 1984; 1989; Li and Naldrett, 1989; 1990; 1992; Li et al., 1992; Money, 1992) believe that a hydrothermal origin for the Cu zone-type deposits be ruled-out on the basis of a lack of "significant" alteration associated with the Cu-rich deposits. Alteration is associated with footwall Cu-Ni-PGE mineralization (Barnett and Tirschmann, 1989; Tirschmann, 1989; Foy, 1989; Farrow and Watkinson, 1992) and Footwall Breccia-hosted Cu and Ni mineralization (Sweeny et al., 1990). Although this alteration is not as extensive as that encountered in, for example, porphyry copper deposits, there is a significant spatial association with the $\mathrm{Cu}-\mathrm{Ni}$ mineralization suggesting the existence of a hydrothermal system during Cu-rich mineralizing events.

With the information discussed above it is possible to construct the following brief geologic history of the Barnet property:

1) Migmatization of gneissic rocks causing melting and formation of tonalitic diatexite (2711 Ma $\pm 7 \mathrm{Ma}, \mathrm{Krogh}$ et al., 1984). Fine-grained dioritic xenoliths remain as restitic material.

2) Emplacement of later granitic/pegmatitic/aplitic bodies, the result of a pre-SDBX event, possibly the intrusion of the Cartier Batholith to the north.

3) Formation of SDBX, resulting in extensive brecciation, rounding and rotation of footwall units (tonalitic diatexite, felsic gneiss, metatexite, etc.) as a result of the propagation of shock waves through footwall rocks during the explosive event responsible for the formation of the Sudbury Structure. 
4) Development of dilation zones due to the subsequent rebound or tensional event.

5) Metasomatism caused by intrusion of the Sudbury Igneous Complex. Structural control of the veining was caused by the tensional regime of 4$)$.

6) Establishment of a hydrothermal system responsible for the genesis of $\mathrm{Cu}$-rich veins in the dilation zones. The fluids were driven by the heat of the Sudbury Igneous Complex. They may have scavenged $\mathrm{Cu}$ and PGE from earlier emplaced Footwall Breccia Cu-Ni-PGE deposits and precipitated the metals in the footwall. 
Table I-1. Summary of controls on Barnet Trench sulphide mineralization.

\begin{tabular}{|c|c|c|}
\hline CONTROL & VEIN TYPE & COMMENTS \\
\hline \multirow[t]{3}{*}{ STRUCTURAL } & Chalcopyrite & $\begin{array}{l}\text {-large (>10 cm wide) chalcopyrite-rich veins } \\
\text { trend between } 033^{\circ} \& 074^{\circ} . \\
\text {-smaller veins \& stringers show similar NE- } \\
\text { SW trends. }\end{array}$ \\
\hline & $\begin{array}{l}\text { Veins related to } \\
\text { metasomatism. }\end{array}$ & $\begin{array}{l}\text {-dominant trends } \sim 40^{\circ}-50^{\circ} \text {. } \\
\text {-other common trend } \sim 137^{\circ}-152^{\circ} \text { (roughly } \\
\text { orthogonal to above orientations) }\end{array}$ \\
\hline & Sudbury Breccia & $\begin{array}{l}\text {-veins in tonalitic diatexite trend between } \\
31^{\circ} \& 55^{\circ} \text {. }\end{array}$ \\
\hline ROCK FABRIC & & $\begin{array}{l}\text {-ccp stringers, blebs \& disseminations are } \\
\text { concentrated along foliations \& gneissosity } \\
\text { within intermediate \& felsic clasts in Sudbury } \\
\text { Breccia \& more rarely within the tonalitic } \\
\text { diatexite. }\end{array}$ \\
\hline LITHOLOGIC & & $\begin{array}{l}\text {-chalcopyrite mineralization is concentrated } \\
\text { along the following contacts: } \\
\text { a) Sudbury Breccia matrix/clast } \\
\text { b) Tonalitic diatexite/xenolith } \\
\text { c) Sudbury Breccia/Tonalitic diatexite. }\end{array}$ \\
\hline
\end{tabular}




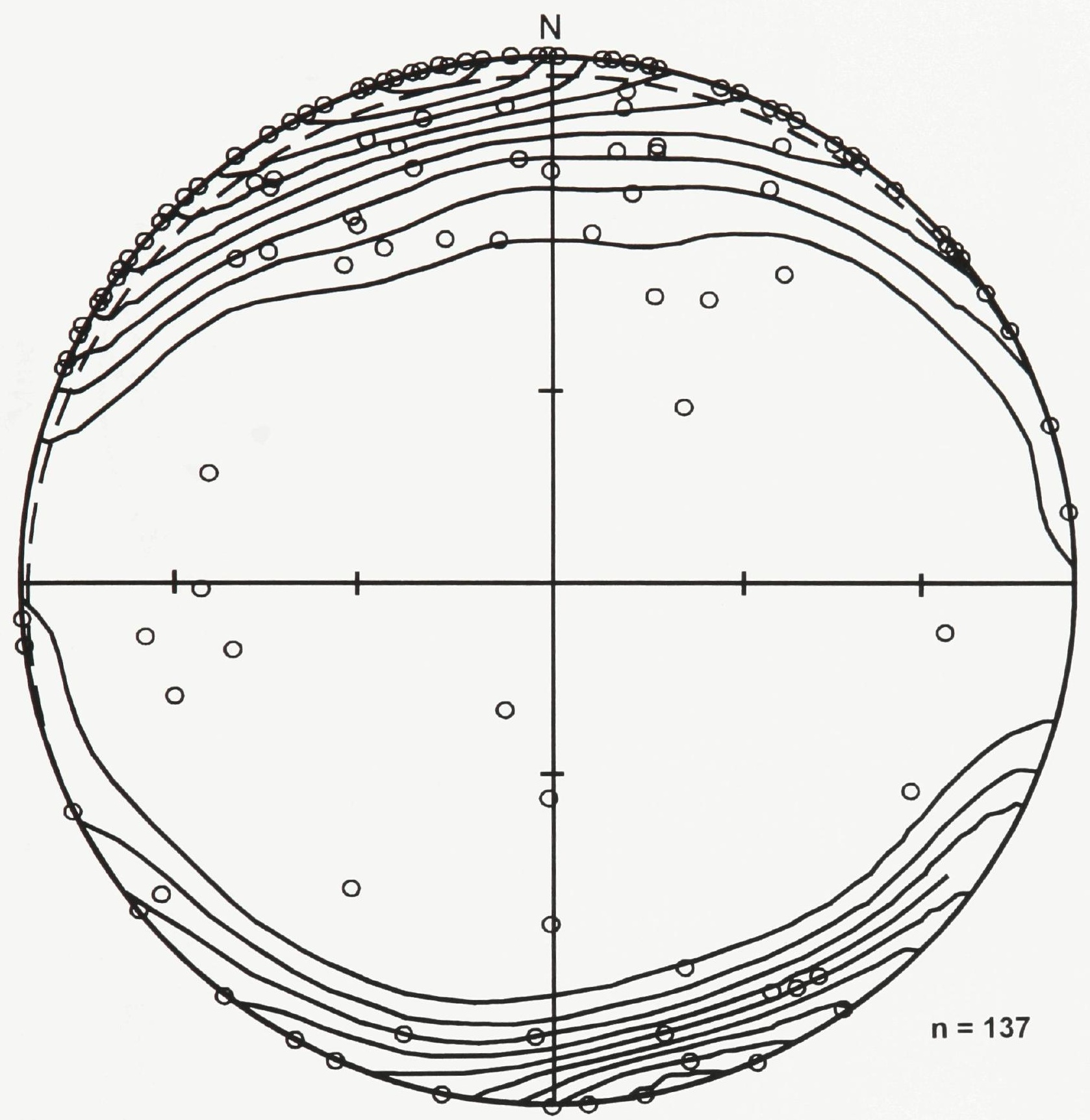

Figure 1-1: Poles to chalcopyrite stringers and veins in the Barnet, Inco Wedge and Longvack area. 

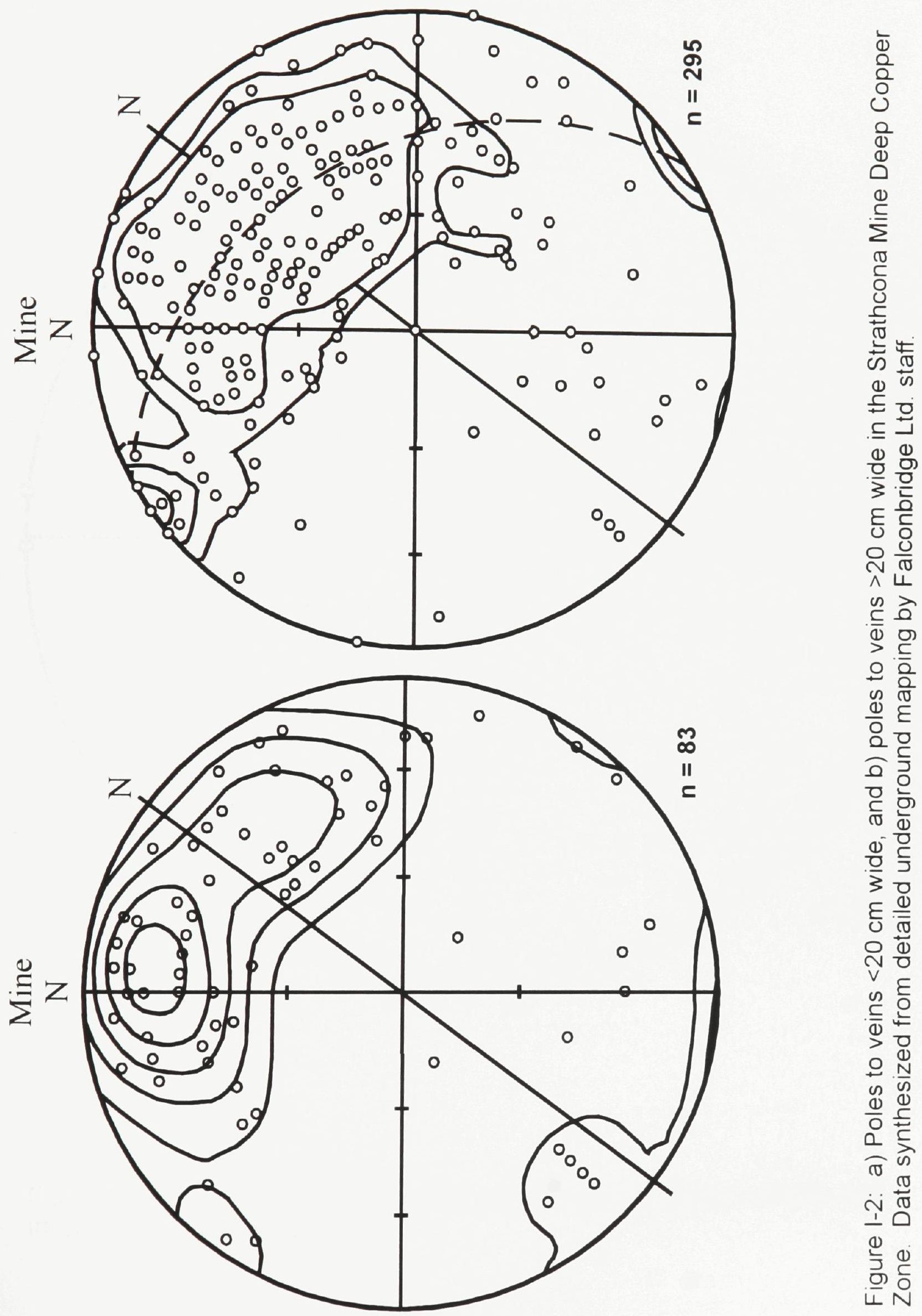


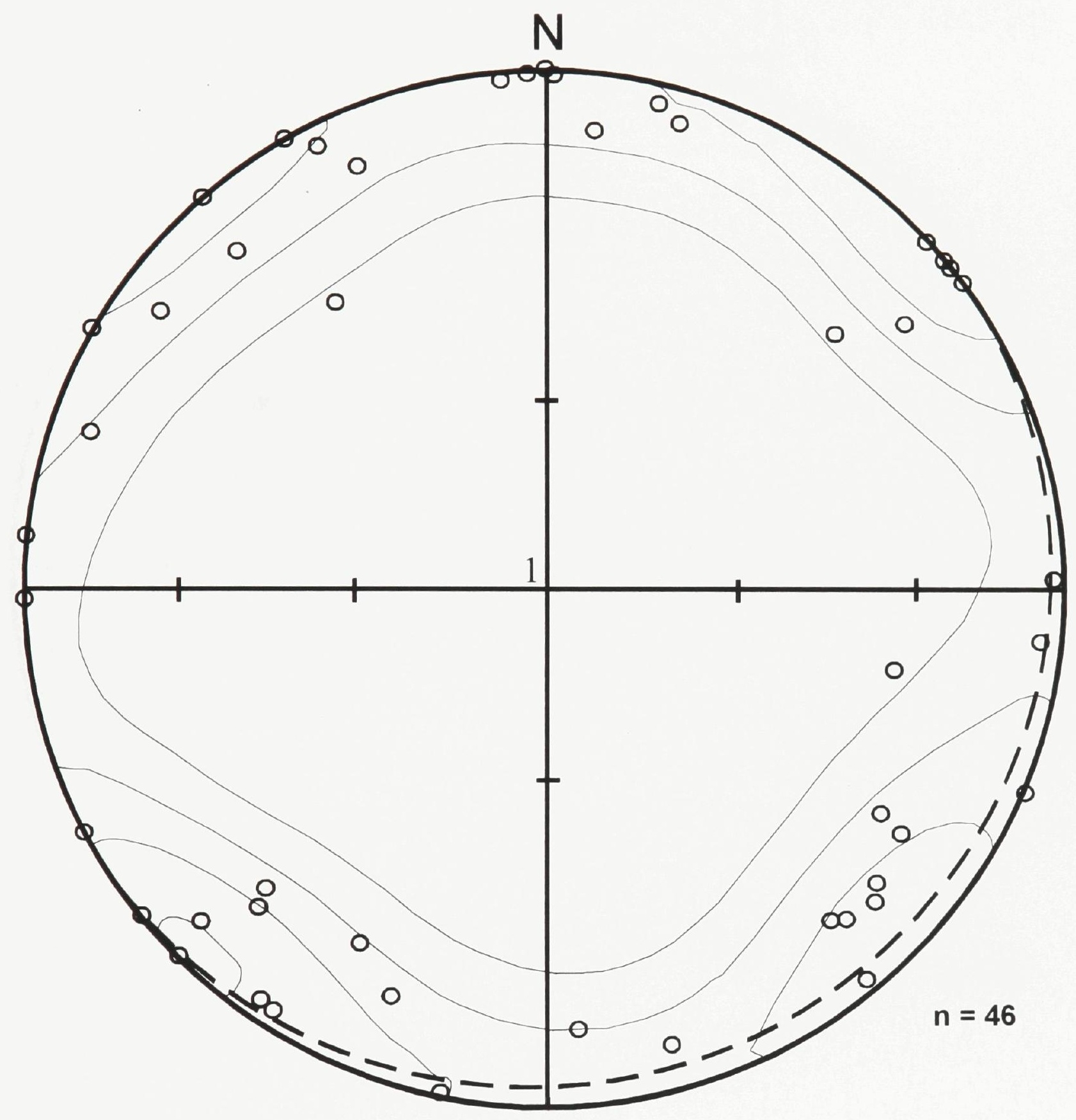

Figure 1-3: Poles to metasomatic veins and stringers exposed in the Barnet trenches and Inco Wedge. 


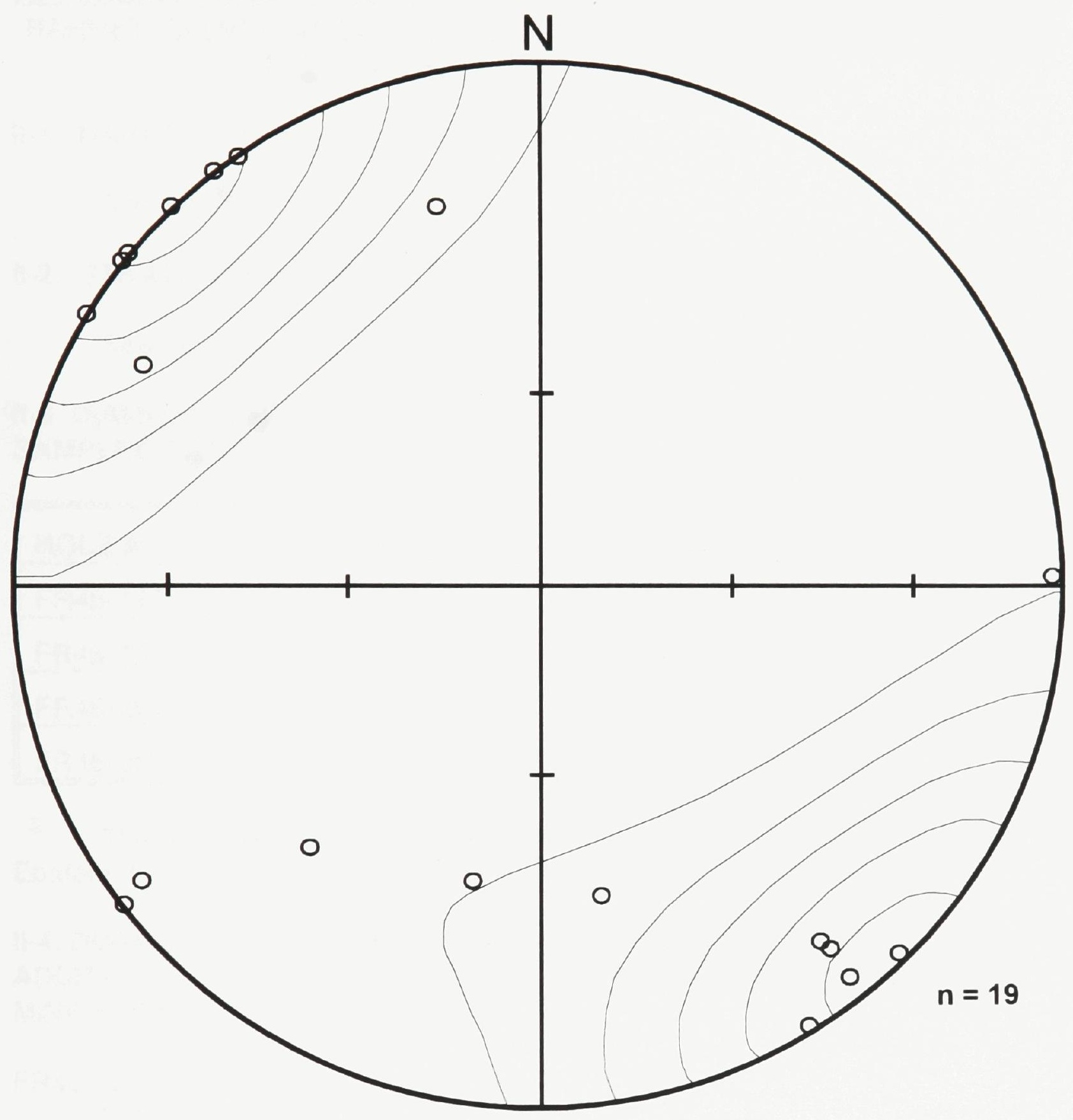

Figure 1-4: Poles to Sudbury Breccia veins in tonalitic diatexite exposed in the Barnet trenches and the Inco Wedge. 
APPENDIX II: SAMPLE LOCATION INFORMATION AND MAPPING FOR THE BARNET TRENCH AREA, THE STRATHCONA MINE DEEP COPPER ZONE, AND THE FRASER MINE EPIDOTE ZONE

\section{II-1. BARNET TRENCH COMPILATION}

See Figure II-1 in back pocket.

II-2. STRATHCONA MINE DEEP COPPER ZONE SAMPLE LOCATIONS

See Figures II-2a, $b$ and $c$.

II-3. DIAMOND DRILL CORE FROM FRASER MINE EPIDOTE ZONE SAMPLED FOR THIS STUDY

\begin{tabular}{||l|l|l||}
\hline HOLE \# & SECTION & DDH SETUP LOCATION \\
\hline FR46-147 & S5600 & 47-177 Exploration Drift \\
\hline FR46-150 & S5475 & 46-190 Exploration Drift \\
\hline FR46-264 & S5712 & 46-189 Drift \\
\hline FR46-287 & S5425 & 46-190 Exploration Drift \\
\hline
\end{tabular}

These holes were split by Falconbridge Limited where they intersected Epidote Zone patches and kept for further study (Figures II-3a, b and c).

II-4. DIAMOND DRILL CORE LOGS FROM WHICH LITHOLOGICAL AND ADDITIONAL GEOCHEMICAL DATA WAS SYNTHESIZED FROM FRASER MINE EPIDOTE ZONE.

FR46-027

028

030

031

037

039

147

149

150

168

169

171 
FR46-172

209

211

212

215

264

287 


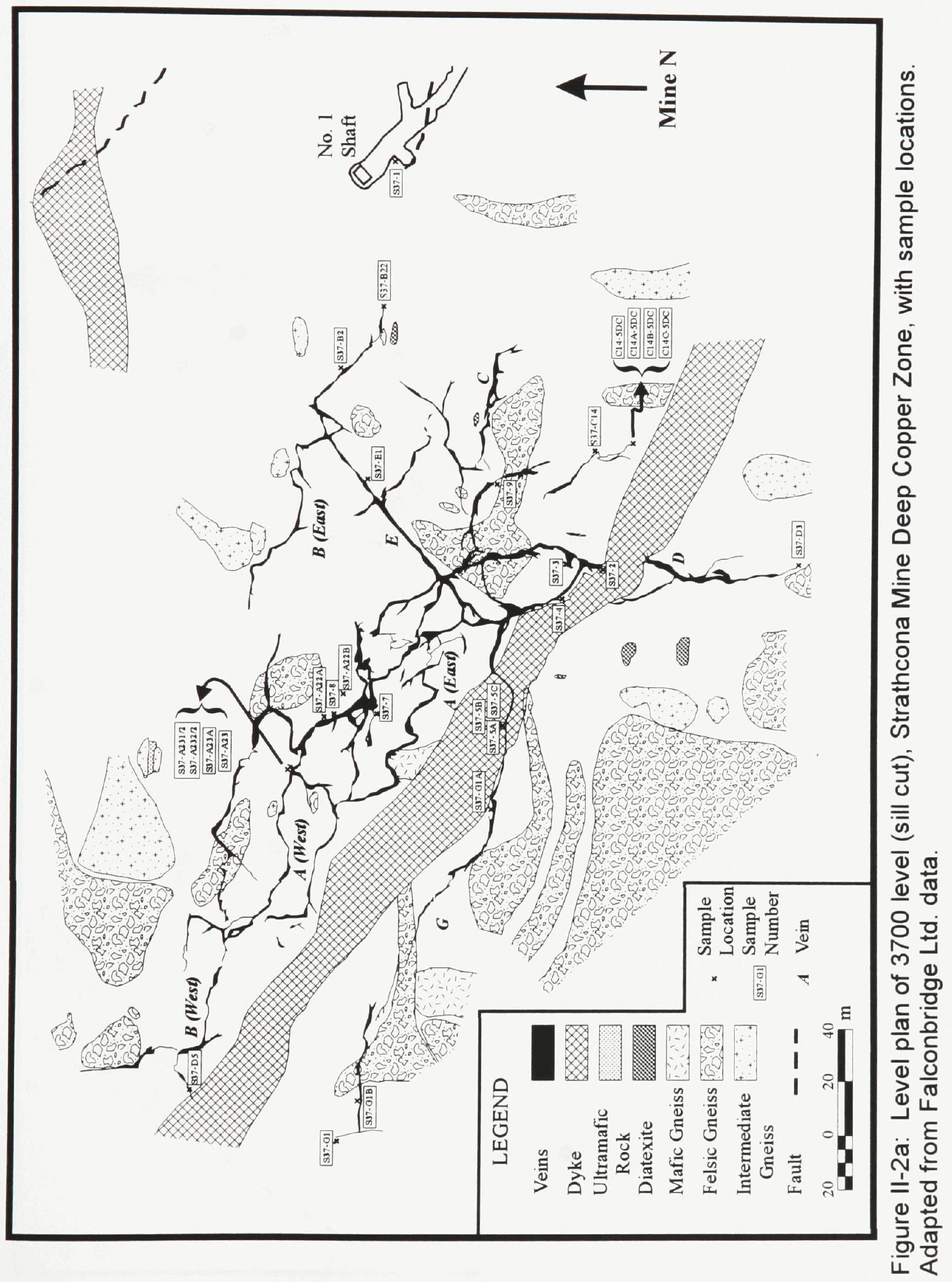




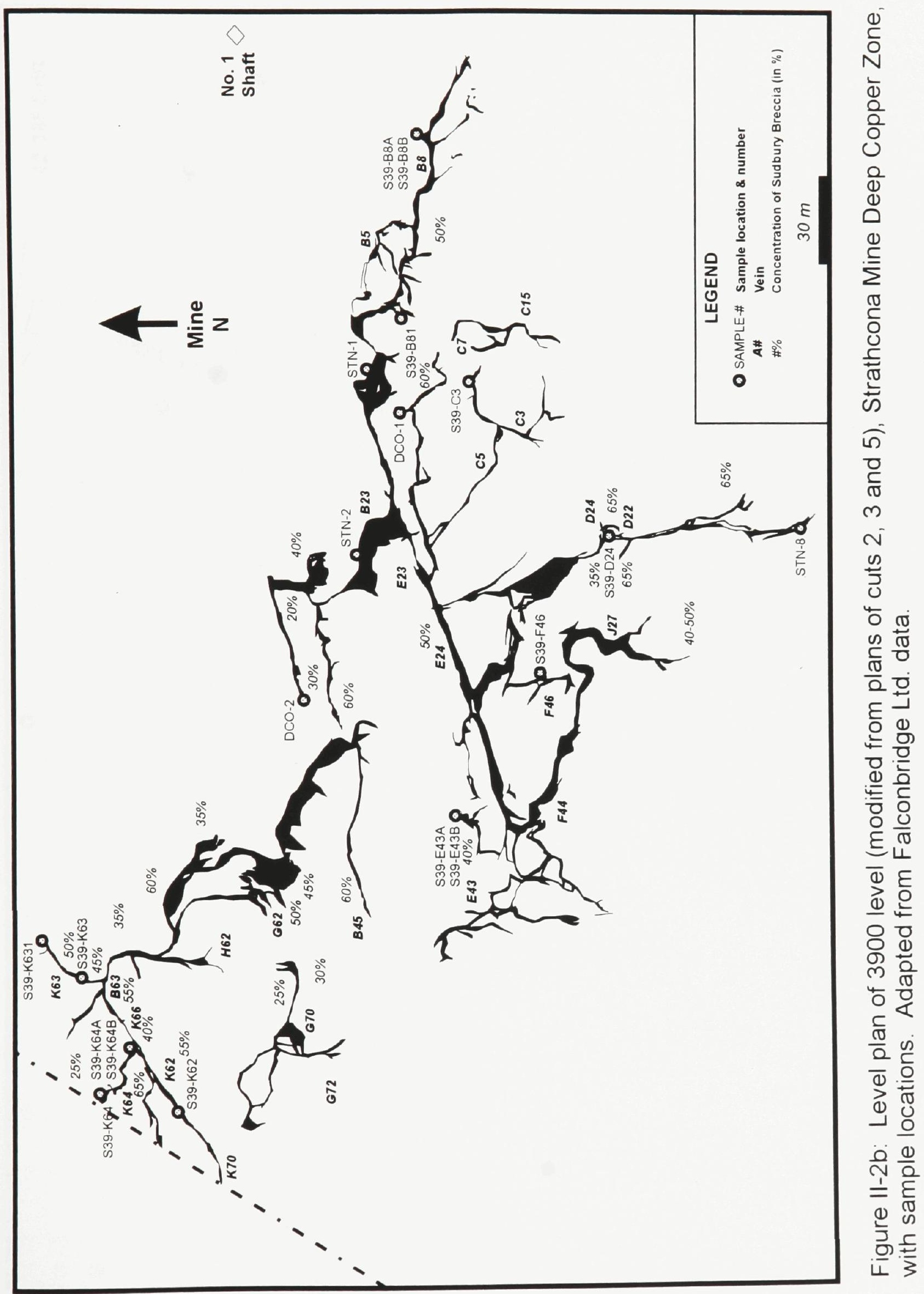




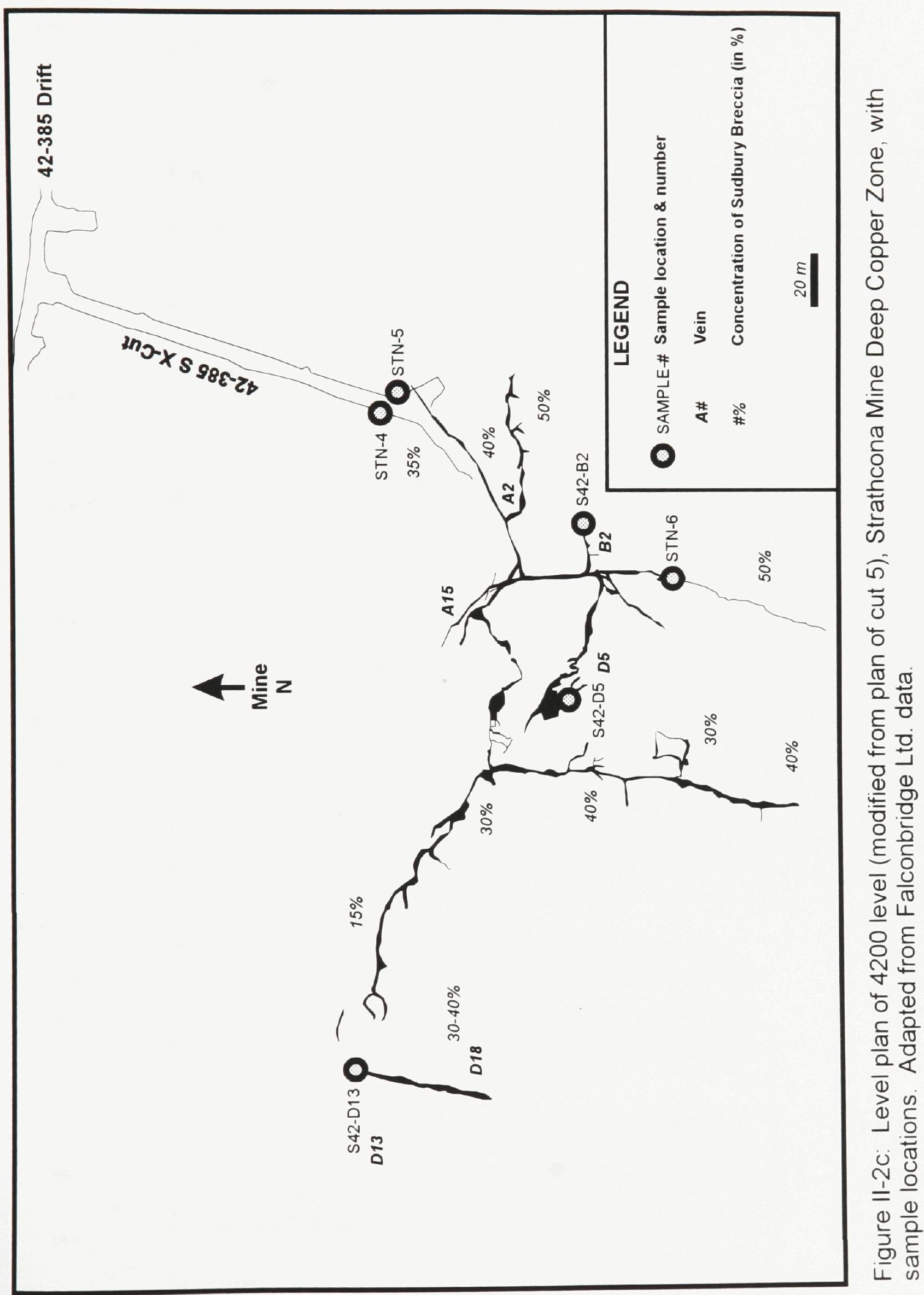




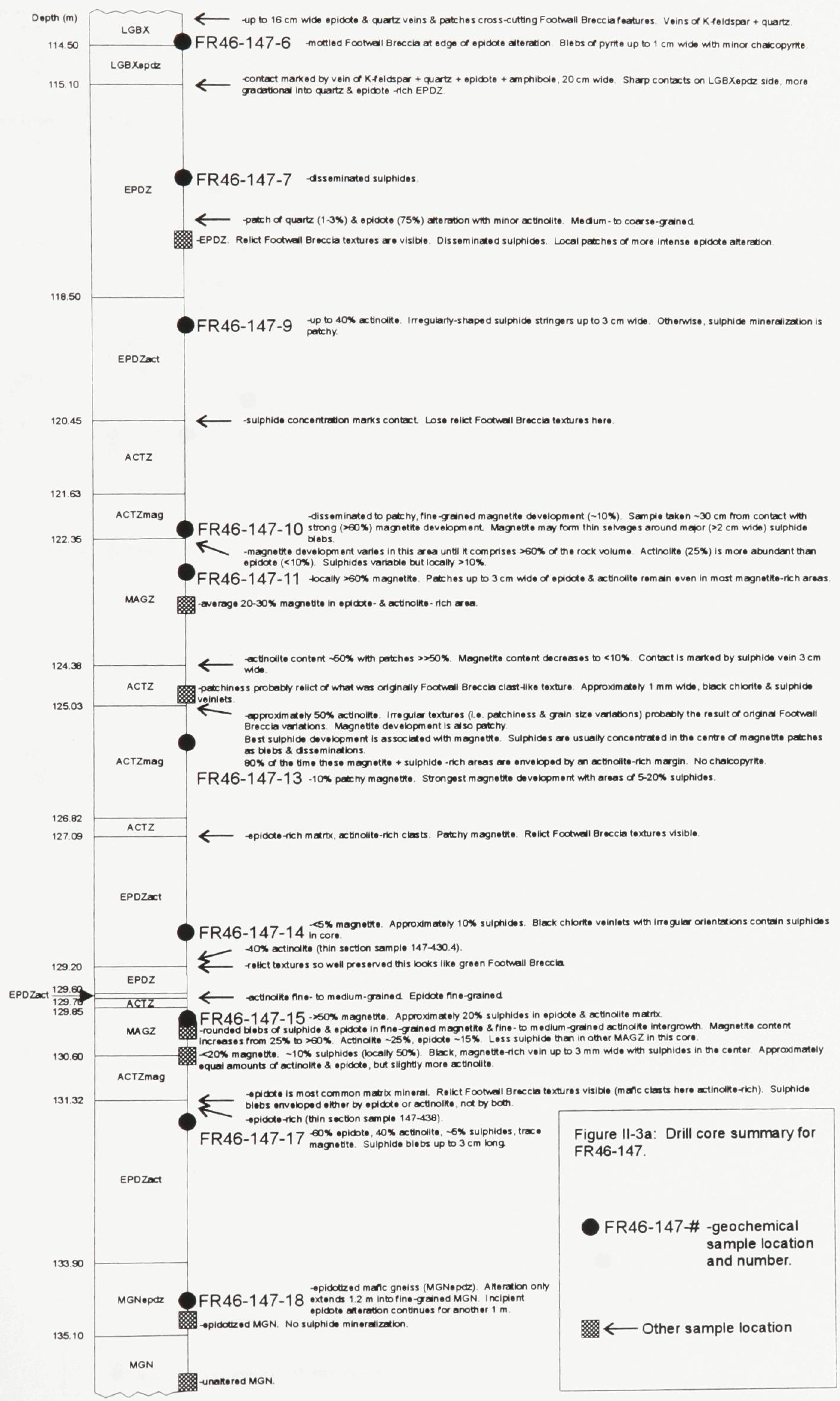




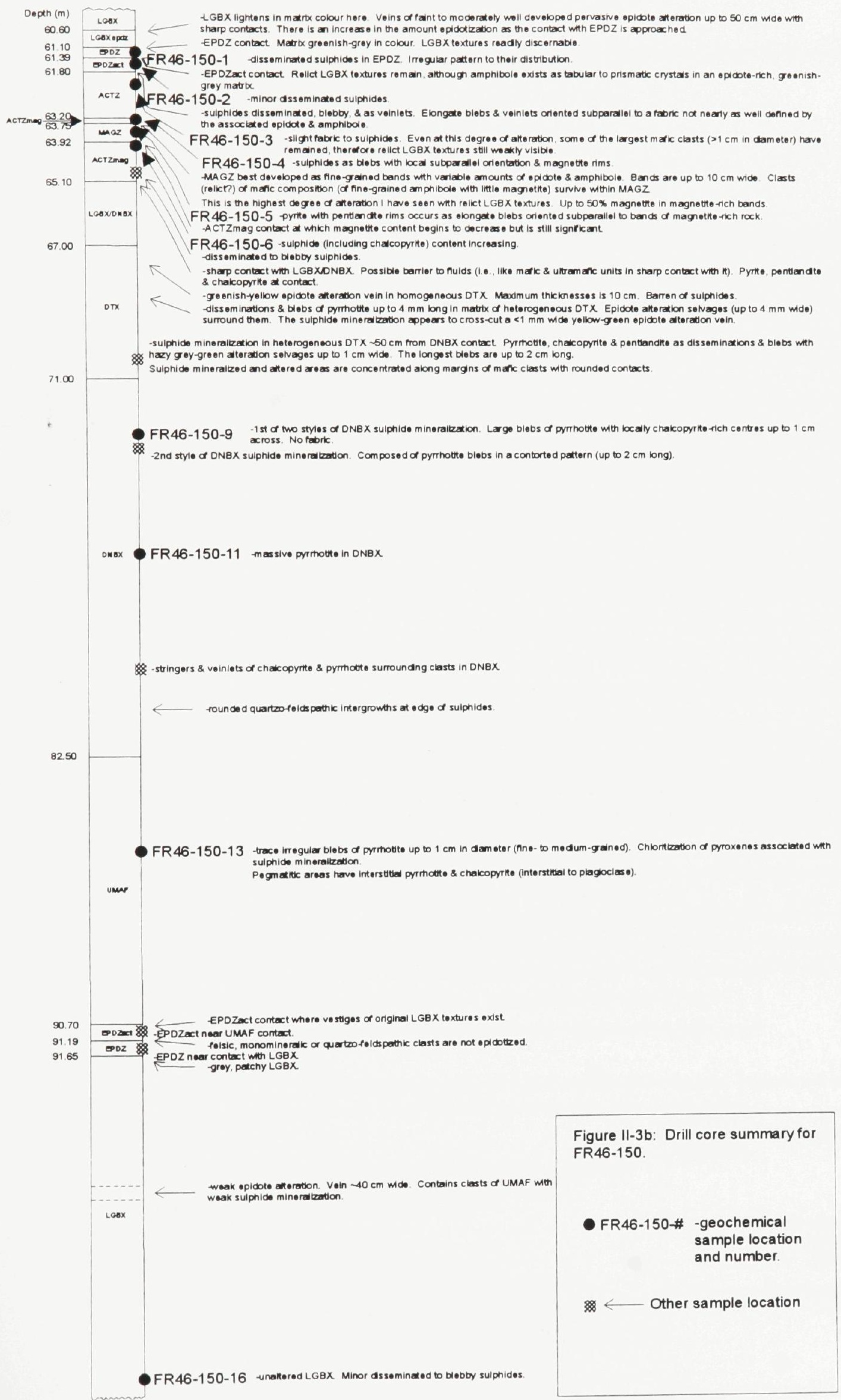




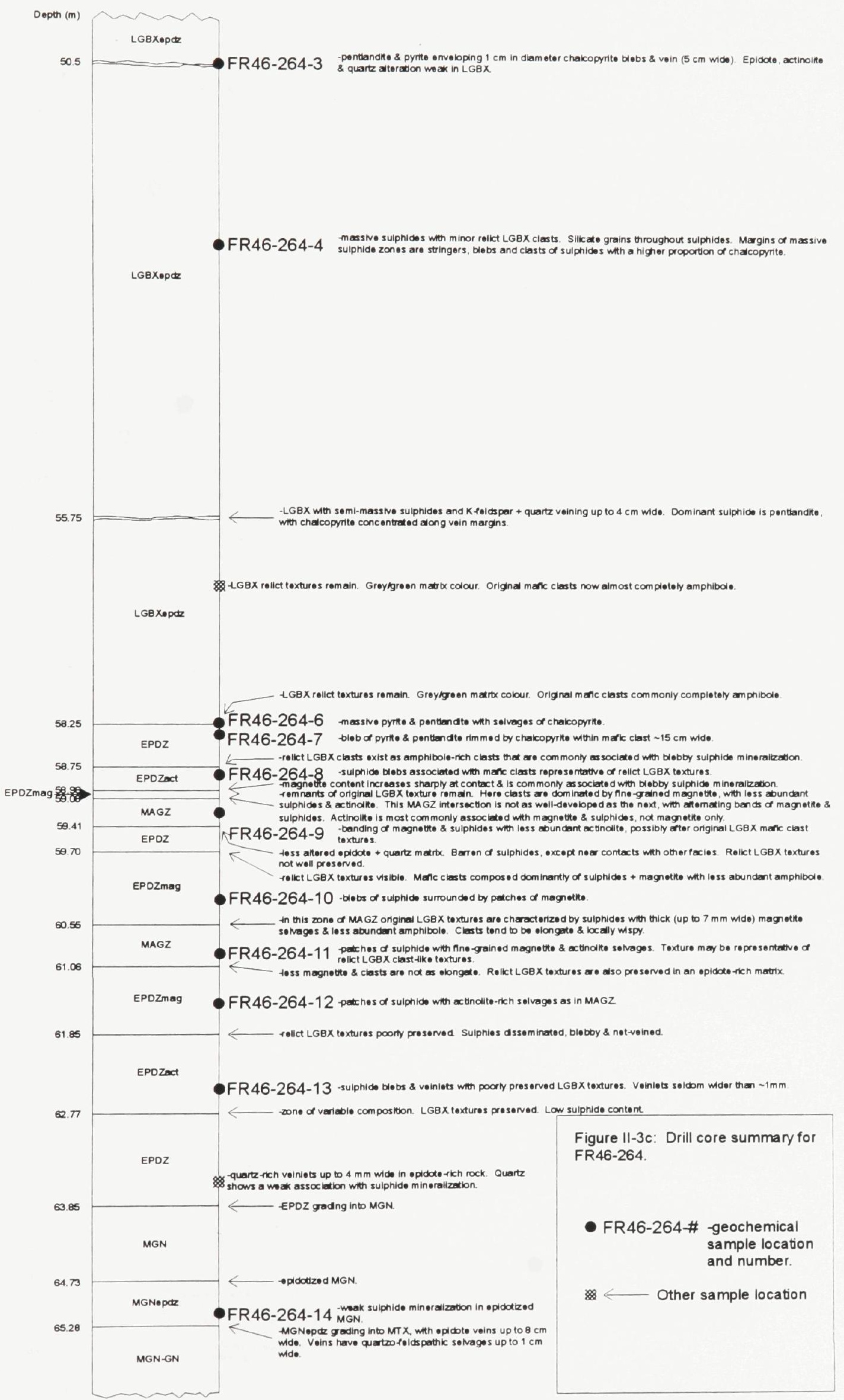




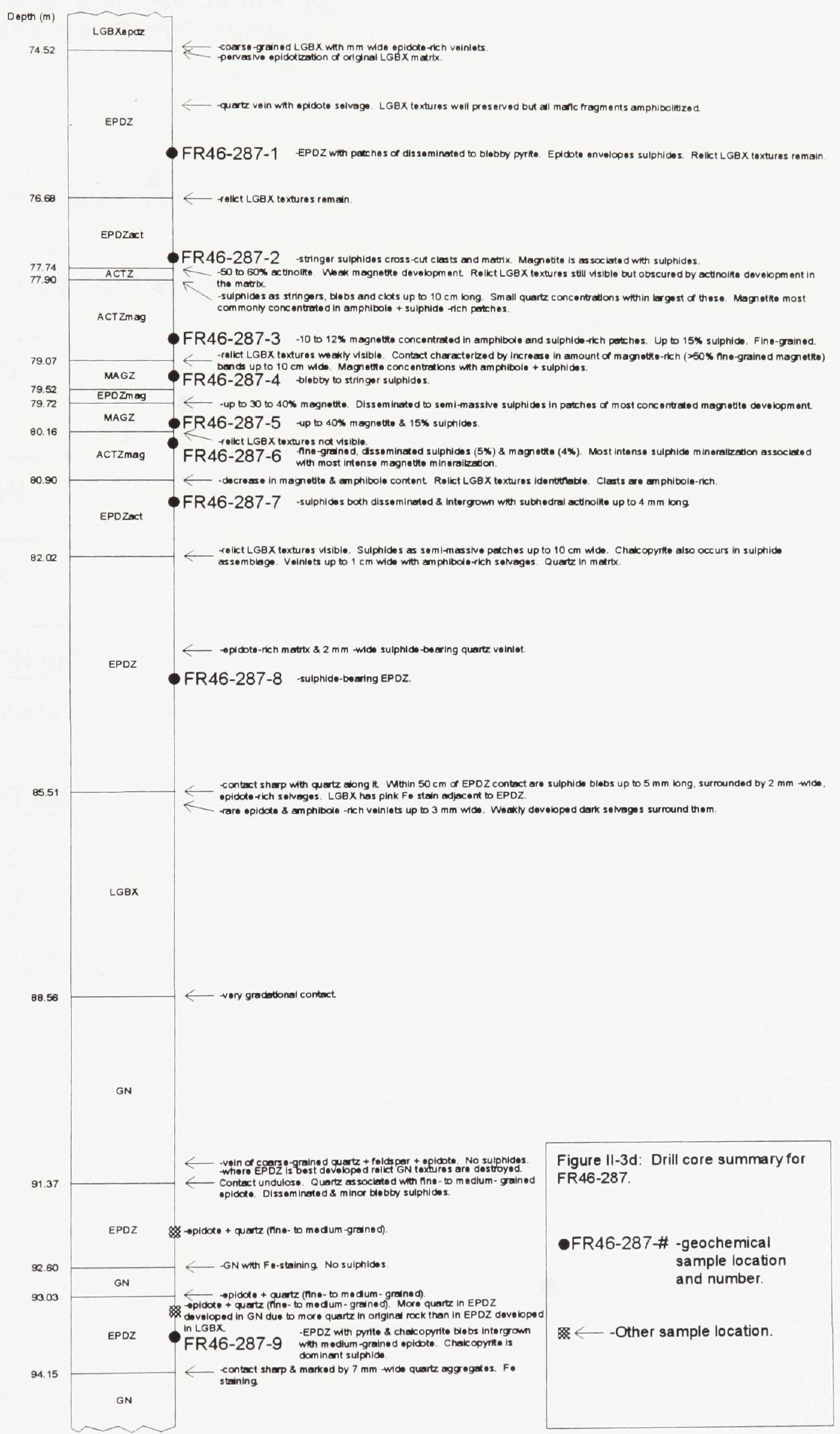


APPENDIX III: MODIFICATION OF LAYERED COMPLEX TERMINOLOGY TO METAMORPHIC TERMINOLOGY FOR FIGURE 1-2 (1989 Field Season, Morgan Property Mapping)

The following generalizations can be made to apply appropriate metamorphic terms to footwall units in Figure 1-2 (1989 field season, Morgan property mapping) using existing notes and descriptions:

\begin{tabular}{||l|l||}
\hline METAMORPHIC TERMINOLOGY & $\begin{array}{l}\text { LAYERED COMPLEX } \\
\text { TERMINOLOGY }\end{array}$ \\
\hline DTX & $\begin{array}{l}\text { LCF } \\
\text { LCFf } \\
\text { LCFf-b }\end{array}$ \\
\hline FGN & $\begin{array}{l}\text { LCFb } \\
\text { LCF/LCI }\end{array}$ \\
\hline GN & $\begin{array}{l}\text { LCIb } \\
\text { LCI/LCF }\end{array}$ \\
\hline MGN or PXT & LCM \\
\hline Metadioritic rocks & $\begin{array}{l}\text { LCIm } \\
\text { LCIm-f }\end{array}$ \\
\hline METAMORPHIC TERMINOLOGY & LEUCOSOME (GR) \\
\hline DTX & $\geq 50 \%$ GR \\
\hline MTX & $>10 \%$ to $<50 \%$ GR \\
\hline No change in terminology & $\leq 10 \%$ GR \\
\hline
\end{tabular}




\section{APPENDIX IV: SILICATE, OXIDE AND CARBONATE MINERAL CHEMISTRY}

\section{IV-1. ANALYTICAL METHODS}

Most of the mineral chemical data was collected by back-scattered electron imagery using Carleton University's JEOL 6400 digital scanning electron microscope, interfaced with a LINK SYSTEMS eXL energy dispersive Xray analyser. The operating conditions for analysis were: accelerating voltage, $20 \mathrm{kV}$; beam current, $0.2 \mathrm{nA}$; counting time, 120 seconds.

The mineral chemical data is tabulated in Data File 1. 


\section{APPENDIX V: METAL GEOCHEMISTRY METHODS AND ANALYSES}

\section{V-1. BARNET METAL GEOCHEMISTRY METHODS}

\section{V-1a. ANALYTICAL METHODS}

Barnet Property PGE analyses were carried out by Dr. G. Chai at the Geological Survey of Canada (601 Booth St., Ottawa), using a standard Ni sulphide preconcentration method and a SCIEX ELAN 5000 ICP-MS instrument. Each sample aliquot was measured twice and a blank reagent was used for at least 30 seconds to avoid any contamination. The instrument operation, ion counting and data reduction were controlled by an IBM microcomputer and software provided by SCIEX. Detection limits are as follows: $R u=0.35 ; R h=0.14$; $P d=0.33 ; \mathrm{Ir}=0.08 ; \mathrm{Pt}=0.30 ; \mathrm{Au}=1.69$.

\section{V-2. FRASER EPIDOTE ZONE METAL GEOCHEMISTRY METHODS}

\section{V-2a. ISOCON METHODS}

Because of the lack of reference points (i.e. immobile elements) or accurate volume data for the Epidote Zone rocks, the best-fit isocon was estimated using all the data. Since all gains and losses were calculated with respect to this line, that in some cases was poorly constrained due to wide scatter in the data, considerable error is inherent in the application of this method. Another important source of error is the inhomogeneity in composition of altered and least altered rocks and sulphides (with which most of the analyzed metals are associated). These problems are compounded for interpretation of elements with abundances that approach detection limits, such as $\mathrm{Os}, \mathrm{Re}, \mathrm{Au}$ 
and $\mathrm{Cu}$. As a result, these elements tend to show strong gains and losses.

Uncertainty as to absolute gains or losses for all other elements is probably in the range of $\pm 25 \%$. For $\mathrm{Os}, \mathrm{Re}, \mathrm{Au}$ and $\mathrm{Cu}$ it is at least doubled.

The Epidote Zone geochemical data is tabulated in Data File 2. 


\section{APPENDIX VI: PLATINUM-GROUP MINERAL AND UNCOMMON MINERAL}

\section{CHEMISTRY}

\section{VI-1. ANALYTICAL METHODS}

The platinum-group and trace minerals were identified by back-scattered electron imagery using Carleton University's JEOL 6400 digital scanning electron microscope, interfaced with a LINK SYSTEMS eXL energy dispersive Xray analyser. The operating conditions for analysis were: accelerating voltage, $20 \mathrm{kV}$; beam current, $0.1 \mathrm{nA}$; counting time, 120 seconds. Various pure metals were used as standards.

The precious metal mineral chemical data is tabulated in Data File 3. 


\section{APPENDIX VII: FLUID INCLUSION STUDY}

\section{VII-1. MICROTHERMOMETRY}

Microthermometric analyses are tabulated in Data File 4.

\section{VII-2. SEM-EDS}

\section{VII-2a. TECHNIQUE DEVELOPMENT AND ANALYTICAL METHODS}

Semi-quantitative and quantitative EDS data from accidental and daughter phases were obtained with Carleton University's JEOL 6400 digital scanning electron microscope, interfaced with a LINK SYSTEMS eXL energy dispersive X-ray analyser and an Oxford instruments CT 1500 cryo-system. Broken mineral surfaces and fluid inclusions were imaged from 5 to $15 \mathrm{kV}$. X-ray analyses were performed at $15 \mathrm{kV}$ in thin window mode to detect light elements with a take-off angle of $40^{\circ}$. Beam current ranged from 0.1 to $0.2 \mathrm{nA}$ and was measured with a Faraday cup. Counting times ranged from 50 to 150 seconds. Natural mineral and synthetic compounds were used as standards.

Observation methods for solid phases in fluid inclusions using the SEM were perfected using fluid inclusions in quartz that had previously been studied by conventional petrographic and microthermometric methods. Early in the study, a cryo-system method involved sample cooling to $-190^{\circ} \mathrm{C}$ in liquid $\mathrm{N}_{2}$ slush within a small, vice-like sample holder. Specimens were then transported under vacuum to the cryo-preparation chamber on the SEM where they were fractured under in-vacuo, sputter-coated with $\mathrm{Al}$, transferred to the cryo-stage on the SEM and held at $-160^{\circ} \mathrm{C}$ for observation and $\mathrm{x}$-ray analysis. The abundance 
of daughter minerals hidden from view by ice, and the volatility of ice in the electron beam limited the use of this method. It was difficult to determine whether or not the spectra were representative of the dense ice or the solid phases hidden from view below. Because of the escape and evaporation of fluid phases upon fluid inclusion breakage in vacuum without freezing, it was deemed easier to view the solid phases without the ice. Adequate results were also found if the chips were broken in air, mounted on glass slides with carbon tape and/or carbon paste, and coated with carbon. The room temperature methods resulted in local precipitation of a film of $\mathrm{Na}$ - and $\mathrm{Ca}$ - rich chlorides around and within the inclusion opening (see discussion of precipitates in Chapter 6).

To address the limitations associated with doing quantitative EDS analyses on uneven surfaces, samples were rotated and tilted in the chamber to optimize the specimen position with respect to the EDS detector. As a test of accuracy of the quantitative analyses, chemically pure $\mathrm{NaCl}$ was fractured, mounted on carbon tape, carbon-coated and analysed in a variety of orientations. Although analytical totals ranged from 65 to $104 \%, \mathrm{Na} / \mathrm{Cl}$ ratios were between 0.87 and 1 .

Minerals with strong cleavage, including pyrite and millerite were not as easy to utilize in this process as minerals such as quartz and chalcopyrite because they tend to break along preferential planes. This led to uncertainty as to whether breakage had occurred along previously disrupted planes. In addition, fluid inclusions were not as well-developed or well-preserved along 
these planes. 


\section{APPENDIX VIII: ISOTOPE GEOCHEMISTRY}

\section{VIII-1. STABLE ISOTOPE STUDY}

\section{VIII-1a. DEFINITIONS}

Oxygen, hydrogen and carbon isotope ratios are reported in the standard $\delta$-notation. $\delta^{18} \mathrm{O}, \delta \mathrm{D}$ and some $\delta^{13} \mathrm{C}$ values are related to the Standard Mean Ocean Water (SMOW) standard (Craig, 1961) by:

$$
\delta^{18} \mathrm{O}, \delta \mathrm{D} \& \delta^{13} \mathrm{C}=\left[\left(\mathrm{R}_{\mathrm{A}}-\mathrm{R}_{\text {Stnd }}\right) / \mathrm{R}_{\text {Stnd }}\right] \times 10^{3}
$$

where $\mathrm{R}_{\mathrm{A}}$ is the ${ }^{18} \mathrm{O} /{ }^{16} \mathrm{O}$ ratio, $\mathrm{D} / \mathrm{H}$ ratio and ${ }^{13} \mathrm{C} /{ }^{12} \mathrm{C}$ ratio in the sample and $\mathrm{R}_{\mathrm{Stnd}}$ is the equivalent ratio in the standard.

Fractionation between minerals, such as quartz and epidote, are approximated by the difference between $\delta$ values for the two minerals as follows:

$$
\Delta_{\mathrm{Qz}-\mathrm{Ep}}=\left(1000+\delta_{\mathrm{Qz}}\right) /\left(1000+\delta_{\mathrm{Ep}}\right)
$$

and

$1000 \ln \alpha_{Q z-E p} \approx \delta_{Q z}-\delta_{E p}=\Delta_{Q z-E p}$

\section{VIII-1b. SEPARATION TECHNIQUES AND ANALYTICAL METHODS}

Mineral samples were handpicked under a binocular microscope to $>95 \%$ purity, which was tested by $\mathrm{x}$-ray diffractrometry.

Oxygen and hydrogen isotope analyses were completed by A.-M. Fouillac of CNRS, Orleans, France by conventional methods of conversion to $\mathrm{CO}_{2}$, and were measured using a Finnigan MAT 252 mass spectrometer. All of the samples were analyzed in duplicate. The oxygen and hydrogen isotope results have a precision of $\pm 0.2 \%$ and $\pm 3 \%$, respectively, and their reproducibility is 
commonly better than this. Some oxygen isotope analyses were reproduced using a coaxial $\mathrm{CO}_{2}$ and $\mathrm{He}-\mathrm{Ne}$ laser-based extraction line.

\section{VIII-2. RADIOGENIC ISOTOPE STUDY}

\section{VIII-2a. RUBIDIUM-STRONTIUM}

Mineral separates $(50 \mathrm{~g})$ were dissolved in $\mathrm{HF}$ and perchloric acid. $\mathrm{Rb}$ and $\mathrm{Sr}$ were separated using BioRad AG $50 \mathrm{X}-8$ ion exchange resin, and $2.5 \mathrm{M}$ $\mathrm{HCl} .{ }^{87} \mathrm{Rb}$ and ${ }^{84} \mathrm{Sr}$ spikes were used for concentration measurements.

VIII-2b. NEODYMIUM-SAMARIUM

Dissolution methods were the same as those for $\mathrm{Rb}-\mathrm{Sr}$. The same column and resin was used as for $\mathrm{Rb}-\mathrm{Sr}$, except the REE were eluted with $6 \mathrm{M}$ $\mathrm{HCl}$. Samarium and neodymium were separated using reverse-phase chromatography. ${ }^{145} \mathrm{Nd}$ and ${ }^{149} \mathrm{Sm}$ spikes were used for concentration measurements.

\section{VIII-2c. MASS SPECTROMETRY}

The mass spectrometer used for isotopic measurements was a Finnigan MAT 261 thermal ionization mass spectrometer equiped with 5 Faraday collectors and an electron multiplier. 

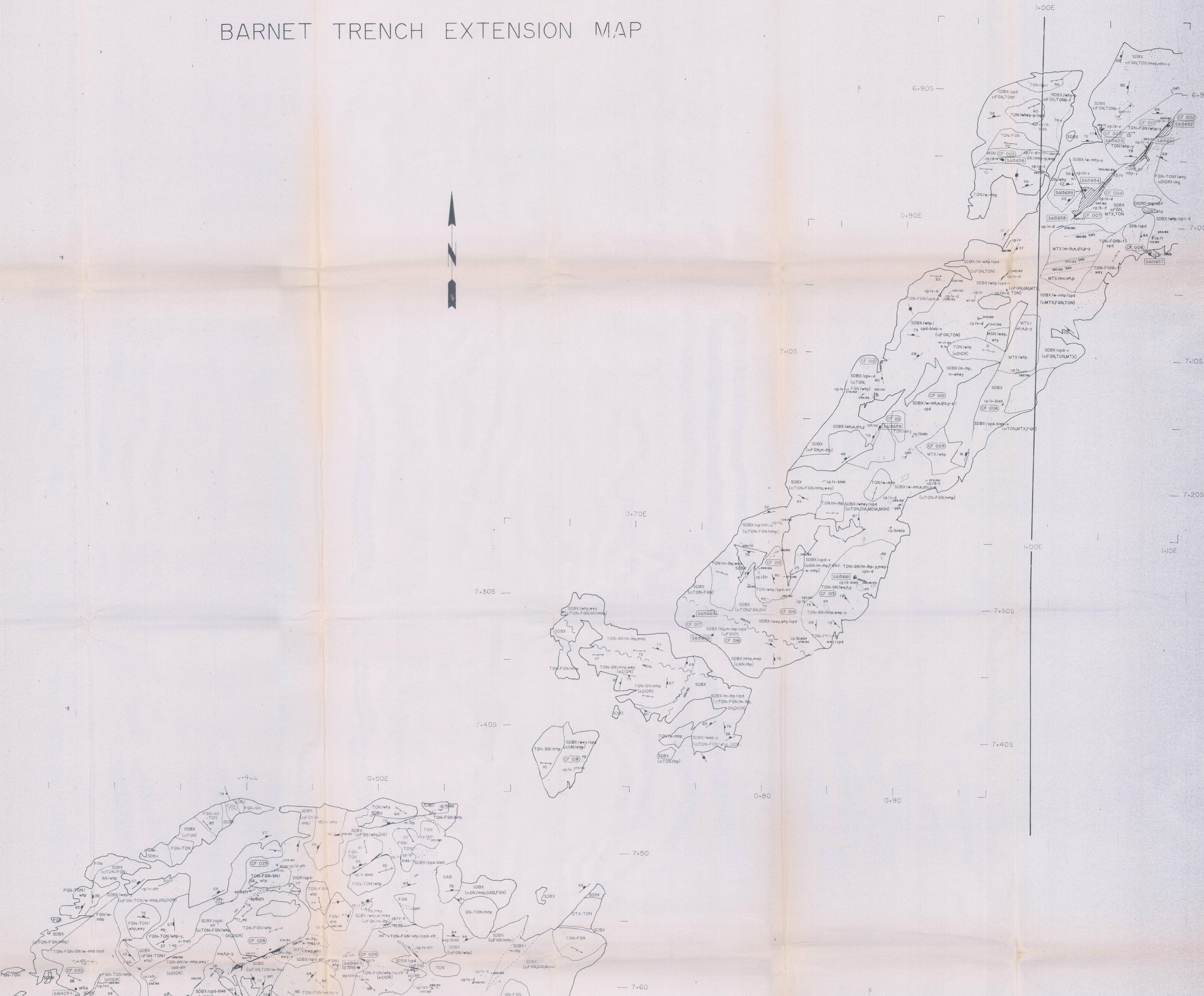

(1)

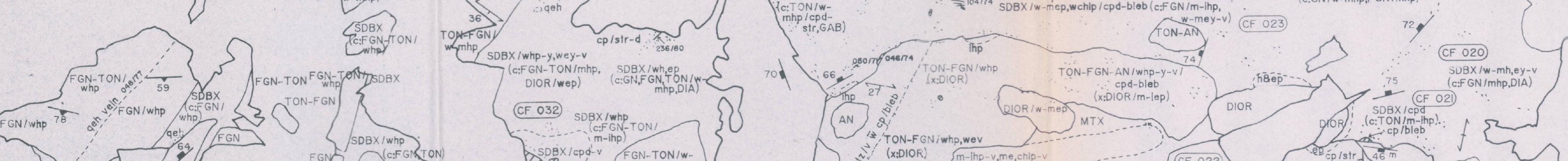

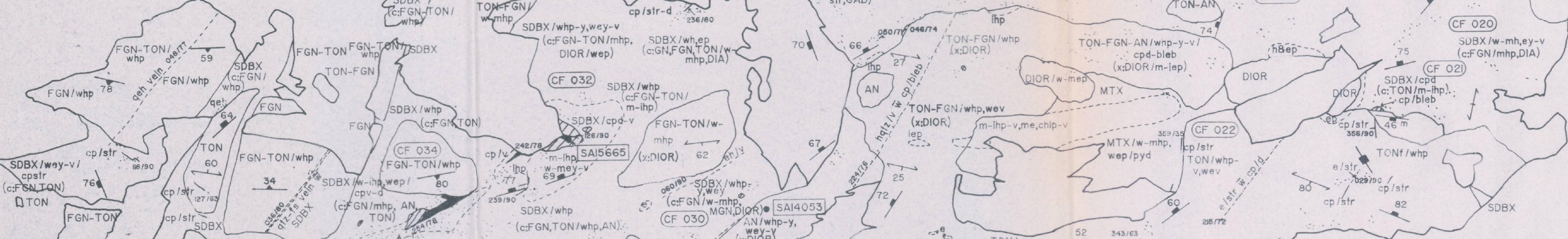

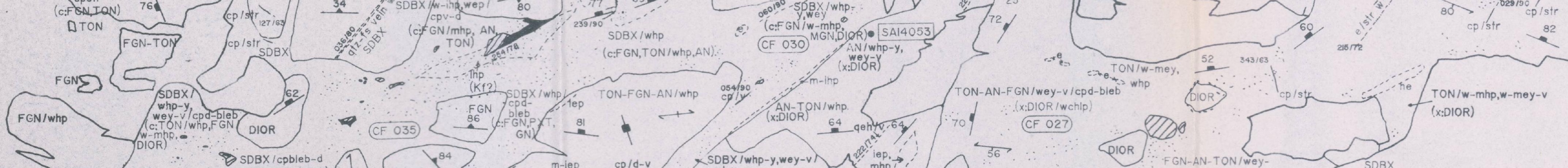

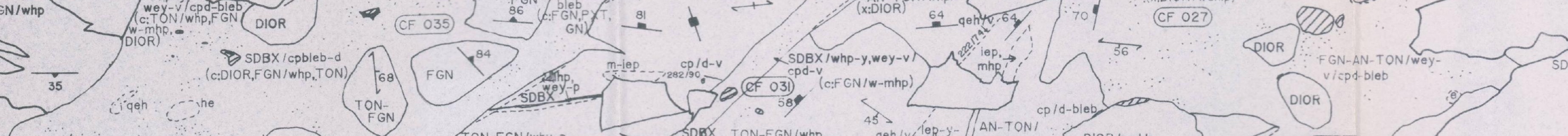

-

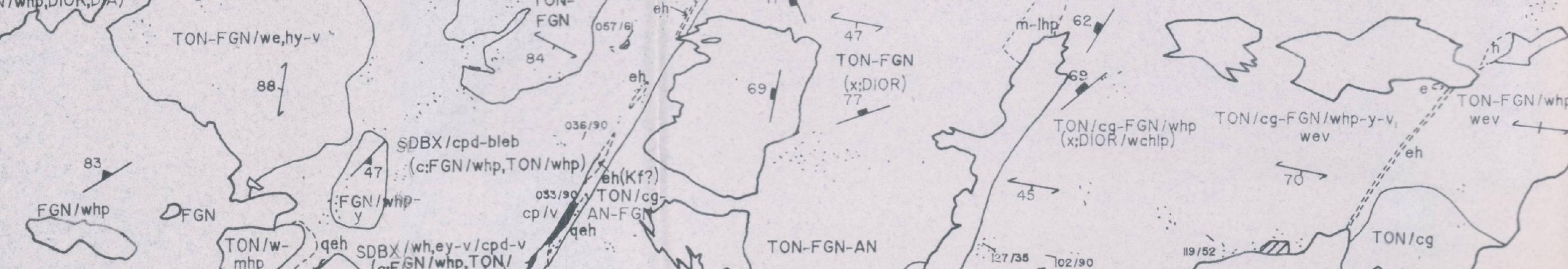

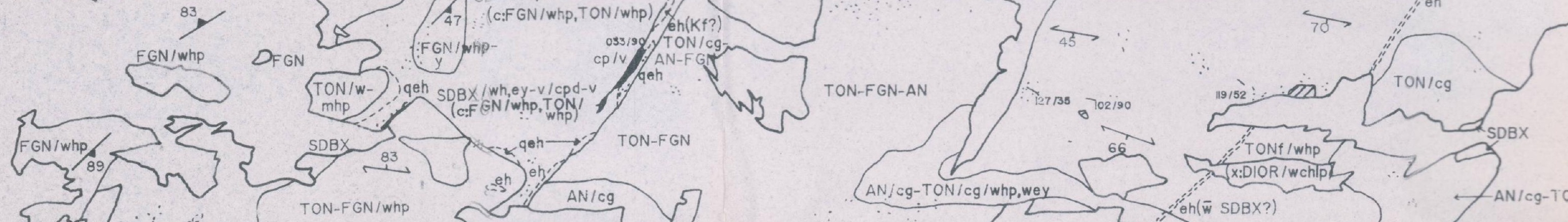

$=0$

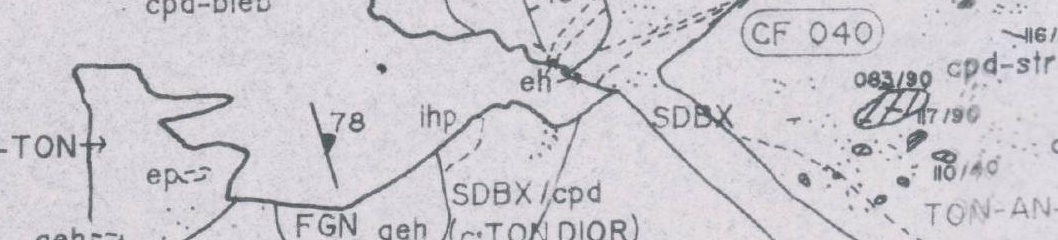

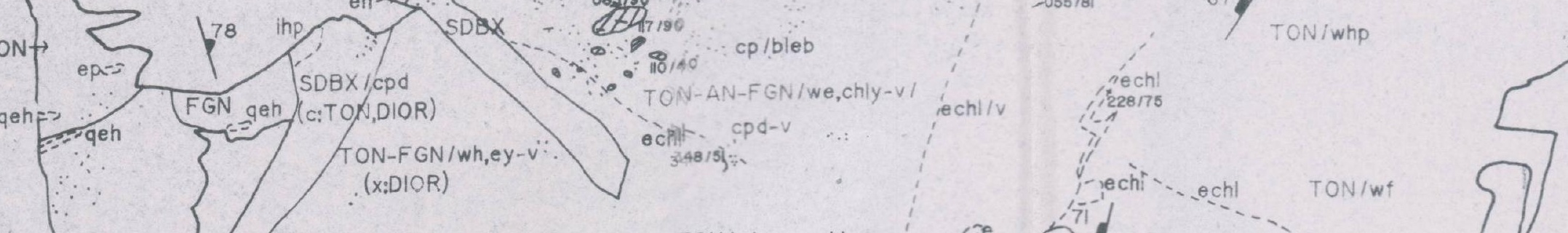

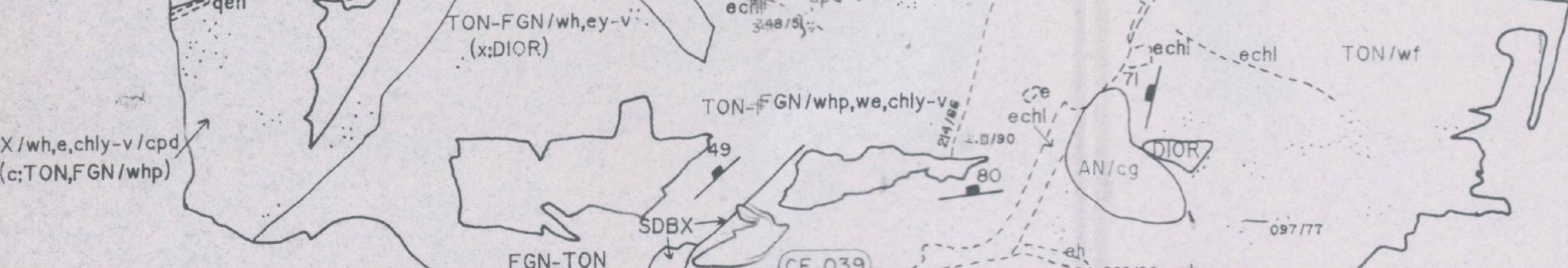

$P=-2=-2$
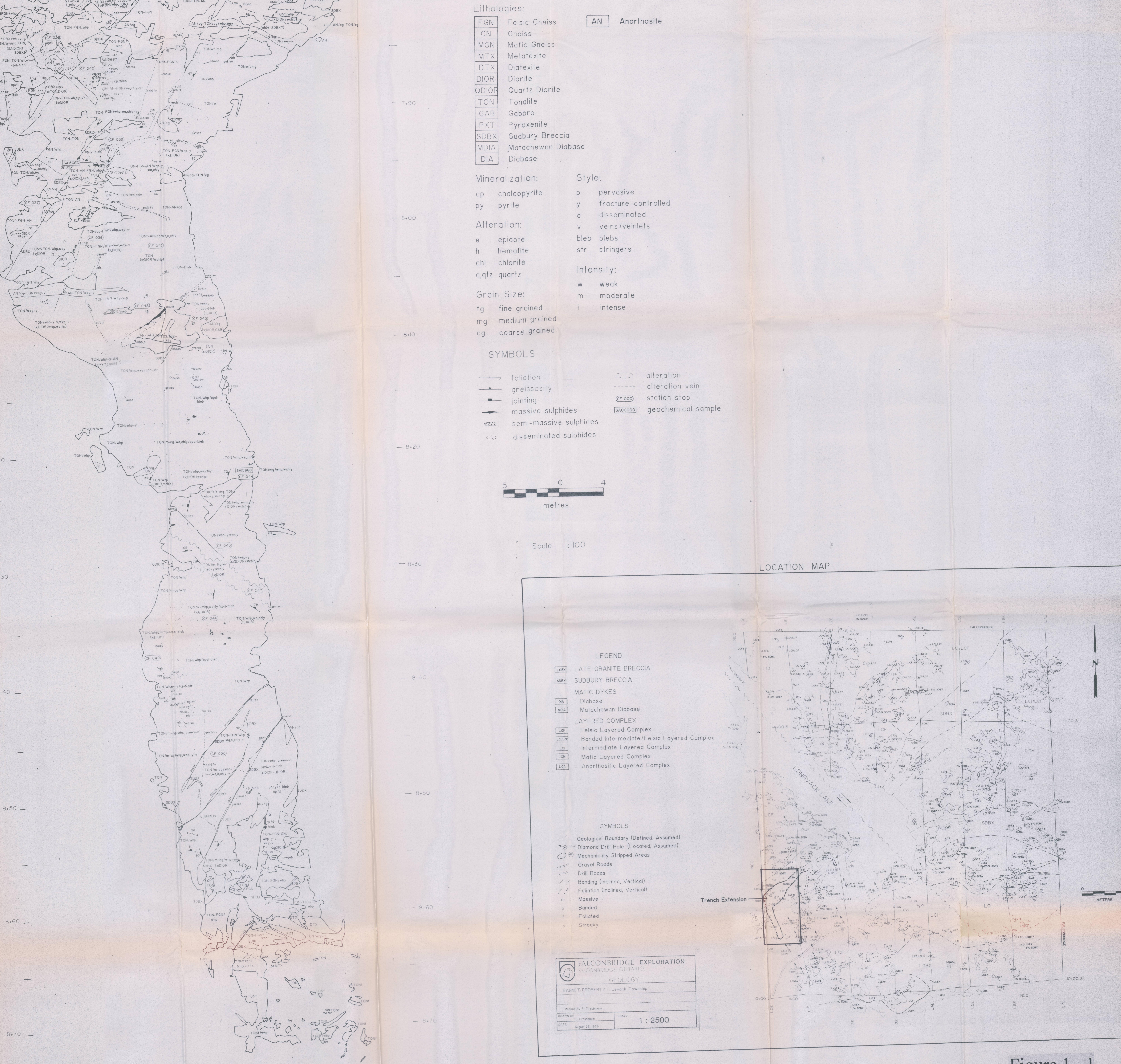

scole $1: 100$

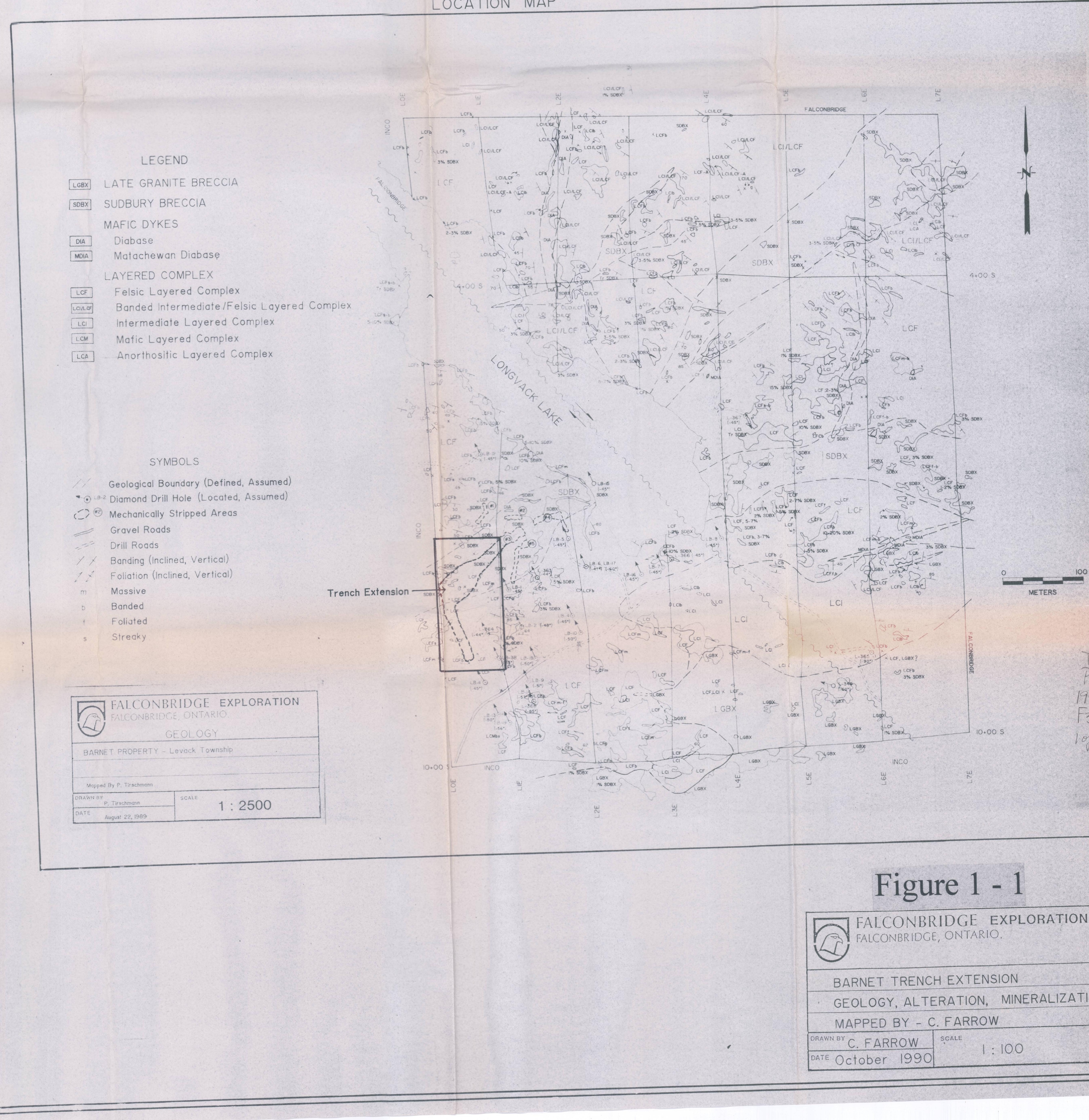





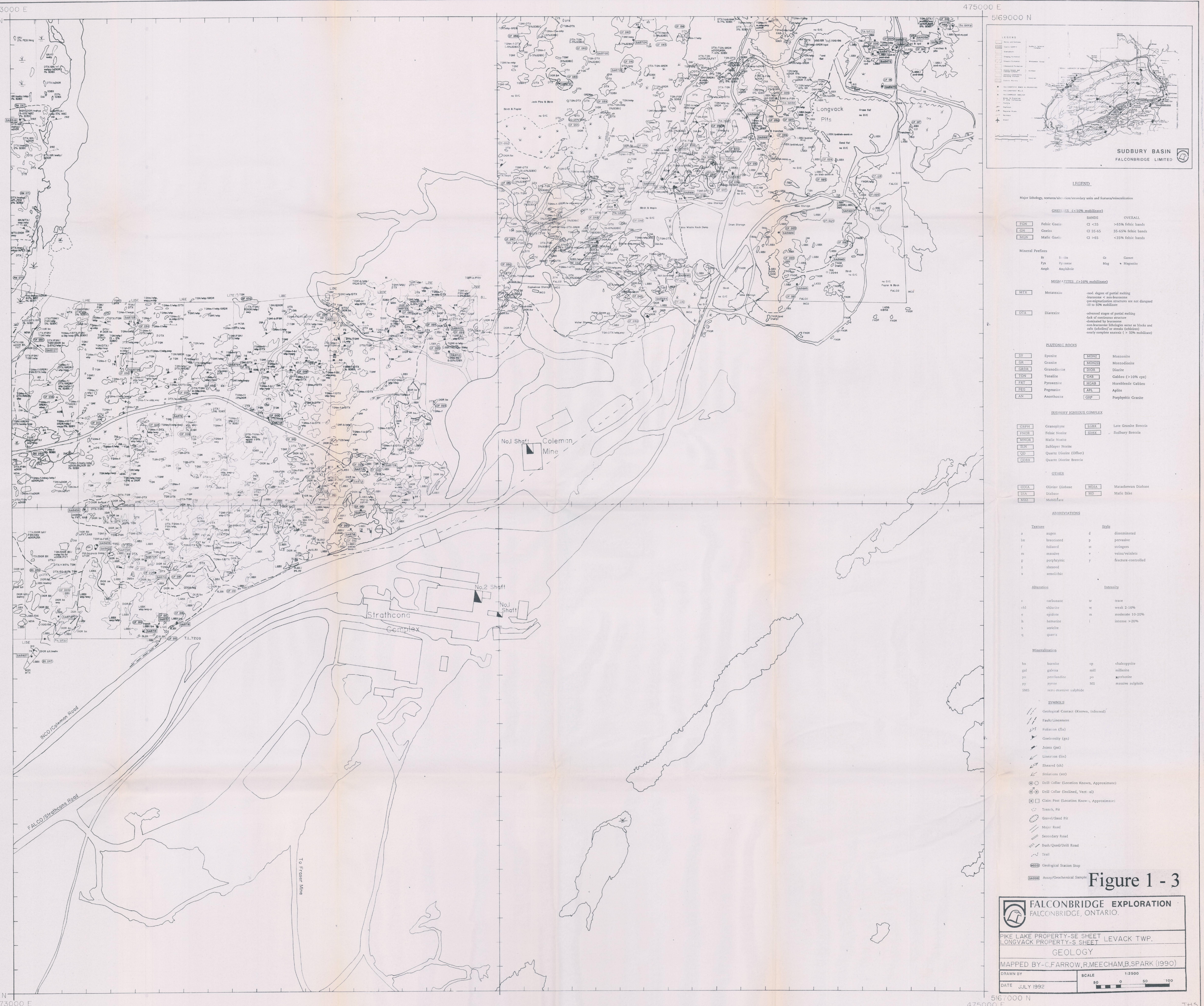




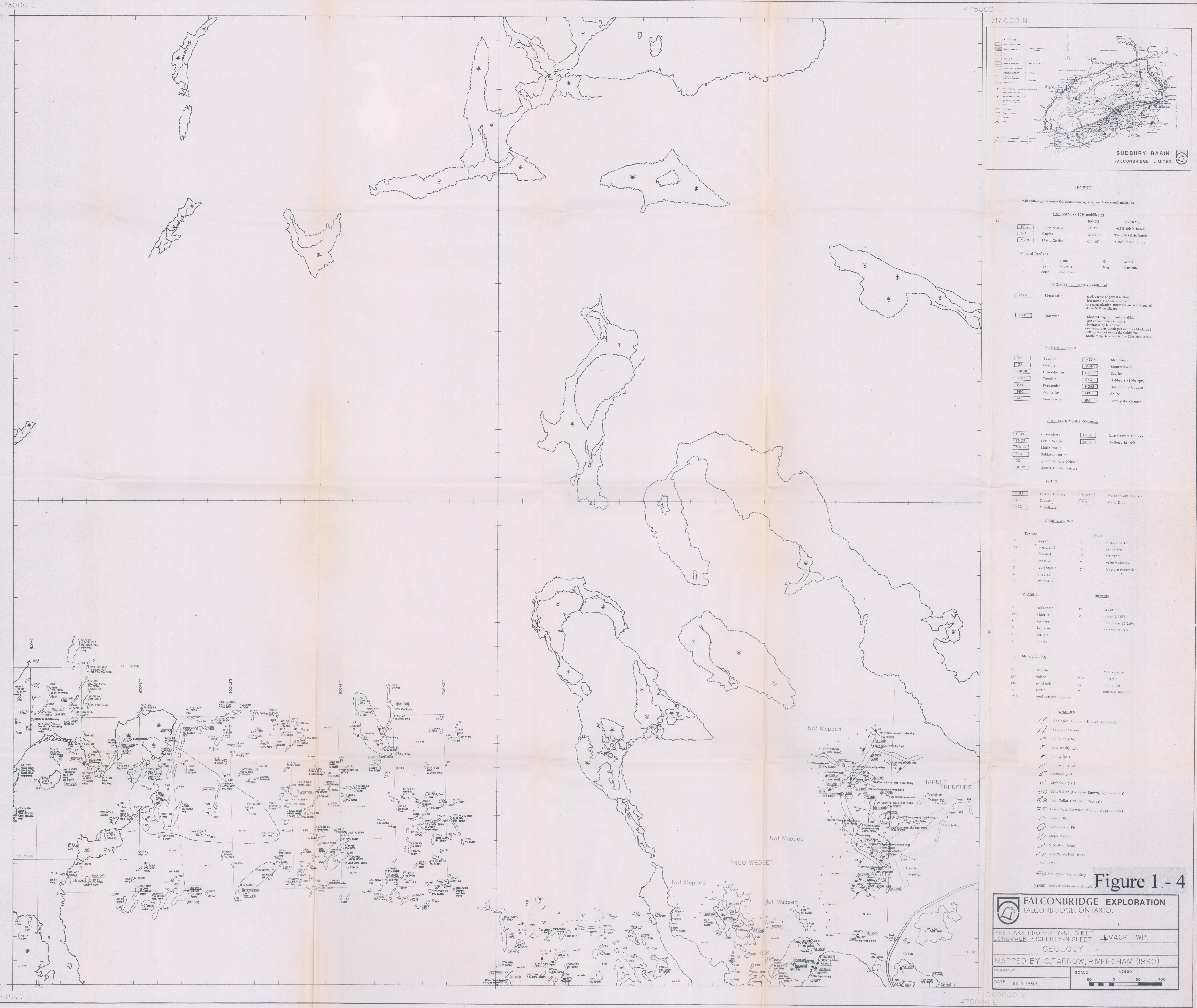

